\title{
Instrumenty i efekty wsparcia Unii Europejskiej dla regionalnego rozwoju obszarów wiejskich w Polsce
}


Katarzyna Zawalińska

\section{Instruments and effects of European Union support for regional rural development in Poland}

Institute of Rural and Agricultural Development

Polish Academy of Sciences

Warsaw 2009 
Katarzyna Zawalińska

\section{Instrumenty i efekty wsparcia Unii Europejskiej dla regionalnego rozwoju obszarów wiejskich w Polsce}




\section{PROBLEMY ROZWOJU WSI I ROLNICTWA}

\section{Komitet Redakcyjny}

Leszek Klank, Marek Kłodziński, Andrzej Rosner (redaktor naczelny), Maria Wieruszewska,

Elżbieta Wierzbicka (sekretarz redakcji)

Adres Redakcji

Instytut Rozwoju Wsi i Rolnictwa PAN

Nowy Świat 72, 00-330 Warszawa, tel./fax (+48-22) 8266371

e-mail: irwir@irwirpan.waw.pl

\section{Recenzenci}

Prof. dr hab. Andrzej Czyżewski

Prof. dr hab. Andrzej Wiatrak

Redaktor prowadzący

Elżbieta Wierzbicka

Projekt okładki

Radosław Baturo

Tłumaczenie na $\mathbf{j}$. angielski

Sylwia Wesołowska-Betkier

Redakcja techniczna

Dorota Majcher

\section{Korekta}

Irena Biśta-Kanciała

Druk i oprawa

Fabryka Druku, Warszawa

Copyright by Instytut Rozwoju Wsi i Rolnictwa PAN 2009 
r00.qxd 2011-10-31 09:35 Page 5

Ksiażkę tę dedykuję mojemu zmartemu tacie

Wiestawowi Leszczewskiemu 


\section{PoDZIĘKOWANIA}

Autorka jest wdzięczna wielu osobom za pomoc okazaną na różnych etapach powstawania tej pracy. Trudno wymienić wszystkich, jednak szczególne podziękowania należą się profesorowi Hannu Törmä z Ruralia Institute (University of Helsinki) za dostęp do modelu i pomoc w jego adaptacji do warunków polskich. Z kolei dzięki dyrektorowi Ruralia Institute profesorowi Sami Kurki autorka odbyła staż postdoktorski w tym Instytucie. Wśród sponsorów należy wymienić również CERGE-EI (Bank Światowy), University Consortium w Seinäjoki (Finlandia) oraz Ministerstwo Nauki i Szkolnictwa Wyższego. Serdeczne podziękowania autorka kieruje także do: Jerzego Wilkina (WNE UW i IRWiR PAN), Mirosława Drygasa (IRWiR PAN), Andrzeja Rosnera (IRWiR PAN), Izasława Frenkla (IRWiR PAN), Marka Kłodzińskiego (IRWiR PAN), Barbary Fedyszak-Radziejowskiej (IRWiR PAN), Radosława Hoffmanna (IRWiR PAN), Iwony Lisztwan (DG-AGRI, KE), Joanny Grochowskiej (DG-EMPLOYMENT, KE), Olgi Kiuiły (WNE UW), Andrzeja Kwiecińskiego (OECD), Iwony Nurzyńskiej (ARiMR), Pawła Szabelaka (MRiRW), Marka Horridge'a (Monash University, CoPS), Jamesa Giesecke (Monash University, CoPS), Mikko Koutaniemi (Statistics Finland), Heikki Lehtonen (MTT Finland), Olli Voutilainen (MTT Finland), Patricka Canninga (USDA), Zhi Wanga (USITC), Ulrike Lyhs (Ruralia), Sari Soini (Ruralia), Kaariny Reini (Ruralia) i wielu innych osób, m.in. z Ministerstwa Rolnictwa i Rozwoju Wsi, Agencji Restrukturyzacji i Modernizacji Rolnictwa oraz kolegów i koleżanek z IRWiR PAN.

Szczególne podziękowania należą się też recenzentom wydawniczym, prof. dr. hab. Andrzejowi Czyżewskiemu (Uniwersytet Ekonomiczny w Poznaniu) oraz prof. dr. hab. Andrzejowi Wiatrakowi (Uniwersytet Warszawski i Polska Akademia Nauk), których uwagi i rady przyczyniły się do nadania ostatecznego szlifu tej książce. 


\section{SPIS TREŚCI}

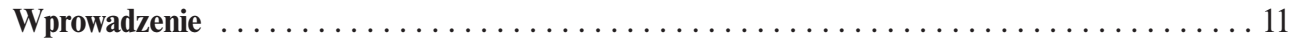

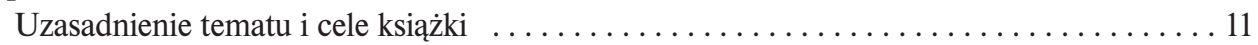

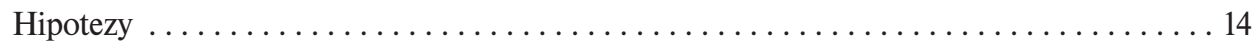

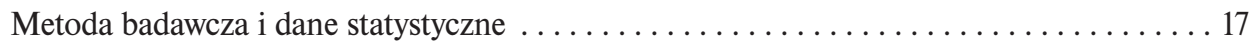

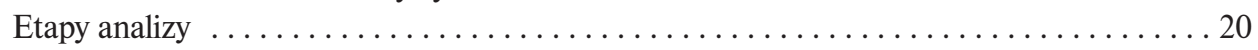

Rozdzial 1. Rozwój obszarów wiejskich w teorii i praktyce $\ldots \ldots \ldots \ldots \ldots \ldots \ldots \ldots \ldots \ldots \ldots \ldots \ldots$

1.1. Obszary wiejskie jako przedmiot analizy przestrzennej $\ldots \ldots \ldots \ldots \ldots \ldots \ldots 24$

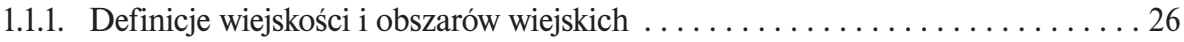

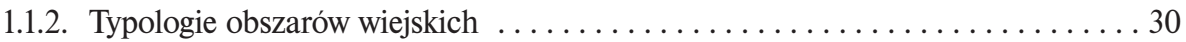

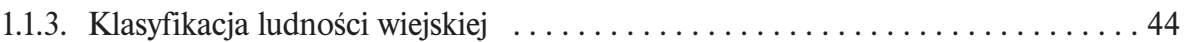

1.2. Rozwój obszarów wiejskich $w$ ujęciu wielokryterialnym $\ldots \ldots \ldots \ldots \ldots \ldots \ldots \ldots 2$

1.2.1. Rozwój obszarów wiejskich i rolnictwa a rozwój całej gospodarki . . . . . . . 54

1.2.2. Rozwój obszarów wiejskich a rozwój rolnictwa $\ldots \ldots \ldots \ldots \ldots \ldots \ldots \ldots \ldots \ldots \ldots \ldots$

1.2.3. Rozwój obszarów wiejskich a rozwój zrównoważony $\ldots \ldots \ldots \ldots \ldots \ldots \ldots 72$

1.2.4. Rozwój obszarów wiejskich a rozwój zintegrowany $\ldots \ldots \ldots \ldots \ldots \ldots \ldots 78$

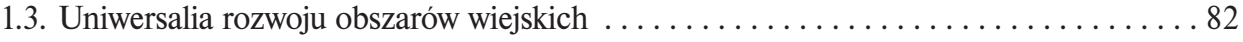

Rozdział 2. Polityka wspierania rozwoju obszarów wiejskich $\ldots \ldots \ldots \ldots \ldots \ldots \ldots$

2.1. Paradygmaty polityki rozwoju obszarów wiejskich $\ldots \ldots \ldots \ldots \ldots \ldots \ldots$

2.2. Polityka rozwoju obszarów wiejskich w Unii Europejskiej $\ldots \ldots \ldots \ldots \ldots \ldots \ldots 90$

2.2.1. Przejście od Wspólnej Polityki Rolnej do Wspólnej Polityki Rolnej

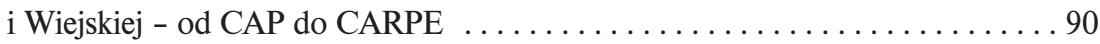

2.2.2. Wspieranie obszarów wiejskich w ramach Wspólnej Polityki Rolnej ........ 93

2.3. Polska polityka wobec obszarów wiejskich po wstapieniu do UE . . . . . . . . . . 99

2.3.1. Instrumenty unijnej polityki ROW w Polsce . . . . . . . . . . . . . . . . . . 101

2.3.2. Konflikt między spójnością a efektywnością w polityce ROW . . . . . . . . . . 105

2.3.3. Klasyfikacja pozyskanych funduszy ROW ..................... 109

2.3.4. Indykatywny podział środków pomiędzy działania i województwa $\ldots \ldots \ldots 123$

2.3.5. Zastosowanie modelu RegPOL do ewaluacji programów rozwoju

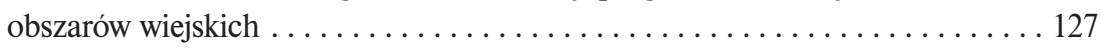

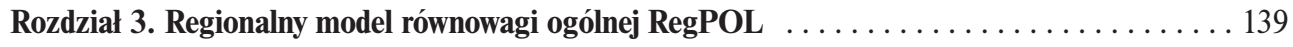

3.1. Wybór metody badawczej . . . . . . . . . . . . . . . . . . . . . 139

3.1.1. Wykorzystanie modeli równowagi ogólnej do oceny polityki gospodarczej . . . 140 
3.1.2. Regionalne modele równowagi ogólnej . . . . . . . . . . . . . . . . 147

3.1.3. Adekwatność i wiarygodność modelu RegPOL . . . . . . . . . . . . . . . 150

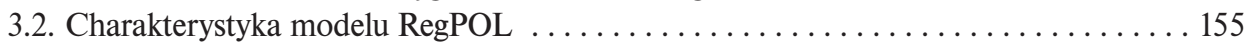

3.2.1. Baza danych dla modelu RegPOL . . . . . . . . . . . . . . . . . . . . . . 159

3.2.2. Teoretyczna struktura modelu RegPOL $\ldots \ldots \ldots \ldots \ldots \ldots \ldots \ldots \ldots \ldots \ldots$

3.2.2.1. Struktura produkcji w modelu RegPOL . . . . . . . . . . . . 168

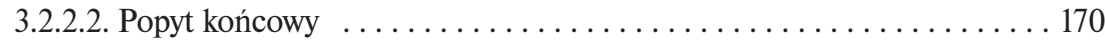

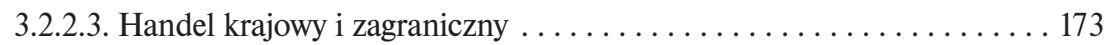

3.2.2.4. Ceny . . . . . . . . . . . . . . . . . . . . . . . . . . . . . . . . . . 173

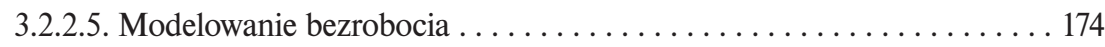

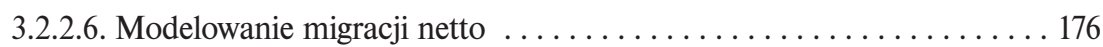

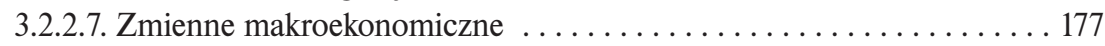

3.2.2.8. Warunki zrównoważenia rynku i domknięcie modelu . . . . . . . . 178

3.3. Scenariusze symulacyjne dla polityki ROW $\ldots \ldots \ldots \ldots \ldots \ldots \ldots \ldots \ldots \ldots$

Rozdział 4. Analiza efektów wsparcia rozwoju obszarów wiejskich przy zastosowaniu

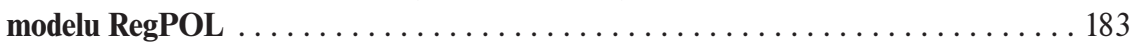

4.1. Skuteczność instrumentów ROW w skali krajowej i regionalnej . . . . . . . . . . 188

4.2. Efektywność instrumentów ROW w skali krajowej i regionalnej $\ldots \ldots \ldots \ldots \ldots 200$

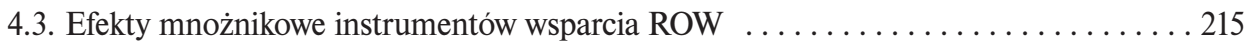

4.4. Rozkład korzyści z polityki ROW w ujęciu typologicznym ............... 224

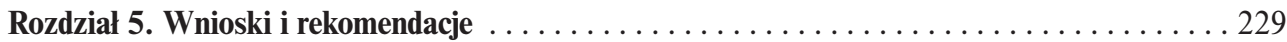

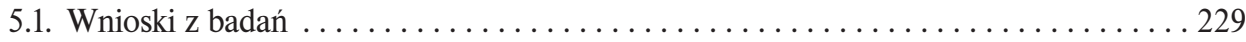

5.2. Sugestie co do dalszych badań . . . . . . . . . . . . . . . . . . . . . . . . 235

5.3. Rekomendacje dla polityki rozwoju obszarów wiejskich $\ldots \ldots \ldots \ldots \ldots \ldots \ldots 237$

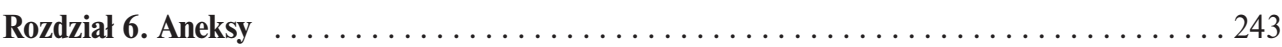

2.1. Wyprowadzenie klasyfikacji wg kryteriów ekonomicznych . . . . . . . . . . . 243

2.2. Regionalna struktura pozyskanych funduszy ROW $\ldots \ldots \ldots \ldots \ldots \ldots \ldots \ldots 263$

2.3. Zasady podziału środków SPO Rolnictwo na województwa $\ldots \ldots \ldots \ldots \ldots \ldots 266$

2.4. E-ankieta rozesłana do regionalnych oddziałów ARiMR . . . . . . . . . . . . . . . . 269

3.1. Stworzenie bazy danych dla modelu RegPOL . . . . . . . . . . . . . . . . . . . 277

Regionalne tablice przepływów międzygałęziowych . . . . . . . . . . . . 277

Regionalne macierze rachunkowości społecznej . . . . . . . . . . . . . . . . 291

3.2. Równania modelu RegPOL w języku TABLO . . . . . . . . . . . . . . . . . . . . 293

3.3. Podstawowe zmienne w modelu RegPOL . . . . . . . . . . . . . . . . . . . . 313

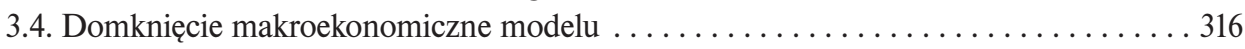

4.1. Wpływ polityki ROW 2004-2006 na poszczególne sektory gospodarki . . . . . . . 318

Wykaz skrótów ze słowniczkiem terminów w języku angielskim $\ldots \ldots \ldots \ldots \ldots \ldots \ldots \ldots \ldots \ldots$

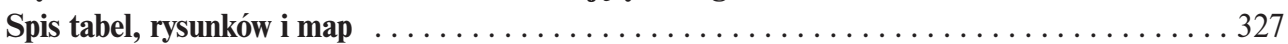

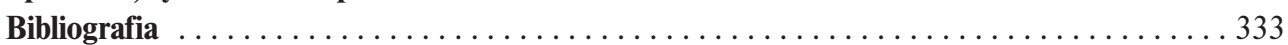

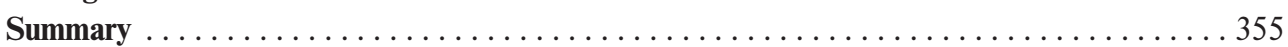




\section{CONTENTS}

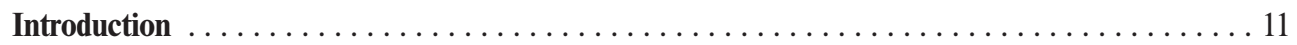

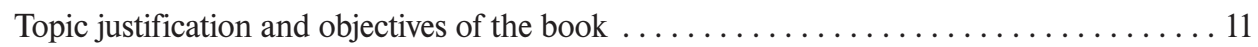

Hypotheses .............................................. 14

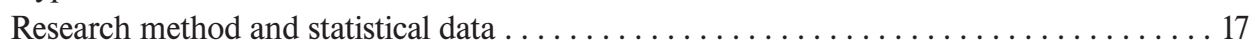

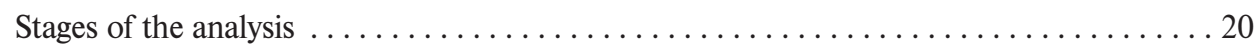

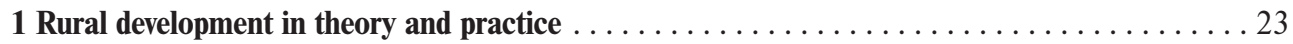

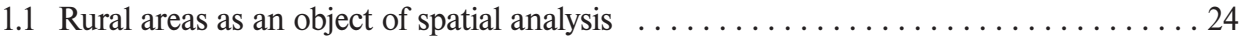

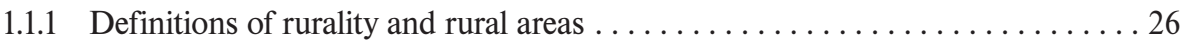

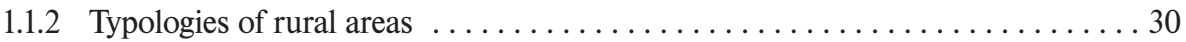

1.1.3 Classification of the rural population $\ldots \ldots \ldots \ldots \ldots \ldots \ldots \ldots \ldots \ldots 4$

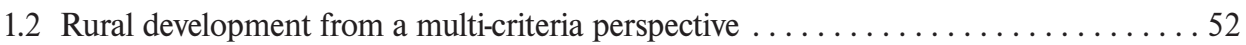

1.2.1 Rural and agricultural development versus wider economic development . . . . 54

1.2.2 Rural development versus agricultural development ............... 61

1.2.3 Rural development versus sustainable development . . . . . . . . . . . . 72

1.2.4 Rural development versus integrated development ................ 78

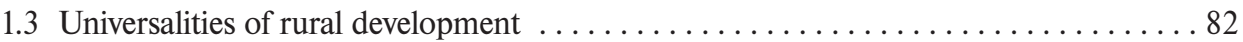

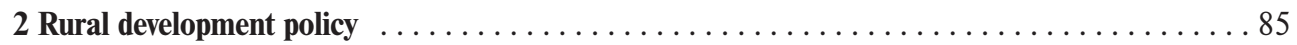

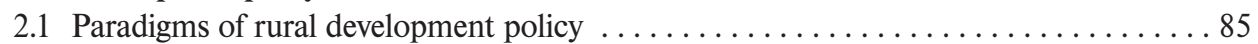

2.2 Rural development policy in the European Union $\ldots \ldots \ldots \ldots \ldots \ldots \ldots \ldots$

2.2.1 Transition from Common Agricultural Policy to Common Agricultural

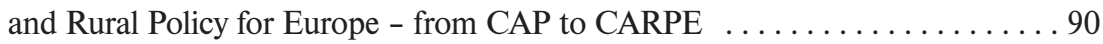

2.2.2 Support to rural areas as part of Common Agricultural Policy ........... 93

2.3 Polish policy on rural areas after EU entry . . . . . . . . . . . . . . . . 99

2.3.1 Instruments of the EU rural development policy in Poland . . . . . . . . . . . . 101

2.3.2 Conflict between cohesion and efficiency in RD policy . . . . . . . . . . . 105

2.3.3 Classification of RD funding absorbed ..................... 109

2.3.4 Indicative allocation of funding among measures and provinces . . . . . . . 123

2.3.5 Application of the RegPOL model to evaluate rural development

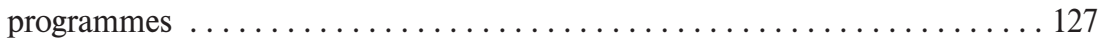

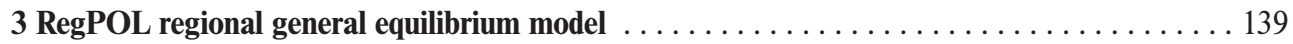

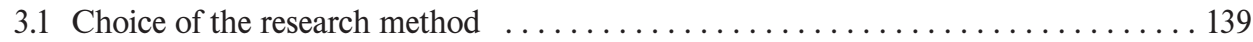

3.1.1 Use of general equilibrium models for the evaluation of economic policy . . . . 140 
3.1.2 Regional general equilibrium models . . . . . . . . . . . . . . . . . . . . 147

3.1.3 Adequacy and credibility of the RegPOL model . . . . . . . . . . . . . 150

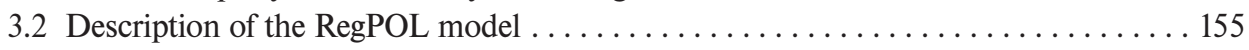

3.2.1 Database for the RegPOL model . . . . . . . . . . . . . . . . . . . . 159

3.2.2 Theoretical structure of the RegPOL model . ................. 167

3.2.2.1 Structure of production in the RegPOL model . . . . . . . . . . 168

3.2.2.2 Final demand . . . . . . . . . . . . . . . . . . . . . . . 170

3.2.2.3 Domestic and foreign demand $\ldots \ldots \ldots \ldots \ldots \ldots \ldots \ldots \ldots \ldots \ldots \ldots \ldots$

3.2.2.4 Prices .......................................... 173

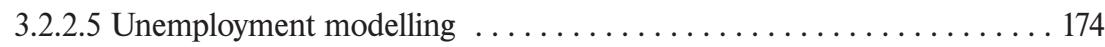

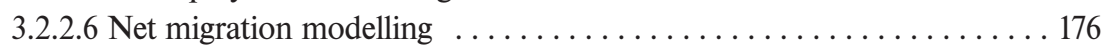

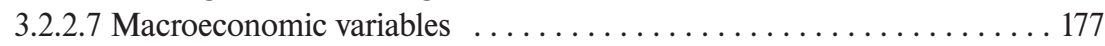

3.2.2.8 Conditions for balancing the market and model closure . . . . . . . 178

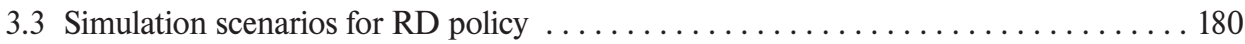

4 Analysis of effects of support for rural development with the use of the RegPOL model $\ldots \ldots 183$

4.1 Effectiveness of RD instruments at national and regional level . . . . . . . . . . 188

4.2 Efficiency of RD instruments at national and regional level . . . . . . . . . 200

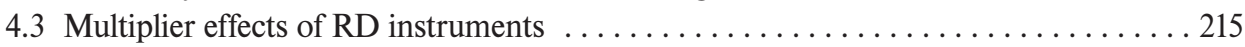

4.4 Distribution of benefits resulting from RD policy from a typological perspective . . . 224

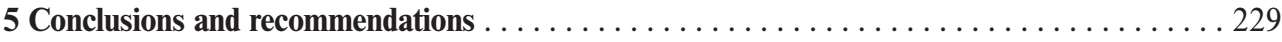

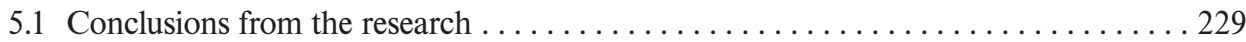

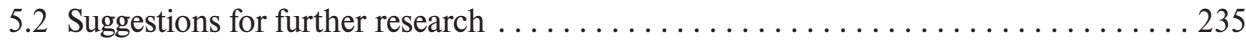

5.3 Recommendations for rural development policy $\ldots \ldots \ldots \ldots \ldots \ldots \ldots \ldots \ldots \ldots \ldots$

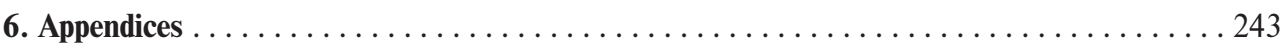

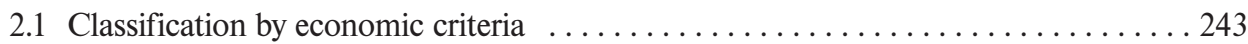

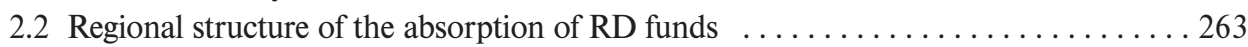

2.3 Rules for the distribution of SOP Agriculture funding among provinces . . . . . . 266

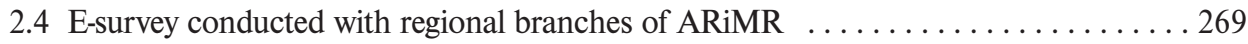

3.1 Creating the database for the RegPOL model . . . . . . . . . . . . . . . . 277

Regional input-output tables ................................ 277

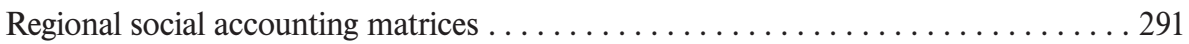

3.2 Equations of the RegPOL model in the TABLO language . . . . . . . . . . . . 293

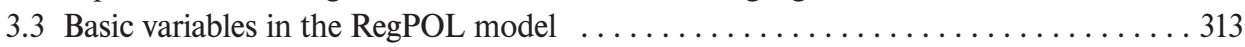

3.4 Macroeconomic closure of the model . . . . . . . . . . . . . . . . . . . 316

4.1 Impact of rural development policy (PROW 2004-2006) on individual

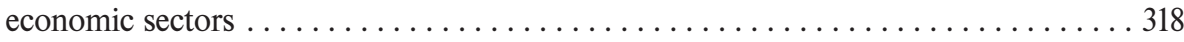

List of abbreviations with a glossary of English terms $\ldots \ldots \ldots \ldots \ldots \ldots \ldots \ldots \ldots \ldots \ldots \ldots \ldots$

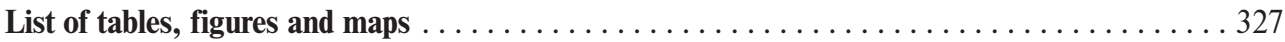

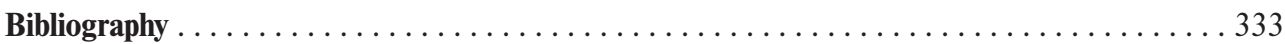

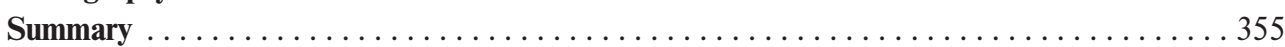




\section{WPROWADZENIE}

\section{Uzasadnienie tematu i cele książki}

Członkostwo w Unii Europejskiej (UE) umożliwiło Polsce wzmocnienie realizacji polityki rozwoju obszarów wiejskich (ROW), głównie dzięki dostępowi do środków unijnych. W latach 2004-2006 były to fundusze pochodzące z Europejskiego Funduszu Orientacji i Gwarancji Rolnej (EFOiGR), a w latach 2007-2013 z Europejskiego Funduszu Rolnego na rzecz Rozwoju Obszarów Wiejskich (EFRROW). Już przed integracją polska wieś korzystała z kilku programów pomocowych UE - SAPARD (2000-2004) czy PHARE (1990-2007). Wcześniej realizowane były także programy (pożyczki) Banku Światowego, np. Program Dostosowawczy dla Sektora Rolniczego, ASAL (1994-1996) czy Program Aktywizacji Obszarów Wiejskich PAOW (2000-2004) [Milczarek, Zawalińska 2005]. Oczywiście wszystkim środkom zagranicznym towarzyszyły również środki z polskiego budżetu, które uzupełniały uzyskane płatności.

Polska, jako pełnoprawny członek UE, może wpływać na kształtowanie polityki unijnej zarówno na poziomie krajowym, jak i całej Wspólnoty, na przykład poprzez aktywny udział w pracach koncepcyjnych i legislacyjnych. Może też wybierać z zaproponowanych działań te, które uważa za najbardziej pożądane z punktu widzenia realizacji własnych celów rozwojowych, określać ich formę, sposoby implementacji, warunki ich przyznawania oraz decydować o alokacji środków pomiędzy działania, a nawet regiony (województwa). Możliwości te są jednocześnie szansą - przy trafnych decyzjach, ale przy błędnych - zagrożeniem dla rozwoju tych obszarów. Dlatego jednym z celów niniejszej książki jest dostarczenie naukowych przesłanek dokonywania trafnych wyborów działań i opracowywania doskonalszych instrumentów wsparcia dla polityki ROW.

Mieszkańców obszarów wiejskich nadal często kojarzy się głównie z rolnikami, chociaż liczba rolników wśród ludności wiejskiej maleje. Problemów ludności wiejskiej nie rozwiąże się jednak, korzystając $\mathrm{z}$ instrumentów wąskiej polityki sektorowej (polityki rolnej), mają one złożony, ekonomiczno-socjologiczny charakter, 
a rozwój obszarów wiejskich ma polegać na zwiększeniu przede wszystkim nierolniczych źródeł dochodów ich ludności. Kolejnym zatem celem pracy jest zbadanie skutków ekonomicznych polityki ROW pod kątem nie tylko sektora rolnego i obszarów wiejskich, lecz także rozwoju całych województw (regionów) i różnych sektorów. Dzięki wdrażaniu omawianych powyżej programów powstało wiele efektów pośrednich i mnożnikowych, które dalece wykraczają poza sektor rolny. Dlatego w pracy proponuje się metodę pozwalającą na ujęcie całej gospodarki poprzez zastosowanie regionalnego modelu równowagi ogólnej, pokazującego, jak przenoszone są efekty programów ROW pomiędzy wszystkie sektory gospodarki w poszczególnych województwach.

Polityka unijna wobec obszarów wiejskich formalnie stosowana jest od końca lat 90., kiedy wraz z ogłoszeniem Agendy 2000 stała się oficjalnie II filarem Wspólnej Polityki Rolnej. Wcześniej dominowała polityka sektorowa, która nie dostrzegała specyfiki rozwoju obszarów wiejskich. W Polsce, po wstąpieniu do UE, polityka ta realizowana była za pomocą trzech programów. W latach 2004-2006 ${ }^{1}$ poprzez Program Rozwoju Obszarów Wiejskich (PROW 2004-2006) i Sektorowy Program Operacyjny „Restrukturyzacja i modernizacja sektora żywnościowego oraz rozwój obszarów wiejskich" (SPO Rolnictwo). Obecnie, w drugim okresie finansowym 2007-2013, opierając się na Programie Rozwoju Obszarów Wiejskich (PROW 2007-2013), spójnym z Krajowym Planem Strategicznym dla Obszarów Wiejskich. PROW 2007-2013 wykorzystuje większość działań z obu programów z poprzedniego okresu, co ułatwia jego analizę i pozwala prześledzić większość działań w dłużej perspektywie. Finansowanie tych programów odbywa się zarówno ze środków publicznych (unijnych i polskiego budżetu), jak i prywatnych (kontrybucji beneficjentów). W latach 2007-2013 Polska ma do wykorzystania z UE na rozwój wsi i rolnictwa ponad 28,4 mld EUR, z czego w ramach PROW 2007 -2013 ok. 13,2 mld EUR, a w ramach płatności bezpośrednich ponad 15,2 mld EUR, czyli rocznie co najmniej ok. 4 mld EUR. Dlatego bardzo ważna jest pogłębiona analiza instrumentarium tej polityki, a szczególnie stosowanych mechanizmów ekonomicznych, kryjących się za poszczególnymi działaniami programów ROW (co często pomijane jest w debacie publicznej). Jasne jest bowiem, że inne efekty uzyskujemy za pomocą transferów dochodowych, inne zaś stosując subsydia inwestycyjne, a jeszcze inne dzięki subsydiom obszarowym. Debata publiczna nazbyt skupia się jednak na omawianiu liczby celów i działań polityki ROW, a nie na jakości instrumentów je wspierających oraz alokacji środków pomiędzy nimi.

\footnotetext{
${ }^{1}$ Trzeba przypomnieć, że fundusze w ramach tych programów miały być wydawane do końca 2008 r., zgodnie $\mathrm{z}$ regułą $\mathrm{n}+2$, czyli do dwóch lat po formalnym zakończeniu programu (były wydawane do końca czerwca 2009 r.).
} 
Chociaż uzyskano konsensus co do tego, że za pomocą środków ROW trzeba wspierać: konkurencyjność rolnictwa, poprawę środowiska oraz poprawę jakości życia na wsi, to wciąż brakuje uzgodnień co do tego, jak cele te najefektywniej można osiągnąć. Które z istniejących działań są najlepsze, które można poprawić lub jakie nowe można zaproponować, aby zwiększyć efektywność polityki ROW. Dlatego kolejnym zadaniem niniejszego opracowania jest pokazanie różnic $\mathrm{w}$ mechanizmach ekonomicznych, kryjących się za poszczególnymi narzędziami tej polityki oraz tego, jak determinują one skuteczność i efektywność omawianej polityki.

Wraz z rozwojem polityki ROW Komisja Europejska (KE) zwiększyła nacisk na monitorowanie i ewaluację programów realizowanych w jej ramach. $\mathrm{Z}$ oceną programów wiąże się zwykle wiele problemów metodologicznych, wynikających z trudności wychwycenia „czystego wpływu programów” na beneficjentów, zarówno pozytywnych, jak i negatywnych efektów zewnętrznych oraz oceny wpływu programu na różnych jego poziomach (produktów, rezultatów, oddziaływania). Powszechnie zalecaną przez KE metodą są wskaźniki zawarte we Wspólnych Ramach Monitorowania i Oceny [WRMO 2006]. Są one dość przydatne na poziomie produktów i rezultatów programów, jednak nie są wystarczające na poziomie oddziaływania programów na całą gospodarkę. Kolejnym zatem celem tego opracowania jest próba oceny podstawowych kryteriów ewaluacyjnych polityki ROW (skuteczności, efektywności, trwałości, efektów mnożnikowych) na poziomie oddziaływania programu, a więc jej efektów w szerszym kontekście, najtrudniejszym do uchwycenia, gdyż obejmującym jego szeroki zakres przestrzenny i czasowy. Dlatego niniejsza książka ma częściowo charakter ewaluacji ex post dwóch programów SPO Rolnictwo i PROW 2004-2006, od zakończenia których minęło wymagane 2 lata, co zgodnie $\mathrm{z}$ regułą $\mathrm{n}+2$ ustanowioną przez KE oznacza, że można już taką analizę przeprowadzić, gdyż do tego czasu wszystkie środki powinny zostać wydane i większość efektów programu powinna się ujawnić.

Głównym celem książki jest zatem przeanalizowanie instrumentów i efektów wsparcia Unii Europejskiej dla rozwoju obszarów wiejskich w Polsce, ze szczególnym uwzględnieniem aspektów regionalnych. Analizą objęto dostępne dane - okres od wstąpienia do UE w 2004 r. do 2008 r. Rezultaty przedstawiono zarówno na poziomie krajowym, jak i wojewódzkim. W realizacji celu głównego pomocne było sformułowanie szczegółowych celów badawczych. Pierwszym z nich było dokonanie kompleksowej analizy polityki wspierania rozwoju obszarów wiejskich, zarówno jako czynnika rozwoju, jak i elementu pomocy socjalnej. Drugim z nich było dokonanie, w analizowanym okresie, oceny skuteczności i efektywności różnych instrumentów, które do tej pory zastosowano w ramach tej polityki w Polsce. 
Trzeci cel szczegółowy to ocena wpływu polityki rozwoju obszarów wiejskich nie tylko na sektor rolny, lecz także na pozostałe sektory gospodarki. Polityka rozwoju obszarów wiejskich wykracza bowiem poza sektor rolny, a fundusze wydawane przez rolników krążą dalej w gospodarce, wywołując pośrednio wpływ też na inne sektory. Czwartym celem szczegółowym było zbadanie korzyści z polityki rozwoju obszarów wiejskich w układzie regionalnym, czyli zbadanie, które województwa najwięcej skorzystały i rozwinęły się dzięki pozyskanym funduszom.

Zgodnie z podstawowym założeniem, niniejsza praca ma prezentować wyważone połączenie zaawansowanych metod analitycznych z ich praktycznym zastosowaniem. Do jej praktycznego wkładu w dotychczasowe polskie badania zaliczyć można stworzenie regionalnych tablic przepływów międzygałęziowych, jako ważnego narzędzia regionalnej analizy ekonomicznej oraz zastosowanie regionalnego modelu równowagi ogólnej do ewaluacji programów rozwoju obszarów wiejskich na poziomie ich oddziaływania. Naukowe wsparcie procesu decyzyjnego w wyborze najskuteczniejszych i najefektywniejszych instrumentów polityki obszarów wiejskich wydaje się szczególnie ważne teraz, kiedy trwa debata nad kształtem tej polityki po 2013 r. Istotne jest również zmodyfikowanie typologii wiejskości, stosowanej przez OECD poprzez dodanie jej wymiaru rolniczości. Do teoretycznego wkładu książki w literaturę przedmiotu zaliczyć można jej kontrybucję w rozwój regionalnych modeli równowagi ogólnej dla Polski i propozycje metod tworzenia regionalnych tablic przepływów międzygałęziowych i macierzy rachunków społecznych, których brak jest barierą powstawania regionalnych modeli CGE w Polsce. Ponadto problematyka książki nawiązuje do wielu teorii z dziedzin nauk ekonomicznych, w tym do teorii: rozwoju gospodarczego, wyboru publicznego, równowagi ogólnej, ekonomiki rolnictwa i obszarów wiejskich oraz do dorobku w zakresie metod ilościowych ekonomii, w tym strukturalnych modeli ekonomicznych. Wkład metodologiczny badań przedstawionych w tej pracy, na tle polskiej literatury przedmiotu, polega na połączeniu modelu równowagi ogólnej z problematyką rozwoju wsi, zwłaszcza na poziomie regionalnym. Tam gdzie to było możliwe, publikacja nawiązuje również do doświadczeń i porównań międzynarodowych.

\section{Hipotezy}

W pracy poddano weryfikacji cztery hipotezy badawcze, które uzupełnione pytaniami pomocniczymi służyły osiąnnięciu założonych celów książki. Wybór i szczegółowe uzasadnienie hipotez ma miejsce w kolejnych rozdziałach, gdzie pojawiają się w kontekście poszczególnych zagadnień. Tutaj przedstawione są 
jedynie w formie zestawienia, by wprowadzić czytelnika w zakres i obszar analizowanych w książce zagadnień. Informacje na temat sposobu i wyników weryfikacji hipotez pokazuje też ostatni rozdział książki i tabela 5.1.

Pierwsza hipoteza mówi o tym, że polityka rozwoju obszarów wiejskich w Polsce faworyzuje działania prorównościowe nad rozwiazaniami proefektywnościowymi. Ma ona swoją genezę w teorii wyboru publicznego. Nawiązuje do odwiecznego dylematu polityki rozwoju, która jest kompromisem pomiędzy równością społeczną a efektywnością (equality vs. efficiency). Dylemat ten jest widoczny w podstawowych założeniach funkcjonowania UE, gdzie obok polityki spójności, która ma wyrównywać szanse krajów i regionów biedniejszych, manifestuje się politykę konkurencyjności (m.in. w Strategii Lizbońskiej), która generalnie ma faworyzować jak najwyższy wzrost gospodarczy i postęp technologiczny. Te dwa cele, jak pokazuje rozdział 2.3.2, nie zawsze idą w parze. Hipotezie tej towarzyszy dodatkowe pytanie, dotyczące proporcji działań proefektywnościowych w stosunku do działań prorównościowych w polityce rozwoju obszarów wiejskich zrealizowanej w latach 2004-2006 oraz planowanej na lata 2007-2013.

Najpierw dokonano klasyfikacji poszczególnych działań polityki ROW ze względu na charakter instrumentów użytych do realizacji celów tych działań, a następnie zbadano proporcję działań prorównościowych i proefektywnościowych na poziomie krajowym i regionalnym. Hipoteza ta została celowo sformułowana jako pierwsza, gdyż jest wprowadzeniem do dyskusji nad teoretycznymi przesłankami polityki rozwoju obszarów wiejskich, zanim dojdzie do empirycznej analizy jej skutków ekonomicznych. Te bowiem powinny być interpretowane na podbudowie teoretycznej i z uwzględnieniem tła historycznego.

Druga hipoteza głosi, iż wspieranie rozwoju poprzez inwestycje jest dużo skuteczniejszą i efektywniejszą polityką rozwoju obszarów wiejskich niż wspieranie rozwoju poprzez różnego rodzaju subsydia nieinwestycyjne. Wiadomo, że stosowanie każdego narzędzia polityki ma swoje plusy i minusy; różnią się też one relatywną efektywnością. $Z$ jednej strony, można oczekiwać, że inwestycje są lepszym narzędziem niż subsydia i należałoby po nie sięgać w pierwszej kolejności. $Z$ drugiej strony, powstaje dylemat absorpcji, gdyż działania proinwestycyjne są w polityce ROW dużo trudniejsze do pozyskania i zastosowania przez beneficjentów niż działania innego rodzaju, szczególnie o charakterze transferów bezpośrednich. Stojąc zatem przed wyborem małej absorpcji, ale za to wysoko efektywnościowych środków czy dużej absorpcji środków z przewagą mniej efektywnych, odpowiedź nie jest taka oczywista. $Z$ przeprowadzonych analiz wynika, że korzyści ze stosowania środków proefektywnościowych mogą tak bardzo przewyższać korzyści ze środków prorównościowych, że należałoby raczej uprościć te pierwsze dla 
zwiększenia ich absorpcji niż zadowalać się dużą ilością mało efektywnych środków prorównościowych. Empiryczna analiza porównawcza pokazuje, jak duża jest różnica w tej efektywności. Trzeba rozstrzygnąć, czy jest ona na tyle znacząca, że warto forsować środki „trudne”, czy może na tyle nieistotna, że rozsądna ilość środków „łatwych” pokryje straty w efektywności, a jednocześnie wpłynie na zachowanie spokoju społecznego z pozytywnym rezultatem dla rozwoju gospodarki. Wiążą się z tą kwestią następujące pytania pomocnicze:

- Jakie skutki ekonomiczne wywołały działania proefektywnościowe, a jakie prorównościowe?

- Jakie są różnice w efektywności instrumentów wykorzystanych w polityce ROW, które zostały pogrupowane na: subsydia inwestycyjne, bezpośrednie transfery dochodowe, subsydia obszarowe?

- Jakie są koszty polityki „maksymalizacji absorpcji środków łatwych”?

Hipoteza trzecia zakłada, że polityka rozwoju obszarów wiejskich nakierowana jest głównie na sektor rolny, ale ze względu na duża różnorodność instrumentów generuje również znaczace efekty mnożnikowe w różnych innych sektorach gospodarki. Pierwsza część tej hipotezy mówi o tym, o czym często można usłyszeć w debacie publicznej, że program rozwoju obszarów wiejskich bardziej adresowany jest do rolników niż do pozostałych mieszkańców wsi, mimo iż rolnictwo na obszarach wiejskich traci na znaczeniu, a potrzebne jest wspieranie nierolniczych miejsc pracy. Jednak w drugiej części podkreśla, że nie tylko rolnicy są beneficjentami tej polityki, gdyż dzięki niej następuje przepływ czynników wytwórczych i zasobów również do pozostałych sektorów gospodarki. Pytania pomocnicze do tej hipotezy są następujące:

- Które sektory zyskały najwięcej, a które najmniej na polityce rozwoju obszarów wiejskich w ujęciu krajowym i regionalnym?

- Jaki wpływ mają efekty mnożnikowe na pozarolnicze zatrudnienie ludności wiejskiej?

Ostatnia, czwarta hipoteza, jest sformułowana zgodnie z oczywistą intencją omawianej polityki, mówiąc, że najwięcej na polityce rozwoju obszarów wiejskich zyskuja regiony najbardziej wiejskie i najbardziej uzależnione od rolnictwa. Jest to również zgodne z intuicją, że największymi beneficjentami polityki ROW powinni być mieszkańcy obszarów wiejskich, czyli oprócz rolników również - przeważająca zresztą - ludność wiejska niezwiązana z rolnictwem i najbardziej wiejsko-rolnicze regiony kraju. Jednak uwzględniając efekty mnożnikowe, może się okazać, że inne regiony skorzystały więcej. Do weryfikacji tej hipotezy została zaproponowana pomocniczo typologia wiejskości i rolniczości województw oparta na zmodyfikowanej typologii OECD, tak aby w jak najmniej kontrowersyjny sposób 
zdefiniować województwa pod względem wiejskości oraz zależności od rolnictwa. Pomocne w weryfikacji tej hipotezy było następujące pytanie:

- Które regiony pogrupowane według typologii wiejsko-rolniczej odniosły największe, a które najmniejsze pozytywne/negatywne skutki ekonomiczne polityki rozwoju obszarów wiejskich?

Wyżej wymienione hipotezy zostały zweryfikowane za pomocą metod zarówno ilościowych, jak i jakościowych, o czym mowa jest w kolejnych rozdziałach właściwych dla weryfikacji poszczególnych hipotez, zaś tabela 5.1 zawiera ich podsumowanie.

\section{Metoda badawcza i dane statystyczne}

W książce przeważają metody ilościowe, a głównym narzędziem badawczym jest regionalny model równowagi ogólnej RegPOL. Jest to model odzwierciedlający strukturę całej gospodarki w podziale na 16 gospodarek wojewódzkich (regionalnych). Obrazuje on interakcje zachodzące między województwami (poprzez handel krajowy, rynki pracy, czynniki produkcji) oraz między wszystkimi sektorami gospodarki zagregowanymi do 15 sekcji $\mathrm{PKD}^{2}$. Dzięki modelowi możliwe jest pokazanie wpływu polityki rozwoju obszarów wiejskich na sektor rolny oraz na pozostałe sektory gospodarki, wśród których w pracy wyróżniono: sektor rybactwa, przetwórstwa przemysłowego (w tym rolno-spożywczego), sektor górniczy i wydobywczy, energetyczny, budowlany, handel i naprawy, hotele i restauracje, transport, usługi: finansowe, mieszkaniowe, edukacyjne, zdrowotne, administrację publiczną i pozostałe usługi. Szczegółowe powiązania rolnictwa z innymi sektorami gospodarki dla każdego województwa odzwierciedlają regionalne macierze SAM (Social Acounting Matrix), które są wbudowane w model jako główna baza danych. Model może być wykorzystywany zarówno do analiz statycznych, jak i dynamicznych (recursive dynamic), procesów zachodzących w gospodarce z roku na rok. Opiera się na założeniach ekonomii neoklasycznej, tj. maksymalizacji użyteczności (przez gospodarstwa domowe), minimalizacji kosztów (przez firmy), konkurencji doskonałej, bezrobociu klasycznym i funkcji migracji. Model RegPOL opisuje rzeczywistość za pomocą ponad 50 tysięcy równań charakteryzujących szczegółowe zależności ekonomiczne. Genezę, budowę i dyskusję nad adekwatnością modelu RegPOL przedstawia rozdział 3.1.3.

Istotną wartość ma stworzona i wykorzystana w tej książce baza danych. Punktem wyjścia była krajowa tablica przepływów międzygałęziowych za 2000 r.

\footnotetext{
${ }^{2}$ Tylko ostatnie sekcje O, P, Q zostały zagregowane razem.
} 
(uaktualniona) oraz bazy statystyk regionalnych dla każdego województwa za lata 2000-2006. Dzięki nim i opierając się na literaturze tematu, zostało stworzonych 16 oryginalnych (autorskich) tablic przepływów międzygałęziowych (IO) i 16 macierzy rachunków społecznych (SAM). Autorka wykorzystała do tego celu metodę hybrydową, polegającą na połączeniu rozszerzonych współczynników lokalizacji Flegga (AFLQ) ze statystykami regionalnymi i współczynnikami z krajowej tablicy IO. Ponadto do zbilansowania macierzy wykorzystała też metodę RAS (szczegóły w aneksie 3.4 ). Wymagało to dużego nakładu pracy oraz poznania wielu technik regionalizacji tablic IO i macierzy SAM, ale było warunkiem koniecznym do uruchomienia modelu, jakiego jeszcze w Polsce nie zbudowano. Samo opublikowanie algorytmów tworzenia tych tablic może być uznane za wkład w literaturę tematu, gdyż nie ma jeszcze w Polsce tego typu opracowania. Jednocześnie tablice takie są bardzo pożądane ze względu na możliwość rozpoczęcia bardziej zaawansowanych metod analiz regionalnych, w tym regionalnych modeli przepływów międzygałęziowych, modeli SAM oraz regionalnych modeli równowagi ogólnej ${ }^{3}$. Szerszy opis danych wykorzystanych do modelu zawarto w rozdziale 3.2.1, opatrzonym dodatkowo obszernymi aneksami technicznymi wyjaśniającymi proces tworzenia bazy.

Ponadto w pracy wykorzystano wiele opracowań GUS za lata 2000-2008, m.in. Bank Danych Regionalnych, roczniki poszczególnych województw, bazę danych regionalnych HERMIN, opracowania BAEL, dane zamawiane w GUS (np. handel zagraniczny województw, rachunki regionalne spójne z tablicą IO etc.). Do tego wykorzystano też dane z Agencji Restrukturyzacji i Modernizacji Rolnictwa dotyczące regionalnego zróżnicowania środków wydatkowanych w ramach PROW i SPO Rolnictwo 2004-2006, dane i opracowanie Ministerstwa Rolnictwa i Rozwoju Wsi oraz wiele innych materiałów statystycznych.

Na potrzeby pracy przeprowadzono również wywiady indywidualne, badania ankietowe i analizy dokumentacji. Ankietę przeprowadzono drogą elektroniczną (ankieta internetowa) wśród 80 pracowników z wszystkich regionalnych oddziałów ARiMR. Dane uzyskane tą metodą służyły głównie uzyskaniu opinii urzędników co do tego, jak rolnicy radzili sobie $\mathrm{z}$ wnioskami o pomoc w ramach omawianych programów. Jeśli chodzi o dokumentację, składała się ona głównie z dyrektyw i dokumentów programowych dotyczących analizowanych programów: tj. SPO Rolnictwo, PROW 2004-2006 oraz PROW 2007-2013. Ponadto $\mathrm{w}$ pracy wykorzystano materiały zbierane w czasie prowadzenia szkoleń dla

\footnotetext{
${ }^{3}$ Według najlepszej wiedzy autorki, w obecnym momencie model RegPOL jest w Polsce jedynym regionalnym modelem równowagi ogólnej, który modeluje poszczególne województwa, uwzględniając zdezagregowane sektory gospodarki i handel krajowy między województwami oparte na pełnych SAM-ach.
} 
pracowników ODR-ów. Wszystkie te techniki i materiały zostały omówione w odpowiednich rozdziałach książki (por. też aneks 2.4).

Mimo wykorzystania dużej liczby danych i zastosowania wielu metod badawczych, trzeba wspomnieć o pewnych ograniczeniach, nakazujących ostrożność w interpretowaniu wyników. Po pierwsze, rzeczywistość, jaką ukazuje model, jest odzwierciedleniem tylko tej rzeczywistości, która wynika z danych, a te - jak wiadomo - są tylko pewnym przybliżeniem realnego świata. Sam model zawiera też wiele uproszczeń, wyniki modelu lepiej zatem pokazują skalę i kierunek zmian, a nie dokładne wartości. Ponadto analizę można by wzbogacić o badania jakościowe poprowadzone na większą skalę, np. pytając o motywacje rolników przy wydatkowaniu funduszy ROW, czy o uwarunkowania regionalne determinujące efektywność wydatkowania funduszy ROW w poszczególnych województwach. Ale taka analiza oznaczałaby dużo obszerniejszą rozprawę od założonej. Mając jednak na uwadze przyszłe opracowania, rozdział 5.3 zawiera kilka bardziej szczegółowych sugestii co do możliwości rozszerzenia i kontynuacji badań zapoczątkowanych w tejże książce.

$\mathrm{Na}$ koniec warto syntetycznie podsumować wykorzystaną w pracy literaturę. Spośród około 350 pozycji, nieco ponad połowa jest w języku angielskim. Dotyczy ona głównie zagadnień związanych z modelami równowagi ogólnej, technikami regionalizacji tablic IO, metodami ewaluacji programów rozwojowych, zaawansowanymi technikami obliczeniowymi wykorzystywanymi w modelach oraz kodami modeli, a więc problematyki niedostatecznie często poruszanej $\mathrm{w}$ polskich opracowaniach. Z literatury polskiej wybrano opracowania dotyczące typologii obszarów wiejskich, makroekonomicznych uwarunkowań rozwoju wsi i rolnictwa, specyfiki rozwoju regionów polskich, przeglądu dotychczasowych modeli polskich zastosowanych do rolnictwa oraz bardziej uniwersalnych, a także opracowań na temat zdobywania i wykorzystywania przez rolników środków z UE. Ponadto z polskich źródeł pochodził większość materiałów statystycznych i dokumentów programowych. Niniejsza książka może zatem wzbogacić polski dorobek teoretyczny i aplikacyjny, w takich obszarach jak: teoria rozwoju (na przykładzie rolnictwa i obszarów wiejskich), ekonomia polityczna (na przykładzie Wspólnej Polityki Rolnej), teorie rozwoju regionalnego (pokazując analizy oparte na regionalnych tablicach przepływów międzygałęziowych i regionalnym modelu równowagi ogólnej), teorie wyboru publicznego (pokazując koszty i korzyści z przyjęcia instrumentów wsparcia dla obszarów wiejskich o różnej efektywności) czy teoria rozwoju zintegrowanego wsi (pokazując wieś w kontekście całej gospodarki i teorii równowagi ogólnej). 


\section{Etapy analizy}

Wychodząc od definicji obszarów wiejskich i ich rozwoju, w książce zaproponowano wiejsko-rolniczą typologię tych obszarów, ułatwiającą analizę porównawczą uzyskanych rezultatów empirycznych. Następnie przeanalizowano rozwój obszarów wiejskich w szerszym kontekście, tj. rozwoju rolnictwa, rozwoju zrównoważonego, zintegrowanego oraz wielofunkcyjności wsi. Przechodząc potem od teorii do empirii, przeanalizowano dane dotyczące rozwoju obszarów wiejskich i wynikające $z$ nich tzw. fakty stylizowane (rozdział 1).

$\mathrm{Na}$ podbudowie teoretyczno-empirycznej przedstawiono następnie uniwersalia oraz paradygmaty polityki rozwoju obszarów wiejskich, w tym instrumenty, za pomocą których jest ona realizowana. W szczególności przyjrzano się działaniom, które zostały zrealizowane w Polsce po wstąpieniu do UE. Kolejnym krokiem było porównanie struktury wybranych działań według trzech klasyfikacji: tzw. klasyfikacji unijnej (opartej na terminologii KE), klasyfikacji wg Rowińskiego (opartej na większej liczbie kryteriów) oraz klasyfikacji wg kryteriów ekonomicznych (opartej na faktycznych mechanizmach ekonomicznych poszczególnych działań). Na tej podstawie dokonano podziału funduszy ROW na proefektywnościowe i prorównościowe (rozdział 2).

Sprawom metodologicznym poświęcony jest cały rozdział 3, do którego dołączonych jest również wiele obszernych załączników o charakterze technicznym. Opisano w nim główne ilościowe narzędzie badawcze, którym posłużono się w książce, czyli regionalny model równowagi ogólnej dla Polski o nazwie RegPOL. Po wstępnym wyjaśnieniu, dlaczego tego typu model został wybrany do ewaluacji polityki ROW w Polsce, przeszliśmy do bardziej szczegółowego omówienia jego właściwości i charakterystyki. W kolejnych etapach omówiono bazę danych, jaka została stworzona i wykorzystana na potrzeby modelu. Pokazano stronę warsztatową dochodzenia do ostatecznej bazy danych. Następnie omówiono strukturę równań, które tworzą model i ich poszczególne moduły. W aneksie książki znajduje się cały kod modelu w języku Tablo. W dalszej części zaprezentowane są główne zmienne modelowane w RegPOL-u oraz scenariusze, które posłużyły symulacjom. Na koniec przeprowadzono dyskusję nad poprawnością zastosowania i użytecznością modelu. Ocena ta odnosi się zarówno do wykorzystywanych danych, jak i zastosowanych równań modelu.

Kolejna część książki prezentuje wyniki przeprowadzonych badań empirycznych w formie ocen o charakterze ewaluacyjnym. Wyniki te podzielone zostały na cztery części, z których pierwsze trzy wyraźnie odnoszą się do głównych kryteriów ewaluacyjnych. Najpierw omówiono skuteczność instrumentów wsparcia 
ROW, od czego zależała skala zróżnicowania korzyści z polityki ROW w poszczególnych województwach. W drugiej kolejności przedstawiono efektywność poszczególnych grup działań oraz całej polityki ROW. Następnie zaprezentowano efekty mnożnikowe, czyli wpływ polityki ROW na różne sektory gospodarki oprócz sektora rolnego. Pokazano tu między innymi analizę wpływu efektów mnożnikowych na pozarolnicze zatrudnienie ludności wiejskiej. W końcu korzyści z polityki ROW porównane zostały między województwami pogrupowanymi w zależności od ich stopnia wiejskości i rolniczości (rozdział 4).

W rozdziale 5, przedstawiono główne wnioski z badań w odniesieniu do poszczególnych hipotez i sposoby ich weryfikacji. W zwięzłej formie tabelarycznej zawarto przypomnienie poszczególnych hipotez i towarzyszących im pytań badawczych wraz z wynikami ich weryfikacji. Rozdział ten kończą rekomendacje dla polityki rozwoju obszarów wiejskich, zarówno na szczeblu krajowym, jak i unijnym.

Książkę zamykają obszerne aneksy do rozdziałów 2, 3 i 4, spis tabel, rysunków i map, bibliografia oraz podsumowanie w języku angielskim. 
r01.qxd 2011-10-31 09:37 Page 22 


\section{$\lceil$ ROZWÓJ OBSZARÓW WIEJSKICH W TEORII I PRAKTYCE}

W ekonomii rozwoju (economics of development) nie ma wyodrębnionej części poświęconej rozwojowi obszarów wiejskich. W teorii tej rozpatruje się sprawy wsi bądź przez pryzmat problemów rozwoju rolnictwa, bądź wybranych problemów rozwoju, na przykład ubóstwa, marginalizacji, wykluczenia, migracji. Obszary wiejskie nie stanowią wyodrębnionego subsystemu gospodarki. Nie ma też czegoś w rodzaju teorii rozwoju obszarów wiejskich czy teorii rozwoju wsi. Problem specyfiki i integralności rozwoju obszarów wiejskich zaczął być dostrzegany, zwłaszcza w Europie, dzięki upowszechnianiu koncepcji zrównoważonego rozwoju (sustainable development), a także w wyniku coraz powszechniejszego powiązania polityki rolnej z polityką rozwoju obszarów wiejskich [Wilkin 2008a].

Co najmniej kilkadziesiąt lat temu w ramach nauk ekonomicznych wyodrębniła się specjalizacja, jaką jest ekonomika rolnictwa, traktowana zazwyczaj jako ekonomika szczegółowa. Wykorzystuje ona kategorie, narzędzia i podstawy metodologiczne ogólnej ekonomii do badania specyficznych problemów rolnictwa jako działu gospodarki narodowej. Ekonomika rolnictwa ma też swój wkład do rozwoju ogólnej teorii ekonomii. W ostatnich dwóch dekadach nabierała znaczenia analiza powiązań rolnictwa $\mathrm{z}$ innymi składnikami gospodarki żywnościowej i agrobiznesu oraz powiązań rozwoju rolnictwa z rozwojem wsi. Temu ostatniemu kierunkowi badań sprzyja dostrzeganie i docenianie wielofunkcyjności rolnictwa, zwłaszcza w odniesieniu do środowiska wiejskiego. Badanie rozwoju wsi (obszarów wiejskich) wymaga integracji wielu nauk społecznych i wypracowania innych podejść metodologicznych niż te, które dominowały dotychczas w ekonomice rolnictwa [Wilkin 2008a].

Znacznie więcej uwagi rozwojowi wsi, jako wyodrębnionej dziedzinie badań, poświęcają socjologowie. Socjologia wsi (rural sociology) jest dobrze zakorzenioną częścią współczesnej socjologii, także w Polsce. Doczekała się w naszym kraju nawet kilku opracowań podręcznikowych, z których wymienić należy prace: B. Gałęskiego: 
Socjologia wsi. Pojęcia podstawowe [Gałęski 1966], J. Turowskiego: Socjologia wsi i rolnictwa [Turowski 1995], K. Gorlacha: Socjologia obszarów wiejskich. Problemy i perspektywy [Gorlach 2004] i I. Bukraby-Rylskiej: Socjologia wsi polskiej [Bukraba-Rylska 2008]. Wiele publikacji o rozwoju socjologii wsi, w tym studia przypadków w wybranych krajach, ma na swoim koncie A. Kaleta [Kaleta 1993, Kaleta i Vonderach 2006]. Ponadto bogaty dorobek w zakresie socjologii wsi mają pracownicy Instytutu Rozwoju Wsi i Rolnictwa PAN (patrz publikacje IRWiR PAN).

\subsection{Obszary wiejskie jako przedmiot analizy przestrzennej}

Biorąc pod uwagę kryteria administracyjne, obszary wiejskie stanowią w Polsce ponad 93\% terytorium kraju [GUS 2008a]. Podobnie jest w innych krajach europejskich, gdzie obszary wiejskie zajmują od 80 do $95 \%$ powierzchni. Można więc powiedzieć, że zarówno Polska, jak i cała Europa pozostają w znacznym stopniu wiejskie. Wiadomo jednak, że „wiejskość”, jako cecha przestrzeni, gospodarki i społeczności jest stopniowalna ${ }^{4}$, a kryteria administracyjne są tu bardzo ułomne w określaniu charakteru różnych typów „wiejskości”. Mamy więc w Polsce zarówno obszary wiejskie silnie zurbanizowane, niewiele różniące się od terenów miejskich, jak i obszary wiejskie o tradycyjnej, rozproszonej zabudowie i zdominowane przez działalność rolniczą [Wilkin 2008a].

Sposób definiowania obszarów wiejskich jest bardzo ważny, gdyż determinuje to, w jaki sposób badacze i politycy formułują cele związane z rozwojem gospodarczym obszarów wiejskich. Pewne ukryte założenia, które zwykle towarzyszą podejściu do rozwoju obszarów wiejskich, mogą nadawać niewłaściwy kierunek polityce im dedykowanej [Porter, Ketels, Miller i in. 2004]. Obszary wiejskie traktowane są jako - z natury rzeczy - różne od regionów miejskich, co prowadzi do tworzenia dla nich odrębnych instytucji i polityk. Bez wątpienia regiony wiejskie mają jedną ważną cechę wspólną, która odróżnia je od regionów miejskich - jest nią mniejsza gęstość zaludnienia. To ważna cecha, ponieważ niska gęstość zaludnienia zmniejsza możliwości powstawania pozytywnych efektów zewnętrznych w biznesie, a jednocześnie zwiększa koszty doprowadzenia infrastruktury technicznej, utrudnia specjalizację różnych instytucji (np. edukacyjnych), zmniejsza poziom konkurencji oraz stwarza bariery utrudniające osiągnięcie masy krytycznej pokrewnych i wspierających gałęzi przemysłu. Wśród czynników, które powodują ekonomiczne upośledzenie regionów wiejskich na skutek niskiej gęstości

\footnotetext{
${ }^{4} \mathrm{~W}$ socjologii zjawisko to wiąże się z koncepcją folk-urban continuum, zaproponowaną przez amerykańskiego antropologa kultury Roberta Redfielda. Pisze o tym Gorlach [ 2004, s. 30].
} 
zaludnienia, Stauber [2001] stawia na pierwszym miejscu wyższe koszty związane $\mathrm{z}$ dostarczaniem istotnych usług, ponoszone przez biznes i społeczności lokalne. Może to powodować błędne koło, w którym mniej korzystne warunki dla działalności gospodarczej prowadzą do utraty miejsc pracy, co z kolei skłania ludzi do opuszczania obszarów wiejskich, pogłębiając problem związany z niską gęstością zaludnienia. Inni autorzy wskazują także, iż regiony wiejskie cierpią na skutek niskiej jakości siły roboczej oraz niekorzystnego rozkładu kwalifikacji. Ludność wiejska jest też zwykle słabiej wykształcona oraz ma mniejsze możliwości wykorzystywania nowoczesnych usług i zaawansowanych technologii. Obszary wiejskie na ogół charakteryzują się gorszą siecią transportową i komunikacyjną, co jest szczególnie widoczne na przykładzie Polski. Jednak niska gęstość zaludnienia nie zawsze musi być niekorzystna. $\mathrm{Z}$ punktu widzenia pewnych rodzajów działalności, jak turystyka, rekreacja, wypoczynek oraz życie na emeryturze może być ona atutem. Obszary wiejskie w coraz większym stopniu przyciągają byłych mieszkańców miast, poszukujących lepszej jakości życia. Proces ten widoczny jest w Polsce, gdzie udział ludności wiejskiej w ogólnej liczbie ludności zwiększył się pomiędzy rokiem 2000 i 2007 z 38,1\% do 38,8\% [Frenkel 2008c]. Lokalne zasoby - takie jak góry, jeziora, morze, lasy - mogą przyciągać gości oraz mieszkańców, którzy stymulują rozwój lokalnej gospodarki, pobudzają popyt na usługi lokalne wyższej jakości oraz zwiększają dochód na mieszkańca.

Ogólnie biorąc, niska gęstość zaludnienia jest jedną z kwestii, którą na pewno powinna zajmować się polityka wiejska. Technologia informacyjna umożliwia częściowe rekompensowanie ujemnych stron niskiej gęstości zaludnienia poprzez kształcenie na odległość, transakcje internetowe itp. Jednak fakt, że przy formułowaniu polityki rozwoju obszarów wiejskich trzeba brać pod uwagę niskie zaludnienie, nie implikuje tego, że rozwój tych obszarów podlega fundamentalnie innym mechanizmom niż rozwój ekonomiczny jako taki. Regiony te podlegają tym samym mechanizmom konkurencyjnym co regiony miejskie [Porter, Ketels i inni 2004].

Zakłada się zwykle, że różnice między obszarami wiejskimi a miejskimi są znacznie większe niż różnice wewnętrzne, występujące w ramach tych dwóch typów obszarów. Jest wiele badań, które przeczą jednorodności obszarów wiejskich. Na przykład prace A. Rosnera i M. Stanny [Rosner 1999, 2002, 2007b, Rosner i Stanny 2007] wyraźnie pokazują, że obszary wiejskie są bardzo zróżnicowane regionalnie i właściwie bardziej spójna ich typologia powstaje, opierając się na czynnikach strukturalnych, uwidaczniających problemy, jakie w nich występują, niż na ich układzie przestrzennym i administracyjnym. Różnice te są jednak powszechnie traktowane jako mniej ważne od tego, co różni obszary wiejskie od miejskich. Tymczasem w rzeczywistości można znaleźć obszary miejskie, które mają te 
same czynniki problemowe, co wiejskie (np. wysokie bezrobocie, uzależnienie od jednego sektora zatrudnienia, położenie peryferyjne itd.). Zatem założenie, że problemy obszarów wiejskich są wewnętrznie bardziej podobne niż te w relacji miasto -wieś dość często prowadzi do uproszczeń i uogólnień [por. też Jałowiecki 1987].

Regiony wiejskie dość często analizowane były w przeszłości z ekonomicznego punktu widzenia jako obszary odrębne i niezależne od miejskich. Jednak w coraz większej liczbie badań (z polskich badań warto tu przywołać takie prace jak: [Heffner, Rosner, Czarnecki i in. 2004, Rydz 2006, Bański 2007]), zwłaszcza tych z zakresu nowej geografii ekonomicznej i geografii człowieka (antropogeografii), regiony wiejskie traktowane są jako osadzone w swoim otoczeniu i wchodzące w ważne i o różnej sile interakcji relacje z sąsiadującymi obszarami miejskimi.

Biorąc pod uwagę wszystkie powyższe kwestie różni autorzy [Porter, Ketels $\mathrm{i}$ in. 2004] sugerują badanie rozwoju gospodarczego w regionach wiejskich z zastosowaniem tej samej optyki analitycznej, co w przypadku badania rozwoju gospodarczego ogółem, ponieważ każdy region stanowi jednostkę gospodarczą o własnej odrębnej strukturze gospodarczej, środowisku biznesu i stosunkach z regionami sąsiadującymi. Analizę obszarów wiejskich w tym duchu sugerują również prace E. Saraceno [1994]. Jej zdaniem kontekst gospodarki lokalnej, lepiej niż relacje miasto-wieś, wyjaśnia rozwój obszarów wiejskich, co pokazała na przykładzie Włoch. Takie podejścia, nakierowane na wszechstronne zrozumienie obszarów wiejskich i ich otoczenie, powinny pomóc w ukształtowaniu bardziej dopasowanych polityk ROW niż te oparte na granicach administracyjnych.

Po tych ogólnych spostrzeżeniach przyjrzyjmy się bliżej definicjom oraz typologii obszarów wiejskich.

\subsubsection{DEFINICJE WIEJSKOŚCI I OBSZARÓW WIEJSKICH}

W poszczególnych dziedzinach nauki (np. geografii, ekonomii, socjologii etc.) i w różnych krajach stosowane są odmienne kryteria definiowania obszarów wiejskich, np. [Lewis 1979, Hoggart i Buller 1987, Halfacree 1993, Malinen, Keränen i Keränen 1994]. Zwykle definicje te przybierają formę continuum wieś -miasto [White 1986, s. 415-416]. Brytyjski socjolog P. Cloke [2006] definiuje wiejskość (rurality) jako cechę obszarów, które:

- są zdominowane przez ekstensywne wykorzystanie ziemi, zwłaszcza przez rolnictwo i leśnictwo,

- funkcjonują w niewielkich jednostkach osiedleńczych, charakteryzujących się silnym powiązaniem między zabudowaniami i ekstensywnym krajobrazem, a sami mieszkańcy tych budynków uważają je za wiejskie, 
- generują sposób życia, którego cechą jest ścisła identyfikacja oparta na szacunku dla środowiska i jakości życia, jako części funkcjonowania w rozległym krajobrazie (extensive landscape).

Rozległość czy ekstensywność krajobrazu, wielokrotnie wymieniana przez tego autora [Cloke 2006], to inny niż w mieście sposób korzystania z przestrzeni, który ma liczne implikacje dla sposobu gospodarowania i stylu życia na wsi. Zatem w naukach socjologicznych wiejskość to przede wszystkim szczególny, odmienny od miejskiego, związek człowieka z przyrodą, krajobrazem i zabudową. $\mathrm{Z}$ bardziej demograficzno-geograficznego punktu widzenia określenie wiejskości wiąże się z gęstością zaludnienia. Jest to podstawowe kryterium stosowane zarówno przez Unię Europejską (EUROSTAT), jak i przez OECD.

W istocie z każdą klasyfikacją i definicją wiążą się co najmniej trzy aspekty [Tarling, Rhodes, North i in. 1993]:

- Stopień szczegółowości - im bardziej szczegółowa jest klasyfikacja, tym lepiej oddaje istotę wiejskości, gdyż unika uogólnień i uśrednień. Idealna klasyfikacja mogłaby być oparta np. na kodzie pocztowym, jednak większość danych nie jest dostępna na tak niskim poziomie dezagregacji i jest możliwa dopiero na poziomie szczebla władz lokalnych. Wynikają z tego różne przybliżenia, które zawyżają lub zaniżają faktyczny rozmiar obszarów wiejskich, na przykład w Anglii szacuje się, że około 1/4 obszarów znajdujących się w granicach regionów wiejskich ma zdecydowanie charakter miejski, a około 1/4 obszarów o charakterze wiejskim znajduje się w granicach administracyjnych miejskich [Tarling, Rhodes i in. 1993].

- Precyzja delimitacji - tzn. kwestia tego, gdzie należy ustawić granicę pomiędzy tym, co wiejskie i tym, co miejskie. To ma znaczenie, gdyż w zależności od tej granicy mamy inne wielkości populacji wiejskiej i obszarów wiejskich. Na przykład w Finlandii zastosowanie klasyfikacji OECD daje nieco zawyżone - w stosunku do krajowej klasyfikacji - wielkości dla obszarów wiejskich i ludności wiejskiej. Według fińskiej definicji wiejskości, ludność wiejska stanowi 41,7\% ogółu ludności Finlandii i zamieszkuje obszar stanowiący 94\% ogólnego obszaru kraju, a według OECD w Finlandii jest 55,9\% ludności wiejskiej, która zamieszkuje 98,6\% obszaru tego kraju [OECD 2008].

- Metoda identyfikacji - tzn. kwestia wyboru kryteriów, które powinny zdecydować o tym, czy dany obszar powinien być klasyfikowany jako wiejski czy jako miejski. Najbardziej rozpowszechnionym kryterium (zgodnie z kryteriami OECD), jest gęstość zaludnienia, ale w wielu krajach stosuje się klasyfikację według jednostek administracji państwowej. 
Rozdział 1. Rozwój obszarów wiejskich w teorii i praktyce

Tabela 1.1. Podstawowe kryteria wydzielenia obszarów wiejskich w wybranych krajach Europy

\begin{tabular}{|c|c|c|c|c|}
\hline \multirow[b]{2}{*}{ Kraj } & \multicolumn{2}{|c|}{ Udział (w \%) } & \multirow[b]{2}{*}{$\begin{array}{l}\text { Wartości graniczne pozwalające zaklasyfikować obszar } \\
\text { jako wiejski }\end{array}$} & \multirow[b]{2}{*}{$\begin{array}{c}\text { Najmniejsza } \\
\text { jednostka } \\
\text { terytorialna } \\
\text { definiująca } \\
\text { obszary } \\
\text { wiejskie }\end{array}$} \\
\hline & $\begin{array}{c}\text { ludności } \\
\text { obszarów } \\
\text { wiejskich } \\
\text { w ludności } \\
\text { ogółem }\end{array}$ & \begin{tabular}{|c|} 
powierz- \\
chni obsza- \\
rów wiej- \\
skich w po-- \\
wierzchni \\
ogółem
\end{tabular} & & \\
\hline Austria & 12,8 & 99,7 & $\begin{array}{l}\text { Nie ma wyraźnej wartości granicznej, a obszary wiejskie } \\
\text { są zdefiniowane jako obszary inne niż ośrodki miejskie; } \\
\text { w zasadzie ośrodki miejskie zamieszkuje więcej niż } 1 \text { tys. } \\
\text { ludności i są one wyposażone w rozpoznawalne atrybuty } \\
\text { miejskie, takie jak np. ulice }\end{array}$ & $\begin{array}{l}\text { okręg } \\
\text { spisowy }\end{array}$ \\
\hline Bułgaria & 43,7 & 81,4 & $\begin{array}{l}\text { Gęstość zaludnienia niższa niż } 150 \text { osób } / \mathrm{km}^{2} \\
\text { i największe miasto w gminie o populacji mniejszej } \\
\text { niż } 30 \text { tys. mieszkańców }\end{array}$ & gmina \\
\hline$\overline{\text { Czechy }}$ & 26,5 & 73,7 & mniej niż 2 tys. mieszkańców w gminie & gmina \\
\hline Dania & 14,7 & $\begin{array}{l}\text { brak } \\
\text { danych }\end{array}$ & $\begin{array}{l}\text { Obszary, które nie są miejskie (wszystkie wioski, } \\
\text { w których mieszka } 200 \text { lub więcej osób, są traktowane } \\
\text { jako miejskie) }\end{array}$ & adres \\
\hline Estonia & 32,6 & 98,4 & Do 2,5 tys. mieszkańców & gmina \\
\hline Francja & 24,0 & 82,0 & Osady zamieszkane przez mniej niż 2 tys. osób & gmina \\
\hline Litwa & 33,1 & 97,0 & $\begin{array}{l}\text { Małe miasta (populacja mniejsza niż } 3 \text { tys. osób) } \\
\text { i wioski(inne zamieszkane obszary nieposiadające } \\
\text { typowych atrybutów miasta) są przypisane } \\
\text { do obszarów wiejskich }\end{array}$ & $\begin{array}{l}\text { obszar } \\
\text { wyznaczony } \\
\text { kodem } \\
\text { pocztowym }\end{array}$ \\
\hline Łotwa & 47,5 & 98,2 & brak danych & $\begin{array}{l}\text { parafie } \\
\text { i obszary } \\
\text { wiejskie }\end{array}$ \\
\hline Rosja & 27,0 & $\begin{array}{c}\text { brak } \\
\text { danych }\end{array}$ & brak danych & $\begin{array}{l}\text { gospodarstwo, } \\
\text { wieś, } \\
\text { miasteczko } \\
\text { wiejskie }\end{array}$ \\
\hline Niemcy & 13,0 & 30,4 & $\begin{array}{l}\text { Obszary o gęstości zaludnienia do } 100 \text { osób/ } / \mathrm{km}^{2} \\
\text { z ośrodkiem miejskim zamieszkanym przez } 100 \text { tys. lub } \\
\text { więcej mieszkańców oraz obszary o gęstości zaludnienia } \\
\text { poniżej } 150 \text { osób } / \mathrm{km}^{2} \text { nieposiadające ośrodka } \\
\text { miejskiego zamieszkanego przez } 100 \text { tys. lub więcej osób }\end{array}$ & (NTS 3) \\
\hline Rumunia & 45,5 & 89,0 & $\begin{array}{l}\text { Brak wartości granicznej - termin „wiejski” definiowany } \\
\text { jest prawnie bez uwzględniania wielkości } \\
\text { demograficznych ani gęstości zaludnienia }\end{array}$ & wieś/gmina \\
\hline Szwecja & $35-40$ & ok. 95 & $\begin{array}{l}\text { Wszystkie osady liczące mniej niż } 1 \text { tys. mieszkańców są } \\
\text { osadami wiejskimi }\end{array}$ & $\begin{array}{l}\text { współrzędne } \\
\text { demografi- } \\
\text { czne/adres }\end{array}$ \\
\hline Szwajcaria & 32,0 & 77,0 & $\begin{array}{l}\text { Za wiejskie uważane są aglomeracje liczące mniej } \\
\text { niż } 20 \text { tys. mieszkańców }\end{array}$ & $\begin{array}{l}\text { społeczność } \\
\text { (gmina) }\end{array}$ \\
\hline $\begin{array}{l}\text { Wielka } \\
\text { Brytania }\end{array}$ & $\begin{array}{c}\text { brak } \\
\text { danych }\end{array}$ & $\begin{array}{c}\text { brak } \\
\text { danych }\end{array}$ & $\begin{array}{l}\text { Szkocja - wszystkie obszary poza osadami liczącymi } \\
10 \text { tys. lub więcej mieszkańców; Walia - wszystkie } \\
\text { obszary z wyjątkiem średnich i dużych miast }\end{array}$ & $\begin{array}{c}\text { Szkocja - } \\
\text { jednostka ko- } \\
\text { du poczto- } \\
\text { wego; Walia } \\
\text { - hrabstwo } \\
\text { (NTS 3) }\end{array}$ \\
\hline
\end{tabular}

Źródło: [GUS 2006a]. 
W praktyce kryteria definiujące obszary wiejskie oraz związane z nimi kategorie różnią się znacznie w zależności od kraju i oparte są albo na kryteriach demograficznych/ekonomicznych albo administracyjnych [OECD 1988, CEPFAR 1990]. Na przykład we Francji za wiejskie uznaje się osady zamieszkane przez mniej niż 2000 osób, w Danii obszary wiejskie definiuje się jako te zamieszkane przez mniej niż 200 osób, w Rumunii zaś termin ten określany jest za pomocą kryteriów prawnych (praw miejskich), bez uwzględnienia wielkości demograficznych (por. tab. 1.1).

Polska definicja obszarów wiejskich oparta jest na kryteriach administracyjnych, zgodnie z Dz.U. z 1998 r. nr 157, poz. 1031. Wyróżnia się trzy rodzaje gmin: wiejskie (takie, które składają się tylko ze wsi); miejsko-wiejskie (takie, które mają przynajmniej jedno miasto w obszarze swojego terytorium) oraz miejskie (których terytorium zajmuje miasto). Obszary wiejskie stanowią zatem według tej definicji wszystkie gminy wiejskie (1591 - 64,2\% ogółu gmin w Polsce) oraz obszary wiejskie gmin miejsko-wiejskich (których jest 580, czyli 23,4\% ogółu kraju), a więc w sumie 2171 jednostek terytorialnych. Innymi słowy, w Polsce wsią jest wszystko, co nie jest miastem, a to, co jest miastem, ustalone zostało przez Radę Ministrów. Według definicji polskiej (dane publikowane przez GUS) wielkości dotyczące obszarów wiejskich dają nieco inne, zwykle wyższe, wskaźniki wiejskości niż te opierające się na gęstości zaludnienia - jak podaje OECD (gdzie do obszarów wiejskich zalicza się tereny o gęstości zaludnienia do 150 os. na $\mathrm{km}^{2}$ ) czy EUROSTAT (gdzie zalicza się tereny o gęstości zaludnienia do 100 os. na $\mathrm{km}^{2}$ ).

Obszary wiejskie, według definicji GUS, OECD i EUROSTAT, zajmowały w Polsce w 2005 r. odpowiednio 93,2\%, 91,0\% i 85,7\% powierzchni Polski, a zamieszkiwało na nich odpowiednio 38,6\% (czyli 14,7 mln osób), 34,4\% i 29,3\% ludności Polski - patrz tabela 1.2.

Analizując regionalne dysproporcje dotyczące wielkości obszarów wiejskich, to według GUS zajmowały one od 69,3\% w województwie śląskim do 97,5\% w województwie warmińsko-mazurskim, a zamieszkiwało na nich od 21,4\% ludności w województwie śląskim do 59,6\% ludności w województwie podkarpackim. W przypadku kryterium OECD najbardziej wiejskimi obszarami pod względem powierzchni były województwa: warmińsko-mazurskie (97,5\%) i podlaskie (96,8\%), a według liczby ludności województwa: lubelskie (53,7\%) i świętokrzyskie (53,5\%). Z kolei województwami o najmniejszym powierzchniowym udziale obszarów wiejskich były śląskie $(54,6 \%)$ i małopolskie $(67,2 \%)$, a o najmniejszym udziale ludności śląskie $(11,4 \%)$ i dolnośląskie (29,7\%). Natomiast według klasyfikacji EUROSTATU obszary wiejskie zajmowały największą powierzchnię w województwach warmińsko-mazurskim (97,5\%) i podlaskim (96,4\%), a najmniejszą w małopolskim (33,0\%) i śląskim (41,9\%). W przypadku analizy regionalnej udziału ludności zamieszkującej obszary uznane za wiejskie 
Rozdział 1. Rozwój obszarów wiejskich w teorii i praktyce

Tabela 1.2. Udział ludności wiejskiej w ludności ogółem według wybranych kryteriów i województw w latach 2000, 2005 i 2006 [w \%]

\begin{tabular}{|c|c|c|c|c|c|c|c|}
\hline \multirow{3}{*}{ Województwa } & \multicolumn{7}{|c|}{ Kryterium według* } \\
\hline & \multicolumn{3}{|c|}{ GUS } & \multicolumn{2}{|c|}{ OECD } & \multicolumn{2}{|c|}{ EUROSTAT } \\
\hline & 2000 & 2005 & 2006 & 2000 & 2005 & 2000 & 2005 \\
\hline$\overline{\text { POLSKA }}$ & 38,1 & 38,6 & 38,7 & 34,5 & 34,4 & 29,7 & 29,3 \\
\hline Dolnośląskie & 28,5 & 29,0 & 29,1 & 29,2 & 29,7 & 27,8 & 28,2 \\
\hline Kujawsko-Pomorskie & 37,6 & 38,5 & 38,7 & 37,6 & 37,7 & 36,5 & 36,6 \\
\hline Lubelskie & 53,4 & 53,3 & 53,4 & 53,7 & 53,7 & 50,0 & 48,3 \\
\hline Lubuskie & 35,3 & 35,9 & 36,0 & 35,7 & 36,2 & 35,3 & 35,9 \\
\hline Łódzkie & 34,9 & 35,4 & 35,4 & 34,3 & 34,7 & 33,4 & 33,4 \\
\hline Małopolskie & 49,4 & 50,4 & 50,5 & 32,1 & 30,0 & 12,0 & 10,8 \\
\hline Mazowieckie & 35,3 & 35,3 & 35,3 & 32,8 & 31,9 & 29,4 & 28,2 \\
\hline Opolskie & 47,4 & 47,4 & 47,4 & 45,8 & 45,7 & 43,5 & 44,1 \\
\hline Podkarpackie & 59,3 & 59,6 & 59,5 & 47,9 & 47,9 & 30,2 & 29,7 \\
\hline Podlaskie & 41,4 & 40,8 & 40,5 & 43,0 & 42,4 & 42,2 & 41,7 \\
\hline Pomorskie & 31,6 & 32,7 & 33,0 & 32,1 & 32,5 & 28,6 & 29,3 \\
\hline Śląskie & 20,8 & 21,4 & 21,5 & 11,4 & 11,4 & 7,3 & 7,4 \\
\hline Świętokrzyskie & 54,0 & 54,6 & 54,7 & 54,1 & 53,5 & 42,8 & 43,0 \\
\hline Warmińsko-Mazurskie & 39,7 & 40,0 & 40,0 & 39,7 & 40,0 & 39,7 & 40,0 \\
\hline Wielkopolskie & 42,1 & 42,9 & 43,1 & 41,0 & 41,6 & 40,7 & 38,9 \\
\hline Zachodniopomorskie & 30,3 & 30,8 & 31,0 & 30,4 & 30,9 & 30,2 & 30,2 \\
\hline Współczynnik & & & & & & & \\
\hline zmienności & 25,3 & 24,8 & 24,6 & 27,1 & 27,1 & 32,7 & 32,9 \\
\hline
\end{tabular}

* za obszary wiejskie uznaje się wg GUS gminy wiejskie i część wiejską gmin miejsko-wiejskich, wg OECD - tereny o gęstości zaludnienia do 150 osób $/ \mathrm{km}^{2}$, wg EUROSTAT- tereny o gęstości zaludnienia do 100 osób $/ \mathrm{km}^{2}$

Źródło: [Frenkel 2008b] na podstawie Rocznika Demograficznego 2007. GUS, Tablica: Ludność według płci, gmin, powiatów i województw.

według definicji EUROSTAT, województwem o najwyższym odsetku ludności wiejskiej było województwo lubelskie (48,3\%), a najniższym województwo śląskie $(7,4 \%)$. $\mathrm{Z}$ analizy wynika, że zróżnicowanie przestrzenne obu cech było zbliżone według przyjętego w kraju kryterium GUS, jak również kryterium OECD [GUS 2006a].

Oprócz definiowania (delimitacji) obszarów wiejskich, ważnym zagadnieniem jest też ich typologizacja, czyli sklasyfikowanie według kryteriów, które pozwalają uzyskać homogeniczne grupy (typy) obszarów wiejskich. Temu zagadnieniu poświęcamy kolejną sekcję tego rozdziału.

\subsubsection{TYPOLOGIE OBSZARÓW WIEJSKICH}

Zróżnicowanie obszarów wiejskich pod względem rozwoju społeczno-gospodarczego jest zarówno w Polsce, jak i na świecie bardzo duże i można traktować je jako skumulowany efekt m.in. takich czynników, jak: struktura demograficzna, poziom infrastruktury ekonomicznej, poziom edukacji czy struktura sieci osadniczej. 
W Polsce są one uwarunkowane głównie historycznie, ale miały też na to wpływ uwarunkowania naturalne, np. jakość gleb, okres wegetacji i występowanie surowców naturalnych [Rosner 1999]. Rosnąca świadomość dotycząca heterogeniczności obszarów wiejskich zaowocowała licznymi próbami stworzenia typologii obszarów wiejskich i podzielenia pojęcia wiejskości na kategorie bardziej ją odróżniające. Jest to przydatne chociażby dla planowania skuteczniejszych polityk do nich adresowanych, tj. polityki rozwoju obszarów wiejskich, polityki spójności czy polityki regionalnej. Z góry trzeba jednak zaznaczyć, że nie istnieje jedna „właściwa” typologia obszarów wiejskich. Każda propozycja związana jest z celem, któremu ma służyć [Terluin 2001].

W literaturze polskiej można znaleźć wiele analiz typologicznych zróżnicowania przestrzennego obszarów wiejskich, służących różnym celom. Były one podejmowane wielokrotnie przez Instytut Ekonomiki Rolnictwa i Gospodarki Żywnościowej (IERiGŻ), Instytut Geografii i Przestrzennego Zagospodarowania Kraju PAN, Instytut Uprawy Nawożenia i Gleboznawstwa (IUNG), Instytut Rozwoju Wsi i Rolnictwa Polskiej Akademii Nauk (IRWiR PAN) i wiele innych ośrodków. Poniżej przedstawiamy kilka przykładów.

Instytut Ekonomiki Rolnictwa i Gospodarki Żywnościowej (IERiGŻ) opracował typologię regionów według standardowej nadwyżki bezpośredniej (SGM), co miało pomóc w wyłonieniu gospodarstw rolnych wchodzących do polskiego FADN (Sieci Danych Rachunkowych z Gospodarstw Rolnych) [Polski_FADN 2007] ${ }^{5}$. W badaniu tym, dążąc do wyłonienia jednorodnych regionów rolniczych pod względem SGM, posłużono się 7 kryteriami statystycznymi: • powierzchnia użytków rolnych w średnim indywidualnym gospodarstwie rolnym w 1996 r. - procentowy udział trwałych użytków zielonych w użytkach rolnych ogółem w 2001 r. • liczba krów mlecznych w średnim indywidualnym gospodarstwie rolnym (średnio z lat 1999-2001) • liczba trzody ogółem w średnim indywidualnym gospodarstwie rolnym (średnio z lat 1999-2001) • plon zbóż w całym rolnictwie (średnio z lat 1999-2001) - roczna produkcja mleka od jednej krowy (średnio z lat 1999-2001) i • zużycie NPK w kg na 1 ha użytków rolnych ogółem w 2001 r. $\mathrm{Na}$ podstawie przeprowadzonej analizy odchyleń wymienionych parametrów (przy założonej maksymalnej liczbie regionów) wyłoniono 4 spójne obszary, pokrywające się z granicami zagregowanych województw. Region Pomorze i Mazury skupia gospodarstwa bardzo duże, charakteryzuje się średnim poziom intensywności produkcji i najwyższą obsadą krów mlecznych, zajmuje też drugie

\footnotetext{
${ }^{5}$ Opracowanie w ramach projektu PHARE 2000 Nr PL0006.09.06 Przygotowanie i wdrożenie wybranych mechanizmów Wspólnej Polityki Rolnej (CAP) - Pomoc techniczna (FADN).
} 
miejsce pod względem obsady trzody chlewnej w gospodarstwie. Region Wielkopolska i Śląsk skupia gospodarstwa duże, w których produkcja prowadzona jest w sposób bardzo intensywny (ma najwyższe w kraju zużycie nawozów mineralnych i najwyższe plony zbóż). Region ten charakteryzuje się także najwyższą wydajnością mleczną krów i zajmuje pierwsze miejsce pod względem obsady trzody chlewnej w gospodarstwie. Region Mazowsze i Podlasie skupia gospodarstwa średnie, wykazujące średni poziom intensywności produkcji; zajmuje drugie miejsce pod względem obsady krów mlecznych w gospodarstwie. Małopolska i Pogórze zawiera gospodarstwa małe, o niskim poziomie intensywności produkcji (parametry wszystkich badanych cech są najniższe), a region charakteryzuje duże rozdrobnienie agrarne. Regiony SGM przedstawia mapa 1.1.

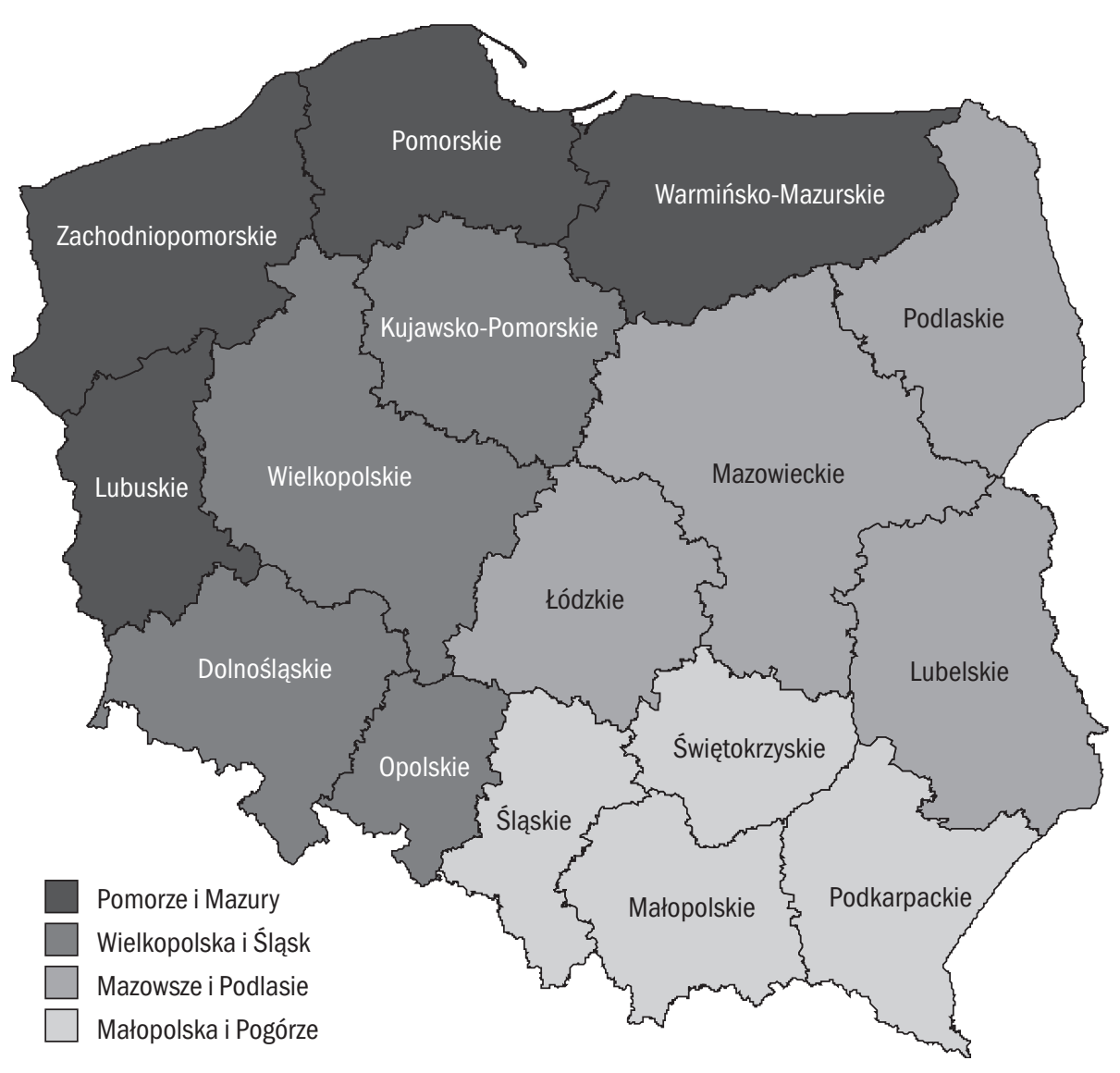

Mapa 1.1. Podział Polski na regiony SGM

Źródło: [Polski FADN 2007]. 
Innym przykładem są prace J. Hellera nad regionalizacją obszarów wiejskich. Zaproponował on podział kraju na 4 megaregiony, skupiajace po kilka województw (NUTS 2) według kryteriów społeczno-ekonomicznych, z których największą rolę odgrywały wskaźniki intensywności organizacji rolnictwa, gęstości zaludnienia oraz stopy bezrobocia [Heller 2000b]. Megaregion 1 obejmował województwa: podkarpackie, świętokrzyskie, małopolskie i śląskie; Megaregion 2 obejmował województwa: warmińsko-mazurskie, pomorskie, zachodniopomorskie, lubuskie i dolnośląskie; Megaregion 3 - mazowieckie, kujawsko-pomorskie, wielkopolskie, łódzkie i opolskie, a Megaregion 3a - podlaskie i lubelskie.

Na podobnym poziomie agregacji megaregionalnej badania typologiczne prowadził też W. Michna [1999], który dla celów realizacji polityki regionalnej w sferze rolnictwa i obszarów wiejskich zaproponował podział Polski na 3 megaregiony, skupiające następujące województwa: Megaregion 1: podkarpackie, świętokrzyskie, małopolskie i śląskie; Megaregion 2: warmińsko-mazurskie, pomorskie, zachodniopomorskie, lubuskie, dolnośląskie, opolskie; megaregion 3: mazowieckie, kujawsko-pomorskie, wielkopolskie, łódzkie, podlaskie i lubelskie.

Typologie przeprowadzane w Instytucie Rozwoju Wsi i Rolnictwa [Rosner 1999, 2002, 2007b] mniej skupiają się na właściwościach rolnictwa jako głównego kryterium wyróżniania regionów, a bardziej próbują pokazać specyfikę społeczno-ekonomiczną obszarów wiejskich i definiowane są na najniższym poziomie jednostek terytorialnych, czyli na poziomie gmin (NUTS 5, LAU 2). Na przykład Rosner i inni [2002] w celu wyłonienia gmin problemowych zbadali wszystkie obszary wiejskie (2171 gmin), waloryzując kilkadziesiąt wskaźników. Wskaźniki te należały do 5 grup tematycznych: gospodarczej, demograficznej, infrastrukturalnej, osadnictwa i edukacji. Wyłoniono 7 typów gmin, z których pierwsze dwa skupiały najwięcej gmin problemowych. W przypadku typu 1 najbardziej niekorzystnie przedstawiała się sytuacja pod względem struktury demograficznej, wyposażenia infrastrukturalnego, charakterystyki osadniczej i edukacji gmin. Z kolei typ 2 utworzyły gminy o niekorzystnej charakterystyce pod każdym z branych pod uwagę czynników, z wyjątkiem charakterystyki osadniczej. W sumie według zaproponowanej klasyfikacji ok. 14\% ogółu gmin wiejskich stanowiły obszary kumulacji barier rozwojowych. Chociaż gminy uznane za problemowe nie tworzą zwartego skupiska, ogromna ich większość znajduje się we wschodniej i środkowej części Polski, na terenie tzw. ściany wschodniej, na obszarze dawnego Centralnego Okręgu Przemysłowego oraz na terenach położonych peryferyjnie w stosunku do dużych miast województw Polski wschodniej. Gminy problemowe znajdują się dużo rzadziej na terenach Wielkopolski, Mało- 
polski, Dolnego i Górnego Śląska oraz nie występują w bezpośrednim sąsiedztwie wielkich miast [Rosner 2002].

Inne opracowanie typologiczne opisane w pracy A. Rosnera [2007] miało z kolei na celu stworzenie typologii służącej do oceny poziomu rozwoju społeczno-gospodarczego obszarów wiejskich, jego determinantów oraz związków z dynamiką rozwoju. Do oceny poziomu rozwoju społeczno-gospodarczego wykorzystano 30 wskaźników. Osobno zdefiniowano te dla komponentu gospodarczego i dla społecznego.

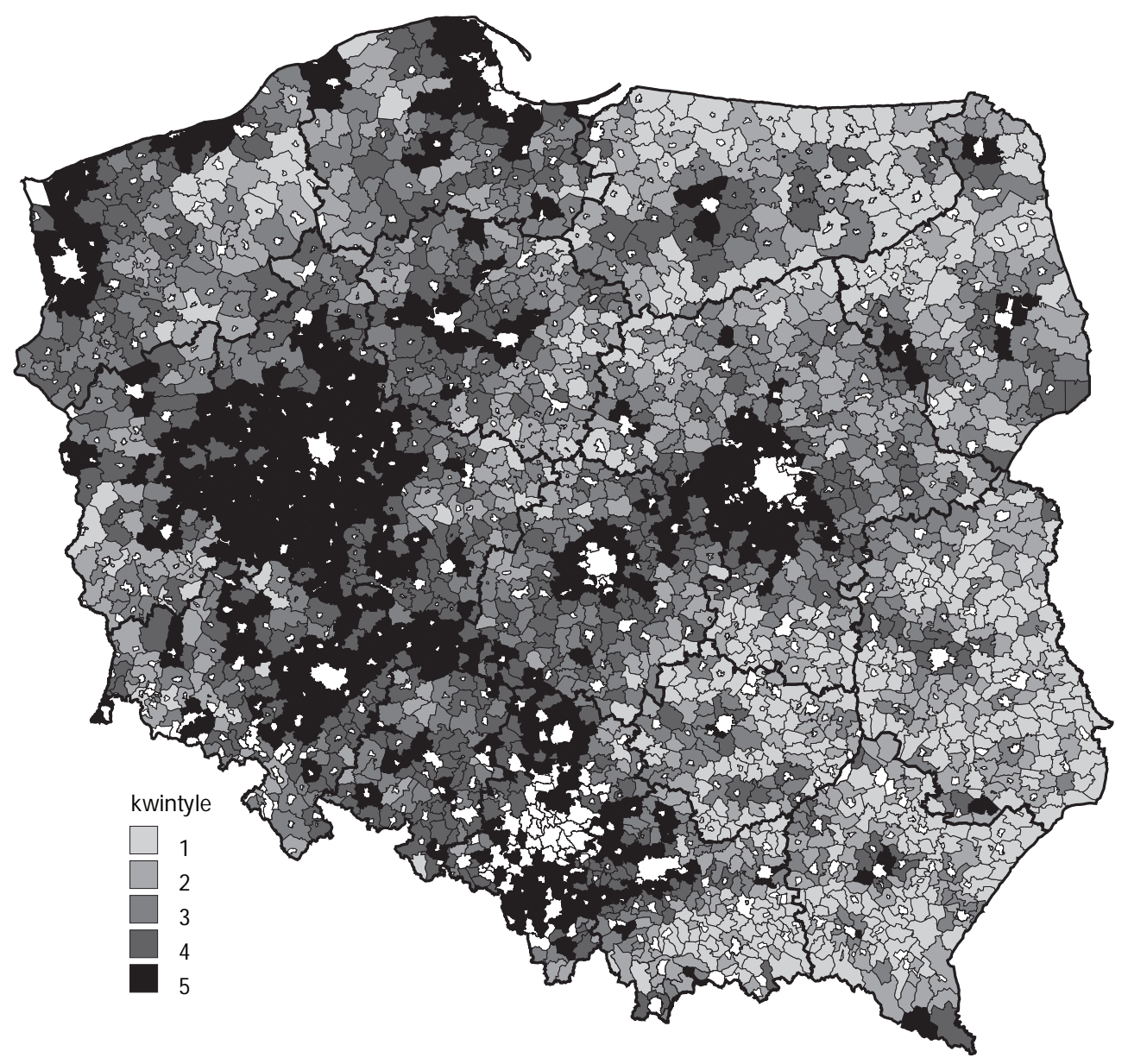

Mapa 1.2. Syntetyczna ocena poziomu rozwoju gospodarczego w Polsce w ujęciu gminnym*

* według metody sum standaryzowanych

Źródło: [Rosner i Stanny 2007]. 


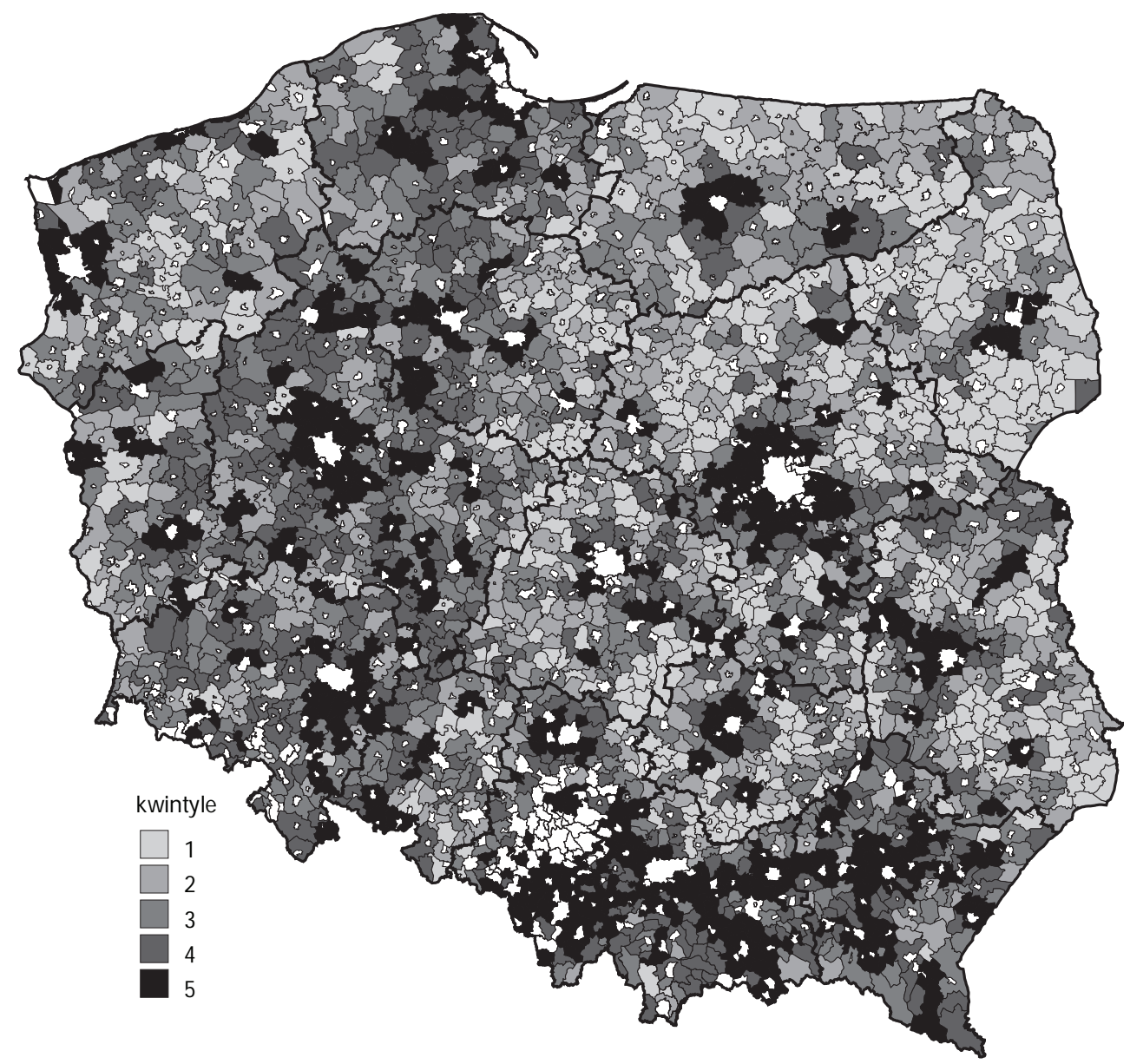

Mapa 1.3. Syntetyczna ocena poziomu rozwoju społecznego w Polsce w ujęciu gminnym*

* według metody sum standaryzowanych

Źródło: [Rosner i Stanny 2007].

Komponent gospodarczy składał się z pięciu subkomponentów: • poziomu dezagraryzacji struktury gospodarczej $\bullet$ poziomu rozwoju sektora rolniczego $\bullet$ poziomu rozwoju sektora pozarolniczego $\bullet$ poziomu zrównoważenia rynku pracy oraz $\bullet$ poziomu zamożności i wyposażenia infrastrukturalnego.

W skład komponentu społecznego wchodziły trzy subkomponenty opisujące: - strukturę demograficzną • lokalny system edukacyjny oraz • aktywność społeczną. Badania wykazały, że największe skupisko gmin mających najwyższy poziom rozwoju gospodarczego na wsi znajduje się w Wielkopolsce, gdzie ośrod- 
kiem centralnym jest Poznań. Drugi biegun wzrostu koncentruje się na Mazowszu wokół Warszawy, ze słabszymi miernikami od wschodniej strony aglomeracji. Do biegunów wzrostu należą również region Niziny Śląskiej, Kujawy i Trójmiasto. Wysoki poziom rozwoju gospodarczego uzyskują też gminy z dobrze rozwiniętą sferą usług turystycznych (np. gminy Pobrzeża Zachodniopomorskiego, Beskidów Zachodnich i Bieszczad) (mapa 1.2). Z kolei najwyższy poziom rozwoju społecznego wystąpił w dwóch typach obszarów, po pierwsze wokół miast (czyli wiejskich gminach podmiejskich) oraz w obrębie skupień pewnych grup etnicznych, np. dotyczy to Wielkopolan i Kaszubów (łańcuch gmin od woj. pomorskiego przez zachodnią część woj. kujawsko-pomorskiego, wielkopolskiego aż po Dolny Śląsk, następnie w Małopolsce (Górale) i w podkarpackim (Podgórzanie i Rzeszowiacy), czyli dawna Galicja (mapa 1.3). Ważnym wnioskiem z analizy było stwierdzenie faktu, że pomimo prowadzonej polityki zmniejszania różnic w poziomie rozwoju społeczno-gospodarczego obszarów wiejskich, nie tylko różnice te nie zmniejszają się, ale nawet wykazują tendencję do powiększania się [Rosner i Stanny 2007].

Powyższy opis typologii obszarów rolniczych i wiejskich dalece nie wyczerpuje literatury tematu. Warto sięgnąć jeszcze do kilkunastu innych autorów ([Józwiak, Niewęgłowska, Świetlik i in. 1998], [Szemberg 1999], [Mierosławska 1999], [Wasilewski 1999], [Heller 2000a, 2000b, 2000c], [Poczta, Wysocki 2002], [Bański 2000], [Bański, Czapiewski i Świątek 2002-2004], [Bański 2008]). Z kolei jednym z wcześniejszych podejść metodologicznych do typologii wiejskich jest opracowanie Hellwiga [1968].

Ciekawe jest porównanie typologii polskich z tymi stosowanymi w innych krajach. Na przykład w Stanach Zjednoczonych Bureau of Economic Analyses proponuje cztery regionalne klasyfikacje obszarów wiejskich. Pierwsza, zwana Urban Influence Codes, dzieli hrabstwa (powiaty) na 9 kategorii, opierając się na ich wielkości, gęstości zaludnienia, obecności miast oraz bliskości ośrodków miejskich. Drugi system, zwany Rural-Urban Continuum Codes, identyfikuje 10 kategorii na podstawie liczby ludności. Trzeci, zwany County Typology Codes - Acivities, opiera się na sześciu kategoriach podstawowej działalności gospodarczej (rolnictwo, górnictwo, usługi, przemysł wytwórczy, sektor publiczny oraz pozostałe). Czwarty system, zwany County Typology Codes - Policy, opiera się na pięciu kategoriach regionów wyznaczonych według stopnia znaczenia różnych polityk rządowych w regionie [Porter, Ketels i in. 2004].

W Europie pionierami w tworzeniu typologii wiejskich dla celów polityki ROW byli Finowie [Malinen, Keränen i in. 1994]. OECD [2008] uznało Finlandię za jeden z pierwszych krajów na świecie, który dzięki stosowaniu typologii 
w opracowywaniu strategii wobec obszarów wiejskich stworzył prawdziwie ponadsektorową politykę wsparcia dla ich rozwoju. Finowie stosują pięć kategorii w podziale na: • peryferyjne regiony wiejskie • regiony wyspiarskie • regiony pośrednie - regiony ekonomicznie zintegrowane (w sąsiedztwie miast) i • miasta [Malinen, Keränen i in. 1994]. Dla każdego z typów obszarów stosują inną strategię rozwoju, inne priorytety i inny typ polityki. Przykład wykorzystania typologii w planowaniu rozwoju obszarów wiejskich przedstawia tabela 1.3.

Tabela 1.3. Podejście do polityki ROW w Finlandii w zależności od 3 głównych typów regionów

\begin{tabular}{|c|c|c|c|}
\hline \multirow[b]{2}{*}{ Typ regionu } & \multicolumn{2}{|c|}{ Polityka wiejska } & \multirow{2}{*}{$\begin{array}{c}\text { Polityka sektorowa } \\
\text { np. rolna }\end{array}$} \\
\hline & $\begin{array}{l}\text { podejście strategiczne } \\
\text { polegające na: }\end{array}$ & nastawienie na: & \\
\hline $\begin{array}{r}\text { Ekonomicznie } \\
\text { zintegrowany }\end{array}$ & $\begin{array}{l}\text { Interaktywności na linii } \\
\text { miasto-wieś }\end{array}$ & Otoczenie ekonomiczne & $\begin{array}{l}\text { Kierunek specjalizacji } \\
\text { w rolnictwie albo } \\
\text { wycofywanie się } \\
\text { z rolnictwa }\end{array}$ \\
\hline Pośredni & $\begin{array}{l}\text { Rozwój na podstawie } \\
\text { mocnych stron regionu }\end{array}$ & $\begin{array}{l}\text { Zatrudnienie na wsi, } \\
\text { w tym w rolnictwie }\end{array}$ & $\begin{array}{l}\text { Podtrzymywanie przewag } \\
\text { komparatywnych }\end{array}$ \\
\hline Peryferyjny & $\begin{array}{l}\text { Wykorzystanie } \\
\text { wszystkich szans }\end{array}$ & $\begin{array}{l}\text { Nowe formy żywotności, } \\
\text { dostęp do infrastruktury }\end{array}$ & $\begin{array}{l}\text { Pomnażanie } \\
\text { różnorodności aktywności } \\
\text { i zachowanie krajobrazu }\end{array}$ \\
\hline
\end{tabular}

Źródło: [Malinen, Keränen i in. 1994].

Jeśli chodzi o typologię porównywalną i uniwersalną dla wszystkich krajów w Europie, panuje duża zgodność, iż pomimo pewnych mankamentów i uproszczeń, typologia OECD oparta na gęstości zaludnienia jest nadal najbardziej użyteczna i najpowszechniej stosowana w badaniach międzynarodowych. Po pierwsze, dlatego, że umożliwia ona wiarygodne porównania między krajami, gdyż to samo kryterium jest stosowane w ten sam sposób do wszystkich regionów we wszystkich krajach. Po drugie, ponieważ metodologia ta jest prosta, zrozumiała i łatwa w zastosowaniu, to umożliwia weryfikację badań na niej opartych i prowadzenie własnych badań porównawczych. Po trzecie, istnieje na tyle długo, że zdążyła się sprawdzić i pozyskać zaufanie, jako przydatna w porównaniach funkcjonowania społeczno-gospodarczego pomiędzy różnymi typami regionów oraz w ramach tych samych regionów. Po czwarte, jest często dobrym punktem wyjścia do dalszej specyfikacji obszarów wiejskich. Metodologię tę różni autorzy próbują ulepszyć, eksperymentując z wartościami brzegowymi, dotyczącymi np. gęstości zaludnienia lub dodają nowe kryteria. Na przykład projekt SERA (Study on Employment in Rural Areas) zrealizowany na zamówienie Komisji Europejskiej 
proponuje rozszerzenie klasyfikacji OECD o wskaźnik peryferyjności, uzyskując tym sposobem nie trzy, ale pięć typów obszarów: • przeważająco miejskie • znacząco wiejskie - dostępne • znacząco wiejskie - peryferyjne • przeważająco wiejskie - dostępne • przeważająco wiejskie - peryferyjne [SERA 2006]. Ostatnim argumentem za zostaniem przy metodologii OECD jest zdrowy rozsądek, gdyż mnożenie typologii może prowadzić do zamieszania i wymagałoby udowodnienia,

Regiony w przeważającym stopniu wiejskie

Regiony w znacznym stopniu wiejskie

Regiony w przeważającym stopniu miejskie

Odsetek osób mieszkających na terenach wiejskich (wg klasyfikacji OECD)

Mapa 1.4. Typologia województwa w Polsce wg OECD

Źródło: Opracowanie własne na podstawie Spisu Powszechnego $2002^{6}$.

${ }^{6}$ Dane pochodzą z ostatniego Spisu Powszechnego 2002, gdyż nie istnieją tak dokładne dane na poziomie gmin (jak zatrudnienie w rolnictwie według miejsca zamieszkania) w żadnym innym bardziej aktualnym źródle. 
że nowe typologie są lepsze i neutralne politycznie. Jak dotąd, stworzenie bardziej szczegółowych, ale uniwersalnych dla wszystkich krajów UE typologii, nie powiodło się, tzn. metodologie powstają, ale nie wchodzą do powszechnego użytku, gdyż brak im tego autorytetu, który zapewnia OECD [Terluin 2001].

Przypomnijmy, że według oryginalnej typologii OECD regiony można podzielić na wiejskie i miejskie, stosując dwa kryteria. Pierwszym jest gęstość zaludnienia na danym terytorium, drugim - odsetek ludności wiejskiej w ogólnej populacji danego terytorium. Pierwszym krokiem w tej procedurze jest obranie jak najmniejszej jednostki terytorialnej (zwykle najmniejszej dostępnej jednostki administracyjnej, np. w Polsce jest to gmina) i policzenie, które z nich mają gęstość zaludnienia poniżej 150 osób na $\mathrm{km}^{2}$ (te nazywamy wiejskimi), a które powyżej 150 osób na $\mathrm{km}^{2}$ (te nazywamy miejskimi). Następnie, w drugim kroku, w ramach większych jednostek terytorialnych (np. województw) określamy, jaki procent ludności w ogólnej populacji regionu żyje w wyżej zdefiniowanych terytoriach wiejskich, a ile w miejskich. W zależności od wyniku i według poniższych kryteriów zaliczamy je jak następuje:

- regiony w przeważającym stopniu wiejskie (Predominantly Rural, PR) - jeśli więcej niż 50\% populacji regionu żyje na terytoriach wiejskich (określonych jak powyżej);

- regiony w znacznym stopniu wiejskie (Significantly/Intermediate Rural, SR) - jeśli między 15\% a 50\% ludności regionu żyje na terytoriach wiejskich;

- regiony w przeważającym stopniu miejskie (Predominantly Urban, PU) - jeśli mniej niż 15\% ludności danego regionu żyje na terytoriach wiejskich.

W wyniku takiego podziału Polska ma 6 regionów przeważająco wiejskich, 9 znacząco wiejskich oraz 1 przeważająco miejski, co prezentuje mapa 1.4.

Jednak w naszych analizach ważny jest też sektor rolny i jego znaczenie dla gospodarki wiejskiej. Dlatego rozszerzyliśmy typologię OECD o dodatkowy wymiar, a mianowicie uzależnienia ludności wiejskiej od rolnictwa. Jest ono mierzone poprzez odsetek ludności wiejskiej pracującej wyłącznie lub głównie w rolnictwie. Naśladując zatem logikę nazewnictwa oryginalnej typologii OECD, mamy $^{7}$ :

- regiony w przeważającym stopniu rolnicze (zwane dalej przeważająco rolnicze, PR) - jeśli więcej niż 50\% ludności wiejskiej tego regionu pracuje w rolnictwie; - regiony w znacznym stopniu rolnicze (znacząco rolnicze, ZR) - jeśli między $15 \%$ a $50 \%$ ludności wiejskiej tego regionu pracuje w rolnictwie,

\footnotetext{
${ }^{7}$ Analogicznie do oryginalnej typologii OECD nowe typy regionów nosiłyby w jęz. angielskim następujące nazwy: Typ Przeważająco Rolniczy - Predominantly Rural, PR; Typ Znacząco Rolniczy - Intermediate/Significantly Agricultural, IA; Typ Przeważająco Nierolniczy - Predominantly Non-agricultural, NA.
} 

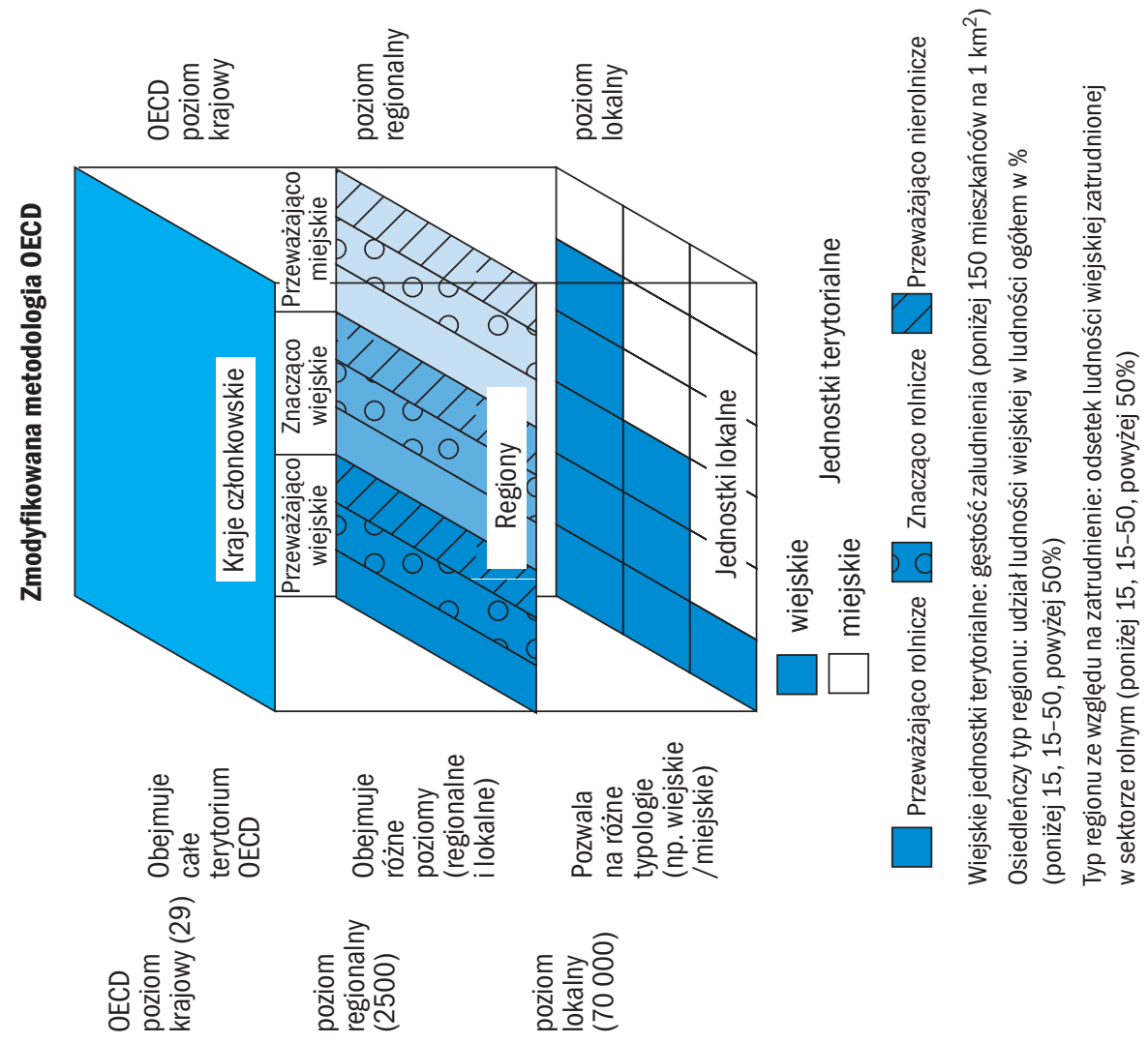

岀 宁

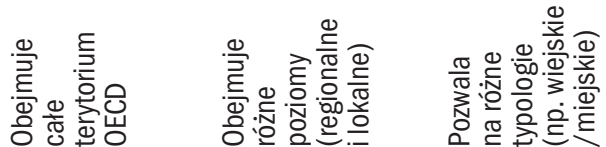

능흐옹

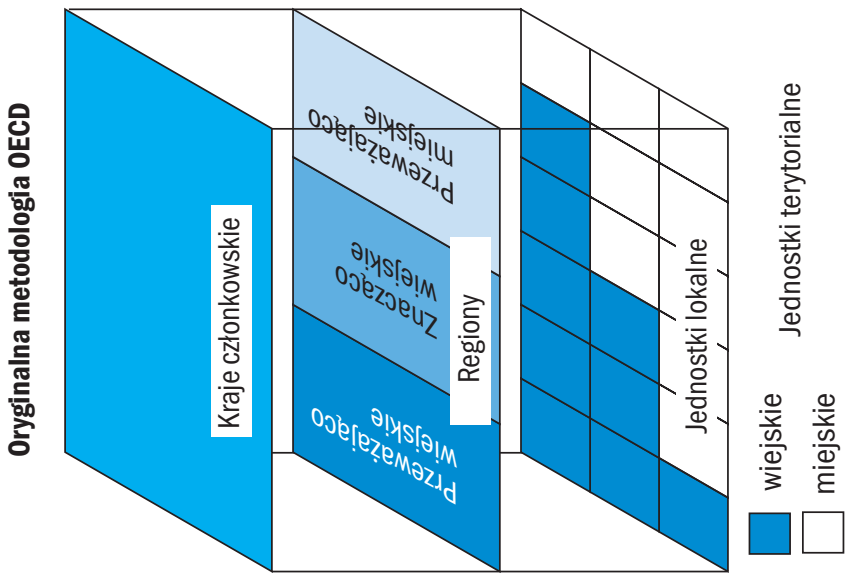

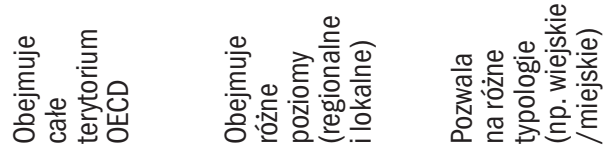

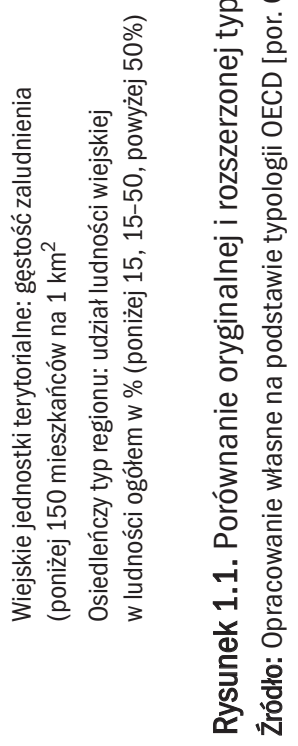


- regiony w przeważającym stopniu nierolnicze (przeważająco nierolnicze, PN) - jeśli mniej niż 15\% ludności wiejskiej tego regionu pracuje w rolnictwie.

Graficzne porównanie oryginalnej typologii OECD oraz zmodyfikowanej przedstawia rysunek 1.1.

Według nowej typologii uzyskaliśmy 9 rodzajów obszarów wiejskich, co przedstawia tabela 1.4 i rysunek 1.2.

Tabela 1.4. Dwuwymiarowa typologia obszarów wiejskich - rozszerzone podejście OECD

\begin{tabular}{|c|c|c|c|}
\hline$\leftarrow$ LUDNOŚĆ WIEJSKA $\rightarrow$ & pracująca $\mathbf{W}$ & ze rolnym $w \%$ & \\
\hline $\begin{array}{c}\text { TYPY REGIONÓW } \\
\text { (w nawiasach liczba } \\
\text { województw należących }\end{array}$ & $\begin{array}{c}\text { Przeważająco } \\
\text { rolnicze } \\
\text { powyżej } 50 \% \\
\end{array}$ & 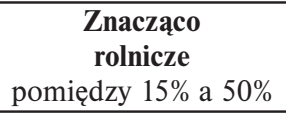 & $\begin{array}{c}\text { Przeważająco } \\
\text { nierolnicze } \\
\text { poniżej } 15 \% \\
\end{array}$ \\
\hline $\begin{array}{c}\text { Przeważająco wiejskie } \\
\text { powyżej } 50 \%\end{array}$ & $\begin{array}{c}\text { Typ } 1 \\
\text { PW-PR (\#2) }\end{array}$ & $\begin{array}{c}\text { Typ } 2 \\
\text { PW-ZR (\#4) }\end{array}$ & $\begin{array}{c}\text { Typ 3 } \\
\text { PW-PN (\#0) }\end{array}$ \\
\hline $\begin{array}{c}\text { Znacząco wiejskie } \\
\text { pomiędzy } 15 \% \text { a } 50 \%\end{array}$ & $\begin{array}{c}\text { Typ } 3 \\
\text { ZW-PR (\#2) } \\
\end{array}$ & $\begin{array}{c}\text { Typ } 4 \\
\text { ZW-ZR (\#7) }\end{array}$ & $\begin{array}{c}\text { Typ } 5 \\
\text { ZW-PN (\#0) }\end{array}$ \\
\hline $\begin{array}{c}\text { Przeważająco miejskie } \\
\text { poniżej } 15 \%\end{array}$ & $\begin{array}{c}\text { Typ } 7 \\
\text { PM-PR (\#0) }\end{array}$ & $\begin{array}{c}\text { Typ } 8 \\
\text { PM-ZR (\#1) }\end{array}$ & $\begin{array}{c}\text { Typ } 9 \\
\text { PM-PN (\#0) }\end{array}$ \\
\hline
\end{tabular}

Źródło: Opracowanie własne z wykorzystaniem [OECD 1994].

TYP 1 to regiony przeważajaco wiejskie - przeważajaco rolnicze (PW-PR). Oznacza to, że ponad $50 \%$ populacji tych regionów żyje na terytoriach wiejskich i ponad 50\% tej ludności wiejskiej pracuje w rolnictwie. W Polsce mamy dwa województwa należące do tego typu: lubelskie i świętokrzyskie.

TYP 2 to regiony przeważajaco wiejskie - znaczaco rolnicze (PW-ZR). Ponad $50 \%$ populacji tych regionów żyje na terytoriach wiejskich oraz między $15 \%$ a 50\% ludności wiejskiej tego regionu pracuje w rolnictwie. Takich województw wyróżniliśmy cztery: warmińsko-mazurskie, podkarpackie, wielkopolskie i lubuskie.

TYP 3 przeważajaco wiejski - przeważajaco nierolniczy (PW-PN) zawiera regiony, w których ponad 50\% populacji mieszka na terytoriach wiejskich, ale mniej niż 15\% ludności wiejskiej pracuje w rolnictwie. Ten typ nie występuje w Polsce, ale dla przykładu warto przytoczyć, iż w Finlandii jest on z kolei najbardziej popularnym typem, gdyż należy do niego aż połowa regionów (NUTS 3) tego kraju (rys. 1.3).

Do TyPU 4, który jest znaczaco wiejski - przeważajaco rolniczy (ZW-PR), zaliczają się regiony, w których między 15\% a 50\% ludności regionu żyje na terytoriach wiejskich oraz więcej niż 50\% ludności wiejskiej tego regionu pracuje w rolnictwie. Dwa województwa spełniają takie kryterium: podlaskie oraz łódzkie. 
TYP 5 znaczaco wiejski - znaczaco rolniczy (ZW-ZR) charakteryzuje się tym, że między $15 \%$ a 50\% ludności żyje tam na terytoriach wiejskich i taki sam odsetek ludności wiejskiej tego regionu pracuje w rolnictwie. Jest to najliczniejszy typ w Polsce, należą tu takie województwa jak: mazowieckie, kujawsko-pomorskie, opolskie, zachodniopomorskie, pomorskie, dolnośląskie i małopolskie.

TYP 6 znaczaco wiejski - przeważajaco nierolniczy (ZW-PN) posiada między 15\% a 50\% ludności na terytoriach wiejskich, a jednocześnie mniej niż 15\% ludności wiejskiej pracuje w rolnictwie. Znów jest to typ, który nie występuje w Polsce, za to jest reprezentowany przez 3 regiony w Finlandii, wliczając region stołeczny (Uusimaa).

TYP 7 przeważajaco miejski - przeważajaco rolniczy (PM-PR) jest raczej typem hipotetycznym, gdyż mało prawdopodobne jest istnienie regionów, w których mniej niż 15\% ludności żyje na terytoriach wiejskich, a jednocześnie więcej niż $50 \%$ tej ludności pracuje w rolnictwie. W praktyce nie występuje on ani w Polsce, ani w Finlandii. Jednak ciekawie byłoby przeanalizować, czy istnieje taki nietypowy region gdzieś na świecie.

Do TyPU 8, o nazwie przeważajaco miejski - znaczaco rolniczy (PM-ZR) należą regiony, w których mniej niż 15\% ludności żyje na terytoriach wiejskich, a jed-

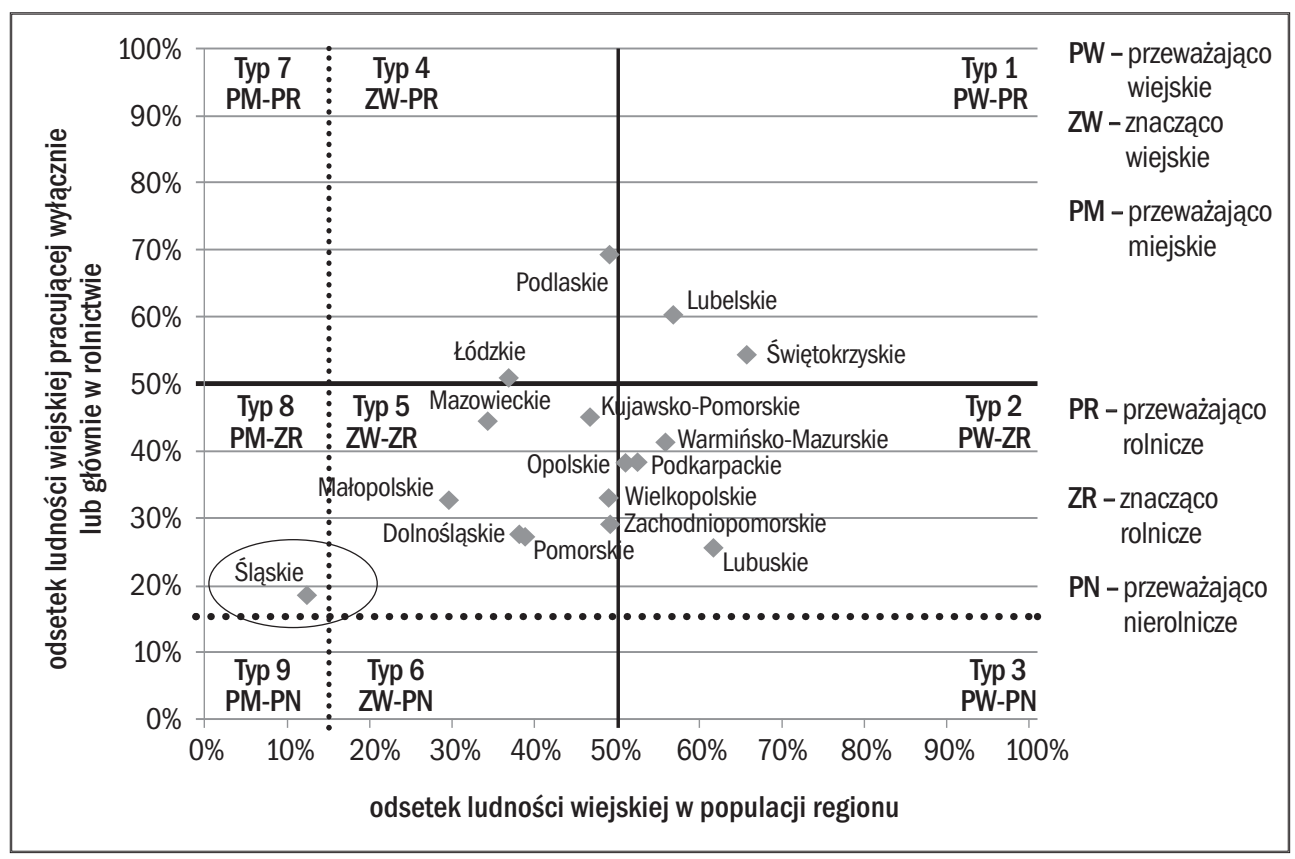

Rysunek 1.2. Dwuwymiarowa typologia wiejsko-rolnicza dla Polski

Źródło: Obliczenia własne na podstawie Spisu Powszechnego 2002 i [OECD 2004]. 


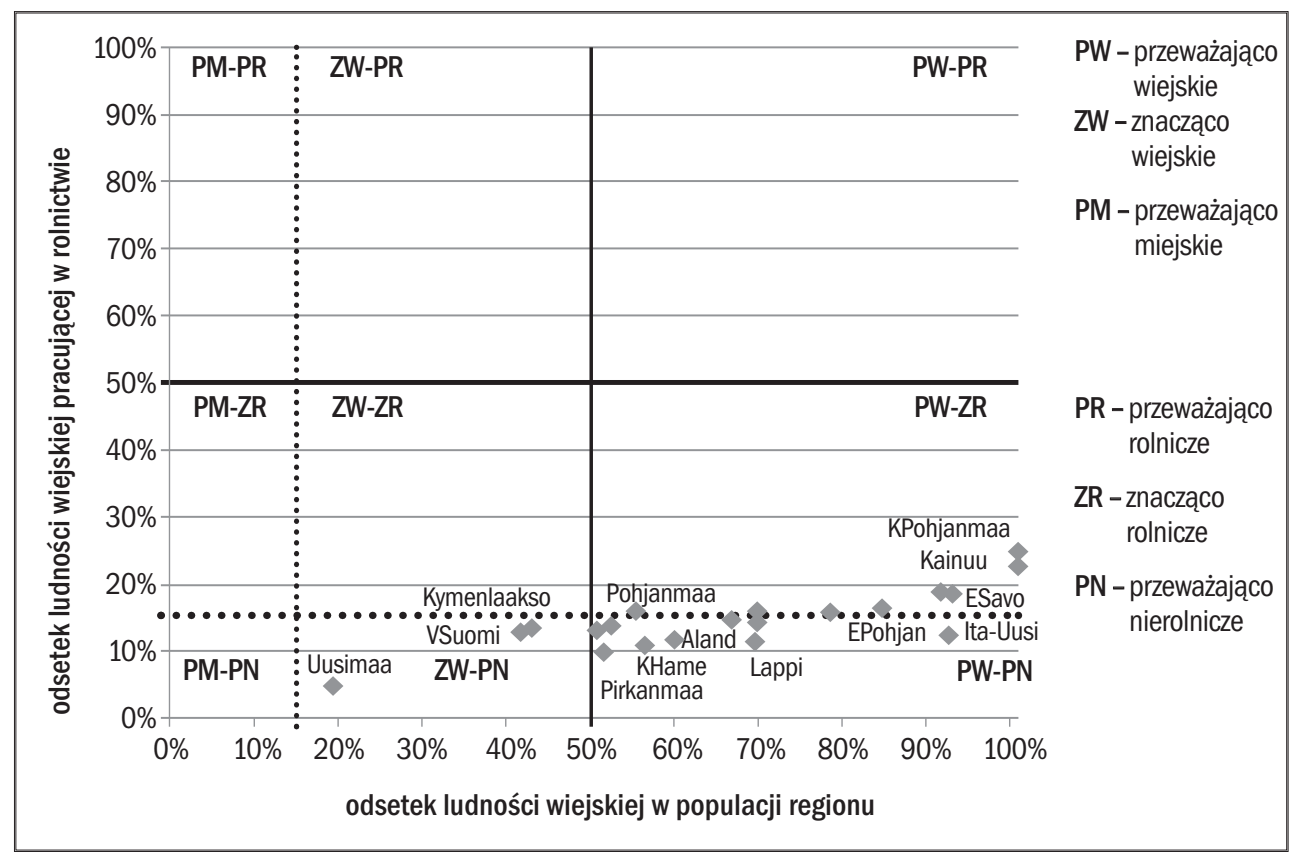

Rysunek 1.3. Dwuwymiarowa typologia wiejsko-rolnicza dla Finlandii

Źródło: Obliczenia własne na postawie Statistics Finland 2006.

nocześnie między $15 \%$ a $50 \%$ tej ludności pracuje w rolnictwie. Zalicza się tu najbardziej zurbanizowane województwo w Polsce (wg OECD jedyny przeważająco miejski region), czyli województwo śląskie.

TYP 9 przeważajaco miejski - przeważajaco nierolniczy (PM-PN) charakteryzuje się tym, że mniej niż 15\% ludności żyje tam na terytoriach wiejskich, a jednocześnie mniej niż 15\% tej ludności pracuje w rolnictwie. Taki typ nie występuje w Polsce, ale naturalnym kandydatem jest województwo śląskie. W procesach zmniejszania się ludności związanej z rolnictwem jej odsetek wśród ludności wiejskiej może tam spaść w przyszłości poniżej 15\% (jak np. w najbardziej zurbanizowanym regionie Finlandii, Uusimaa, gdzie wynosi on 5\%). Taki typ regionów występuje na przykład w Chinach, w regionie Pekinu i Szanghaju.

W naszej typologii najbardziej wiejsko-rolniczy jest Typ 1, a najbardziej zurbanizowany i niezwiązany z rolnictwem jest Typ 9. Typ ostatni nie występuje w Polsce, zatem najbardziej zurbanizowanym regionem jest Typ 8.

Zaletą tej typologii jest to, że pozostaje nadal prosta (jak metodologia OECD), a jednocześnie pozwala w sposób wizualny ocenić różnice między wiejskością i rolniczością różnych regionów w Europie i na świecie. Na przykład już 
na pierwszy rzut oka widać, że regiony Finlandii są o wiele bardziej wiejskie niż polskie (leżą w większości na prawo od pionowej linii 50\%). Z kolei polskie są dużo bardziej rolnicze niż fińskie (leżą ponad lub blisko poziomej linii 50\%) podczas gdy w Finlandii w większości zeszły one poniżej poziomej linii 20\%, wskazując na duże uniezależnienie się regionów wiejskich od rolnictwa (rys. 1.2 i rys. 1.3). Powodem, dla którego proponujemy tę typologię, jest chęć zinterpretowania naszych wyników empirycznych, uzyskanych przy weryfikacji hipotezy 4 , w ujęciu regionów o spójnej charakterystyce zarówno wiejskości, jak i rolniczości. Typologia ta pozwala w prosty sposób na porównanie tych dwóch cech dla dużej liczby regionów, np. wszystkich regionów NUTS 2 w UE, które partycypują w tej samej polityce rozwoju obszarów wiejskich. Wyniki empiryczne według tej typologii przedstawia rozdział 4.4 .

\subsubsection{KLASYFIKACJA LUDNOŚCI WIEJSKIEJ}

Do ludności wiejskiej w Polsce zaliczamy wszystkich mieszkańców gmin wiejskich oraz obszarów wiejskich w gminach miejsko-wiejskich, innymi słowy, wszystkich, którzy mieszkają poza granicami administracyjnymi miast. Liczba mieszkańców wsi rośnie w ostatnich latach w Polsce, mimo że od końcowych lat XX w. następuje spadek ogólnej liczby ludności w kraju. Ludność wiejska wzrosła z 14584 tys. w końcu 2000 r. do 14799 tys. w końcu 2007 r., a jej udział w ogólnej liczbie ludności zwiększył się z 38,1\% do 38,8\% [Frenkel 2008c] ${ }^{8}$. W $2007 \mathrm{r}$. odsetek ludności wiejskiej wzrósł we wszystkich województwach, z wyjątkiem podlaskiego, gdzie zmniejszył się z 41,4\% do 40,5\%. Najniższy odsetek ludności wiejskiej miało woj. śląskie (21,6\%), a najwyższy woj. podkarpackie $(59,4 \%)$ [Frenkel 2008c]. Ludności wiejskiej przybywa zwłaszcza w miejscowościach położonych wokół większych miast. Na tych terenach można zaobserwować największe nasilenie urbanizacji wsi i ograniczenia jej rolniczego charakteru. Produkcyjno-rolnicze funkcje wsi wypierane są tam przez funkcje konsumpcyjne [Wilkin 2008b]. W najtrudniejszej sytuacji są miejscowości wiejskie o słabo zdywersyfikowanej gospodarce, w której rolnictwo jest głównym źródłem dochodów jej mieszkańców. Wsie te ulegają w większości depopulacji i natrafiają na liczne bariery rozwoju. Wśród województw, które na przestrzeni lat 2000-2006 utraciły największy odsetek ludności wiejskiej, znajdują się podlaskie, opolskie, lubelskie, łódzkie i świętokrzyskie (tab. 1.5).

\footnotetext{
${ }^{8}$ Trzeba jednak pamiętać, że w tym czasie zachodziły zmiany w definicjach administracyjnych dotyczących podziału na miasta i wsie (tj. niektóre wsie stawały się w kolejnym okresie miastami itp.), zatem podawane wartości odzwierciedlają w pewnym stopniu zmiany czysto techniczne.
} 
Tabela 1.5. Ludność wiejska według województw w latach 2000-2006

\begin{tabular}{|c|c|c|c|c|c|c|c|c|c|c|}
\hline \multirow{2}{*}{ Województwa } & \multicolumn{4}{|c|}{ Stan ludności w tysiącach } & \multirow{2}{*}{\begin{tabular}{|c|}
$\begin{array}{c}\text { Ludność } \\
\text { wiejska } \\
\text { w lud- } \\
\text { ności } \\
\text { ogółem }\end{array}$ \\
2006 \\
\end{tabular}} & \multirow{2}{*}{$\begin{array}{c}\begin{array}{c}\text { Ludność } \\
\text { wiejska } \\
\text { Polska } \\
=100\end{array} \\
2006\end{array}$} & \multicolumn{4}{|c|}{ Przyrost (ubytek) ludności w \% } \\
\hline & 2000 & 2002 & 2004 & 2006 & & & $\begin{array}{c}2000 \\
-2002\end{array}$ & $\begin{array}{c}2002 \\
-2004\end{array}$ & $\begin{array}{c}2004 \\
-2006\end{array}$ & $\begin{array}{c}2000 \\
-2006\end{array}$ \\
\hline Polska & 14584 & 14647 & 14704 & 14757 & 38,7 & $100 \%$ & 0,4 & 0,4 & 0,4 & 1,2 \\
\hline Dolnośląskie & 829 & 834 & 840 & 840 & 29,1 & $6 \%$ & 0,6 & 0,7 & 0,0 & 1,3 \\
\hline \multicolumn{11}{|l|}{ Kujawsko- } \\
\hline -Pomorskie & 777 & 784 & 791 & 799 & 38,7 & $5 \%$ & 0,8 & 1,0 & 1,0 & 2,8 \\
\hline Lubelskie & 1177 & 1172 & 1165 & 1160 & 53,4 & $8 \%$ & $-0,4$ & $-0,6$ & $-0,5$ & $-1,5$ \\
\hline Lubuskie & 356 & 358 & 361 & 363 & 36,0 & $2 \%$ & 0,4 & 0,8 & 0,6 & 1,8 \\
\hline Łódzkie & 918 & 915 & 913 & 909 & 35,4 & $6 \%$ & $-0,3$ & $-0,2$ & $-0,4$ & $-1,0$ \\
\hline Małopolskie & 1593 & 1612 & 1639 & 1653 & 50,5 & $11 \%$ & 1,2 & 1,6 & 0,9 & 3,7 \\
\hline Mazowieckie & 1807 & 1815 & 1816 & 1825 & 35,3 & $12 \%$ & 0,4 & 0,1 & 0,5 & 1,0 \\
\hline Opolskie & 507 & 504 & 498 & 494 & 47,4 & $3 \%$ & $-0,7$ & $-1,2$ & $-0,7$ & $-2,5$ \\
\hline Podkarpackie & 1247 & 1253 & 1249 & 1248 & 59,5 & $8 \%$ & 0,5 & $-0,3$ & $-0,1$ & 0,1 \\
\hline Podlaskie & 501 & 496 & 492 & 485 & 40,5 & $3 \%$ & $-0,9$ & $-1,0$ & $-1,4$ & $-3,2$ \\
\hline Pomorskie & 687 & 699 & 713 & 726 & 33,0 & $5 \%$ & 1,7 & 20 & 1,9 & 5,7 \\
\hline Śląskie & 989 & 993 & 998 & 1003 & 21,5 & $7 \%$ & 0,3 & 0,5 & 0,5 & 1,4 \\
\hline Świętokrzyskie & 703 & 703 & 702 & 700 & 54,7 & $5 \%$ & $-0,1$ & $-0,1$ & $-0,3$ & $-0,5$ \\
\hline \multicolumn{11}{|l|}{ Warmińsko- } \\
\hline -Mazu & 567 & 569 & 57 & 1 & 40 , & 70 & 0,3 & 0,2 & 0,2 & 0,7 \\
\hline Wielkopolskie & 1409 & 1421 & 1437 & 1457 & 43,1 & $10 \%$ & 0,8 & 1,1 & 1,4 & 3,4 \\
\hline \multicolumn{11}{|l|}{ Zachodnio- } \\
\hline pomorskie & 515 & 519 & 521 & 525 & 31,0 & $4 \%$ & 0,9 & 0,2 & 0,8 & 1,9 \\
\hline
\end{tabular}

Źródło: Na podstawie [Frenkel 2008b].

Oficjalne dane dotyczące ludności wiejskiej powinny być jednak skorygowane o migracje zagraniczne, które po wstapieniu Polski do UE bardzo się nasiliły. W 2006 r. według [GUS 2007a] liczba osób przebywających czasowo za granicą (przez ponad 2 miesiące) wyniosła 1950 tys. osób. Frenkel [2008b] szacuje, że ok. 1/3 stanowią migranci ze wsi. To oznacza według autora, że absolutna liczba ludności wiejskiej w Polsce w 2006 r. była faktycznie nie większa, lecz mniejsza niż w 2000 r. W 2007 r. wśród ludności wiejskiej ponad połowę stanowiła ludność bezrolna 6367 tys. (54\%), a ludność związana z rolnictwem 5471 tys. (46\%). Sytuacja ta kształtowała się odwrotnie jeszcze kilka lat temu, np. w 2000 r. ludność związana z rolnictwem stanowiła większość mieszkańców wsi (54\%), a bezrolna $46 \%$ - tabela 1.6.

Podstawowe parametry rynku pracy (wskaźnik zatrudnienia, stopa bezrobocia i wskaźnik bierności zawodowej) wskazywały na pogarszanie się sytuacji zarówno ludności rolniczej, jak i bezrolnej w pierwszej połowie 2000-2007, a polepszanie w drugiej. W latach 2000-2003 wskaźnik zatrudnienia ludności 
Rozdział 1. Rozwój obszarów wiejskich w teorii i praktyce

Tabela 1.6. Ludność w wieku 15 lat i więcej według aktywności ekonomicznej, miejsca zamieszkania i związków z gospodarstwem rolnym na wsi w latach 2000-2007

\begin{tabular}{|c|c|c|c|c|c|c|c|}
\hline \multirow{3}{*}{ Rok } & \multicolumn{4}{|c|}{ Liczba ludności (w tys.) } & \multirow{3}{*}{$\begin{array}{c}\text { Wskaźnik } \\
\text { zatrudnienia } \\
\text { w \% }\end{array}$} & \multirow{3}{*}{$\begin{array}{c}\text { Stopa } \\
\text { bezrobocia } \\
\text { w \% }\end{array}$} & \multirow{3}{*}{$\begin{array}{c}\text { Wskaźnik } \\
\text { bierności } \\
\text { zawodowej } \\
\text { w \% }\end{array}$} \\
\hline & \multirow{2}{*}{ ogółem } & \multicolumn{2}{|c|}{ aktywni zawodowo } & \multirow{2}{*}{$\begin{array}{c}\text { bierni } \\
\text { zawodowo }\end{array}$} & & & \\
\hline & & pracujący & bezrobotni & & & & \\
\hline \multicolumn{8}{|c|}{ Ogółem } \\
\hline 2000 & 30598 & 14526 & 2785 & 13287 & 47,5 & 16,1 & 43,4 \\
\hline 2001 & 30843 & 14207 & 3170 & 13466 & 46,1 & 18,2 & 43,7 \\
\hline 2002 & 31063 & 13782 & 3431 & 13850 & 44,4 & 19,9 & 44,6 \\
\hline 2003 & 30953 & 13617 & 3329 & 14008 & 44,0 & 19,6 & 45,3 \\
\hline 2004 & 31123 & 13795 & 3230 & 14098 & 44,3 & 19,0 & 45,3 \\
\hline 2005 & 31258 & 14116 & 3045 & 14097 & 45,2 & 17,7 & 45,1 \\
\hline 2006 & 31366 & 14594 & 2344 & 14427 & 46,5 & 13,8 & 46,0 \\
\hline 2007 & 31392 & 15240 & 1619 & 14533 & 48,5 & 9,6 & 46,3 \\
\hline \multicolumn{8}{|c|}{ Wieś } \\
\hline 2000 & 11317 & 5546 & 945 & 4826 & 49,0 & 14,6 & 42,6 \\
\hline 2001 & 11417 & 5477 & 1073 & 4868 & 48,0 & 16,4 & 42,6 \\
\hline 2002 & 11526 & 5350 & 1152 & 5024 & 46,4 & 17,7 & 43,6 \\
\hline 2003 & 11473 & 5264 & 1137 & 5073 & 45,9 & 17,8 & 44,2 \\
\hline 2004 & 11583 & 5342 & 1140 & 5102 & 46,1 & 17,6 & 44,0 \\
\hline 2005 & 11672 & 5483 & 1056 & 5132 & 47,0 & 16,2 & 44,0 \\
\hline 2006 & 11779 & 5630 & 838 & 5311 & 47,8 & 13,0 & 45,1 \\
\hline 2007 & 11838 & 5824 & 590 & 5424 & 49,2 & 9,2 & 45,8 \\
\hline \multicolumn{8}{|c|}{ Ludność związana z gospodarstwem rolnym } \\
\hline 2000 & 6131 & 3714 & 346 & 2071 & 60,6 & 8,5 & 33,8 \\
\hline 2001 & 6342 & 3759 & 420 & 2164 & 59,3 & 10,0 & 34,1 \\
\hline 2002 & 6312 & 3639 & 444 & 2229 & 57,7 & 10,9 & 35,3 \\
\hline 2003 & 5902 & 3404 & 399 & 2098 & 57,7 & 10,5 & 35,6 \\
\hline 2004 & 5809 & 3387 & 368 & 2054 & 58,3 & 9,8 & 35,4 \\
\hline 2005 & 5733 & 3380 & 323 & 2030 & 59,0 & 8,7 & 35,4 \\
\hline 2006 & 5606 & 3323 & 261 & 2022 & 59,3 & 7,3 & 36,1 \\
\hline 2007 & 5471 & 3313 & 184 & 1974 & 60,6 & 5,3 & 36,1 \\
\hline \multicolumn{8}{|c|}{ Ludność bezrolna } \\
\hline 2000 & 5186 & 1832 & 600 & 2755 & 35,3 & 24,7 & 53,1 \\
\hline 2001 & 5076 & 1718 & 654 & 2704 & 33,8 & 27,6 & 53,3 \\
\hline 2002 & 5214 & 1711 & 708 & 2795 & 32,8 & 29,3 & 53,6 \\
\hline 2003 & 5572 & 1860 & 738 & 2975 & 33,4 & 28,4 & 53,4 \\
\hline 2004 & 5774 & 1955 & 772 & 3047 & 33,9 & 28,3 & 52,8 \\
\hline 2005 & 5939 & 2103 & 734 & 3102 & 35,4 & 25,9 & 52,2 \\
\hline 2006 & 6173 & 2307 & 576 & 3289 & 37,4 & 20,0 & 53,3 \\
\hline 2007 & 6367 & 2511 & 406 & 3450 & 39,4 & 13,9 & 54,2 \\
\hline
\end{tabular}

Źródło: Na podstawie [Frenkel 2008c, 2008b].

wiejskiej spadł z 49 w 2000 r. do 45,9 w 2003 r. (analogicznie dla ludności rolniczej i bezrolnej), ale wzrósł z 45,9 w 2003 r. do 49,2 w 2007 r. Analogiczny wzrost w tym okresie odnotowała zarówno ludność rolnicza (z 57,7 do 60,6), jak i bezrolna (z 33,4 do 39,4) - por. tabela 1.6. Problemy związane z bezrobociem ludności 
rolniczej i bezrolnej bardzo się różnią. Ludność bezrolna, nie posiadając gospodarstwa rolnego, może oficjalnie rejestrować się jako osoby bezrobotne, stąd bezrobocie jawne tej grupy dominuje wśród bezrobotnych na wsi. W 2007 r. na 590 tys. bezrobotnych na wsi 406 tys. stanowili bezrolni mieszkańcy wsi (69\%), a tylko 184 tys. ludność rolnicza [Frenkel 2008c]. Z kolei wśród ludności rolniczej panuje głównie bezrobocie ukryte, wpływające na niską produktywność pracy sektora rolnego, prowadząc do niewystarczających dochodów części ludności rolniczej. Jest to skutek braku równowagi między nadmiernymi zasobami pracy w rolnictwie a ograniczonymi możliwościami ich racjonalnego wykorzystania. Sektor rolny w 2007 r. zatrudniał 15,2\% ogółu ludności, podczas gdy wytwarzał tylko 4,3\% PKB [GUS 2009], zatem produktywność pracy wynosiła 0,28. W tym samym roku sektor przemysłu i sektor budownictwa wykazywały produktywność pracy na poziomie odpowiednio 1,06 i 1,24, a więc ok. 4 razy większym.

Szacunki ukrytego bezrobocia wśród ludności rolniczej są trudne, gdyż zależą od kryterium kwalifikowania osób jako zbędne (całkowicie lub częściowo). A. Rosner [2007a] szacuje, że tzw. zbędnych w rolnictwie jest ok. 900 tys., ale wraz z tzw. ułamkowymi przerostami zatrudnienia (zbędnymi częściowo) bezrobocie ukryte na wsi może sięgać ok. 1200 tys. ${ }^{9}$ Oficjalna stopa bezrobocia rejestrowanego na wsi wzrosła w latach 2000-2003 z 14,6\% do 17,8\%, ale znacząco zmalała w latach 2003-2007, z 17,8\% do 9,2\%. W analogicznym okresie spadek stopy bezrobocia nastąpił wśród ludności rolniczej, z 10,5\% w 2003 r. do 5,3\% w 2007 r., oraz ludności bezrolnej, z 28,4\% w 2003 r. do 13,9\% w 2007 r. [Frenkel 2008c]. W poszczególnych województwach można było zaobserwować podobne tendencje (patrz tab. 1.7).

Spośród trzech analizowanych głównych wskaźników dla rynku pracy tylko wskaźnik bierności zawodowej wykazywał przez cały czas tendencję niekorzystną i w latach 2000-2007 wzrósł na wsi z 42,6\% do 45,8\% (wśród ludności rolniczej z $35,6 \%$ do 36,1\%, a ludności bezrolnej z 53,1\% do 54,2\%) (tab. 1.6). Przyczyną tego wzrostu było znaczne zwiększenie się w populacji biernych zawodowo emerytów, zarówno w ujęciu absolutnym, jak i relatywnym.

$\mathrm{Z}$ opisanej powyżej poprawy sytuacji na rynku pracy ludności wiejskiej w latach 2003-2007 najbardziej skorzystali mężczyźni, osoby w młodszym wieku produkcyjnym oraz osoby posiadające zasadnicze lub średnie wykształcenie zawodowe, co odnosi się zarówno do ludności rolniczej, jak i bezrolnej. Wzrost wskaźnika zatrudnienia na wsi w latach 2003-2007 łączył się głównie ze wzro-

\footnotetext{
${ }^{9}$ Trzeba zauważyć, że „ułamkowe przerosty zatrudnienia” są liczone w jednostki przeliczeniowych, a osoby zbędne są liczone jako osoby fizyczne.
} 
Rozdział 1. Rozwój obszarów wiejskich w teorii i praktyce

Tabela 1.7. Stopa bezrobocia według miejsca zamieszkania i związków z gospodarstwem rolnym na wsi wg województw w latach 2002 i $2007 *$

\begin{tabular}{|c|c|c|c|c|c|c|c|c|}
\hline \multirow{3}{*}{ Województwa } & \multirow{2}{*}{\multicolumn{2}{|c|}{ Miasta }} & \multicolumn{4}{|c|}{ Wieś } & & \\
\hline & & & \multicolumn{2}{|c|}{ ogółem } & \multicolumn{2}{|c|}{$\begin{array}{l}\text { ludność związana } \\
\text { z gospodarstwem } \\
\text { rolnym }\end{array}$} & \multicolumn{2}{|c|}{ ludność bezrolna } \\
\hline & 2002 & 2007 & 2002 & 2007 & 2002 & 2007 & 2002 & 2007 \\
\hline Polska & 21,3 & 9,8 & 17,8 & 9,2 & 10,9 & 5,3 & 29,3 & 13,9 \\
\hline Dolnośląskie & 25,5 & 11,7 & 27,5 & 15,1 & 15,4 & 11,4 & 34,8 & 16,9 \\
\hline Kujawsko-Pomorskie & 22,5 & 11,5 & 19,9 & 10,9 & 11,4 & 5,3 & 31,1 & 16,8 \\
\hline Lubelskie & 23,3 & 12,6 & 11,0 & 7,0 & 7,0 & 3,5 & 32,8 & 22,4 \\
\hline Lubuskie & 26,6 & 9,4 & 25,7 & 10,7 & 21,8 & 4,8 & 28,5 & 13,0 \\
\hline Łódzkie & 23,1 & 10,9 & 15,1 & 6,7 & 10,0 & 3,9 & 27,5 & 13,0 \\
\hline Małopolskie & 17,7 & 9,7 & 14,7 & 7,4 & 11,4 & 4,9 & 23,0 & 11,0 \\
\hline Mazowieckie & 18,2 & 9,0 & 15,0 & 9,4 & 8,9 & 5,6 & 28,5 & 13,5 \\
\hline Opolskie & 19,4 & 9,1 & 19,7 & 9,2 & 7,6 & 5,0 & 28,7 & 11,9 \\
\hline Podkarpackie & 19,9 & 10,9 & 17,2 & 8,8 & 14,9 & 6,8 & 29,2 & 16,5 \\
\hline Podlaskie & 21,8 & 10,1 & 9,8 & 7,2 & 4,2 & 2,6 & 35,2 & 21,7 \\
\hline Pomorskie & 18,8 & 7,9 & 28,0 & 12,6 & 13,8 & 7,2 & 35,1 & 15,2 \\
\hline Śląskie & 20,7 & 8,5 & 17,4 & 6,3 & 14,5 & 4,6 & 19,4 & 6,9 \\
\hline Świętokrzyskie & 23,2 & 15,2 & 14,5 & 10,1 & 10,9 & 6,4 & 28,1 & 19,7 \\
\hline Warmińsko-Mazurskie & 25,1 & 9,1 & 27,4 & 13,5 & 14,5 & 5,4 & 38,6 & 17,8 \\
\hline Wielkopolskie & 19,7 & 8,1 & 16,2 & 8,5 & 9,6 & 5,4 & 25,3 & 11,0 \\
\hline Zachodniopomorskie & 23,0 & 10,6 & 34,3 & 13,7 & 24,6 & 6,7 & 38,0 & 15,6 \\
\hline
\end{tabular}

* Średnio w roku

Źródło: Na podstawie [Frenkel 2008c, 2008b].

stem liczby pracujących poza rolnictwem ${ }^{10}$, która zwiększyła się w tym czasie o 10,6\%, czyli do 12300 tys. Wśród mieszkańców wsi wzrost ten był szybszy (o 18,5\%). W odróżnieniu od pracujących poza rolnictwem, liczba pracujących w rolnictwie, zarówno ogółem, jak i na wsi, wykazywała tendencję zniżkową w całym badanym okresie, chociaż znacznie słabszą w początkowych niż końcowych latach tego okresu. W wyniku tych wszystkich zmian odsetek pracujących w rolnictwie zmniejszył się z 18,7\% średnio w 2000 r. do 15\% w 2007 r. w tym na wsi odpowiednio z 45,5\% do 36\% [Frenkel 2008b, 2008a]. Jednak mimo wzrostu wskaźników zatrudnienia w Polsce są one nadal dużo niższe niż w prawie wszystkich pozostałych krajach UE. Szczególnie duże różnice charakteryzowały wskaźniki zatrudnienia młodzieży w wieku 15-24 lata i osób starszych w wieku 55-64 lata. W pierwszej grupie były one o ponad 1/2 niższe niż średnio w UE-27,

\footnotetext{
${ }^{10}$ Podział pracujących według kategorii zawodowych, w tym na pracujących w rolnictwie i poza rolnictwem, przeprowadzany jest w BAEL na podstawie kryterium głównego miejsca pracy. Główne miejsce pracy ustalane jest na podstawie subiektywnej oceny respondenta. O ile nie zaznaczono inaczej, dane dotyczące rolnictwa obejmują także pracujących w leśnictwie i łowiectwie.
} 
a w drugiej prawie o 1/3 niższe. Wśród ogółu osób w wieku produkcyjnym (według definicji EUROSTAT osoby w wieku 15-64 lata) były one niższe o ok. 13\%, w tym w wieku 25-54 lata o ok. 8\%. Różnice te były jeszcze większe w porównaniu ze starymi krajami UE-15 [Frenkel 2008b].

W przyszłości, wraz z malejącą rolą rolnictwa w zatrudnieniu na wsi, dalej spadać będzie udział dochodów z pracy na roli w dochodach użytkowników gospodarstw rolnych. W 2005 r. około 38\% dochodów ludności wiejskiej pochodziło z pracy najemnej poza rolnictwem, $15 \%$ z gospodarstw rolnych, $8 \%$ z pracy na własny rachunek poza rolnictwem i ok. 37\% ze świadczeń społecznych [Zegar 2008b]. Nie należy jednak spodziewać się, iż nastąpi szybka redukcja liczby gospodarstw rolnych, a zatem jedyną szansą, aby mogły one utrzymywać się, i to nie ze świadczeń społecznych, jest stworzenie możliwości uzupełniania dochodów z produkcji rolnej dochodami z innej działalności. Obecnie na wsi jest 4130 tys. osób posiadających niezarobkowe źródło utrzymania (35\% ogółu mieszkańców wsi) [Frenkel 2008b]. W strukturze wiejskich gospodarstw domowych (według głównego źródła utrzymania w 2002 r. dominowały dochody z emerytur i rent $(39,4 \%)$, następnie pochodziły one $\mathrm{z}$ pracy $\mathrm{w}$ sektorze prywatnym poza rolnictwem $(23,5 \%)$, pracy W sektorze publicznym $(15,6 \%)$, pracy w swoim gospodarstwie rolnym $(14,3 \%)$ i pozostałych $(7,2 \%)$. Wyraźnie udział pracy w sektorze publicznym zmalał na rzecz rent i emerytur - w 1988 r. udział tej pierwszej wynosił 40\%, a tej drugiej 22,7\%, czyli miała miejsce odwrotna sytuacja niż obecnie [Zegar 2008b].

Rozwiązywanie problemów pracy grupy bezrolnej na wsi musi odbywać się poprzez stwarzanie możliwości pozarolniczego zatrudnienia. Dlatego warto przyjrzeć się, w jakich pozarolniczych działach gospodarki ludność ta znajduje zatrudnienie. W 2006 r. najliczniejszą grupę pracujących poza rolnictwem na wsi stanowiły osoby zatrudnione w „Przetwórstwie przemysłowym” (31,9\%), na drugim miejscu w sekcji „Handel i naprawy” (15,9\%) i na trzecim „Budownictwo” (9,6\%) według sekcji PKD ${ }^{11}$. Analogiczne miejsca sekcje te zajmowały w 2000 r., chociaż udział pierwszej z nich był wówczas nieco mniejszy, a pozostałych nieco większy niż w 2006 r. W przetwórstwie przemysłowym i budownictwie mieszkańcy wsi pracowali znacznie częściej niż mieszkańcy miast, w handlu i naprawach w przybliżeniu równie często, natomiast w działalności usługowej na ogół rzadziej niż w miastach (tab. 1.8). Według Frenkla [2008a] wzrost liczby pracujących poza rolnictwem w latach 2003-2006 był na wsi znacznie większy w populacji pracowników najemnych niż pracujących na własny rachunek $^{12}$ i wynosił

\footnotetext{
${ }^{11}$ Polska Klasyfikacja Działalności. Dane odnoszą się do klasyfikacji obowiązującej do 1 stycznia 2008 r.

${ }^{12}$ Kategoria ta obejmuje pracodawców, osoby prowadzące własną działalność gospodarczą i niezatrudniające pracowników oraz pomagających członków rodziny.
} 
odpowiednio $20,0 \%$ i $6,8 \%$, (w miastach $8,3 \%$ i 4,1\%). W rezultacie udział pracujących na własny rachunek zmniejszył się w tym czasie z 11,3\% do 10,2\% (w miastach z 13,2\% do 12,8\%).

Tabela 1.8. Pracujący poza rolnictwem ${ }^{\mathrm{a}}$, ogółem i na własny rachunek, według miejsca zamieszkania i sekcji PKD ${ }^{b}$ w głównym miejscu pracy w latach 2000, 2006 i $2007^{d}$

\begin{tabular}{|c|c|c|c|c|c|c|c|c|c|c|c|c|}
\hline \multirow{4}{*}{ Sekcje PKD } & \multicolumn{6}{|c|}{ Ogólem } & \multicolumn{6}{|c|}{ W tym na własny rachunek } \\
\hline & \multicolumn{3}{|c|}{ miasta } & \multicolumn{3}{|c|}{ wieś } & \multicolumn{3}{|c|}{ miasta } & \multicolumn{3}{|c|}{ wieś } \\
\hline & 2000 & 2006 & 2007 & 2000 & 2006 & 2007 & 2000 & 2006 & 2007 & 2000 & 2006 & 2007 \\
\hline & \multicolumn{6}{|c|}{ struktura według sekcji (\%) } & \multicolumn{6}{|c|}{$\begin{array}{c}\text { udział w ogólnej liczbie pracujących } \\
\text { w danej sekcji (\%) }\end{array}$} \\
\hline $\begin{array}{l}\text { Ogółem } \\
\text { w tym: }\end{array}$ & 100,0 & 100,0 & 100,0 & 100,0 & 100,0 & 100,0 & 13,1 & 12,8 & 12,5 & 10,9 & 10,2 & 10,5 \\
\hline Górnictwo i & 2,6 & 2,0 & (.) & 2,3 & 1,8 & (.) & 0,2 & 1,1 & (.) & 0,7 & 0,8 & (.) \\
\hline Przetwórstwo przemysłowe & 22,3 & 21,2 & 21,1 & 31,0 & 31,9 & 31,9 & 8,0 & 8,4 & 6,6 & 6,3 & 6,0 & 6,4 \\
\hline $\begin{array}{l}\text { Wytwarzanie } \\
\text { i zaopatrywanie } \\
\text { elektryczną, gaz }\end{array}$ & 2,4 & 1,9 & (.) & 1,8 & 1,6 & (.) & 0,6 & 0,9 & (.) & (.) & (.) & (.) \\
\hline Budownictwo & 7,9 & 6,7 & 8,0 & 10,8 & 9,6 & 9,9 & 19,9 & 22,8 & 22,2 & 14,3 & 15,9 & 18,1 \\
\hline Handel i napra & 17,7 & 17,1 & 17,5 & 16,1 & 15,9 & 17,1 & 30,6 & 25,6 & 23,9 & 29,1 & 24,1 & 20,9 \\
\hline Hotele i restauracje & 1,9 & 2,0 & 2,1 & 2,4 & 2,6 & 2,5 & 19,2 & 15,0 & 13,3 & 19,5 & 14,1 & 11,3 \\
\hline $\begin{array}{l}\text { Transport, } \\
\text { magazyno }\end{array}$ & 7,5 & 7,5 & 7,4 & 7,9 & 8,1 & 7,8 & 17,3 & 17,0 & 14,0 & 14,5 & 13,1 & 15,4 \\
\hline Pośrednictwo finan & 3,7 & 3,2 & 3,4 & 1,7 & 1,4 & 1,4 & 10,5 & 9,3 & 10,6 & 7,2 & 7,5 & 9,3 \\
\hline $\begin{array}{l}\text { Obsługa nieruchomości } \\
\text { i firm }\end{array}$ & 5,3 & 8,2 & 9,0 & 2,2 & 3,3 & 3,4 & 17,4 & 19,6 & 19,7 & 10,3 & 13,6 & 17,4 \\
\hline $\begin{array}{l}\text { Administracja publiczna } \\
\text { i obrona }\end{array}$ & 6,8 & 7,9 & 7,7 & 5,6 & 6,2 & 6,5 & (.) & (.) & (.) & (.) & (.) & (.) \\
\hline Edukacja & 8,7 & 9,7 & 8,5 & 8,2 & 8,2 & 7,6 & 1,6 & 2,0 & 1,6 & 0,6 & 0,7 & (.) \\
\hline $\begin{array}{l}\text { Ochrona zdrowia i opieka } \\
\text { społeczna }\end{array}$ & 8,4 & 7,7 & 7,4 & 6,5 & 5,5 & 4,9 & 4,2 & 7,9 & 8,2 & 2,2 & 4,8 & 3,2 \\
\hline $\begin{array}{l}\text { Pozostała działalność } \\
\text { usługowa }\end{array}$ & 4,7 & 4,7 & 4,1 & 3,2 & 3,5 & 3,2 & 16,4 & 15,9 & 22,2 & 15,1 & 16,5 & 13,7 \\
\hline
\end{tabular}

a oraz leśnictwem i łowiectwem, ${ }^{\mathrm{b}}$ Polska Klasyfikacja Działalności, ${ }^{\mathrm{c}}$ średnio w roku, ${ }^{\mathrm{d}}$ W III kwartale,

Znak (.) oznacza brak wiarygodnych informacji

Źródło: [Frenkel 2008b] według BAEL z odpowiednich lat.

W 2006 r. najwyższy odsetek pracujących na własny rachunek na wsi odnotowano w sekcji „Handel i naprawy” (24,1\%), stosunkowo wysoki (ok. 13-17\%) w sekcjach „Budownictwo”, „Hotele i restauracje”, „Transport, gospodarka magazynowa, łączność”, „Obsługa nieruchomości i firm” i „Pozostała działalność usługowa” i niski (ok. 5-8\%) w sekcjach „Przetwórstwo przemysłowe”, „Pośrednictwo finansowe” 
oraz „Ochrona zdrowia i opieka społeczna”. W porównaniu z 2000 r. najbardziej charakterystyczną zmianą było zmniejszenie się odsetka pracujących na własny rachunek w sekcji „Handel i naprawy”, który w 2000 r. wynosił 29,1\% oraz wzrost tego odsetka w ochronie zdrowia, który wynosił wówczas 2,2\%. Podobne zmiany miały także miejsce w miastach. W obu środowiskach związane one były zapewne głównie z rozwojem sieci handlowych i zwiększaniem się liczby prywatnych placówek służby zdrowia [Frenkel 2008b]. Z kolei w 2007 r. najliczniejszą grupę pracujących poza rolnictwem ogółem na wsi stanowiły osoby zatrudnione w branżach „Przetwórstwo przemysłowe” (31,9\%), „Handel i naprawy” (17,1\%), „Budownictwo” (9,9\%). Natomiast najwyższy odsetek pracujących na własny rachunek w ogólnej liczbie pracujących poza rolnictwem na wsi odnotowano w sekcji „Handel i naprawy" (20,9\%), ale spadł on znacząco z 24,1\% w 2006 r. i jeszcze bardziej w porównaniu z 2000 r., kiedy wynosił 29,1\% - tabela 1.8 [Frenkel 2008a].

Dla ułatwienia zdobywania pracy poza rolnictwem oraz zakładania własnej działalności gospodarczej z pewnością potrzebna jest poprawa poziomu wykształcenia

Tabela 1.9. Pracujący według miejsca zamieszkania, płci, wieku, wykształcenia oraz pracy w rolnictwie indywidualnym i poza nim w latach 2000 i $2007^{a}$

\begin{tabular}{|c|c|c|c|c|c|c|c|c|}
\hline \multirow{5}{*}{ Wyszczególnienie } & \multicolumn{2}{|c|}{ Miasta } & \multicolumn{6}{|c|}{ Wieś } \\
\hline & \multirow{4}{*}{2000} & \multirow{4}{*}{2007} & \multirow{2}{*}{\multicolumn{2}{|c|}{ ogółem }} & \multicolumn{4}{|c|}{ pracujący } \\
\hline & & & & & \multicolumn{2}{|c|}{$\begin{array}{c}\text { w rolnictwie } \\
\text { indywidualnym }\end{array}$} & \multicolumn{2}{|c|}{$\begin{array}{l}\text { poza rolnictwem } \\
\text { indywidualnym }\end{array}$} \\
\hline & & & 2000 & 2007 & 2000 & 2007 & 2000 & 2007 \\
\hline & & & \multicolumn{6}{|c|}{ w odsetkach } \\
\hline OGÓŁEM & 100,0 & 100,0 & 100,0 & 100,0 & 100,0 & 100,0 & 100,0 & 100,0 \\
\hline w tym kobiety & 46,2 & 46,4 & 41,9 & 43,0 & 45,4 & 45,3 & 39,2 & 41,9 \\
\hline \multicolumn{9}{|l|}{ Wiek $^{\text {b: }}$} \\
\hline Przedprodukcyjny & 0,2 & 0,1 & 0,9 & 0,7 & 1,6 & 1,6 & 0,4 & 0,2 \\
\hline Produkcyjny & 97,7 & 98,3 & 93,6 & 95,9 & 86,1 & 89,2 & 99,2 & 99,3 \\
\hline młodszy & 64,6 & 63,0 & 66,4 & 64,4 & 53,3 & 48,9 & 76,3 & 72,1 \\
\hline starszy & 33,1 & 35,2 & 27,1 & 31,6 & 32,8 & 40,3 & 22,9 & 27,2 \\
\hline Poprodukcyjny & 2,1 & 1,7 & 5,5 & 3,4 & 12,3 & 9,2 & 0,3 & 0,5 \\
\hline \multicolumn{9}{|l|}{ Wykształcenie: } \\
\hline Wyższe & 19,8 & 29,5 & 5,0 & 10,9 & 0,5 & 2,3 & 8,4 & 15,1 \\
\hline Średnie ogółem ${ }^{\mathrm{c}}$ & 44,3 & 41,3 & 26,5 & 32,3 & 17,9 & 22,0 & 33,0 & 37,4 \\
\hline zawodowe $\mathrm{c}^{\mathrm{c}}$ & 35,5 & 31,6 & 22,5 & 26,3 & 15,0 & 18,4 & 28,1 & 30,3 \\
\hline ogólnokształcące & 8,8 & 9,7 & 4,0 & 6,0 & 2,9 & 3,6 & 4,9 & 7,1 \\
\hline Zasadnicze zawodowe & 28,7 & 23,9 & 41,4 & 39,9 & 36,9 & 42,8 & 44,7 & 38,5 \\
\hline Gimnazjum, podstawowe ${ }^{\mathrm{d}}$ & 7,2 & 5,2 & 27,1 & 16,9 & 44,7 & 32,9 & 13,8 & 8,9 \\
\hline
\end{tabular}

Źródło: [Frenkel 2008a, 2008b]. 
ludności wiejskiej, chociaż widać już pewne zmniejszenie luki edukacyjnej między miastem a wsią. Według danych BAEL odsetek osób z wyższym wykształceniem w ogólnej liczbie ludności w wieku 15 lat i więcej był w 2006 r. dwukrotnie wyższy niż w 2000 r., a z wykształceniem średnim o ponad 1/4, podczas gdy w miastach odsetki te zwiększyły się odpowiednio o połowę i 3\%. W rezultacie w 2006 r. odsetek osób z wyższym wykształceniem na wsi wynosił 6,5\%, a ze średnim 25,3\% (w mieście odpowiednio $18,8 \%$ oraz 39\%). Natomiast osoby, które ukończyły tylko szkołę podstawowa, stanowiły na wsi $37,5 \%$, wobec $19,7 \%$ w miastach [Frenkel 2008b].

Kolejnym ważnym elementem, który determinuje strukturę zatrudnienia ludności wiejskiej, jest poziom wykształcenia osób pracujących. Zwiększał się on szybciej na wsi niż w miastach, jednak nadal pozostaje znacznie niższy w pierwszej niż drugiej populacji. Mieszkańcy wsi z wykształceniem wyższym lub średnim stanowili 34,7\% pracujących w 2003 r. i 43,7\% w 2007 r. (w miastach odpowiednio $67,2 \%$ i 70,8\%), w tym z wykształceniem wyższym 7,1\% i 10,9\% (w miastach 24,8\% i 29,5\%). Najniższy poziom wykształcenia wykazują mieszkańcy wsi pracujący w rolnictwie indywidualnym, z których wykształcenie wyższe lub średnie miało 20,9\% w 2003 r. i 24,3\% w 2007 r. (w tym z wykształceniem wyższym 1,3\% i 2,3\%). Struktura wykształcenia mieszkańców wsi pracujących poza rolnictwem była znacznie korzystniejsza niż pracujących w rolnictwie, jednak wyraźnie mniej korzystna niż w miastach (tab. 1.9).

\subsection{Rozwój obszarów wiejskich w ujęciu wielokryterialnym}

Rozwój już jako pojęcie samo w sobie jest ciekawy. Nie zawsze oznacza on zwiększanie parametrów, np. rozwój rolnictwa nie kojarzy nam się już ze zwiększaniem liczby zatrudnionych w rolnictwie, czy nawet ze zwiększaniem produkcji za wszelką cenę. W naukach społecznych postęp (rozwój) definiujemy raczej jako takie kierunkowe zmiany określonego obiektu, klasy obiektów lub dziedziny rzeczywistości, które sa ważne dla obserwatora, a jednocześnie sa przez niego pozytywnie oceniane [Nowak 1990, s. 230].

W ekonomii przez długi czas utożsamiano pojęcie rozwoju ze wzrostem produktu narodowego brutto i czysto ekonomicznymi wskaźnikami. Jednak niedoskonałość związana $\mathrm{z}$ jednowymiarowością takiej definicji spowodowała poszukiwanie nowych aspektów rozwoju. Jednym z najbardziej znanych przykładów wielowymiarowego podejścia do rozwoju jest to zaproponowane przez noblistę Amarty’a Sena i spopularyzowane w jego książce z 1999 r. Developemnt as Freedom. Sen umiejętnie połączył podejście ekonomiczne, społeczne, politologiczne i filozoficzne, dochodząc do wniosku, że rozwój polega na usuwaniu róż- 
nego rodzaju zniewoleń (ubóstwa, tyranii, ograniczonych możliwości ekonomicznych, społecznych represji, braku społecznych zabezpieczeń oraz nietolerancji i tyranii systemowej), które pozostawiają ludziom niewielki wybór i niewielkie szanse realizacji ich działania. Skala swobód staje się zarazem podstawową miarą rozwoju. Sen nie neguje wzrostu gospodarczego jako ważnego aspektu rozwoju, ale nazywa go środkiem do celu (means), a nie celem samym w sobie, gdyż dążeniem ostatecznym jest osiągnięcie różnego rodzaju swobód (ends), w tym swoboda dostępu do dóbr materialnych [Sen 1999].

Poza głównym nurtem ekonomii, w koncepcji realizmu krytycznego można znaleźć autorów, którzy szukają analogii rozwoju ekonomicznego do ewolucji biologicznej opisanej przez Karola Darwina [Lawson 2003]. Nurt ten znany jest pod nazwą ekonomii ewolucyjnej (evolutionary economics). Przedstawicielami tego nurtu myślowego są m.in. Hodgson [2001], Dopfer [2001] czy Dugger i Sherman [2000]. Niezależnie od doktryny kluczowe zatem dla oceny rozwoju jest zdefiniowanie kryteriów, które uznane są za ważne i pozwalają badaczowi ocenić za pomocą obranych wskaźników, czy zmiany zachodzące w obserwowanym zjawisku (obiekcie) mają na nie pozytywny wpływ (dokonuje się rozwój), czy nie mają żadnego (brak rozwoju), a może wpływ ten jest nawet negatywny (następuje regres).

W latach 80. XX wieku we wszystkich językach europejskich pojawiło się pojęcie rural development, developpment rural, desenvolvimento rural, czy polskie rozwój obszarów wiejskich lub rozwój wiejski, które powszechnie zaczęto używać w praktyce (administracji, polityce) i które zdominowało także język nauk społecznych, zajmujących się wsią [Halamska i Śpiewak 2008]. Są autorzy, np. M. Halamska i R. Śpiewak [2008], którzy wykazują, że termin ten ma różny zakres znaczeniowy. Może być to skrót myślowy dla określenia ewolucji i dynamiki wsi czy obszarów wiejskich; ale również oznaczać różne działania, podejmowane w różnych okresach na obszarach wiejskich. Można się tu odwołać do pojęcia rozwoju wiejskiego jako rozszerzonego rozwoju rolnictwa, opisanego przez Perrier-Corneta [2001]. Termin ten może także oznaczać specyficzny program rozwoju obszarów wiejskich, któremu towarzyszy swoisty cel - rozwój szeroko rozumianej „wiejskości”. Wieś oznacza wtedy nie tylko teren pewnych działań, ale samą wieś. Wiejskość staje się przedmiotem działań rozwojowych, zmierzających do ulepszenia albo tylko zachowania wiejskości pewnych obszarów. Autorki definiują rozwój wiejski, nawiązując do ONZ-owskiej definicji rozwoju lokalnego, jako: serię planowanych, ujętych $w$ formalne ramy organizacyjne zmian, podjętych przez ludzi, władze centralne i lokalne dla polepszenia ekonomicznych, społecznych i kulturowych warunków egzystencji społeczności wiejskich i ich integracji z życiem całego społeczeństwa [Halamska i Śpiewak 2008]. 
Przez pewien czas rozwój obszarów wiejskich był równoznaczny z postępującą urbanizacją. Zakładano bowiem, że niesie ona dla obszarów wiejskich głównie pozytywne konsekwencje. Jednak miejski styl życia i upodabnianie się do miejskiej infrastruktury nie przynosiło wysokiego poziomu rozwoju społeczno-gospodarczego wsi, a procesy urbanizacyjne uruchomiły wiele negatywnych zjawisk, obniżających jakość życia i możliwości rozwoju [Rosner 2007b, por. Czyżewski 1983].

Obserwując procesy rozwojowe zachodzące na wsi można, ogólnie ujmując, wyłonić trzy kryteria, które najlepiej identyfikują rozwój obszarów wiejskich. Należą do nich: • podnoszenie poziomu życia rodzin wiejskich poprzez działania na rzecz modernizacji rolnictwa i zmiany w strukturze agrarnej (postęp techniczny, innowacyjność, poprawa infrastruktury, dostęp do informacji, specjalizacja) - tworzenie miejsc pracy poza rolnictwem na obszarach wiejskich i wstrzymywanie odpływu ludności (uprzemysłowienie wsi, wspieranie przedsiębiorczości wiejskiej, rozszerzanie usług gospodarek lokalnych) • rozbudzanie lokalnych inicjatyw oraz wypracowanie własnych ścieżek zmian przez społeczności wiejskie (przyciąganie zewnętrznych inwestorów, działania integracyjne na poziomie lokalnym, wypracowywanie wizerunku i wizji rozwoju) [Kłodziński 2006]. Ponieważ obszary wiejskie są integralną częścią gospodarki, ich rozwój należy rozpatrywać jednak w szerszym kontekście ekonomicznym. Po pierwsze, wpływa on na rozwój całej gospodarki, ale i też od niego zależy, ponadto w różnych województwach sprzężenie to może być zróżnicowane. Po drugie, mimo że dość powszechnie jeszcze uważa się, że w największej mierze zależy on od rozwoju sektora rolnego - to obraz ten ulega zmianie i jest o wiele bardziej zróżnicowany. Po trzecie, rozwój obszarów wiejskich wpisuje się w koncepcje związane z „nowym paradygmatem wiejskim" (który opisujemy w rozdziale 2.1), przez co łączy się z tzw. rozwojem zrównoważonym, rozwojem zintegrowanym oraz z wielofunkcyjnością wsi. Powyższe aspekty rozwoju obszarów wiejskich rozważamy w kolejnych sekcjach niniejszego rozdziału.

\subsubsection{ROZWÓJ OBSZARÓW WIEJSKICH I ROLNICTWA A ROZWÓJ CAŁEJ GOSPODARKI}

Związki obszarów wiejskich z gospodarką narodową stanowią ogół powiązań osobowych, materialnych, instytucjonalnych oraz informacyjnych, jakie wieś i rolnictwo mają z innymi działami i gałęziami gospodarki narodowej. $Z$ jednej strony, to rolnictwo i całe obszary wiejskie zależą od rozwoju pozostałych sektorów i miast, a z drugiej, same dostarczają różnych dóbr pozostałym sektorom i miastom [por. Woś 1975]. Związki rolnictwa z pozostałą częścią gospodarki najła- 
Tabela 1.10. Przepływ dóbr materialnych i usług do rolnictwa z gałęzi gospodarki narodowej w 2000 r. [w cenach bieżących, mln PLN]

\begin{tabular}{|c|c|c|c|c|}
\hline Wyszczególnienie & $\begin{array}{l}\text { Produkty } \\
\text { rolnictwa, } \\
\text { lowiectwa } \\
\text { i leśnictwa } \\
\text { (w mln zl) }\end{array}$ & \begin{tabular}{|c|} 
Udzial \\
w produkcie \\
globalnym \\
rolnictwa, \\
lowiectwa, \\
leśnictwa (w \%)
\end{tabular} & $\begin{array}{c}\text { Udzial } \\
\text { w produkcie } \\
\text { globalnym } \\
\text { sektorów } \\
\text { nierolniczych } \\
\text { (w \%) }\end{array}$ & $\begin{array}{c}\text { Produkt } \\
\text { globalny } \\
\text { sektorów } \\
\text { nierolniczych } \\
\text { (w mln zl) }\end{array}$ \\
\hline \multicolumn{5}{|l|}{ A produkty rolnictwa, łowiectwa } \\
\hline i leśnictwa & 16288 & 25,9 & - & - \\
\hline B produkty rybactwa & 6 & 0,0 & 1,0 & 630 \\
\hline $\mathrm{C}$ produkty górnictwa & 374 & 0,6 & 1,6 & 22662 \\
\hline D produkty przetwórstwa & & & & \\
\hline przemysłowego & 9835 & 15,7 & 2,2 & 437250 \\
\hline E energia elektryczna, gaz, para wodna & & & & \\
\hline i woda & 1132 & 1,8 & 2,3 & 48218 \\
\hline $\mathrm{F}$ roboty budowlane & 246 & 0,4 & 0,2 & 134185 \\
\hline G usługi w zakresie handlu hurtowego & & & & \\
\hline i detalicznego; naprawy & 7253 & 11,6 & 3,5 & 209252 \\
\hline H usługi hotelarskie i gastronomiczne & 11 & 0,0 & 0,1 & 19311 \\
\hline I usługi transportowe, magazynowe & & & & \\
\hline oraz łączności & 667 & 1,1 & 0,6 & 103336 \\
\hline $\mathrm{J}$ usługi pośrednictwa finansowego & 455 & 0,7 & 1,3 & 36237 \\
\hline $\begin{array}{l}\text { K usługi związane z nieruchomościami, } \\
\text { nauka i działalność gospodarcza }\end{array}$ & 559 & 0,9 & 0,3 & 165322 \\
\hline $\mathrm{L}$ usługi w zakresie administracji & & & & \\
\hline publicznej i ubezpieczeń & 1 & 0,0 & 0,0 & 59045 \\
\hline M usługi w zakresie edukacji & 7 & 0,0 & 0,0 & 38014 \\
\hline $\begin{array}{l}\mathrm{N} \text { usługi w zakresie ochrony zdrowia } \\
\text { i pomocy społecznej }\end{array}$ & 268 & 0,4 & 0,7 & 37826 \\
\hline $\begin{array}{l}\text { O usługi komunalne pozostałe, } \\
\text { społeczne i indywidualne }\end{array}$ & 59 & 0,1 & 0,1 & 42593 \\
\hline $\mathrm{P}$ usługi gospodarstw domowych & 0 & 0,0 & 0,0 & 5 \\
\hline Razem produkty bez rolnictwa & 20872 & 33,0 & 1,5 & 1353886 \\
\hline $\begin{array}{l}\text { Wykorzystanie produktów } \\
\text { importowanych, cif }\end{array}$ & 2377 & 3,8 & - & - \\
\hline $\begin{array}{l}\text { Podatki od produktów pomniejszone } \\
\text { o dotacje do produktów }\end{array}$ & 1294 & 2,1 & - & - \\
\hline $\begin{array}{l}\text { Razem zużycie pośrednie/popyt końcowy } \\
\text { w cenach nabywcy }\end{array}$ & 40830 & 65,0 & - & - \\
\hline Koszty związane z zatrudnieniem & 4334 & 6,9 & - & - \\
\hline Podatki od producentów & 701 & 1,1 & - & - \\
\hline Dotacje dla producentów & -60 & $-0,1$ & - & - \\
\hline Nadwyżka operacyjna brutto & 16985 & 27,0 & - & - \\
\hline Wartość dodana brutto & 21960 & 35,0 & - & - \\
\hline Produkcja globalna w cenach bazowych & 62790 & 100,0 & - & - \\
\hline
\end{tabular}

Żródło: Opracowanie własne na podstawie [GUS 2004, Tablica: Bilans przepływów międzygałęziowych w bieżących cenach bazowych dla produkcji krajowej w 2000 r.]. 
twiej pokazać na przykładzie powiązań międzygałęziowych (niestety, nie istnieją takie rachunki dla wyodrębnionych obszarów wiejskich). Tablice przepływów międzygałęziowych pokazują strumienie dóbr i usług płynących do rolnictwa i z rolnictwa, a zatem pozwalają określić stopień jego sprzężenia z całą gospodarką. Z ostatniej dostępnej tablicy przepływów międzygałęziowych [GUS 2004] możemy wywnioskować, że w 2000 r. do rolnictwa ${ }^{13}$ napłynęły krajowe wyroby i usługi na łączną sumę 20,8 mld PLN plus z importu na sumę 2,3 mld PLN. Łączny strumień wyniósł 23,2 mld PLN, co stanowiło 37\% produktu globalnego rolnictwa. Jednocześnie rolnictwo zużyło wytworzone przez siebie produkty na sumę 16,3 mld PLN, tj. 26\% swojego produktu globalnego (tab. 1.10).

W tym samym czasie wartość strumienia surowców i produktów rolniczych, jaki wypłynął do nierolniczych sektorów gospodarki, wyniósł 46,5 mld PLN, z czego 27,6 mld PLN podlegało dalszemu przerobowi (popyt pośredni), natomiast 18,9 mld PLN trafiło do konsumpcji finalnej (dla gospodarstw domowych, na inwestycje, przyrost środków obrotowych i eksport). Z prostego porównania strumieni wychodzących z rolnictwa oraz przypływających do rolnictwa wynika, że na jednostkę wyrobów i usług płynących do rolnictwa przypadały 2 jednostki surowców i produktów rolniczych wypływających z rolnictwa w 2000 r. (tab. 1.11). W przeszłości wskaźnik ten był ponaddwukrotnie większy, ale stopniowo spada, np. w 1962 r. wynosił 4,5, w 1972 r. wyniósł 2,6, w 1989 r. wyniósł 2,5.

Rolnictwo jest relatywnie małym odbiorcą dóbr i usług innych sektorów w skali kraju, gdyż wykorzystuje zaledwie 1,5\% globalnego produktu nierolniczego (tab. 1.10). Jednak w relacji do rolniczego produktu globalnego jest to $33 \%$. Z nierolniczych sektorów sektor handlowy przeznacza ok. 3\% swojego produktu, a przetwórstwo przemysłowe, energia i górnictwo z kopalnictwem przeznaczają po ok. 2\% swoich produktów na rolnictwo. W strukturze kosztów sektora rolnego największy udział mają produkty przemysłu przetwórczego ( $16 \%$ globalnego produktu rolniczego) oraz usługi w zakresie handlu (12\% globalnego produktu rolniczego) - tabela 1.10 .

Jednocześnie waga surowców i produktów rolniczych dla gałęzi nierolniczych jest większa i wynosi dla sfer popytu pośredniego i końcowego razem 3,4\%. W wartościach poszczególnych gałęzi rolnictwo najwięcej wnosi do przetwórstwa przemysłowego - 6\% (głównie rolno-spożywczego), rybactwa (5\%), handlu, usług hotelowych i gastronomicznych (po 1\%). Wartość surowców i produktów rolnictwa przeznaczonych dla nierolniczych sektorów w relacji do produktu globalnego rolnictwa jest znacząco wyższa i wynosi 44\%, z czego aż 40\% przypada na przemysł rolno-spożywczy (tab. 1.11). (O związkach rolnictwa z gospodarką, opierając się

${ }^{13}$ Rolnictwo jest tu analizowane razem $\mathrm{z}$ leśnictwem i łowiectwem. 
Tabela 1.11. Przepływy produktu globalnego z rolnictwa do poszczególnych gałęzi gospodarki narodowej w roku 2000 [w cenach bieżących, mIn PLN]

\begin{tabular}{|c|c|c|c|c|}
\hline Wyszczególnienie & $\begin{array}{l}\text { Produkty } \\
\text { rolnictwa, } \\
\text { lowiectwa } \\
\text { i leśnictwa } \\
\text { (w mln zl) }\end{array}$ & \begin{tabular}{|c|} 
Udzial \\
w produkcie \\
globalnym \\
rolnictwa, \\
lowiectwa, \\
leśnictwa (w \%)
\end{tabular} & $\begin{array}{c}\text { Udzial } \\
\text { w produkcie } \\
\text { globalnym } \\
\text { sektorów } \\
\text { nierolniczych } \\
\text { (w \%) }\end{array}$ & $\begin{array}{l}\text { Produkt } \\
\text { globalny } \\
\text { sektorów } \\
\text { nierolniczych } \\
\text { (w mln zl) }\end{array}$ \\
\hline \multicolumn{5}{|c|}{ Popyt pośredni: } \\
\hline \multicolumn{2}{|c|}{ A produkty rolnictwa, łowiectwa i leśnictwa 16288} & 25,9 & - & - \\
\hline B produkty rybactwa & 34 & 0,1 & 5,4 & 630 \\
\hline $\mathrm{C}$ produkty górnictwa & 20 & 0,0 & 0,1 & 22662 \\
\hline $\begin{array}{l}\text { D produkty przetwórstwa } \\
\text { przemysłowego }\end{array}$ & 25202 & 40,1 & 5,8 & 437250 \\
\hline $\begin{array}{l}\text { E energia elektryczna, gaz, para wodna } \\
\text { i woda }\end{array}$ & 5 & 0,0 & 0,0 & 48218 \\
\hline $\mathrm{F}$ roboty budowlane & 77 & 0,1 & 0,1 & 134185 \\
\hline \multicolumn{5}{|l|}{ G usługi w zakresie handlu hurtowego } \\
\hline $\mathrm{H}$ usługi hotelarskie i gastronomiczne & 229 & 0,4 & 1,2 & 19311 \\
\hline \multicolumn{4}{|l|}{ I usługi transportowe, magazynowe } & 103336 \\
\hline $\mathrm{J}$ usługi pośrednictwa finansowego & 6 & 0,0 & 0,0 & 36237 \\
\hline K usługi związane z nieruchomościami, & 91 & 0,1 & 0,1 & 165322 \\
\hline \multicolumn{4}{|l|}{ L usługi w zakresie administracji } & 59045 \\
\hline M usługi w zakresie edukacji & 6 & 0,0 & 0,0 & 38014 \\
\hline \multicolumn{3}{|l|}{$\mathrm{N}$ usługi w zakresie ochrony zdrowia } & 0,3 & 37826 \\
\hline \multicolumn{4}{|l|}{ O usługi komunalne pozostałe, } & 42593 \\
\hline $\mathrm{P}$ usługi gospodarstw domowych & 0 & 0,0 & 0,0 & 5 \\
\hline Razem zużycie pośrednie & 43928 & $\mathbf{7 0 , 0}$ & & 1353886 \\
\hline \multicolumn{4}{|l|}{ Zużycie pośrednie bez rolnictwa, } & \\
\hline \multicolumn{5}{|c|}{ Popyt końcowy: } \\
\hline$\overline{\text { Spożycie przez gospodarstwa domowe }}$ & 17702 & 28 & - & - \\
\hline Spożycie pozostałe & 5 & 0 & - & - \\
\hline Nakłady na środki trwałe & 66 & 0 & - & - \\
\hline Przyrost rzeczowy środków obrotowych & -1029 & -2 & - & - \\
\hline Eksport & 2118 & 3 & - & - \\
\hline Razem popyt końcowy & 18862 & 30 & 1,4 & - \\
\hline Ogółem zużycie pośrednie i popyt końcow & vy 62790 & 100 & 4,6 & - \\
\hline
\end{tabular}

Źródło: Opracowanie własne na podstawie [GUS 2004, Tablica: Bilans przepływów międzygałęziowych w bieżących cenach bazowych dla produkcji krajowej w 2000 r.]. 
na analizie przepływów międzygałęziowych, pisali m.in. [Woś 1998], [Czyżewski 2005a], [Kujaczyński 2007].) Czyżewski [2007a], badając związki rolnictwa z gospodarką, zauważa, że rolnictwo w warunkach rynkowych jest partnerem słabszym wobec pozarolniczego otoczenia z kilku powodów, do których zalicza:

- sztywność i ograniczoność popytu na produkty rolne (rolno-żywnościowe) oraz jego niską elastyczność względem dochodów w warunkach przymusu konsumpcji;

- wolniejszy wzrost popytu na produkty rolno-żywnościowe w stosunku do podaży, co jest bezpośrednią przyczyną spadku cen rolnych;

- wydłużony okres zwrotu zainwestowanego w produkcję rolniczą kapitału;

- osobliwości ekonomiczne czynnika ziemi związane z naturalnymi uwarunkowaniami produkcji żywności i potrzebą opłaty rent (różniczkowej, absolutnej i dobrostanu środowiska);

- preferowanie liberalnej optyki w procesie równoważenia rynku.

W pracach A. Czyżewskiego [2000] oraz A. Czyżewskiego i A. Grzelaka [2002] znajdujemy analizy związków rolnictwa z resztą gospodarki, które pokazują, jak różnego rodzaju reżimy polityki gospodarczej (monetarnej i fiskalnej) wpływają na sektor rolny (w UE i Polsce). Między innymi autorzy ci badają relację naprzemiennie występujących ekspansywnych i restrykcyjnych (defensywnych) reżimów obu polityk (tzw. zasadę wahadła). Związek tych polityk z sektorem rolnym wyjaśniany jest poprzez wzajemne relacje stóp procentowych, kursu walutowego, warunków handlu (terms of trade), nożyc cen w rolnictwie i parytetu dochodów rolniczych (w stosunku do pozarolniczych). Przy ekspansywnej polityce monetarnej spadek realnych stóp procentowych wywołuje wzrost krajowych cen rolnych oraz rolniczych środków produkcji. Jeśli nie ma korekty poprzez zwiększone wydatki rządowe, następuje tendencja do rozwierania się nożyc cen ze względu na wyższą elastyczność cenową i dochodową popytu na produkty pozarolnicze i szybsze tempo zwrotu z inwestycji poza rolnictwem. Towarzyszy temu deprecjacja waluty, a więc korzystne zmiany terms of trade dla produktów rolnych i w konsekwencji wzrost ich eksportu. W przypadku restrykcyjnej polityki monetarnej dochodzi do podwyższenia stóp procentowych i relatywnego spadku cen produktów rolniczych na rynku krajowym. Spadek ten jest jednak wolniejszy niż spadek cen rolniczych środków produkcji. Pojawia się zatem korzystne zwieranie nożyc cen, wynikające z bardziej sztywnego popytu na żywność niż na produkty nierolnicze. Pogorszeniu jednak ulegnie terms of trade dla produktów rolnych ze względu na aprecjację waluty krajowej. Bez dodatkowych wydatków rządowych nie ma gwarancji wzrostu popytu na żywność i nie ma też pewności co do wzrostu dochodów producentów rolnych. W przypadku ekspansywnej polityki fiskalnej rosną wydatki rządowe, m.in. na wsparcie produkcji i dochodów rolniczych, jednocześnie tanieją 
kredyty, co wywołuje wzrost popytu na środki produkcji i w efekcie wzrost ich cen. To prowadzi (ze względu na różne elastyczności cenowe i dochodowe popytu) do niekorzystnego rozwarcia nożyc cen. Wzrost dochodów producentów rolnych zależy wtedy od tego, jak kształtują się wydatki rządowe i czy ich alokacja wywołuje obniżkę kosztów jednostkowych bardziej niż proporcjonalnie od poniesionych nakładów i wzrost wydajności pracy. Jeśli tak jest, to wzrost dochodów ma wymiar realny. W przypadku restrykcyjnej polityki fiskalnej następuje ograniczenie wydatków i transferów rządowych, co pociąga za sobą spadek dochodów rolniczych i popytu na żywność. Ceny produktów rolniczych, jak też rolniczych środków do produkcji rolnej ulegają relatywnemu obniżeniu i dochodzi do zwierania nożyc cen.

Analizując powyższe zależności w praktyce np. dla Unii Europejskiej, A. Czyżewski [2007a] wykazał, że naprzemienne wzrosty i spadki stóp procentowych wywoływały korzystny dla rozwoju gospodarczego wzrost PKB. Jednak wpływało to negatywnie na nożyce cen produktów rolniczych, które się rozwierały (ceny środków do produkcji rolniczej rosły szybciej niż ceny produktów rolnych). Było to rezultatem tego, że w okresie wzrostu gospodarczego pozarolnicze sektory przystosowują się szybciej niż sektor rolny (gdyż ten charakteryzuje się nieelastycznością popytową i podażową, dłużej trwającym procesem produkcyjnym i niemobilnością czynników wytwórczych). Rozwieranie się nożyc cen nie determinowało jednak pogorszenia sytuacji dochodowej rolników, gdyż stwarzało presję na politykę, która przez interwencje w ramach Wspólnej Polityki Rolnej skutecznie rekompensowała ubytek dochodów. Jednak dla Polski trudniej było w praktyce uchwycić efekt wahadła.

Szukając powiązań rozwoju wsi z rozwojem reszty gospodarki, w ujęciu dynamicznym możemy próbować je ocenić na podstawie korzyści płynących dla wsi ze stabilnego wzrostu gospodarczego. Choć jasne jest, że gospodarka jako całość zyskuje na skutek wysokiej dynamiki PKB, to redystrybucyjne efekty tego procesu mogą być różne. Niektóre grupy ludności korzystają na nim bardziej niż inne. Dla pewnych grup nawet szybki wzrost gospodarczy może być neutralny lub wręcz negatywny [Gallaway 1971]. Niektórzy sądzą, że obszary wiejskie, ludność wiejska i rolnictwo nie zyskują na ogólnym wzroście gospodarki tyle, ile pozostałe sektory i grupy społeczne, a może wręcz tracą. Taka sytuacja powstała w Polsce na początku transformacji w latach 90., kiedy to szybkiemu wzrostowi gospodarczemu w latach 1992-1997 (średnio o 5,2\%) towarzyszył spadek globalnej produkcji rolniczej o 7,5\% (1991-1997), co przyczyniło się do utrzymywania dużego dysparytetu między dochodami ludności wiejskiej i miejskiej (parytet średnio wynosił 84,5\% w latach 1992-1997) [Woś 2000]. Było to jednak spowodowane burzliwą reakcją tego sektora na procesy urynkowienia (liberalizacji cen nakładów, liberalizacji cen produktów, zmiany ustrojowe i strukturalne), które spowodowały załamanie się zyskowności 
produkcji rolnej (wskaźnik nożyc cen, czyli stosunek indeksu cen produktów sprzedawanych przez rolników do indeksu towarów i usług nabywanych przez rolników w latach 1991-1997 wynosił średnio 98,6\%) [Woś 2000]. Jednak w latach 2004-2007, w czasie okresu ponownego szybkiego wzrostu gospodarczego (średnio $5,35 \%$ ), sektor rolniczy i przemysł rolno-spożywczy, które przeszły już w dużej mierze procesy dostosowania do Unii Europejskiej, odnosiły znaczne korzyści ze wzrostu całej gospodarki, czego dowodem były m.in. dynamiczny wzrost dochodów rolniczych (rys. 1.4), wzrost dynamiki eksportu produktów rolnych (eksport ten wzrósł o 18\% między 2004 a 2006 r.) i wyrobów przemysłu spożywczego (eksport ten wzrósł o 41\% między 2004 a 2006 r.) [Woś 2007].

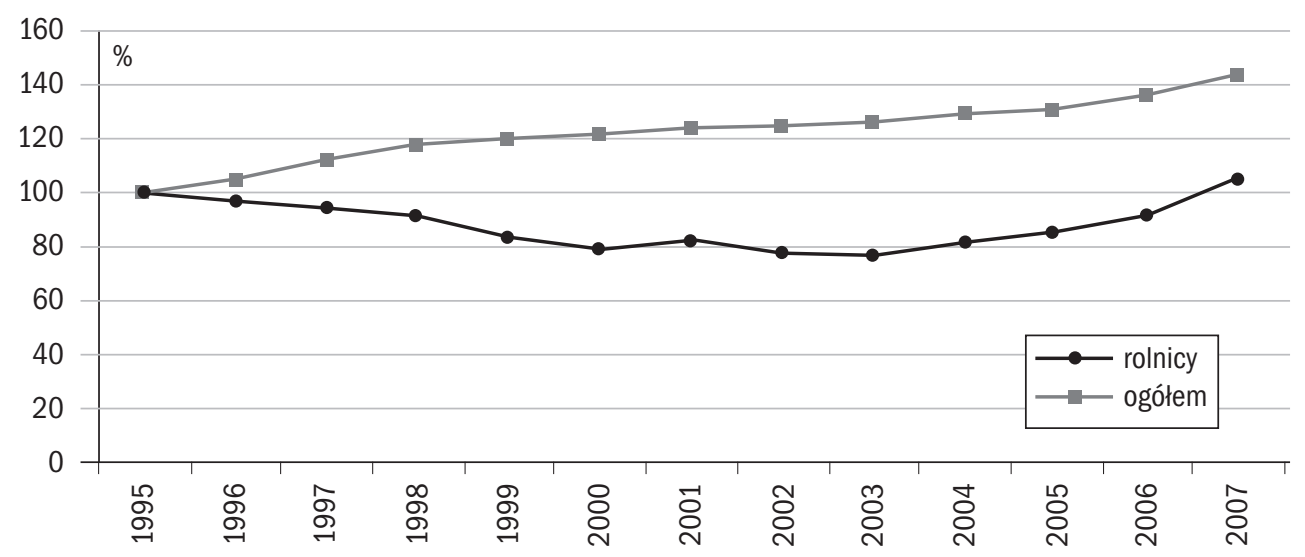

Rysunek 1.4. Dynamika realnych dochodów w gospodarstwach domowych ogółem i rolników w latach 1995-2007 [1995 = 100]

Źródło: [Zegar 2008a].

Na zmiany w tempie rozwoju gospodarczego wrażliwa jest również stopa bezrobocia na wsi. W latach przyspieszającego wzrostu gospodarczego (1992-1997), bezrobocie w kraju zaczynało spadać przy wzroście gospodarczym ok. 4\%, natomiast na wsi stopa bezrobocia reagowała spadkiem dopiero przy wzroście dynamiki PKB przekraczającym 5\% i spadek ten był wolniejszy niż średnio w gospodarce ${ }^{14}$ (rys. 1.5).

Natomiast na spadek dynamiki PKB (w latach 1998-2002), bezrobocie na wsi reagowało dużo szybciej niż pozostała część gospodarki, gdyż zaczynało rosnąć przy wzroście PKB poniżej 5\%. W kolejnej fazie przyspieszonej dynamiki PKB (2003-

\footnotetext{
14 Trzeba dodać, że nie uwzględniamy tu bezrobocia ukrytego na wsi, które mogło wpływać na jeszcze mniejszą wrażliwość bezrobocia na wsi na wzrost gospodarczy.
} 


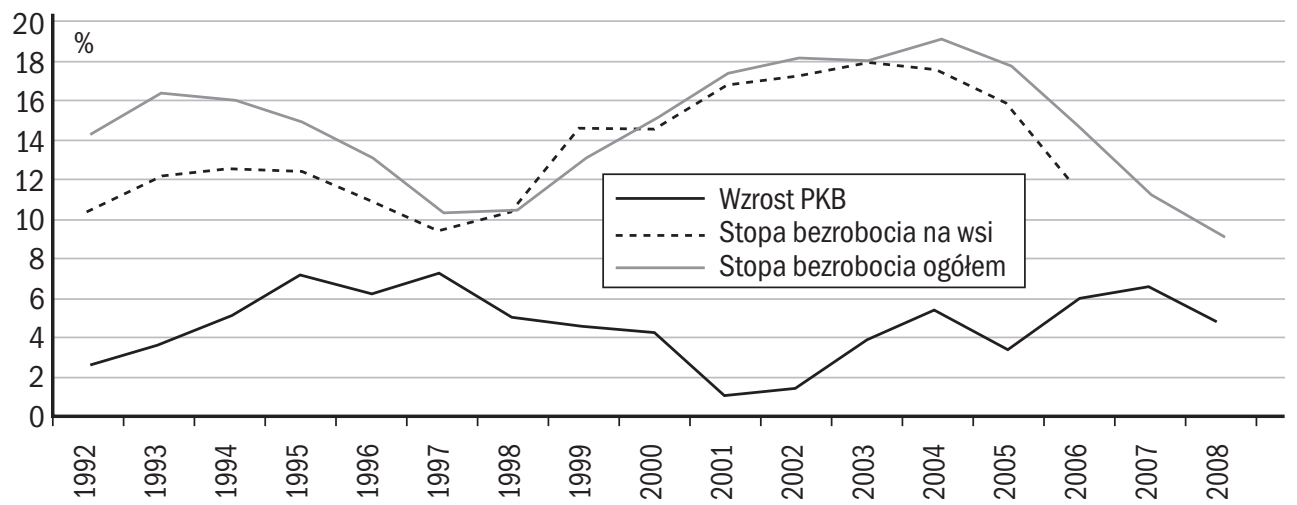

Rysunek 1.5. Wrażliwość bezrobocia (rejestrowanego) na zmiany tempa wzrostu gospodarczego w Polsce

Źródło: Opracowanie własne na podstawie BAEL z różnych lat.

2007) reakcje spadku stopy bezrobocia na wsi i w mieście upodobniły się. Uogólniając, można stwierdzić, iż stopa bezrobocia na wsi jest mocno skorelowana ze zmianami we wzroście gospodarczym, ale szybciej reaguje na załamanie się koniunktury niż na jej poprawę, porównując ze stopą bezrobocia ogółem. Trzeba zauważyć też, że nominalnie stopa bezrobocia na wsi była zawsze o kilka punktów procentowych niższa niż stopa bezrobocia w mieście (z wyjątkiem 1999 i 2003 r.).

\subsubsection{ROZWÓJ OBSZARÓW WIEJSKICH A ROZWÓJ ROLNICTWA}

W Polsce wieś nadal kojarzy się powszechnie z rolnictwem i o ile jest to trafne, gdy chodzi o zagospodarowanie powierzchni obszarów wiejskich, gdzie użytki rolne stanowią około 60\% powierzchni, o tyle udział rolników w społecznościach wiejskich i udział dochodów rolniczych w dochodach rodzin wiejskich szybko się kurczy. W 2006 roku tylko 15\% dochodów rodzin wiejskich pochodziło z rolnictwa, a ponad $50 \%$ gospodarstw domowych na wsi nie użytkowało ziemi rolniczej [Wilkin 2008a]. W debacie na temat znaczenia rolnictwa w rozwoju obszarów wiejskich można usłyszeć niejednokrotnie dwa skrajne stanowiska. Z jednej strony, to, że priorytetem dla Polski jest zabezpieczenie interesów rolnictwa i rolników, gdyż bez tego dalszy rozwój wsi jest niemożliwy. Z drugiej strony, zwolennicy radykalnych reform polityki rolnej sugerują wycofanie się ze wspierania rolnictwa na rzecz wspierania rozwoju obszarów wiejskich. Jednak, jak stwierdza Kłodziński [2006], przyszłość polskiej wsi zależy zarówno od dobrze prosperującego rolnictwa, jak i większej dywersyfikacji gospodarki wiejskiej. Dywersyfikacja gospodarki wiejskiej i wielofunkcyjny rozwój sta- 
ją się niezbędnym składnikiem polityki wiejskiej, zapewniającym dochody dla części tych, którzy z rolnictwa nie będą mogli się utrzymać. Nie należy więc dopatrywać się sprzeczności czy konkurencyjności między rozwojem rolnictwa a rozwojem obszarów wiejskich. Rozwój obszarów wiejskich kreujący nowe pozarolnicze miejsca pracy nie jest skierowany przeciw rolnikom. Z dywersyfikacji obszarów wiejskich i ich rozwoju skorzystają zarówno mniejsi, jak i więksi rolnicy. Więksi poprzez możliwość wykupu ziemi z małych gospodarstw, a mniejsi - znajdując lepiej płatną pracę w bardziej produktywnym sektorze na wsi lub małym miasteczku [Kłodziński 2006].

Rola rolnictwa na obszarach wiejskich w Polsce jest wciąż ważna, choć nieustannie się zmniejsza. Zatrudnienie ${ }^{15}$ w sektorze rolnym w 2007 r. wynosiło 14,7\% pracujących ogółem, podczas gdy w 2000 r. wynosiło ono 17,2\%, a w 1995 r. 26,0\% ${ }^{16}$. Wśród ludności wiejskiej zatrudnienie w rolnictwie wynosi 2239 tys., tj. 35,3\% ogółu pracujących mieszkających na wsi [BAEL 2008]. W istocie istnieje znaczne zróżnicowanie udziału rolnictwa w ogólnym zatrudnieniu ludności wiejskiej i waha się od zaledwie 1\% (powiat Izabelin, województwo mazowieckie) do 95\% (powiat Lipsk, województwo podlaskie). Rolnictwo jest ważnym lub dominującym źródłem zatrudnienia w mniej niż połowie obszarów wiejskich ${ }^{17}$. Jedynie w $3 \%$ obszarów wiejskich

Tabela 1.12. Zależność ludności wiejskiej od zatrudnienia w rolnictwie w ujęciu wojewódzkim

\begin{tabular}{|c|c|c|c|c|c|c|c|c|}
\hline & \multicolumn{2}{|c|}{ Typ 1 PW-PR } & \multicolumn{4}{|c|}{ Typ 2 PW-ZR } & \multicolumn{2}{|c|}{ Typ 4 ZW-PR } \\
\hline & Lubelskie & \begin{tabular}{|c|}
$\begin{array}{c}\text { Święto- } \\
\text { krzyskie }\end{array}$ \\
\end{tabular} & $\begin{array}{l}\text { Warm.- } \\
\text {-Mazur. }\end{array}$ & $\begin{array}{l}\begin{array}{l}\text { Wielko- } \\
\text { polskie }\end{array} \\
\end{array}$ & $\begin{array}{c}\text { Podkar- } \\
\text { packie }\end{array}$ & Lubuskie & Podlaskie & Łódzkie \\
\hline Średnia dla gmin & $62 \%$ & $55 \%$ & $43 \%$ & $41 \%$ & $40 \%$ & $27 \%$ & $71 \%$ & $52 \%$ \\
\hline Odch. Stand. & $13 \%$ & $20 \%$ & $12 \%$ & $13 \%$ & $15 \%$ & $10 \%$ & $16 \%$ & $15 \%$ \\
\hline Minimum & $21 \%$ & $6 \%$ & $15 \%$ & $4 \%$ & $7 \%$ & $6 \%$ & $13 \%$ & $5 \%$ \\
\hline Maximum & $88 \%$ & $87 \%$ & $64 \%$ & $80 \%$ & $85 \%$ & $53 \%$ & $95 \%$ & $85 \%$ \\
\hline \multirow[t]{3}{*}{ Liczba gmin } & 193 & 97 & 100 & 207 & 144 & 74 & 105 & 159 \\
\hline & \multicolumn{7}{|c|}{ Typ 5 ZW-ZR } & $\begin{array}{c}\text { Typ } 8 \\
\text { PM-ZR }\end{array}$ \\
\hline & $\begin{array}{l}\text { Mazo- } \\
\text { wieckie }\end{array}$ & \begin{tabular}{|c|} 
Kujawsko- \\
-Pomor.
\end{tabular} & $\begin{array}{l}\text { Mało- } \\
\text { polskie }\end{array}$ & Opolskie & \begin{tabular}{|c|}
$\begin{array}{c}\text { Zach.- } \\
\text { pomorskie }\end{array}$ \\
\end{tabular} & Pomorskie & $\begin{array}{l}\text { Dolno- } \\
\text { śląskie }\end{array}$ & Śląskie \\
\hline Średnia & $50 \%$ & $48 \%$ & $35 \%$ & $33 \%$ & $31 \%$ & $30 \%$ & $29 \%$ & $20 \%$ \\
\hline Odch. Stand. & $20 \%$ & $14 \%$ & $19 \%$ & $12 \%$ & $10 \%$ & $11 \%$ & $11 \%$ & $16 \%$ \\
\hline Minimum & $1 \%$ & $6 \%$ & $2 \%$ & $11 \%$ & $5 \%$ & $5 \%$ & $5 \%$ & $2 \%$ \\
\hline Maximum & $84 \%$ & $75 \%$ & $77 \%$ & $61 \%$ & $49 \%$ & $59 \%$ & $52 \%$ & $70 \%$ \\
\hline Liczba gmin & 279 & 127 & 166 & 68 & 103 & 98 & 133 & 118 \\
\hline
\end{tabular}

Źródło: Opracowanie własne na podstawie Spisu Rolnego 2002.

\footnotetext{
15 Dotyczy pracujących wyłącznie lub głównie w rolnictwie.

16 Trzeba pamiętać, że liczba ta odzwierciedla nie tylko odpływ faktyczny z rolnictwa, ale też zmianę metodologiczną liczenia zatrudnionych w rolnictwie, która wpływa na zmniejszenie liczby tam pracujących.

${ }^{17}$ Obszary wiejskie oznaczają gminy wiejskie oraz obszary wiejskie w gminach miejsko-wiejskich.
} 


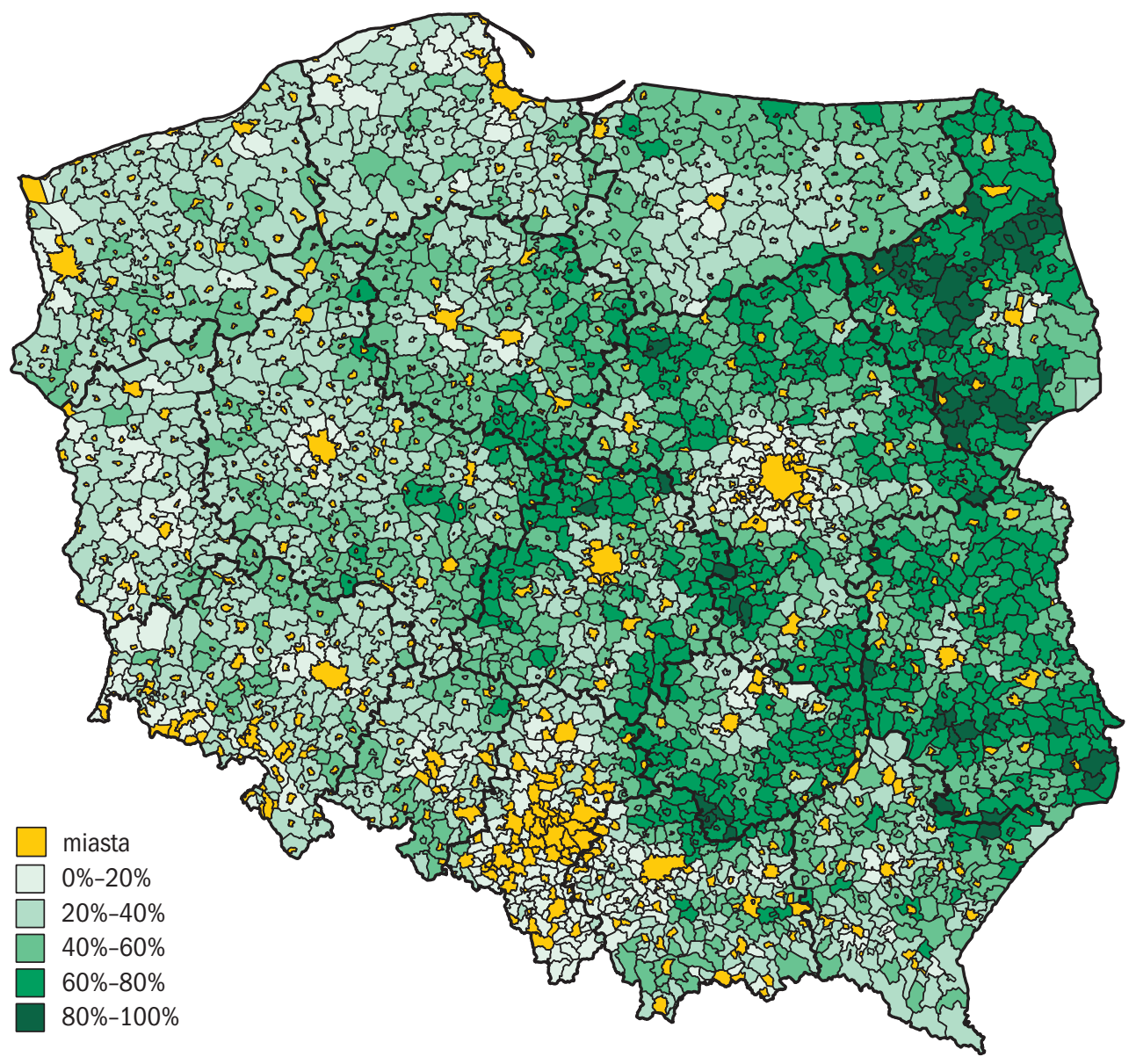

Mapa 1.5. Zatrudnienie ludności wiejskiej w rolnictwie Źródło: Opracowanie własne na podstawie Spisu Rolnego 2002.

udział rolnictwa w zatrudnieniu wynosi $80 \%$ lub więcej. Sytuacja zróżnicowana jest także między gminami tego samego województwa. Najwyższa dyspersja pod względem zatrudnienia w rolnictwie występuje w województwach świętokrzyskim (od 6\% do $87 \%$ ), mazowieckim (od 1\% do 84\%) oraz małopolskim (od 2\% do 77\%). A więc nawet regiony PR (przeważająco rolnicze) wykazują duże zróżnicowanie pod względem uzależnienia od rolnictwa (tab. 1.12).

Najwyższe uzależnienie ludności wiejskiej od rolnictwa występuje w środkowej i wschodniej części Polski, czyli na terenach historycznego zaboru rosyjskiego, co obrazuje mapa 1.5 . 
Związki pomiędzy rolnictwem i rozwojem ekonomicznym obszarów wiejskich ulegają osłabieniu, dlatego próby rozwiązania ekonomicznych problemów wsi poprzez koncentrację wsparcia finansowego na rolnictwie nie obiecują stworzenia optymalnej strategii dla obszarów wiejskich w przyszłości. Polityka wiejska powinna koncentrować się na tym, w jakich sferach i w jaki sposób zdynamizować proces pod-

Tabela 1.13. Zatrudnienie ludności wiejskiej według grup PKD w 2002 r.

\begin{tabular}{|c|c|c|c|}
\hline Ranking & Ogółem (mieszkańcy wsi) & $100 \%$ & 5078425 \\
\hline \multirow[t]{7}{*}{1} & Rolnictwo, lowiectwo i leśnictwo & $41 \%$ & 2070165 \\
\hline & Rolnictwo & $40 \%$ & 2028565 \\
\hline & Łowiectwo i leśnictwo & $1 \%$ & 41600 \\
\hline & Rybołówstwo i rybactwo & $\mathbf{0} \%$ & 4392 \\
\hline & Górnictwo i kopalnictwo & $1 \%$ & 60987 \\
\hline & Górnictwo i kopalnictwo surowców energetycznych & $1 \%$ & 46833 \\
\hline & Górnictwo i kopalnictwo surowców innych niż energetyczne & $0 \%$ & 14154 \\
\hline 2 & Przetwórstwo przemysłowe & $17 \%$ & 871975 \\
\hline \multirow[t]{15}{*}{$2 \mathrm{a}$} & Produkcja artykułów spożywczych, napojów i wyrobów tytoniowych & $4 \%$ & 203220 \\
\hline & Produkcja wyrobów włókienniczych i odzieży & $2 \%$ & 107782 \\
\hline & Produkcja skór wyprawionych i wyrobów ze skór wyprawionych & $0 \%$ & 20289 \\
\hline & Produkcja drewna i wyrobów z drewna & $2 \%$ & 95198 \\
\hline & $\begin{array}{l}\text { Produkcja masy włóknistej, papieru oraz wyr. z pap.; działalność } \\
\text { publikacyjna i poligraficzna }\end{array}$ & $1 \%$ & 25839 \\
\hline & Wytwarzanie koksu, produktów rafinacji ropy naftowej i paliw jądrowych & $0 \%$ & 3579 \\
\hline & Produkcja wyrobów chemicznych & $1 \%$ & 28630 \\
\hline & Produkcja wyrobów gumowych i z tworzyw sztucznych & $1 \%$ & 27459 \\
\hline & Produkcja wyrobów z surowców niemetalicznych pozostałych & $1 \%$ & 60111 \\
\hline & Produkcja metali i wyrobów z metali & $2 \%$ & 77911 \\
\hline & Produkcja maszyn i urządzeń, gdzie indziej nie sklasyfikowana & $1 \%$ & 49707 \\
\hline & Produkcja urządzeń elektrycznych i optycznych & $1 \%$ & 41373 \\
\hline & Produkcja sprzętu transportowego & $1 \%$ & 43681 \\
\hline & Produkcja, gdzie indziej nie sklasyfikowana & $2 \%$ & 87196 \\
\hline & Wytwarzanie i zaopatrywanie w energię elektryczną, gaz i wodę & $1 \%$ & 48914 \\
\hline 4 & Budownictwo & $\mathbf{5 , 5} \%$ & 277453 \\
\hline \multirow[t]{2}{*}{3} & $\begin{array}{l}\text { Handel hurtowy i detaliczny; naprawa pojazdów oraz artykułów użytku } \\
\text { osobistego i domowego }\end{array}$ & $10 \%$ & 499011 \\
\hline & Hotele i restauracje & $1 \%$ & 68946 \\
\hline \multirow[t]{3}{*}{5} & Transport, gospodarka magazynowa i lączność & $4,7 \%$ & 236916 \\
\hline & Pośrednictwo finansowe & $1 \%$ & 48901 \\
\hline & $\begin{array}{l}\text { Obsługa nieruchomości, wynajem, nauka i usługi związane z prowadzeniem } \\
\text { dział. gosp. }\end{array}$ & $2 \%$ & 107151 \\
\hline \multirow[t]{7}{*}{5} & $\begin{array}{l}\text { Administracja publiczna i obrona narodowa, obowiązkowe ubezpieczenia } \\
\text { spoleczne i zdrowotne }\end{array}$ & $4,7 \%$ & 238385 \\
\hline & Edukacja & $4,4 \%$ & 225844 \\
\hline & Ochrona zdrowia i opieka społeczna & $4,0 \%$ & 202289 \\
\hline & Pozostała działalność usługowa komunalna, społeczna i indywidualna & $2 \%$ & 98853 \\
\hline & Gospodarstwa domowe zatrudniające pracowników & $\mathbf{0} \%$ & 2857 \\
\hline & Organizacje i zespoly eksterytorialne & $\mathbf{0} \%$ & 23 \\
\hline & Nieustalony rodzaj działalności & $\mathbf{0} \%$ & 15363 \\
\hline
\end{tabular}

Żródło: Obliczenia własne na podstawie wyników Spisu Powszechnego 2002. 
noszenia produktywności regionów wiejskich, zgodnie z podejściem opartym na przewagach komparatywnych, co postulują różni autorzy [m.in. Porter, Ketels i in. 2004]. Dlatego ważnym zadaniem jest określenie, które rodzaje sektorów produkcji przemysłowej i usług będą w przyszłości potencjalnym pracodawcą na obszarach wiejskich.

Jak zaznaczono już w rozdziale 1.1.3, najwyższy udział w zatrudnieniu ludności wiejskiej po „Rolnictwie, łowiectwie i leśnictwie”, ma „Przetwórstwo przemysłowe”, „Handel i naprawy”, a następnie „Budownictwo”, „Administracja publiczna”, „Transport” i „Edukacja”. Tabela 1.13 przedstawia w nieco bardziej szczegółowym niż poprzednio ujęciu (na podstawie danych Spisu Powszechnego 2002) zatrudnienie ludności wiejskiej w różnych sektorach gospodarki, według grup PKD.

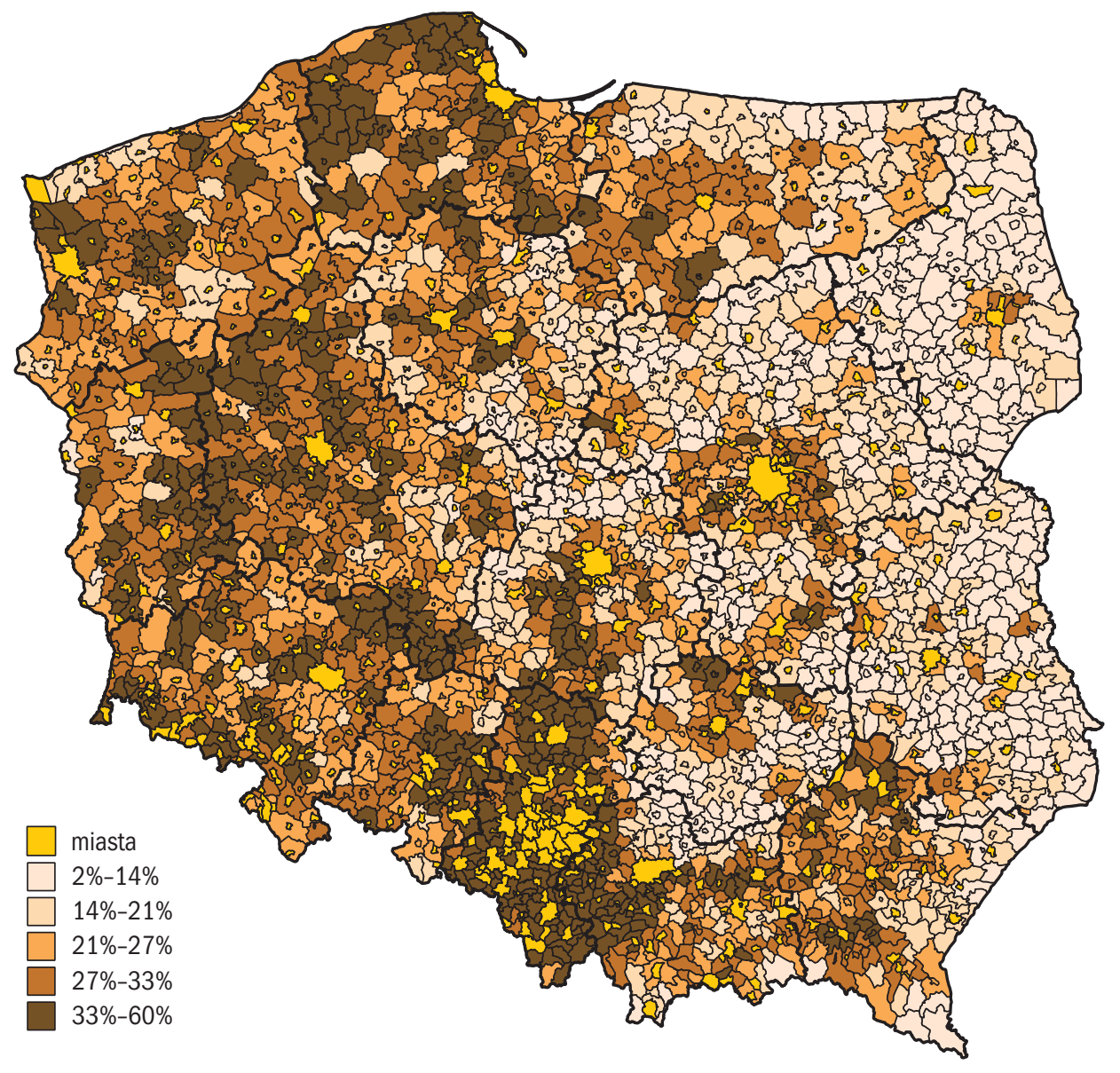

Mapa 1.6. Zatrudnienie ludności wiejskiej w przemyśle

Źródło: Opracowanie własne na podstawie Spisu Rolnego 2002. 
Obszary wiejskie najbardziej uzależnione od działalności pozarolniczej znajdują się w zachodniej, północnej i południowej części Polski. W dużym stopniu można to tłumaczyć uwarunkowaniami historycznymi. W przeszłości część zachodnia i północna znajdowała się przez długi czas pod zaborem pruskim (Niemcy), a południowa pod austriackim. Innym typem regionów wiejskich, które z powodzeniem konkurują w działalności produkcyjnej, są te położone w pobliżu największych miast (takich jak Warszawa, Łódź, Katowice, Poznań, Kraków, Gdańsk, Gdynia) oraz wokół regionów górniczych. Zatrudnienie ludności wiejskiej w przemyśle przedstawia mapa 1.6.

Większość obszarów wiejskich nastawionych na działalność usługową znajduje się wokół miast (szczególnie tych będących stolicami województw), wzdłuż tras

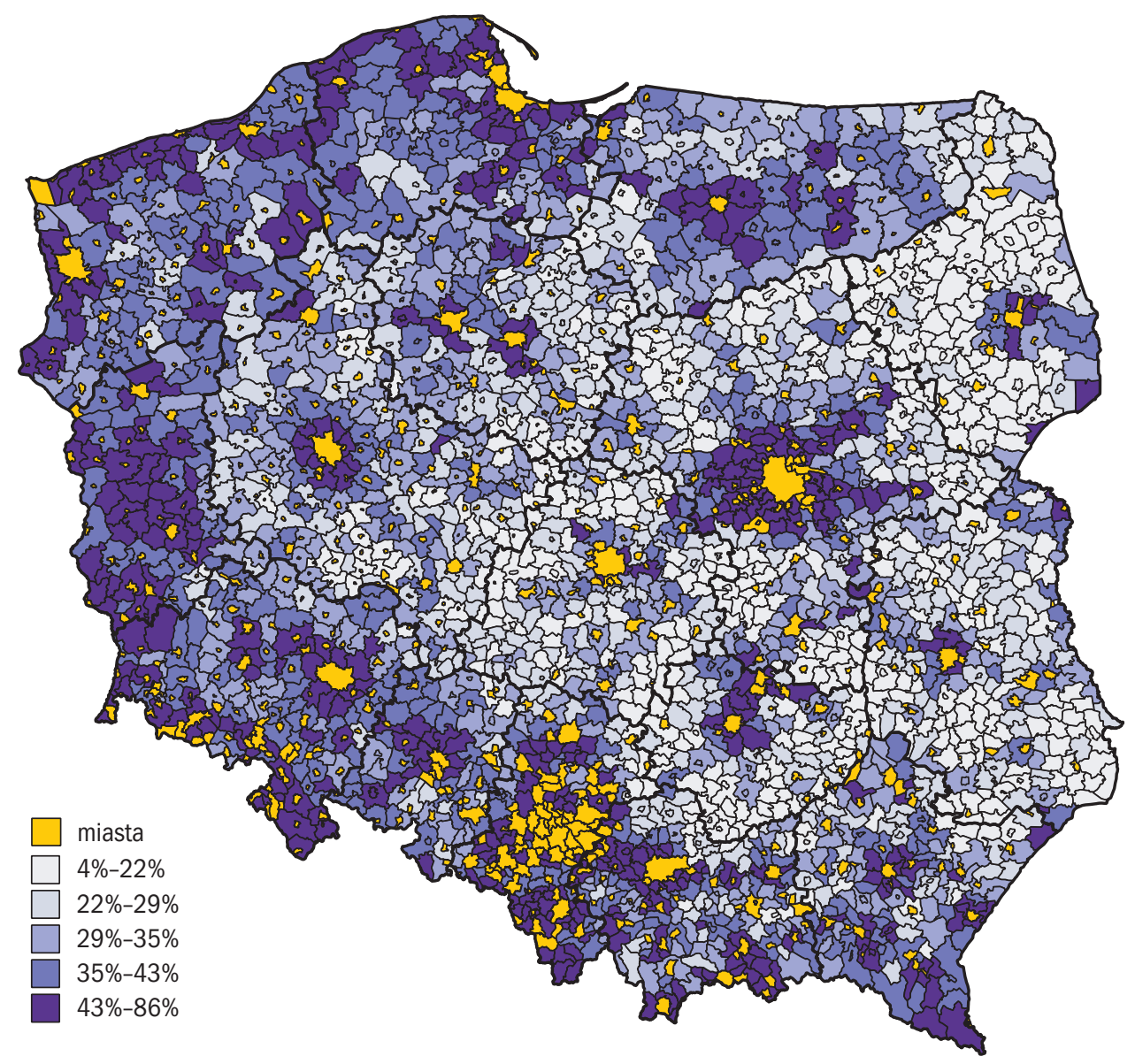

Mapa 1.7. Zatrudnienie ludności wiejskiej w usługach Źródło: Obliczenia własne na podstawie Spisu Rolnego 2002. 


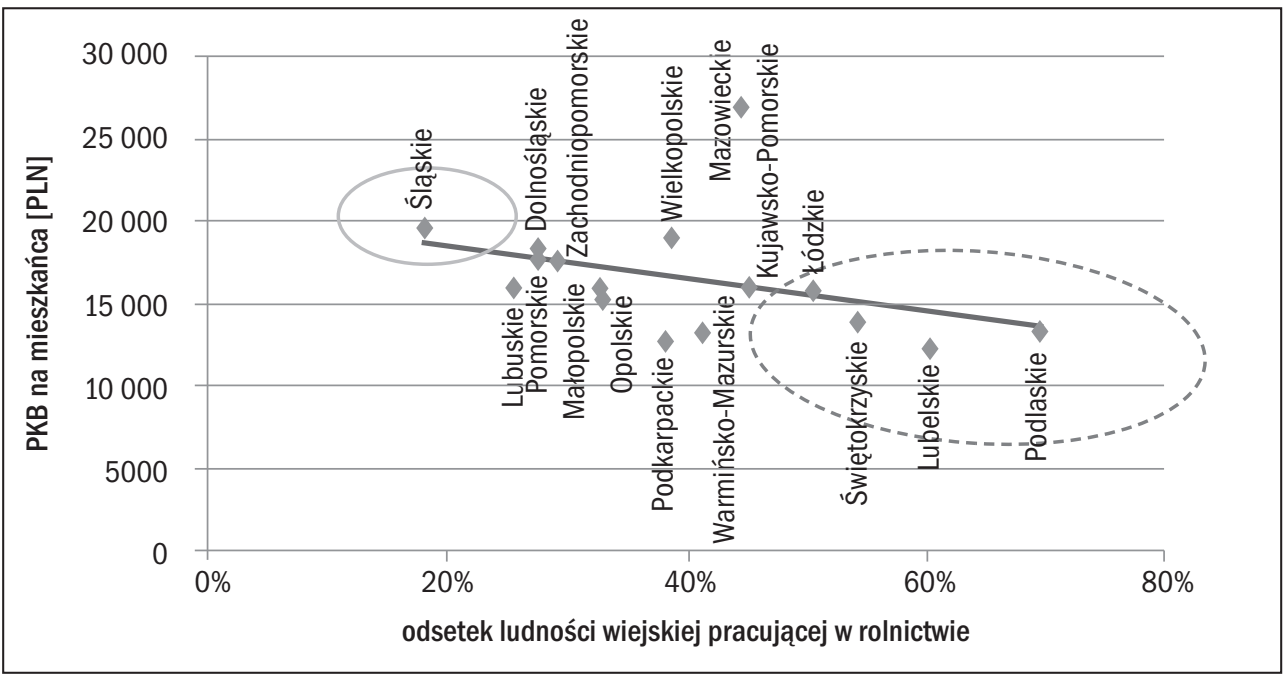

Rysunek 1.6. Związek pomiędzy zamożnością województw a uzależnieniem ekonomicznym od rolnictwa w $2002 \mathrm{r}$.

Źródło: Obliczenia własne na podstawie Spisu Rolnego 2002.

komunikacyjnych, w rejonach turystycznych (nad morzem, w górach, nad jeziorami itp.) oraz wzdłuż granic kraju (w mniejszym stopniu wzdłuż granicy wschodniej). Dobrze ilustruje to mapa 1.7 .

Związek pomiędzy rolnictwem a obszarami wiejskimi nie jest tak oczywisty, jak mogłoby się to wydawać. Z jednej strony województwa bardziej zależne od rolnictwa są nadal biedniejsze od pozostałych. Obserwujemy negatywny związek między PKB na mieszkańca w danym regionie a udziałem ludności wiejskiej pracującej (głównie lub wyłącznie) w rolnictwie (rys. 1.6). Po lewej stronie na rysunku znalazły się najbardziej zurbanizowane województwa, w tym m.in. śląskie (przeważająco miejskie), w którym jest wyraźnie wyższy dochód na mieszkańca niż w województwach po prawej stronie, które są przeważająco rolnicze (podlaskie, lubelskie, świętokrzyskie i łódzkie).

Sytuacja ta jest wynikiem niższej produktywności rolnictwa w porównaniu z innymi sektorami, więc jeżeli rolnictwo zbliży się do innych sektorów pod względem produktywności, to powinno mieć pozytywny wkład w dobrobyt regionów i obszarów wiejskich. Dowody tego pozytywnego wpływu wysoko efektywnego rolnictwa na zamożność regionów rolniczych można łatwo zaobserwować. Jako miarę efektywności można przyjąć stosunek wartości dodanej brutto do zużycia pośredniego jak proponują W. Poczta i A. Mrówczyńska [2002]. Regionalne 
zróżnicowanie efektywności nakładów w rolnictwie do efektywności całej gospodarki policzone według tej miary pokazuje tabela 1.14.

W przypadku województw najbardziej rolniczych (przeważająco rolniczych), tj. podlaskiego, lubelskiego, świętokrzyskiego i łódzkiego, możemy stwierdzić następującą zależność: im mniejsza jest różnica w efektywności rolnictwa w stosunku do innych sektorów gospodarki, tym region jest bogatszy. Zależność tę lepiej obrazuje rysunek 1.7. Analiza ta potwierdza zatem nasze oczekiwania, że efektywne rolnictwo powinno pozytywnie wpływać na poziom bogactwa regionów w znacznym stopniu od niego uzależnionych.

Tabela 1.14. Efektywność nakładów w rolnictwie polskim według województw w 2000 i 2006 r.

\begin{tabular}{|c|c|c|c|c|c|c|}
\hline \multicolumn{5}{|c|}{$\begin{array}{c}\text { Efektywność nakładów } \\
\text { wartość dodana brutto/zużycie pośrednie }\end{array}$} & \multicolumn{2}{|c|}{ Relatywna efektywność } \\
\hline Wyszczególnienie & $\begin{array}{c}\text { w rolnictwie } \\
2000\end{array}$ & $\begin{array}{c}\text { w calej } \\
\text { gospodarce } \\
\text { województwa } \\
2000\end{array}$ & $\begin{array}{c}\text { w rolnictwie } \\
2006\end{array}$ & $\begin{array}{c}\text { w calej } \\
\text { gospodarce } \\
\text { województwa } \\
2006\end{array}$ & $\begin{array}{c}\text { rolnictwa } \\
\text { do całej } \\
\text { gospodarki } \\
2000\end{array}$ & $\begin{array}{c}\text { rolnictwa } \\
\text { do całej } \\
\text { gospodarki } \\
2006\end{array}$ \\
\hline Rok 2000 & A00 & B00 & A06 & B06 & $\begin{array}{c}\mathrm{CO0}= \\
\mathrm{A} 00 / \mathrm{B} 00\end{array}$ & $\begin{array}{c}\text { C06= } \\
\text { A06/B06 }\end{array}$ \\
\hline POLSKA & 0,73 & $\mathbf{0 , 8 1}$ & 0,79 & 0,84 & 0,90 & 0,94 \\
\hline Dolnośląskie & 0,67 & 0,77 & 0,62 & 0,69 & 0,86 & 0,90 \\
\hline Kujawsko- & & & & & & \\
\hline -Pomorskie & 0,69 & 0,82 & 0,76 & 0,77 & 0,85 & 0,99 \\
\hline Lubelskie & 0,55 & 0,9 & 0,58 & 0,90 & 0,60 & 0,65 \\
\hline Lubuskie & 0,73 & 0,83 & 0,67 & 0,76 & 0,88 & 0,88 \\
\hline Łódzkie & 0,72 & 0,91 & 0,89 & $\mathbf{0 , 8 1}$ & 0,79 & 1,09 \\
\hline Małopolskie & 0,63 & 0,8 & 0,75 & 0,83 & 0,79 & 0,91 \\
\hline Mazowieckie & 1,05 & 0,78 & 1,18 & $\mathbf{0 , 7 0}$ & 1,35 & 1,69 \\
\hline Opolskie & 0,6 & 0,76 & 0,62 & 0,76 & 0,80 & 0,82 \\
\hline Podkarpackie & 0,49 & 0,81 & 0,48 & 0,78 & 0,61 & 0,61 \\
\hline Podlaskie & 0,57 & 0,88 & 0,76 & 0,81 & 0,64 & 0,94 \\
\hline Pomorskie & 0,57 & 0,78 & 0,64 & 0,68 & 0,73 & 0,94 \\
\hline Śląskie & 1,00 & 0,78 & 0,70 & 0,69 & 1,29 & 1,02 \\
\hline Świętokrzyskie & 0,74 & 0,84 & 0,84 & 0,83 & 0,88 & 1,01 \\
\hline Warmińsko- & & & & & & \\
\hline -Mazurskie & 0,81 & 0,88 & 0,79 & 0,80 & 0,93 & 0,99 \\
\hline Wielkopolskie & 0,79 & $\mathbf{0 , 8 2}$ & $\mathbf{0 , 8 1}$ & 0,72 & 0,97 & 1,13 \\
\hline $\begin{array}{l}\text { Zachodnio- } \\
\text { pomorskie }\end{array}$ & 0,75 & 0,88 & 0,74 & 0,88 & 0,85 & 0,85 \\
\hline
\end{tabular}

Žródło: Obliczenia na podstawie [Poczta i Mrówczyńska 2002] oraz [BDR 1999-2007], [GUS 2006b].

Analizując dane obrazujące relację efektywności nakładów w rolnictwie do wydajności nakładów w całej gospodarce w 2006 r., można stwierdzić, że w grupie województw przeważająco rolniczych 1 złotówka nakładu w rolnictwie przy- 


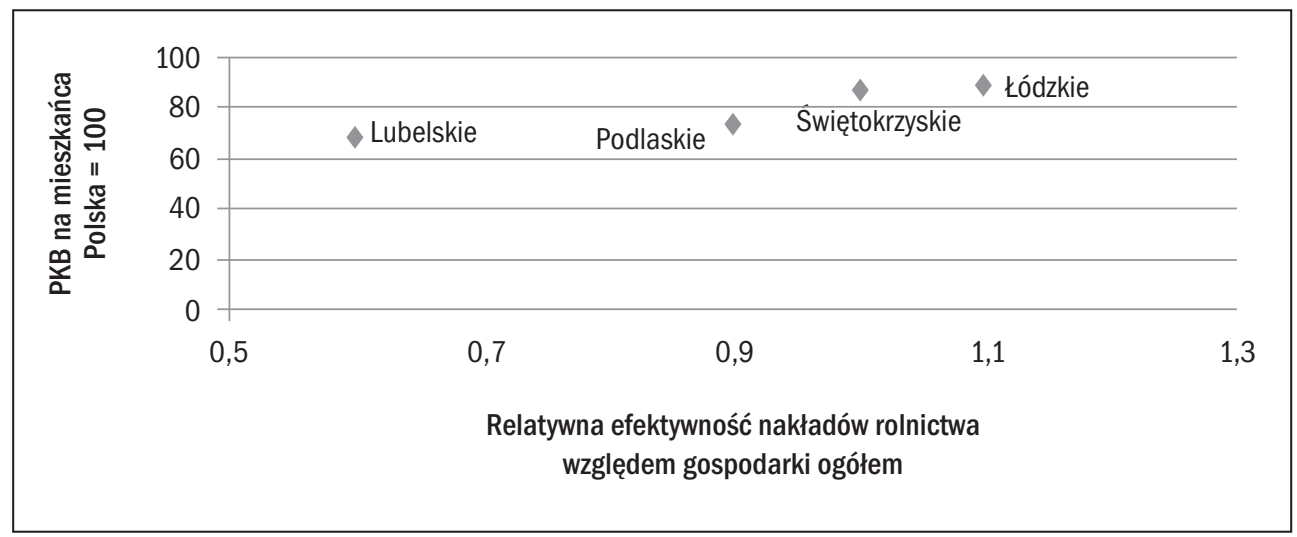

Rysunek 1.7. Zależność między efektywnością nakładów w rolnictwie a zamożnością województw o charakterze przeważająco rolniczym w 2006 r.

Źródło: Opracowanie własne na podstawie [GUS 2008a] i tabeli 1.14.

nosiła wartość dodaną brutto w wysokości $0,5 \mathrm{zł}$ w województwie lubelskim, $0,76 \mathrm{zł} \mathrm{w}$ podlaskim, $0,84 \mathrm{zł}$ w świętokrzyskim i $0,89 \mathrm{zł}$ w łódzkim. Średnio dla Polski wielkość ta w rolnictwie wynosiła 0,79 zł (tab. 1.14). Jest to sytuacja niekorzystna, ponieważ oznacza, iż regiony te specjalizują się w produkcji sektora, który jest przeciętnie około $15 \%$ mniej efektywny niż średnio wszystkie sektory razem. Regionami, w których efektywność nakładów pośrednich w rolnictwie jest zdecydowanie wyższa niż efektywność tych nakładów dla wszystkich sektorów gospodarki, są tylko województwa: mazowieckie (relacja ta wynosi 1,69) i wielkopolskie (relacja wynosi 1,13). Oba regiony są znacząco rolnicze, ale nie przeważająco rolnicze. Jest jednak jeden region, w którym efektywność rolnictwa jest podobnie niska, jak w województwie lubelskim. Jest to województwo podkarpackie, które należy do województwo znacząco rolniczych. Chociaż jego sytuacja gospodarcza jest nieco lepsza, ponieważ inne sektory kompensują nieefektywność występującą w rolnictwie, niska efektywność w tym sektorze bez wątpienia przyczynia się tam do niskiego PKB na mieszkańca (rys. 1.8). Tak więc, o ile efektywne sektory zwiększają poziom bogactwa regionu, o tyle nieefektywny sektor rolny wpływa negatywnie na ten poziom. Skala tego wpływu zależy od znaczenia sektora rolnego w gospodarce regionu.

Niepokój budzi nie tylko skala względnej nieefektywności i niskiej produktywności sektora rolnego w gospodarce wiejskiej, lecz także trwałość tego zjawiska. W ostatniej dekadzie produktywność (pracy) mierzona jako stosunek udziału rolnictwa w PKB do udziału rolnictwa w zatrudnieniu nadal kształtuje się poniżej 1/3 (w roku 1995 stosunek ten wynosił 0,31, a w latach 2003-2007 średnio 0,29), 


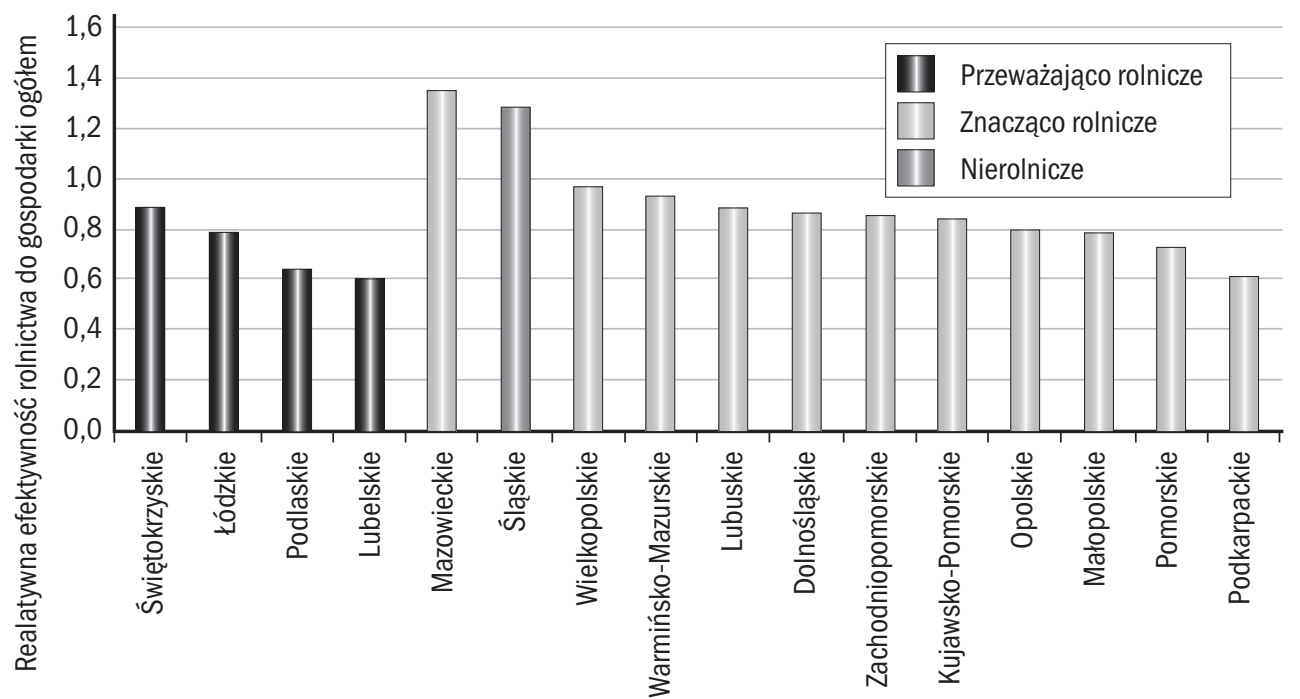

Rysunek 1.8. Relatywna efektywność nakładów w rolnictwie według typów regionów w 2000 r. Źródło: Opracowanie własne na podstawie tabeli 1.14, kolumna C00.

podczas gdy w sektorze przemysłowym i budowlanym relacja ta kształtowała się w tym okresie średnio powyżej 1 .

Widoczne są jednak nieznaczne sygnały zmniejszania się luki pomiędzy sektorem rolnym i przemysłowym - różnica między tymi sektorami zmniejszyła się z 0,81 (w 1995) do 0,78 (w 2007). Powiększa się jednak różnica w efektywności pracy między sektorem rolnym a budowlanym: w 1995 r. wynosiła 0,87, a w 2007 r. już 0,95.

Kluczowym elementem w związkach rolnictwa z rozwojem obszarów wiejskich jest zatem poprawa produktywności rolnictwa. Warto więc przytoczyć badania, które dogłębnie analizowały determinanty poprawy lub braku produktywności, efektywności i konkurencyjności polskiego rolnictwa. Problemem tym zajmowało się wielu autorów [Woś 2001a, 2001b], [Kulawik 2008], [Poczta 2003], [Adamowicz i Guzal-Dec 2005], [Davidova, Gorton, Ratinger i in. 2006], [Latruffe, Balcombe, Davidova i in. 2005], [Davidova, Gorton, Ratinger i in. 2005], [Mańko, Sobczyński i Sass 2007], [Orłowski 1996], [Wiatrak 1980, Osuch 1999], [Nieć 1999] i inni. Z badań empirycznych autorki wynika, że w latach 1996-2000 tylko około 30\% indywidualnych gospodarstw rolnych było efektywnych [Zawalińska, 2004a $]^{18}$. Głównymi powodami nieefektywności, zidentyfikowanymi na podstawie

\footnotetext{
${ }^{18}$ Efektywność określana była na podstawie dekompozycji wskaźnika produktywności całkowitej (Total Factor Productivity, TFP) mierzonego metodami nieparametrycznymi Data Envelopment Analysis (DEA).
} 
Tabela 1.15. Różnica między produktywnością pracy w rolnictwie a przemyśle i budownictwie w latach 1995-2007

\begin{tabular}{|c|c|c|c|c|c|c|c|}
\hline Wyszczególnienie & 1995 & 2003 & 2004 & 2005 & 2006 & 2007 & $\begin{array}{l}\text { Średnia } \\
2003 \\
-2007\end{array}$ \\
\hline A. Udział rolnictwa w PKB & 8,00 & 4,40 & 5,10 & 4,60 & 4,20 & 4,30 & \\
\hline B. Udział rolnictwa w zatrudnieniu & 26,00 & 16,10 & 16,00 & 15,90 & 15,70 & 15,20 & \\
\hline C. Produktywność pracy w sektorze & & & & & & & \\
\hline rolniczym $(C=A / B)$ & 0,31 & 0,27 & 0,32 & 0,29 & 0,27 & 0,28 & 0,29 \\
\hline D. Udział przemysłu w PKB & 28,40 & 23,80 & 25,30 & 24,70 & 24,70 & 24,50 & \\
\hline E. Udział przemysłu w zatrudnieniu & 25,50 & 22,90 & 23,20 & 22,90 & 22,90 & 23,10 & \\
\hline $\begin{array}{l}\text { F. Produktywność pracy w sektorze } \\
\text { przemysłu }(F=D / E)\end{array}$ & 1,11 & 1,04 & 109 & 108 & 108 & 106 & 107 \\
\hline G. Udział budownictwa w PKB & 6,70 & 5,80 & 5,50 & 6,10 & 6,40 & 7,30 & \\
\hline $\begin{array}{l}\text { H. Udział budownictwa } \\
\text { w zatrudnieniu } \\
\text { I. Produktywność pracy w sektorze }\end{array}$ & 5,70 & 5,50 & 5,10 & 5,20 & 5,40 & 5,90 & \\
\hline $\begin{array}{l}\text { 1. Produktywnosc pracy w sektorze } \\
\text { budowlanym }(\mathrm{I}=\mathrm{G} / \mathrm{H})\end{array}$ & 1,18 & 1,05 & 1,08 & 1,17 & 1,19 & 1,24 & 1,15 \\
\hline $\begin{array}{l}\text { J. Różnica między rolnictwem } \\
\text { a przemysłem (J=F-C) } \\
\text { K. Różnica miedzy rolnictwem }\end{array}$ & 0,81 & 0,77 & 0,77 & 0,79 & 0,81 & 0,87 & 0,78 \\
\hline a budownictwem $(\mathrm{K}=\mathrm{I}-\mathrm{C})$ & 0,87 & 0,78 & 0,76 & 0,88 & 0,92 & 0,95 & 0,86 \\
\hline
\end{tabular}

Żródło: Obliczenia własne na podstawie [GUS 2008a].

analizy czynnikowej, były: duże rozdrobnienie gospodarstw, przewaga starego parku maszynowego, słabości w zarządzaniu, niski poziom edukacji oraz niska jakość ziemi. Analiza klastrów (skupień) pozwoliła na wyodrębnienie 7 grup gospodarstw rolnych według stopnia produktywności i cech homogenicznych grupy, z których najbardziej produktywna okazała się grupa relatywnie dużych gospodarstw (53 ha - średnia wielkość gospodarstw) produkujących zboża, wykazujących najniższy współczynnik zatrudnienia na hektar ( 1 os./36 ha). Gospodarstwa te charakteryzowały się też najwyższym odsetkiem wysokiej jakości ziemi (30\% gospodarstw w klasterze), wysokim odsetkiem osób z wyższym wykształceniem prowadzących gospodarstwo (19,4\%) oraz uprawiających głównie własną ziemię (niski odsetek ziemi dzierżawionej 13,8\%). Z kolei W. Rembisz [2007, 2008], posługując się teoretycznym modelem analitycznym, pokazał poprzez równania matematyczne mikroekonomiczne zależności między produktywnością i efektywnością a zmianami dochodów producentów rolnych.

Podsumowując, z analizy wynika, że rolnictwo może przyczyniać się do istotnego rozwoju wsi jedynie wówczas, gdy jest konkurencyjne w stosunku do innych sektorów gospodarki, czyli gdy jest produktywne. Takie rolnictwo ma szanse mieć pozytywny wkład w rozwój regionalnych gospodarek i pozytywny wpływ na obszary wiejskie. W przeciwnym razie nie zapewni wystarczających dochodów lud- 
ności rolniczej. Wzrost produktywności oznacza między innymi konieczność zmniejszenia udziału ludności wiejskiej zaangażowanej w produkcji rolnej, ponieważ spadek jej udziału w PKB jest nieunikniony wraz z rozwojem ogólnym gospodarki. Tak więc, z jednej strony, konieczne są wysiłki w celu zwiększenia produktywności rolnictwa, tam gdzie jest to możliwe, przy uwzględnieniu naturalnych ograniczeń wzrostu produktywności całkowitej tego sektora, wynikających ze specyfiki czynnika ziemi czy jego niepożądanych skutków dla środowiska (należy zachować równowagę rolno-środowiskową) etc. Z drugiej strony, polityka powinna koncentrować się na przyciąganiu na obszary wiejskie bardziej produktywnych sektorów, stwarzających nowe możliwości zatrudnienia ludności wiejskiej.

\subsubsection{ROZWÓJ OBSZARÓW WIEJSKICH A ROZWÓJ ZRÓWNOWAŻONY}

Pojęcie rozwoju zrównoważonego (sustainable development) po raz pierwszy zostało użyte podczas zorganizowanego przez ONZ szczytu poświęconemu ochronie środowiska w Sztokholmie w 1972 r. Tam też po raz pierwszy zwrócono uwagę, że zasadniczą cechą trwałego i zrównoważonego rozwoju jest odpowiedni stosunek do środowiska przyrodniczego [Piontek 2002]. W formie pisanej pojęcie „zrównoważoności” pojawiło się w artykule zatytułowanym A Blueprint for Survival, opublikowanym na potrzeby tego szczytu w tym samym roku [Ecologist 1972].

Ważna dla zdefiniowania i popularyzacji pojęcia rozwoju zrównoważonego była działalność Światowej Komisji Środowiska i Rozwoju (World Commission on Environment and Development), a przede wszystkim jej publikacja pt. „Nasza Wspólna Przyszłość” (Our Common Future), znana lepiej pod nazwą Raport Brundtlanda, wydana w 1987 r. Zawiera najbardziej rozpowszechnioną obecnie definicję tego pojęcia, mówiąca, że rozwój zrównoważony jest rozwojem, który zaspokaja potrzeby obecnej generacji, nie zmniejszajac możliwości zaspokajania potrzeb przysztych pokoleń (Brundtland 1987, s. 43).

Początkowo termin ten odnosił się wyłącznie do środowiska naturalnego i ekologii, dopiero z czasem objął swoim znaczeniem także sferę ekonomii i systemu społecznego. Duży wpływ na to miała Konferencja w Rio de Janeiro z 1992 r., znana również pod nazwą „Szczyt Ziemi” zorganizowana pod hasłem „Środowisko i Rozwój”. Tam bowiem postawiono znak równości między strategią ochrony środowiska i rozwojem społeczno-gospodarczym [Piontek, Piontek i Piontek 1997]. Współcześnie uważa się, iż rozwój zrównoważony jest procesem zachodzącym równolegle na co najmniej trzech, powiązanych ze sobą, płaszczyznach: ekologicznej, ekonomicznej i społecznej (tzw. paradygmat 3 x E: economy, 
ecology, equity), por. [Goodland 1995], [Lawrence 2005], [Klekotko 2008], [Podedworna i Ruszkowski 2008]. W wymiarze ekologicznym (środowiskowym) idea zrównoważenia wyraża sprzeciw wobec gospodarki rabunkowej, wskazuje na potrzebę ochrony zasobów naturalnych i ograniczenia produkcji odpadów. Rośnie znaczenie zasobów wspólnych (dóbr publicznych), wśród których na pierwszym miejscu wymienia się zasoby środowiskowe. Zrównoważenie ekonomiczne polega na utrzymywaniu kapitału w stanie optymalnym, a więc ograniczeniu konsumpcji do takiego stopnia, w którym nie redukuje ona liczby wyjściowych zasobów. Okazuje się też, że neoklasyczna doktryna maksymalizacji zysku jednostek nie przynosi pożądanego optimum społecznego. Zrównoważenie społeczne jest tożsame $\mathrm{z}$ upodmiotowieniem i zapobieganiem marginalizacji jednostek. Zapewnia ono spokój społeczny, który jest warunkiem koniecznym dla każdego rozwoju [Woś i Zegar 2002, Klekotko 2008]. Pojęcie rozwoju zrównoważonego jest więc wielowymiarowe i zajmuje się nim wiele dyscyplin naukowych (np. ekologia, ekonomia, socjologia, nauki polityczne [Keith, Howe 2005]). Dlatego też jest wiele definicji tego pojęcia, a ich dogłębny przegląd proponuje B. Piontek [2002], która opierając się na przeglądzie literatury wyróżniła aż 44 definicje rozwoju zrównoważonego i trwałego, identyfikując jednocześnie wymiary dyscyplinarne każdej z nich. Wyłoniła 9 takich wymiarów, do których należą: gospodarowanie zasobami ekonomicznymi, gospodarowanie zasobami przyrodniczymi, gospodarowanie zasobami ludzkimi, rozwiązania instytucjonalne, przestrzeń, kształcenie świadomości i wybór modelu życia, wymiar moralny, wymiar duchowy oraz element integrujacy i kryterialny. Autorka stwierdza, że mimo różnych definicji rozwój zrównoważony jest jednością i oznacza nową jakość. Spośród autorów polskich sposobem kwantyfikowania zrównoważonego rozwoju zajmował się m.in. T. Borys [2007], poszukując adekwatnych wskaźników, które by mierzyły zrównoważony rozwój [por. też Poskrobko 2007].

Nie zawsze jednak taki rozwój uważany jest za stan pożądany, można bowiem spotkać się z opiniami, że rozwój zrównoważony jest polityczna ideologia lub utopia propagowana początkowo przez Organizację Narodów Zjednoczonych, aby skusić państwa Trzeciego Świata do podpisania niekorzystnego dla nich, opracowanego przez Pótnoc programu ochrony środowiska [Crabbe 1997, s. 7]. Stwierdzenie to, choć prowokacyjne, wskazuje na istotny fakt, że krajom bogatszym bardziej zależy na ochronie środowiska i przykładają zwykle więcej uwagi do stanu zrównoważenia niż kraje biedniejsze i słabiej rozwinięte. Krytykę tego rodzaju można usłyszeć nie tylko pod adresem krajów Trzeciego Świata, lecz także pod adresem krajów przechodzących transformację gospodarczą. Na przykład zarzut opieszałości we wprowadzaniu rozwiązań prośrodowiskowych zarzucano również Polsce, 
której struktura gospodarki przechodząca transformację opiera się w dużym stopniu na nieprzyjaznej środowisku energetyce węglowej. Powolne zmiany we wprowadzaniu technologii prośrodowiskowych nie wynikają jednak z negatywnego nastawienia Polski do problemów ochrony środowiska, ale z powodu wysokich kosztów dostosowania struktury gospodarki do bardziej przyjaznych technologii, które to koszty musiałoby ponieść społeczeństwo polskie i gospodarka [DemosPolska 2008]. Zależność między stopniem rozwoju i bogactwa kraju a stopniem ochrony środowiska jest faktem i wyjaśnia go tzw. środowiskowa krzywa Kuznet$\mathrm{za}^{19}$. Jest to krzywa w kształcie odwróconego U, wskazująca na zależność dodatnią pomiędzy zanieczyszczeniem i wzrostem zamożności kraju (czyli wraz ze wzrostem dochodu narodowego na mieszkańca), ale tylko do pewnego momentu. Po jego przekroczeniu zanieczyszczenie zaczyna spadać wraz ze wzrostem zamożności kraju [Meier i Rauch 2000]. Zależność tę obrazuje rysunek 1.9.

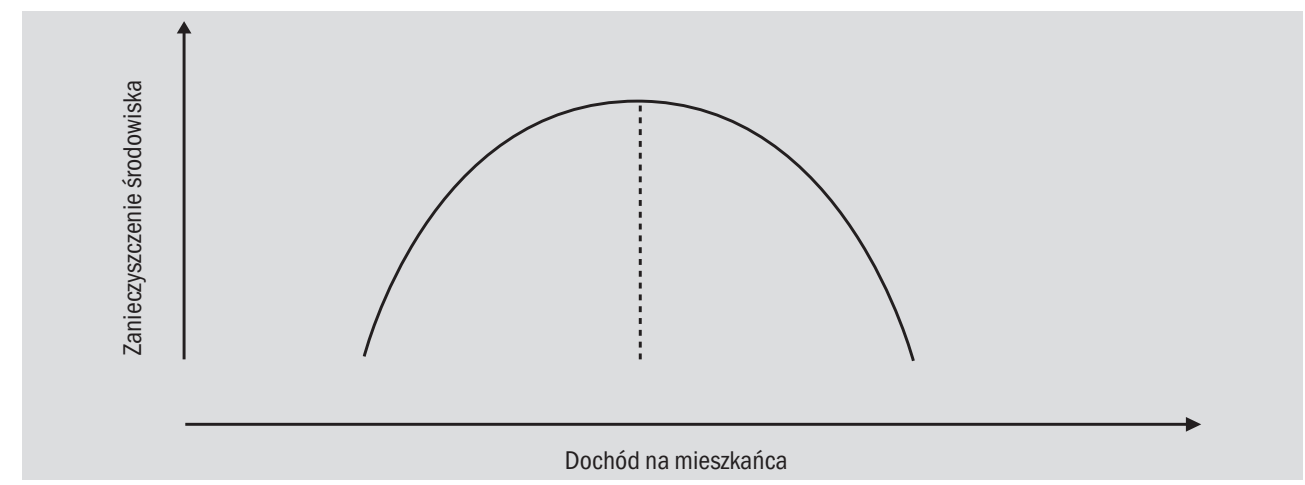

Rysunek 1.9. Środowiskowa krzywa Kuznetza

Źródło: Opracowanie własne na podstawie [Meier i Rauch 2000].

Początkowy wzrost zanieczyszczenia kraju jest spowodowany wzrostem uprzemysłowienia, większą produkcją. Natomiast spadek emisji po przekroczeniu pewnego progu zamożności jest wyjaśniony tym, że bogatsi konsumenci wymagają wyższych standardów ochrony środowiska i bogatszy kraj lepiej egzekwuje takie standardy oraz stosuje „czystsze technologie”. Bogatsze kraje w większym stopniu rozwijają usługi niż przemysł. Produkty „brudnego przemysłu” są z kolei importowane z krajów biedniejszych [Meier i Rauch 2000]. Niestety, w global-

${ }^{19}$ Kuznetz badał wpływ wzrostu gospodarczego na podział dochodu, wykazując, że w krajach biednych wzrost gospodarczy zwiększa różnicę między bogatymi a biednymi, a w krajach wysoko rozwiniętych różnica ta maleje [Andreoni i Levinson 2001]. 
nym rozrachunku światowym oznacza to nie tyle zmniejszenie zanieczyszczeń wraz z bogactwem narodów, ile raczej przesunięcie ich w kierunku krajów mniej rozwiniętych [Gelles 1995]. Istnieje dość bogata literatura, która znajduje empiryczne potwierdzenie tej teoretycznej koncepcji, np. w pracach [Garson, Jeon i McCubbin 1997].

W Polsce pojęcie rozwoju zrównoważonego jest tłumaczeniem angielskiego terminu sustainable development. Początkowo termin ten tłumaczono jako rozwój samopodtrzymujący [Jankowska-Kłapkowska 1985], a następnie na podstawie różnego rodzaju analiz niektórzy autorzy proponowali inne tłumaczenie, lepiej ich zdaniem oddające istotę charakteru tego rozwoju, czyli „rozwój trwały” [Śleszyński 2000, Majewski 2008]. Obecnie najczęściej używane jest pojęcie „rozwój zrównoważony". W odniesieniu do obszarów wiejskich zastosowanie ma wiele kategorii związanych z omawianym pojęciem, np.: rolnictwo społecznie zrównoważone, zrównoważony rozwój wsi oraz zrównoważony rozwój obszarów wiejskich, które pokrótce omawiamy poniżej.

Ze względu na ścisły związek rozwoju rolnictwa z rozwojem obszarów wiejskich nie może być zrównoważonego rozwoju obszarów wiejskich bez zrównoważonego rolnictwa. Istotą rolnictwa społecznie zrównoważonego jest godzenie interesów jednostkowych (mikroekonomicznych) i społecznych w celu optymalizowania dobrostanu społecznego [Woś i Zegar 2002]. Koncepcja rolnictwa społecznie zrównoważonego traktuje rolnictwo jako system rolniczych podmiotów gospodarczych, których różnorodność jest wartością pozytywną, gdyż w strukturze rolnictwa możliwy jest efekt synergii. Ważne, aby podmioty te były dostosowane do miejscowych warunków środowiskowych, ekonomicznych i społeczno-kulturowych oraz pozostawały w harmonii wewnętrznej i w harmonii ze strukturą nadrzędną (lokalną, regionalną, krajową). Jak stwierdza J. Zegar [2005] model rolnictwa społecznie zrównoważonego powinien jednocześnie spełniać wymogi co najmniej trzech obszarów: ekonomicznego, ekologicznego i społecznego. Według W. Michny rolnictwo zrównoważone harmonizuje cele produkcyjne, ekonomiczne, ekologiczne i społeczne, gdyż bez nich nie byłoby możliwe osiągnięcie równowagi ekologicznej. Z kolei ochrona ekologiczna rolnictwa i jego surowców rolnych oraz żywnościowych przestała być kwestią szlachetnej idei, ale stała się atrybutem konkurencji jakościowej z rolnikami zachodnioeuropejskimi [Michna 1998, 2000]. Natomiast J. Smagacz [2000] podkreśla, że rolnictwo zrównoważone i trwałe ukierunkowane jest na takie wykorzystanie zasobów ziemi, które nie niszczy ich naturalnych źródeł, lecz pozwala na zaspokajanie podstawowych potrzeb kolejnych generacji producentów i konsumentów (więcej na temat definicji zrównoważonego rozwoju i jego relacji z gospodarką można znaleźć m.in. w pracach 
takich autorów, jak: [Kołodziejski 1995a], [Piontek 2001], [Czyżewski 2001], [Bruton i Swinnen 2002], [Kozłowski 2002], [Anania, Blom, Buckwell i in. 2003, Zegar 2005], [Czyżewski i Henisz-Matuszczak 2005], [Henisz-Matuszczak 2007], [Borys 2007], [Majewski 2008]).

Idea rolnictwa (społecznie) zrównoważonego wypłynęła na fali krytyki polityki rolnej typu sektorowego, w wyniku której powstało wiele negatywnych zjawisk. Niechciany wpływ rolnictwa na środowisko przejawia się w wielu aspektach, m.in. w zanieczyszczeniu wód, niekorzystnych zmianach w krajobrazie, zanieczyszczeniu powietrza, gleb i wielu innych [Niewęgłowska 2005]. Wpływ polityki rolnej na pogłębianie się tych negatywnych zjawisk podsumowuje J. Wilkin [2003], zaliczając do nich:

- zniekształcanie parametrów rynkowych, co prowadzi do wadliwej alokacji zasobów produkcyjnych i produktów;

- kumulowanie nadwyżek produktów rolnych, rosnące koszty ich przechowywania i upłynniania;

- wypieranie z międzynarodowego rynku żywnościowego produktów pochodzących z krajów rozwijających się przez wysoko subsydiowane produkty z krajów wysoko rozwiniętych;

- nadmierna intensyfikacja rolnictwa i wpływ tego procesu na stan środowiska naturalnego;

- niesprawiedliwa dystrybucja korzyści z polityki wspierania rolnictwa przez państwo pomiędzy różne grupy gospodarstw;

- nieskuteczność w rozwiązywaniu problemów dochodowych dużej części rodzin rolniczych;

- wysokie koszty budżetowe polityki rolnej i jej malejąca społeczna legitymizacja. Zrównoważony rozwój wsi i zrównoważony rozwój obszarów wiejskich jest nieco innym pojęciem niż zrównoważony rozwój rolnictwa. Dotyczy przede wszystkim rozwoju społeczności, a nie sektorów gospodarki i podkreśla wagę różnych rodzajów wiedzy w rozwoju. M. Klekotko [2008] wyróżnia cztery modele zrównoważonego rozwoju wsi, związane z różnymi wzorami społeczeństwa obywatelskiego: model agencyjny, model aliansów, model bottom-up i model zintegrowany.

W modelu agencyjnym mieszkańcy wsi wybierają samorząd lokalny i powierzają mu interesy całej społeczności. Aktywność mieszkańców ogranicza się do wyboru odpowiednich władz, a samorząd lokalny sam decyduje o rozwoju. W procesie decyzyjnym dominuje zatem wiedza menedżerska i ekspercka z minimalnym udziałem wiedzy lokalnej.

W modelu aliansów lokalny samorząd współpracuje z organizacjami pozarządowymi, które opierają się na wiedzy eksperckiej, bądź reprezentują interesy okre- 
ślonych grup społecznych. Te organizacje pozarządowe są głównie „nowego” typu, tzn. powstają na podstawie podobieństwa interesów, wspólnych zainteresowań i poglądów. Są mniej formalne od tradycyjnych i opierają się na wiedzy lokalnej. Często przyjmują postać stowarzyszeń, a nie wspólnot. Lokalny samorząd sprawuje władzę nad społecznością, budując alianse między aktorami instytucjonalnymi, w czym decydującą rolę odgrywa wiedza menedżerska i ekspercka.

Cechą modelu bottom-up jest przekonanie o bezwzględnym prawie lokalnej ludności do decydowania o kierunkach rozwoju. Samorząd lokalny współpracuje z mieszkańcami przy ustalaniu celów polityki lokalnej, a pomysły na rozwój wyrastają ze społeczności wiejskich. W modelu tym mieszkańcy oraz wiedza lokalna odgrywają decydującą rolę. Mieszkańcy sami zwracają się po wiedzę ekspercką, jeśli uznają to za niezbędne.

W modelu zintegrowanym wszyscy aktorzy (samorząd lokalny, organizacje pozarządowe, lokalna ludność) uczestniczą w procesie decyzyjnym. Kierunki rozwoju określane są w wyniku publicznej debaty i społecznych konsultacji. Dochodzi tu do integracji wszystkich typów wiedzy [Klekotko 2008].

Jeśli chodzi o politykę wspierającą rozwój zrównoważony rolnictwa i wsi, to widać jej wpływ w zmianach instrumentarium WPR, w którym pojawia się coraz więcej działań oraz zasad finansowania uwzględniających poszanowanie dla środowiska. Cała oś II PROW 2007-2013 ma właśnie na celu poprawę środowiska naturalnego. Unia $w$ ramach tego priorytetu zaproponowała do wyboru aż 13 działań ${ }^{20}$. W zasadach finansowania wspierającego ideę zrównoważenia, bardzo wiele zmieniła ostatnia reforma WPR (Luksemburg 2003 r.). Po pierwsze, wprowadzona została zasada współzależności (cross-compliance), polegająca na uzależnieniu otrzymywanych płatności bezpośrednich od spełnienia przez gospodarstwo określonych przepisów z zakresu ochrony środowiska i dobrostanu zwierząt. Ponadto wzmocniono zasadę rozdziału wsparcia od produkcji (decoupling) poprzez zastąpienie wypłacanych płatności bezpośrednich opierając się na specyficznych (dla poszczególnych rodzajów i wielkości produkcji) kwotach wsparcia dla rolników na rzecz systemu jednolitej płatności (Single Payment Scheme, SPS). Reforma, poprzez mechanizm modulacji (czyli redukcji płatności oraz ograniczeń dla największych beneficjentów płatności bezpośrednich, otrzymują-

\footnotetext{
${ }^{20}$ Do działań tych należą: 211 - Płatności ONW na obszarach górskich, 212 - Płatności ONW poza obszarami górskimi, 213 - Natura 2000 i płatności wynikające z Dyrektywy 2000/60/EC, 214 - Płatności rolnośrodowiskowe, 215 - Płatności z tytułu dobrostanu zwierząt, 216 - Inwestycje nieprodukcyjne (typ I), 221 - Pierwsze zalesianie gruntów rolniczych, 222 - Pierwsze zakładanie systemów rolnoleśnych na gruntach rolnych, 223 - Pierwsze zalesianie gruntów nierolniczych, 224 - Natura 2000, 225 - Płatności leśnośrodowiskowe, 226 - Przywrócenie potencjału leśnego oraz działania zapobiegawcze, 227 - Inwestycje nieprodukcyjne (typ II).
} 
cych powyżej 100 tys. EUR), zagwarantowała większe finansowanie dla II filaru, w tym i jego osi II. Szerzej o polityce WPR w kontekście rozwoju zrównoważonego będzie mowa w rozdziale 2.2 [por. też Buckwell 1997].

\subsubsection{ROZWÓJ OBSZARÓW WIEJSKICH A ROZWÓJ ZINTEGROWANY}

Od dawna w dokumentach Komisji Europejskiej i coraz częściej w Polsce pojawia się sformułowanie „zintegrowany rozwój obszarów wiejskich”. Zintegrowanie to można rozumieć na różnych płaszczyznach. Po pierwsze, może być to interpretowane jako integracja sektora rolnego z sektorami przemysłu i usług. Po drugie, można to rozumieć jako integrację pewnych grup społecznie wykluczonych na wsi (np. osób starszych, kobiet, mniejszości etnicznych) z resztą społeczeństwa. Podejście to opiera się na adresowaniu problemów wsi i rolnictwa bardziej terytorialnie niż sektorowo.

Definicję zintegrowanego rozwoju obszarów wiejskich podaje G. Nemes [2005, s. 24], nazywając go: procesem taczacym interwencję zewnętrzna z lokalnymi aspiracjami; majacym na celu zarówno poprawę bytu różnych grup społecznych zamieszkujacych obszary wiejskie, jak i podtrzymanie oraz powiększanie wartości wiejskich zasobów; poprzez odgórna redystrybucję środków, usuwanie przeszkód na drodze do zwiększania przewag komparatywnych oraz znajdowanie nowych sposobów wzmacniania i wykorzystywania walorów wiejskich. Autor podkreśla, że chodzi o taki rozwój, który zarządzany jest lokalnie, ale wspierany finansowo i instytucjonalnie odgórnie. Nie chodzi o rozwój napędzany tylko siłami wewnętrznymi (lokalnymi), ale o wzmocnienie tych sił od zewnątrz. Nie jest to jednak to samo co rozwój poprzez partycypację, czyli selekcję grup liderów, kierujący rozwojem w imieniu pozostałych członków ${ }^{21}$. W rozwoju zintegrowanym chodzi raczej o to, jak lokalne siły rozwojowe mogą być wzmocnione czy przekonfigurowane dzięki interwencjom odgórnym.

G. Grosse [2008] wskazuje na podobne elementy, mówiąc, że zintegrowane podejście do rozwoju powinno zobowiązywać wszystkich jego aktorów do kreowania długofalowych strategii uwzględniających uwarunkowania zarówno regionalne, jak i globalne. Strategie te powinny być urzeczywistniane w ramach powiązanych polityk (wspólnotowych i krajowych polityk regionalnych i sektorowych) oraz przy zastosowaniu zróżnicowanych instrumentów finansowych, opartych na zasadach ustalania priorytetów i koordynacji, w celu uzyskania efektów synergii.

${ }^{21}$ Autor wskazuje na różnice między podejściem typu LEADER a podejściem zintegrowanym, gdyż to pierwsze może prowadzić do powstawania z jednej strony grupy dominujących i z drugiej wykluczonych, natomiast w procesie zintegrowanym są inne struktury. 
Najważniejsze elementy podejścia do rozwoju zintegrowanego według Jerzego Wilkina [2003] to:

- kompleksowe rozwiązywanie problemów wsi i rolnictwa - pod uwage trzeba wziąć różne aspekty pracy i życia na obszarach wiejskich, a instrumenty sektorowo zorientowanej polityku rolnej tego nie uwzględniają;

- holistyczny charakter funkcjonowania obszarów wiejskich i konieczność holistycznego podejścia do konstruowania programów. Jest to przeciwieństwo wycinkowości, sektorowości i rozpatrywania różnych aspektów pracy i życia na wsi w oderwaniu od siebie;

- uznanie terytorialności obszarów wiejskich przez przyjęcie, że obszary wiejskie to przede wszystkim kategoria terytorialna, a pojęcie terytorium spełnia ważną rolę integratora w konceptualizacji rozwoju obszarów wiejskich i polityki w tym zakresie. Terytorialne zorientowanie strategii rozwoju wsi pozwala uwzględniać szczególne cechy danego obszaru, odpowiednio je wyeksponować i wykorzystać;

- wielofunkcyjność obszarów wiejskich i wielofunkcyjność rolnictwa (rozważaniom na ten temat poświęcony jest następny podrozdział);

- wzbogacenie lub dowartościowanie funkcji spełnianych przez rolników w społeczeństwie i gospodarce. Między innymi postuluje się wynagradzanie rolników ze środków publicznych za realizację innych, pozarolniczych funkcji;

- podkreślanie wartości różnorodności pod względem przyrodniczym, gospodarczym, społecznym i kulturowym. Koncepcja zintegrowanego rozwoju obszarów wiejskich uwzględnia wszystkie te aspekty i traktuje różnorodność jako szczególną wartość, którą należy chronić i wzbogacać;

- oddolny proces kształtowania strategii rozwoju - zgodnie z zasadą subsydiarności, leżącej u podstaw polityki wspólnotowej, wynika z konieczności decentralizacji decyzji wszędzie tam, gdzie jest to możliwe oraz upowszechnianie inicjatyw oddolnych;

- partnerstwo publiczno-prywatne - jest niezbędnym wymogiem, gdyż rozwój zintegrowany wymaga dużego zaangażowania środków finansowych i potencjału osobowego. Zadanie to nie może być wykonane jedynie przy udziale środków publicznych, stąd potrzeba budowania partnerstwa. Bardzo ważnym efektem takiego partnerstwa jest budowa kapitału społecznego i mobilizacja społeczna na rzecz rozwoju;

- udział wszystkich interesariuszy (stakeholders) polityki rozwoju obszarów wiejskich jest warunkiem koniecznym społecznej legitymizacji publicznego wsparcia dla ich rozwoju i poszerzania grup mających w tym interes. Obszary wiejskie nie miały wyraźnego i równie skutecznego lobby jak rolnictwo. O ile interesariusze 
polityki rolnej to stosunkowo wąska i sprawnie działająca grupa, o tyle interesariusze rozwoju wsi są grupą relatywnie dużą, zróżnicowaną i słabo zorganizowaną. Te różnice wyjaśniają, przynajmniej częściowo, dotychczasową nieskuteczność w formułowaniu i wdrażaniu kompleksowej polityki rozwoju obszarów wiejskich. Mechanizm kształtowania grup interesu oraz powiązanie skuteczności z rozmiarami owych grup przeanalizował najpełniej M. Olson [1971];

- dialog społeczny - zakłada szerokie społeczne uczestnictwo w przygotowaniu koncepcji rozwoju i jej realizacji. Sprawy rozwoju wsi stają się sprawami całego społeczeństwa, co wymaga ukształtowania nowych form dialogu społecznego. Słabość dyskursu publicznego w węzłowych problemach kraju jest jedną $\mathrm{z}$ istotnych przyczyn niedostatecznego postępu transformacji systemowej.

Podobne cechy zintegrowanego rozwoju przedstawiają M. Murray i J. Greer [1992], dodając jeszcze, że towarzyszyć powinny mu:

- rozwój ekonomiczny, inicjowany przez działania w zakresie edukacji, szkoleń oraz rozwoju infrastruktury społecznej;

- skoncentrowanie uwagi na biedniejszych obszarach oraz ludziach, którzy pozostają w tyle;

- aktywizowanie ludności wiejskiej, tak aby angażowała się nie tylko w określanie swych potrzeb oraz możliwości wykorzystania lokalnego potencjału, lecz także w realizację konkretnych projektów rozwojowych;

- zmiany instytucjonalne, polegające na przekazywaniu uprawnień ze strony administracji państwowej na rzecz władz regionalnych i lokalnych.

W zrozumieniu podejścia zintegrowanego do rozwoju może pomóc spójna analiza modelu zaproponowanego przez G. Nemes [2005] - rysunek 1.10.

Według autora zintegrowany system rozwoju obszarów wiejskich musi łączyć dynamiczną współpracę lokalnego i centralnego systemu rozwojowego. Kompetencje, środki i kontrola powinny być podzielone pomiędzy różne szczeble administracji. Warunkiem koniecznym jest istnienie zaawansowanych lokalnych instytucji rozwojowych. Przepływy środków na rozwój obszarów wiejskich w tym modelu (patrz cyfry na strzałkach na rys. 1.10) kształtują się następująco: najpierw Centralne Środki Rozwojowe zostają rozdysponowane przez Centralny System Administracyjny (1), z czego duża pula środków przeznaczona jest bezpośrednio na usunięcie utrudnień na obszarach wiejskich zwiazanych z dostępem do zasobów (2) dotyczy to dostępu do infrastruktury, środków finansowych etc. Kolejna, ale mniejsza część środków zostaje przekazana na cele związane z powiększaniem zasobów gospodarek lokalnych (3) - określonych jako usuwanie utrudnień zwiazanych z niewystarczajacymi zasobami. Cele te obejmują utrzymanie dóbr publicznych i różnego rodzaju subsydia. Znacząca część Centralnych Środków Rozwojowych 


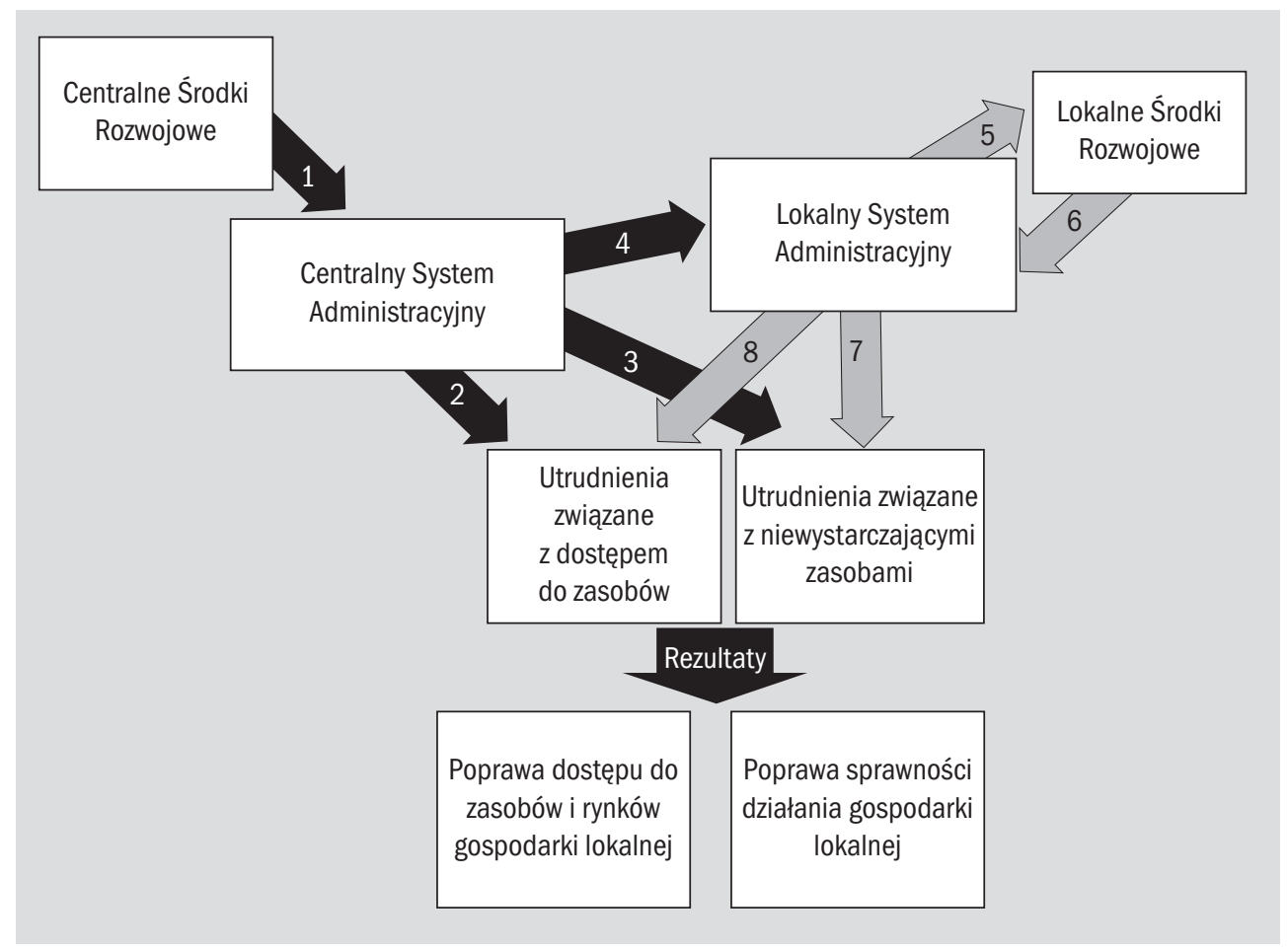

Rysunek 1.10. Przykład zintegrowanego systemu rozwoju obszarów wiejskich Źródło: Na podstawie [Nemes 2005].

przeznaczona jest następnie na wsparcie Lokalnego Systemu Administracyjnego (4), co zapewnia jego wzmocnienie i rozwój. Ten z kolei zasila (5) Lokalne Środki Rozwojowe przeznaczone na zachowanie wartości wiejskich. Wartość dodana z tego procesu przeznaczona jest na wzmocnienie i potrzymanie tego systemu (6). Środki uzyskane tą drogą wspierają ponownie dwa cele: usuwanie utrudnień związanych z niedostatkiem zasobów rozwojowych (7) oraz z utrudnionym dostępem do tych zasobów (8), włączając środowisko biznesowe i samorządowe.

Powyższa propozycja jest tylko jednym przykładem modelu zintegrowanego rozwoju obszarów wiejskich, jednak wskazuje na kilka ważnych cech takiego systemu. Po pierwsze, wagę instytucji i ich powiązań na poziomie centralnym i lokalnym. Po drugie, przepływ środków finansowych trafiających różnymi kanałami do obszarów wiejskich (nie tylko pośrednio przez szczeble hierarchii administracji od centralnej do lokalnej). Po trzecie, podejście do przepływu informacji i podziału kompetencji jest bardziej holistyczne i dokładniej pozwala zidentyfikować faktyczne problemy i potrzeby obszarów wiejskich [Nemes 2005]. 


\subsection{Uniwersalia rozwoju obszarów wiejskich}

Mimo że obszary wiejskie różnią się bardzo charakterem i uwarunkowaniami zewnętrznymi w poszczególnych krajach i na różnych kontynentach, to jednak można zauważyć pewne prawidłowości uniwersalne, które powtarzają się na świecie. Można je nazwać faktami stylizowanymi ${ }^{22}$ lub uniwersaliami, czyli obserwacjami, które potwierdziły się w tak wielu kontekstach (geograficznych, politycznych, klimatycznych etc.), że powszechnie uznawane są za prawdy udowodnione. Są o tyle ważne, że powstające teorie ekonomiczne muszą do nich pasować. W przypadku rozwoju obszarów wiejskich można sformułować następujące konkluzje oparte na faktach stylizowanych:

- W krajach wysokorozwiniętych maleje rola sektora rolnego w rozwoju obszarów wiejskich, a większą rolę zaczynają odgrywać pozarolnicze sektory gospodarki. Udział sektora rolnego w tworzeniu produktu krajowego spada zatem z kilkunastu czy kilkudziesięciu procent PKB (w krajach rozwijających się) do zaledwie kilku procent PKB (w krajach rozwiniętych).

- W krajach rozwijających się przeważają małe gospodarstwa rodzinne, podczas gdy w krajach rozwiniętych następują procesy koncentracji ziemi i produkcji prowadzące do powstawania dużych gospodarstw farmerskich. Stąd wraz z rozwojem krajów nieuchronnie zmienia się ekonomiczny charakter obszarów wiejskich, jak też ich krajobraz.

- Do głównych problemów obszarów wiejskich w krajach rozwiniętych najczęściej zaliczyć można: starzenie się ludności wiejskiej, niższą średnią wydajność pracy, niższy poziom edukacji, wyludnianie się terenów wiejskich [OECD 2006], co obniża masę krytyczną niezbędną dla istnienia efektywnych usług publicznych, infrastruktury, przedsiębiorczości, co dalej pogłębia procesy wyludniania i prowadzi do marginalizacji [Rosner 2002]. Inaczej jest w krajach rozwijających się. Tam głównym problemem obszarów wiejskich jest zbytnie uzależnienie się ludności wiejskiej od rolnictwa, które jest tam zwykle jednym z najmniej wydajnych sektorów gospodarki. To wpływa na niskie dochody prowadzące często do ubóstwa dużej części społeczności wiejskiej. Ponadto problemem jest brak dostępu do infrastruktury społecznej, słaby kontakt z rynkową częścią gospodarki (przeważa barter i konsumpcja własna) i następuje rabunkowa eksploatacja zasobów naturalnych [Meier 2000].

- Dowody z większości kontynentów zebrane w ciągu ostatniej dekady pokazują, że generalnie udział dochodów wiejskich gospodarstw domowych uzyskiwanych ze źródeł pozarolniczych rośnie w procesie rozwoju obszarów wiejskich

${ }^{22}$ Porównaj definicje $\mathrm{z}$ http://economics.about.com/od/economicsglossary/g/stylized.htm 
i pozostaje znaczący. Badania empiryczne wskazują, że źródła pozarolnicze stanowią 40-45\% średnich dochodów wiejskich gospodarstw domowych w Afryce Subsaharyjskiej i Ameryce Łacińskiej, 30-40\% w Azji Południowej, 30-50\% w Europie Środkowo-Wschodniej oraz 60-70\% w USA [Tomczak 2004].

- Większość dochodów pozarolniczych pochodzi z lokalnych źródeł wiejskich, a nie ze źródeł miejskich. Z drugiej strony, obszary wiejskie przylegające do dużych ośrodków miejskich rozwijają się wyraźnie szybciej i są bogatsze niż obszary wiejskie o charakterze peryferyjnym. Wpływa na to dostęp do większego rynku dóbr i usług, w tym i rynku pracy.

- Kraje rozwijające się zwykle opodatkowują rolnictwo, faworyzując tym samym sektor przemysłowy (otrzymuje on tanie środki do produkcji) i konsumentów (otrzymują oni subsydiowaną żywność). Z kolei kraje wysoko rozwinięte czynią odwrotnie, subsydiują netto sektor rolny ${ }^{23}$ kosztem konsumentów, którzy zgadzają się płacić rolnikom nie tylko za produkcję żywności, lecz także za dobra „nieprodukcyjne” dostarczane obszarom wiejskim i konsumentom, do których należą zachowanie krajobrazu wsi, ochrona środowiska naturalnego czy produkcja żywności o wyższej jakości (m.in. ekologicznej). To inne podejście krajów rozwijających się wynika z chęci szybkiego doganiania krajów rozwiniętych poprzez szybki wzrost gospodarczy, do którego rolnictwo przyczynia się w niewielkim stopniu, więc jego kosztem wolą wspierać szybko rozwijający się pod względem technologii przemysł oraz swoich relatywnie biedniejszych konsumentów [Schaff i Valdes 1998], [por. też Schultz 1964].

- Formy i wielkość wsparcia dla rolnictwa na świecie są zróżnicowane. Od przewagi instrumentów cenowych i celnych (Chiny, Indie, Japonia), poprzez wspieranie głównie dochodów rolniczych (USA i Europa), do wspierania głównie edukacji i innowacyjnych technologii (Australia, Nowa Zelandia). Przy tym w krajach rozwiniętych oprócz polityki rolnej (lub w jej ramach) wyodrębnia się też politykę lub chociaż programy wspierające rozwój obszarów wiejskich, co z kolei jest mniej eksponowane w krajach rozwijających się.

- W krajach wysoko rozwiniętych przez rozwój obszarów wiejskich coraz częściej rozumie się ochronę środowiska, poprawę jakości życia na wsi i zapewnienie wystarczającego dochodu, zatrzymującego ludność na obszarach wiejskich. Popularne pojęcia związane z tą polityką to wielofunkcyjność wsi, rozwój zrównoważony, rozwój zintegrowany itp. Natomiast w krajach mniej rozwiniętych głównie nacisk położony jest na sektor rolny, eksploatację obszarów wiejskich kosztem środowiska i kapitału ludzkiego.

\footnotetext{
${ }^{23} \mathrm{Nie}$ wyklucza to stosowania podatków.
} 


$$
\text { r01.qxd 2011-10-31 09:37 Page } 84
$$


Nie przetrwaja najsilniejsze gatunki ani najbardziej inteligentne, ale te, które będa mogty najlepiej przystosować się do zmian i się rozwijać.

Karol Darwin

\section{POLITYKa WSPIERANIA ROZWOJU OBSZARÓW WIEJSKICH}

\subsection{Paradygmaty polityki rozwoju obszarów wiejskich}

Mówiąc o „paradygmatach” polityki rozwoju obszarów wiejskich, mamy na myśli podstawowe twierdzenia, sposoby analizy i inne osiąnnięcia nauk społecznych w zakresie rozwoju obszarów wiejskich, obecne dotychczas w literaturze tematu ${ }^{24}$. Według T. Kuhna jest to „siatka teoretyczna” czy „matryca dyscyplinarna”, za pomocą której naukowcy przedstawiają świat. Dokładna historyczna analiza danej dziedziny $w$ określonym czasie ujawnia zbiór powtarzajacych się quasi-standardowych ilustracji rozmaitych teorii w ich pojęciowych, doświadczalnych $i$ instrumentalnych zastosowaniach. Sa to wtaśnie paradygmaty obowiazujace $w$ danej spoteczności, przedstawiane $w$ podręcznikach, wykładach $i$ ćwiczeniach laboratoryjnych [Kuhn 2001, s. 87 za Wilkin 2008a]. Powstawanie, rozwijanie i upowszechnianie, a następnie odrzucanie paradygmatów jest istotnym czynnikiem rozwoju poszczególnych dyscyplin naukowych. Następuje to w trzech etapach: pierwszy to powstanie paradygmatu, który staje się przyjętą podstawą badań, w drugim następuje wykrywanie faktów niezgodnych z paradygmatem, co prowadzi do konfrontacji teorii z rzeczywistością, trzeci zaś charakteryzuje się koncentracją badań ujawnionych niezgodności i jeśli etap ten zakończy się sformułowaniem nowego paradygmatu, to cykl można uznać za zamknięty [Heller 2000b]. W niniejszym opracowaniu staramy się prześledzić kolejne paradygmaty dotyczące rozwoju wsi i rolnictwa w kontekście zmian zachodzących w Polsce i na świecie.

Zgodnie z trendami światowymi lat 60 ., w naukach społecznych nacisk kładziono przede wszystkim na fizyczny (techniczny) rozwój obszarów wiejskich.

\footnotetext{
24 Termin „paradygmat” został spopularyzowany w kręgach filozofii i metodologii nauk przez Thomasa S. Kuhna. Nie jest terminem jednoznacznym, ale najczęściej odnosi się do „powszechnie uznawanych osiąnnięć naukowych” w danej tematyce [Kuhn 1985, s. 407 za Wilkin 2008a].
} 
Miał on następować poprzez industrializację (industrialization), rozwój infrastruktury na wsi (rural infrastructure development) oraz urbanizację wiejską (rural urbanization) [Martin 1981]. Marksiści wylansowali tezę, iż podstawowym kryterium postępu na wsi będzie wyrównywanie różnic między miastem a wsią, przy czym wieś miała naśladować miasto, a nie odwrotnie. Wzorcem i źródłem postępu były uprzemysłowione, duże ośrodki miejskie. To one generowały postęp w różnych dziedzinach: technice, organizacji, wydajności pracy, edukacji, usługach społecznych itp. Wieś była jedynie odbiorcą tego postępu, a modernizacja wsi polegała na upowszechnianiu wzorów i osiągnięć ukształtowanych w miastach. W długim okresie najszybciej jednak rozwinęły się te kraje, w których wieś i rolnictwo zostały włączone w główne nurty postępu technicznego, ekonomicznego i społecznego. Rozwój wsi także w tych krajach miał charakter rozwoju zależnego, podporządkowanego centrom miejskim. Można powiedzieć, że był to rozwój indukowany z zewnątrz. Przykładem realizacji tej idei były w Polsce wsie pegeerowskie z miejskim systemem zagospodarowania przestrzeni [Wilkin 2008a]. Modernizacja była koncepcją uniwersalną na całym globie, wprowadzaną z nadzieją, że zapoczątkuje serię przekształceń, które ułożą się w znane sekwencje zmian ekonomicznych, społecznych, politycznych. Zatem rozpoznany był i opisany mechanizm zmian, a za nim stała wielka socjologiczna teoria modernizacji [Halamska i Śpiewak 2008].

W latach 70. dostrzeżono dużą, choć niedocenioną, rolę instytucji w rozwoju obszarów wiejskich i nacisk przesunął się w stronę rozwoju instytucjonalnego (institutional development) tych obszarów. W tym samym czasie przesunęło się też centrum ciężkości ze wspierania infrastruktury technicznej w stronę wspierania rozwoju infrastruktury społecznej (social infrastructure). Załamanie się cen surowców żywnościowych we wczesnych latach 80. doprowadziło do przesunięcia się zainteresowania $\mathrm{z}$ podstawowych surowców rolnych na bardziej przetworzone produkty rolne (value-added activities), których cena była wyższa. W tym samym czasie powstała też idea tworzenia specjalnych stref ekonomicznych dla firm wiejskich (rural enterprise zones) oraz większe zorientowanie na gospodarkę lokalną (w USA local community development) [Martin 1981]. Kolejne paradygmaty powstające w latach 90. podkreślały m.in. rolę przedsiębiorczości wiejskiej (rural entrepreneurship), agroturystyki (rural tourism) i powiązań wieś-miasto (urban growth linkages) [Martin 1981, Kilkenny i Otto 1994].

Na początku XXI wieku następuje proces, który można nazwać dowartościowywaniem wsi, a paradygmat narzuconej industrialno-urbanistycznej modernizacji wsi zastępowany jest paradygmatem zrównoważonego, zintegrowanego i wielofunkcyjnego rozwoju wsi. Idzie za tym wzrost zainteresowania wsią zarówno 
ze strony nauki, społeczeństwa, jak i polityki gospodarczej. Możemy zaobserwować wręcz proces idealizacji wsi wśród mieszkańców miast ${ }^{25}$.

Zmiany w światowych paradygmatach z pewnością uwarunkowane były przełomowymi wydarzeniami gospodarczymi. Analizując je, należy mieć w pamięci odpowiadające im tło historyczne, a więc m.in. takie wydarzenia, jak:

- Wielki Kryzys Gospodarczy (na początku lat 30. ubiegłego wieku),

- II wojnę światową (w pierwszej połowie lat 40.),

- wytworzenie i zastosowanie hybrydów nasiennych (początek lat 50.),

- boom produkcyjny na początku lat 70.,

- kryzys energetyczny (w końcu lat 70.),

- kryzys zadłużeniowy rolnictwa (początek lat 80.),

- globalne ocieplenie (od początku lat 90. do dziś),

- akceptacja przez znaczną część konsumentów żywności genetycznie modyfikowanej GMO (od końca lat 90.),

- zmiana charakteru transferu informacji przez upowszechnienie Internetu (od lat 90. do dziś),

- zawirowania w polityce światowej i gospodarce (od końca lat 90. do dziś),

- industrializacja rolnictwa (całe lata 90.),

- rynkowe zastosowanie osiąnnięć biotechnologicznych (koniec lat 90.),

- wpływ nowych upraw w rolnictwie (XXI wiek),

- procesy globalizacyjne (XXI wiek) [Just 2001, Tomczak 2004].

W Europie w XXI wieku występuje wyraźny proces poszukiwania nowej tożsamości obszarów wiejskich i ich ważnych funkcji w społeczeństwie, gospodarce, kulturze i środowisku przyrodniczym. W Unii Europejskiej znajduje to coraz szersze odbicie nie tylko we Wspólnej Polityce Rolnej, lecz także w programach strukturalnych. Dla Polski duże znaczenie w społecznym dowartościowywaniu wsi miało przystapienie do Unii Europejskiej i uzyskana dzięki temu możliwość dofinansowania rozwoju obszarów wiejskich ze środków unijnych. Integracja europejska miała bez wątpienia najsilniejszy wpływ na modernizację polskiej wsi wśród wszelkich innych działań, podejmowanych w Polsce w ostatnich dekadach [Wilkin 2008a].

Według [OECD 2006] można wymienić trzy czynniki, które w ostatnich latach najbardziej wpłynęły na powyżej opisane zmiany w polityce krajów europejskich i OECD wobec obszarów wiejskich. Należą do nich:

- DoCENIENIE WALORów WSI. Wyraźny wzrost poszanowania dla zasobów naturalnych i dziedzictwa kulturowego, zarówno w ocenie społeczności wiejskich,

\footnotetext{
${ }^{25}$ Jak Wilkin [2008a] cytuje za G.E. Coulton: Wyolbrzymianie szczęścia życia na wsi przekroczyło już wszelkie granice rozsqdku [Blythe 1979, s. 16].
} 
jak i miejskich. Uznanie, że w Europie obszary wiejskie oprócz wartości naturalnych przechowują też wartości historyczne, kulturowe, rekreacyjne etc. Uświadomienie sobie znaczenia tych funkcji w percepcji społecznej stało się przyczynkiem do bardziej wszechstronnej polityki rozwoju obszarów wiejskich.

- Presja reformy Wspólnej Polityki Rolnej. Jest wiele czynników, które powodują presję na reformę tej polityki w stronę większego wsparcia dla obszarów wiejskich. W grupie czynników zewnętrznych na pierwszy plan wysuwają się negocjacje w ramach WTO. Wymusiły one już wprowadzenie takich mechanizmów wsparcia rolnictwa, które nie zakłócają handlu. Coraz częściej wskazuje się, że do takich instrumentów mogą też należeć instrumenty wspierające rozwój obszarów wiejskich, a nie produkcji, a zatem II filar może zyskać na znaczeniu kosztem I filara WPR. Jeśli chodzi o czynniki wewnętrzne, to głównym z nich jest ograniczenie budżetowe. W związku z rozszerzeniem Unii, jak również ekonomicznym kryzysem światowym, wsparcie dla wybranego sektora gospodarki (i to nie najbardziej efektywnego) staje się mało przekonywające. Co innego, jeśli jest to wsparcie dla wsi jako całości, gdyż 75\% UE to obszary w przeważającym stopniu wiejskie (predominantly rural).

- Decentralizacyjne trendy w POlityce RegionalneJ. Zarówno teoria, jak i praktyka wykazały, że dla rozwoju regionów ważne jest nie tylko to, ile funduszy się przeznacza, ale na ile instrumenty, poprzez które to następuje, są dopasowane do potrzeb i możliwości konkretnych społeczności i gospodarek lokalnych. Dlatego nastąpiło przesunięcie ze wsparcia „odgórnego” (top-down) w formie subsydiów, ku wsparciu „oddolnemu” (bottom-up), i to w różnych formach, mających na celu wzrost konkurencyjności tych obszarów.

W rezultacie działania powyższych czynników wiele krajów zaczęło realizować własne inicjatywy oraz bardziej wszechstronne i kompleksowe podejście wobec obszarów wiejskich. Na przykład Wielka Brytania w 2001 r. powołała w miejsce byłego Ministerstwa Rolnictwa nowe ciało o nazwie DEFRA (Departament for Environment, Food and Rural Affairs), czyli Departament do spraw Środowiska, Żywności i Wsi, w którym nawet nie pojawia się już słowo rolnictwo. Ma to podkreślać wielofunkcyjne podejście do rozwoju obszarów wiejskich i kompleksowość programów dla nich realizowanych. Wiele krajów, w tym Finlandia jako przykład jednego z najaktywniejszych krajów, zaczęło wdrażać na dużą skalę program LEADER, który z założenia jest oddolnym i zintegrowanym podejściem do rozwoju obszarów wiejskich, biorącym pod uwagę różnych interesariuszy rozwoju obszarów wiejskich i różne jego aspekty. Innym przykładem jest Holandia, która opublikowała w 2004 r. „Agendę dla Żywotności Okolic Wiejskich” (Agenda for a Vital Countryside), w której wprowadziła istotne zmiany w podejściu do rozwoju 
obszarów wiejskich, polegające na obowiązkowym włączaniu celów tej polityki do lokalnych i regionalnych strategii rozwoju.

Według OECD [2006], obserwowane zmiany wskazują na to, że można mówić o „nowym paradygmacie wiejskim” (new rural paradigm), który opiera się w szczególności na dwóch zasadach: pomocy dla „obszarów”, a nie dla „sektorów”, co dotyczy obszarów wiejskich i sektora rolnego, oraz inwestowaniu raczej niż subsydiowaniu obszarów wiejskich, co jest potwierdzeniem tego, że wzmocnienie efektywności powinno następować przed wyrównywaniem nierówności. Paradygmat ten różni się od poprzednich w kwestiach realizowanych celów, obiektów wsparcia, instrumentów wsparcia oraz głównych beneficjentów (tab. 2.1). Zgodnie z nim celem polityki ROW nie jest wyrównywanie dochodów rolniczych i wzrost konkurencyjności samego rolnictwa, ale zwiększanie konkurencyjności całych obszarów wiejskich przy jednoczesnym zachowaniu waloryzacji zasobów lokalnych (przyrodniczych, historycznych, kulturowych etc.). Zamiast jednego sektora rolniczego, beneficjentami polityki ROW w coraz większym stopniu mogą być różne sektory na obszarach wiejskich, mające pozytywny wpływ na ich rozwój, np. sektor turystyczny, przemysłowy, usługowy itd. W instrumentarium wsparcia środek ciężkości przenosi się z subsydiów na inwestycje, jako bardziej efektywnej formy pobudzenia rozwoju. Do udziału w korzystaniu ze środków na politykę ROW, oprócz władz centralnych i rolników, dopuszczone są wszystkie szczeble sektora rządowego oraz różni interesariusze polityki ROW (prywatni, publiczni i partnerstwa publiczno-prywatne). Podsumowanie nowego paradygmatu przedstawia tabela 2.1 .

Tabela 2.1. Nowy paradygmat wiejski według OECD

\begin{tabular}{l|l|l}
\hline & \multicolumn{1}{c}{ Stare podejście } & \multicolumn{1}{c}{ Nowe podejście } \\
\hline Cele polityki & $\begin{array}{l}\text { Wyrównywanie szans; } \\
\text { zwiększenie dochodów } \\
\text { rolniczych; konkurencyjność } \\
\text { gospodarstw rolnych }\end{array}$ & $\begin{array}{l}\text { Konkurencyjność obszarów wiejskich; } \\
\text { waloryzacja zasobów lokalnych; } \\
\text { zrównoważona eksploatacja zasobów }\end{array}$ \\
\hline Sektor głównego wsparcia & Rolnictwo & $\begin{array}{l}\text { Różne sektory gospodarki (np. turystyka } \\
\text { wiejska, przemysł, informatyzacja etc.) }\end{array}$ \\
\hline Główne instrumenty wsparcia & Subsydia & $\begin{array}{l}\text { Inwestycje } \\
\text { Główni odbiorcy wsparcia }\end{array}$ \\
& Władze centralne, rolnicy & $\begin{array}{l}\text { Wszystkie szczeble sektora rządowego } \\
\text { (od centralnego do lokalnych), różni } \\
\text { interesariusze polityki rozwoju obszarów } \\
\text { wiejskich (publiczni, prywatni } \\
\text { i partnerstwa publiczno-prywatne) }\end{array}$ \\
\hline
\end{tabular}

Źródło: [OECD 2006]. 
O nowym paradygmacie rozwoju obszarów wiejskich mówią też inni autorzy, ale proponują inne nazwy, np. paradygmat sieci (network paradigm) [Murdoch 2000, Nemes 2005]. Sieci mogą być rozumiane na wiele sposobów. Na przykład jako relacje między lokalnymi firmami a aktorami społecznymi [Cooke i Morgan 1993, Amin i Thrift 1994] albo jako synteza między kontaktami oddolnymi (bottom-up) i odgórnymi (top-down) w celu rozwijania procesów uczenia i wprowadzania innowacyjności [Lowe, Murdoch i Ward 1995, OECD 1996]. Te ostatnie z kolei uważane są dość powszechnie za „motory wzrostu” i warunki rozwoju [Powell 1990, Cooke i Morgan 1993, Capello 1996]. D. Knoke i J. Kuklinski [1990, s. 175-176], definiują sieć jako specyficzny typ relacji łaczacy zdefiniowana grupę ludzi, obiektów wydarzeń [...] różne typy relacji tworza podstawe różnych sieci. Paradygmat rozwoju obszarów wiejskich poprzez sieci opiera się zatem na transferze wiedzy i technologii rozprzestrzenianych w efektywny sposób, gdyż sieci (zwłaszcza nieformalne) pozwalają na redukcję kosztów transakcyjnych, które powszechnie uważane są za przeszkodę w rozwoju. Nawiązuje on do nowej ekonomii instytucjonalnej i wcześniejszego paradygmatu rozwoju instytucjonalnego w rozwoju obszarów wiejskich. Szerzej o ekonomii instytucjonalnej w kontekście rozwoju obszarów wiejskich pisali m.in. J. Wilkin [2003], A. Czyżewski [2005b, 2007b] i inni.

\subsection{Polityka rozwoju obszarów wiejskich w Unii Europejskiej}

\subsubsection{Przejście od Wspólnej Polityki Rolnej DO WSPÓlNeJ POLITYKI ROLNEJ I WIEJSKIEJ - OD CAP DO CARPE}

Przez długie lata tereny wiejskie były traktowane jedynie jako miejsce wytwarzania surowców żywnościowych, co po II wojnie światowej było spowodowane głównie koniecznością zapewnienia niezbędnej żywności dla zubożałej i zrujnowanej Europy. Instrumenty polityki rolnej były nakierowane na szybki wzrost produkcji rolniczej. Następnie szybkie uprzemysłowienie krajów dzisiejszej Unii Europejskiej spowodowało, że rolnictwo zaczęło odgrywać coraz mniejszą rolę w gospodarce narodowej. Nastąpiło więc przewartościowanie roli rolnictwa w rozwoju obszarów wiejskich [Kłodziński 2006]. To pociągnęło za sobą zmianę optyki wobec obszarów wiejskich, która nastąpiła w konkretnym czasie historycznym i społecznym: globalizacji, ale jednocześnie powrotu lokalizmu, kryzysu społeczeństwa przemysłowego i produktywizmu oraz kryzysu opiekuńczego państwa dobrobytu [Halamska i Śpiewak 2008]. Przejawem doceniania roli obszarów wiejskich w UE i krokami milowymi w kierunku zmiany traktowania obszarów wiej- 
skich były europejskie konferencje, deklaracje i reformy. Uchwalona w 1996 r. Europejska Karta Obszarów Wiejskich odzwierciedlała nurt światowych tendencji, wyrażających się w podejmowaniu różnorodnych działań na rzecz społeczeństwa wiejskiego [European 1995]. Następnym krokiem była Deklaracja z Cork (1996), która zawierała dziesięciopunktowy program polityki wspierania obszarów wiejskich w Unii Europejskiej, ustalony na I europejskiej konferencji poświęconej temu tematowi, zainicjowanej przez Komisję Europejską, pod hasłem: „Wieś Europejska - Perspektywy Na Przyszłość” (Rural Europe - Future Perspectives). Deklaracja ta mówiła m.in., że potrzebne są:

- Preferencje dla wsi - trwały rozwój obszarów wiejskich musi być jednym z najważniejszych zadań Unii Europejskiej, a w najbliższej przyszłości, podstawą jej całej polityki rolnej.

- KOMPLEKSOWE PODEJŚCIE - polityka rozwoju wsi ma w praktyce obejmować wiele sektorów, z wyraźnym podkreśleniem aspektu terytorialnego.

- ZRóżNICOWANIE - wysiłek wspierania zróżnicowania działalności ekonomicznej i społecznej musi się skoncentrować na tworzeniu warunków realizacji indywidualnych i zbiorowych inicjatyw mieszkańców.

- ZACHOWANIE KRAJOBRAZU W NATURALNYM STANIE - polityka wobec wsi powinna promować model rozwoju, który nie narusza stanu, charakteru i uroku wiejskiego krajobrazu Europy, aby obecne pokolenie, czerpiąc z jego zasobów, nie ograniczało korzystania z nich przez pokolenia przyszłe.

- SubSYDIARNość - kładzie nacisk na działania grupowe i „oddolne”, w celu wyzwolenia potencjału twórczego i pogłębienia solidarności środowisk wiejskich.

- UPRoszCZENIE - polityka rozwoju wsi w kwestiach legislacyjnych musi zostać radykalnie uproszczona, szczególnie w samym aspekcie rolnym.

- Programy rozwoJu - realizacja programów, których celem jest rozwój wsi, ma przebiegać na podstawie powszechnie znanych i jasno określonych procedur.

- FinANSOWANIE - przy realizacji lokalnych programów rozwoju wsi należy zachęcać do korzystania z miejscowych środków finansowych. Trzeba tworzyć warunki, umożliwiające $\mathrm{w}$ większym zakresie posługiwanie się projektowaniem finansowym w programach kredytowania wsi.

- ZARZĄDZANiE - jeśli istnieją takie potrzeby, należy wspierać skuteczność i zwiększone kompetencje administracyjne władz lokalnych i regionalnych oraz samorządów poprzez udzielanie pomocy technicznej, prowadzenie szkoleń, usprawnienie łączności, współpracę w zakresie badań naukowych oraz wymianę informacji i doświadczeń.

- OCENA I ROZWÓJ NAUKOWY - potrzebne jest wzmocnienie systemu kontroli, oceniania oraz sposobów szacowania korzyści - takie przedsięwzięcia powinny 
bowiem zapewniać jawność procedur i trybu postępowania oraz zagwarantować, iż pieniądze publiczne będą wydatkowane właściwie; stymulować wynalazczość i rozwój naukowy.

W tym samym 1996 r. grupa naukowców kierowana przez A. Buckwella przygotowała dla Komisji Europejskiej opracowanie na temat pożądanych kierunków reformy WPR [Sotte 2004]. Autorzy zalecali w nim zmniejszenie interwencji rynkowych w rolnictwie na korzyść zwiększenia wagi polityki strukturalnej, ekologicznej i ogólnego rozwoju obszarów wiejskich. Nazwano to przejściem od Common Agricultural Policy (CAP) do Common Agricultural and Rural Policy for Europe (CARPE), co można przetłumaczyć jako przejście od Wspólnej Polityki Rolnej do Wspólnej Polityki Rolnej i Wiejskiej dla Europy. Schemat zaproponowanego przejścia przedstawia rysunek 2.1 [por. też Henisz-Matuszczak 2007, s. 111].

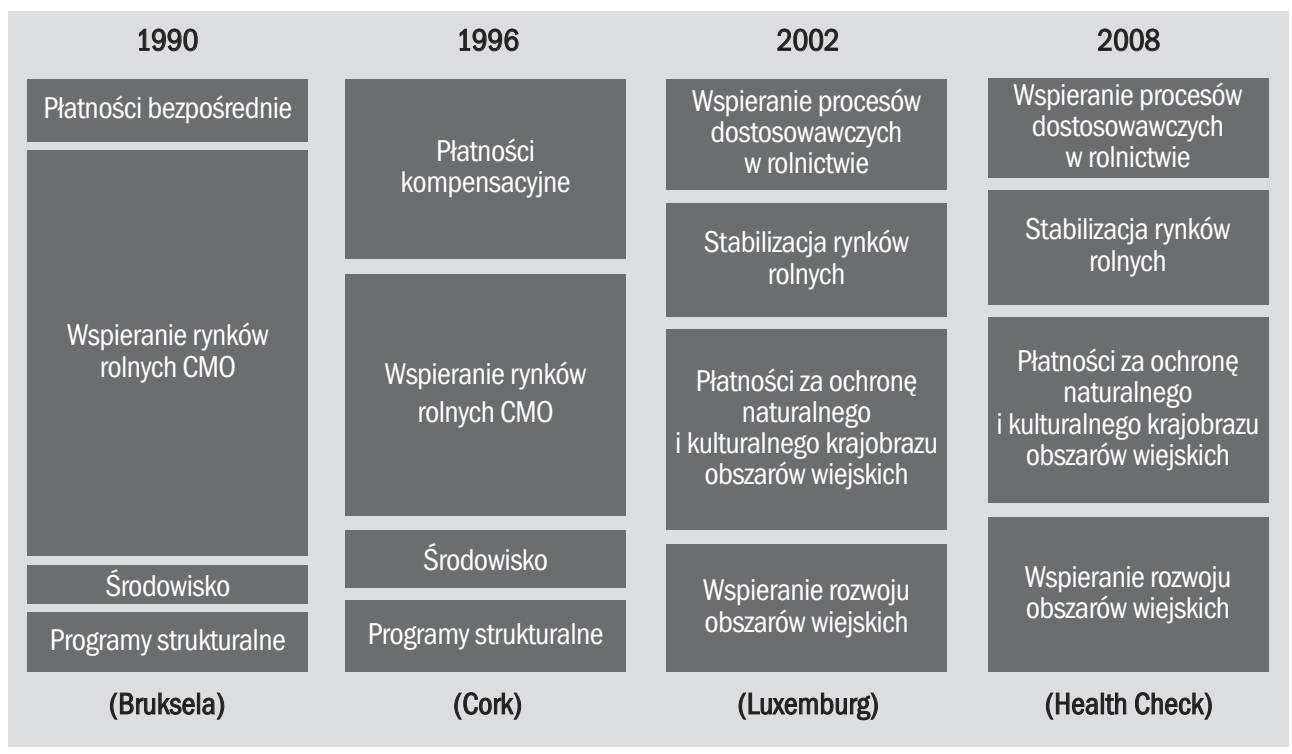

Rysunek 2.1. Ewolucja polityki rolnej od CAP do CARPE Źródło: [Wilkin 1998].

W lipcu 1997 r. Komisja Europejska przedstawiła dokument Agenda 2000, który sformalizował kierunki ewolucji WPR oraz sprecyzował wymagania dla krajów kandydujących do członkostwa w UE. W sprawach dotyczących wsi i rolnictwa Agenda 2000 przewidywała zwiększenie wydatków na fundusze strukturalne i kontynuowanie zmian w polityce rolnej, zapoczątkowanych przez MacSharrego w 1992 r. Do ważniejszych postanowień należało przeznaczenie prawie 0,5\% PKB UE 
na fundusze nakierowane na poprawę społecznej i ekonomicznej spójności UE, kontynuowanie reform polegających na przechodzeniu od wspierania cen do bezpośrednich płatności uzupełnionych zintegrowaną polityką wobec obszarów wiejskich, zwiększenie wewnętrznej i zewnętrznej konkurencyjności rolnictwa europejskiego, chęć zapewnienia godnego standardu życiowego ludności rolniczej i dążenie do ustabilizowania dochodów rolniczych [Agenda 2000, 1997].

Kontynuacją idei zapoczątkowanych w Cork był dokument, jaki powstał podczas drugiej europejskiej konferencji zainicjowanej przez Komisję Europejską na temat obszarów wiejskich, która odbyła się w Salzburgu (2003 r.), zatytułowanej Planting Seeds for Rural Futures - Rural Policy Perspectives for a Wider Europe. W dokumencie pokonferencyjnym zaproponowano m.in. znaczne uproszczenie polityki rozwoju obszarów wiejskich, gdyż poprzedni system oparty był na różnych źródłach finansowania o różnych procedurach. Trzeba zauważyć, że część postulatów wypracowanych na drodze konsultacji społecznych została wzięta pod uwagę przez polityków odpowiadających za politykę wobec obszarów wiejskich. Polityka rolna rzeczywiście zaczęła bardziej preferować wieś (co widać chociażby w rosnących transferach pieniężnych na ten cel), ponadto większy nacisk zaczęto kłaść na kompleksowość i indywidualność terytorialną obszarów wiejskich (co widać po większym zróżnicowaniu działań adresowanych do obszarów wiejskich). Różnicowanie działalności w stronę zatrudnienia nierolniczego doczekało się osobnego wsparcia (np. działanie 2.4 w SPO Rolnictwo zatytułowane „Różnicowanie działalności rolniczej i zbliżonej do rolnictwa w celu zapewnienia różnorodności działań lub alternatywnych źródeł dochodów”), a zarządzanie finansami dla wsi uproszczono (poprzez powołanie Europejskiego Funduszy Rolnego Rozwoju Obszarów Wiejskich). Więcej szczegółów na temat ewolucji wsparcia dla obszarów wiejskich w ramach polityki rolnej omawiamy w następnej części opracowania.

\subsubsection{WSPIERANIE OBSZARÓW WIEJSKICH W RAMACH WSPÓlNEJ POLITYKI ROLNEJ}

Traktat Rzymski, który ustanowił Europejską Wspólnotę Gospodarczą w 1958 r., głosił, że wspólny rynek powinien obejmować również rolnictwo i handel produktami rolnymi (Artykut 38) oraz że Europejska Wspólnota Gospodarcza powinna opierać się na wspólnocie celnej (Artykuł 9). To stwarzało podstawy do Wspólnej Polityki Rolnej, której cele zostały następująco sformułowane w Artykule 39: • zwiększenie wydajności produkcji rolnej w drodze rozwoju postępu technicznego • zapewnienie racjonalnego rozwoju produkcji rolnej oraz jak najpełniejszego wykorzystania 
czynników produkcji • zapewnienie w ten sposób sprawiedliwego poziomu życia ludności rolniczej, w szczególności przez podniesienie indywidualnego dochodu osób zatrudnionych w rolnictwie • stabilizacja rynków • zapewnienie ciągłości zaopatrzenia $\bullet$ zabezpieczenie odpowiednich cen przy dostawach dla konsumenta. Trzeba jednak podkreślić, że Traktat Rzymski w części dotyczącej polityki rolnej nie wspominał jeszcze o wspieraniu obszarów wiejskich.

W zasadzie od początku powstania WPR towarzyszyła jej krytyka i postulaty jej reform. Jednym z pierwszych zarzutów wobec WPR było to, że za pomocą jednego instrumentu (wtedy wsparcia cen) próbuje osiągnąć wiele celów, i to niekoniecznie spójnych ze sobą (np. wzrost dochodów rolniczych, wzrost produkcji etc.). T.E. Josling [1969] stwierdził, że warunkiem koniecznym (choć niewystarczającym) dla osiągnięcia kilku celów ilościowych jednocześnie jest stosowanie podobnej liczby instrumentów co celów. Przyjęcie tego stanowiska może tłumaczyć w dużym stopniu to, że wraz z pojawianiem się nowych celów, głównie związanych $\mathrm{z}$ rozwojem obszarów wiejskich znacznie rozszerzyła się gama instrumentarium wsparcia (działań) w ramach WPR. Szczególnie jest to widoczne w II filarze, gdzie do osiągnięcia jest wiele celów związanych z poprawą jakości życia ludności wiejskiej, infrastruktury technicznej, przedsiębiorczości, jakości środowiska, co wymaga wielu różnych form działania.

W odniesieniu do instrumentów i celów WPR krytykowane jest też to, że decyzje dotyczące hierarchii ważności celów oraz relacji między celami a ograniczeniami (np. budżetowymi) są bardzo upolitycznione. Na przykład w latach 70. XX w. dochody stanowiły główny cel, a równość i efektywność stanowiły cele dodatkowe. Ograniczeniem miękkim zaś był budżet, który można było dostosować. Ale od lat 80. XX w., a zwłaszcza teraz, budżet z ograniczenia stał się celem głównym - tzn. nieprzekraczalność budżetu determinuje pozostałe cele [Ritson i Harvey 1997]. Działania dotyczące rozwoju obszarów wiejskich zaczęły pojawiać się w WPR dopiero na początku lat 90. wraz z reformą MacSharry’ego [1992], która wprowadziła odłogowanie części użytków rolnych (set-asides), zalesianie, programy rolno-środowiskowe. Następnie instrumentarium to wzbogacone zostało o pomoc dla rolników prowadzących działalność na obszarach o niekorzystnych warunkach gospodarowania (ONW) [Hardt 2008].

II filar polityki WPR, formalnie regulujący wsparcie dla rozwoju obszarów wiejskich, utworzony został jednak stosunkowo niedawno, bo w Agendzie 2000 [Dwyer 2005]. Początkowa wielkość funduszy przeznaczonych na ten cel to zaledwie 15\% budżetu EFOiGR, pozostałe 85\% stanowiło wsparcie dla poszczególnych rynków rolnych. To, że coraz większy nacisk zaczęto kłaść na kwestie rozwoju obszarów wiejskich, zaowocowało pojawieniem się większej liczby instru- 
mentów adresowanych do ludności wiejskiej (nie tylko rolniczej) oraz innych interesariuszy tej polityki (firm, sektora publicznego, partnerstw etc.). Rosnąca rola rozwoju obszarów wiejskich w polityce WPR wynika $\mathrm{z}$ malejącej funkcji rolniczej obszarów wiejskich oraz powszechnie rosnącego docenienia dóbr publicznych, jakich mogą dostarczać obszary wiejskie (np. krajobraz, czyste powietrze, bioróżnorodność itp.). Ponadto wsparcie dla rozwoju obszarów stało się politycznie wygodne, gdyż stanowi pewną alternatywę dla niepopularnych form wspierania rolnictwa, czyli form preferujących wąski sektor rolniczy (płatności bezpośrednie), form wpływających na konkurencyjność handlu (dopłaty do eksportu, cła itd.). Wspieranie wsi jest wygodniejszą formą interwencji rządowej gdyż: uzyskuje większą aprobatę ze strony konsumentów żywności unijnej, pozostaje w większej zgodzie z międzynarodowymi regulacjami handlowymi WTO, uznaje interesy szerszej liczby interesariuszy tej polityki, wśród nich bezrolnych mieszkańców wsi oraz mieszkańców miast, którzy na wsparciu wsi zyskają lepszą infrastrukturę turystyczną, oraz jakość żywności itp.

Przez lata udział funduszy na ROW zmieniały się w strukturze budżetu WPR. Na początku lat 80 . XX w. stanowiły zupełnie marginalną część wydatków w porównaniu z filarem I. W latach 90. udział ten znacznie się zwiększył, osiągając w końcu dekady udział podobny do wsparcia dla eksportu, który wcześniej był historycznie wiodącym instrumentem WPR. Wprowadzenie Agendy 2000 przyniosło kolejny wzrost znaczenia ROW w wydatkach WPR, które uległo kolejnemu wzmocnieniu w wyniku reformy z Luksemburga z 2003 r. (rys. 2.2). Ostatnia reforma stworzyła ku temu nowe możliwości, głównie dzięki oszczędnościom zaplanowanym m.in. z: • wprowadzenia obowiązkowej modulacji (redukcji) płatności bezpośrednich na poziomie 3\% (w 2005), 4\% (w 2006) oraz 5\% (rocznie w latach 2007-2012) oraz - wprowadzenia zasady wzajemnej zgodności (cross-compliance), czyli uzależnienia płatności bezpośrednich od przestrzegania zasad związanych ze standardami ochrony środowiska, zdrowotności ludzi i zwierząt, dobrą praktyką, na które zostały przeznaczone dodatkowe środki finansowe. Ponadto zaplanowano nowe instrumenty, w tym programy rolno-środowiskowe adresowane do obszarów wiejskich [FAPA 2004].

W listopadzie 2007 r. KE zapoczątkowała przegląd WPR (Health-Check). W dokumencie inicjującym tę debatę zaproponowała między innymi zwiększenie skali obowiązkowej modulacji płatności z 5\% do 13\%, a także wprowadzenie ograniczeń dla największych beneficjentów płatności bezpośrednich, otrzymujących powyżej 100 tys. EUR. Oszczędności uzyskane tą drogą mają być przeznaczone na zasilenie funduszu programu obszarów wiejskich, podobnie jak w latach poprzednich. Ponadto Komisja Europejska sugeruje, iż naturalnym źródłem dodat- 


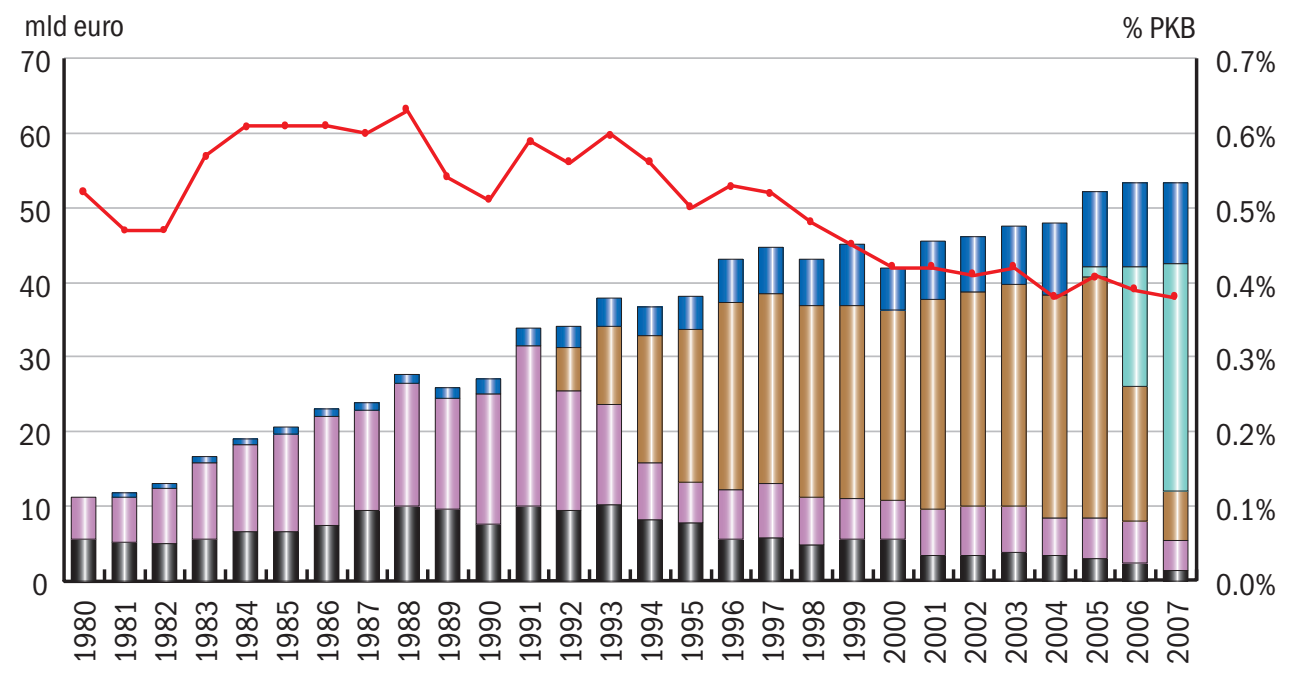

\begin{tabular}{|ll|}
$\square$ Dopłaty do eksportu & $\square$ Wsparcie rynkowe \\
$\square$ Płatności bezpośrednie & $\square$ Płatności niezwiązane z produkcją \\
\hline
\end{tabular}

Rysunek 2.2. Reformowanie wydatków na WPR w latach 1980-2007

Źródło: [Plewa 2008].

kowego finansowania programu rozwoju obszarów wiejskich w przyszłości będą płatności bezpośrednie [Guba 2008]. Jest to ciekawa propozycja, zwłaszcza jeśli weźmiemy pod uwagę, że do tej pory istniało duże zróżnicowanie kontrybucji funduszy z modulacji do programów rozwoju obszarów wiejskich. O ile przeciętny wpływ funduszy z modulacji do II filara na poziomie EU wynosił $25 \%$ całkowitych wydatków UE na PROW, o tyle między krajami wahał się on od 6\% w przypadku Finlandii do 73\% w przypadku Wielkiej Brytanii. Ilustruje to tabela 2.2.

Oprócz ogólnego wzrostu środków na rozwój obszarów wiejskich, zmieniony został także system ich dystrybucji. Dla okresu budżetowego 2007-2013 zrezygnowano $\mathrm{z}$ dawnego sposobu finansowania rozwoju obszarów wiejskich przez obie sekcje EFOiGR oraz fundusze strukturalne na rzecz jednego Europejskiego Funduszu Rolnego Rozwoju Obszarów Wiejskich (EFRROW). Powstał on na mocy Rozporządzenia Rady (RR) nr 1290/2005 z dnia 21 czerwca 2005 r. w sprawie finansowania Wspólnej Polityki Rolnej (to samo rozporządzenie ustanowiło też powstanie Europejskiego Funduszu Gwarancji Rolnej finansującego działania rynkowe). System ten znacznie uprościł sposób wspierania obszarów wiejskich, gdyż wprowadził: • jeden fundusz (wcześniej obszary wiejskie wspierane były zarówno z sekcji gwarancji, jak i orientacji EFOiGR) • jedno główne rozporządzenie 
Tabela 2.2. Kontrybucje z modulacji do krajowych Programów Rozwoju Obszarów Wiejskich w latach 2000-2006

\begin{tabular}{lcc|c|c}
\hline & $\begin{array}{c}\text { PROW 2000-2006 } \\
\text { (mln EUR) }\end{array}$ & $\begin{array}{c}\text { Rocznie PROW } \\
\text { (mln EUR) }\end{array}$ & $\begin{array}{c}\text { Modulacja } \\
\text { (mln EUR) }\end{array}$ & $\begin{array}{c}\text { Modulacja/PROW } \\
\text { (\%) }\end{array}$ \\
\hline Belgia & 360,2 & 51,5 & 12,7 & 24,7 \\
Dania & 336,4 & 48,1 & 22,9 & 47,7 \\
Niemcy & 5269,4 & 752,8 & 158,3 & 21,0 \\
Grecja & 993,4 & 141,9 & 56,9 & 49,8 \\
Hiszpania & 3481,0 & 497,3 & 198,4 & 39,9 \\
Francja & 5086,6 & 726,7 & 246,8 & 34,0 \\
Irlandia & 2388,9 & 341,3 & 32,2 & 9,4 \\
Włochy & 4512,3 & 644,6 & 136,5 & 21,2 \\
Luksemburg & 91,0 & 13,0 & 1,1 & 8,8 \\
Holandia & 417,0 & 59,6 & 24,9 & 41,8 \\
Austria & 3208,1 & 458,3 & 40,4 & 9,0 \\
Portugalia & 1516,8 & 216,7 & 47,0 & 21,7 \\
Finlandia & 2199,3 & 314,2 & 19,0 & 6,1 \\
Szwecja & 1130,1 & 161,4 & 23,3 & 14,4 \\
Wielka Brytania & 1167,5 & 166,8 & 121,3 & 72,7 \\
EU-15 & 32157,9 & 4594,0 & 1141,8 & 24,9 \\
\hline
\end{tabular}

Uwagi: założono 5\% modulację

Źródło: [Henke i Sardone 2004].

- RR 1968/2005 regulujące wsparcie rozwoju obszarów wiejskich przez EFRROW (wcześniej wymagało to wielu rozporządzeń, m.in. RR 1257/1999; RR 1260/1999 i RK 817/2004, RK 1750/1999) • jeden program - Program Rozwoju Obszarów Wiejskich (wcześniej były dwa, SPO oraz PROW) • jeden system zarządzania finansowego i kontroli (wcześniej były 3: Gwarancja, Gwarancja - nowe państwa UE, Orientacja). Porównanie starego i nowego sposobu finansowania przedstawia rysunek 2.3 .

Jednak II filar WPR nadal jest dużo mniejszy niż I filar. W 2006 r. same płatności bezpośrednie absorbowały 68\% budżetu WPR i 32\% całego budżetu UE [Guba 2008], a więc II filar ciągle jest pewnego rodzaju kompromisem, gwarantującym uprzywilejowaną pozycję beneficjentów związanych z rolnictwem [Hardt 2008]. Liczne reformy WPR, bez względu na ewolucję narzędzi regulacji rynków, organizacji ich działania w czasie oraz instytucji rolniczych, utrzymywały na relatywnie stabilnym poziomie warunki dochodowe producentów rolnych [Czyżewski i Henisz-Matuszczak 2005]. Trzeba jednak zauważyć, że przy zachowaniu silnej pozycji rolników powstaje coraz więcej działań adresowanych do szerszego grona mieszkańców wsi. Jak dotąd jedynym systemem zapewniającym przepływ funduszy z filaru I do II jest system modulacji [Van Huylenbroeck, Verbeke i Lauwers 2004]. 


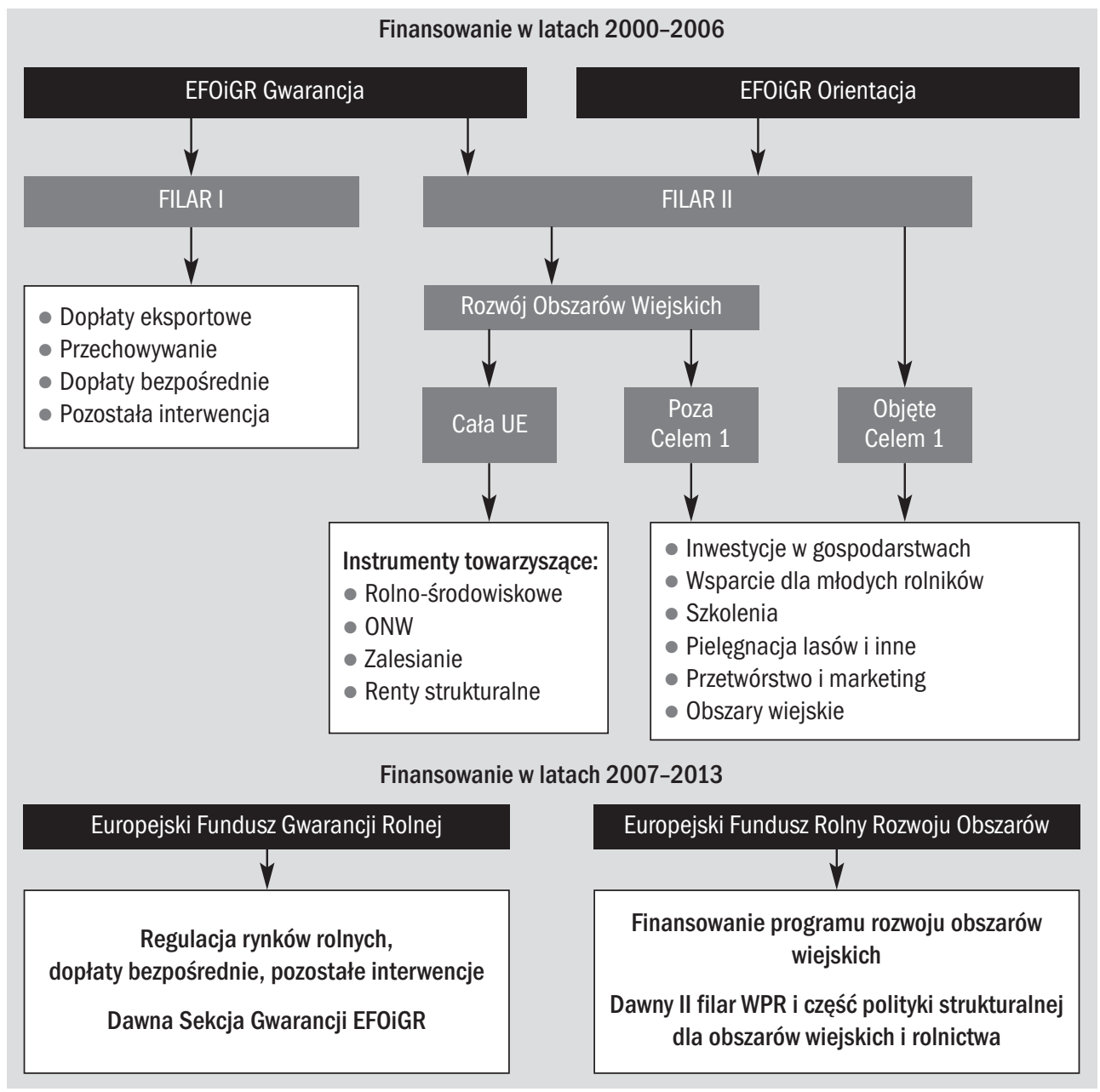

Rysunek 2.3. Porównanie sposobu finansowania rolnictwa i rozwoju obszarów wiejskich w UE w latach 2000-2006 i 2007-2013

Źródło: Na podstawie [Shuckmith, Thomson i Roberts 2005] i [Morten 2006].

Komisja Europejska szacuje, że w latach 2007-2013 wydatki na rozwój obszarów wiejskich w UE sięgną w sumie 225,6 bln EUR. W tym zawiera się 90,8 bln EUR z budżetu EFRROW; 57,7 bln EUR z dofinansowania na poziomach krajowych; 64,8 bln EUR wydatków prywatnych oraz 12,4 bln EUR z krajowych uzupełnień dobrowolnych (national top-ups). Polityka ROW w tym okresie będzie realizowana poprzez 94 programy rozwoju obszarów wiejskich (PROWs), do których należy 88 PROW na poziomie regionalnym i krajo- 
wym $^{26}, 2$ Narodowe Sieci Rozwoju Obszarów Wiejskich (Niemcy, Hiszpania) i 4 Programy dotyczące Krajowych Sieci Rozwoju Obszarów Wiejskich (Niemcy, Włochy, Portugalia, Hiszpania) [KE 2008].

Jeśli chodzi o przyszłość finansowania rozwoju obszarów wiejskich, może się okazać, że najbardziej optymalny z punktu widzenia Polski będzie scenariusz, w którym WPR (poprzez II filar) wspierać będzie rolnictwo, natomiast wielowymiarowa polityka ROW realizowana będzie w ramach polityki spójności. Kontynuacja obecnego trendu zmian w ramach WPR (tj. redukcja subsydiów dla rolnictwa i wzrost znaczenia nierolniczej części II filaru), może okazać się dla polskiej wsi niekorzystna, gdyż będzie oznaczała, po pierwsze, redukcję środków niezbędnych dla wzrostu produktywności rolnictwa, po drugie, będzie utrzymywała iluzję, iż II filar jest skutecznym narzędziem polityki ROW [Hardt 2008].

\subsection{Polska polityka wobec obszarów wiejskich po wstąpieniu do UE}

Unia Europejska uzasadnia potrzebę uczestniczenia każdego kraju we wspólnej polityce rozwoju obszarów wiejskich przynajmniej trzema argumentami. Po pierwsze, poszczególne kraje na tyle różnią się zarówno zamożnością, jak i wiejskością, że byłyby zbyt duże różnice we wsparciu obszarów wiejskich, gdyby poszczególne kraje finansowały je same. Krajów biedniejszych, które są też z reguły bardziej wiejskie, nie byłoby stać na wsparcie tak duże, jakie mogą dostać z budżetu UE, więc różnice w rozwoju i zamożności obszarów wiejskich między krajami jeszcze by się pogłębiały. To byłoby z kolei niezgodne z unijną polityką spójności. Po drugie, pewnych aspektów rozwoju obszarów wiejskich nie da się efektywnie rozwiązywać na poziomie krajowym, bo z definicji są międzynarodowe (np. ochrona środowiska). Jak wiadomo, zanieczyszczenie powietrza wymaga prowadzenia polityki ponad granicami krajów. Trzecim argumentem dla wspólnej polityki rozwoju obszarów wiejskich jest to, że polityka ta zazębia się z innymi politykami, które też są wspólne na poziomie UE, np. z polityką rozwoju regionalnego, polityką rozwoju lokalnego, polityką spójności, a to implikuje wspólne podejmowanie decyzji również w zakresie tej polityki. Dowodem na to, jak bardzo polityka rozwoju obszarów wiejskich w Polsce jest zintegrowana $\mathrm{z}$ innymi politykami unijnymi, jest choćby schemat zależności dokumentów programowych UE i Polski, który przedstawia rysunek 2.4.

Polska, dzięki wstąpieniu do UE, zaczęła korzystać z różnych funduszy rozwojowych, w tym jednym $\mathrm{z}$ najbardziej znaczących jest EFRROW, fundusz

\footnotetext{
${ }^{26}$ Do regionalnych PROWs zaliczają się: 2 w Belgii, 5 we Francji, 14 w Niemczech, 21 we Włoszech, 3 w Portugalii, 17 w Hiszpanii, 4 w Wielkiej Brytanii. Pozostałe kraje realizują po jednym krajowym PROW.
} 
Rozdział 2. Polityka wspierania rozwoju obszarów wiejskich

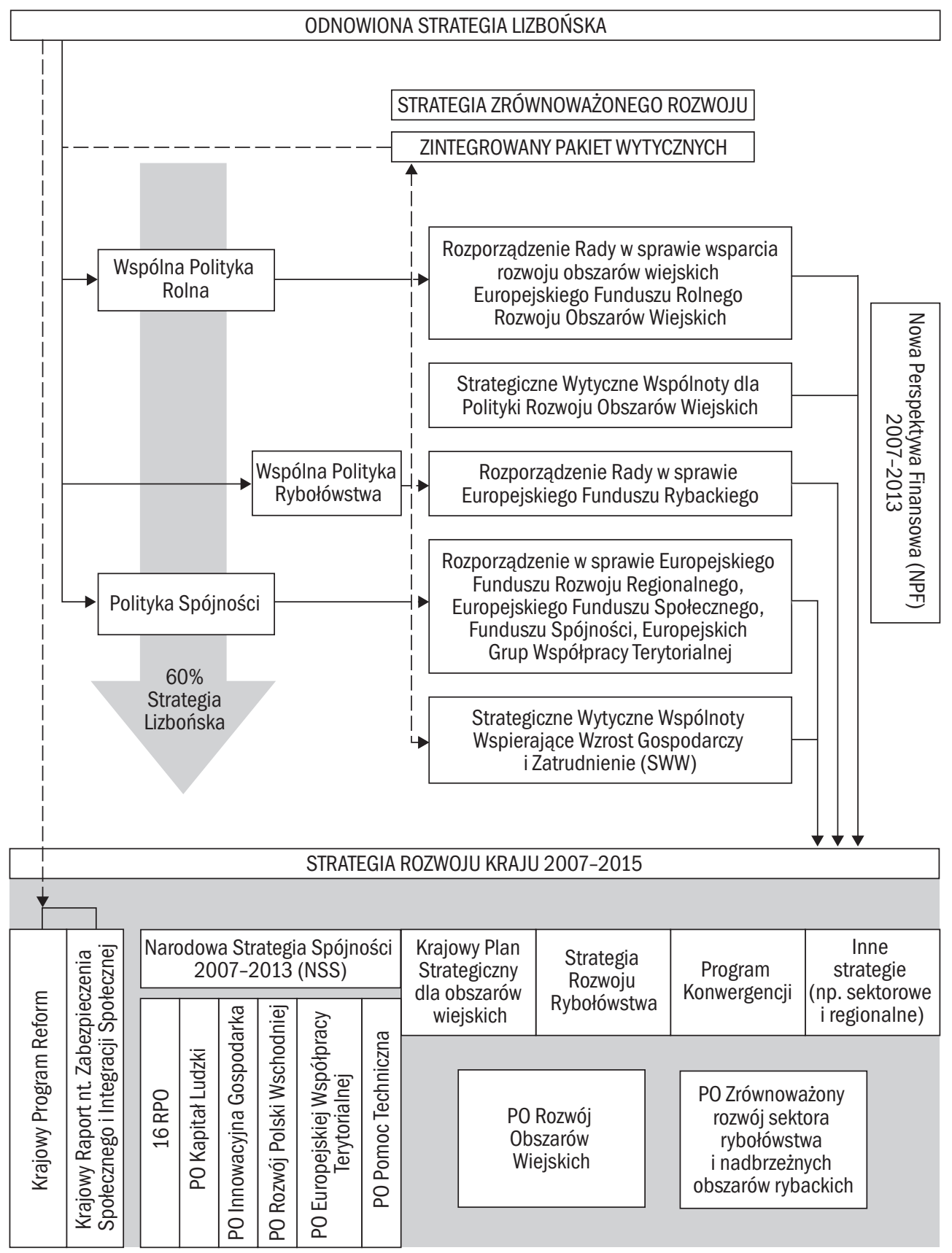

Rysunek 2.4. Spójność pomiędzy politykami wspólnotowymi i dokumentami programowymi UE i Polski

Źródło: [Strategia Rozwoju Kraju 2006]. 
przeznaczony na rozwój obszarów wiejskich, którego Polska została największym beneficjentem. To stworzyło nową, niespotykaną wcześniej szansę na poprawienie kondycji polskiego rolnictwa i całej gospodarki żywnościowej [Wilkin 2006]. Jednak rodzi się ważne pytanie, czy Polska potrafi wykorzystywać tę szansę rozwoju? Autonomia wykorzystywania funduszy na rozwój obszarów wiejskich przez Polskę sprowadza się do samodzielnego dokonania kilku wyborów. Wyboru liczby działań (spośród propozycji KE), rodzaju tych działań (udzielane są one w różnych postaciach, m.in. transferów dochodowych, subsydiów inwestycyjnych, subsydiów obszarowych itp.), dystrybucji środków na te działania (w przypadku wielu działań możliwe jest zastosowanie tzw. kopert regionalnych, które determinują podział środków na województwa). Właśnie decyzje dotyczące tych wyborów wpływają na to, w jakim tempie i do jakiego stopnia Polska korzysta ze środków przeznaczonych na rozwój obszarów wiejskich. W kolejnych podrozdziałach omawiamy każdy z nich z osobna.

\subsubsection{INSTRUMENTY UNIJNEJ POLITYKI ROW w POLSCE}

Zgodnie z Rozporządzeniem Rady (WE) nr 1698/2005 (EC) z 20 września 2005 r. w sprawie wsparcia rozwoju obszarów wiejskich przez Europejski Fundusz Rolny na rzecz Rozwoju Obszarów Wiejskich (EFRROW), Unia zaproponowała 37 działań, z których każdy kraj mógł zbudować własny program odpowiadający jego potrzebom, a równocześnie zgodny z ogólnym kierunkiem polityki rozwoju

Tabela 2.3. Podział EFRROW w latach 2007-2013 między państwa członkowskie [w mln EUR]

\begin{tabular}{l|r|r|l|r|r}
\hline \multicolumn{1}{c}{ Państwo } & $\begin{array}{c}\text { Kwota } \\
\text { wsparcia }\end{array}$ & $\begin{array}{c}\text { Udział (w \%) } \\
\text { EFRROW }\end{array}$ & Państwo & $\begin{array}{r}\text { Kwota } \\
\text { wsparcia }\end{array}$ & $\begin{array}{c}\text { Udział (w \%) } \\
\text { EFRROW }\end{array}$ \\
\hline Austria & 3911,5 & 5,0 & Luksemburg & 90,0 & 0,1 \\
Belgia & 418,6 & 0,5 & Łotwa & 1041,1 & 1,3 \\
Czechy & 2815,5 & 3,6 & Malta & 76,6 & 0,1 \\
Cypr & 162,5 & 0,2 & Niemcy & 8112,5 & 10,4 \\
Dania & 444,7 & 0,6 & Polska & 13230,0 & 17,0 \\
Estonia & 714,7 & 0,9 & Portugalia & 3929,3 & 5,1 \\
Finlandia & 2079,9 & 2,7 & Słowacja & 1969,4 & 2,5 \\
Francja & 6442,0 & 8,3 & Słowenia & 900,3 & 1,2 \\
Grecja & 3707,3 & 4,8 & Szwecja & 1825,6 & 2,4 \\
Hiszpania & 7213,9 & 9,3 & Węgry & 3805,8 & 4,9 \\
Holandia & 486,5 & 0,6 & Wielka Brytania & 1909,6 & 2,5 \\
Irlandia & 2339,9 & 3,0 & Włochy & 8292,0 & 10,7 \\
Litwa & 1743,4 & 2,2 & Ogółem & 77662,8 & 100,0 \\
\hline
\end{tabular}

Źródło: [Rowiński 2007] na podstawie Decyzji Komisji z 12 września 2006 r. ustalającej podział kwoty wsparcia wspólnotowego na poszczególne lata na rzecz rozwoju obszarów wiejskich według państw członkowskich na okres od 1 stycznia 2007 r. do 31 grudnia 2013 r. Dz.Urz. UE. z 2006 r. L 261. 
obszarów wiejskich Wspólnoty [Rowiński 2007]. Strategie co do wyboru liczby i rodzaju działań były różne w różnych krajach. Przy tym obowiązywała zasada, że im większa liczba działań, tym większe rozdrobnienie funduszy na poszczególne cele, gdyż pula środków przeznaczonych na każdy kraj nie mogła ulec zmianie.

Polska uzyskała z EFRROW na lata 2007-2013 największą pulę środków ze wszystkich państw członkowskich, ponad 13,2 mld EUR, w cenach bieżących (prawie 2 mld EUR rocznie, tj. 17\% funduszu ogółem) - tabela 2.3.

Tabela 2.4. Środki z EFRROW rozdysponowane na poszczególne państwa członkowskie w okresie 2007- 2013 w przeliczeniu na 1 ha użytków rolnych i jednego pracującego w rolnictwie [w cenach bieżących]

\begin{tabular}{|c|c|c|c|c|c|}
\hline \multirow[b]{2}{*}{ Państwo } & \multirow{2}{*}{$\begin{array}{c}\text { Kwota wsparcia } \\
\text { (mln EUR) }\end{array}$} & \multirow{2}{*}{$\begin{array}{c}\text { Powierzchnia } \\
\text { użytków } \\
\text { (tys. ha) }\end{array}$} & \multirow{2}{*}{$\begin{array}{c}\text { Liczba } \\
\text { pracujących } \\
\text { (tys.) }\end{array}$} & \multicolumn{2}{|c|}{ Kwota wsparcia (w EUR) } \\
\hline & & & & $\begin{array}{c}\text { na ha } \\
\text { powierzchni }\end{array}$ & $\begin{array}{c}\text { na jednego } \\
\text { pracującego }\end{array}$ \\
\hline Austria & 3911,5 & 3257 & 181 & 1201 & 21610 \\
\hline Belgia & 418,6 & 1394 & 92 & 300 & 4550 \\
\hline Czechy & 2815,5 & 3632 & 208 & 775 & 1353 \\
\hline Cypr & 162,5 & 156 & 17 & 1042 & 9560 \\
\hline Dania & 444,7 & 2658 & 90 & 166 & 4941 \\
\hline Estonia & 714,7 & 796 & 33 & 898 & 21656 \\
\hline Finlandia & 2079,9 & 2245 & 119 & 926 & 17478 \\
\hline Francja & 6442,0 & 27795 & 965 & 232 & 6676 \\
\hline Grecja & 3707,3 & 3968 & 545 & 934 & 6802 \\
\hline Hiszpania & 7213,9 & 25968 & 979 & 278 & 7369 \\
\hline Holandia & 486,5 & 2007 & 256 & 242 & 1900 \\
\hline Irlandia & 2339,9 & 4372 & 117 & 535 & 19999 \\
\hline Litwa & 1743,4 & 2491 & 235 & 700 & 7419 \\
\hline Luksemburg & 90,0 & 128 & 4 & 703 & 22510 \\
\hline Łotwa & 1041,1 & 1489 & 135 & 699 & 7712 \\
\hline Malta & 76,6 & 11 & 3 & 6967 & 25544 \\
\hline Niemcy & 8112,5 & 16982 & 835 & 478 & 9716 \\
\hline Polska & 13230,0 & 14426 & 2409 & 917 & 5491 \\
\hline Portugalia & 3929,3 & 3725 & 619 & 1054 & 6348 \\
\hline Słowacja & 1969,4 & 2138 & 109 & 921 & 18068 \\
\hline Słowenia & 900,3 & 486 & 92 & 1852 & 9786 \\
\hline Szwecja & 1825,6 & 3127 & 107 & 584 & 17062 \\
\hline Węgry & 3805,8 & 4352 & 205 & 875 & 18565 \\
\hline Wielka Brytania & 1909,6 & 16106 & 355 & 119 & 5379 \\
\hline Włochy & 8292,0 & 13116 & 943 & 632 & 8793 \\
\hline Ogółem & 77662,8 & 156033 & 9652 & 498 & 8046 \\
\hline
\end{tabular}

Źródło: [Rowiński 2007].

Jednak inaczej przedstawia się sytuacja wsparcia w przeliczeniu na jednego pracującego w rolnictwie oraz na jednostkę powierzchni użytków rolnych (tab. 2.4). Polska znajduje się wśród państw, które w przeliczeniu na jednostkę powierzchni 
otrzymają w latach 2007-2013 znacznie wyższe wsparcie niż przeciętne (917 EUR na 1 ha przy przeciętnym 498 EUR ha). Natomiast równocześnie wsparcie dla Polski w przeliczeniu na jednego pracującego w rolnictwie kształtuje się znacznie poniżej przeciętnej unijnej (Polska - 5491 EUR przy przeciętnym UE-25 - 8046 EUR) [Rowiński 2007]. Oczywiście ostatni wskaźnik jest wynikiem nadwyżek zasobów pracy w sektorze rolnym.

Oprócz środków z EFRROW (13,2 mld EUR) przewiduje się ich uzupełnienie środkami krajowymi w wysokości 4 mld EUR (co w sumie daje 17,2 mld EUR środków publicznych), uzupełnionych przez ok. 7,8 mld EUR środków prywatnych. W sumie zatem w 2007-2013 na realizację PROW w Polsce przeznaczone zostanie ok. 25 mld EUR [Rowiński 2007].

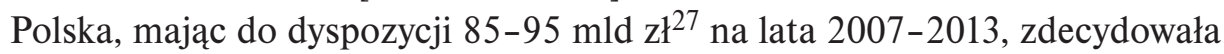
się na realizację 23 działań $^{28}$. W latach 2004-2006 wybrała nieco mniej, bo 21 działań (ale także oferta działań zaproponowanych przez KE w tych latach było mniejsza) - tabela 2.5. Działania, które Polska pominęła z propozycji w PROW 2007-2013, w większości związane były z ochroną środowiska - 6 działań pochodziło z obszaru priorytetowego drugiego, 5 działań z obszaru priorytetowego pierwszego i 3 z obszaru priorytetowego trzeciego - dokładniej omawia je J. Rowiński [2007] i według niego rezygnacja z tych działań była słuszna. Wybór, jakiego dokonała Polska w kwestii liczby działań do realizacji, nasuwa co najmniej dwa wnioski. Po pierwsze, działań tych było i jest bardzo dużo, a to oznacza, że środki są w dużej mierze rozproszone, zamiast koncentrować się na celach priorytetowych. Duża liczba działań oznacza też większe koszty transakcyjne związane z przyjmowaniem i rozpatrywaniem wniosków, z budową skomplikowanego systemu komputerowego, z wysokimi kosztami kontroli itp. Po drugie, aż około 80\% działań przewidzianych na lata 2004-2006 jest realizowanych dalej w okresie 2007-2013 ${ }^{29}$. Z jednej strony, oznacza to pewną dłuższą perspektywę realizowania obranej wcześniej polityki, z drugiej, jest to kontynuacja rozpraszania środków. Ponadto przed zdecydowaniem, które działania są najbardziej efektywne i warte powtórzenia, nie przeprowadzono gruntownej analizy (przynajmniej w debacie publicznej), która dałaby możliwość bardziej świadomego ich wyboru. Można

\footnotetext{
${ }^{27}$ W zależności od kursu złotówki, zakładając, że wynosi między 3,5 a 3,8 za 1 EUR.

${ }^{28}$ Niektóre działania w Polsce były stworzone z dwóch proponowanych przez KE, np. Zalesienie gruntów rolnych oraz zalesianie gruntów innych niż rolne to wg KE dwa różne działania. Zatem licząc poszczególne działania wg terminologii KE, Polska realizowała 25 działań w latach 2007-2013.

${ }^{29}$ Mimo że część działań się powtarzała, miała nieco zmienione zasady, trzeba więc pamiętać, że nie były one identyczne, lecz tylko podobne. Przytaczamy je jednak razem jako powtarzające się, gdyż obszar interwencji był bardzo podobny i nawet nazwy większości z nich były prawie identyczne albo wskazujące na ten sam obszar interwencji.
} 
Rozdział 2. Polityka wspierania rozwoju obszarów wiejskich

Tabela 2.5. Działania polityki ROW wybrane przez Polskę w latach 2004-2006 i w latach 2007-2013

\begin{tabular}{|c|c|c|}
\hline $\begin{array}{l}\text { Nazwa działania } \\
\text { SPO lub PROW i oś* }\end{array}$ & $\begin{array}{c}\text { SPO i PROW } \\
2004-2006 \\
\text { RR lub RK } \\
\end{array}$ & $\begin{array}{c}\text { PROW } \\
\text { 2007-2013 } \\
\text { RR 1698, art. }\end{array}$ \\
\hline 1 & 2 & 3 \\
\hline \multicolumn{3}{|l|}{ OŚ 1} \\
\hline $\begin{array}{l}\text { Szkolenia zawodowe dla osób zatrudnionych w rolnictwie i leśnictwie } \\
\text { (SPO) / (oś 1) }\end{array}$ & $\begin{array}{l}\text { RR 1257/99 } \\
\text { RR1783/03 } \\
\text { RK 445/02 } \\
\text { RK 963/03 }\end{array}$ & 21 \\
\hline Ułatwianie startu młodym rolnikom (SPO) / (oś 1) & $\begin{array}{l}\text { RR 1257/99 } \\
\text { RR1783/03 } \\
\text { RK 445/02 }\end{array}$ & 22 \\
\hline Renty strukturalne (PROW) / (oś 1) & RR 1257/99 & 23 \\
\hline $\begin{array}{l}\text { Wsparcie doradztwa rolniczego (SPO) / Korzystanie z usług } \\
\text { doradczych przez rolników i posiadaczy lasów (oś 1) }\end{array}$ & $\begin{array}{l}\text { Art. } 33 \text { pkt g Traktat } \\
\text { Akcesyjnego }\end{array}$ & tu \\
\hline Modernizacja gospodarstw rolnych (oś 1) & - & 26 \\
\hline $\begin{array}{l}\text { Dostosowanie gospodarstw rolnych do standardów Unii Europejskiej } \\
\text { (PROW) }\end{array}$ & \multicolumn{2}{|l|}{$\begin{array}{l}\text { RR1257/99 } \\
\text { RK 817/04 } \\
\text { RK141/04 }\end{array}$} \\
\hline Inwestycje w gospodarstwach rolnych (SPO) & \multicolumn{2}{|l|}{$\begin{array}{l}\text { RR 1257/99 } \\
\text { RR1783/03 } \\
\text { RK 445/02 }\end{array}$} \\
\hline $\begin{array}{l}\text { Poprawa przetwórstwa i marketingu (SPO) / Zwiększanie wartości } \\
\text { dodanej podstawowej produkcji rolnej i leśnej (oś 1) }\end{array}$ & \multicolumn{2}{|l|}{ Sekcja Orientacji } \\
\hline $\begin{array}{l}\text { Poprawianie i rozwijanie infrastruktury związanej z rozwojem } \\
\text { i dostosowaniem rolnictwa i leśnictwa (oś 1) }\end{array}$ & \multicolumn{2}{|l|}{$\begin{array}{l}\text { RR 1257/99 } \\
\text { RR1783/03 } \\
\text { RK 445/02 }\end{array}$} \\
\hline Uczestnictwo rolników w systemach jakości żywności (oś 1) & \multicolumn{2}{|l|}{-} \\
\hline Działania informacyjne i promocyjne (oś 1) & \multicolumn{2}{|l|}{-} \\
\hline Grupy producentów rolnych (PROW) / (oś 1) & \multicolumn{2}{|l|}{$\begin{array}{l}\text { RR1257/99 } \\
\text { RK 817/04 } \\
\text { RK141/04 }\end{array}$} \\
\hline Gospodarstwa rolne niskotowarowe (PROW) / (oś 1) & \multicolumn{2}{|l|}{$\begin{array}{l}\text { RR1257/99 } \\
141 / 2004\end{array}$} \\
\hline Scalanie gruntów (SPO) & \multicolumn{2}{|l|}{$\begin{array}{l}\text { RR 1257/99 } \\
\text { RR1783/03 } \\
\text { RK 445/02 }\end{array}$} \\
\hline \multicolumn{3}{|l|}{ OŚ 2} \\
\hline $\begin{array}{l}\text { Wspieranie gospodarowania na obszarach górskich i innych obszarach } \\
\text { o niekorzystnych warunkach gospodarowania ONW (PROW)/(oś 2) }\end{array}$ & \multicolumn{2}{|l|}{$\begin{array}{l}\text { RR1257/99 } \\
\text { RK } 817 / 04\end{array}$} \\
\hline $\begin{array}{l}\text { Program rolno-środowiskowy (Płatności rolno-środowiskowe) } \\
\text { (PROW) / (oś 2) }\end{array}$ & \multicolumn{2}{|l|}{$\begin{array}{l}\text { RK } 817 / 04 \\
\text { RR1257/99 }\end{array}$} \\
\hline $\begin{array}{l}\text { Zalesienie gruntów rolnych (PROW) (oś 2) } \\
\text { oraz }\end{array}$ & \multicolumn{2}{|l|}{$\begin{array}{l}\text { RR 1145/03 } \\
\text { RR 1257/99 } \\
\text { RK 817/04 }\end{array}$} \\
\hline zalesianie gruntów innych niż rolne (oś 2) & - & 45 \\
\hline
\end{tabular}


2.3. Polska polityka wobec obszarów wiejskich po wstąpieniu do UE

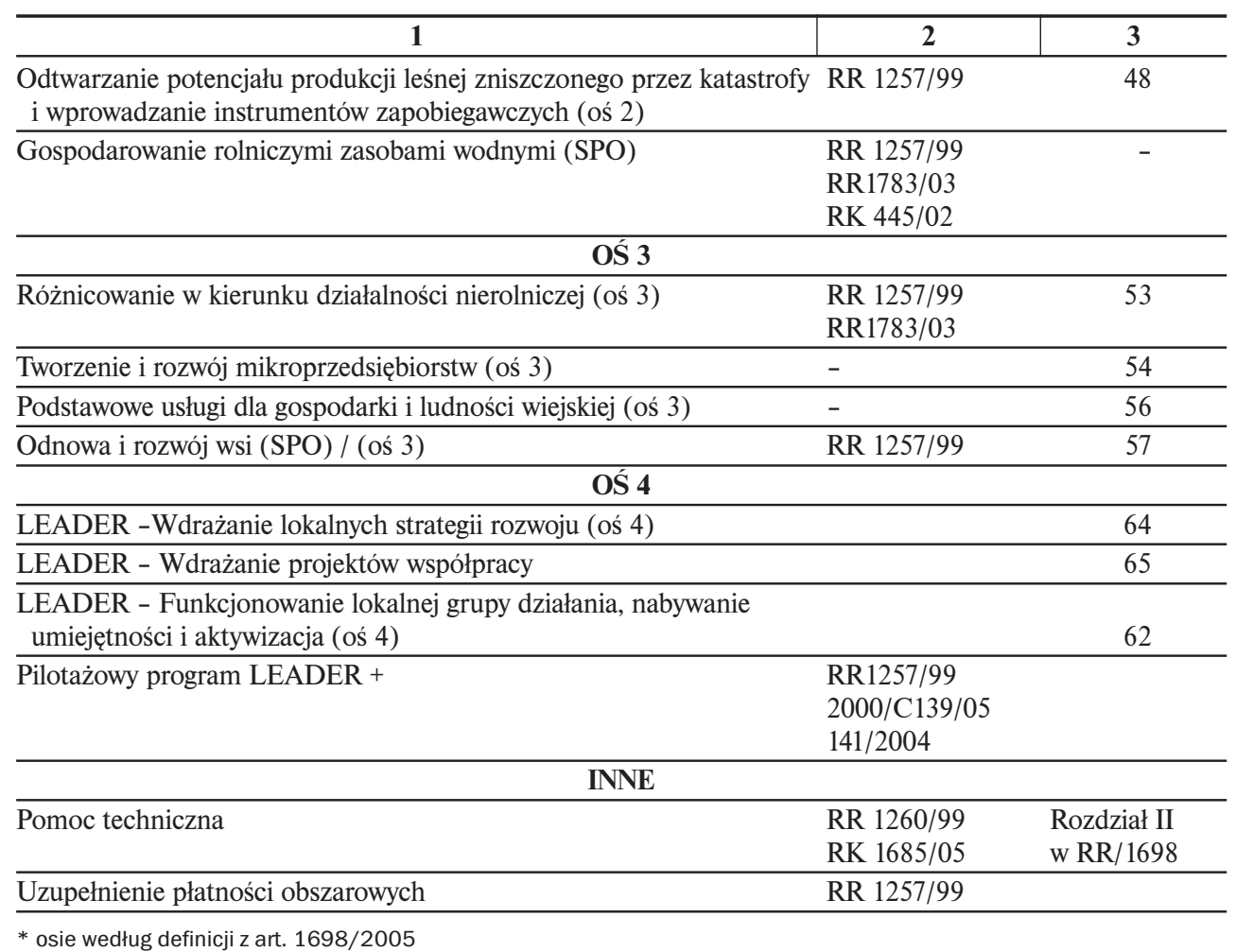

Źródła: Na podstawie Rowiński [2007] i odpowiednie rozporządzenia Rady (RR) lub rozporządzenia Komisji (RK).

zatem powiedzieć, że Polska starała się wybierać „na wszelki wypadek” raczej więcej działań niż za mało. To dawało możliwość „Zabezpieczenia interesów” większej liczbie beneficjentów oraz pewne pole manewru dla sprawdzenia, które działania są najkorzystniejsze.

\subsubsection{KONFLIKT MIĘDZY SPÓJNOŚCIĄ A EFEKTYWNOŚCIĄ W POLITYCE ROW}

Drugi autonomiczny wybór Polski w kwestii prowadzenia polityki ROW dotyczył rodzaju działań, które chce realizować. Wybór ten powinien wiązać się z analizą kosztów i korzyści każdego z działań oraz z rozstrzygnięciem dylematu, czy działania w pierwszej kolejności powinny być proefektywnościowe czy prorównościowe, zgodnie z ideą doganiania zapóźnionych obszarów wiejskich oraz jaka powinna być proporcja jednych względem drugich. 
Dylemat wyboru pomiędzy „równością” a „efektywnością” (equality vs. efficiency) jest nieodłącznym elementem każdej polityki rozwoju [Acocella 1998], a zatem i polityki rozwoju obszarów wiejskich. Jak to ujął wybitny ekonomista [Okun 1975]: [Konflikt] między równościa i efektywnościa [jest] naszym największym społeczno-gospodarczym dylematem i trapi nas $w$ wielu wymiarach polityki społecznej. Nie możemy jednocześnie cieszyć się owocami efektywności rynkowej i równo ich dzielić.

Podejmując działania w celu redystrybucji dochodów od bogatszej części społeczeństwa do biedniejszej (np. za pomocą podatków, płatności transferowych itp.) państwo może zaszkodzić efektywności ekonomicznej i zmniejszyć rozmiary dochodu narodowego do podziału. $Z$ drugiej strony, jeżeli równość jest czymś społecznie pożądanym, warta jest jakiejś ceny. Zasadne jest więc pytanie, jaki koszt w postaci spadku efektywności jesteśmy gotowi ponieść dla większej równości (spójności) i czy polityka rozwoju obszarów wiejskich powinna mieć jakieś preferencje w stronę któregoś $\mathrm{z}$ tych priorytetów.

Koszt redystrybucji dochodów można przedstawić zgodnie z argumentacją Okuna w postaci graficznej, używając do tego „krzywej możliwości dochodów” (AE). Przedstawia to rysunek 2.5 , gdzie na osi X mierzony jest dochód realny połowy populacji o wysokim dochodzie, a na osi Y dochód realny połowy populacji o niskim dochodzie. Punkt A na AE jest w gospodarce wolnorynkowej punktem najbardziej efektywnym, z maksymalnym produktem narodowym. Jednak w punkcie A grupa o wyższych dochodach otrzymuje znacznie większy dochód niż grupa uboższa. Wyrównanie dochodów dla tej grupy może odbywać się poprzez różne instrumenty ekonomiczne, które jednak w praktyce doprowadzają do strat efektywności.

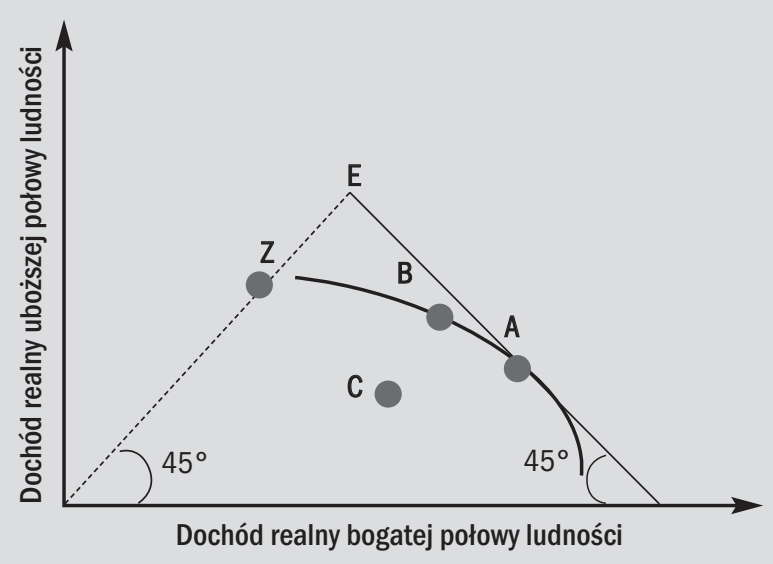

Rysunek 2.5. Redystrybucja dochodu kosztem efektywności ekonomicznej Źródło: [Samuelson i Nordhaus 2004]. 
Nakładanie podatków na bogatych może prowadzić do ich omijania, obniżania inwestycji, zmniejszenia oszczędności, osłabienia bodźców do pracy itp. To oznacza, że społeczeństwo nie może znaleźć się w punkcie E (oznaczającym najwyższy dochód przy wyrównanych dochodach obu grup), ale porusza się po krzywej ABZ, która oznacza straty w efektywności na skutek poprawiania nierówności dochodowych. Decyzją polityczno-społeczną jest zatem, ile efektywności, a co za tym idzie, i dochodu narodowego, zostanie poświęcone dla uzyskania większej równości. W praktyce obserwowaliśmy różnego rodzaju próby wyrównywania dochodów na poziomie krajowym. $\mathrm{Z}$ jednej strony, doświadczenia krajów socjalistycznych pokazały, że przy znoszeniu własności prywatnej wprawdzie zmniejszały się nierówności, ale dochodziło do zaniku bodźców do pracy, inwestowania $\mathrm{i}$ innowacji, aż całe narody popadły w nędzę [Samuelson i Nordhaus 2004]. Z drugiej strony, obserwujemy model „państwa opiekuńczego”, inaczej „państwa dobrobytu”, czyli gospodarki kapitalistycznej z silnym interwencjonizmem państwowym, będącym przeciwieństwem liberalizmu ekonomicznego. Państwa takie kładą szczególny nacisk na dostęp do nieodpłatnej służby zdrowia, szkolnictwa, osłon socjalnych itp. Według typologii [Esping-Andersen 1990] są trzy typy państw dobrobytu i zaliczają się do nich: reżimy liberalne (np. USA), reżimy konserwatywne (np. Niemcy) oraz reżimy socjaldemokratyczne (np. Szwecja). A więc reprezentantami tego modelu są państwa, które uchodzą za dobrze funkcjonujące i rozwijające się. Jednak wyrównywanie dochodów w tych krajach również nie obywało się bez sporów i kosztów [Samuleson i Nordhaus 2004]. W Europie toczy się debata na temat konieczności demontażu państwa opiekuńczego ze względu na zbyt słaby wzrost gospodarczy oraz kryzys demograficzny i konieczność przechodzenia od państwa wspierającego równość społeczną do państwa wspierającego pracę [Golinowska 2003].

W polskiej literaturze dylemat ten przewijał się już niejednokrotnie w kontekście polityki regionalnej [np. Gorzelak 2003, 2004, Gorzelak i Tucholska 2007]. $Z$ jednej strony, mamy autorów uznających zwiększające się różnice między regionami za nieuchronne, argumentujących, że polaryzacja jest naturalną w gospodarce rynkowej tendencją na pewnym etapie rozwoju gospodarczego i najkrótszą drogą do uzyskania efektywności, a więc jest zjawiskiem pozytywnym. Na przykład M. Kołodziejski [1995b] stwierdza, że najpierw powinna być efektywność, a potem równość, jeśli nie można obu wartości osiagnąć równocześnie. A w warunkach polskiej niestabilności gospodarczej praktyczna realizacja tej równoczesności jest mało realna. Wskazuje on jednak na trudność realizacji tych celów w takiej kolejności, gdyż w Polsce panuje uformowane historycznie przywiązanie do egalitaryzmu (PRL promował równość nawet bez efektywności). Podobnie 
uważa B. Jałowiecki [1999]: polaryzacja rozwoju regionalnego jest zjawiskiem powszechnym, zwiazanym z koncentracja najszybciej rosnacych dziedzin gospodarki i najsilniej występuje $w$ krajach postsocjalistycznych przechodzacych przyspieszona restrukturyzację, takich jak Polska. Natomiast W. Michna [1999] uważa, że gospodarcze i ekonomiczne dysproporcje w rozwoju obszarów wiejskich mogą być korzystne dla ogólnego tempa oraz skali rozwoju, gdyż sprzyjają procesom regionalnej specjalizacji, a w konsekwencji mogą być jednym z ważniejszych czynników poprawy konkurencyjności polskiego rolnictwa. Z kolei G. Gorzelak [2007] poddaje pod dyskusję, czy warto w ogóle wspierać regiony słabiej rozwinięte [Błąd 2007]. Inni polscy autorzy przypisują z kolei polityce regionalnej ważną misję wyrównywania szans rozwoju, gdyż nierówności zaszły zbyt daleko (np. [Wiatrak 1996, Heller 2000a, Winiarski 2000, Woś i Zegar 2002], stwierdzając, że obecny rozmiar zróżnicowań regionalnych jest nadmierny, a mechanizmy rynkowe mogą go jeszcze powiększyć. Regiony bardziej rozwinięte cechuje z reguły wyższa efektywność nakładów, a to sprzyja kumulacji czynników rozwoju na tych obszarach, w przeciwieństwie do regionów mniej rozwiniętych, które podlegają względnej degradacji.

Dylemat efektywności i równości jest też szczególnie widoczny w podstawowych założeniach funkcjonowania UE, bowiem oprócz polityki konkurencyjności zawartej w strategii lizbońskiej, mówiącej o stworzeniu najbardziej konkurencyjnej gospodarki na świecie opartej na wiedzy, realizuje się jednocześnie politykę wyrównywania szans. Do tej drugiej niewątpliwie należą: polityka spójności (mówiąca o przyspieszeniu konwergencji najsłabiej rozwiniętych państw członkowskich i regionów), deklaracja $z$ Göteborga (mówiąca o rozwoju, ale zrównoważonym) i różne inicjatywny wspólnotowe (np. EQUAL), mające prowadzić do objęcia szczególną opieką grup i obszarów wykluczonych społecznie. Trzeba uznać, że dylemat wyboru między efektywnością a równością nie jest jednoznacznie rozstrzygnięty. Ważna w prowadzeniu polityki jest jednak świadomość, że między tymi dwoma pojęciami zachodzi w dużym stopniu relacja „coś za coś”. W następnym podrozdziale przyglądamy się, jak ten dylemat jest obecny w przypadku polityki ROW w Polsce. Wcześniej na ten temat pisali m.in. J. Rowiński [2007] - w kontekście kryteriów zaliczania działań na wsparcie konkurencyjności a wsparcie dochodów ludności wiejskiej; E. Kiryluk-Dryjska [2008] - o optymalizacji alokacji wydatków na poszczególne działania wspierające rozwój obszarów wiejskich; czy K. Zawalińska [2008] - zajmując się proporcjami między funduszami przeznaczonymi na poprawę konkurencyjności a na poprawę dochodów. W książce działania ROW zostały poddane analizie pod kątem tego, jak kształtuje się proporcja środków nastawionych na wyrównywanie dochodów 
(prorównościowych) w stosunku do środków nastawionych na maksymalizowanie efektywności, a więc rozwoju. W dalszej części rozprawy, w podrozdziale 4.2, dokonujemy też próby oszacowania kosztów związanych z utratą efektywności na poczet równości.

\subsubsection{KLASYFIKACJA POZYSKANYCH FUNDUSZY ROW}

Spróbujmy rozstrzygnąć, czy Polska dokonała dobrego wyboru działań pod względem ich potencjału rozwojowego dla obszarów wiejskich, pamiętając o kontekście ówczesnych realiów. Trzeba wziąć pod uwagę, że Polska przystąpiła do WPR w dość specyficznym momencie, kiedy kładziono większy niż kiedykolwiek wcześniej nacisk na II filar, czyli rozwój obszarów wiejskich. W dodatku w momencie wstępowania Polski do UE stare kraje członkowskie miały podzielone środki między I i II filar w dużej dysproporcji na korzyść tego pierwszego, czyli około 90\% do $10 \%$, podczas gdy Polska otrzymała mniej więcej tyle samo środków na I i II filar. Ponadto przystapiła w rekordowo dużej grupie krajów, i to generalnie biedniejszych od starych krajów UE, a ich politykom zależało na przekonaniu swoich obywateli do UE. Można się zatem spodziewać, że w nowych krajach członkowskich na znaczeniu zyskały działania prorównościowe, których początkową rolą było nie tylko (a może nawet nie przede wszystkim) zapewnienie rozwoju, lecz pozyskanie dla sprawy integracji szerokiego grona społecznego. Kwestia absorpcji środków była stawiana w debacie publicznej na pierwszym miejscu, a kwestie efektywnościowe na drugim. W tej sytuacji zasadne jest postawienie tezy, że polityka rozwoju obszarów wiejskich w Polsce faworyzowała działania prorównościowe kosztem rozwiązań proefektywnościowych, przynajmniej w pierwszym okresie realizacji unijnej polityki ROW.

Żeby zweryfikować tę hipotezę, dokonaliśmy podziału wszystkich działań SPO i PROW 2004-2006 według trzech klasyfikacji, doprowadzając w konsekwencji do wyłonienia działań prorównościowych i proefektywnościowych. Następnie, opierając się na płatnościach zrealizowanych, oceniliśmy proporcję jednych względem drugich.

Pierwsza klasyfikacja działań, nazwana klasyfikacją wg kryteriów unijnych, oparta jest na definicjach i nazewnictwie z PROW 2007-2013, czyli podziale na trzy osie priorytetowe. Oś 1. to Poprawa konkurencyjności rolnictwa i leśnictwa, oś 2. to Poprawa stanu środowiska naturalnego i obszarów wiejskich, a oś 3, to Jakość życia na obszarach wiejskich i różnicowanie działalności rolniczej. Dodatkową osią 4. jest program LEADER. Mimo iż taki podział na 3 osie pojawił się później niż analizowany przez nas okres, to ze względu na powtarzające się w przeważającej 
większości działania i priorytety, używanie tej nomenklatury jest zasadne, pozwala bowiem na ujednolicenie terminologii dotyczącej polityki ROW od wstapienia Polski do UE, co zwiększa porównywalność programów z obu okresów finansowych.

Do osi 1 zaliczono takie działania jak: renty strukturalne, gospodarstwa niskotowarowe, dostosowania do standardów UE, wsparcie dla grup producenckich, inwestycje w gospodarstwa rolne, wsparcie dla młodych rolników, szkolenia, doradztwo, poprawa przetwórstwa i marketingu sektora żywnościowego i scalanie gruntów.

Do osi 2 zaliczono: wsparcie dla ONW, programy rolno-środowiskowe, zalesianie oraz przywracanie potencjału produkcji leśnej.

Do osi 3 zaliczono: odnowę wsi i zachowanie dziedzictwa kulturowego, różnicowanie działalności rolniczej, gospodarowanie zasobami wodnymi oraz rozwój infrastruktury technicznej.

W wyniku tej klasyfikacji i opierając się na płatnościach zrealizowanych (stan na 31 grudnia 2007 r.), możemy stwierdzić, że w latach 2004-2006 fundusze na ROW rozłożyły się następująco: $61,6 \%$ środków przeznaczono na poprawę konkurencyjności rolnictwa, nieco ponad 31,3\% na poprawę środowiska, 7\% na poprawę jakości życia i znikomą część, 0,1\%, na program LEADER (rys. 2.6).

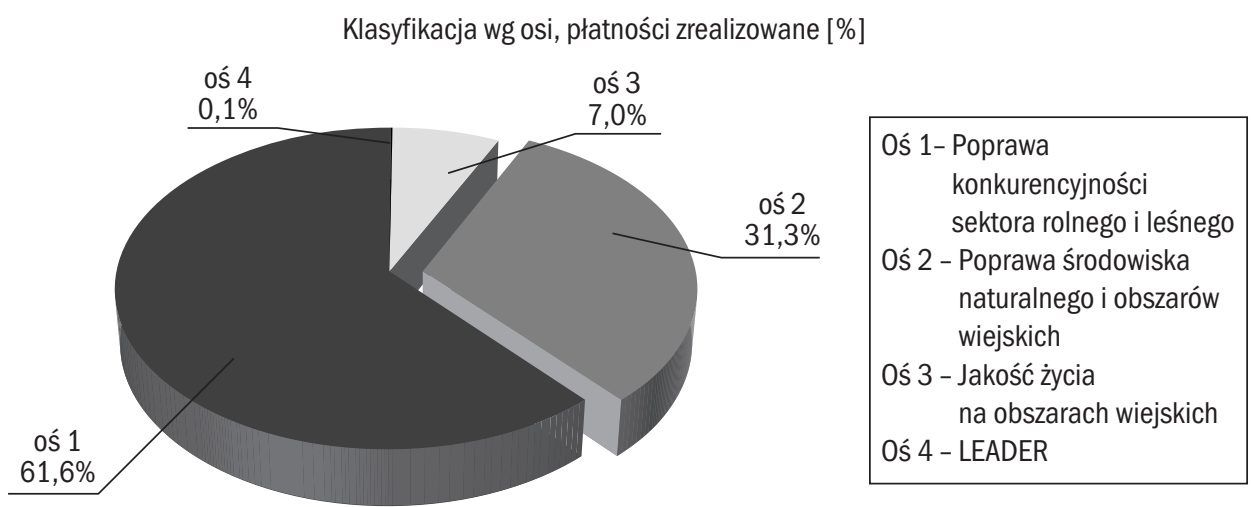

Rysunek 2.6. Klasyfikacja funduszy ROW w latach 2004-2006 wg kryteriów unijnych

Źródło: Obliczenia własne na podstawie płatności zrealizowanych stan na 31 grudnia 2007 r., ARiMR [2008].

Taka klasyfikacja wydawałaby się wskazywać, że w strukturze wsparcia przeważały środki proefektywnościowe, czyli przeznaczone na poprawę konkurencyjności. Jednak taki wniosek jest zbyt pochopny, co najmniej z dwóch 
względów. Po pierwsze, jak już wskazywał na to Rowiński [2007] przy analizie okresu 2007-2013, tak i tutaj można śmiało stwierdzić, że tytuły osi nie w pełni oddają istotę ekonomiczną i społeczną włączonych do nich działań. Po drugie, nawet gdyby nazwy osi były adekwatne do nazw działań, to i tak byłby problem z kwalifikacją tych środków na proefektywnościowe i prorównościowe, gdyż nazwy osi nie odpowiadają takiemu podziałowi. Na przykład, wzrost konkurencyjności rolnictwa ma wprawdzie odniesienie proefektywnościowe, bo konkurencyjność mierzy się m.in. poprzez wzrost efektywności, więc można by się pokusić o nadanie tej osi nazwy proefektywnościowej. Ewentualnie osi Poprawa jakości życia i różnicowanie działalności można by nadać określenie prorównościowej, ale z osią Poprawa środowiska naturalnego byłby już problem praktycznie nie do rozstrzygnięcia. Podobnie na podstawie samych nazw działań nie sposób rozstrzygnąć, które należą do proefektywnościowych, a które do prorównościowych.

Przechodzimy zatem do drugiego rodzaju klasyfikacji, która stara się nieco urealnić nazwy priorytetów i podlegających im działań na podstawie tego, jaką rolę odgrywają one w rzeczywistości. Klasyfikacja ta nazwana została klasyfikacją wg J. Rowińskiego. Metodologia Rowińskiego [2007] jest tutaj zastosowana do okresu 2004-2006 (w oryginale odnosi się do lat 2007-2013) oraz występuje z mała modyfikacją ${ }^{30}$, przy zachowaniu analogi podejścia tego autora. Działania zostały podzielone na pięć następujących grup: A. Rozwój gospodarki żywnościowej, B. Rozwój środowiska, C. Rozwój pozarolniczych działów gospodarki ${ }^{31}$, D. Dochody i transfery socjalne, E. Pomoc o charakterze technicznym.

Do grupy A zaliczono takie działania, jak: dostosowania do standardów UE, wsparcie dla grup producenckich, inwestycje w gospodarstwach rolnych, szkolenia, doradztwo, poprawa przetwórstwa i marketingu sektora żywnościowego, scalanie gruntów.

Do grupy B zaliczono: programy rolno-środowiskowe, zalesianie oraz przywracanie potencjału produkcji leśnej.

\footnotetext{
${ }^{30}$ Modyfikacja polegała na kilku drobnych zmianach. Po pierwsze, autorka zmieniła nieco brzmienie oraz porządek liter przypisanych poszczególnym grupom. Dokładniej, grupie B przypisała „środki na rozwój środowiska”, grupie C środki na „rozwój pozarolniczych działów gospodarki” a grupie E środki na „pomoc o charakterze technicznym”, podczas gdy w oryginalnej klasyfikacji to grupie B przypisane były „środki wspierające inne działy gospodarki”, a w grupie C „środki wspierające ochronę środowiska”. Z kolei grupa E w oryginalnym brzmieniu to ,inne środki”. Po drugie, autorka przeniosła z grupy A do grupy D działanie ,wsparcie dla gospodarstw niskotowarowych” oraz działanie „wsparcie dla młodych rolników”, uznając je tym samym za działania wspierające dochody, a nie konkurencyjność rolnictwa.

${ }^{31}$ Rozwój pozarolniczych działów gospodarki jest tu w przeważającym stopniu rozdzielny z rozwojem gospodarki żywnościowej.
} 
Do kolejnej grupy, C, zaliczono: odnowę wsi i dziedzictwa kulturowego, różnicowanie w kierunku działalności nierolniczej, gospodarowanie zasobami wodnymi oraz rozwój infrastruktury technicznej na wsi.

W grupie D znalazły się: renty strukturalne, wsparcie dla gospodarstw niskotowarowych, wsparcie dla ONW oraz wsparcie dla młodych rolników.

Do ostatniej kategorii E zakwalifikowano program pilotażowy LEADER i pomoc techniczną.

W wyniku klasyfikacji drugiej (i na podstawie płatności zrealizowanych) ujawnił nam się zgoła odmienny podział funduszy. Tym razem przewagę nad pozostałymi kategoriami osiągnęły środki stanowiące dochody i transfery socjalne (grupa D), składające się na prawie 50\% całych funduszy na ROW w analizowanym okresie. Środki na rozwój gospodarki żywnościowej tym razem stanowią tylko około 35\% funduszy, a środki na rozwój środowiska niecałe 8\%. Pozostałe 7\% przypadło na rozwój pozarolniczych działów gospodarki oraz $0,1 \%$ na pomoc o charakterze technicznym. Podział ten obrazuje rysunek 2.7.

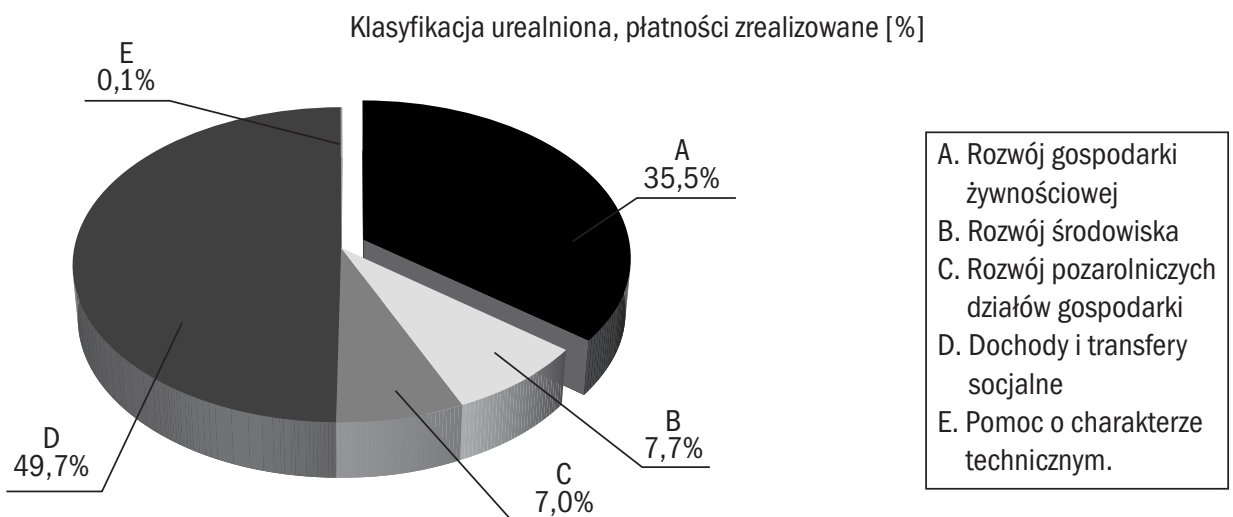

Rysunek 2.7. Klasyfikacja funduszy polityki ROW 2004-2006 wg klasyfikacji J. Rowińskiego Źródło: Obliczenia własne na podstawie płatności zrealizowanych stan na 31 grudnia 2007 r., ARiMR [2008] oraz Rowiński [2007].

Powyższa klasyfikacja wydawałaby się wskazywać na sytuację odwrotną do poprzedniej - w strukturze wsparcia przeważały środki prorównościowe. Ale i ten wniosek, podobnie jak przy poprzedniej klasyfikacji, wydaje się nazbyt pochopny. Wciąż bowiem brakuje „ostrego” podziału na środki prorównościowe i proefektywnościowe. Do tego jednak potrzebne nam są kryteria ekonomiczne oraz wni- 
kliwa analiza wydatkowanych funduszy pod kątem tego, na co faktycznie zostały przeznaczone. Przechodzimy teraz do trzeciej klasyfikacji, nazwanej klasyfikacją wg kryteriów ekonomicznych. Opiera się ona, po pierwsze, na analizie ilościowej płatności zrealizowanych, pod kątem struktury faktycznie poniesionych kosztów kwalifikowanych. Źródłem danych są tu raporty ARiMR. Po drugie, opiera się na analizie jakościowej, czyli wywiadach z pracownikami ODR-ów oraz ankietach przeprowadzonych z pracownikami regionalnych oddziałów ARiMR (aneks 2.4). Każde działanie zostało wnikliwie przeanalizowane pod kątem jego charakteru ekonomicznego oraz faktycznego przeznaczenia. Wynik klasyfikacji poszczególnych działań wg klasyfikacji ekonomicznej prezentuje tabela 2.6, a szczegóły analizy poprzedzającej zakwalifikowanie każdego działania do konkretnej grupy zawiera aneks 2.1.

Tabela 2.6. Podział działań z PROW i SPO Rolnictwo 2004-2006 wg kryteriów ekonomicznych

\begin{tabular}{lll}
\hline \multicolumn{1}{c}{ Nazwa działania } & \multicolumn{1}{c}{ Narzędzie ekonomiczne } & Symbol \\
\hline 1. RENTY STRUKTURALNE & Transfer bezpośredni & TB \\
2. GOSPODARSTWA NISKOTOWAROWE & Transfer bezpośredni & TB \\
3. OBSZARY ONW & Subsydium obszarowe & SO \\
4. PROGRAMY ROLNO-ŚRODOWISKOWE & Subsydium obszarowe & SO \\
5. ZALESIANIE GRUNTÓW ROLNYCH & Transfer bezpośredni & TB \\
6. DOSTOSOWANIE DO STANDARDÓW UE & Subsydium inwestycyjne w infrastrukturę & SI_b \\
7. GRUPY PRODUCENCKIE & Transfer bezpośredni & TB \\
1.1. Inwestycje w gospodarstwach rolnych & Subsydium inwestycyjne w infrastrukturę & SI_b \\
1.2. Wsparcie dla młodych rolników & Transfer bezpośredni & TB \\
1.3. Szkolenia & Subsydium inwestycyjne (edukacja) & SI_e \\
1.4. Doradztwo rolnicze & Subsydium inwestycyjne (edukacja) & SI_e \\
1.5 Poprawa przetwórstwa i marketingu & Subsydium inwestycyjne w infrastrukturę & SI_b \\
2.1. Przywracanie potencjału produkcji leśnej & Subsydium inwestycyjne w infrastrukturę & SI_b \\
2.2. Scalanie gruntów & Subsydium inwestycyjne w infrastrukturę & SI_b \\
2.3. Odnowa wsi i dziedzictwo kulturowe & Subsydium inwestycyjne w infrastrukturę & SI_b \\
2.4. Różnicowanie działalności rolniczej & Subsydium inwestycyjne w infrastrukturę & SI_b \\
2.5. Gospodarowanie zasobami wodnymi & Subsydium inwestycyjne w infrastrukturę & SI_b \\
2.6. Rozwój infrastruktury technicznej & Subsydium inwestycyjne w infrastrukturę & SI_b \\
2.7. LEADER+ & Subsydium inwestycyjne (edukacja) & SI_e \\
\hline
\end{tabular}

Uwaga: dużymi literami zaznaczono działania PROW, a małymi SPO 2004-2006

Źródło: Obliczenia własne.

Według tej klasyfikacji działania podzielone zostały na cztery następujące grupy:

1. Transfery bezpośrednie (TB), 2. Subsydia obszarowe (SO), 3. Subsydia inwestycyjne w infrastrukturę/budownictwo (SI_b), 4. Subsydia inwestycyjne w kapitał ludzki/edukację (SI_e). 
$\mathrm{Z}$ rozkładu płatności zrealizowanych wynika, że największe wsparcie na rozwój obszarów wiejskich (42\% środków) przyznano w formie subsydiów inwestycyjnych ( $41 \%$ na inwestycje w infrastrukturę, a $1 \%$ na inwestycje w kapitał ludzki). Na drugim miejscu były subsydia obszarowe (29\%), a na trzecim transfery bezpośrednie $(29 \%)$ - rysunek 2.8 .

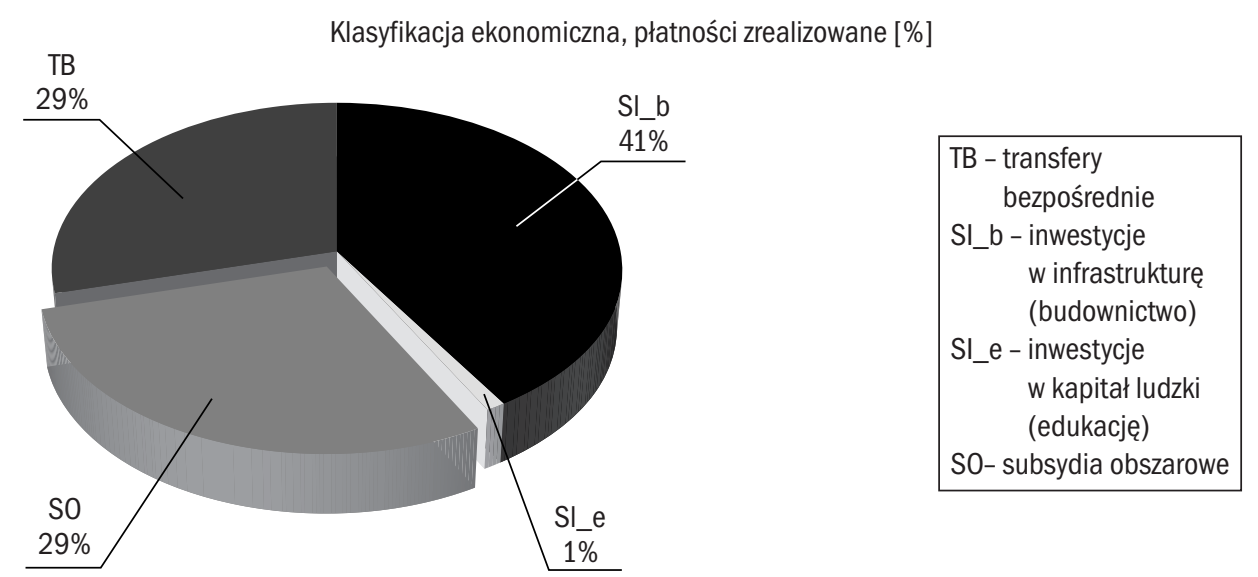

Rysunek 2.8. Klasyfikacja funduszy ROW w latach 2004-2006 wg kryteriów ekonomicznych Źródło: Obliczenia własne na podstawie płatności zrealizowanych stan na 31 grudnia 2007 r., ARiMR [2008].

Następnie wszystkie działania zostały podzielone na proefektywnościowe i prorównościowe ze względu na ich zakładane przeznaczenie i sposób przekazania beneficjentom. Oczywiście poprzez zaklasyfikowanie działania jako instrument proefektywnościowy czy prorównościowy nie determinujemy a priori jego efektywności. Stwierdzamy jedynie, że jest to instrument, który z racji konstrukcji (sposobu przekazania i przeznaczenia) nastawiony jest na poprawę efektywności (proefektywnościowy) lub raczej na wyrównywanie szans (prorównościowy). Dopiero dalej, w wyniku empirycznej analizy ilościowej przeprowadzonej w rozdziale 4 za pomocą modelu RegPOL, oceniamy faktyczną efektywność jednych i drugich typów instrumentów, opierając się na wiedzy i założeniach co do faktycznego przeznaczenia tych funduszy w ramach poszczególnych grup instrumentów. Ze względu na formę przekazania i przeznaczenia funduszy do kategorii proefektywnościowych zaliczono wszystkie subsydia inwestycyjne (SI_b i SI_e), gdyż jest udokumentowane, że służyły faktycznym inwestycjom budowlanym lub modernizacyjnym, np. w instalację maszyn i urządzeń, infrastrukturę drogową, 
środki transportu, nowe technologie etc. ${ }^{32}$ Natomiast transfery bezpośrednie (TB) nie wymuszały konkretnego przeznaczenia i często respondenci ${ }^{33}$ określali je jako wydatki na dobra konsumpcyjne. Dlatego z dużym prawdopodobieństwem możemy założyć, że przeważnie fundusze te przeznaczane były na konsumpcję. Na przykład w oczywisty sposób służyły temu największe TB, tj. renty strukturalne, które były formą emerytury na utrzymanie się po przekazaniu gospodarstwa (a więc na konsumpcję bieżąca). Na pewno w dużym stopniu wydatkami prorównościowymi było „wsparcie dla gospodarstw niskotowarowych”, które z założenia były gospodarstwami socjalnymi, poniżej progu żywotności ekonomicznej (tzn. ich wielkość wynosiła 2-4 ESU podczas gdy próg żywotności określa się w granicy 8 ESU). Tylko należące do TB wsparcie dla grup producentów rolnych (przeznaczone na założenie i prowadzenie grupy) i zalesianie możemy wykluczyć ze środków prorównościowych i zaliczyć do proefektywnościowych, ale były to stosunkowo małe fundusze. Możemy więc przyjąć, że ok. 90\% środków w ramach TB przeznaczono na wsparcie socjalne, a ok. $10 \%$ na cele proefektywnościowe. Subsydia obszarowe (SO), mogłyby teoretycznie odgrywać rolę zarówno proefektywnościową, tj. subsydium czynnika produkcji (jeśli przeznaczono je na inwestycje), jak i prorównościową (jeśli przeznaczono je na konsumpcję). Z analiz jakościowych (wywiady i ankiety) wynika, że część subsydiów obszarowych, np. na ONW stanowiła quasi-transfery socjalne, a część przeznaczona była na niewielkie inwestycje [Klepacka-Kołodziejska 2007]. Wobec braku jednoznacznych danych dla całego kraju co do struktury wydatków inwestycyjnych względem konsumpcyjnych finansowanych z płatności ONW, możemy w przybliżeniu założyć, że rozkład ten był w mniej więcej 75\% na cele prorównościowe, a 25\% wydatki na dobra inwestycyjne i podobnie założyć o reszcie SO.

Otrzymaliśmy obraz, który świadczyłby o tym, że na poziomie krajowym proporcje pomiędzy wsparciem proefektywnościowym a prorównościowym są porównywalne. Wskazuje na to suma środków proefektywnościowych wynosząca 53\% funduszy ROW 2004-2006 (wynik sumowania 100\% SI, 10\% TB i 25\% SO) w porównaniu z sumą środków prorównościowych wynoszących 47\% (wynik sumowania 90\% TB i 75\% SO). Środki proefektywnościowe nawet nieco przeważały nad środkami prorównościowymi i wynik ten otrzymaliśmy mimo przyjętych wysokich proporcji wydatków prorównościowych w ramach TB i SO. Gdyby się jednak

\footnotetext{
32 Stwierdzony jest fakt wydatkowania tych środków przez beneficjentów, gdyż musieli się oni rozliczać fakturami z tego typu wydatków. Nie wiadomo natomiast, jaka była jakość i późniejsze wykorzystanie tych inwestycji. Do tego potrzebne byłoby przeprowadzenie ogólnokrajowych badań na próbie reprezentatywnej z beneficjentami tych działań.

${ }^{33}$ Chodzi o pracowników regionalnych oddziałów ARiMR.
} 
okazało, że większa niż zakładana część TB i SO była jednak przeznaczana na inwestycje (tj. większa od 10\% TB i 25\% SO), to wynik byłby jeszcze bardziej zdecydowany na korzyść środków proefektywnościowych (a więc przeciwko tezie o przeważająco socjalnym charakterze polityki ROW). Z kolei jeśli wszystkie środki TB i SO okazałyby się tylko prorównościowe, co jest jednak mało prawdopodobne, to i tak w dalszym ciągu proporcja byłaby zbliżona - wtedy środki prorównościowe wyniosłyby $58 \%$, a proefektywnościowe $42 \%$, a zatem nie byłaby to wielka przewaga. W sumie przy tej wiedzy, jaką mamy, możemy stwierdzić, że polityka ROW nie miała przeważającego charakteru socjalnego, jeśli chodzi o strukturę i sposób przyznawanych funduszy.

Zasadne jest teraz pytanie, czy równowaga tych środków jest również zachowana na poziomie regionalnym? Intuicja podpowiada, że niekoniecznie musi tak być, szczególnie, że regiony w Polsce są bardzo zróżnicowane pod względem ekonomicznym oraz pod względem kapitału społecznego. Ponadto trzeba pamiętać, że dużą rolę w regionalnym rozdziale środków pomiędzy działania odgrywały predefiniowane „koperty regionalne” oraz quasi-kopertowanie”. Omówieniu tych zagadnień poświęcamy rozdział 2.3.4, dotyczący indykatywnego podziału środków pomiędzy działania. Regionalne zróżnicowanie w podziale środków może wynikać z różnicy w skali potrzeb pomiędzy województwami. Te, które były bardziej doinwestowane, z pewnością potrzebowały mniej środków inwestycyjnych niż województwa zapóźnione $\mathrm{w}$ inwestycjach $\mathrm{w}$ gospodarstwach (stąd m.in. nastąpiło kopertowanie). Ale różnice $\mathrm{w}$ absorpcji mogą wynikać $\mathrm{z}$ różnicy w możliwościach zagospodarowania ich w województwach. Tam, gdzie gospodarstwa są silniejsze, łatwiej o zdobycie środków bardziej ambitnych (takich jak duże subsydia inwestycyjne) niż środków łatwiejszych (takich jak wsparcie dla młodych rolników). Ponadto różnice $\mathrm{w}$ absorpcji musiały wynikać $\mathrm{z}$ właściwości społecznych, demograficznych, geograficznych, które determinowały dostęp do takich środków, jak np. renty strukturalne (gdzie decydowało kryterium wieku), wsparcie dla ONW czy programy rolno-środowiskowe (gdzie decydowało kwalifikowanie się do wyznaczonego obszaru objętego tymi działaniami).

Analiza empiryczna na poziomie województw uwidoczniła wyraźne różnice w strukturze absorpcji działań proefektywnościowych w porównaniu z prorównościowymi. Rysunek 2.9 pokazuje te różnice na przykładzie województw, które zaabsorbowały największy odsetek środków finansowych w poszczególnych grupach instrumentów wsparcia (TB, SO, IS_b, IS_e), natomiast aneks 2.2 pokazuje rozkład absorpcji środków dla wszystkich województw w kraju.

Największy odsetek transferów bezpośrednich (TB) w strukturze wykorzystanych środków miało województwo świętokrzyskie (47\%), z kolei największy odse- 
Świętokrzyskie

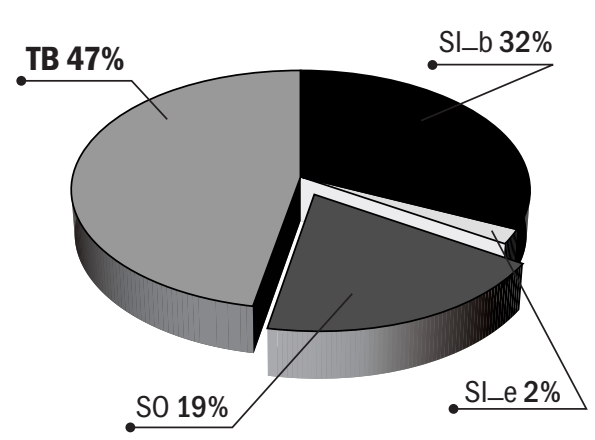

Kujawsko-Pomorskie

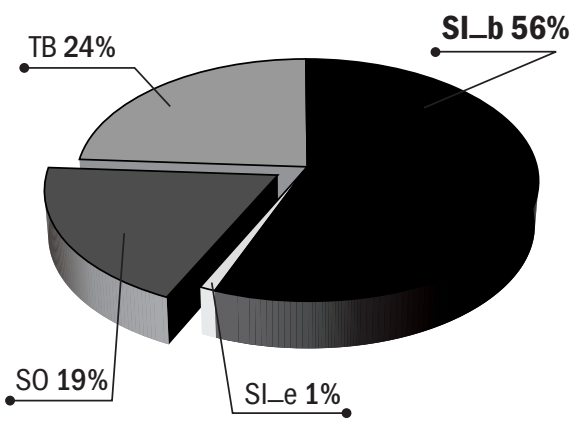

Zachodniopomorskie

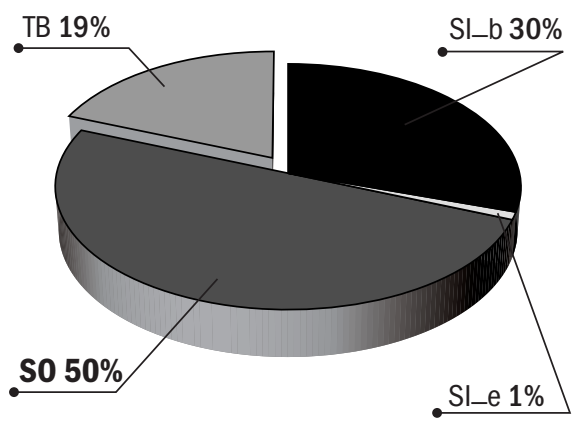

Podkarpackie

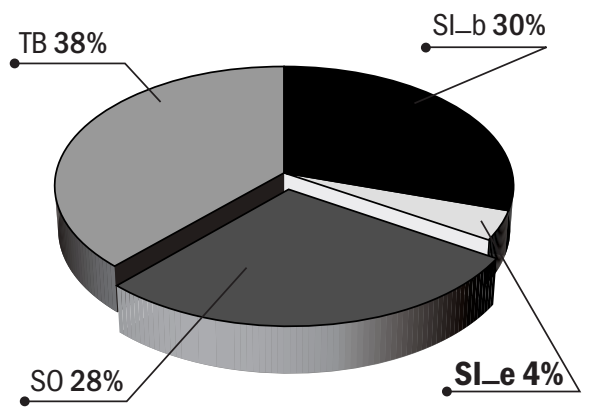

Rysunek 2.9. Różnice w strukturze absorpcji środków w ramach SPO Rolnictwo i PROW 2004-2006 w wybranych województwach

Źródło: Obliczenia własne na podstawie danych o płatnościach zrealizowanych w ramach PROW (stan na 31 grudnia 2007 r.), ARiMR 2008.

tek subsydiów obszarowych ( $\mathrm{SO}$ ) odnotowało województwo zachodniopomorskie (50\%). Pozytywnie wśród województw wyróżniało się województwo kujawsko-pomorskie, które w strukturze wykorzystanych środków miało najwięcej subsydiów inwestycyjnych w infrastrukturę (SI_b), stanowiących 56\% zaabsorbowanych środków. Inwestycje w edukację stanowiły zwykle bardzo mały odsetek działań, ale największy miało województwo podkarpackie i małopolskie, po $4 \%$ w każdym z nich. Różnice w strukturze wykorzystanych środków są z pewnością wypadkową wielu czynników. Mogą do nich należeć np. charakterystyka sektora rolniczego i pozarolniczego, aktywność ekonomiczna i społeczna ludności wiejskiej, struktura demograficzna gospodarstw, położenie geograficzne i jeszcze wiele innych czynników [Rosner 2007]. Rzetelne ustalenie dokładnych przyczyn wyjaśniających wszystkie różnice $\mathrm{w}$ absorpcji środków pomiędzy województwami 
wymagałoby osobnego i dogłębnego badania, obejmującego nie tylko aspekty ekonomiczne, ale co najmniej też socjologiczne, geograficzne, demograficzne i historyczne. Taka analiza wykracza dalece poza ramy niniejszego opracowania. Możemy jedynie skojarzyć pewne fakty, wskazujące kierunek poszukiwań. Na przykład w województwie świętokrzyskim, w którym przeważały transfery bezpośrednie (TB), przyczyną może być w pewnym stopniu to, że przeważają tam małe, rodzinne gospodarstwa, zwykle nietowarowe (to by tłumaczyło wysoki w tym województwie udział działania „pomoc dla gospodarstw niskotowarowych” TB) oraz niekorzystna sytuacja demograficzna z dużą przewagą osób w wieku podeszłym w gospodarstwach rolnych (to by tłumaczyło wysoki w tym województwie odsetek działania „renty strukturalne” też z grupy TB). Województwo zachodniopomorskie, gdzie przeważały subsydia obszarowe (SO) w postaci „wsparcia dla ONW” oraz „programy rolno-środowiskowe”, zawdzięczać to może swojej strukturze obszarowej, dużym i prężnym gospodarstwom powstałym po likwidacji byłych PGR-ów. Jeśli chodzi zaś o województwo kujawsko-pomorskie, które charakteryzuje się silnym rolnictwem ze względu na sprzyjające warunki klimatyczno-glebowe, z przewagą dużych i towarowych gospodarstw, nie dziwi fakt, że w strukturze wykorzystanych środków przeważały ,inwestycje w gospodarstwa rolne” oraz „dostosowania do standardów UE”. Podobna sytuacja dotyczy województwa wielkopolskiego. Województwa podkarpackie i małopolskie, należące do byłej Galicji, charakteryzują się z kolei największym w kraju poziomem rozwoju społecznego i młodą strukturą demograficzną [Rosner 2007]. Stąd może wynikać największy udział tych województw w działaniach edukacyjnych (doradztwo i szkolenia).

Ciekawe byłoby porównanie podziału środków w PROW 2007-2013 według wyżej zaproponowanych trzech klasyfikacji. Jednak w odróżnieniu od podziału z lat 2004-2006 analizować możemy jedynie wstępną, zatwierdzoną przez KE tabelę finansową, a nie faktycznie wydatkowane środki. Zatem do poniższej interpretacji trzeba podchodzić $\mathrm{z}$ dużą rezerwą.

Na podstawie dokumentu PROW 2007-2013 ${ }^{34}$ klasyfikacja według kryteriów unijnych kształtuje się następująco: na oś 1 przeznaczono 44,5\%, na oś $2-36,6 \%$, na oś 3 - 16,2\% a na oś 4 (LEADER) - 2,7\%. Porównując strukturę płatności zrealizowanych z poprzedniego okresu z wydatkami planowanymi w obecnym okresie można zauważyć zmniejszenie wagi osi konkurencyjności rolnictwa na korzyść poprawy jakości życia na wsi oraz poprawy kapitału społecznego (LEADER). $\mathrm{Z}$ kolei wydatki na poprawę środowiska w obu okresach mają podobny udział

${ }^{34}$ Program Rozwoju Obszarów Wiejskich na lata 2007-2013 (PROW 2007-2013). Warszawa, lipiec 2007 r. 
w całym budżecie programu. W efekcie w latach 2007-2013 zachodzą mniejsze różnice w proporcjach wydatków na poszczególne osie, szczególnie oś I i oś II bardzo się do siebie zbliżyły pod względem udziału w całym budżecie.

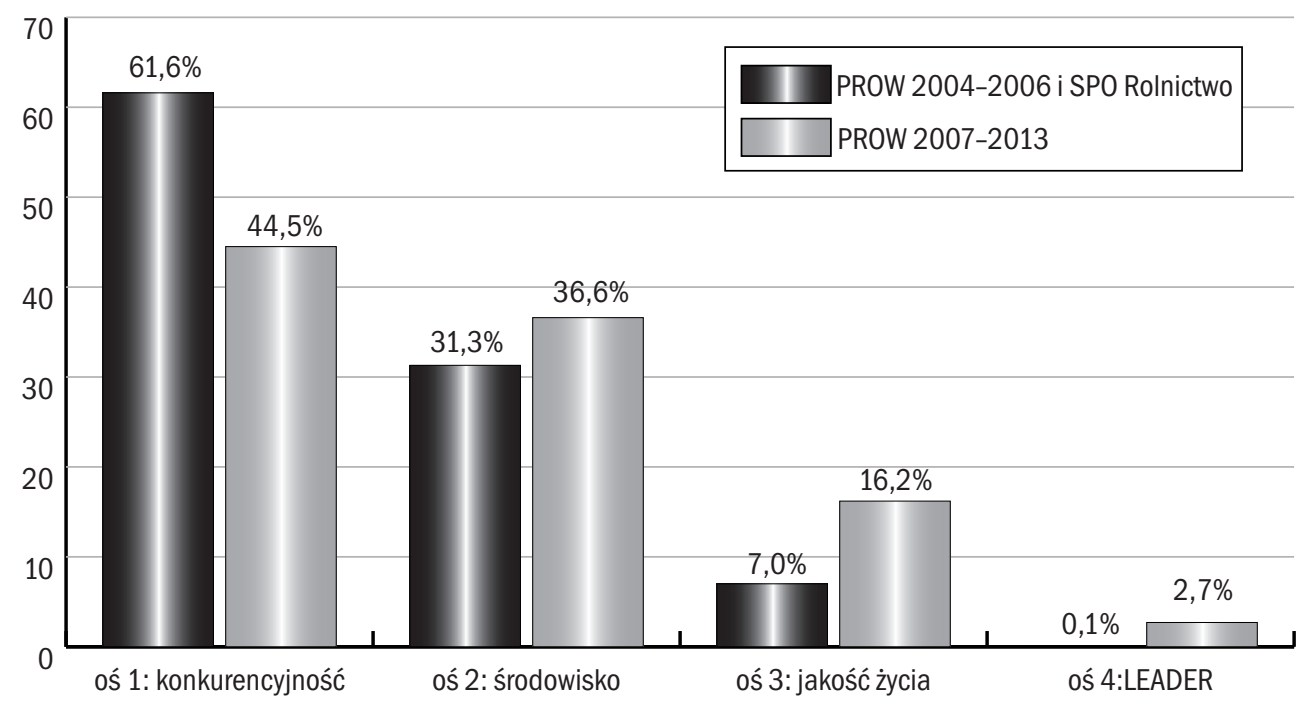

Rysunek 2.10. Porównanie wydatków na unijną politykę ROW w Polsce w dwóch okresach finansowych wg kryteriów unijnych

Źródło: Obliczenia własne na podstawie danych ARiMR oraz PROW 2007-2013 (unijne i polskie środki budżetowe razem).

Interesująco prezentuje się porównanie rozkładu funduszy PROW 2007-2013 finansowanych z EFRROW (bez środków krajowych) w podziale na osie w Polsce z rozkładem dla całej UE. W Polsce można zauważyć większy udział środków przeznaczonych na oś I (związanych z poprawą konkurencyjności), gdzie przeznaczono ok. 40\% w porównaniu z 34\% w UE, oraz na oś III (związaną z poprawą jakości życia na wsi), gdzie przeznaczono $19 \%$ w porównaniu z 13\% w UE. Z kolei sporo mniejszy udział w Polsce mają zaplanowane wydatki na oś II (związane z poprawą środowiska) - przeznaczono w Polsce 34\% w porównaniu z 44\% w UE oraz wydatki na oś IV (LEADER), zaplanowano bowiem ok. $5 \%$ wydatków w porównaniu z $6 \% \mathrm{w}$ całej UE. Na pomoc techniczną Polska przeznaczyła ok. 2\% środków EFRROW w porównaniu z 3\% w całej UE (rys. 2.11).

Nie mniej ciekawe jest porównanie struktury funduszy EFRROW podzielonych między osie dla poszczególnych krajów. Jeśli chodzi o oś I, to do krajów 


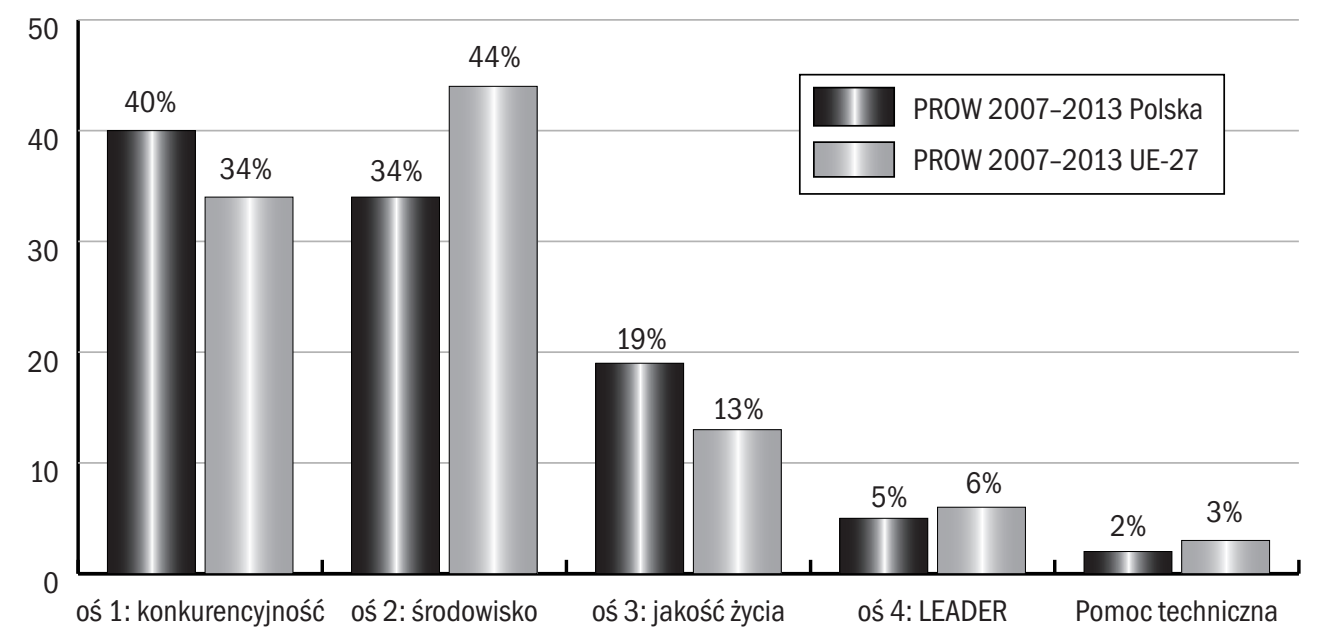

Rysunek 2.11. Porównanie planowanych wydatków z EFRROW w Polsce i w UE w latach 2007-2013

Źródło: Opracowanie własne na podstawie [KE 2008].

o największym udziale tych środków w strukturze swoich budżetów na ROW należą: Belgia (48,1\%), Łotwa (46,8\%) oraz Portugalia (45,5\%), natomiast najmniejszy udział środków w tej kategorii mają Irlandia (10,3\%), Finlandia (11,1\%) oraz Wielka Brytania (11,9\%). Wśród krajów alokujących największą część środków EFRROW na oś II znalazły się Irlandia $(79,6 \%)$, Finlandia $(73,3 \%)$ oraz Wielka Brytania (72,8\%), podczas gdy kraje o najmniejszym udziale środków na tę oś to trzy nowe kraje członkowskie, tj. Rumunia $(23,4 \%)$, Bułgaria $(24,4 \%)$ oraz Malta $(26,1 \%)$. Kraje, które w kategorii osi III przeznaczyły największy odsetek swoich budżetów z EFRROW, to zarówno bardziej zurbanizowane Malta (32,2\%) i Holandia (29,8\%), jak i bardzo wiejska Bułgaria (26,9\%). Z kolei najmniejszy udział wydatków na tę oś w takich krajach, jak Irlandia (0,1\%), Portugalia $(0,4 \%)$ i Hiszpania $(3,7 \%)$ związany jest nie tyle z brakiem wsparcia dla poprawy jakości życia w tych krajach, ile z faktem, że kraje te wspierały ten cel głównie poprzez program LEADER.

Z porównania profili różnych krajów wynika, że Polska jest najbardziej zbliżona w strukturze swojego podziału środków EFRROW między priorytety do Grecji i Litwy. Te trzy kraje w ok. 40\% wspierają oś: konkurencyjność, w ok. 35\% wspierają oś: środowisko, i w 12-19\% wspierają oś: jakość życia. Dość małe stosunkowo środki przeznaczają na program LEADER (4,8-6,3\%) oraz pomoc techniczną (2-4\%). Dokładny rozkład struktury funduszy EFRROW między wszystkie kraje członkowskie przedstawia rysunek 2.12 . 


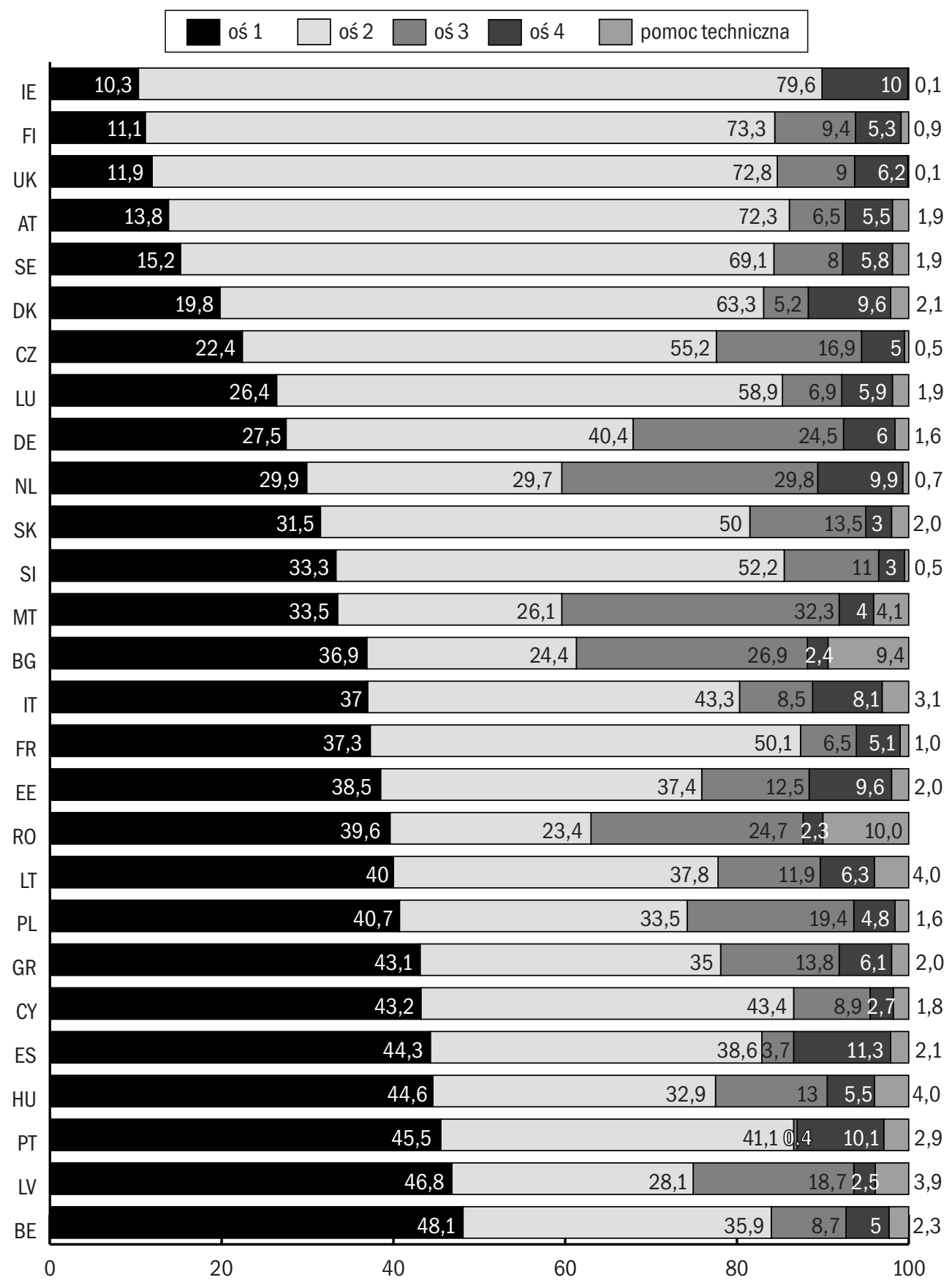

Rysunek 2.12. Struktura podziału środków EFRROW 2007-2013 pomiędzy kraje i osie Źródło: [KE 2008]. 
Jednak, jak pisaliśmy wcześniej, nie należy wyciągać zbyt pochopnych wniosków na podstawie rozkładu funduszy według nomenklatury unijnej, gdyż nazwy priorytetów nie oddają w pełni charakteru zawartych w nich działań. Nazwy osi odzwierciedlają pożądane, a nie zawsze faktycznie osiągane cele. Z pewnością nie można też ustalić jednoznacznie na tej jedynie podstawie proporcji między środkami proefektywnościowymi a prorównościowymi.

$\mathrm{Z}$ porównania funduszy $\mathrm{z}$ obu okresów według klasyfikacji przedstawionej przez Rowińskiego [2007], a proponującej większą liczbę ich kategorii wynika, że więcej środków będzie wydanych na rozwój środowiska oraz pozarolnicze działy gospodarki przy nieco niższym poziomie wsparcia dla rozwoju gospodarki żywnościowej i niższych transferach socjalno-dochodowych. Oczywiście trzeba pamiętać, że działania w obu okresach nie są identyczne, więc tylko w dużym uproszczeniu możemy dokonać takiego porównania z obu okresów finansowych.

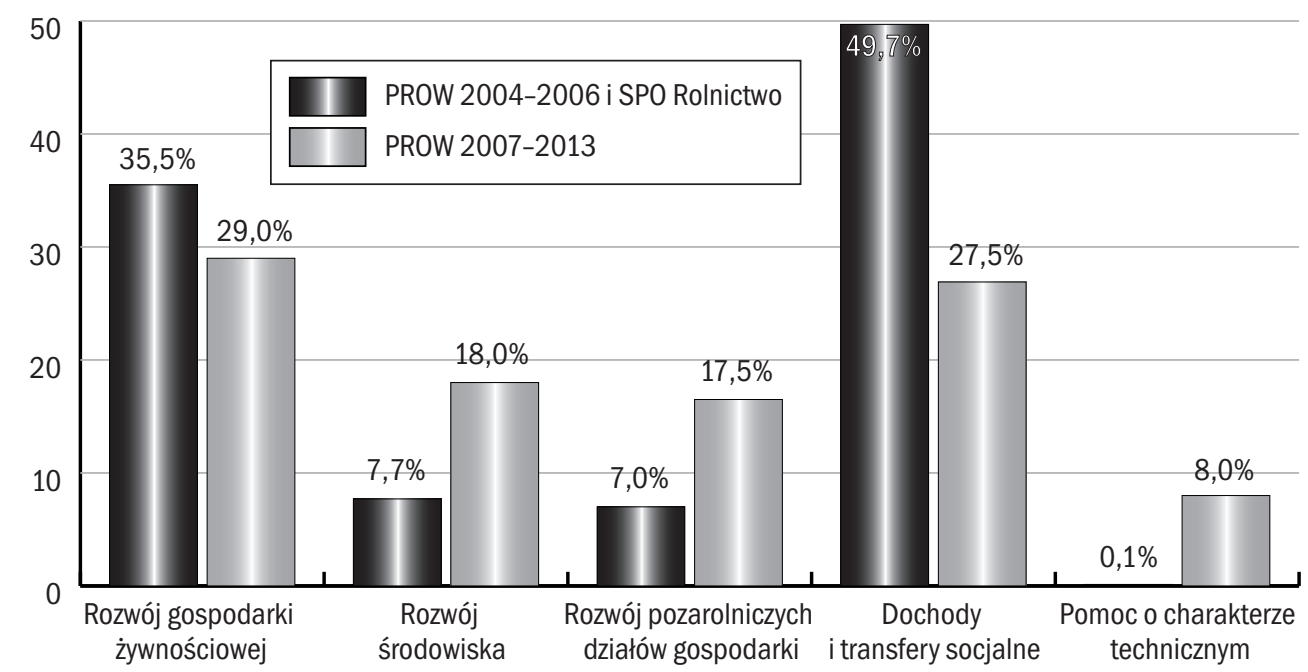

Rysunek 2.13. Porównanie wydatków w ramach unijnej polityki ROW w dwóch okresach finansowych wg klasyfikacji J. Rowińskiego

Źródło: Obliczenia własne na podstawie [Rowiński 2007], dane ARiMR i PROW 2007-2013.

Porównując rozkład funduszy według kryteriów ekonomicznych, można zauważyć, że zwiększa się udział środków na działania proefektywnościowe. Wskazuje na to o połowę zmniejszony udział transferów bezpośrednich na korzyść wzrostu udziału subsydiów inwestycyjnych w infrastrukturę oraz kapitał ludzki. Subsydia obszarowe z kolei zachowano na podobnym poziomie co poprzednio. 


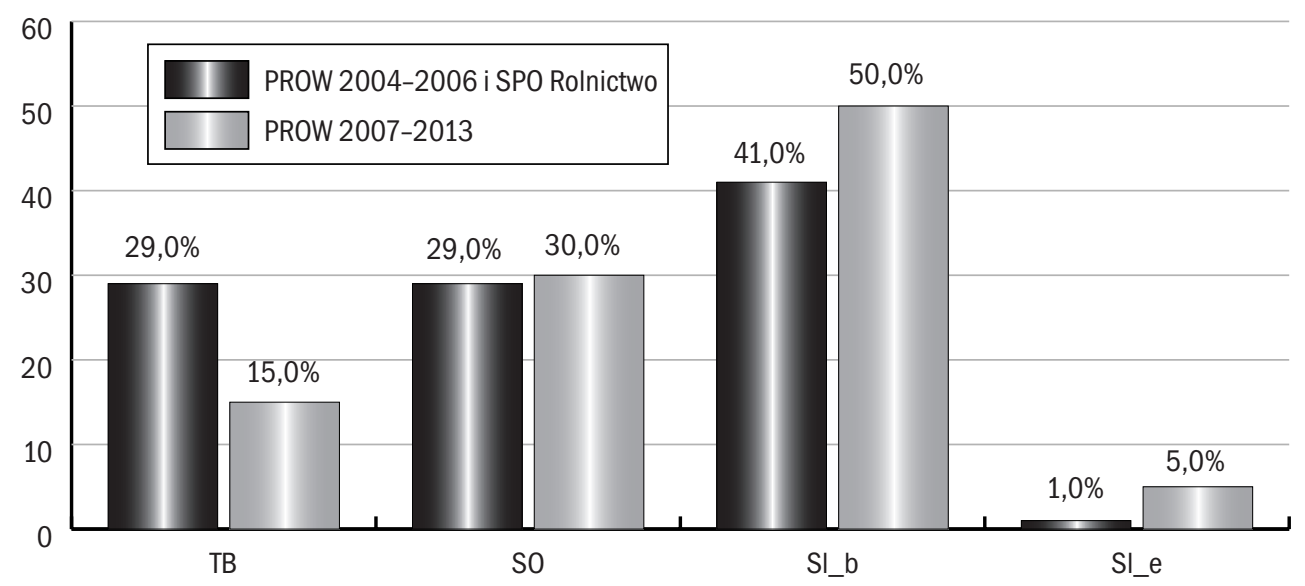

Rysunek 2.14. Porównanie wydatków w dwóch okresach finansowych wg kryteriów ekonomicznych Źródło: Obliczenia własne na podstawie danych [ARiMR 2008] oraz [PROW 2007-2013].

Jeśli będą odgrywać w dużej mierze socjalną rolę, jak w przypadku poprzedniego okresu, to bardziej efektywnym posunięciem byłoby przesunięcie ich na rzecz ostatnich dwóch kategorii.

\subsubsection{INDYKATYWNY PODZIAŁ ŚRODKÓW POMIĘDZY DZIAŁANIA I WOJEWÓDZTWA}

Trzeci i ostatni autonomiczny wybór Polski w kwestii prowadzenia polityki ROW w ramach UE dotyczył podziału środków, a dotyczył zarówno alokacji funduszy na cele i działania na poziomie krajowym, jak i podziału funduszy niektórych działań na województwa (tzw. koperty regionalne i inne formy determinujące ten podział, o czym piszemy dalej).

Rozdzielanie środków między różne obszary interwencji (cele i działania) nigdy nie jest zadaniem łatwym. Tym bardziej gdy w grę wchodzi polityka o zasięgu krajowym, znaczące środki publiczne i wielu interesariuszy. Tak jest w przypadku polityki ROW, a zatem ich podział budzi wiele kontrowersji i domysłów. Mało transparentny sposób podziału tych środków może powodować podejrzenia, że faworyzuje on niektóre grupy społeczne lub też wybrane grupy beneficjentów względem pozostałych. Na przykład można zapytać, dlaczego większość środków została przeznaczona na te działania, których beneficjentami mogą być tylko rolnicy i właściciele lasów, podczas gdy rolnictwo w Polsce nie jest głównym źródłem dochodów ludności wiejskiej w większości województw? Tylko 
w niewielkiej liczbie działań beneficjentami nie byli rolnicy, tylko inne grupy, na przykład: firmy (z branży przetwórczej w działaniu „poprawa przetwórstwa”, firmy szkoleniowe i instytucje doradcze w działaniu „wsparcie doradztwa rolniczego”, małe firmy z różnych branż w działaniu „tworzenie i rozwój mikroprzedsiębiorstw”), urzędy (np. gminy w przypadku działań dotyczących „odnowy i rozwoju wsi”), lokalne grupy działania (LEADER+ i LEADER) i instytucje państwowe (np. Wojewódzki Zarząd Melioracji i Urządzeń Wodnych w przypadku działania „gospodarowanie rolniczymi zasobami wodnymi” czy Państwowe Gospodarstwo Leśne Lasy Państwowe w przypadku działania „przywracanie potencjału produkcji leśnej”.

Jedną z propozycji odpolitycznienia i większego zobiektywizowania decyzji o przyznawanych środkach na poszczególne cele i działania jest zastosowanie modeli optymalizacyjnych, przy uwzględnieniu preferencji interesariuszy polityki rolnej i polityki rozwoju obszarów wiejskich ${ }^{35}$. Jeśli chodzi o polskie obszary wiejskie, to ciekawym przykładem takiej próby są badania Kiryluk-Dryjskiej [2008], która zastosowała model optymalizacyjny do symulacji optymalnego rozdysponowania budżetu PROW 2004-2006 na poszczególne działania w wybranych województwach. Jako współczynniki funkcji celu w modelu autorka wykorzystała średnie oceny działań programu w opinii 800 rolników, uzyskane w wyniku badań ankietowych przeprowadzonych w wytypowanych regionach. Zaletą tego podejścia jest to, że relatywną ważność poszczególnych działań ustalono na drodze rozpoznania preferencji rolników, a nie jako arbitralną decyzję polityczną. Kolejną zaletą tego podejścia jest jego wielowariantowość. Ponadto przedyskutowano w pracy kilka wariantów dyskryminacji pomiędzy regionami. Podobną próbę podziału funduszy, ale dla SPO 2004-2006 na podstawie modelu programowania liniowego przeprowadziła też autorka tej pracy K. Zawalińska [2004b, 2005a].

Podejście oparte na modelach optymalizacyjnych nie musi wskazywać na ostateczną dystrybucję środków pomiędzy działania, gdyż jest pewien obszar preferencji, których nie da się uwzględnić w tak prostych modelach. Jednakże z pewnością podejście to mogłoby stanowić punkt wyjściowy do dyskusji nad alokacją środków, w celu zwiększenia transparentności podejmowania końcowych decyzji. Można by rozważyć zastosowanie dalej metod eksperckich dla uzyskania ostatecznego podziału środków na działania i regiony.

Podział środków SPO Rolnictwo na województwa (tzw. koperty regionalne) dotyczył siedmiu działań: 1.1 inwestycje w gospodarstwach, 1.2 ułatwianie startu młodym rolnikom, 2.2 scalanie gruntów, 2.3 odnowa wsi oraz zachowanie dziedzictwa

35 Zastosowanie programowania liniowego do rozwiązywania problemów decyzyjnych zapoczątkował w naukach społecznych Chiang [1984]. Koncepcję tę rozwinęli potem m.in. Kirshke i inni [2004]. 
kulturowego, 2.4 różnicowanie działalności rolniczej, 2.5 gospodarowanie rolniczymi zasobami wodnymi oraz 2.6 rozwój i ulepszanie infrastruktury technicznej związanej $\mathrm{z}$ rolnictwem. Ten podział w odróżnieniu od podziału krajowego na działania był dość transparentny, gdyż odbywał się na podstawie udostępnionych dla publiczności, a przyjętych przez Komitet Sterujący SPO na posiedzeniu 25 listopada 2004 r. wskaźników zawartych w uchwałach $(2,3,4,5,6)$. Dokładną metodę ich liczenia prezentuje aneks 2.3. Wskaźniki te zostały tak skonstruowane, żeby w ramach danego działania faworyzować województwa najbardziej potrzebujące wsparcia w danej dziedzinie. Uwzględniały one m.in. ekonomiczną wielkość gospodarstw, liczbę miejscowości wiejskich, odsetek ludności wiejskiej, zróżnicowanie terenu, potrzeby modernizacyjne, melioracyjne etc. Na podstawie tych wskaźników otrzymano orien-

Tabela 2.7. Podział środków UE na województwa w ramach SPO Rolnictwo w latach 2004-2006 wg działań [w EUR]

\begin{tabular}{|c|c|c|c|c|c|c|c|}
\hline Województwo & 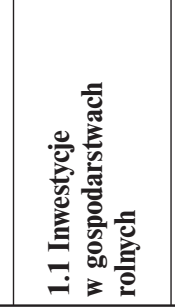 & 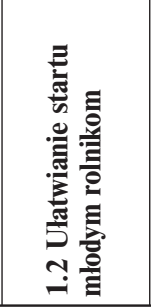 & 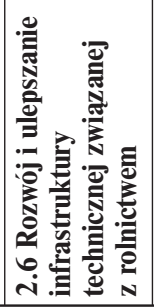 & 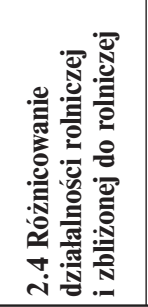 & 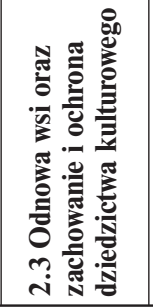 & 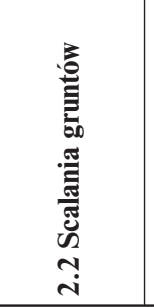 & 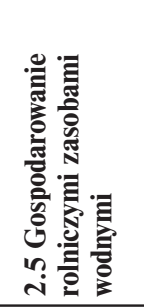 \\
\hline Dolnośląskie & 12048632 & 4816648 & 1055957 & 2733341 & 4188711 & 803751 & 9549411 \\
\hline \multicolumn{8}{|l|}{ Kujawsko- } \\
\hline -Pomorskie & 22249799 & 8894740 & 1950001 & 3201411 & 4400862 & 654814 & 4112378 \\
\hline Lubelskie & 30191941 & 12069749 & 2646060 & 8758163 & 5911660 & 4181608 & 4679544 \\
\hline Lubuskie & 4302770 & 1720106 & 377100 & 878583 & 1940152 & 142197 & 8817019 \\
\hline Łódzkie & 25563216 & 10219336 & 2240393 & 6091336 & 5657422 & 156416 & 2002820 \\
\hline Małopolskie & 10309376 & 4121351 & 903527 & 5273767 & 6525638 & 568785 & 5911022 \\
\hline Mazowieckie & 46028328 & 18400617 & 4033981 & 10358459 & 10567366 & 281691 & 7716287 \\
\hline Opolskie & 7823307 & 3127502 & 685645 & 1511663 & 2402321 & 601206 & 2455542 \\
\hline Podkarpackie & 7259497 & 2902109 & 636232 & 4149677 & 5072664 & 3563153 & 4168218 \\
\hline Podlaskie & 22566275 & 9021257 & 1977737 & 3401466 & 3682750 & 497687 & 5435580 \\
\hline Pomorskie & 11128321 & 4448738 & 975300 & 1981885 & 3828428 & 112335 & 5574133 \\
\hline Śląskie & 6589371 & 2634215 & 577501 & 2289196 & 3930228 & 1701805 & 3729483 \\
\hline Świętokrzyskie & 12193120 & 4874410 & 1068621 & 4452124 & 3731468 & 629986 & 1420228 \\
\hline \multicolumn{8}{|l|}{ Warmińsko- } \\
\hline -Mazurskie & 13662640 & 5461876 & 1197411 & 1799111 & 3873068 & 227514 & 6904398 \\
\hline Wielkopolskie & 36053981 & 14413200 & 3159817 & 5525970 & 7448663 & 142197 & 8135332 \\
\hline \multicolumn{8}{|l|}{ Zachodnio- } \\
\hline pomorskie & 8440279 & 3374147 & 739717 & 1343849 & 3338598 & 184855 & 4388605 \\
\hline RAZEM - 85\% & 276410853 & 110500001 & 24225000 & 63750001 & 76499999 & 14450000 & 85000000 \\
\hline Rezerwa $15 \%$ & 148778385 & 19499999 & 4275000 & 11249999 & 13500001 & 2550000 & 15000000 \\
\hline RAZEM - 100\% & 3251892381 & 130000000 & 28500000 & 75000000 & 90000000 & 170000001 & 100000000 \\
\hline
\end{tabular}


Tabela 2.8. Procentowy udział środków przypadających na województwa w ramach SPO Rolnictwo w latach 2004-2006 [w \%]

\begin{tabular}{|c|c|c|c|c|c|c|c|}
\hline Województwo & 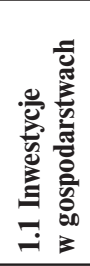 & 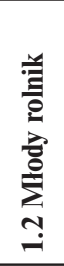 & 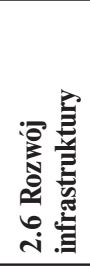 & 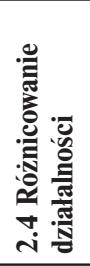 & 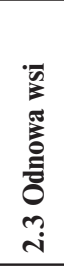 & 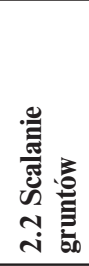 & 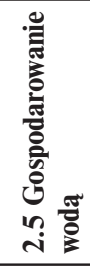 \\
\hline Dolnośląskie & 4 & 4 & 4 & 4 & 5 & 6 & 11 \\
\hline Kujawsko-Pomorskie & 8 & 8 & 8 & 5 & 6 & 5 & 5 \\
\hline Lubelskie & 11 & 11 & 11 & 14 & 8 & 29 & 6 \\
\hline Lubuskie & 2 & 2 & 2 & 1 & 3 & 1 & 10 \\
\hline Łódzkie & 9 & 9 & 9 & 10 & 7 & 1 & 2 \\
\hline Małopolskie & 4 & 4 & 4 & 8 & 9 & 4 & 7 \\
\hline Mazowieckie & 17 & 17 & 17 & 16 & 14 & 2 & 9 \\
\hline Opolskie & 3 & 3 & 3 & 2 & 3 & 4 & 3 \\
\hline Podkarpackie & 3 & 3 & 3 & 7 & 7 & 25 & 5 \\
\hline Podlaskie & 8 & 8 & 8 & 5 & 5 & 3 & 6 \\
\hline Pomorskie & 4 & 4 & 4 & 3 & 5 & 1 & 7 \\
\hline Śląskie & 2 & 2 & 2 & 4 & 5 & 12 & 4 \\
\hline Świętokrzyskie & 4 & 4 & 4 & 7 & 5 & 4 & 2 \\
\hline Warmińsko-Mazurskie & 5 & 5 & 5 & 3 & 5 & 2 & 8 \\
\hline Wielkopolskie & 13 & 13 & 13 & 9 & 10 & 1 & 10 \\
\hline Zachodniopomorskie & 3 & 3 & 3 & 2 & 4 & 1 & 5 \\
\hline RAZEM & 100 & 100 & 100 & 100 & 100 & 100 & $100 \%$ \\
\hline
\end{tabular}

Źródło: Obliczenia własne na podstawie [KS 2004].

tacyjny podział środków UE (alokacji podstawowej, czyli 85\% udziału środków publicznych) na województwa, jak przedstawiają tabele 2.7 i 2.8. Faworyzowanie bardziej potrzebujących województw mogło być podyktowane chęcią osiągnięcia przy okazji wsparcia rozwoju obszarów wiejskich pewnych celów spójnościowych, które też mają swoje uzasadnienie w tej polityce (o czym pisaliśmy w rozdziale 2.3.2).

Przy podziale środków na województwa mieliśmy też do czynienia z innego rodzaju quasi-kopertowaniem, czyli regulacjami, pośrednio determinującymi podział środków między województwa dla takich działań, jak np. wsparcie dla obszarów ONW czy Natura 2000. W tych przypadkach bowiem przyznane środki były zdeterminowane wyznaczonymi przez urzędników typami obszarów kwalifikujących się do wsparcia w ramach tych działań.

Kopertowanie i quasi-kopertowanie w dość znaczącej mierze zdeterminowało strukturę absorpcji środków na rozwój obszarów wiejskich, gdyż dotyczyło w sumie 9 z 22 działań i 25\% środków na ROW w przypadku kopert oraz ok. 28\% środków w przypadku quasi-kopertowania. Na podstawie przeprowadzonej analizy możemy stwierdzić, że z ekonomicznego punktu widzenia środki przeznaczone 
na ROW w latach 2004-2006, jak i planowane na 2007-2013 są dość równomiernie rozłożone pomiędzy działania proefektywnościowe i prorównościowe. W pierwszym okresie finansowym odnotowano niewielką przewagę tych drugich, ale już w nowym okresie planowania przewaga ta przesunęła się na korzyść tych pierwszych. Równowaga ta ujawnia się na poziomie krajowym i ma w dużej mierze charakter planistyczny. Natomiast na poziomie regionalnym, gdzie do głosu dochodzą oprócz decyzji odgórnych dotyczących podziału środków między województwa (koperty) również mechanizmy oddolne (konkurencja o środki między województwami, różnica potrzeb i różnica możliwości pozyskiwania środków przez województwa), zanotowano duże różnice w proporcjach zaabsorbowanych środków proefektywnościowych i prorównościowych pomiędzy województwami. Oczywiście determinanty tych różnic mogły wynikać z wielu względów (uwarunkowań historycznych, społecznych, ekonomicznych etc.), które należałoby dogłębniej zbadać, co jednak wybiega poza obszar niniejszego opracowania.

Wynik weryfikacji hipotezy pierwszej

Weryfikacja hipotezy pierwszej doprowadziła do stwierdzenia, że wbrew oczekiwaniom fundusze o charakterze proefektywnościowym oraz prorównościowym były $w$ badanym okresie dość zrównoważone na poziomie krajowym. Różnice ujawniaja się dopiero na poziomie województw. Wynikaja one w dużym stopniu z zastosowania kopert regionalnych (tj. limitów środków przyznanych województwom na wybrane dziatania) faworyzujacych stabiej rozwinięte województwa, a tylko w niewielkim stopniu różnicami w możliwościach absorpcyjnych opartych na zasadach konkurencji. Zatem jest to wypadkowa możliwości i potrzeb, przy czym potrzeby zostały zdefiniowane odgórnie (przez koperty), a możliwości zależaty od przedsiębiorczości regionów. Zatem hipoteza mówiaca o faworyzowaniu działań prorównościowych nad proefektywnościowymi nie została potwierdzona.

\subsubsection{ZASTOSOWANIE MODELU REGPOL DO EWALUACJI PROGRAMÓW ROZWOJU OBSZARÓW WIEJSKICH}

Modelu RegPOL może być użyteczny w ewaluacji szeroko pojmowanego oddziaływania polityki ROW na gospodarkę Polską, z uwzględnieniem efektów zewnętrznych i ujęciem czystego wpływu tych programów na rozwój regionów. Aby lepiej zrozumieć, w jakim obszarze ewaluacji najbardziej pożyteczna jest tego rodzaju analiza, przedstawimy pokrótce zasady, których muszą przestrzegać obecne opracowania ewaluacyjne, wskażemy też obszary, na których proponowane podejście metodologiczne znajduje uzasadnienie i przynosi największe korzyści. 
Ewaluacja programów dotyczących rozwoju obszarów wiejskich realizowanych w latach 2007-2013 musi odbywać się zgodnie z wytycznymi zawartymi w dokumencie „Wspólne Ramy Monitorowania i Oceny” [WRMO 2006]. Dla poprzednich okresów programowania również obowiązywały wytyczne opublikowane przez Komisję Europejską [DG_AGRI 2008]. Punktem wyjścia w ocenie programu jest zrozumienie jego logiki interwencji oraz określenie hierarchii celów przez niego realizowanych (rys. 2.15).

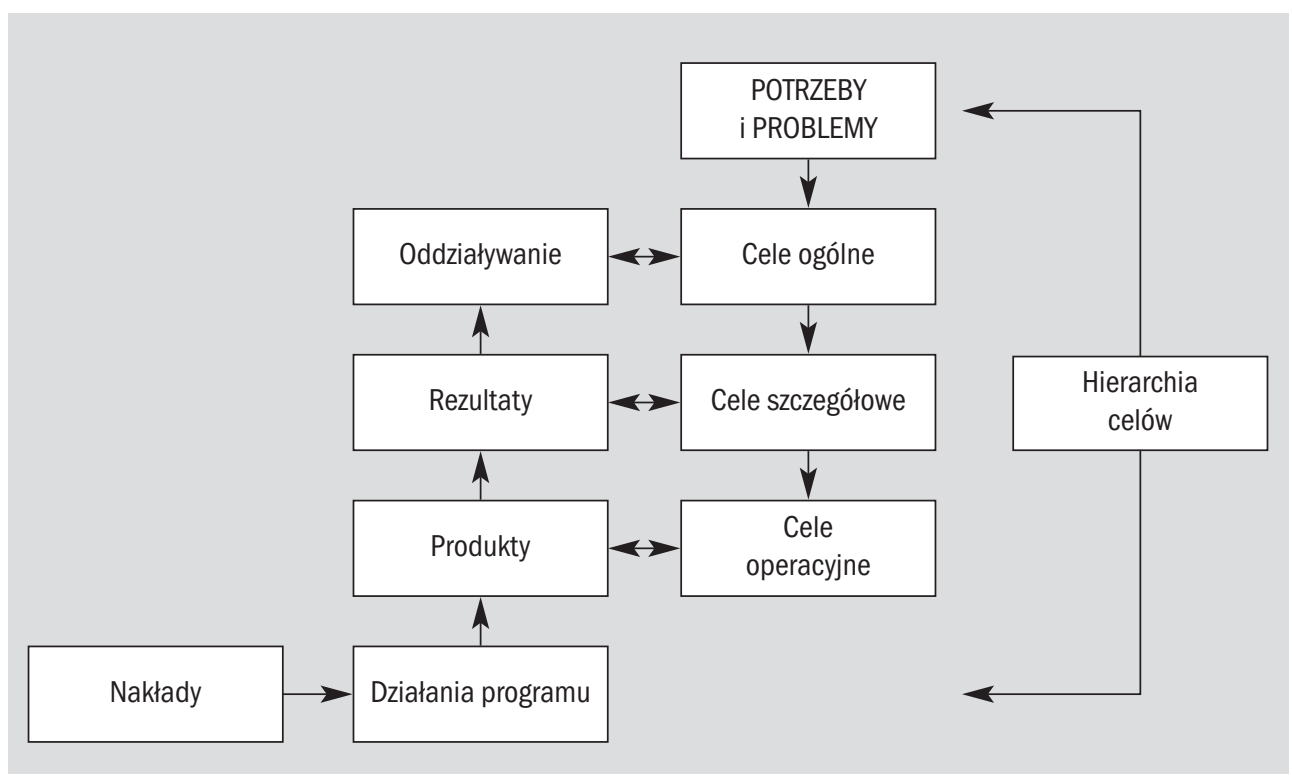

Rysunek 2.15. Logika interwencji i hierarchia celów w programach dotyczących ROW Źródło: Na podstawie [WRMO 2006].

Ewaluacja programów ROW powinna analizować cele na kilku poziomach szczegółowości i oceniać osiągnięcia programu na poziomie:

- celów ogólnych - wyrażanych przez oddziaływanie (impact), czyli efekty generowane przez program w dłuższej i szerszej perspektywie.

- celów strategicznych (szczegółowych) - wyrażanych przez rezultaty (outcomes/results), tzn. efekty uzyskiwane bezpośrednio w wyniku działania programu,

- celów operacyjnych - wyrażanych poprzez produkty (outputs), czyli dobra i usługi wytwarzane bezpośrednio w trakcie realizacji programu.

Ponadto określone są też tzw. cele horyzontalne, które mają odniesienie do wszystkich działań [WRMO 2006, Załącznik 2.D]. 
Głównym celem omawianej polityki jest rozwój obszarów wiejskich w Polsce. Cel ten jest następnie uszczegółowiony poprzez takie cele strategiczne, jak poprawa: • konkurencyjności rolnictwa i leśnictwa • środowiska naturalnego i terenów wiejskich • jakości życia na obszarach wiejskich oraz różnicowanie działalności gospodarczej. Każdemu z tych trzech celów strategicznych odpowiada oś tematyczna, wokół której są opracowywane programy rozwoju obszarów wiejskich, a czwarta oś horyzontalna i metodologiczna ma na celu uwzględnienie podejścia LEADER, pomocnego w realizacji trzech głównych osi programowania [WRMO 2005]. Następnie każdy z programów (zwanych działaniami) w ramach każdej osi posiada swoje własne cele operacyjne. Na przykład działanie Renty strukturalne podlegające osi 1, za cele stawia sobie: poprawę struktury gospodarstw rolnych, przyśpieszenie procesu wymiany pokoleniowej wśród osób prowadzących gospodarstwa rolne, poprawę rentowności i konkurencyjności gospodarstw.

W naszym badaniu koncentrujemy uwagę przede wszystkim na celu ogólnym oraz celach strategicznych. Przyjęty regionalny model równowagi ogólnej, ujmując wszystkie sektory gospodarki polskiej, jest w stanie ocenić całość sfer oddziaływania programów ROW na różne sektory gospodarki. Innymi słowy, dzięki sformalizowaniu oddziaływań międzysektorowych pomiędzy województwami i poszczególnymi podmiotami gospodarczymi (firmy, gospodarstwa, sektor rządowy) model pozwala określić, jak wydatki na rozwój obszarów wiejskich (działania PROW i SPO) wpływają na inne podmioty w poszczególnych województwach i sektorach gospodarki. To, czy poszczególne cele są osiągane, oceniane jest przy wykorzystaniu wskaźników, które zostały sformułowane przez Komisję Europejską dla każdego poziomu celu oraz dla nakładów i kontekstu całego programu [WRMO 2006].

WSKAŹNIKI PRODUKTU mierzą działalności bezpośrednio zrealizowane w ramach programu. Są one pierwszym krokiem w kierunku realizacji celów operacyjnych i są mierzone w jednostkach fizycznych lub pieniężnych. Przykładem może być liczba zorganizowanych sesji szkoleniowych, liczba gospodarstw rolnych otrzymujących wsparcie inwestycyjne, ogólna wielkość inwestycji.

WSKAŹNIKI REZULTATU mierzą bezpośrednie i natychmiastowe skutki interwencji. Dostarczają one informacji na temat zmian zachodzących np. w zachowaniu, zdolnościach lub wynikach bezpośrednich beneficjentów i są mierzone w jednostkach fizycznych lub pieniężnych. Przykładem takich wskaźników mogą być ogólna liczba stworzonych miejsc pracy oraz liczba uzyskanych przez beneficjentów miejsc pracy po szkoleniach itd.

WSKAźNIKI ODDZIAŁYWANIA odnoszą się do korzyści wynikających z programu, wykraczających poza bezpośrednich beneficjentów i ich otoczenie. Są one 
związane z szerszymi celami programu. Zwykle wyrażone są one jako wskaźniki netto, a więc nie obejmują skutków, które nie mogą być uznane za wynik interwencji, a także uwzględniają efekty pośrednie programu (przesunięcia i efekty mnożnikowe). Przykładem może być wzrost zatrudnienia na obszarach wiejskich w pozarolniczych sektorach gospodarki, większa produktywność sektora rolnego, zwiększona produkcja energii odnawialnej itp.

WSKAźNIKI NAKŁADU odnoszą się do budżetu lub innych zasobów przyznanych dla każdego poziomu pomocy. Wskaźniki nakładu finansowego używane są do monitorowania postępów w zakresie (rocznych) zobowiązań i płatności środków dostępnych dla jakiejkolwiek operacji, środka lub programu w stosunku do kosztów kwalifikowanych. Przykładem mogą być koszty jednostkowe towarów i usług w danym projekcie.

WSKAźNIKI BAZOWE używane są w analizie SWOT i przy określeniu strategii programu. Dzielą się na dwie kategorie. WSKAŹNIKI BAZOWE ODNOSZĄCE SIE DO CELU są bezpośrednio związane z szerszymi celami programu. Służą do opracowania analizy SWOT, odnoszącej się do celów wskazanych w rozporządzeniu. Używa się ich również jako punktu wyjścia (lub odniesienia) w ocenie oddziaływania programów. Wskaźniki bazowe odzwierciedlają sytuację na początku okresu programowania i tendencję w czasie. Szacunek wpływu powinien odzwierciedlać tę część zmian w miarę upływu czasu, która może zostać przypisana programowi, jeżeli weźmie się pod uwagę tendencję bazową i inne czynniki, które wpływają na realizację programu. WSKAŹNIKI BAZOWE ODNOSZĄCE SIĘ DO KONTEKSTU - dostarczają informacji na temat odpowiednich aspektów ogólnych, które mają potencjalny wpływ na wykonanie programu.

Proponowany w niniejszym opracowaniu model RegPOL dostarcza najwięcej wskaźników z grupy wskaźników oddziaływania i wskaźników odnoszących się do kontekstu. Pozwala to m.in. opisać zmiany, jakie występują w gospodarce w wyniku wsparcia obszarów wiejskich poprzez: zmiany produktywności całkowitej (oraz pracy i kapitału osobno) w sektorze rolnym, zmiany w zatrudnieniu w sektorze rolnym, zmiany w cenach produktów rolnych, dochody w sektorze rolnym, wielkość produkcji rolnej i wiele innych wskaźników ekonomicznych dla pozostałych sektorów gospodarki w ujęciu wojewódzkim. Oddziaływanie programów ROW na gospodarkę polską można opisać za pomocą modelu RegPOL poprzez 80 zmiennych ekonomicznych, co daje bardzo szczegółowy obraz wpływu poszczególnych działań na poszczególne regiony. Ponadto w wariancie dynamicznym model dostarcza scenariusz bazowy (base line), który jest punktem odniesienia (counterfactual) dla wprowadzanych później interwencji rządowych w postaci programów (rys. 2.17). 


\section{Podstawowe kryteria ewaluacyjne}

Cechą charakterystyczną programów adresowanych do obszarów wiejskich jest bez wątpienia ich różnorodność, rozumiana jako: wielostopniowość i zróżnicowanie celów, wielosektorowość (wykraczanie poza sektor rolniczy), wielokulturowość (obejmowanie zarówno społeczności rolniczych, jak i szerzej rozumianych społeczności wiejskich). Całościowa i systematyczna ewaluacja tego programu wymaga zastosowania szerokiej gamy kryteriów ewaluacyjnych. Podstawowe kryteria, jakie mają tu zastosowanie, to: skuteczność (effectiveness), efektywność/sprawność (efficiency), celność (targeting), użyteczność (utility), ekonomiczność (economy), trwałość (sustainability), adekwatność (relevance), uczestnictwo (participation) oraz świadomość (awareness). Poniżej przedstawiamy krótką charakterystykę tych kryteriów, natomiast schemat zależności pomiędzy nimi a poszczególnymi elementami programu przedstawia rysunek 2.16 .

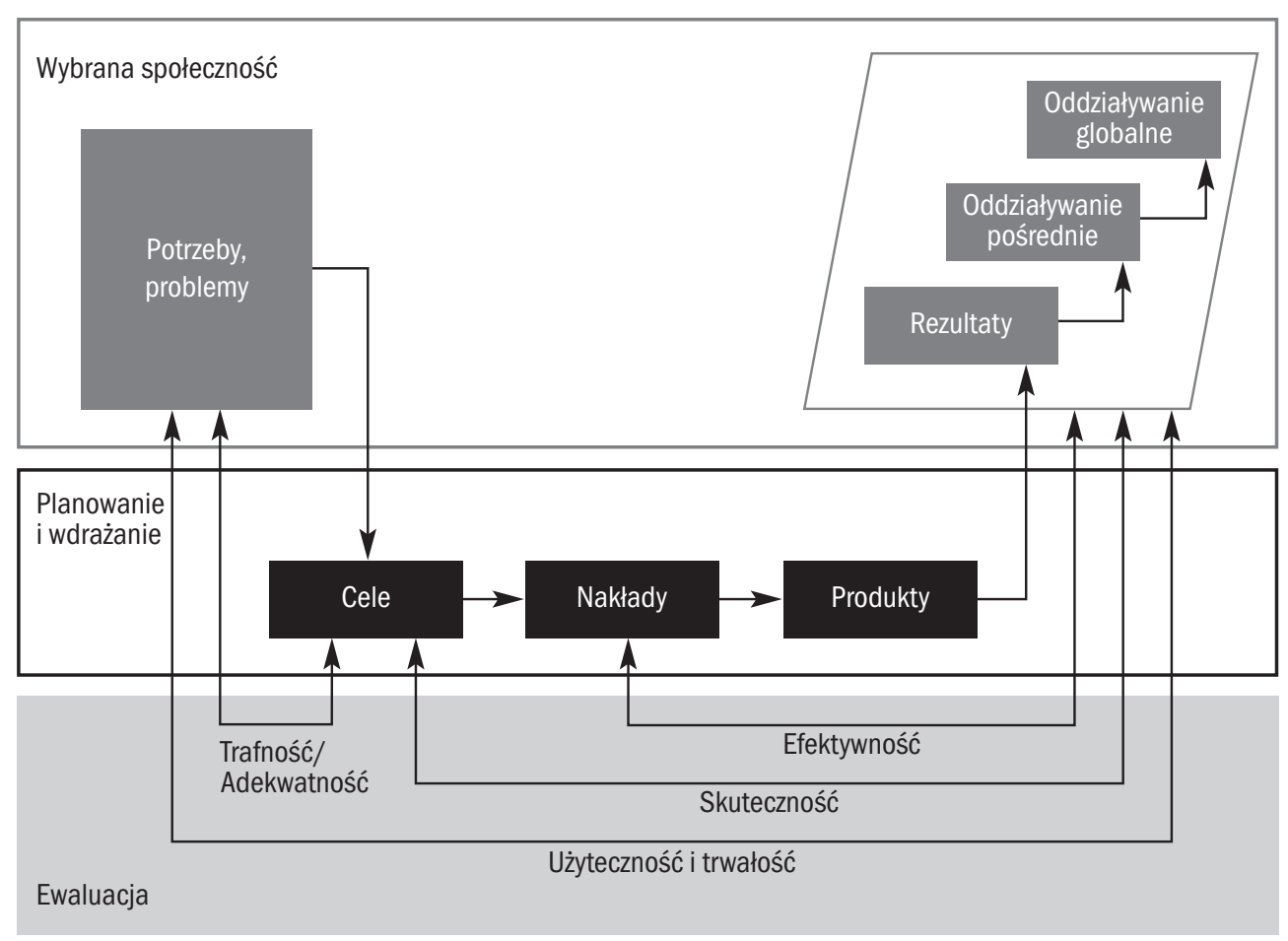

Rysunek 2.16. Sieć powiązań i zależności pomiędzy celami, działaniami i rezultatami programu oraz kryteriami ewaluacyjnymi dla programów społeczno-ekonomicznych

Źródło: [KE 2004]. 
SkUTECZność - pozwala ocenić, czy cele zdefiniowane na etapie tworzenia programu zostały osiągnięte. Porównując rzeczywiste efekty programu na poziomie produktu, rezultatu oraz oddziaływania z założeniami sformułowanymi w dokumentach programowych, pozwala określić poziom realizacji założeń programu.

EFEKTYWNość - porównuje zasoby zaangażowane przy realizacji programu (finansowe, administracyjne, ludzkie itp.) z rzeczywistymi osiągnięciami programu na poziomie produktu, rezultatu lub oddziaływania.

CELność - określa, w jakim stopniu program ten zrealizował założenia polityki państwa w danej dziedzinie.

UŻYTECZNOŚĆ - konfrontuje potrzeby i problemy danego sektora/regionu z faktycznymi osiągnięciami programu po zakończeniu jego realizacji. Innymi słowy, pozwala ocenić, w jakim stopniu pomoc przyczyniła się do zlikwidowania problemów danego sektora/regionu.

EкоNоміCZNoŚć - porównuje nakłady zakładane z nakładami rzeczywistymi programu. Innymi słowy, ocenia wykonanie budżetu.

TrwaŁość - określa, czy efekty programu będą trwałe w perspektywie średnio- i długoterminowej, m.in., czy zostaną zachowane trwałe pozytywne efekty programu po zakończeniu jego finansowania.

AdEKWATNOŚć - dotyczy oceny, w jakim stopniu cele programu trafnie identyfikują i odpowiadają na rzeczywiste problemy i potrzeby, do których program jest adresowany.

UCZESTNICTWo - określa, jaki odsetek stanowią beneficjenci programu w odniesieniu do wszystkich uprawnionych (czyli potencjalnych beneficjentów).

ŚWIADOMość - ocenia, jaki odsetek osób potencjalnie uprawnionych do skorzystania z oferowanego wsparcia był świadomy istnienia takiej możliwości i tego, że kwalifikuje się do wzięcia udziału w programie.

Najwięcej uwagi poświęcamy w książce dwóm pierwszym kryteriom, skuteczności i efektywności. Są one podstawą każdej ewaluacji, gdyż pozwalają odpowiedzieć na podstawowe dylematy interwencji, tzn. czy wydatkowane fundusze przyczyniaja się do pożądanego rozwoju obszarów wiejskich i całej gospodarki oraz czy fundusze te wydatkowane są w najbardziej efektywny sposób, tzn. przynoszący największy zwrot za jednostkę wydatkowanych funduszy. W naszym podejściu ocena skuteczności programu prowadzi do ustalenia, które działania i grupy instrumentów ROW przynoszą najszybszy rozwój (wzrost) gospodarczy w poszczególnych regionach i od czego jest to uzależnione w poszczególnych województwach (rozdział 4.1). W ocenie efektywności na poziomie oddziaływania programu sprawdzamy, które działania i grupy instrumentów adresowane do obszarów wiejskich w poszczególnych województwach przynoszą największy wzrost gospodarczy przy tej samej kwocie wydat- 
kowanych funduszy. Jeśli chodzi o inne podstawowe kryteria ewaluacyjne, model pozwala również na ocenę m.in. trwałości rezultatów, dzięki zastosowaniu analizy krótko- i długoterminowej (short and long run). Inne efekty mogą być osiagnięte w krótkim okresie (kiedy np. czynniki produkcji są mniej mobilne, a ograniczenia budżetowe bardziej miękkie), a inne w długim okresie, kiedy możliwe jest pełne dostosowanie czynników produkcji, ale ograniczenia finansowe mogą być większe (np. możliwość utrzymywania deficytu na rachunku obrotów bieżących). Analizę tego typu prowadzi się, zmieniając tzw. warunki domknięcia (closures) modelu. Dokładniej proces ten opisany jest w podrozdziale 3.2.2.8. W opracowaniu oceniamy też celność polityki ROW, sprawdzając, czy na pewno największe korzyści z niej osiągają regiony najbardziej wiejskie i rolnicze.

\section{Dodatkowe kryteria ewaluacyjne}

Oprócz wyżej opisanych podstawowych kryteriów ewaluacyjnych często analizowane są dodatkowe aspekty oddziaływania i rezultatów programów. Należy do nich ocena tzw. czystej dodatkowości programu. Chodzi o wyłonienie tych efektów w gospodarce, które są czystym efektem wdrożonego programu i mogą być bezpośrednio przypisane tylko działaniom omawianego programu. Innymi słowy, są to takie efekty, które bez programu by nie wystapiły. Analiza ta polega na stworzeniu swoistego bilansu korzyści i strat programu z szerokiej perspektywy. Pozwala na uniknięcie błędu tzw. podwójnego pomiaru, co ma miejsce, kiedy programowi przypisuje się pozytywne zmiany w grupie beneficjentów czy na terenach objętych programem, które jednak de facto nie były wynikiem jego oddziaływania. Systematyczne podejście do oceny czystej dodatkowości programu w uproszczony sposób ilustruje rysunek 2.17.

Dokonanie oceny czystej dodatkowości programu (zwanej też dodatkowością netto) wymaga oceny kilku efektów. Pierwszym z nich jest tzw. efekt straty społecznej. Mierzy on, do jakiego stopnia pewne pozytywne zmiany w obszarze objętym programem pojawiłyby się, nawet gdyby nie było wdrożonego PROW i SPO. Czyli jakie działania podjęto by ze środków pozabudżetowych czy też ze środków innych programów, gdyby nie było polityki rozwoju obszarów wiejskich. Ocenę tego zjawiska przeprowadza się zwykle za pomocą badań ankietowych i pytań związanych z planami inwestycyjnymi czy decyzjami w gospodarstwie, gdyby nie było programu. Przykładem straty społecznej jest sytuacja, w której beneficjent planował budowę pomieszczenia gospodarczego $\mathrm{z}$ funduszy własnych lub funduszy innego programu, a w wyniku polityki ROW skorzystał $\mathrm{z}$ finansowania preferencyjnego $\mathrm{W}$ ramach tego programu. W tej sytuacji program w jakimś stopniu generował stratę społeczną, wypychając inwestycje prywatne poprzez wydatki rządowe. 
Drugim zjawiskiem w ocenie dodatkowości jest tzw. efekt przemieszczenia (przesunięcia). Jego analiza służy określeniu, w jakim stopniu program przyczynił się do faktycznego rozwiązania danego problemu, a w jakim stopniu przesunął go tylko w czasie i/lub przestrzeni. Przykładem takiego przesunięcia jest sytuacja, kiedy stworzenie warunków preferencyjnych dla przedsiębiorczości na pewnym obszarze, np. peryferyjnym, powoduje przenoszenie się firm z sąsiedniego obszaru (gdzie nie ma np. takich korzystnych podatków) i zamiast powstawania nowych miejsc pracy, następuje tylko przesunięciem tych miejsc pracy z jednego obszaru na drugi. W efekcie w gospodarce nie zwiększa się możliwość zatrudnienia.

Trzecim zjawiskiem jest tzw. efekt substytucji. Ocenie poddaje się to, do jakiego stopnia preferencje udzielane jednym grupom beneficjentów (np. rolnikom prowadzącym gospodarstwa ekologiczne) wpływają na obniżenie konkurencyjności innych grup rolników, którzy konkurują z grupą wspieraną.

Czwartym zagadnieniem podlegającym dogłębnej analizie ewaluacyjnej są tzw. efekty mnożnikowe. Wskazują one na to, w jakim stopniu środki wydatkowane w ramach programu uruchomiły przy okazji (współ)finansowanie z innych źródeł publicznych lub prywatnych oraz jak wpłynęły na rozwój innych branż, sektorów czy grup społecznych.

Efekt synergii z kolei określa, w jakim stopniu środki programu przyczyniły się do zwiększenia efektów innych inwestycji czy inicjatyw już istniejących.

\begin{tabular}{|c|c|c|c|c|}
\hline $\begin{array}{l}\text { 1. EFEKT BRUTTO } \\
\text { PROGRAMU } \\
\text { Liczba miejsc pracy } \\
\text { stworzona w trakcie } \\
\text { trwania projektu } \\
\text { (porównanie sytuacji } \\
\text { przed i po programie }\end{array}$ & $\begin{array}{l}=3 . \text { EFEKT } \\
\text { DODATKOWY BRUTTO } \\
\text { PROGRAMU = } \\
\text { Efekt brutto } \\
\text { programu - strata } \\
\text { społeczna }\end{array}$ & \multicolumn{2}{|c|}{$\begin{array}{l}\text { = 5. EFEKT NETTO } \\
\text { PROGRAMU= } \\
\text { Efekt dodatkowy } \\
\text { programu brutto - } \\
\text { efekty przesunięcia } \\
\text { i substytucji }\end{array}$} & $\begin{array}{l}\text { 7. DODATKOWY } \\
\text { EFEKT NETTO } \\
\text { PROGRAMU } \\
\text { Efekt netto programu } \\
\text { + efekty mnożnikowe } \\
\text { i synergii }\end{array}$ \\
\hline $\begin{array}{l}\text { 2. - STRATA } \\
\text { SPOŁECZNA } \\
\text { (DEADWEIGHT) } \\
\text { Liczba miejsc pracy, } \\
\text { które powstałyby, } \\
\text { nawet gdyby program } \\
\text { nie został wdrożony }\end{array}$ & \multicolumn{2}{|c|}{$\begin{array}{l}\text { 4. - PRZESUNIECCIE } \\
\text { Liczba miejsc pracy, które } \\
\text { powstałyby w programie, ale } \\
\text { kosztem niestworzenia ich } \\
\text { gdzie indziej } \\
\text { - SUBSTYTUCJA } \\
\text { Liczba miejsc pracy, które } \\
\text { powstałyby w innych sektorach } \\
\text { niż te wspierane }\end{array}$} & \multicolumn{2}{|c|}{$\begin{array}{l}\text { 6. + MNOŻNIKI } \\
\text { Liczba miejsc pracy powstałych } \\
\text { przy okazji programu, ale } \\
\text { finansowanych spoza programu } \\
\text { + SYNERGIE } \\
\text { Wzmocnienie dodatkowo } \\
\text { znaczenia/wartości } \\
\text { zawodów/prac spoza programu }\end{array}$} \\
\hline
\end{tabular}

Rysunek 2.17. Od efektu brutto do dodatkowego efektu netto programów ROW Źródło: Opracowanie własne na podstawie [Cambridge 2004]. 
Suma wszystkich efektów pozytywnych (ze znakiem plus) i negatywnych (ze znakiem minus) daje możliwość oceny czystego wpływu programu. Zależności między tymi efektami w ocenie dodatkowości programu przedstawia rysunek 2.18.

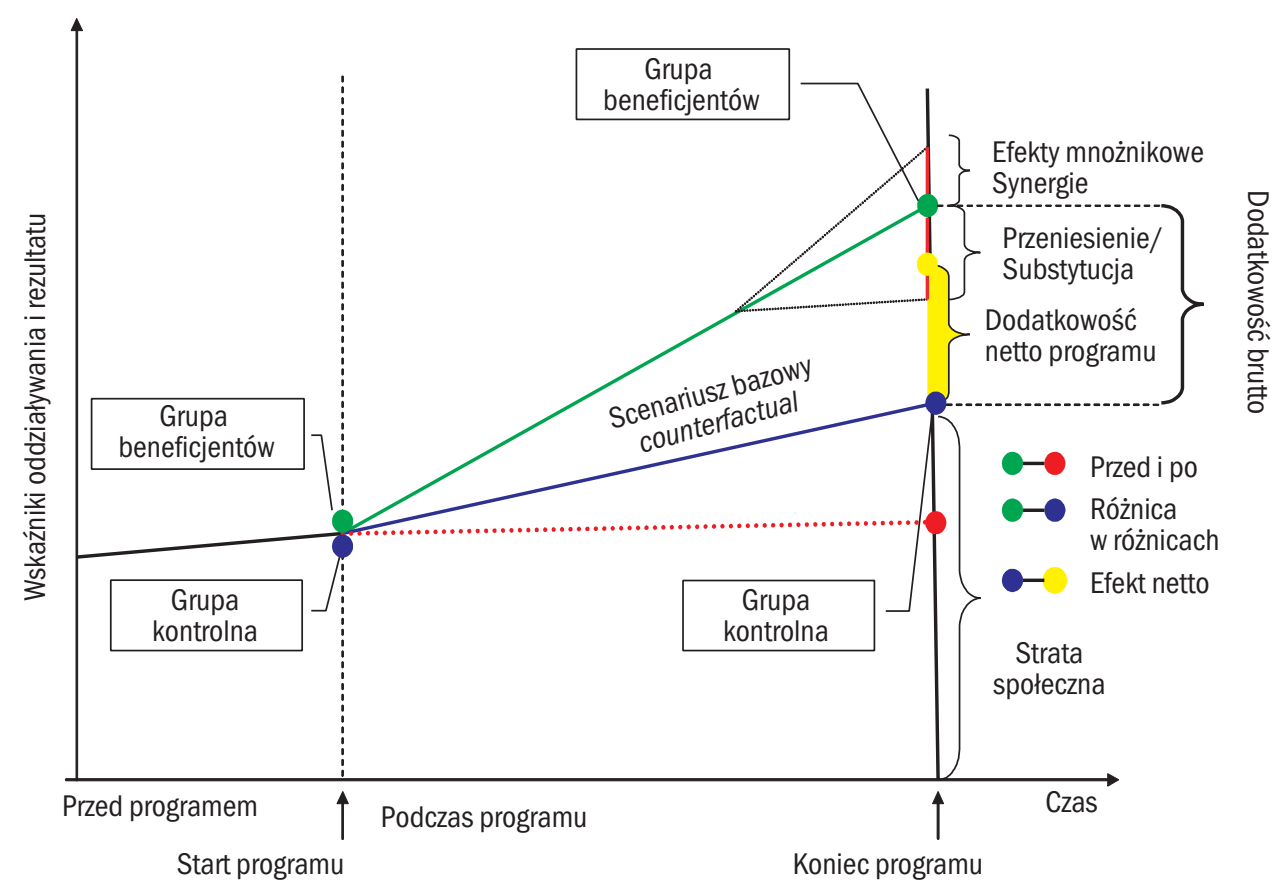

Rysunek 2.18. Schemat oceny efektów dodatkowych netto programów

Źródło: Opracowanie własne na podstawie [Cambridge 2004].

\section{Harmonogram ewaluacji}

Istnieje kilka typów ewaluacji, które różnią się między sobą w zależności od tego, w którym momencie programu są przeprowadzane. Zanim program się rozpocznie sporządzana jest ewaluacja ex ante, która ma za zadanie pomóc w podniesieniu jakości i wydajność programowania, w środku cyklu następuje ewaluacja średniookresowa, która ocenia postępy we wdrażaniu programu odnośnie do wkładu i wyników, a jej rekomendacje mogą przyczynić się do poprawy wdrażania programu. Dwa lata po skończeniu programu następuje ewaluacja ex post, która już całościowo ocenia osiagnnięcia programu co do nakładów, wyników i oddziaływania. Dodatkowo w ciągu całego trwania cyklu programu zalecana jest ewaluacja bieżąca (on-going). Czasem ewaluacja średniookresowa i ex post są częścią takiej 
ewaluacji uchwyconą w dwóch charakterystycznych punktach trwania programu (w środku i po skończeniu) - rysunek 2.19.

Model równowagi ogólnej typu RegPOL jest szczególnie przydatny do ewaluacji typu ex ante oraz ex post. W analizie ex ante pozwala on w eksperymentalny sposób zbadać różne warianty danej polityki, przy różnych założeniach scenariuszy bazowych, żeby doprowadzić do wyselekcjonowania najbardziej korzystnego jej wariantu. Natomiast w analizie ex post, kiedy polityka ta jest już zrealizowana i zamiast założeń w modelu są dane faktyczne, pozwala on ocenić w pełni mechanizmy wpływu konkretnych instrumentów polityki gospodarczej na poszczególnych aktorów i wszystkie sektory gospodarki w ujęciu wojewódzkim.

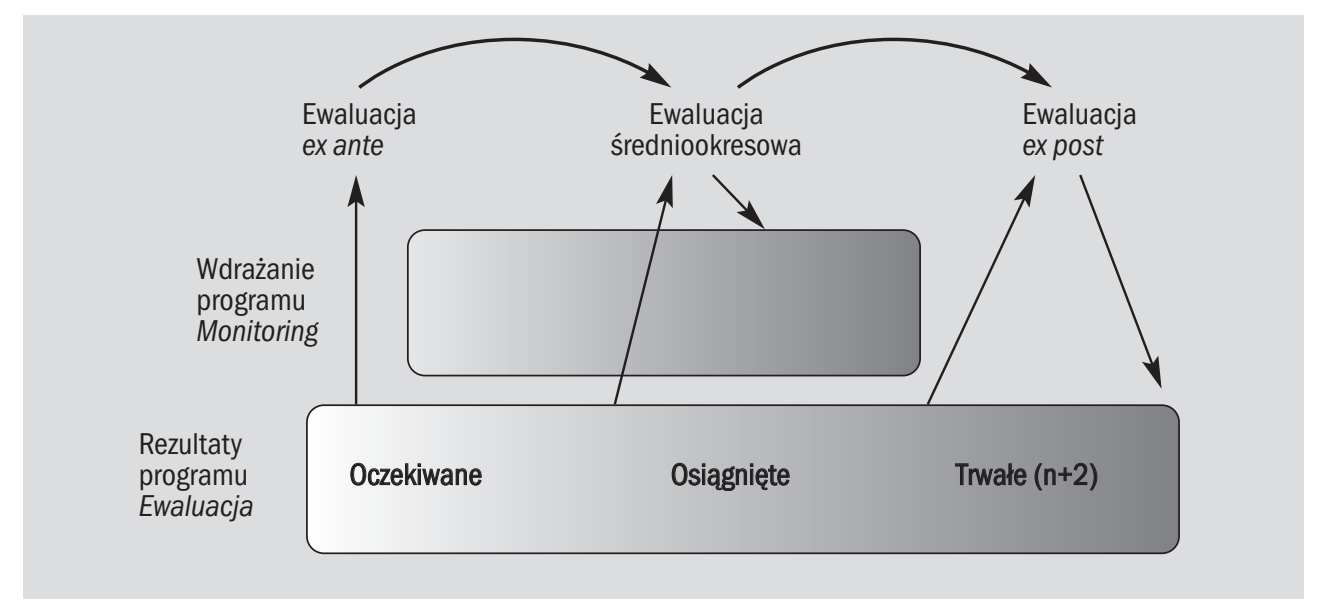

Rysunek 2.19. Harmonogram ewaluacji

Źródło: Na podstawie [Morten 2006].

Na koniec należy stwierdzić, że nie ma jednego narzędzia ilościowego, które nadawałoby się do każdego rodzaju i poziomu ewaluacji. Każda z metod ma swoje silne i słabe strony w poszczególnych obszarach ewaluacji i na poszczególnych jej poziomach. Na przykład, o ile proste metody statystyczne oparte na danych ankietowych dostarczają zwykle najlepszych wskaźników na najniższym poziomie analizy (produktów), o tyle na coraz wyższym poziomie analizy (tj. rezultatów, a w szczególności oddziaływania), potrzebne są coraz bardziej wyrafinowane metody ekonometryczne i modelowania ekonomicznego. Podobnie, o ile w analizie ex post łatwiej stosować metody statystyczne i ekonometryczne, o tyle w analizie ex ante potrzebne są bardziej metody eksperckie i modelowe, gdyż jest to analiza oparta na scenariuszach, które eksperci pomagają stworzyć (np. metodą delficką), 
a ekonomiści mogą w eksperymentalny sposób symulować, w zależności od różnych założeń i wariantów scenariuszy.

Jeśli ewaluacja dotyczy wielu działań w różnych obszarach, a poszczególne instrumenty mogą wzajemnie wpływać na swoje funkcjonowanie, naturalnym wyborem są modele jak najbardziej całościowo ujmujące gospodarkę i powiązania między sektorami, np. modele równowagi ogólnej. Natomiast tam, gdzie mechanizm działania jest relatywnie prosty, a interakcje z otoczeniem ograniczone, bardziej użytecznym narzędziem są modele cząstkowe (równowagi cząstkowej), relatywnie prostsze, ale też szybsze w tworzeniu i łatwiejsze w interpretacji [Kaczor 2008]. Więcej rozważań na temat adekwatności różnych metod przedstawia rozdział 3.1.1.

Punktując wkład niniejszego opracowania w ewaluację programów adresowanych do ROW, to jest on widoczny w następujących obszarach:

- ewaluacji ex post programów PROW 2004-2006 i SPO Rolnictwo,

- oceny tych programów pod względem głównych kryteriów ewaluacyjnych: skuteczności, efektywności, trwałości i celności, zarówno dla całego programu, jak i wybranych działań w poszczególnych województwach,

- analizy dodatkowych kryteriów ewaluacyjnych, takich jak efekty mnożnikowe pomiędzy sektorami,

- obliczenie wielu wskaźników ekonomicznych opisujących skutki działania programu, głównie na poziomie oddziaływania, do których należą między innymi: wzrost gospodarczy konsumpcja, wydatki rządowe, inwestycje, zatrudnienie, produkcja, poziomy cen, handel krajowy i zagraniczny itp.,

- wyznaczenie scenariusza bazowego, stanowiącego punkt odniesienia do zmian, jakie wnosi sama polityka do rozwoju ekonomicznego. 
r02.qxd 2011-10-31 09:40 Page 138 


\section{3 \\ REGIONALNY MODEL RÓWNOWAGI OGÓLNEJ REGPOL}

\subsection{Wybór metody badawczej}

Znalezienie odpowiedniego narzędzia do oceny polityki rozwoju obszarów wiejskich (ROW) dla Polski z pewnością nie jest łatwe, bo polityka ta dotyczy również wielu innych sfer życia i gospodarki. Po pierwsze, wykracza poza wsparcie sektora rolniczego, gdyż w rzeczywistości wiele niezbędnych dóbr i usług nabywanych z funduszy polityki ROW pochodzi z innych sektorów gospodarki, np. budownictwa, transportu, edukacji i wielu innych, o czym dokładniej piszemy w rozdziale 4.3. Po drugie, polityka ta wspiera różne grupy społeczne i podmioty ekonomiczne, czyli m.in. rolników, przedsiębiorstwa przemysłu przetwórczego, mikroprzedsiębiorstwa niezwiązane z rolnictwem, gminy wiejskie i ogólnie mieszkańców wsi. Po trzecie, konstrukcja programów dla terenów wiejskich jest wielopoziomowa, zaczyna się bowiem od celów ogólnych, poprzez cele strategiczne i operacyjne, aż do celów szczegółowych. Dlatego ocenie podlegają potem osobno produkty programu, rezultaty i jego oddziaływanie (dokładniej o tych sprawach patrz rozdział 2.3.5). Każdy z tych poziomów wymaga innych wskaźników oceny i innego podejścia metodologicznego. Po czwarte, zawsze przy ocenie takiej polityki pojawia się trudność z obiektywnym wyekstrahowaniem czystego jej wpływu na otoczenie i beneficjentów. Jednocześnie na dany region czy ludzi oddziałuje tyle czynników, że zmiany powodowane akurat jedynie tą polityką są bardzo trudne do wychwycenia i oceny. W końcu też przy tylu aspektach tej polityki trudno znaleźć dane, które w pełni odzwierciedlają zmiany w bliższym i dalszym otoczeniu jej oddziaływania, a jeśli analiza ma być regionalna, zadanie staje się jeszcze trudniejsze.

Dotychczasowe badania nad polityką ROW w Polsce w zdecydowanej większości mają charakter badań jakościowych oraz analiz o charakterze statystycznym i eksperckim. Mając to na względzie, niniejsza publikacja ma za zadanie 
przyczynić się do uzupełnienia dotychczasowej wiedzy opierając się na nowych narzędziach ilościowych, tak aby z jednej strony mogły one służyć weryfikacji rezultatów uzyskanych innymi metodami, a z drugiej strony, rozszerzały zakres analizy o nowe aspekty i możliwości, jakie oferuje modelowanie ekonomiczne.

Proponowanym narzędziem badawczym jest regionalny (wojewódzki) model równowagi ogólnej dla Polski, o nazwie RegPOL. Po krótkim wprowadzeniu dotyczącym historii wykorzystania tego typu modeli w ocenie polityki na świecie, wyjaśnione zostanie, dlaczego model ten może być zastosowany jako adekwatne narzędzie oceny takiej polityki, jak polityka ROW w Polsce. Następnie opisana jest teoria ekonomiczna leżącą u podstaw równań strukturalnych modelu RegPOL, zastosowane metody obliczeniowe, sposób tworzenia bazy danych, logika działania modelu i oprogramowanie modelu w języku Tablo. W dalszej części omówione są zastosowane scenariusze, służące weryfikacji postawionych hipotez badawczych. Na końcu następuje weryfikacja tego, czy wyniki uzyskane dzięki modelowi RegPOL są wiarygodne, jak należy je interpretować i w jakim zakresie można im ufać.

\subsubsection{WYKORZYSTANIE MODELI RÓWNOWAGI OGÓLNEJ DO OCENY POLITYKI GOSPODARCZEJ}

Istnieje obecnie kilka typów modeli najczęściej wykorzystywanych do oceny polityki, m.in. modele makroekonomiczne i ekonometryczne, modele przepływów międzygałęziowych (input-output), modele SAM, modele równowagi częściowej i modele równowagi ogólnej. Każdy z nich ma swoje wady i zalety. Które zatem wybrać? $\mathrm{Z}$ pewnością wybór ten jest zdeterminowany charakterystyką badanej polityki i tym, co może zaoferować każdy z nich.

Modele makroekonomiczne składają się z systemu powiązanych ze sobą równań, opisujących zachowanie gospodarki w pewnym przedziale czasu i nie wymagają wielu założeń, np. co do tego, że rynki są zrównoważone. Jednocześnie jednak nie uwzględniają bezpośrednio miary dobrobytu (którego maksymalizacja jest ostatecznym celem polityki gospodarczej), lecz raczej zajmują się miarami aktywności gospodarczej. Są zatem najbardziej użyteczne przy opracowywaniu prognoz gospodarczych dotyczących podstawowych wielkości makroekonomicznych, takich jak tempo wzrostu gospodarczego, inflacja, bezrobocie, bilans płatniczy, ale nie do analizowania różnych wariantów polityki i jej długookresowego wpływu na gospodarkę. Z kolei modele przepływów międzygałęziowych opisują szczegółową strukturę powiązań transakcyjnych pomiędzy zdezagregowanymi sektorami gospodarki, co pozwala na określenie niektórych skutków pośrednich danej polityki. Jednak 
opierając się na podejściu zapoczątkowanym przez W. Leontiefa [1937, 1977], modele te nie uwzględniają substytucji czynników produkcji i w ograniczonym zakresie pozwalają na badanie skutków postępu technologicznego. Powszechnie są uznawane za pożyteczne narzędzie do analiz krótkookresowych.

Istota modeli równowagi częściowej polega na tym, że traktują one wybrany sektor gospodarki jako zamknięty system, w którym brak jest powiązań z resztą gospodarki [Poczta-Wajda 2008]. W tym podejściu krzywe popytu i podaży są od siebie niezależne. Takie uproszczenie rzeczywistości może być uzasadnione między innymi z powodu analitycznej wygody i matematycznej łatwości posługiwania się nimi, ale wyklucza analizę polityki, która ma zasięg wielosektorowy [Kiuiła 2000]. Zatem w uproszczeniu można powiedzieć, że korzystanie z modeli równowagi częściowej jest uzasadnione, jeśli związek badanego rynku z resztą gospodarki jest słaby, a jego udział w całkowitym popycie niewielki. W przeciwnym razie ich zastosowanie może prowadzić do błędnych wniosków [Żylicz 2004]. Przykładem najbardziej znanych modeli tego typu w zastosowaniu do polityki rolnej sa modele: CAPRI ${ }^{36}$, ESIM ${ }^{37}$, AGLINK ${ }^{38}$ (Poczta-Wajda 2008).

Obliczeniowe modele równowagi ogólnej (CGE) mają tę główną zaletę, że pozwalają zrozumieć, jak różne rynki zależą od siebie nawzajem. Uwzględniają powiązania funkcjonalne pomiędzy wszystkim rynkami dóbr i czynników produkcji i dążą do osiągnięcia równowagi na wszystkich tych rynkach jednocześnie, poprzez dostosowania cenowe. Modele te szczególnie koncentrują się na optymalizacji dobrobytu, który jest bezpośrednio uwzględniony poprzez założenie o racjonalnym zachowaniu podmiotów gospodarczych. Wpływ polityki może być analizowany poprzez porównanie zmiennych ekonomicznych przed i po egzogenicznie spowodowanym szoku, jakim jest interwencja danej polityki w gospodarkę. Porównując w ten sposób dwa stany równowagi, można zidentyfikować skutki określonych przedsięwzięć polityki [Kiuiła 2000]. Z powyższej charakterystyki wynika bezpośrednio nazwa tych modeli. Są one ogólne, ponieważ zawierają specyfikę zachowania wszystkich podmiotów gospodarczych; ponadto są obliczeniowe, ponieważ generują rezultaty wyrażone w liczbach; wreszcie są modelami równowagi, gdyż mechanizm cenowy zawsze doprowadza wszystkie rynki (nie licząc

${ }^{36}$ CAPRI [Common Agricultural Policy Regional Impact] jest modelem służącym do oceny regionalnego wpływu różnych scenariuszy Wspólnej Polityki Rolnej: http://www.capri-model.org/

${ }^{37}$ ESIM [European Simulation Model] jest modelem służącym do prognozowania zmian zachodzących na rynkach rolnych: https://www.uni-hohenheim.de/1597.html?\&no_cache=1\&typo3state=publications\&lsfid $=15073 \& \mathrm{~L}=1$

${ }^{38}$ AGLINK - jest dynamicznym modelem równowagi częściowej opracowanym przez OECD, używanym również przez FAO, do średniookresowych prognoz dla rolnictwa światowego http://www.agrioutlook.org/document/1/0,3343,en_36774715_36775671_36957313_1_1_1_1,00.html 
rynku pracy) do zrównania popytu z podażą [Dixon, Parmenter, Amman i in. 1996]. Trzeba podkreślić jednak, że ekonomiści zajmują się modelami równowagi ogólnej nie dlatego, że wierzą, iż zawsze zachodzi ona w rzeczywistości, lecz po to, aby poznać mechanizmy popytowo-podażowe, występujące na poszczególnych rynkach i ich wzajemne powiązania. CGE są modelami długookresowymi i nie nadają się do tworzenia precyzyjnych prognoz gospodarczych i interwencji rządowych. Zalecane są jednak do oceny różnych wariantów polityki, zwłaszcza wtedy, gdy polityka ta wywiera wpływ na dużą część gospodarki [Kiuiła 2000]. Dobre porównanie modeli równowagi ogólnej z modelami równowagi częściowej przedstawia Hertel [1985], a z innymi modelami także [Törmä 2008]. Z kolei T. Żylicz [2004] wyjaśnia, na czym polega przystosowanie modeli równowagi ogólnej typu Walrasa do zastosowania w modelowaniu polityki ochrony środowiska (z uwzględnieniem dóbr publicznych i kosztów społecznych). Jednym z najbardziej znanych modeli CGE na świecie, wykorzystywanym m.in. do analiz handlu artykułami rolnymi, jest GTAP ${ }^{39}$.

Wprawdzie wcześniejsze modele (np. przepływów międzygałęziowych) uwzględniały w równaniach to, że interwencja w jednym sektorze rzutuje na funkcjonowanie wszystkich pozostałych, odbijając się tym samym na stanie całej gospodarki, ale tylko w modelach CGE zależności między sektorami odzwierciedlają także ogólne ograniczenia narzucane przez takie czynniki, jak rozmiary deficytu budżetowego i handlowego oraz dostępność siły roboczej, kapitału i ziemi. Ograniczenia te sprawiają, że interwencja może przynieść w skali całej gospodarki odmienne (a nawet odwrotne) skutki niż wtedy, gdyby tych ograniczeń nie było [Ginsburgh i Keyzer 1997, Rutherford i Törmä 2008b]. Badania za pomocą modeli CGE dostarczają czasem rezultaty pozornie sprzeczne z intuicją [Ginsburgh i Keyzer 1997], ponieważ analizują długie łańcuchy przyczynowo-skutkowe, uwzględniające nie tylko bezpośrednie oddziaływanie, lecz także efekty i sprzężenia zwrotne, których nie sposób intuicyjnie przewidzieć. Przykład dobrze ilustrujący to zjawisko przedstawia [Żylicz 2004].

Postuluje się, żeby do analizy rezultatów polityki korzystać z wielu typów modeli i traktować je jako komplementarne, a nie substytucyjne czy rywalizujace, dotyczą bowiem różnych obszarów i mają różne możliwości poznawcze w odniesieniu do badanego zjawiska. Modele bywają mniej lub bardziej doskonałe, ale istotne jest to, czy są w stanie dostarczyć pożytecznych informacji na temat różnych aspektów polityki, przydatnych w podejmowaniu decyzji na szczeblu

${ }^{39}$ GTAP [ Global Trade Analysis Project] dostarcza modeli równowagi ogólnej i baz danych dla gospodarki światowej w dezagregacji na poszczególne kraje, służące do oceny polityki światowego handlu. https://www.gtap.agecon.purdue.edu/models/current.asp 
rządowym [Shoven i Whalley 1984, Kiuiła 2000]. Jednak spośród omawianych metod, modele CGE mają najbardziej wszechstronne zastosowanie praktyczne, o czym świadczyć może ich wykorzystanie przez największe organizacje międzynarodowe, takie jak Komisja Europejska, Międzynarodowy Fundusz Walutowy, Bank Światowy czy OECD, do licznych analiz sektorowych i przekrojowych na całym świecie. Na przykład model opracowany przez OECD posłużył m.in. takim opracowaniom, jak prezentuje to P. Meller [1991] dla Chile, S. Lambert, H. Schneider i A. Suwa [1991] dla Wybrzeża Kości Słoniowej, A. de Janvry, E. Sadoulet i A. Fargeix [1991] dla Ekwadoru, E. Thorbecke [1991] dla Indonezji, czy W.I. Morrisson [1991] dla Maroka. Ponadto o popularności tych modeli może świadczyć też to, że doczekały się osobnej kategorii w Journal of Economic Literature i od 1991 r. mają nadany symbol D 58: Computable and other Applied General Equilibrium Models [Böhringer, Rutherford i Wiegard 2007].

Historia modeli CGE jest opisana w wielu opracowaniach, z tego najbardziej znane i uznane są takich autorów jak J.B. Shoven i J. Walley oraz P. Dixon i B.R. Permenter, przedstawione w wielu ich publikacjach. Z ostatnich opracowań, korygujących nieco te wcześniejsze, polecić można B.H. Mitra-Kahna [2008]. Historia modeli należących do tej rodziny sięga jeszcze XVIII w., kiedy to F. Quesnay opublikował w 1785 r. pracę Tableau Economique, uważaną za pierwszy przykład próby analizy z uwzględnieniem pełnego obiegu gospodarki. Za ojca teorii równowagi ogólnej powszechnie uważa się L. Walrasa, który jako pierwszy w 1874 r. w pracy Elements d'economie politique pure sformalizował teoretyczny model równowagi ogólnej. Potem w latach 1930. W. Leontief stworzył tablicę przepływów międzygałęziowych (IO), która posłużyła stworzeniu macierzy rachunków społecznych. Tymczasem A. Wald [1934] był pierwszym, który udowodnił istnienie równowagi ogólnej w uproszczonym modelu teoretycznym. W latach 50., za jego przykładem, wielu ekonomistów dokonało różnych formalizacji struktury modeli równowagi ogólnej (należeli do nich m.in. K. Arrow, G. Debreu, F. Hahn). L. Johansen, wykorzystując rozwój technologii komputerowej, przedstawił w 1960 r. pierwszy empiryczny model równowagi ogólnej. Następnie, w 1967 r., H.E. Scarf opracował algorytm obliczeniowy, który stał się przełomem w wykorzystywaniu dużych obliczeniowych modeli równowagi ogólnej dla celów praktycznych [Grassini 2004].

Kwestia wykorzystania modeli równowagi ogólnej w kształtowaniu i ocenie konkretnych interwencji publicznych doczekała się licznych opracowań naukowych [Dervis, Melo i Robinson 1982, Borges 1986, Decaluwe i Martens 1988, Bergman, Jorgenson i Zalai 1990, Powell i Snape 1993, Gunning, Keyzer, Behrman $i$ in. 1995, Iqubal i Rizwana 2001, Devarajan, Robinson, Kehoe i in. 2005, 
Mitra-Kahn 2008]. Zakres zagadnień, które analizowano za pomocą tych modeli, jest bardzo szeroki i obejmuje handel międzynarodowy, finanse publiczne (szczególnie reformy podatkowe), rolnictwo, programy dostosowania strukturalnego, programy edukacyjne, dystrybucję dochodu, politykę energetyczną, politykę ochrony środowiska i inne. Jest również wiele dobrych opracowań na temat zastosowania modeli CGE do oceny konkretnych typów polityk [Shoven i Whalley 1984, Horridge 1988, Pereira i Shoven 1988, Bergman, Lundgren, Jorgenson i in. 1990, Bandara 1991, Berck, Robinson, Goldman i in. 1991, Bhattacharyya 1996, Conrad 2001, Arrow, Kehoe, Srinivasan i in. 2005, Horridge i Filho 2005, Horridge, Madden i Wittwer 2005], a długą listę bibliograficzną takich modeli proponuje Ruralia [2008].

O tym, że modele CGE okazywały się przydatne w rozstrzyganiu debat politycznych, decydowały między innymi takie czynniki, jak: • zgodność między wnioskami wynikającymi z modeli CGE a wynikami analiz innego typu (np. w rozmowach dotyczących NAFTA) • fakt, że modele CGE uwzględniały szczególne właściwości gospodarki, takie jak pewne usztywnienia strukturalne czy ograniczenia instytucjonalne, na które nie było miejsca w prostszych, bardziej zdroworozsądkowych metodach analizy • modele CGE oferowały spójny, całościowy obraz sytuacji, umożliwiający ocenę zależności między różnymi wariantami polityki. Dokładniejsze omówienie zalet modeli CGE w ocenie polityki proponują m.in. S. Devarajan, S. Robinson i in. [2005]. Zdarzały się jednak także przypadki niewłaściwego wykorzystania modeli CGE, co przyczyniło się potem do ich krytyki. Błąd najczęściej polegał na: • zastosowaniu modelu poza obszarem jego możliwości zastosowania - zastosowaniu modelu w przypadku, gdy prostsze metody okazywały się skuteczniejsze (innymi słowy było to „strzelanie do komara z armaty”) • syndromie „czarnej skrzynki”, czyli nieumiejętności pokazania przez autorów jasnego związku między wnioskami wypływającymi z modelu a modyfikacją założeń polityki [Devarajan, Robinson i in. 2005]. Można przytoczyć tu też krytykę natury warsztatowej: modele CGE, opierając się na wybranym roku, mogą źle odzwierciedlać strukturę gospodarki, jeśli rok ten jest z jakichś powodów nietypowy [Partridge i Rickman 1998]. Innym zarzutem jest to, że modele te oparte są na wielu upraszczających założeniach [Bourguignon i Pereira da Silva 2003], np. co do formy funkcji produkcji czy użyteczności (zwykle zakłada się funkcję CES lub Cobba-Douglasa), jak również co do zachowań producentów, konsumentów (zwykle zakłada się, że ci pierwsi maksymalizują zysk, a ci drudzy użyteczność) i rynków (zwykle zakłada się konkurencję doskonałą) oraz parametrów (zwykle przyjmuje się z literatury lub estymacji ekonometrycznych, np. elastyczności). Niektórzy autorzy obawiają się zatem, czy modele CGE 
tworzą w takim razie spójny obraz całości ekonomii [Bandara 1991]. Jest też podnoszony problem tzw. domknięcia modeli (closures) ${ }^{40}$, co wiąże się z pewnym wyborem, które zmienne będą endogeniczne, a które egzogeniczne w modelu, to zaś z kolei determinuje kierunek przyczynowości w modelu. W zależności od tego wyboru, model może generować różne wyniki, dlatego trzeba być pewnym i świadomym wyboru domknięcia modelu, a zdarza się, że autorzy przyjmują automatycznie generowane przez program domknięcie modelu, które czasem może nie mieć dobrego sensu ekonomicznego [Mitra-Kahn 2008]. Zarzuca się też modelom CGE, że zbyt wysoki poziom ich agregacji prowadzi do niewystarczająco precyzyjnych wyników, jak na potrzeby ewaluacji [Bourguignon i Pereira da Silva 2003].

Syntetyczne zestawienie najczęstszych założeń modeli CGE prezentuje J. Kornai [1977, s. 45-51]. Zalicza do nich: • statyczny i stacjonarny charakter tych modeli (wszystkie zmienne odnoszone są do jednego punktu w czasie i liczba elementów modelu się nie zmienia) • stałość zbioru organizacji (liczba jednostek organizacyjnych jest niezmienna w czasie) • występowanie wyłącznie dwóch jednostek organizacyjnych, tj. producentów i konsumentów • wytwarzanie niezmiennej liczby produktów • jednoczesność zachodzenia wszystkich procesów w gospodarce • wypukłość zbioru procesów produkcji • maksymalizację zysków przez producentów • maksymalizację użyteczności przez konsumentów • stałość zbiorów produkcji i konsumpcji oraz skali preferencji • wyłączność przepływu informacji tylko co do cen • anonimowość stosunków rynkowych • brak niepewności wśród podmiotów gospodarczych.

Większość z tych zarzutów czy ułomności doczekało się już rozwiązania. Zarzut nieprzejrzystości modeli CGE ze względu na ich wielkość, starano się obalić już w wielu opracowaniach, wyjaśniając w bardzo przystępny sposób wiedzę na temat szczegółów dotyczących tych modeli [np. Böhringer, Rutherford i in. 2007, Lofgren, Lee Harris i Robinson 2002]. Jednocześnie inne artykuły mobilizują autorów do większej przejrzystości i jawności szczegółów technicznych tych modeli, proponując nawet standaryzację procesu raportowania modelu i ich wyników, np.

\footnotetext{
${ }^{40}$ Domknięcie modelu (closure) w języku modeli CGE oznacza określenie założeń makroekonomicznych, które przesądzają o kierunku przyczynowości [Taylor i von Arnim 2007]. W praktyce jest to lista zmiennych przyjętych za egzogeniczne, gdyż w modelu nie może być więcej zmiennych endogenicznych niż równań. W domknięciu modelu decyduje się o zależnościach dotyczących między innymi sektora rządowego, handlu, rynków czynników produkcji itp. Wybór może zależeć np. od przyjętej teorii ekonomicznej, albo od tego, czy analizowany jest krótki czy długi okres. Wtedy inne są założenia co do tego, co może się zmieniać (jest endogeniczne), a co nie (jest egzogeniczne) i to odzwierciedla właśnie domknięcie modelu. Dlatego przez domknięcie modelu decyduje się o kierunku przyczynowości [Mitra-Kahn 2008]. Dokładniej omawiamy tę kwestię w dalszej części tego rozdziału, poświęconej domknięciom w modelu RegPOL.
} 
[Mitra-Kahn 2008]. Dostępne są również opracowania, które stosują metody porównawcze założeń modeli i ich wpływu na wyniki [Partridge i Rickman 1998], co pozwala zrozumieć zależność uzyskiwanych wyników od przyjmowanych założeń. Jeśli chodzi o krytykę wybranego roku bazowego, który jest podstawą całego modelu, to jeśli jest on rzeczywiście bardzo nietypowy, niektórzy autorzy opierają się na kilku historycznych tablicach przepływów międzygałęziowych i tworzą uśrednioną tablicę jako bazową dla modelu [Adams i Higgs 1990]. Z zarzutem o upraszczające założenia poradzono sobie w ten sposób, że modele CGE w miarę rozwoju coraz częściej łagodzą te założenia, starając się bardziej przybliżać do rzeczywistości, między innymi wprowadzając konkurencję niedoskonałą [Richardson 1989, Kinnunen 2005], przyjmując parametry oparte na estymacjach ekonometrycznych spójnych z używanym modelem CGE [Rickman 1995], czy wprowadzając dynamikę [Pereira i Shoven 1988]. Jest też wiele wskazówek do przeprowadzania analizy wrażliwości modelu na przyjęte parametry oraz $\mathrm{w}$ celu oszacowania skali błędu, jaki model może generować [Harrison i Vinod 1992, Harrison i in. 1993, Roberts 1994]. Jeśli chodzi o domknięcie modelu (closures), również jest już coraz więcej opracowań im poświęconych i coraz częściej autorzy opracowań CGE uzasadniają wybrany typ domknięcia (np. [Rickman 1992, Rickman i Treyz 1993, Rutherford i Törmä 2006]). Jednak jest raczej niemożliwe - wbrew sugestiom niektórych autorów [Partridge i Rickman 1998] - przeprowadzenie symulacji dla wszystkich istniejących kombinacji domknięć modelu. Lepsze będzie wybranie takiego domknięcia, które ma największe uzasadnienie ekonomiczne w danej sytuacji i szukanie potwierdzenia jego prawidłowości w sensowności uzyskanych wyników.

Co do krytykowania zbyt dużej agregacji, to wyraźnie widać, że modele CGE w miarę rozwoju ulegają coraz większej dezagregacji, w celu zwiększenia precyzji wyników i w związku z tym ich użyteczności dla polityki. Może o tym świadczyć rozwój regionalnych modeli równowagi ogólnej (np. australijski model Monash posiada 140 sektorów, 56 regionów i 340 rodzajów zatrudnienia), czy modeli z wieloma typami konsumentów, np. [Kinnunen i Palmer 2006] wyróżnia 8 grup wiekowych i 2 grupy poziomu edukacji) albo modeli ujmujących relacje miasto-wieś [Gelan 2002, Hu 2002]. Wraz z rosnącą dostępnością danych, modele CGE stają się coraz bardziej szczegółowe, a potencjał rozwojowy tych modeli jest nadal bardzo duży i wyraźnie widać postęp w ich zbliżaniu się do rzeczywistości. Trzeba jednak pamiętać, że są to modele bardzo wymagające, jeśli chodzi o ilość szczegółowych danych. Brak dostępu do takich danych powoduje, niestety, pewne ograniczenia.

W Polsce modele CGE też mają już swoją tradycję, chociaż nie tak bogatą, jak w krajach zachodnich, gdyż zajmuje się nimi stosunkowo niewielu jeszcze 
ekonomistów. W skrócie można stwierdzić, że polskie modele CGE były już wykorzystywane do oceny takich polityk, jak:

- integracja Polski z UE [Krześniak 1998, Orłowski 1998, Czyżewski, Orłowski i Zienkowski 1999, Orłowski 1999, 2000, Piazolo 2000, Maliszewska 2004],

- polityka monetarna i fiskalna [Chmiel, Podkaminer, Zienkowski i in. 1991, Orłowski 1991, Jarociński 1998, Honkatukia i Vaittinen 2003],

- polityka rolna [Orłowski 1996],

- liberalizacja handlu, w tym produktami rolniczymi [Maliszewska 2004, Hagemejer i Michałek 2008],

- polityka regionalna [Kaczor 2006],

- polityka prywatyzacji [Roberts 1996],

- polityka ekologiczna i środowiskowa [Peszko 1997, Umer, Jankowski, Niemyski i in. 1998, Kiuiła 2000, Kiuiła 2003, Kiuiła i Śleszyński 2003, Kiuiła i Peszko 2006], w tym polityka energii odnawialnej [Kancs 2002, Kancs 2006].

Istnieją też opracowania o charakterze metodologicznym, uwzględniające niedoskonałości rynku [Tabeau 1996, Żółkiewski 1996]. Dobry przegląd istniejących modeli CGE dla gospodarki polskiej oraz listę ekonomistów zajmujących się nimi prezentuje O. Kiuiła [2000]. Na tle tego przeglądu można powiedzieć, że proponowany model RegPOL jest - o ile autorce wiadomo - pierwszym modelem typu CGE zastosowanym do oceny polityki rozwoju obszarów wiejskich oraz pierwszym w Polsce pełnym regionalnym modelem CGE opartym na regionalnych tablicach przepływów międzygałęziowych, czyli posiadającym pełną informację o strukturze sektorów w regionach i interakcjach zachodzących między nimi.

\subsubsection{REGIONALNE MODELE RÓWNOWAGI OGÓLNEJ}

Regionalnych modeli $\mathrm{CGE}^{41}$ jest znacznie mniej niż modeli krajowych. Najbardziej znane przykłady to: australijskie modele, takie jak MONASH, dla 56 regionów Australii i 140 sektorów [Dixon i Rimmer 1998]; MMRF, dla 8 regionów i 40 sektorów [Peter, Horridge, Meagher i in. 1996] oraz TERM, dla 57 regionów i 40 sektorów [Horridge, Madden i in. 2005]. Ponadto wielosektorowy globalny model GTAP traktujący kraje jako regiony świata, ale posiadający też elementy typowo regionalnych CGE, głównie do analiz dotyczących handlu

\footnotetext{
${ }^{41}$ Nie mówimy tu o wieloregionalnych (multiregional) modelach, które odnoszą się do modelowania krajów jako regionów świata, ale o typowych regionalnych modelach, które odzwierciedlają regiony danego kraju. Z formalnego punktu widzenia modele te dość znacznie się różnią.
} 
światowego [GTAP 2008]. W Europie funkcjonujący regionalny model to fiński RegFIN, mający postać dynamiczną, opracowany dla 27 sektorów i 20 regionów [Rutherford i Törmä 2008b, Törmä 2008]. Kolejny model, który powstał w unijnym projekcie TERA, składa się z dwóch regionów w każdym z dwóch krajów, tj. Szkocji i Grecji (TERA bi-regional CGE) i służy głównie do analizy skutków interwencji polityki rolnej, $\mathrm{z}$ uwzględnieniem relacji miasto-wieś [Balamou, Pouliakas, Reberts i in. 2008]. Następny funkcjonujący regionalny dynamiczny model CGE to GreenMod, rozwijany w Belgii przez Free University of Brussels dla 3 regionów i 26 sektorów, służący głównie do analiz związanych z ochroną środowiska [Bayar, Dramais, Mohora i in. 2006]. Bardzo dobry przegląd wcześniejszych regionalnych modeli z lat 80. i 90. oferują M. Partridge i D.S. Rickman [1998], wymieniając m.in. modele dla 6 regionów Kanady [Jones i Whalley 1989], model relacji regionów wiejskich i miejskich w USA [Kilkenny 1998], model dla 6 regionów w Australii [Liew 1984] i wiele modeli dla analiz pojedynczych regionów.

Wprawdzie regionalne modele CGE przypominają pod wieloma względami modele krajowe (tj. struktura popytu i podaży jest podobna, założenia o zachowaniu producentów i konsumentów, osiąganie stanu równowagi na wszystkich rynkach jednocześnie poprzez mechanizm dostosowania cen), to jednak jest kilka kwestii, które je zdecydowanie odróżniają i znacznie komplikują modelowanie na tym poziomie. Większość różnic bierze się stąd, że regiony w porównaniu z krajami są gospodarkami o wiele bardziej otwartymi ekonomicznie [Vargas, Schreiner, Tembo i in. 1999], co rodzi wiele implikacji [Partridge i Rickman 1998].

Przede wszystkim pojawia się kwestia tego, że regiony handlują nie tylko z zagranicą, ale i między sobą w kraju. O ile statystyki na temat handlu między krajami są łatwo dostępne, o tyle statystyki handlu poszczególnych regionów z innymi regionami zarówno w kraju, jak i z zagranicą są o wiele trudniejsze do zdobycia albo są obarczone różnymi błędami. Na przykład handel regionów z zagranicą zwykle jest podany w statystykach oficjalnych w formie uproszczonej i w dodatku w innej klasyfikacji niż sektory tablic przepływów międzygałęziowych. Z kolei handel regionów między sobą w kraju nigdzie nie jest oficjalnie rejestrowany w ujęciu sektorowym, w związku z tym wymaga bardzo dużej pracy metodologicznej i zbierania danych, żeby go oszacować. Pozostaje jeszcze praca związana z tym, żeby oszacowany handel bilansował się w macierzy SAM (bardziej szczegółowy opis trudności technicznych związanych z oszacowaniem handlu krajowego zawiera aneks 3.1).

Następnym problemem jest czynnik pracy - o wiele bardziej mobilny między regionami niż między państwami. O ile w ujęciu krajowym zakłada się często brak 
mobilności przepływu siły roboczej, o tyle w analizie regionalnej założenie to jest uchylone, i zwykle czynnik pracy jest doskonale lub niedoskonale mobilny.

Luźniejszy jest też związek między inwestycjami a oszczędnościami w danym regionie niż kraju. O ile w kraju istnieje ścisła zależność między wypracowanymi oszczędnościami a inwestycjami, o tyle mniej prawdopodobne jest, że mieszkańcy danego regionu będą lokować oszczędności akurat w inwestycje w tym samym regionie. Raczej będą kierować się wyższą stopą zwrotu, nawet jeśli będzie oferowana $\mathrm{w}$ innym regionie czy nawet za granica. Podobnie luźniejszy jest związek między miejscem zatrudnienia a miejscem wydatkowania uzyskanych dochodów. W przypadku kraju jest to zwykle to samo miejsce (tzn. większość zarobionych funduszy wydaje się w tym samym kraju, bo relatywnie mało znaczące są w tym przypadku wyjazdy za granicę, które zwykle przybierają charakter sezonowy), a w przypadku regionów skala „migracji zakupowych” jest już o wiele większa.

W analizie regionalnej dochodzi ponadto dodatkowy aspekt budżetów regionalnych i ich powiązania $\mathrm{z}$ budżetem centralnym. Te interakcje dotyczące wydatków, podatków czy transferów muszą być uwzględnione w modelu. Na końcu, wskutek zwiększenia rozmiaru analizowanej macierzy SAM (zwykle w modelach regionalnych posiada ona od kilku do kilkudziesięciu regionów, z których każdy ma od kilku do kilkudziesięciu sektorów), analiza staje się o wiele bardziej wymagająca pod względem dostępności danych, dobrego oprogramowania, jak również pod względem technicznym, interpretacyjnym i wymaga więcej czasu. Regionalne modele CGE wymagają danych dla każdego województwa i podmiotu gospodarczego na temat produkcji, technologii, konsumpcji i inwestycji, wydatków rządowych i przychodów z podatków, przepływów handlowych, dochodów z tytułu posiadanych czynników produkcji itd. Takie dane są o wiele trudniejsze do zdobycia na poziomie regionów niż krajów. Przy modelach o tak dużych rozmiarach wymagania sprzętowe rosną i ważna staje się również przejrzystość programów używanych do symulacji. Związane jest to też ze sposobem prezentacji wyników. Dla tak dużych modeli prostsze i bardziej nastawione na wizualizację prezentacje łatwiej ogarnąć całościowo.

Generalnie można wyróżnić trzy sposoby podejścia do budowania regionalnych modeli równowagi ogólnej: z góry do dołu (top-down), z dołu do góry (bottomup) i mieszane (hybrydowe). Pierwsze zakłada stworzenie najpierw modelu krajowego, a potem „zdezagregowanie” jego struktury na poszczególne regiony. Może to być jednak trudne i dalsze od rzeczywistości, ze względu na różnice między modelami krajowymi a regionalnymi, o których pisaliśmy powyżej. Podejście drugie zakłada budowanie struktury modelu na podstawie dostępnych danych regionalnych. Taki model próbuje zatem ująć wszystkie oficjalne dane, które są 
dostępne na poziomie regionów, dla zbudowania najpierw niezależnych modeli dla poszczególnych gospodarek regionalnych, które potem zostają powiązane interakcjami handlowymi, przepływu kapitału, siły roboczej itd. w jeden spójny model. Takie modele są bliższe rzeczywistości, gdyż zawierają mniej uproszczonych założeń, ale z kolei bywają zwykle bardziej zagregowane niż modele pierwszego typu. Wynika to z tego, że w podejściu od góry do dołu stopień rozdrabniania może zejść do bardzo niskiego poziomu szczegółowości, gdyż dane są generowane niejako sztucznie, a nie na podstawie statystyk regionalnych, które zwykle nie schodzą w przypadku takich modeli poniżej poziomu NUTS 2, NUTS 3. Modele hybrydowe mają cechy obu tych podejść. Na przykład mogą to być modele, które najpierw są budowane od dołu do góry, a potem po uzyskaniu wyników, są one od góry rozdrabniane na bardziej szczegółowe za pomocą pewnych wskaźników charakteryzujących niższe poziomy jednostek administracyjnych [CoPS 2008].

\subsubsection{AdEKWATNOŚć I WIARYGODNOŚĆ MOdELU REgPOL}

Model RegPOL - należąc do klasy regionalnych modeli równowagi ogólnej - dzieli zarówno ich wszystkie wady, jak i zalety. Wydaje się jednak, że te drugie przeważają. Będziemy starali się wykazać i udowodnić, że jest on adekwatnym i wiarygodnym narzędziem oceny polityki ROW w Polsce.

Zacznijmy od zalet. Wielką wartością dodaną tego modelu jest fakt, że w eksperymentalny sposób pozwala na wyodrębnienie wpływu jednej tylko polityki na gospodarkę regionów i całej Polski. Uchwycenie takiego „czystego wpływu”, bez zniekształceń spowodowanych wpływem wielu innych czynników i polityk, które w czasie trwania programu niezależnie oddziałują na beneficjentów i obszary nim objęte jest wielkim wyzwaniem i priorytetem ewaluacji programów. Istnieje dość bogata literatura na temat możliwych do zastosowania metod (dobry ich przegląd oferuje [Purdon, Lessof, Woodfield i in. 2001, ODPM 2004]). W przypadku naszego modelu z założenia badamy jedynie wpływ danej polityki, dla której przeprowadzamy symulację, ponieważ model obrazuje nam gospodarkę w równowadze. Przez symulacje wprowadzamy w ten zamknięty układ tylko interwencję wybranej polityki. Zatem w naszym eksperymencie z zastosowaniem modelu RegPOL obserwowany łańcuch reakcji w modelu uruchomiony poprzez szok, jakim jest uruchomienie programów ROW, odzwierciedla wpływ tylko i wyłącznie tej polityki (bo tylko ją w sposób eksperymentalny wprowadziliśmy jako szok zewnętrzny do gospodarki w równowadze).

Kolejną zaletą wykorzystania modelu RegPOL do ewaluacji polityki jest to, że odzwierciedla on całą gospodarkę, a więc wszystkie sektory produkcyjne i usłu- 
gowe. Możliwe jest zatem pokazanie wpływu polityki ROW nie tylko na sektor rolny, ale też na wszystkie pozostałe sektory w kraju. W przypadku takiej polityki, jak ROW, która niejako z założenia oddziałuje na różne pozarolnicze aspekty gospodarki i ma za zadanie m.in. kreować pozarolnicze zatrudnienie, te efekty są bardzo ważne. Pod tym względem model RegPOL jest bardzo adekwatny, gdyż pozwala na oszacowanie tzw. efektów mnożnikowych, czyli interakcji między sektorami w gospodarce. Jest to też ważne, ponieważ według dobrych zasad ewaluacji programów [ODPM 2004, WRMO 2006], takie efekty powinno się koniecznie brać pod uwage przy ocenie tzw. dodatkowości programu. Koncepcja ta wskazuje m.in. na to, żeby oprócz bezpośrednich skutków programów również dodawać pozytywne jego efekty zewnętrzne, a odejmować negatywne efekty zewnętrzne, które mogą się ujawnić, przy jego wdrażaniu, szerzej analizując skutki programu. Wśród takich efektów zewnętrznych wymienia się między innymi efekty mnożnikowe obok efektów straty społecznej, substytucji, przemieszczenia i synergii [ODPM 2004] ${ }^{42}$.

Model RegPOL, co ważne, oferuje możliwość oceny polityki ROW na jej najtrudniejszym poziomie, tj. poziomie oddziaływania. O ile dość łatwo jest ocenić wpływ polityki na poziomie produktów i rezultatów, o tyle stopień trudności zwiększa się znacznie, kiedy przechodzimy do poziomu oddziaływania programu. Nie ma wskaźników, które jednoznacznie pozwoliłyby nam oszacować wpływ poszczególnych działań na zmiany w gospodarce, takich jak wzrost gospodarczy, zatrudnienie, ceny, produkcja sektorowa etc. Model RegPOL umożliwia taką analizę. Oczywiście są zdefiniowane różne wskaźniki oddziaływania [KE 2006], ale zwykle nie jest wyjaśnione, w jaki sposób połączyć dane działania z ich oddziaływaniem na te zmienne.

Ponieważ jest to model strukturalny - jest stabilny, co jest jego następnym plusem. Jak wiadomo, struktura gospodarki jest układem dość stabilnym i jeśli zmienia się, to na skutek długiej ewolucji lub gwałtownej zmiany ustrojowej. Taka zmiana ustroju wprawdzie miała miejsce w Polsce, ale na początku lat 90., a omawiany model odzwierciedla sytuację ponad 10 lat później. Z dużym prawdopodobieństwem można więc stwierdzić, że gospodarka osiągnęła pewną nową równowagę. Jego charakter strukturalny pozwala uniknąć problemu braku długich

\footnotetext{
42 Efekt straty społecznej mierzy to, w jakim stopniu wyniki programu mogłyby zostać osiagnnięte nawet gdyby program nie został uruchomiony, np. sfinansowane zostałyby niezależnie od programu $\mathrm{z}$ funduszy prywatnych. Efekt substytucji mierzy, w jakim stopniu wsparcie programu stwarza konkurencję dla innych rodzajów inicjatyw pozabudżetowych. Efekt przemieszczenia bada, w jakim stopniu program przyczynia się do faktycznego rozwiązania danego problemu, a w jakim przesuwa go tylko w czasie lub przestrzeni. Efekt synergii pokazuje, w jakiej mierze środki programu przyczyniają się do zwiększenia efektów innych inicjatyw/inwestycji.
} 
szeregów czasowych, które w przypadku Polski są problematyczne, co jest słabością w przypadku modeli ekonometrycznych. Model strukturalny bowiem nie jest opisany przez zależności zdefiniowane w czasie, ale zależności opisane w przestrzeni, czyli między wszystkimi sektorami i podmiotami gospodarczymi w jednym momencie. Opiera się on na danych pochodzących z regionalnych tablic przepływów międzygałęziowych z jednego roku, opisujących najbardziej szczegółowo zależności w gospodarce Polski, a nie na trendach zmiennych ekonomicznych w czasie. Dodatkowo model RegPOL opisuje te zależności nie jednym czy kilkoma równaniami regresji, ale prawie 50 tysiącami równań behawioralnych.

Zaletą modelu RegPOL jest też jego regionalny charakter. Podobnie jak niepełna byłaby analiza polityki ROW na podstawie jednego sektora gospodarki, tj. rolnego, tak samo niepełna byłaby analiza wybranych województw, gdyż wszystkie regiony są ze sobą silnie powiązane (konkurują o czynniki produkcji i handlują ze sobą), co model uwzględnia. Dlatego zmiany zachodzące w jednych pod wpływem interwencji polityki mają wpływ na sytuację innych. Żadne inne modele nie pokazują tych relacji tak dokładnie, jak regionalne modele CGE, do których należy RegPOL, a których, jak wspomnieliśmy wcześniej, nie ma jeszcze zbyt wielu.

Warto dodać, że RegPOL jest modelem budowanym od dołu do góry, więc stara się być jak najbliższy rzeczywistości, przynajmniej tej, jaką odzwierciedlają tablice przepływów międzygałęziowych na podstawie oficjalnych danych GUS wykorzystywanych w modelu. Model może analizować skutki interwencji rządowych nie tylko na poziomie NUTS 2, jak w niniejszej pracy, ale nawet na poziomie powiatów czy gmin (LAU 1 LAU 2), tylko, że jego konstrukcja wymagałaby zaangażowania znacznie większej ilości czasu i danych.

Ostatnim argumentem za użyciem modelu RegPOL jest to, że podobne modele sprawdziły się już w zastosowaniu oceny polityki (w teorii i praktyce) na świecie, a obecnie przeżywają swój renesans. Warto zatem spróbować, idąc za przykładem krajów bardziej zaawansowanych od Polski w metodach ilościowych, wprowadzać te nowe i skomplikowane narzędzia, które jeszcze nie zostały wypróbowane do oceny polityki ROW w Polsce. Dla przykładu, podobny model był wykorzystany do oceny ex ante PROW 2007-2013 w Finlandii [Ruralia PTT, MTTL $\mathrm{i}$ in. 2006]. Warto podkreślić, że model RegPOL może służyć nie tylko do oceny polityki ROW, ale i innych interwencji politycznych, gdyż zawiera wszystkie sektory gospodarki w ujęciu sekcji PKD.

Model RegPOL ma więc wiele zalet, które pozwalają na zbadanie oddziaływania polityki ROW w skali kraju i regionów pod kątem, pod jakim inne narzędzia ilościowe nie są w stanie tego zrobić. Jednak trzeba przyznać, że model ten 
ma również wady. Zatem pytanie, jakie się nasuwa, to, czy wady mogą przesądzić o jego przydatności do naszego badania, mimo iż z punktu widzenia celu badania jest on adekwatny?

Przejdźmy do przedstawienia wad modelu. Po pierwsze, jego krytyka może dotyczyć tego, że generowane przez niego wyniki nie dają się łatwo zweryfikować, bowiem model ten może analizować takie aspekty procesów zachodzących w gospodarce, które za pomocą innych narzędzi byłyby po prostu niemożliwe do zbadania. Zatem kosztem niepewności co do dokładności generowanych wyników możemy dokonywać analiz, których inaczej nie moglibyśmy dokonać. Można powiedzieć, że zawęzilibyśmy znacznie możliwości poznawcze danej materii ze względu na ryzyko popełnienia błędu.

Mimo niepewności generowanych wyników, mamy jednak możliwość oceny, w jakiej mierze i w jakim kierunku model może się mylić, innymi słowy, do jakiego stopnia możemy mu wierzyć. To, że się w jakiejś mierze myli, jest oczywiste i nieuchronne, jak każde przybliżenie rzeczywistości. Ale o której metodzie ilościowej możemy powiedzieć, że wiernie oddaje rzeczywistość? Najważniejsze jest, że możemy w przybliżeniu ocenić kierunki i skalę błędów, wiedząc gdzie ich szukać. Przede wszystkim możemy spodziewać się błędów zarówno w danych, jak i przyjętych założeniach. Dane, pomimo że pochodzą z najlepszego oficjalnego źródła [GUS], to odzwierciedlają tylko rzeczywistość zawartą w formularzach GUS i nie wiadomo, na ile odbiegają od stanu faktycznego ${ }^{43}$. Ponadto sama konstrukcja 16 tablic IO i macierzy SAM wymagała pewnych kompromisów (szczegółowy opis tego procesu przedstawia aneks 3.1). Z kolei po stronie równań mamy liczne założenia, np. co do statyczności i stacjonarności badanych procesów, co do zachowania się konsumentów (maksymalizacja użyteczności) i producentów (minimalizacja kosztów), kształtu funkcji produkcji (CES) i funkcji użyteczności (Cobba-Douglasa), wyłączności przepływu informacji cenowej i inne. Syntetyczne zestawienie najważniejszych z nich w modelu RegPOL prezentuje rozdział 3.2. Omawiając wyniki modelu, trzeba mieć na uwadze, że jest to model strukturalny, toteż bardziej możemy wierzyć wielkościom relatywnym niż wielkościom absolutnym. Bardziej możemy też wierzyć kierunkom zmian (czyli znakom) i ich skali, niż faktycznej wielkości absolutnej tych zmian.

Trzeba podkreślić, że wyników modelu CGE nie można interpretować dosłownie. Może się zdarzyć na przykład, że w ramach pewnego scenariusza cena dobra w równowadze ustali się na poziomie, przy którym zysk sektora wytwarza-

\footnotetext{
${ }^{43}$ Długoletnie doświadczenie GUS i sprawozdawczy, a nie opiniotwórczy charakter ankiet pozwalają przypuszczać, że zebrane tą metodą dane są bliskie rzeczywistości.
} 
jącego dane dobro będzie ujemny, więc produkcja tego sektora w ujęciu modelowym powinna spaść do zera. W praktyce oczywiście tak się nie dzieje, bo działalność gospodarcza wiąże się nie tylko z produkcją, lecz także tworzeniem miejsc pracy, grupami interesów lobby politycznych; działa więc wiele zabezpieczeń, które nie dopuszczają czystego działania rynku. Obliczony przez model zerowy poziom produkcji należałoby więc interpretować jako wysoką presję, jaką może odczuć dany sektor na skutek danej polityki i odczytać jako wskazówkę dla rządu, żeby zaplanować przeciwdziałanie negatywnym jej skutkom [Kiuiła 2000].

$\mathrm{Na}$ koniec trzeba dodać, że model posiada liczne zabezpieczenia, chroniące przed błędami na różnych etapach procesu przetwarzania danych. Już na poziomie budowania bazy danych, model sprawdza wiele warunków, które świadczą o tym, czy wprowadzane dane mają sens, np. czy PKB liczone metodą dochodową równa się PKB liczonemu metodą wydatków, czy suma migracji na poziomie krajowym równa się zeru, czy dane się bilansują itd. Model nie dopuszcza oczywistych sprzeczności ekonomicznych już na etapie wprowadzania danych. Potem, na etapie zapisu modelu w postaci równań, używany program GEMPACK ma wbudowane moduły sprawdzające poprawność zapisywanych równań, i w razie oczywistych przeoczeń wskazuje problematyczne miejsca. Następnym sprawdzianem jest moment rozwiązania modelu, czyli znalezienia równowagi. Jeśli są jakieś uchybienia w danych, które zostały wcześniej przeoczone, lub gdy dane zostały „zbilansowane na siłę”, to na tym etapie model to wskazuje i nie generuje rezultatów. Kolejnym etapem - jeśli model znalazł ceny równowagi, jest ich normalizacja do jedności w roku bazowym (jest to normalna procedura wyrażenia wszystkich cen w sposób relatywny i dla ułatwienia w roku bazowym są zrównane do jedności). Pozwala to łatwiej sprawdzić, z jaką dokładnością ceny równoważą wszystkie rynki. W tym celu przeprowadza się test na homogeniczność tzw. numeraire check. W praktyce „szokowi” poddaje się zmienną, która jest ceną referencyjną (np. kurs walutowy, CPI itp.) i sprawdza, czy wszystkie ceny zmieniły się o tyle samo co numeraire (powinny się zmienić o tyle samo, gdyż jest to szok nominalny i żadne realne zmiany nie powinny zaistnieć). Model nie pozwala na prowadzenie dalszych analiz, jeśli rząd wielkości błędu rachunkowego jest w okolicach trzech miejsc po przecinku. Na końcu, po uzyskaniu przez model wyników, program GEMPACK, który go obsługuje, pozwala na przeprowadzenie analizy wrażliwości modelu na parametry oraz na wielkości szoków. Tym sposobem można ocenić, o ile wyniki modelu różniłyby się od tych przez nas uzyskanych, gdyby nasze przyjęte parametry (np. elastyczności) byłyby niedoszacowane czy przeszacowane. Tak samo działa on w stosunku do przyjętych wartości szoków (interwencji). 
Podsumowując ocenę adekwatności modelu RegPOL do celów naszej analizy, można powiedzieć, że ogólnie obowiązuje zasada ograniczonego zaufania co do wyników modelu, nie należy ich interpretować zbyt dosłownie ani absolutnie, lecz relatywnie. Jednocześnie większą pewność co do ich poprawności wnosi fakt, że program GEMPACK, w którym działa model, jest zaopatrzony w wiele „wentyli bezpieczeństwa”, opracowanych przez programistów na podstawie wielu lat doświadczeń z modelami, które korzystają z tego programu.

\subsection{Charakterystyka modelu RegPOL}

Zastosowany w niniejszej książce model jest regionalnym obliczeniowym modelem równowagi ogólnej o nazwie RegPOL, który posiada zarówno wersję statyczną, jak i dynamiczną. Powstał na bazie modelu RegFIN opracowanego w latach 90. przez prof. Hannu Törmä i prof. Thomasa F. Rutherforda dla gospodarki Finlandii. O jego wyborze jako matrycy dla Polski zadecydowało m.in. to, że był dobrze opisany pod względem technicznym, sprawdził się w wielu praktycznych zastosowaniach, w tym w planowaniu polityki rozwoju obszarów wiejskich (np. wykorzystano go przy ewaluacji ex ante PROW 2007-2013 w Finlandii). Prace naukowe, powstałe na jego podstawie, zostały wnikliwie zweryfikowane pod względem metodologicznym, o czym mogą świadczyć publikacje w prestiżowych czasopismach naukowych. Finlandia i Polska mają podobny obszar kraju oraz podobną liczbę porównywalnych obszarowo regionów - Polska ma 16 województw, a Finlandia 20 maakunnat. Oba kraje można też zaliczyć do małych gospodarek otwartych. Ostatnim, ale nie mniej ważnym, argumentem przemawiającym za tym modelem było to, że funkcjonował on, opierając się na bardzo dobrych regionalnych tablicach przepływów międzygałęziowych, opublikowanych przez fiński Główny Urząd Statystyczny, co jest ewenementem w Europie i stało się dobrym bodźcem do stworzenia podobnych tablic dla Polski. Model RegPOL zatem powstał na podstawie modelu RegFIN, ale ma swój własny kod i unikalną, stworzoną od początku bazę danych dla Polski.

Poprzednikiem modelu RegFIN był model GEMFIN, działający na poziomie ogólnokrajowym [Törmä i Rutherford 1993, Törmä, Rutherford i Vaittinen 1995]. Potem od 1994 roku H. Törmä i T.F. Rutherford rozpoczęli pracę nad modelem regionalnym o nazwie RegFIN. Jego pierwsza, bardzo uproszczona wersja powstała w Excelu i służyła głównie jako pomoc naukowa w prowadzeniu wykładów [Törmä, Sihvonen i Aku 1995]. Następnie w 1998 roku skonstruowali oni pełnowymiarowy model RegFIN obejmujący 12 regionów, którego pierwsze zastosowanie dotyczyło wpływu polityki ograniczenia wydatków budżetowych na po- 
ziom dobrobytu i realokację zasobów w Finlandii [Törmä i Rutherford 1998]. Najnowsza wersja modelu RegFIN obejmuje 20 regionów i 27 sektorów i funkcjonuje w programie GEMPACK ${ }^{44}$ (General Equilibrium Modeling PACkage), który jest australijskim oprogramowaniem przeznaczonym specjalnie dla modeli równowagi ogólnej [Harrison i Pearson 1996 i 2002]. Program ten oparty jest na dość przejrzystym języku programowania o nazwie Tablo i pozwala wszystkie rezultaty modelu generować w łatwo interpretowalnej formie, tj. w postaci zmian procentowych $^{45}$. (Najlepsze omówienie statycznej wersji RegFIN można znaleźć w: [Rutherford i Törmä 2008a] oraz [Törmä 2008].) Ponadto model RegFIN nadal się rozwija, oprócz tego, że posiada wersję dynamiczną (RegFinDyn) i moduł związany z energią odnawialną RegFinDynBio. Model RegPOL również posiada dynamiczną formę RegPolDyn, ale w niniejszym opracowaniu zastosowana była tylko analiza statyczna (comparative static), ze względu na stopień skomplikowania polityki ROW i pionierski charakter pracy.

Ponieważ RegFIN konstruowano z myślą o małej gospodarce otwartej (a można obronić tezę, że taką jest zarówno Finlandia, jak i Polska w obrębie większości rynków) i powstawał on oddolnie na podstawie tablic IO (a tablice te są standardowe dla wszystkich krajów UE, a zatem takie same dla Finlandii, jak i Polski), to dostosowanie jego struktury równań do specyfiki polskiej nie wymagało dużych zmian. Wyjściowy model przekształcono tak, aby obejmował 16 województw polskich (NUTS 2) i 15 sektorów (sekcje PKD od A do $\mathrm{N}$ i zagregowane sekcje $\mathrm{O}, \mathrm{P}$ i Q $)^{46}$. Zatem cała struktura powiązań gospodarczych w RegPOL jest wiernym odzwierciedleniem struktury RegFIN. W ujęciu graficznym przedstawia ją rysunek 3.1 .

Funkcjonowanie modelu w sposób uproszczony polega na tym, że przy danym poziomie dochodów i alokacji czynników produkcji (pracy, ziemi i kapitału) popyt na dobra i usługi dzieli się pomiędzy popyt na import oraz popyt na produkcję krajową, w zależności od relacji cenowych pomiędzy produkcją krajową a importem. Następnie popyt na produkcję krajową konfrontowany jest na poszczególnych rynkach z poziomem podaży. Jeśli rynki nie są w równowadze, następują zmiany cen, a co za tym idzie, także rentowność produkcji. Wpływa to na zmianę struktury popytu (reakcja konsumentów na zmiany cen) oraz zmianę struktury alokacji czynników produkcji między różne gałęzie gospodarki (reakcja

\footnotetext{
${ }^{44}$ Istnieje również wersja tego modelu w programie GAMS.

45 Wynika to z tego, że model zamiast kalibracji przechodzi linearyzację. Nie oznacza to oczywiście, że model sam w sobie jest liniowy.

46 PKD - Polska Klasyfikacja Działalności zgodna z Systemem Rachunków Narodowych. Więcej informacji na temat sektorów podano $\mathrm{w}$ aneksie 3.1 .
} 
producentów na zmiany rentowności produkcji). Odbywa się to w poszczególnych sektorach i we wszystkich regionach. Popyt na czynniki produkcji zgłaszany przez producentów konfrontowany jest na rynku pracy, ziemi i kapitału z ich podażą (przy czym podaż ziemi jest stała), wyznaczając ich ceny. Popyt na czynniki produkcji oraz ich ceny, determinują poziom i strukturę dochodów pierwotnych, które następnie - po uwzględnieniu transferów występujących w gospodarce - służą do wyznaczania ostatecznego podziału dochodów między gospodarstwa domowe (jeden typ gospodarstw), rząd (centralny i regionalne) oraz firmy (sektor prywatny). Dochody generują popyt konsumpcyjny oraz inwestycyjny, podczas gdy popyt zagraniczny generuje zapotrzebowanie na eksport. Łącznie daje to nowy popyt na dobra i usługi. Model rozwiązuje się tak długo, aż zostanie wyliczony wektor cen zapewniających równowagę na wszystkich rynkach (oprócz rynku pracy). Podstawowe właściwości modelu prezentuje rysunek 3.1 i tabela 3.1, jest również szczegółowy opis techniczny obu modeli (RegFIN i RegPOL) [Törmä i Zawalińska 2007] ${ }^{47}$.

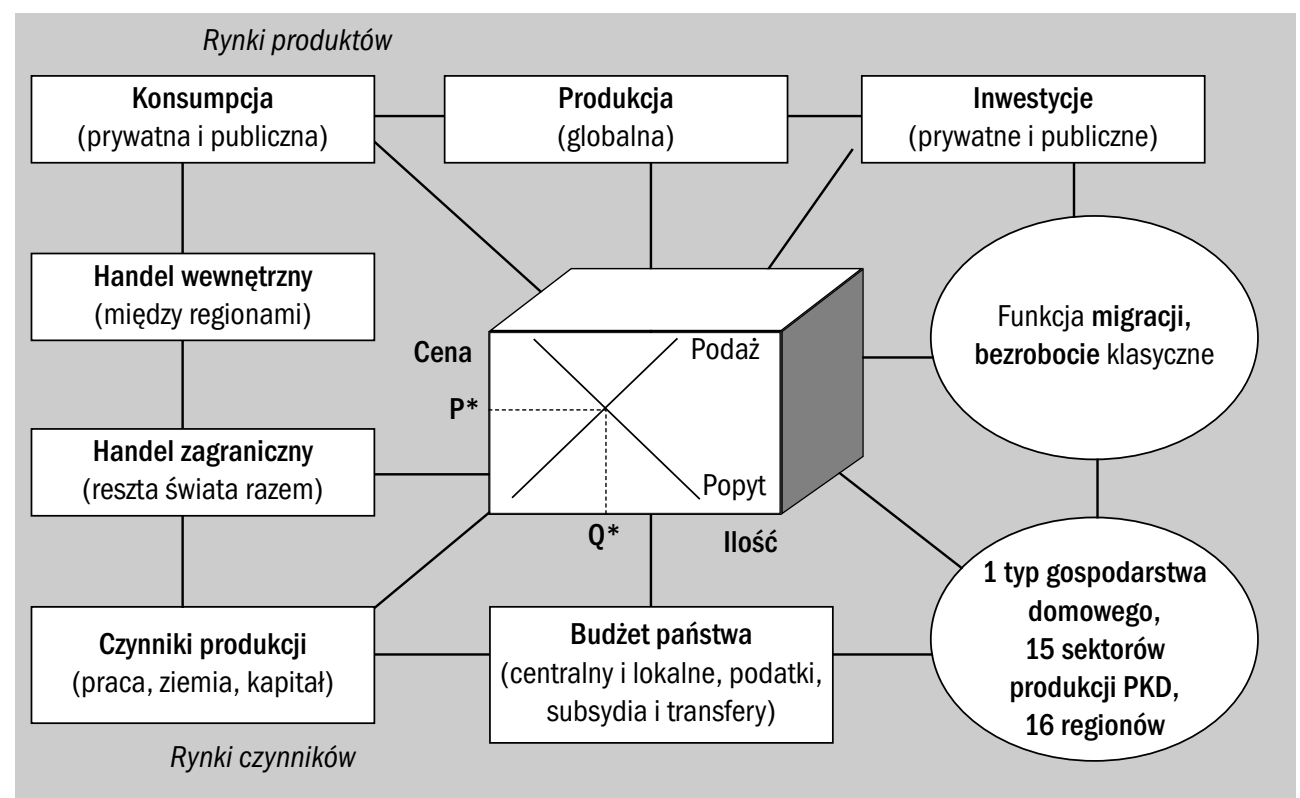

Rysunek 3.1. Budowa modelu RegPOL w ujęciu graficznym

Źródło: Na podstawie [Törmä i Zawalińska 2007].

47 Podobny opis działania gospodarki w równowadze można znaleźć w bardziej uniwersalnych źródłach, np. [Begg, Fisher i Dornbush 1993] czy [Spychalski 2005]. 
Rozdział 3. Regionalny model równowagi ogólnej RegPOL

Największą trudnością w adaptacji modelu RegPOL było skonstruowanie bazy danych do modelu, co wymagało stworzenia 16 regionalnych tablic IO i 16 macierzy SAM. W przeciwieństwie do Finlandii nie występują one w oficjalnych statystykach polskich dla regionów. Skonstruowano je na potrzeby niniejszej pracy,

Tabela 3.1. Model RegPOL w skrócie

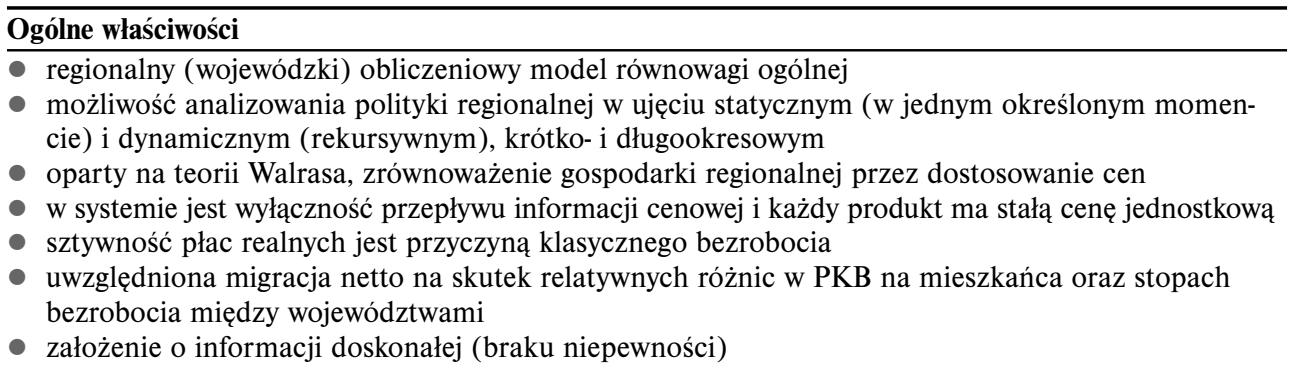

\section{Dane bazowe dostarczone przez Główny Urząd Statystyczny}

- tablice przepływów międzygałęziowych i macierze SAM dla 16 województw

- oparte na rachunkach regionalnych i narodowych

- oparte na danych dotyczących regionalnych dochodów i wydatków

- rok bazowy $2000 \mathrm{z}$ danymi uaktualnionymi do $2006 \mathrm{r}$.

\section{Konsumpcja prywatna i publiczna}

- każdy region ma przypisane reprezentatywne gospodarstwo domowe, które dąży do maksymalizacji dobrobytu (funkcja użyteczności Cobba-Douglasa)

- sektor publiczny podzielony na dwa wzajemnie powiązane podmioty: administrację centralną i regionalną, które funkcjonują jako odrębne podmioty decyzyjne

\begin{tabular}{l}
\hline Produkcja \\
założenie o stałych efektach skali i konkurencji doskonałej \\
produkcja regionalna modelowana przy założeniu minimalizacji kosztów przez przedsiębiorstwa \\
praca, ziemia i kapitał są podstawowymi czynnikami produkcji (funkcja CES - stała stopa substytucji) \\
przepływy międzysektorowe ujęte w postaci modelu przepływów międzygałęziowych (struktura \\
Leontiefa) \\
wszystkie sektory gospodarki zagregowane do 15 sekcji PKD* w każdym z 16 województw \\
\hline Handel krajowy i zagraniczny \\
produkcja krajowa i eksport modelowane łącznie (funkcja produkcji CET) \\
towary krajowe i importowane traktowane jako jakościowo różne (założenie Armingtona) \\
\hline Opodatkowanie i transfery dochodów \\
\hline określone opodatkowanie czynników produkcji \\
opreślone regionalne dochody i wydatki pochodzące z budżetu publicznego
\end{tabular}

* Trzy ostatnie sekcje PKD są zagregowane, pozostałe zostały niezmienione

Źródło: Opracowanie własne na podstawie [Törmä i Zawalińska 2007]. 
opierając się na literaturze przedmiotu i konsultacjach z pracownikami Centralnego Urzędu Statystycznego Finlandii. Procedurę tę szczegółowo opisuje aneks 3.1.

Warto dodać, że po adaptacji modelu RegFIN do warunków polskich powstały dwa bardzo podobne do siebie modele regionalne CGE, co stwarza duże pole do wszelkich badań porównawczych między regionami obu krajów w zakresie różnych interwencji rządowych. Zwykle porównania międzykrajowe czy międzyregionalne za pomocą CGE są bardzo trudne, o ile nie niemożliwe, gdyż nie sposób kontrolować wyników na skutek różnic w metodologii. W tym wypadku różnice wynikają tylko z danych, a więc badania porównawcze są bardziej wiarygodne. Ponadto fakt, że model RegFIN dał się zaadaptować do warunków polskich pozwala przypuszczać, że jest też możliwa jego adaptacja do innych małych gospodarek otwartych, przynajmniej w UE, gdzie logika tablic IO jest analogiczna we wszystkich krajach.

\subsubsection{BAZA DANYCH DLA MODELU REGPOL}

Większość danych wykorzystanych w modelu RegPOL pochodzi z Głównego Urzędu Statystycznego (GUS) i regionalnych urzędów statystycznych (US). Za podstawę tworzenia bazy danych posłużyła ostatnia opublikowana krajowa tablica przepływów międzygałęziowych za rok 2000 [CSO 2004] ${ }^{48}$. Rok ten pełni w modelu funkcję roku bazowego. Duża część danych została zamówiona specjalnie w GUS, co szczególnie dotyczy rachunków regionalnych w podziale na sekcje PKD, zgodnych pod względem metodologicznym z krajową tablicą przepływów międzygałęziowych. Obejmują one: podstawowe elementy produktu regionalnego brutto w cenach bazowych, w tym: produkcję globalną w cenach bazowych, wartość dodaną brutto, nadwyżkę operacyjną brutto, koszty związane z zatrudnieniem (wynagrodzenia plus pośrednie koszty pracy), zużycie pośrednie, podatki związane z produkcją, import i eksport, zatrudnienie. Jako trzecie podstawowe źródło danych posłużyły ogólnodostępne publikacje i statystyki opracowane przez GUS, w tym Bank Danych Regionalnych (BDR), Roczniki Statystyczne Województw, Roczniki Statystyczne Pracy, Rachunki Narodowe, Rachunki Finansowe i inne oficjalne publikacje regionalnych urzędów statystycznych. Wszystkie źródła danych w podziale na główne grupy zmiennych przedstawia tabela 3.2.

Istotną częścią bazy danych dla regionalnego modelu CGE jest handel wewnętrzny (krajowy) między regionami. Dane na ten temat są jednak niedostępne

\footnotetext{
48 Tablice przepływów międzygałęziowych GUS obejmują okresy co 5 lat (poprzednie tablice dotyczyły 1995 r., a następne będą dotyczyły 2005 r.) i wydawane są ok. 4-5 lat po okresie, którego dotyczą.
} 


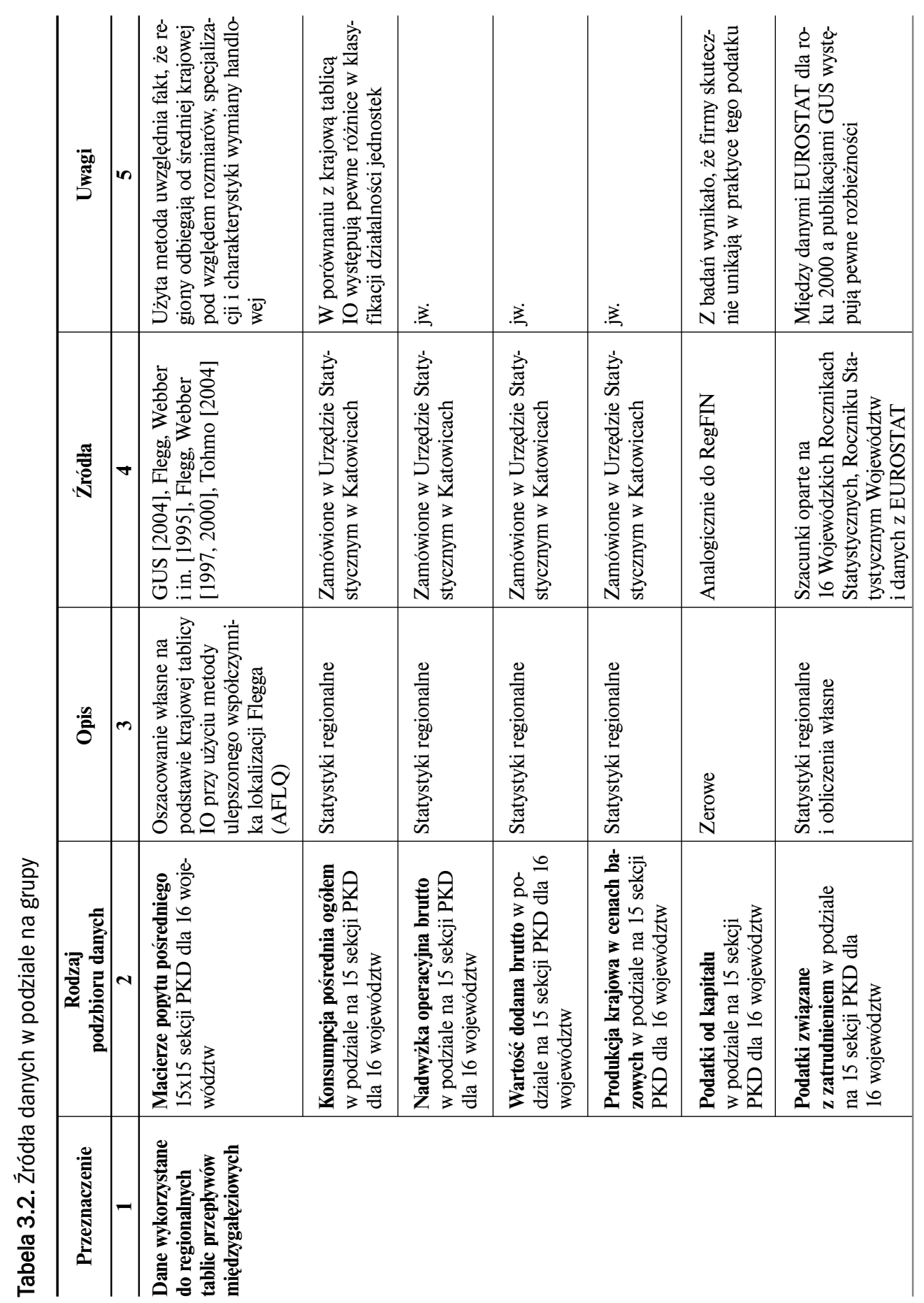




\begin{tabular}{|c|c|c|c|c|c|c|c|}
\hline in & 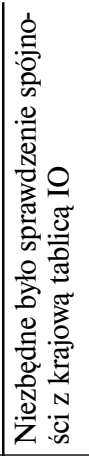 & 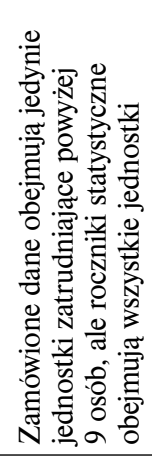 & 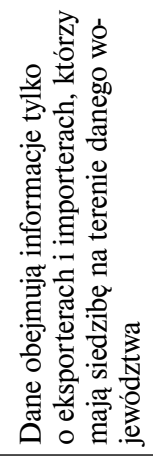 & 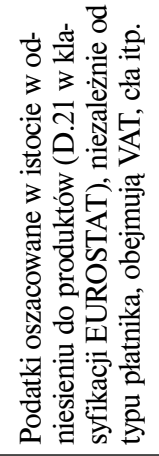 & 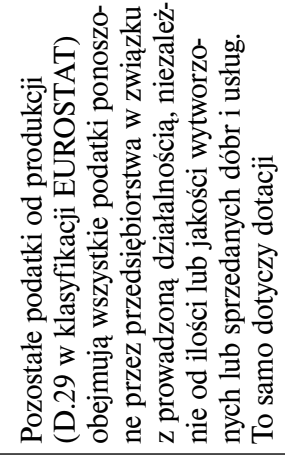 & 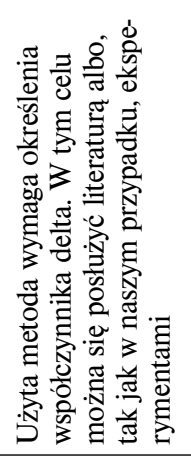 & 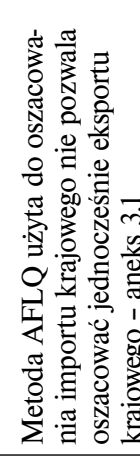 \\
\hline$\nabla$ & 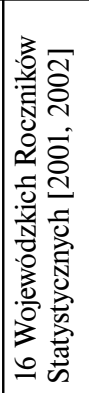 & 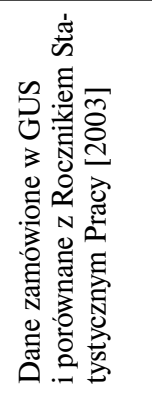 & 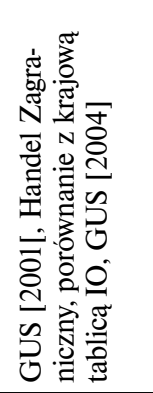 & 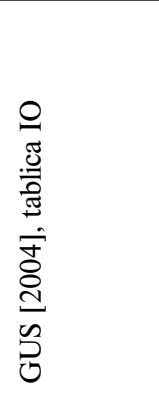 & 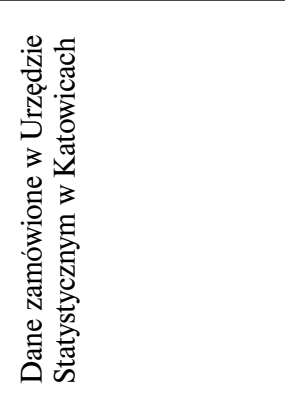 & 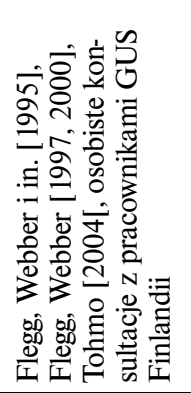 & \\
\hline$m$ & 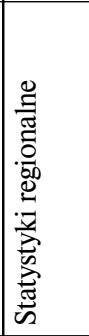 & 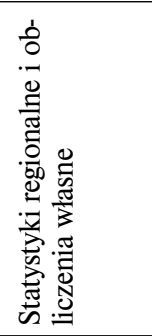 & 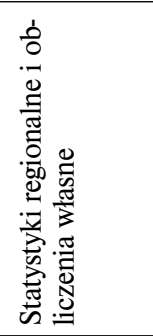 & 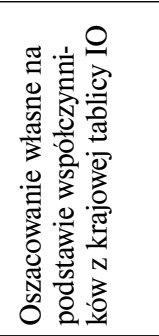 & 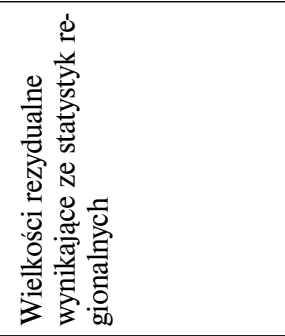 & 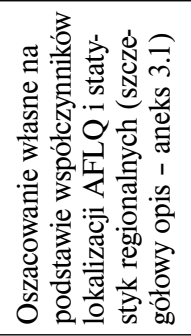 & 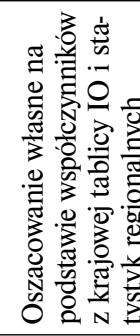 \\
\hline $1 N$ & 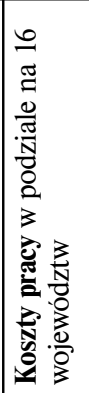 & 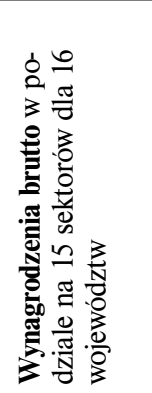 & 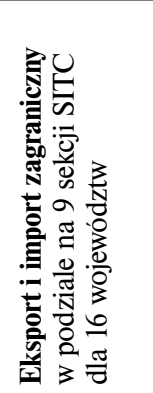 & 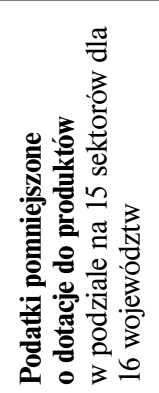 & 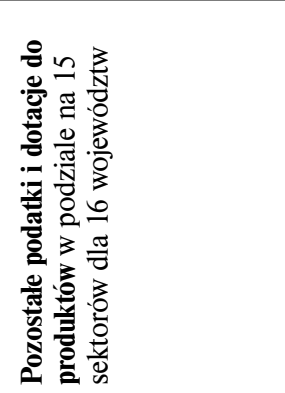 & 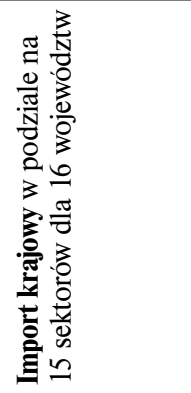 & 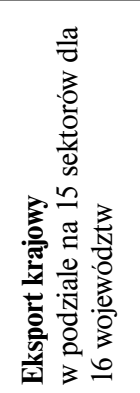 \\
\hline
\end{tabular}




\begin{tabular}{|c|c|c|c|c|c|c|c|c|}
\hline in & 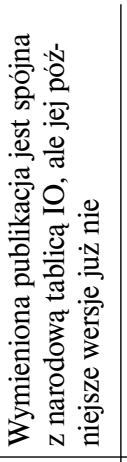 & 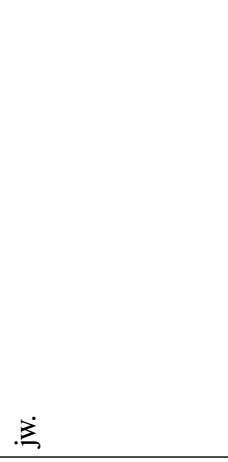 & 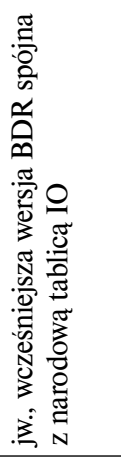 & 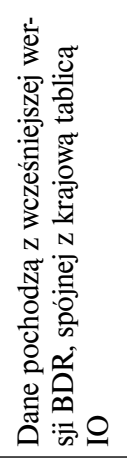 & 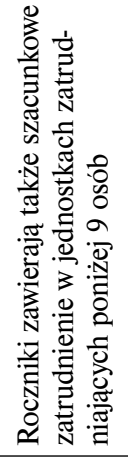 & & & 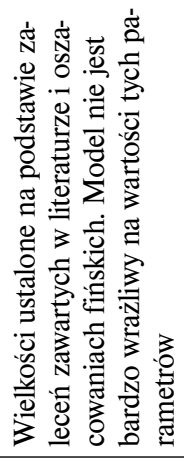 \\
\hline$\nabla$ & 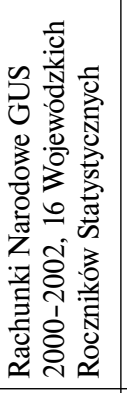 & 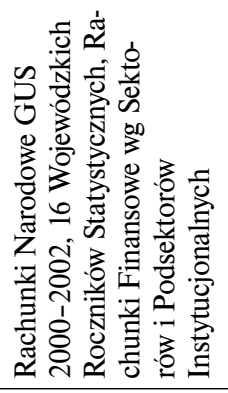 & 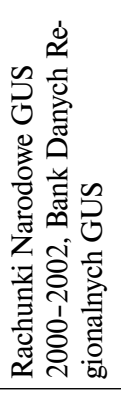 & 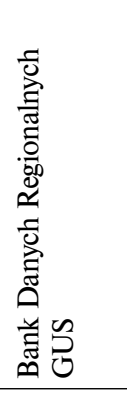 & 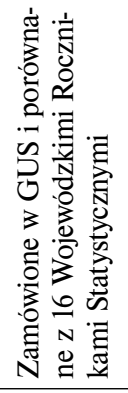 & 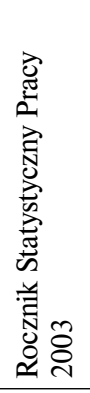 & 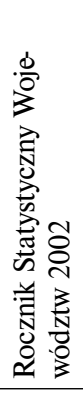 & \\
\hline$m$ & 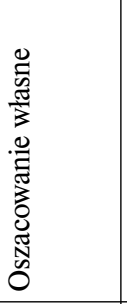 & 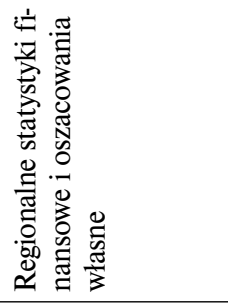 & 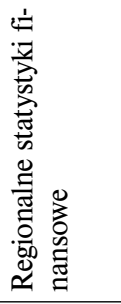 & 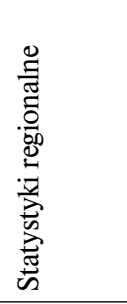 & & & & \\
\hline$N$ & 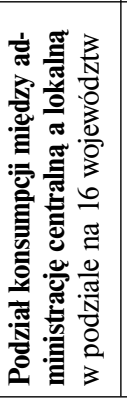 & 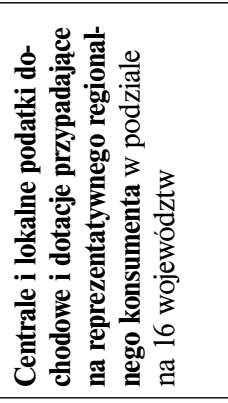 & 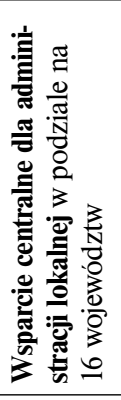 & 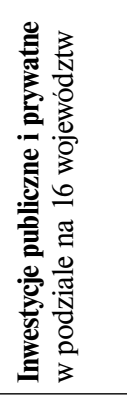 & 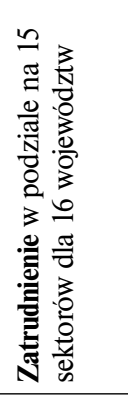 & 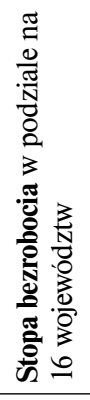 & 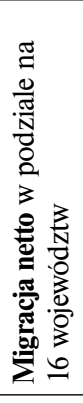 & 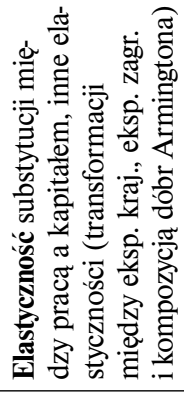 \\
\hline & 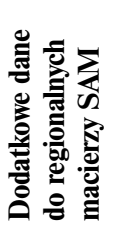 & & & & 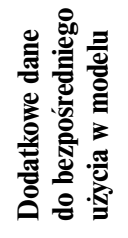 & & & \\
\hline
\end{tabular}


w oficjalnych statystykach polskich, dlatego oszacowano krajowy import i eksport we własnym zakresie, korzystając w tym celu z różnych istniejących w literaturze i praktyce metod. Proces ten był żmudny, a szczegóły na ten temat zawiera aneks 3.1: Stworzenie bazy danych dla modelu RegPOL.

Wszystkie zebrane i oszacowane dane zostały uporządkowane w format zrozumiały dla modelu RegPOL, który reprezentuje bardziej złożone zależności między podmiotami gospodarczymi i instytucjami, niż tylko tablica przepływów międzygałęziowych. Jest to postać macierzy rachunkowości społecznej (SAM). Macierz ta stanowi syntetyczny zapis wszystkich transakcji zawartych w danym okresie pomiędzy poszczególnymi podmiotami (rachunkami). Wiersze macierzy SAM odpowiadają stronie przychodowej rachunków, a kolumny odpowiadają wydatkom. Zapis macierzowy pozwala na pojedyncze „księgowanie” każdej transakcji zamiast zasady podwójnego księgowania w tradycyjnym układzie wektorowym. Macierz SAM zawiera zatem głównie dane o przepływach międzygałęziowych, o dystrybucji dochodów z czynników produkcji między podmiotami instytucjonalnymi, o wydatkach na różne towary dokonane przez te podmioty, ich oszczędnościach i inwestycjach. Ale nie ma jednej jedynej postaci macierzy SAM w każdym modelu przybiera ona nieco inną postać. Schematyczną strukturę bazy danych SAM w modelu RegPOL przedstawia tabela 3.3.

Dokładniej w naszej macierzy SAM wyróżnione są poniżej opisane macierze rachunków.

Macierz popytu pośredniego (Macierz A) opisuje przepływy między sektorami, czyli zależności międzygałęziowe. W kolumnach znajduje się popyt danego sektora na produkty pośrednie poszczególnych sektorów, który przekłada się na dochody poszczególnych sektorów, a jednocześnie odzwierciedla strukturę kosztów danego sektora. W wierszach pokazano wykorzystanie produktów pośrednich danego sektora w poszczególnych sektorach, które przekładają się na ich wydatki, a jednocześnie odzwierciedlają strukturę popytu dla danego sektora. RegPOL obejmuje te wzajemne powiązania dla 15 sektorów. Macierz popytu końcowego na produkty (Macierz B) zawiera spożycie (konsumpcję prywatną i publiczną), akumulację (inwestycje) oraz eksport (krajowy i zagraniczny). Z kolei Macierz C (znajdująca się pod macierzą A) zawiera informacje dotyczące wynagrodzenia czynników wytwórczych w procesie tworzenia produktu globalnego gospodarki narodowej oraz import (krajowy i zagraniczny). W tym zawarte są też podatki od produktów i czynników produkcji. Podatki wraz z dochodami z czynników produkcji składają się na wartość dodaną. Dochody generowane przez podstawowe czynniki produkcji podzielono na dochody z pracy i nadwyżkę operacyjną. W modelu występują dwa źródła oszczędności: różnica między wydatkami a dochodami 


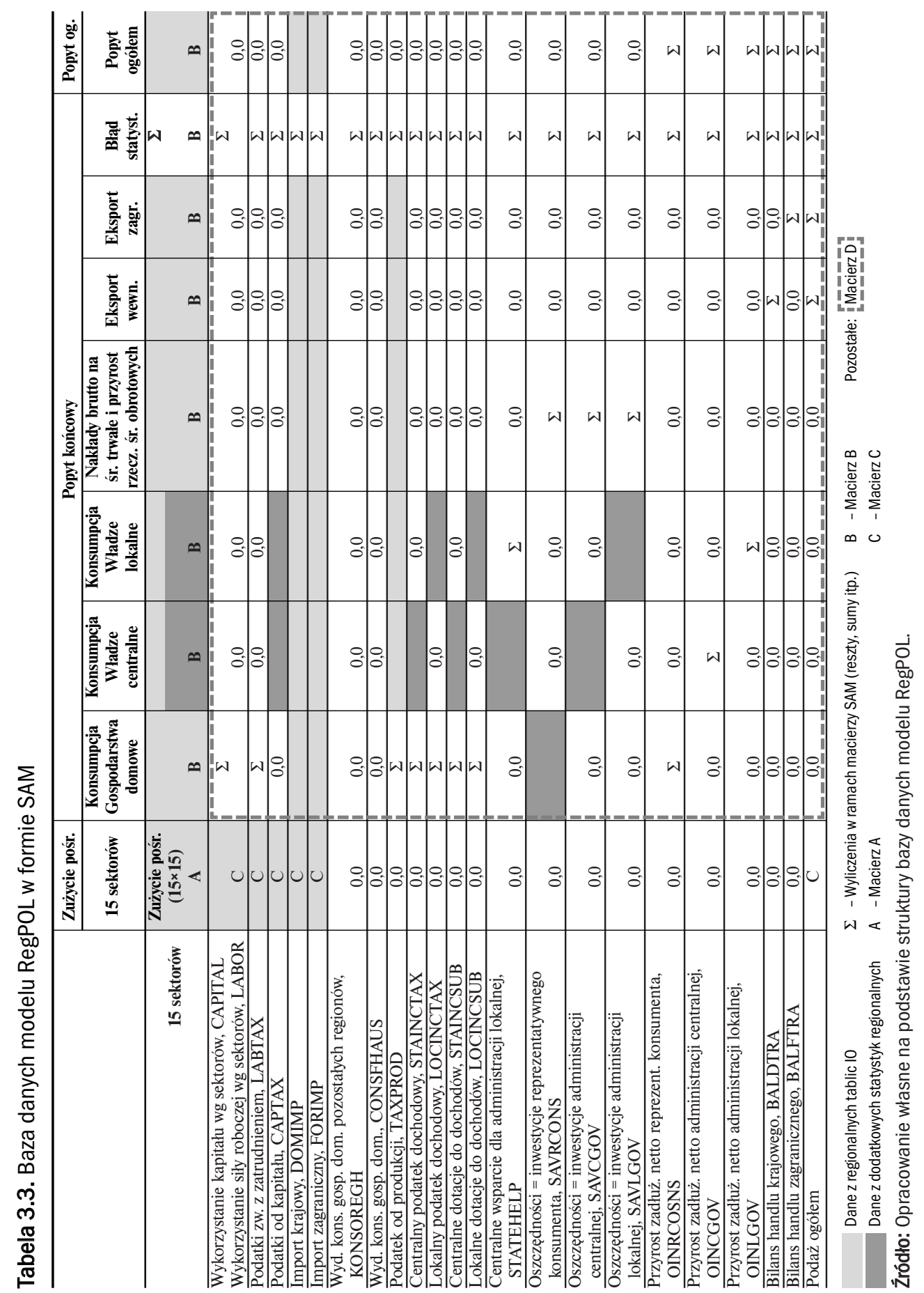


publicznymi (centralnymi i lokalnymi) oraz różnica między inwestycjami a oszczędnościami gospodarstw domowych (reprezentatywnego konsumenta). Ich suma musi wynosić zero, by rachunki się bilansowały. Handel krajowy (różnica między krajowym eksportem a importem) również musi sumować się do zera w ujęciu zagregowanym (na poziomie krajowym), natomiast w handlu zagranicznym model dopuszcza wystąpienie nadwyżki lub deficytu. To samo dotyczy budżetu publicznego i budżetu reprezentatywnego konsumenta, gdzie także może wystąpić nadwyżka lub deficyt. Macierz D odzwierciedla strumienie efektywnego podziału wytworzonych dochodów między podmiotami zgłaszającymi popyt finalny. Wynika z niej, że gospodarstwa domowe czerpią dochód z czynników produkcji. Rząd czerpie dochody z podatków, z tego część transferów trafia do władz lokalnych. Inwestycje równają się oszczędnościom. Dokładniejsze omówienie przedstawione jest $\mathrm{w}$ aneksie 3.1.

16 tablic i macierzy SAM dla województw nie tylko stanowi bazę danych dla modelu RegPOL, lecz także może być wykorzystane jako gotowy materiał do osobnych analiz. Bilans przepływów międzygałęziowych jest bowiem uniwersalnym i bardzo użytecznym narzędziem analizy ekonomicznej. Przepływy międzygałęziowe można traktować jako gotowy model makroekonomiczny gospodarki [Czyżewski 2005a]. Jego przydatność można uzasadnić na co najmniej trzech płaszczyznach: ekonomicznej (bazuje na teorii równowagi ogólnej i pozwala na zobaczenie pełnego obrazu gospodarki), statystycznej (przepływy międzygałęziowe dają obraz powiązań od produkcji do tworzenia i podziału dochodów i popytu w gospodarce) oraz matematycznej (metody matematyczne umożliwiają estymację i prognozowanie zjawisk ekonomicznych). Opracowanie T. Kujaczyńskiego [2007] jest dobrym przykładem, jak można wykorzystać tablice przepływów międzygałęziowych do analizy zjawisk zachodzących w rolnictwie. Autor przeanalizował zmiany zachodzace w sektorze rolnym i sektorze przemysłu przetwórczego na przestrzeni ponad 20 lat na podstawie tablic IO z 1977, 1995 oraz 2000 r. Porównał m.in. takie kategorie zmiennych ekonomicznych, jak koszty związane z zatrudnieniem, nadwyżka operacyjna brutto, wartość dodana brutto.

Parametry modelu zostały przyjęte na podstawie przeglądu literatury oraz szacunków analogicznych do modelu fińskiego. Dla przykładu, współczynniki elastyczności (CES) między pracą i kapitałem przedstawia tabela 3.4. Z analizy wrażliwości na parametry wynikało, że model nie jest bardzo wrażliwy na zmiany parametrów, więc ich ewentualne przeszacowanie lub niedoszacowanie nie powinno wywierać wpływu na interpretację wyników.

Problemy z danymi. Stworzenie spójnej i kompletnej regionalnej bazy danych na potrzeby modelu RegPOL nastręczało wiele trudności. Nawet GUS nie opra- 
Rozdział 3. Regionalny model równowagi ogólnej RegPOL

Tabela 3.4. Elastyczność substytucji pracy względem kapitału w Polsce w 2000 roku

\begin{tabular}{clc}
\hline \multicolumn{1}{c}{ Sekcje PKD } & Elastyczności \\
\hline A. & Rolnictwo, leśnictwo i łowiectwo & 0,24 \\
B. & Rybactwo & 1,24 \\
C. & Górnictwo i kopalnictwo & 0,75 \\
D. & Przetwórstwo przemysłowe & 0,67 \\
E. & Wytwarzanie i zaopatrywanie w energię elektryczną, gaz i wodę & 0,72 \\
F. & Budownictwo & 0,40 \\
G. & Handel hurtowy i detaliczny; naprawa pojazdów samochodowych itp. & 0,55 \\
H. & Hotele i restauracje & 0,72 \\
I. & Transport, gospodarka magazynowa i łącznośćc & 0,35 \\
J. & Pośrednictwo finansowe & 0,69 \\
K. & Obsługa nieruchomości, wynajem i usługi związane z prowadzeniem & \\
& działalności gospodarczej & 0,21 \\
L. & Administracja publiczna i obrona narodowa; obowiązkowe zabezpieczenia & \\
& społeczne & 0,66 \\
M. & Edukacja & 0,65 \\
N. & Opieka zdrowotna i pomoc społeczna & 0,81 \\
O, P, Q Działalność usługowa komunalna, społeczna i indywidualna, pozostała & 0,56 \\
\hline
\end{tabular}

Źródło: Szacunki analogiczne do modelu RegFIN.

cowuje regionalnych tablic przepływów międzygałęziowych, gdyż jest to zajęcie bardzo trudne metodologicznie i pracochłonne. Wśród problemów, z którymi należało się uporać w wypadku tworzenia regionalnych tablic dla Polski, można wymienić następujące:

- brak spójności między tablicami przepływów międzygałęziowych a innymi statystykami narodowymi, wynikający np. z odmienności definicji podmiotów gospodarczych przyjętych na potrzeby tablicy IO i Rachunków Narodowych;

- brak spójności między danymi regionalnymi a ogólnokrajowymi, wynikający np. z odmiennej klasyfikacji działalności niektórych jednostek, nieuwzględniania jednostek zatrudniających poniżej 9 osób na poziomie regionalnym itp.;

- kwestię metod oszacowania krajowego importu i eksportu między regionami, co wiąże się z wyborem metod i oszacowaniem różnych współczynników (np. współczynników lokalizacji, jak AFLQ (Augmented Flegg Location Quotient) zastosowany przez nas, do którego potrzebne było oszacowanie parametru delta. Szczegółowy opis trudności z tym związanych zawiera aneks 3.1;

- poufność danych statystycznych na poziomie zdezagregowanym, np. statystyki dla grup PKD (jeden szczebel poniżej sekcji) w podziale na województwa często były niedostępne ze względu na poufność danych jednostkowych;

- zmiany wprowadzane w metodologii; np. Główny Urząd Statystyczny wprowadził wiele zmian, w tym również wstecz, w celu dostosowania swoich statystyk do standardów UE (EUROSTAT); 
- niereprezentatywność danych, np. w pozycji handel zagraniczny w podziale na województwa wykazano w rzeczywistości tylko wartości importu/eksportu przypadającego na przedsiębiorstwa zarejestrowane jako importerzy/eksporterzy w danym regionie, co wcale nie jest równoważne $\mathrm{z}$ wartością importu/eksportu dla regionu jako całości;

- różnorodność systemów klasyfikacji, np. krajowa tablica przepływów międzygałęziowych jest sporządzona w układzie PKWiU, podczas gdy wszystkie regionalne statystyki potrzebne do skonstruowania tablic przepływów międzygałęziowych oparto na klasyfikacji PKD, dlatego konieczne było zagregowanie narodowej tablicy przepływów międzygałęziowych do postaci sekcji PKD; innym przykładem jest klasyfikacja regionalnego handlu zagranicznego, która opiera się na układzie SITC zamiast, jakbyśmy sobie tego życzyli, PKD;

- brak spójności między źródłami danych (np. występują pewne rozbieżności między statystykami publikowanymi przez EUROSTAT i GUS, co dotyczy to zwłaszcza okresu przed rokiem 2005), które prawdopodobnie wynikają ze wspomnianego wyżej wstecznego korygowania niektórych danych przez GUS. Problemy, o których tu mowa, są też wymienione w odniesieniu do poszczególnych bloków zmiennych tabeli 3.2 (w ostatniej kolumnie zatytułowanej „Uwagi”) oraz w aneksie 3.1.

\subsubsection{TEORETYCZNA STRUKTURA MODELU REgPOL}

RegPOL ma strukturę teoretyczną typową dla wielu obliczeniowych modeli równowagi ogólnej, z tym że budowana była ona oddolnie, na podstawie logiki i dostępnych danych ze standardowej tablicy przepływów międzygałęziowych EUROSTAT. Ponadto uwzględnia ona migracje wewnętrzne oraz nierównowagę na rynku pracy (bezrobocie).

Pozostałe elementy i założenia modelu są raczej typowe. Podmioty działają w sposób racjonalny, przy czym producenci maksymalizują zyski, a konsumenci użyteczność. Ceny towarów i usług są elastyczne i równoważą rynek. Płace z kolei nie równoważą rynku pracy, w rezultacie czego utrzymuje się bezrobocie (z powodu niedoskonałości rynków i działania grup interesów). Kapitał i praca sa mobilne między regionami i sektorami, z tym że praca jest homogeniczna (taka sama dla wszystkich, więc ma jedną cenę), a kapitał heterogeniczny (różne ceny, w zależności od sektorów i regionów). Ziemia jest stała i stanowi czynnik produkcji tylko dla sektora rolnego. Inwestycje równają się oszczędnościom.

Jest to model statyczny, gdyż nie zawiera żadnych mechanizmów akumulacji kapitału. Umożliwia jednak badanie ewolucji gospodarki przez analizę sekwencji 
stanów równowagi. Dlatego przy użyciu modelu RegPOL można prognozować zarówno krótko-, jak i długoterminowe skutki polityki, ale nie można pokazać szczegółowo drogi dojścia do nowego stanu równowagi. W celu rozróżnienia symulacji krótko- i długoterminowej zmieniają się tzw. domknięcia modelu (closures), o czym więcej piszemy w aneksie 3.4. W domknięciu krótkookresowym kapitał pozostaje egzogeniczny, a w drugim przypadku jest endogeniczny. To samo dotyczy płac realnych - możemy przeprowadzić symulację dynamiczną, zmieniając co roku poziom płac realnych. Ta publikacja koncentruje się na podejściu statycznym i wyniki interpretujemy jako skumulowany efekt długoterminowy (czyli ok. 8-10 lat).

RegPOL opiera się na założeniu o istnieniu konkurencji doskonałej, gdzie żaden pojedynczy nabywca ani sprzedawca nie ma wpływu na cenę. Równania popytu i podaży wyprowadzono z rozwiązań problemów optymalizacji ( $\mathrm{tj}$. maksymalizacji zysku i użyteczności) dla podmiotów sektora prywatnego. Model pozwala uwzględnić w symulacjach jednego reprezentatywnego konsumenta (w każdym województwie), który jest jedynym dostarczycielem pracy i kapitału. Każdy przepływ w bazie danych modelu jest opisany przez cenę i ilość. Model składa się z 81 bloków równań sformułowanych w postaci zlinearyzowanej, na wzór modeli równowagi ogólnej (CGE) opartych na pracach Johannesa [1960]. Poniżej przedstawiamy nietechniczny opis poszczególnych bloków modelu. W aneksie 3.2 zawarto szczegółowy zapis w postaci równań (zlinearyzowanych) w bardzo czytelnym języku Tablo, wraz z opisem zmiennych.

\subsubsection{Struktura produkcji w modelu RegPOL}

Zakładamy, że we wszystkich sektorach panuje konkurencja doskonała, a przedsiębiorstwa dążą do maksymalizacji zysku (minimalizacji kosztów produkcji). Decyzja dotycząca kombinacji wytwarzanych i nabywanych produktów reprezentuje wielostopniowy problem decyzyjny, który przy założeniu rozdzielności (separability assumption) można przedstawić w formie „zagnieżdżonej” (nested structure). Założenie to jest rzeczą normalną w dziedzinie modelowania CGE i bardzo ułatwia liczenie, gdyż znacząco ogranicza liczbę parametrów, które trzeba oszacować [Honkatukia i Vaittinen 2003]. Zagnieżdżoną strukturę produkcji, na której opiera się model RegPOL, przedstawia rysunek 3.2.

W pierwszej kolejności branża ustala optymalną kombinację pracy, ziemi i kapitału, przy uwzględnieniu zasady minimalizacji kosztów i przy technologii o stałej elastyczności substytucji (CES). Na następnym poziomie przedsiębiorstwa łączą wartość dodaną z dobrami Armingtona ${ }^{49}$ i opierając się na funkcji

${ }^{49}$ Dobra Armingtona - tu produkty dostępne lokalnie, tj. kupione w danym regionie. 
Leontiefa przekształcają je w produkcję lokalną, która przechodzi na następny szczebel (pierwszy poziom zagnieżdżenia struktury Armingtona). Tam produkcja lokalna łączy się z odpowiednimi dobrami z pozostałych stron Polski (Rest of Poland, RoP), tworząc kompozycję dóbr POL. W tym miejscu zakłada się, że każda firma korzysta tylko z jednego rodzaju dóbr RoP, to znaczy, że na przykład dobra RoP wykorzystywane przez przemysł spożywczy obejmują wyłącznie żywność.

\section{Poziom zagnieżdżenia: ACT dzieli się za pośrednictwem mechanizmu CET na dobra Armingtona, eksport do RoP i eksport do RoW}

\section{Poziom zagnieżdżenia:}

ACT, czyli kombinacja Armingtona, to mieszanka dóbr POL i dóbr importowanych z zagranicy

\section{Poziom zagnieżdżenia:} Dobra PoL to kombinacja dóbr lokalnych i pochodzących z reszty Polski (RoP) powstająca za pośrednictwem mechanizmu CES

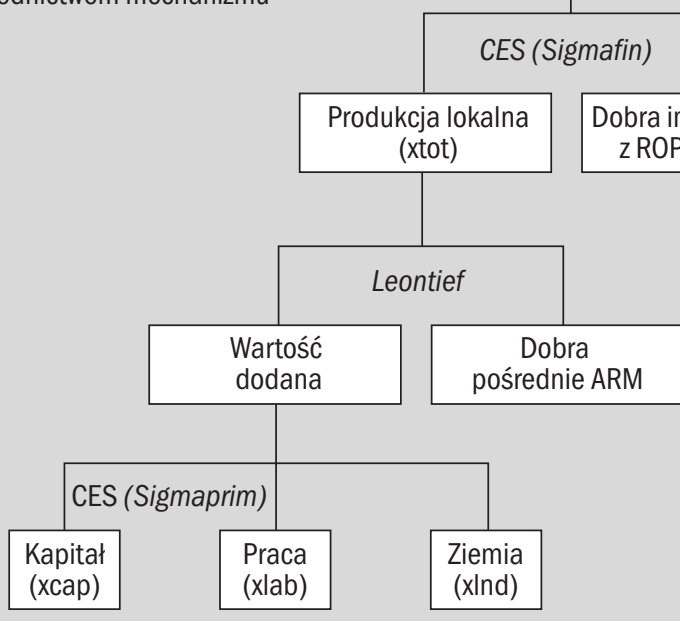

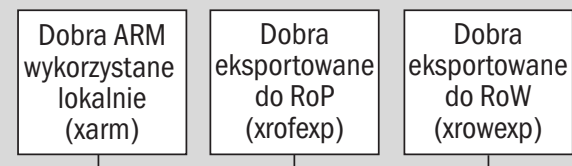

\section{CET (ETRN)}
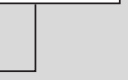
Na kolejnym etapie (drugi poziom zagnieżdżenia struktury Armingtona) kompozycja dóbr POL łączy się za pośrednictwem mechanizmu stałej elastyczności substytucji (CES) z dobrami importowanymi z reszty świata (RoW), tworząc kompozycję dóbr Armingtona (ACT). W ostatniej fazie (trzeci poziom zagnieżdżenia struktury Armingtona) składnik ACT zostaje podzielony za pośrednictwem mechanizmu stałej elastyczności transformacji (constant elasticity of transformation, CET) na trzy elementy: • dobra Armingtona wykorzystywane lokalnie • dobra RoP wysyłane do innych regionów Polski • dobra RoW (rest of the world) wysyłane do innych krajów.

Struktura produkcji zastosowana w modelu porządkuje zatem w dużej mierze kwestię substytucji między dobrami RoP, RoW i wytwarzanymi lokalnie. Każdy podmiot konsumuje dobra Armingtona, RoP i RoW. Jednak dobra Armingtona zawierają też w sobie dobra RoW i RoP, więc dobra importowane mogą być konsumowane pośrednio lub bezpośrednio. Ale, jak zaznaczono wyżej, jedynym dobrem RoP wykorzystywanym przez dany sektor są dobra tego samego sektora (np. w przemyśle spożywczym jest to żywność RoP). Jeśli oprócz tego potrzebne są artykuły rolne RoP, muszą być dostarczone po ścieżce Armingtona (xint). Natomiast końcowi nabywcy mogą bezpośrednio konsumować różne dobra RoP. $\mathrm{Z}$ punktu widzenia istniejących modeli CGE taka struktura jest raczej niecodzienna. Odzwierciedla bowiem strukturę dostępnych danych, która przypomina typową regionalną tablicę przepływów międzygałęziowych (jak mówiliśmy wcześniej, wynika to z podejścia budowania modelu od dołu do góry).

\subsubsection{Popyt końcowy}

Na popyt końcowy składają się cztery podstawowe źródła: konsumpcja prywatna (gospodarstw domowych), konsumpcja publiczna (rządu centralnego i lokalnych), inwestycje/rozbudowa majątku oraz eksport. Identyczną klasyfikację popytu finalnego stosuje się w tablicach przepływów międzygałęziowych, które stanowiły podstawowe źródło danych do modelu.

Popyt ZE STRONy GosPodARSTw DOMOWyCH. Gospodarstwa domowe są reprezentowane przez jednego reprezentatywnego konsumenta, ponieważ brak danych na poziomie regionalnym uniemożliwił wyodrębnienie większej liczby typów gospodarstw domowych (np. w podziale na grupy dochodowe czy w podziale na grupy zawodowe itd.). Reprezentatywny konsument dąży do maksymalizacji funkcji użyteczności, która ma formę funkcji Cobba-Douglasa, dzieląc swój budżet między produkty pochodzenia lokalnego, produkty z innych województw oraz produkty z importu. Popyt po stronie gospodarstw domowych reaguje zatem na zmiany względnych cen towarów krajowych i zagranicznych, zastępując jedne 
drugimi [Armington 1996]. Dobra lokalne i RoP są opodatkowane, natomiast dobra RoW - nie. Struktura popytu po stronie gospodarstw domowych jest stosunkowo prosta i przedstawia ją rysunek 3.3.

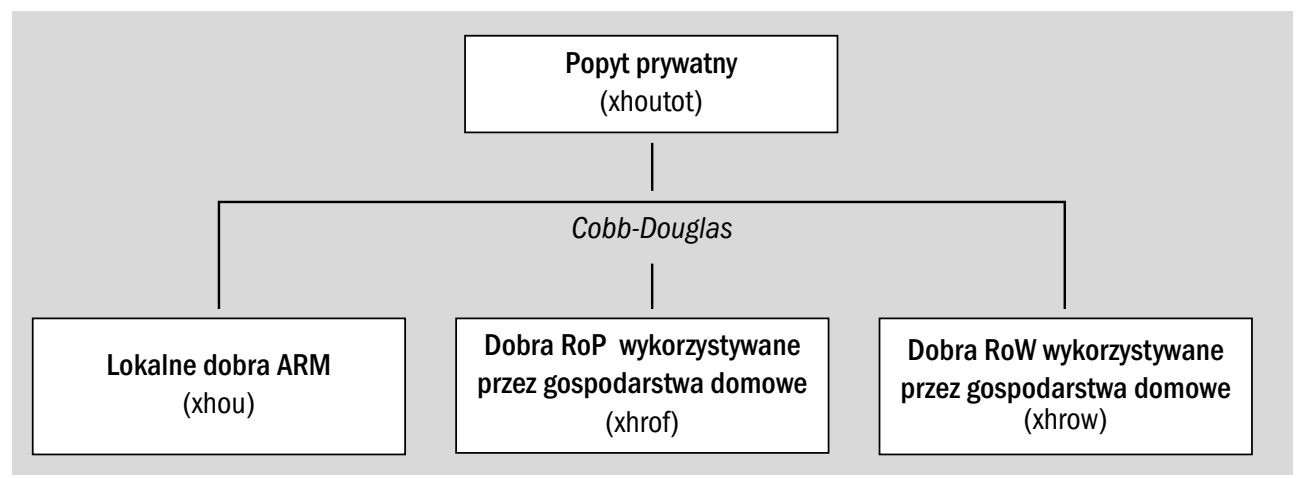

Rysunek 3.3. Struktura popytu gospodarstw domowych w modelu RegPOL

Uwaga: dobra lokalne oznaczają dobra wyprodukowane w danym województwie

Źródło: Opracowanie własne na podstawie [Törmä i Zawalińska 2007].

Reprezentatywny konsument jest wyłącznym źródłem pracy i kapitału oraz właścicielem ziemi w gospodarce regionalnej. Sprzedaje je na rynkach czynników produkcji, a uzyskany z tego tytułu dochód przeznacza na prywatną konsumpcję, której struktura zależy od realnych cen konsumpcyjnych. Reprezentatywny konsument płaci również podatek dochodowy i otrzymuje transfery od administracji centralnej i lokalnej.

Popyt PUbliCzNy. Popyt publiczny to popyt generowany przez administrację rządową, która dzieli się na dwa wzajemnie powiązane podmioty decyzyjne: władze centralne i władze lokalne/regionalne. Polityka regionalna opiera się na przepływie pieniędzy między tymi podmiotami a sektorem prywatnym oraz systemie centralnego wsparcia dla administracji lokalnej. Oba podmioty publiczne pobierają podatki i opłaty, z których finansują zaopatrzenie w dobra i usługi publiczne. $\mathrm{W}$ bazie danych modelu uwzględniono wszystkie stosowne kategorie podatków, w tym opodatkowanie produkcji, czynników produkcji i dochodów osobistych na szczeblu centralnym i lokalnym, jak również dotacje i transfery dochodowe. Administracja lokalna i centralna wykorzystuje wyłącznie dobra Armingtona - w formie nieopodatkowanej i zgodnie z funkcją produkcji Leontiefa narzuca stałą strukturę konsumowanych dóbr. Strukturę popytu publicznego przedstawia rysunek 3.4. 


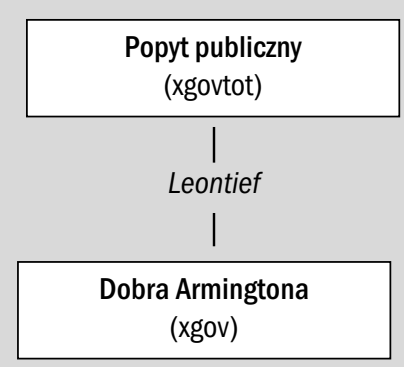

Rysunek 3.4. Struktura popytu sektora publicznego w modelu RegPOL

Źródło: Opracowanie własne na podstawie [Törmä i Zawalińska 2007].

POPYT INWESTYCYJNY. Struktura popytu inwestycyjnego jest analogiczna, jak w przypadku innych kategorii popytu końcowego. Dotyczy kapitału rzeczowego, który jest kombinacją dóbr sektorowych Armingtona oraz dóbr RoP i RoW opartych na funkcji Leontiefa i w całości opodatkowanych (rys. 3.5). Oznacza to, że sektor minimalizuje koszty, korzystając z tych trzech typów dóbr w stałych proporcjach. Zgodnie z założeniem Armingtona możliwa jest substytucja między dobrami krajowymi a importowanymi. Jeśli chodzi o alokację inwestycji między sektorami, przyjęto założenie, że zależy ona od stopy zwrotu z kapitału, czyli kapitał jest mobilny i trafia do tych sektorów, gdzie jest ona najwyższa. Dla całej gospodarki obowiązuje zasada tożsamości oszczędności i inwestycji, co znaczy, że suma oszczędności jest równa sumie inwestycji z nich finansowanych $(\mathrm{S}=\mathrm{I})^{50}$.

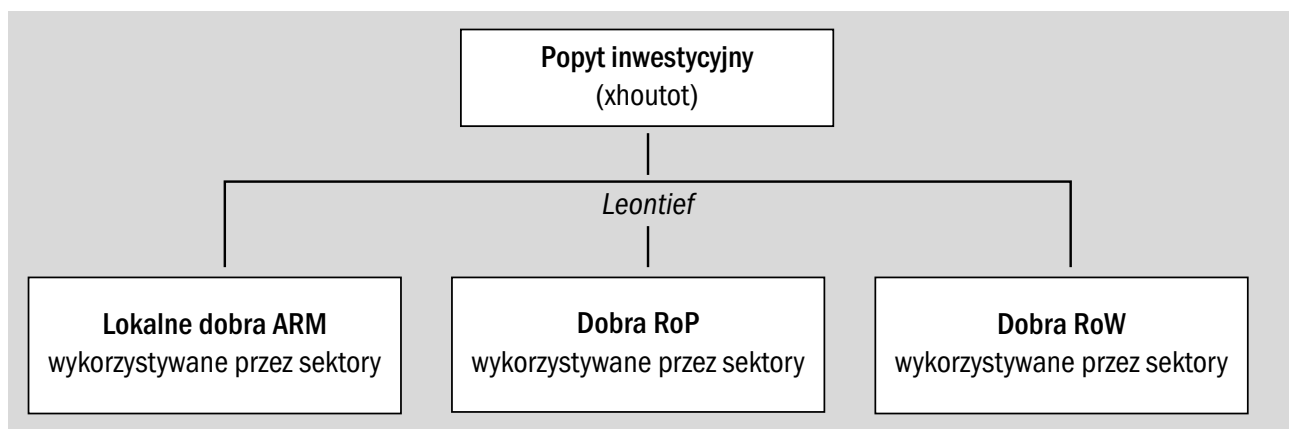

Rysunek 3.5. Struktura popytu inwestycyjnego

Uwaga: dobra lokalne oznaczają dobra wyprodukowane w danym województwie

Źródło: Opracowanie własne na podstawie [Törmä i Zawalińska 2007].

${ }^{50}$ Założenie to jest konieczne dla osiągnięcia równowagi w modelu typu CGE. 
Ten sposób modelowania inwestycji jest dość uproszczony, gdyż nie reprezentuje formalnej teorii inwestycji objaśniającej zachowanie gospodarki w dłuższej perspektywie, ale wystarcza na potrzeby statycznego modelu równowagi ogólnej. Dlatego w wypadku statycznych modeli CGE analiza inwestycji w krótkim i długim okresie opiera się zwykle na doborze równań domykających model (closure). Przy standardowym domknięciu (closure) dla analizy krótkookresowej zmiana stanu kapitału w przemyśle ustawiana jest na zero, a zmiana zagregowanej wartości inwestycji określana jest egzogenicznie. Takie domknięcie oznacza, że krótki okres odnosi się do przedziału czasu, w którym szok w postaci interwencji rządowej odznaczył się na inwestycjach podejmowanych przez sektory, ale inwestycje jeszcze nie zdążyły przełożyć ich na zmiany w stanie wykorzystywanego przez nie kapitału. W długim okresie zagregowana wartość inwestycji staje się zmienną determinowaną endogenicznie, a bieżące stopy zwrotu dla sektorów określane są egzogenicznie. Jeśli rynki kapitału i produktów finalnych danego kraju są niewielkie w skali świata, nie ma on żadnego wpływu na osiąganą na jego obszarze stopę zwrotu - jest to tzw. założenie małego, otwartego kraju, które odnosi się m.in. do Polski [Honkatukia i Vaittinen 2003].

\subsubsection{Handel krajowy i zagraniczny}

Handel krajowy i zagraniczny modelowano, opierając się na założeniu, że dobra krajowe i zagraniczne pochodzące z tego samego sektora różnią się jakością. Jest to założenie Armingtona ${ }^{51}$ o regionalnym zróżnicowaniu produktów, które pozwala wyjaśnić istnienie międzynarodowej wymiany handlowej [Armington 1969a, Armington 1969b]. Dobra krajowe są produkowane łącznie z dobrami eksportowanymi w technologii zgodnej z funkcją CET (stała elastyczność transformacji). Dobra importowane konkurują $\mathrm{z}$ dobrami krajowymi. Dobra importowane z zagranicy są wykorzystywane przez regiony do zaspokojenia krajowego popytu na dobra zagraniczne.

\subsubsection{Ceny}

Wszystkie ceny w modelu są definiowane relatywnie, w odniesieniu do tzw. numeraire (zgodnie z postulatem Walrasa). W naszym przypadku jest to nominalny kurs walutowy (nominal exchange rate). Wszystkie ceny należy zatem traktować jako względne wobec numeraire. Jest to podejście typowe dla większości

\footnotetext{
${ }^{51}$ Założenie Armingtona polega na uznaniu tych samych dóbr za różne, jeśli pochodzą z różnych krajów. Dobra te stają się niedoskonałymi substytutami dla siebie samych w poszczególnych krajach. Takie założenie ułatwia modelowanie dużych struktur, zwłaszcza wykorzystujących międzynarodowe statystyki dotyczące handlu.
} 
modeli CGE. Rzutuje ono na interpretację wyników symulacji wszystkich zmiennych cenowych, wymagając ich odpowiedniego, relatywnego odczytania.

\subsubsection{Modelowanie bezrobocia}

Jak mówiliśmy wcześniej, zmiany cen na wszystkich rynkach prowadzą do zrównoważenia gospodarki regionalnej, z wyjątkiem rynku pracy, gdzie występuje bezrobocie. Bezrobocie można modelować na kilka sposobów (co opisują np. [Rutherford i Törmä 2006]). W podejściu zaproponowanym przez G. Gillespiego, P. McGregora i innych [2002], domknięcie modelu (closure) decyduje, o tym, że płaca realna jest ujemnie skorelowana ze stopą bezrobocia. Poziom płac kształtuje się w zgodzie z tą regionalną krzywą płacy. Płace realne częściowo determinują zatrudnienie, więc bezrobocie jest różnicą między regionalną podażą pracy a regionalnym zatrudnieniem. Inne podejście prezentują M.W. Peter, M. Horridge i inni [1999] - zgodnie z ich koncepcją bezrobocie można traktować jako zmienną endo- lub egzogeniczną. W tym pierwszym przypadku podaż siły roboczej jest wyznaczana przez blok równań rynku pracy i funkcję migracji wewnętrznej. Przy ustalonej podaży siły roboczej, o wysokości regionalnych stóp bezrobocia decydują równania dotyczące rynku pracy i funkcja migracji wewnętrznej, przy uwzględnieniu międzyregionalnego zróżnicowania płac. Przy danej regionalnej stopie bezrobocia i regionalnej podaży siły roboczej, regionalne zatrudnienie ustala się jako zmienną rezydualną. Przez ustalenie różnic w płacach determinuje się popyt na siłę roboczą, tak więc przy danej regionalnej podaży siły roboczej, model wyznaczy regionalne bezrobocie jako zmienną rezydualną. W drugim przypadku regionalne różnice w płacach i stopy bezrobocia są wyznaczane egzogenicznie [Rutherford i Törmä 2006].

W modelu RegPOL zastosowano koncepcję bezrobocia klasycznego, które wynika ze sztywności płac realnych. Jego modelowanie polegało na przyjęciu minimalnej płacy realnej i luki płacowej (tj. różnicy między płacą faktyczną a rynkową), jako warunków ograniczających, które muszą być spełnione w stanie równowagi ogólnej. Ponieważ płaca realna jest wyższa od wartości zapewniającej zrównoważenie rynku, mamy do czynienia z nadpodażą siły roboczej. Bezrobocie wynika zatem z przewagi podaży nad popytem. Warunki ograniczające dla płacy realnej zostały określone tak, by wynikowe regionalne stopy bezrobocia były takie jak w roku bazowym. Rysunek 3.6 przedstawia funkcjonowanie rynku pracy $\mathrm{w}$ modelu. Jest to oczywiście bardzo uproszczone modelowanie bezrobocia. $\mathrm{Z}$ pewnością płace realne wyższe od płacy równoważącej rynek pracy i wiążący się $\mathrm{z}$ tym nadmiar podaży nad popytem trudno przyjąć za wyjaśnienie tego złożonego zjawiska w Polsce, zwłaszcza jeśli wziąć pod uwagę poziom płacy minimalnej, 
udział płac w PKB, relacje między dostawcą i odbiorcą na rynku (monopole, oligopole, monopson) czy skalę ubóstwa. Jednak w tak uproszczonym modelu bezpieczniejsze jest przyjęcie bardzo przejrzystego mechanizmu na rynku pracy, zanim w pełni nie zostanie opracowana bardziej adekwatna koncepcja. Nie powinno to jednak przynieść większej szkody przy analizowaniu polityki ROW, gdyż nie wpływa ona bezpośrednio na płace.

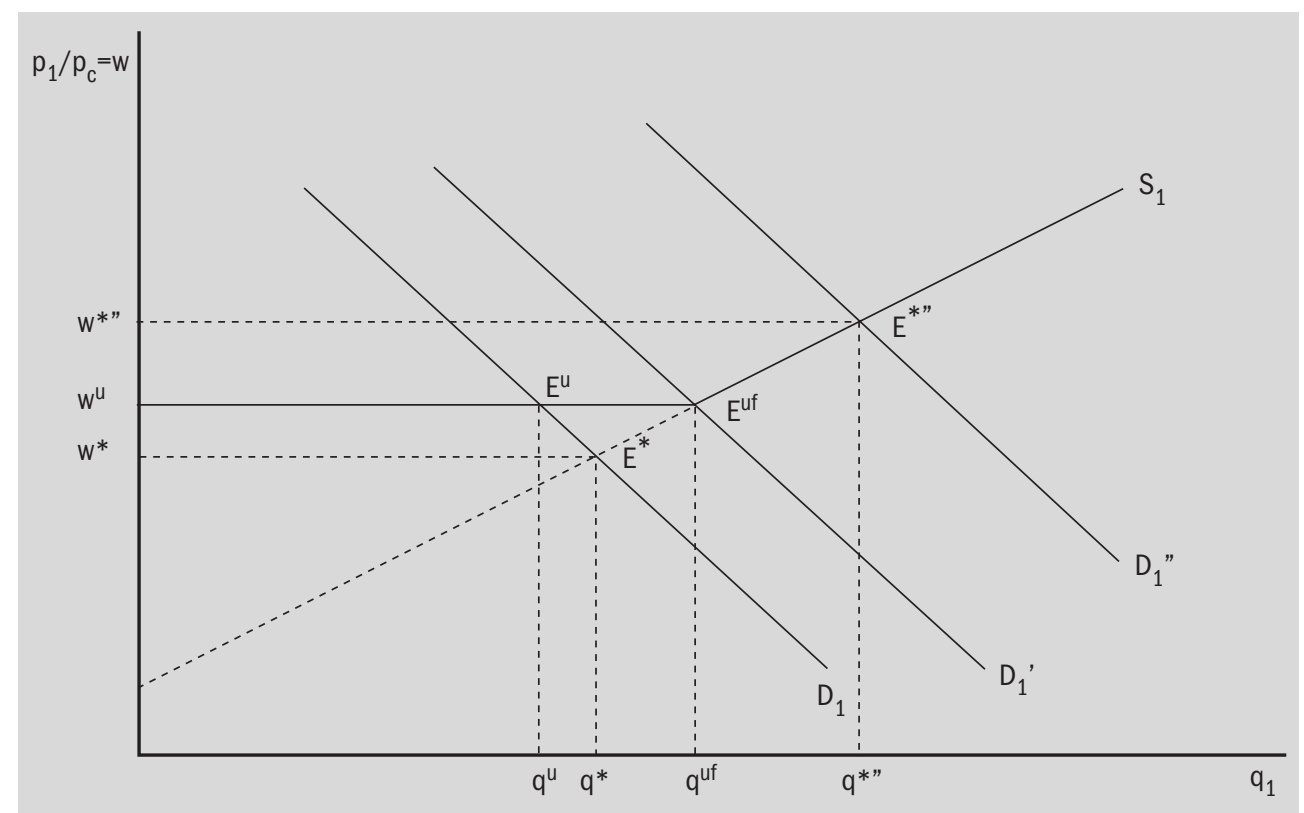

Rysunek 3.6. Rynki pracy w modelu RegPOL

gdzie: $w^{\mathrm{u}}=$ płaca wynegocjowana ze związkami (dolny próg); $\mathrm{w}^{\mathrm{u}}-\mathrm{w}^{*}=$ luka płacy realnej; $\mathrm{q}^{\mathrm{u}}-\mathrm{q}^{*}$ = luka realnej podaży siły roboczej; $q^{\text {uf }}-q^{\mathrm{u}}=\mathrm{u}=$ bezrobocie; $\mathrm{E}^{\mathrm{u}}=$ równowaga początkowa przy płacy wynegocjowanej przez związki; $\mathrm{E}^{*}=$ równowaga początkowa przy płacy rynkowej; $\mathrm{E}^{\text {uf }}=$ punkt równowagi przy pełnym zatrudnieniu; $\mathrm{E}^{*}$ " = inny punkt równowagi przy pełnym zatrudnieniu

Źródło: [Rutherford i Törmä 2006].

Rysunek 3.6 przedstawia złamaną krzywą podaży siły roboczej i trzy opadające krzywe popytu. Z powodu ograniczenia w postaci płacy minimalnej krzywa podaży siły roboczej w pewnym przedziale biegnie poziomo. Minimalna płaca wynegocjowana przez związki zawodowe sprawia, że $S_{1}>D_{1}$, co prowadzi do powstania bezrobocia. Luka płacy realnej to różnica między płacą wynegocjowaną przez związki a płacą rynkową. Gdyby rynki pracy funkcjonowały w warunkach pełnej swobody, poziom płac byłby niższy, a zapotrzebowanie na siłę roboczą większe niż w sytuacji, gdy realna płaca jest przedmiotem zbiorowych uzgodnień. 
Dla osiągnięcia pełnego zatrudnienia przy płacy wynegocjowanej przez związki, popyt na siłę roboczą powinien wzrosnąc z $\mathrm{D}_{1}$ to $\mathrm{D}_{1}^{\prime}$. Przyjmuje się przy tym, że w odniesieniu do cen konsumpcyjnych (pc) płaca utrzymuje się na stałym poziomie, aż do momentu całkowitego wyeliminowania bezrobocia. Jeśli popyt na siłę roboczą zwiększa się po osiągnięciu punktu równowagi z pełnym zatrudnieniem, realna cena siły roboczej może swobodnie wzrosnąć, ponieważ ograniczenie w postaci płacy minimalnej przestaje się liczyć [Rutherford i Törmä 2006].

\subsubsection{Modelowanie migracji netto}

Jak ustalili T.F. Rutherford i H. Törmä [2006], istnieje wiele sposobów sformułowania równania migracji w modelach CGE. Jeden z nich, zaproponowany przez R. Jonesa i J. Whalleya [1989], opiera się na specyficznych dla danego miejsca preferencjach, jeśli chodzi o reakcję na międzyregionalne zróżnicowanie dochodów. Inni autorzy [Ferguson, Learmonth, McGregor i in. 2004] zastosowali równanie, w którym migracja jest zdeterminowana przez stosunek płacy realnej i stopy bezrobocia między regionami (tę metodę przyjął także [Gillespie, McGregor $\mathrm{i}$ in. 2002]). Jeszcze inaczej do kwestii modelowania migracji netto podeszli F.J. Harrigan i P.G. McGregor [1989], a nieco później [McGregor, Swales, Yin 1995] i właśnie ich pomysł wykorzystano przy konstruowaniu modelu RegPOL. Zgodnie z nim zakładamy, że migracja netto (zrelatywizowana wielkością siły roboczej z poprzedniego okresu) jest funkcją relatywnego poziomu życia (stosunku PRB na głowę mieszkańca danego regionu w stosunku do PKB na głowę mieszkańca) i międzyregionalnego zróżnicowania stopy bezrobocia (regionalnej stopy bezrobocia w stosunku do krajowej). Zatem model migracji ma charakter prostej regresji liniowej, której postać przedstawia równanie 3.1:

\section{Równanie 3.1.}

RNetmigij/Lforcei, j-1 = a + b (Rgdpij/Ngdpj) + c (RUnempij/NUnempj) + e

gdzie:

RNetmig = regionalna migracja netto

Lforce $=$ wielkość siły roboczej

Rgdp = PRB na głowę mieszkańca

Ngdp $=$ PKB na głowę mieszkańca

RUnemp = regionalna stopa bezrobocia

NUnemp = krajowa stopa bezrobocia

$\mathrm{i}=$ region, $\mathrm{j}=$ rok

$a, b, c=$ parametry funkcji regresji

$\mathrm{e}=$ błąd 0 wartości oczekiwanej 0 
Przyjmujemy, że wzrost zróżnicowania regionalnych PKB jest dodatnio skorelowany ze zróżnicowaniem poziomu życia. Oczekujemy, że współczynnik b powinien mieć wartość dodatnią, tak by podwyższenie poziomu życia w danym regionie w stosunku do średniej krajowej skutkowało wzrostem migracji netto do danego regionu. Współczynnik (zróżnicowania bezrobocia) powinien mieć z kolei wartość ujemną, by wzrost stopy bezrobocia w danym regionie w stosunku do średniej krajowej powodował spadek migracji netto w tym regionie.

W celu określenia wartości współczynników występujących w równaniu migracji przeanalizowano szeregi przekrojowe i czasowe dla danych za okres 1999-2005 dla wszystkich 16 województw. Oszacowane na tej podstawie współczynniki składają się na następujące równanie migracji wchodzące do modelu:

\section{Równanie 3.2.}

RNetmigij/Lforcei, j-1 = -0,006 + 0,0085(Rgdpij/Ngdpj) - 0,00178 (RUnempij/NUnempj) + e (t-statystyka) $(12,507)^{1 \%}$ $(-3,137)^{1 \%}$

$$
\begin{array}{ll}
\mathrm{F}=105,22^{1 \%} & \mathrm{n}=112 \\
\mathrm{R}^{2}=0,658 & \mathrm{df}=109
\end{array}
$$

W pierwszej kolejności odnotowujemy, że oszacowane parametry mają właściwe znaki, a wszystkie współczynniki regresji są istotne na poziomie 1\%. Wybrane dwie zmienne w równaniu objaśniają aż $66 \%$ zmienności migracji netto, czyli całkiem dużo jak na tak prostą zależność. Powyższe równanie wykorzystano następnie w modelu jako funkcję wyznaczającą migrację netto i powiązano z innymi zmiennymi w modelu.

\subsubsection{Zmienne makroekonomiczne}

Omawiany model skonstruowano z myślą o wyliczaniu wszystkich najważniejszych zmiennych makroekonomicznych, zmieniających się na skutek różnego rodzaju interwencji rządowych. Model posiada zatem takie bloki zmiennych jak: produkt krajowy brutto (PKB) i wszystkie zmienne składające się na jego dekompozycje (konsumpcja prywatna i publiczna, inwestycje, eksport, import), wszystkie dochody czynników produkcji (wynagrodzenia pracy, ziemi, kapitału), dochody rządowe (podatki), stawki podatków, indeksy cen dóbr konsumpcyjnych i produkcyjnych, produkcja wszystkich sektorów gospodarki, stopy bezrobocia, 
migracji, siła robocza, skłonność do konsumpcji czy współczynniki postępu technicznego. Dokładną listę ponad 80 zmiennych wraz z określeniem ich wymiaru (zmienne regionalne oznaczone są skrótem REG, a sektorowe skrótem IND) zawiera aneks 3.3.

Najważniejszą zmienną jest produkt krajowy brutto (PKB). Wyliczany jest on w modelu zarówno od strony dochodów, jak i wydatków, zarówno na szczeblu krajowym, jak i regionalnym w ujęciu realnym i nominalnym. PKB od strony dochodów (zmienna wgdpinc) zdefiniowano jako sumę wszystkich zagregowanych płatności przypadających na wynagrodzenie pracy, ziemi i kapitału, powiększoną o zagregowaną wartość netto podatków pośrednich. PKB od strony wydatków zdefiniowano jako sumę wszystkich zagregowanych wydatków obejmujących konsumpcję, inwestycje, nakłady publiczne, przyrost rzeczowego kapitału obrotowego i eksport netto. Procedury kontrolne wbudowane w model (plik diagnostyczny) służą m.in. sprawdzeniu, czy te dwie wartości PKB zawsze są takie same.

$\mathrm{Z}$ kolei stosowane indeksy cenowe to deflator PKB, indeks cen towarów i usług konsumpcyjnych (CPI), indeks cen rządowych i indeksy cen dóbr inwestycyjnych (z uwzględnieniem i bez uwzględnienia podatków). Wielkości te są wyliczane jako średnie ważone procentowej zmiany odpowiednich cen. Na przykład w wypadku CPI są to ceny dóbr konsumpcyjnych, a w wypadku inwestycji - ceny dóbr inwestycyjnych. Więcej szczegółów na temat obliczania poszczególnych wskaźników można przeczytać w przystępnym (nawet dla osób nieznających Tablo) kodzie programu - aneks 3.2.

\subsubsection{Warunki zrównoważenia rynku i domknięcie modelu}

Ponieważ RegPOL jest modelem równowagi, zawiera szereg warunków składających się na zrównanie podaży z popytem. Dla każdego dobra i czynnika produkcji istnieje równanie równowagi rynkowej. Jedynie na rynkach pracy możliwy jest brak równowagi, oznaczający występowanie bezrobocia. Każdy z trzech typów konsumentów (gospodarstwa domowe oraz administracja centralna i lokalna) ma narzucone ograniczenie budżetu, zgodnie z którym konsumpcja nie może przekroczyć uzyskanych przez niego dochodów, dotacji i transferów dochodowych razem wziętych.

Zmienne egzogeniczne domykające model (closure) dobraliśmy tak, by odzwierciedlały neoklasyczne podejście analizy długookresowej dla małej otwartej gospodarki rynkowej. Wybór tych zmiennych jest ważny także dlatego, że zmienne te można poddawać szokom. Dokładny opis zmiennych wchodzących do domknięcia modelu (closure) przedstawia aneks 3.4. Najpierw przedstawione jest domknięcie generowane automatycznie, a poniżej jego zmiany, dokonane w celu 
dostosowania go do analizy długookresowej. Poniżej wyjaśniamy wybór kolejnych bloków jako egzogenicznych w domknięciu naszego modelu.

Blok pierwszy to wszystkie współczynniki postępu technicznego (zgodnie z teoriami egzogenicznego wzrostu gospodarczego). Jednak możliwa jest endogenizacja tych zmiennych w przypadku symulacji, w wyniku których oczekiwane są zmiany w technologii. Drugi jest blok stawek podatkowych - ponieważ są to zmienne narzucane przez działania polityczne, w naturalny sposób są one egzogeniczne. Zmienne te poddaje się szokom przy wszelkich symulacjach zmian systemów podatkowych. Kolejny blok to zmienne dotyczące ograniczenia budżetu centralnego i regionalnych. W naszym przypadku, zarówno krajowy deficyt budżetowy, jak i deficyty regionalne nie ulegają zmianie na skutek interwencji modelowanej przez nas polityki, ze względu na to, że rozważamy długi okres. Kolejną zdeterminowaną zmienną jest skłonność do konsumpcji, która jest określona jako stała część dochodu. Jeśli chodzi o rynek pracy, mamy krzywą określająca, jak zmieniają się płace (zakładamy, że są lepkie). Zatem są one endogeniczne i determinuja zatrudnienie oraz bezrobocie. Praca jest czynnikiem mobilnym między regionami i sektorami, ale jest homogeniczna (tzn. nie można odróżnić pracowników wykwalifikowanych od niewykwalifikowanych - płaca jest taka sama dla wszystkich). Podaż siły roboczej jest egzogeniczna w długim okresie. Kolejne założenie dotyczy cen dóbr importowanych i eksportowanych, których producenci i konsumenci są cenobiorcami. Jest to innymi słowy założenie o małej rynkowej gospodarce otwartej, do której zalicza się Polskę. Następnie mamy pozostałe czynniki pracy, gdzie kapitał w długim okresie jest wielkością endogeniczną w przeciwieństwie do ziemi, która jest zmienną egzogeniczną. Kapitał jest mobilny między regionami i sektorami, jest też heterogeniczny. Na końcu, ze względu na to, że jest to model statyczny, inwestycje są egzogeniczne.

Powyższe założenia domykające mają charakter wyjściowy, tzn. opisują gospodarkę jeszcze przed wprowadzeniem „szoków” (shocks). Jednak przy konkretnych symulacjach niektóre z tych założeń zostały zmienione, kiedy miało to swoje uzasadnienie ekonomiczne, jak np. przy symulacji wpływu działania „inwestycje w gospodarstwa rolne” i „dostosowania do standardów UE”, zmienna przedstawiająca postęp techniczny została wprowadzona jako endogeniczna, pozwalając na dostosowanie się technologii na skutek inwestycji. Należy się liczyć z tym, że wyniki symulacji mogą być wrażliwe na zmianę sposobu domknięcia (closure), o czym pisaliśmy przy okazji krytyki modeli CGE. Do symulacji przeprowadzonych w niniejszej pracy wybrane zostało takie domknięcie, które najlepiej da się uzasadnić ekonomicznie. 


\subsection{Scenariusze symulacyjne dla polityki ROW}

Scenariusze symulacji wpływu polityki ROW w Polsce skonstruowano, po pierwsze, opierajac się na hipotezach badawczych (stąd uzyskaliśmy meritum scenariuszy), po drugie - opierając się na dostępnych danych (stąd uzyskaliśmy wartości szoków), po trzecie, kierując się możliwościami modelu (stąd uzyskaliśmy zmienne podlegające szokom).

Przypomnijmy, że model posłużył nam weryfikacji ostatnich trzech z czterech hipotez, gdyż pierwsza została już zweryfikowana w rozdziale 2 (tab. 5.1). RegPOL zastosowany został zatem do obliczenia skuteczności poszczególnych działan, ich grup w podziale na instrumenty ekonomiczne oraz skuteczności całego wsparcia w ramach polityki ROW. Dotyczyło to skutków zarówno regionalnych, jak i krajowych. RegPOL posłużył również obliczeniu efektywności poszczególnych typów działań, w regionach i w całej Polsce. Wyniki skutków polityki ROW zostały także zestawione w typologii wiejsko-rolniczej do analizy ostatniej hipotezy, dotyczącej rozłożenia się korzyści z tej polityki pomiędzy różnego typu regiony, w zależności od ich wiejskości i rolniczości. Skonstruowane zostały w sumie dwa scenariusze, które posłużyły weryfikacji hipotez. $\mathrm{W}$ ramach każdego $\mathrm{z}$ nich przeprowadzono wiele symulacji dla poszczególnych zmiennych i oceniono ich wpływ na szereg głównych wskaźników ekonomicznych. Dokładniej prezentują to odpowiednie sekcje rozdziału 4 (4.1, 4.2, i 4.3).

Za podstawę wyliczenia wartości szoków dla pierwszego scenariusza (dotyczącego skuteczności) posłużyły nam dane regionalne Agencji Restrukturyzacji i Modernizacji Rolnictwa [ARiMR 2008]. Obejmują one pełną informację na temat przedsięwzięć realizowanych $w$ ramach polityki rozwoju obszarów wiejskich w podziale na 16 województw za okres 2004-200752. Dane te dotyczyły złożonych wniosków, kwot wnioskowanego wsparcia, przyznanych kwot wsparcia i, co najważniejsze dla nas, płatności zrealizowanych w ramach każdego działania. To one posłużyły nam do wyliczenia wartości szoków. Konkretniej, jeśli chodzi o działania w ramach SPO Rolnictwo, są to dane wygenerowane z Systemu Informacji Zarządczej ARiMR, sporządzone 10 stycznia 2008 r. w Departamencie Analiz i Sprawozdawczości ARiMR. Dotyczą one płatności zrealizowanych narastająco od uruchomienia Programu do 31 grudnia 2007 r. Jeśli chodzi o działania w ramach PROW 2004-2006, są to dane z tego same-

52 Mimo iż programy przewidziane były na lata 2004-2006, fundusze mogłyby być wydatkowane do końca 2008 r. My posługujemy się obecnie dostępnymi danymi, na stan do końca 2007 r. Do tego czasu wydatkowano ponad $95 \%$ środków. 
go źródła, dotyczące płatności zrealizowanych, sporządzone 18 stycznia 2008 r. i aktualne na 31 grudnia 2007 r. Wszystkie wartości szoków są wobec tego wyliczone na podstawie płatności zrealizowanych do końca 2007 r. i przeskalowane do roku bazowego 2000, za pomocą zrelatywizowania wartości funduszy ROW w relacji do PKB w latach 2004-2006. Następnie wartości te zostały włączone do komend zrozumiałych dla modelu (tzw. shock statements) w postaci zmian procentowych zmiennych ulegających szokom (zmienne te omówione są poniżej). Z kolei do analizy drugiego scenariusza (dotyczącego efektywności), posłużono się hipotetycznymi wartościami przyznanych działań, aby lepiej uwypuklić wyniki analizy. Przyjęto, zgodnie z klasyfikacją wg kryteriów ekonomicznych (omawianą w rozdziale 2.3.3), że każde województwo dostało 4 typy działań, tj. bezpośrednie transfery dochodowe (TB, do których zaliczają się np. renty strukturalne), subsydia obszarowe ( $\mathrm{SO}$, do których zalicza się wsparcie dla obszarów ONW), inwestycje w infrastrukturę (SI_b, np. takie jak inwestycje w gospodarstwa rolne), oraz inwestycje w edukację (SI_e, takie jak szkolenia czy doradztwo). Dla każdego z działań każde województwo dostało tę samą kwotę funduszy, czyli po $50 \mathrm{mln}$ zł na każde działanie. Taki scenariusz hipotetyczny pozwolił zrównać koszty działań, a więc obserwowane różnice odzwierciedlały już tylko różnice w efektywności każdego działania (z definicji efektywność jest relacją kosztów do korzyści). Bardziej szczegółowe omówienie logiki tego podejścia znajduje się w rozdziale 4.2, gdzie weryfikowana jest hipoteza o efektywności. Scenariusz ten jest ciekawy z tego względu, że pozwala na więcej porównań. Pokazuje, jaki jest mechanizm i efekty wykorzystania tej samej kwoty funduszy na te same działania, przez różne województwa. Dowiadujemy się nie tylko, które działania są bardziej efektywne, ale też które województwa bardziej efektywnie wykorzystują jakie działania. To z kolei otwiera możliwości dyskusji, czy lepiej wspierać najbardziej efektywne województwa, czy najbardziej potrzebujące (czytelnik znajdzie te rozważania w dalszej części książki, przy okazji weryfikacji hipotezy 3).

Wybór zmiennych poddawanych szokom podyktowany był możliwościami modelu i charakterem działań. Każde działanie zostało zdefiniowane jako szok dla gospodarki o charakterze najbardziej zbliżonym do jego prawdziwego odpowiednika w rzeczywistości. Dla działań będących subsydiami obszarowymi (SO), szokowi podlegały subsydia do czynnika produkcji, jakim jest ziemia w produkcji rolnej. Z kolei dla działań będących transferami bezpośrednimi (TB) - szokowi podlegały dochody. W przypadku inwestycji w infrastrukturę (SI_b), szokowi ulegały zmienne dotyczące znaczenia sektora budowlanego w rolnictwie, a w inwestycjach w edukację (SI_e), szokowi ulegały zmienne dotyczące znaczenia sektora 
edukacji w rolnictwie. Dodatkowo na proces symulacji każdego scenariusza wpływ miały modyfikacje w domknięciu modelu, czyli endogenizowane były zmienne, które powinny się zmieniać pod wpływem polityki, a egzogeniczne stawały się te, które miały ulegać szokom (była o tym mowa wcześniej przy omawianiu domknięć modelu).

Podsumowując - wymodelowane zostały dwa scenariusze. Jeden oparty na faktycznym przebiegu programu, na podstawie zrealizowanych płatności na poszczególne działania polityki ROW w latach 2004-2006. Drugi zaś, hipotetyczny, pozwolił określić relatywną efektywność każdego działania i każdego województwa. Wyniki uzyskane za pomocą każdego scenariusza przedstawiamy w rozdziale 4. 


\section{ANALIZA EFEKTÓW WSPARCIA ROZWOJU OBSZARÓW WIESSKICH PRZY ZASTOSOWANIU MODELU REGPOL}

Posługując się modelem RegPOL i scenariuszami opisanymi w rozdziale 3 uzyskaliśmy rezultaty empiryczne, dotyczące wpływu funduszy ROW na rozwój kraju oraz na poszczególne województwa. Zanim jednak przejdziemy do interpretacji tych wyników, trzeba poruszyć kilka kwestii, mających znaczenie dla ich zrozumienia. Po pierwsze, kwestia rozkładu funduszy na poszczególne działania, zarówno w wielkościach absolutnych, jak i relatywnych. Tabela 4.1 przedstawia relację funduszy przeznaczonych na poszczególne działania PROW i SPO w latach 2004-2006 (płatności skumulowane na 31 grudnia 2007 r.) w stosunku do produktu regionalnego brutto (PRB) każdego województwa (liczonego jako średnia $\mathrm{z}$ lat 2004-2006) w ujęciu procentowym.

Jak widać, występują duże różnice w znaczeniu poszczególnych działań, zarówno na poziomie krajowym, jak i regionalnym. Na przykład renty strukturalne, jak również dostosowania do standardów UE wyniosły w skali kraju odpowiednio $0,22 \%$ PKB oraz $0,24 \%$ PKB, a więc znacznie więcej niż np. szkolenia $(0,003 \%$ $\mathrm{PKB})$ i doradztwo $(0,02 \% \mathrm{PKB})$. Jednocześnie znaczenie poszczególnych działań było różne, w zależności od województwa, np. renty strukturalne w województwie lubuskim znaczyły dużo mniej dla jego gospodarki $(0,10 \%$ PRB) niż to samo działanie w województwie lubelskim (0,55\% PRB). A działanie dostosowania do UE w województwie dolnośląskim $(0,02 \%$ PRB $)$ dużo mniej ważyło niż w województwie kujawsko-pomorskim ( $0,89 \%$ PRB). Ponadto udział funduszy z całej polityki ROW (tj. wszystkich działań razem) rozłożył się nierównomiernie pomiędzy województwami, więc znaczenie tej polityki dla poszczególnych województw też będzie różne. Na przykład fundusze na politykę ROW dla województwa dolnośląskiego stanowiły tyko $0,8 \%$ jego PRB, a dla podlaskiego aż 6,3\% PRB. Interpretując wyniki, musimy zatem pamiętać o relatywnej ważności (wielkości) poszczególnych funduszy dla gospodarki poszczególnych województw, jak 
również kraju. Ponadto różnice w skuteczności poszczególnych grup instrumentów mogą wynikać po części z wielkości wydanych na nie funduszy. Analizując skuteczność działań, możemy się spodziewać, że działania, które stanowiły mały odsetek PKB (np. doradztwo czy szkolenia), przyniosą generalnie względnie mniejsze skutki niż działania, które miały większą wagę (np. renty strukturalne). Ale, oczywiście, nie determinuje to efektywności tych działań, tzn. nawet działania o małej wadze mogą przynieść relatywnie wysokie efekty, co wykazujemy dalej. Interpretując wyniki, najpierw zajmiemy się skutecznością działań, czyli korzyściami z nich wynikającymi bez względu na poniesione na nie koszty (podrozdział 4.1). Z kolei w podrozdziale 4.2 zajmiemy się efektywnością działań, czyli korzyściami zrelatywizowanymi względem poniesionych na nie kosztów ${ }^{53}$.

Po drugie, musimy uświadomić sobie rząd wielkości tych środków. To pozwoli nam na stworzenie racjonalnych oczekiwań co do skali efektów, jakich możemy się po nich spodziewać. Jak pokazuje tabela 4.1, zarówno na poziomie kraju jak i poszczególnych województw pojedyncze działania stanowiły zaledwie niecały procent krajowego PKB czy wojewódzkich PRB. Największe wsparcie na pojedyncze działanie na poziomie krajowym wyniosło $0,38 \%$ PKB, było to „wsparcie dla ONW”, a najmniejsze na poziomie krajowym (nie licząc LEADER) wyniosło 0,003\% PKB i było przeznaczone na szkolenia. Całe wsparcie na ROW to w skali kraju zaledwie 1,6\% ówczesnego PKB, a w poszczególnych województwach wahało się od 0,3\% PRB (w przypadku Śląska) do 6,3\% PRB (w przypadku województwa podlaskiego). Możemy się więc spodziewać, że efekty tych działań będą o podobnej skali, czyli blisko dziesiątych procenta w skali kraju i kilku procent w skali poszczególnych województw.

Po trzecie, ważną kwestią w zrozumieniu efektów regionalnych jest stosunek wielkości otrzymanego wsparcia do zamożności województwa. Można to zmierzyć stosunkiem otrzymanych funduszy na ROW w danym województwie do udziału danego województwa w krajowym PKB. Jest dość oczywiste, że np. 100 mln PLN funduszy znaczy więcej dla województwa biednego i o niewielkiej sile ekonomicznej (czyli którego PKB na mieszkańca i udział w krajowym PKB jest niski) niż dla województwa zamożnego i silnego ekonomicznie (czyli o relatywnie wysokim PKB na mieszkańca i udziale w krajowym PKB). Porównując więc udział wszystkich województw w funduszach ROW do ich udziału w PKB zbadaliśmy, na ile proporcjonalne są środki ROW do siły ekonomicznej i zamożności województw. W ten sposób wyróżniliśmy kilka grup województw; przedstawia to tabela 4.2.

\footnotetext{
53 Odnosimy się tu do najprostszych definicji skuteczności i efektywności, w myśl których skuteczność mierzy się jako stosunek osiągniętych wyników do zamierzonych celów, podczas gdy efektywność jest zawsze porównaniem korzyści do kosztów. Oczywiście sposób pomiaru tych składowych może być bardzo różny, stąd tak wiele wskaźników skuteczności czy efektywności.
} 


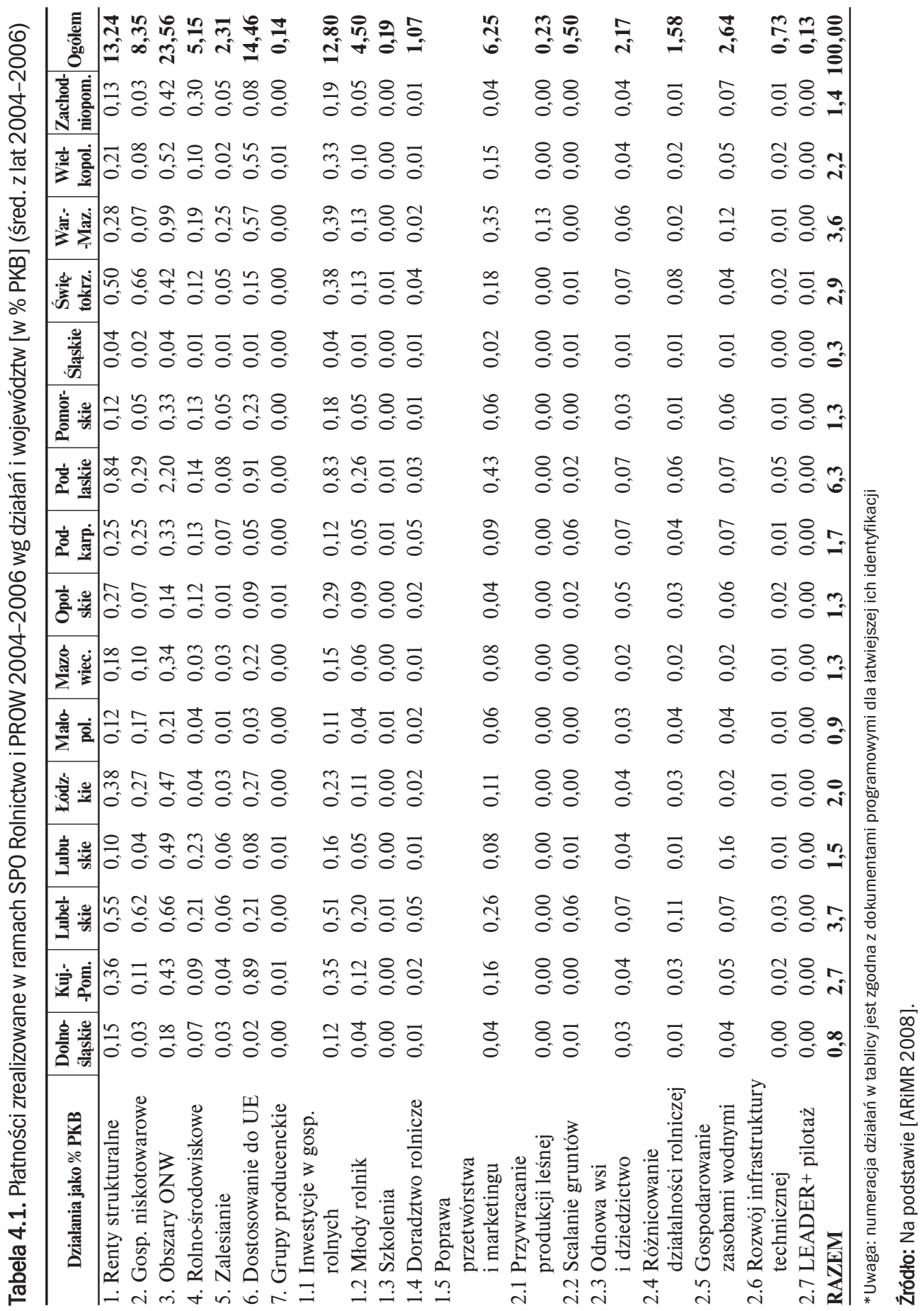


Grupa I składa się z województw, które zajmują wyższe miejsce w kraju ze względu na otrzymane środki ROW niż ze względu na siłę ekonomiczną (tj. udział w PKB). Można powiedzieć, że województwa te odnotowują większą niż proporcjonalnie wartość funduszy w stosunku do swojej zamożności i siły ekonomicznej. Dlatego w kolumnie „Proporcja B/A” mają wartości powyżej 1. W tej grupie zdecydowanie najkorzystniejsza proporcja wystąpiła w przypadku województwa podlaskiego, które - będąc relatywnie biednym regionem (14. lokata w PKB na mieszkańca i ok. 2\% udziału w PKB) - zdobyło środki, stanowiące 9\% krajowych funduszy na ROW. Proporcja otrzymanych środków do siły ekonomicznej tego województwa wyniosła 3,86 (patrz kolumna „proporcja B/A” w tabeli 4.2).

Tabela 4.2. Fundusze ROW w relacji do PKB i między województwami*

\begin{tabular}{|c|c|c|c|c|c|c|}
\hline Wyszczególnienie & $\begin{array}{c}\text { PKB } \\
\text { średnie } z \text { lat } \\
\text { 2004-2006 } \\
{[\mathrm{mln} \text { PLN] }}\end{array}$ & $\begin{array}{c}\text { Suma } \\
\text { płatności zre- } \\
\text { alizowanych } \\
\text { na } \text { ROW }^{*} \\
{[\mathrm{mln} \text { PLN] }} \\
\end{array}$ & $\begin{array}{c}\text { Lokata } \\
\text { wg PKB } \\
\text { na miesz- } \\
\text { kańca }\end{array}$ & $\begin{array}{c}\text { Udzial } \\
\text { w PKB } \\
\text { w \% } \\
\text { (A) }\end{array}$ & $\begin{array}{c}\text { Udzial } \\
\text { w ROW } \\
\text { w \% } \\
\text { (B) }\end{array}$ & $\begin{array}{c}\text { Proporcja } \\
\text { B/A* }\end{array}$ \\
\hline Dolnośląskie & 75080 & 594 & 4 & 7,8 & 3,8 & 0,48 \\
\hline \multicolumn{7}{|l|}{ Kujawsko- } \\
\hline -Pomorskie & 45883 & 1256 & 8 & 4,8 & 8,0 & 1,68 \\
\hline Lubelskie & 37823 & 1398 & 16 & 3,9 & 8,9 & 2,26 \\
\hline Lubuskie & 22910 & 355 & 10 & 2,4 & 2,3 & 0,95 \\
\hline Łódzkie & 59977 & 1228 & 7 & 6,2 & 7,8 & 1,25 \\
\hline Małopolskie & 70261 & 661 & 9 & 7,3 & 4,2 & 0,58 \\
\hline Mazowieckie & 203334 & 2575 & 1 & 21,1 & 16,4 & 0,78 \\
\hline Opolskie & 22235 & 300 & 11 & 2,3 & 1,9 & 0,83 \\
\hline Podkarpackie & 36685 & 606 & 15 & 3,8 & 3,8 & 1,01 \\
\hline Podlaskie & 22518 & 1420 & 14 & 2,3 & 9,0 & 3,86 \\
\hline Pomorskie & 54329 & 726 & 5 & 5,6 & 4,6 & 0,82 \\
\hline Śląskie & 129654 & 328 & 2 & 13,5 & 2,1 & 0,15 \\
\hline Świętokrzyskie & 24570 & 702 & 12 & 2,5 & 4,5 & 1,75 \\
\hline \multicolumn{7}{|l|}{ Warmińsko- } \\
\hline -Mazurskie & 27715 & 999 & 13 & 2,9 & 6,3 & 2,21 \\
\hline Wielkopolskie & 91025 & 2018 & 3 & 9,4 & 12,8 & 1,36 \\
\hline \multicolumn{7}{|l|}{ Zachodnio- } \\
\hline Suma & 963714 & 15733 & 0 & $\begin{array}{r}4,1 \\
100,0\end{array}$ & $\begin{array}{r}5,0 \\
100,0\end{array}$ & 2 \\
\hline
\end{tabular}

* stan na 31 grudnia 2007 r.

Źródło: Obliczenia własne na podstawie [ARiMR 2008] i [GUS 2008a].

Co jednak ciekawe, w tej grupie nie występują jedynie województwa biedne, jak byśmy byli skłonni oczekiwać (zgodnie z zasadą, że więcej środków na rozwój powinny pozyskiwać regiony zapóźnione). Mamy tu bowiem też jedno z najbogat- 
szych województw, wielkopolskie (3. lokata w PKB na mieszkańca), którego udział w PKB wynosi ponad 9\%, a udział w środkach ROW 12,8\%. W tym przypadku udział w środkach ROW był też więcej niż proporcjonalny w stosunku do siły ekonomicznej i skala tego stosunku wyniosła 1,36. Grupa II to województwa, które otrzymały środki ROW bardzo proporcjonalnie do swojej siły ekonomicznej i zamożności. Do województw tych należy lubuskie oraz podkarpackie. Stosunek środków otrzymanych do udziału w PKB wyniósł prawie jak 1 do 1 . W grupie III z kolei znalazły się wszystkie te województwa, które zaabsorbowały relatywnie mniej środków ROW niżby to wynikało z ich zamożności. Znów jednak nie występuje zasada, że im bogatsze województwo, tym mniej proporcjonalnie środków zaabsorbowało, gdyż mamy tu zarówno województwo opolskie (2,3\% PKB), którego udział w środkach ROW wyniósł zaledwie 1,9\% (proporcja zatem poniżej jedności, tj. 0,83), jak i województwo najbogatsze w kraju, mazowieckie, 21,1\%, które zaabsorbowało 16,4\% funduszy ROW. Najlepiej te dysproporcje obrazuje rysunek 4.1, który powstał na podstawie danych z ostatniej kolumny tabeli 4.2).

Prześledzenie proporcji zaangażowanych środków na poszczególne działania przez poszczególne województwa w stosunku do ich zamożności może do pewnego stopnia pomóc później w zrozumieniu wyników zróżnicowania skuteczności i efektywności poszczególnych działań w ujęciu regionalnym jak też krajowym.

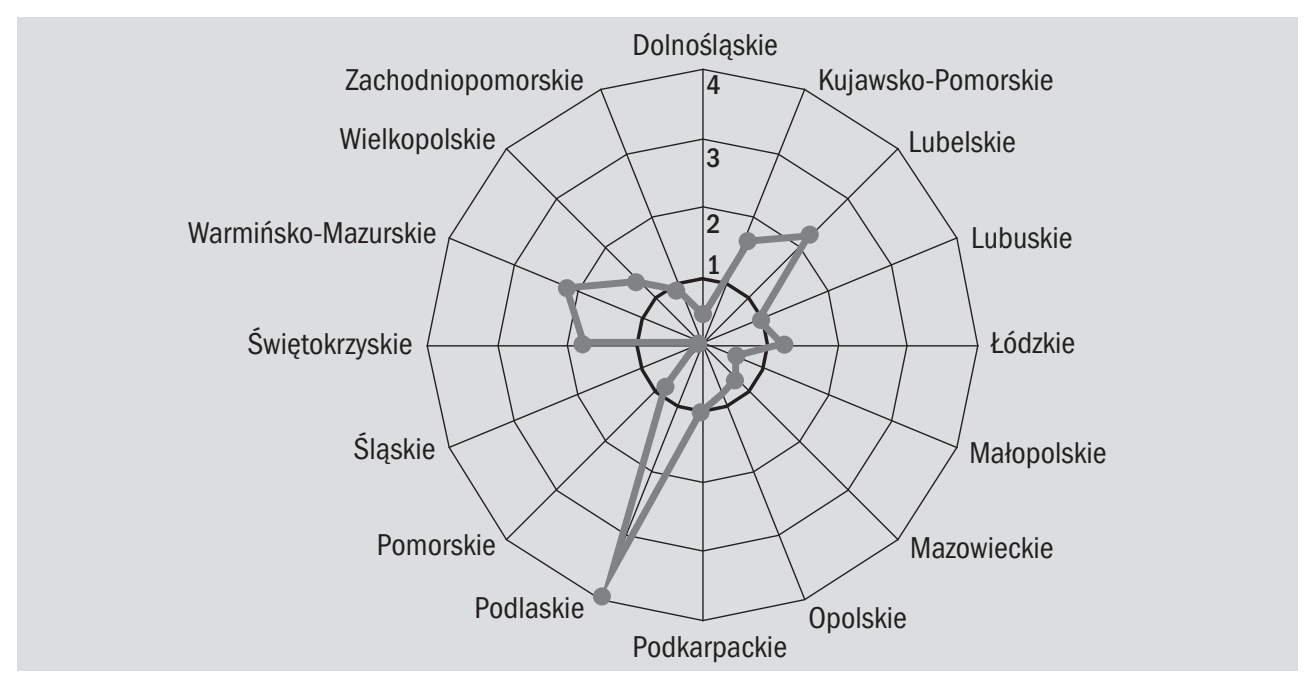

Rysunek 4.1. Relacja środków ROW do zamożności województwa

Uwaga: Wartości powyżej jedności oznaczają większy proporcjonalnie udział województwa w środkach Row niż jego udział w PKB.

Źródło: Opracowanie własne na podstawie ostatniej kolumny tabeli 4.2. 
Po czwarte, musimy pamiętać o specyfice interpretacji wyników z symulacji, uzyskanych za pomocą modeli równowagi ogólnej, do których należy model RegPOL. Więcej o tym była mowa w rozdziale 3, ale tu przypomnijmy, że wszystkie uzyskane wyniki przedstawione sa jako zmiany procentowe, skumulowane w czasie potrzebnym na osiągnięcie przez gospodarkę nowej równowagi, po zaaplikowanym „szoku”, jakim w naszym przypadku były programy ROW. Generalnie możemy przyjąć, że jest to okres ok. 5-8 lat w przypadku symulacji, z jaką mamy tu do czynienia. Jednak trudno go precyzyjniej określić.

Mając już wiedzę o tym, jak rozłożyły się fundusze ROW uzyskane w latach 2004-2006 oraz pewne wskazówki, co do interpretacji wyników modelu RegPOL, możemy przejść do analizy skutków ekonomicznych, jakie programy te wywołały i z czego to wynikało. Ocena ta dokonana jest na podstawie zmian głównych wskaźników makroekonomicznych, takich jak: zatrudnienie w gospodarce, inflacja (wg wskaźnika cen konsumpcyjnych), PKB (krajowe i regionalne), bezrobocie, migracja netto, konsumpcja prywatna oraz eksport i import ${ }^{54}$. Ponadto zbadaliśmy korzyści dla poszczególnych sektorów gospodarki (w ujęciu sekcji PKD), w tym dla rolnictwa.

\subsection{Skuteczność instrumentów ROW w skali krajowej i regionalnej}

Skuteczność w ekonomii, choć może mieć różnie brzmiące definicje, zawsze sprowadza się do porównania celów zamierzonych z faktycznie osiągniętymi [ODPM 2004, s. 113]. W przypadku polityki ROW, najogólniej mówiąc, głównym zaplanowanym celem był jak największy rozwój obszarów wiejskich. Ten z kolei powinien przełożyć się na rozwój województw i w konsekwencji całej gospodarki. Przy takim podejściu do oceny skuteczności na poziomie województwa wystarczy nam porównanie wpływu, jaki miały poszczególne działania na wybrane zmienne ekonomiczne w tych województwach oraz w całej Polsce. Omówienie wyników przeprowadzamy od ogółu do szczegółu, tzn. począwszy od wpływu pogrupowanych działań na poziomie krajowym, a skończywszy na wpływie poszczególnych działań na poziomie regionalnym.

${ }^{54}$ Może dziwić, że wśród omawianych zmiennych ekonomicznych, składających się na dekompozycję PKB, brakuje zmian w inwestycjach i zmian w saldzie budżetu. W przyjętym podejściu założyliśmy, bowiem, że zmiana w inwestycjach jest zmienną egzogeniczną, gdyż inwestycje są tu narzędziem omawianej polityki, a nie skutkiem (innymi słowy, ulegają egzogenicznemu, a nie endogenicznemu zwiększeniu). Co do deficytu budżetowego, to poczynione jest założenie, iż nie zmienia się on pod wpływem tej polityki. 
- WPLyW FUndUSZY ROW NA GOSPODARKE KRAJOWĄ. Analiza skutków ekonomicznych funduszy PROW i SPO Rolnictwo w latach 2004-2006 za pomocą regionalnego modelu równowagi ogólnej RegPOL pokazała, że korzyści z poszczególnych działań zarówno na poziomie krajowym, jak i regionalnym były bardzo zróżnicowane. Najlepsze efekty dały subsydia inwestycyjne w infrastrukturę/budownictwo (SI_b), następnie transfery bezpośrednie (TB), na końcu znalazły się subsydia obszarowe (SO). Skuteczność działań w formie subsydiów inwestycyjnych w edukację (SI_e) jest trudniejsza do jednoznacznej oceny. Z jednej strony ich wpływ na wzrost PKB był tak samo niski, jak w przypadku SO, ale jednak wpływ na inne zmienne ekonomiczne podnosił ocenę skuteczności tego typu instrumentu. Bardziej szczegółowe omówienie jest w dalszej części tego podrozdziału.

Według klasyfikacji wyprowadzonej przez nas wcześniej w rozdziale 2.3.3 i na podstawie uzyskanych rezultatów można zauważyć, że pozytywne skutki ekonomiczne uzyskane przez grupę działań określonych przez nas jako proefektywnościowe, wielokrotnie przewyższyły te $\mathrm{z}$ działań określonych przez nas jako prorównościowe ${ }^{55}$. Rysunek 4.2 obrazuje skuteczność polityki ROW na podstawie działań pogrupowanych według typów ekonomicznych, a rysunek 4.3 na podstawie wybranych najbardziej znaczących działań ze względu na wielkość przeznaczonych na nie funduszy. Poniżej zaś omawiamy bardziej szczegółowo wpływ pogrupowanych i indywidualnych działań na kolejne zmienne ekonomiczne.

- WPŁyW FUNDUSZY ROW NA WZROST GOSPODARCZY. Do wzrostu gospodarczego najbardziej przyczyniły się płatności zrealizowane na SI_b (wzrost PKB o 5,3\%), a w drugiej kolejności - chociaż już w zdecydowanie mniejszym stopniu - TB (wzrost PKB o 0,3\%). SO oraz SI_e wpłynęły na wzrost PKB w znikomym stopniu (oba po 0,1\%). Jeśli chodzi o poszczególne działania, to największy wpływ na wzrost PKB miały inwestycje w gospodarstwach, które pochłaniając 2274 mln PLN przyczyniły się do skumulowanego długookresowego wzrostu PKB o 1,6\%. Jednocześnie płatności ONW, na które przeznaczono podobne fundusze czy renty strukturalne, które pochłonęły o 40\% funduszy więcej, wpłynęły na wzrost PKB zaledwie o $0,1 \%$.

\footnotetext{
${ }^{55}$ Dla przypomnienia, według klasyfikacji wyprowadzonej w rozdziale 2.3.3, wszystkie działania podzielone zostały najpierw na cztery typy instrumentów ekonomicznych: transfery bezpośrednie (TB), subsydia obszarowe (SO), subsydia inwestycyjne w infrastrukturę/budownictwo (SI_b) oraz subsydia inwestycyjne w kapitał ludzki/edukację (SI_e). Następnie, po dalszej analizie, do grupy instrumentów proefektywnościowych zaliczone zostały wszystkie działania występujące $\mathrm{w}$ formie subsydiów inwestycyjnych, a do grupy działań prorównościowych - te występujące w formie transferów bezpośrednich i subsydiów obszarowych.

${ }^{56}$ Dane dotyczące płatności zrealizowanych pochodzą z ARiMR [2008] na stan 18 stycznia $2008 \mathrm{r}$.
} 


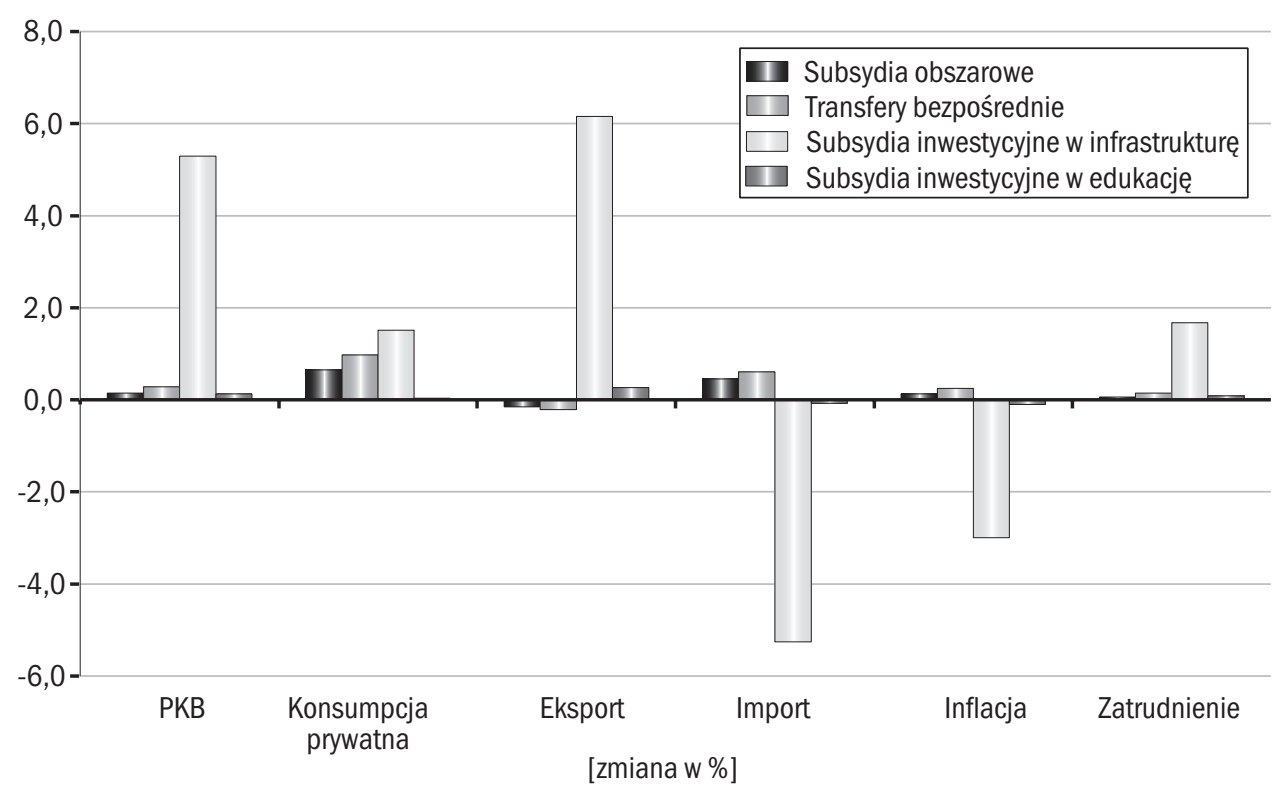

Rysunek 4.2. Skuteczność poszczególnych typów instrumentów polityki ROW 2004-2006 [zmiana w \%]

Źródło: Obliczenia własne na podstawie modelu RegPOL.

- EFEKT KONSUMPCYJNY I DOCHODOWY FUNDUSZY ROW. Największy efekt wZrostu konsumpcji spowodowały SI_b (o 1,5\%), następnie TB (o 1\%), a na trzecim miejscu SO (o 0,6\%). SI_e nie wykazały żadnego wpływu. Jeśli chodzi o poszczególne działania, ciekawe jest to, że 3 z nich należące do trzech odmiennych typów instrumentów i będące ich największymi reprezentantami, tj. wsparcie ONW (SO), renty strukturalne (TB) oraz inwestycje w gospodarstwach (SI_b) wpłynęły z tą samą siłą na wzrost konsumpcji prywatnej (o 0,5\%). Jednakże z faktu, iż wzrost dochodów przeznaczonych na tę konsumpcję miał z założenia fundamentalnie różne pochodzenie (wzrost dochodów z transferów, a nie wzrost związany z inwestycjami) dlatego, mimo takiego samego wzrostu konsumpcji i jej dużego udziału w PKB, wzrost gospodarczy był diametralnie różny na skutek każdego z tych działań. Kolejne różnice wynikające $\mathrm{z}$ odmiennego charakteru tych dochodów ujawniły się w kolejnej składowej PKB, tj. w bilansie handlu zagranicznego.

- WPEYW FUNDUSZY ROW NA HANDEL ZAGRANiCZnY. Działania typu SO oraz TB wyraźnie sprzyjały deficytowi w handlu zagranicznym, prowadziły do wzrostu 
importu (o odpowiednio 0,5\% i 0,6\%) i wypychaniu eksportu (o - $0,2 \%$ ). Z kolei SI_b oraz SI_e sprzyjały tworzeniu nadwyżki w handlu zagranicznym, przyczyniając się do wzrostu eksportu (odpowiednio o 6,2\% oraz 0,3\%) i jednocześnie obniżenia importu (odpowiednio o -5,3\% i -0,1\%). Zatem fundusze prorównościowe przyczyniały się do pogorszenia bilansu handlowego, podczas gdy proefektywnościowe do jego poprawy. Rozpatrując poszczególne działania, do największej presji na deficyt w handlu przyczynia się „wsparcie dla ONW” (spadek eksportu o - $-0,1 \%$ i wzrost importu o $0,4 \%$ ), a do największej dodatniej presji na nadwyżkę w bilansie handlowym przyczyniły się ,inwestycje w gospodarstwach” (wzrost eksportu o $1,9 \%$ i spadek importu o -1,6\%).

- EFEKT CENOWY FUNDUSZY ROW. Spośród wszystkich typów instrumentów ekonomicznych, tylko subsydia inwestycyjne (zarówno infrastrukturalne, jak i edukacyjne) nie tworzyły presji inflacyjnej, a nawet powodowały spadek inflacji o $-3 \%$, podczas gdy pomoc w postaci TB oraz SO miała tendencję do tworzenia lekkiej presji na wzrost inflacji (o $0,1 \%$ ). Łatwo wytłumaczyć ten fakt, gdyż w przypadku subsydiów inwestycyjnych wytwarzany jest kapitał, który nie ma bezpośredniego wpływu na popyt dóbr konsumpcyjnych (najwyżej na popyt dóbr produkcyjnych i indeks cen dóbr inwestycyjnych). Popyt inwestycyjny nie wpływa zatem na wzrost ceny dóbr składających się na wskaźnik inflacji. Inaczej jest przy transferach o charakterze socjalnym, takich jak TB czy SO, kiedy to efekt wpływu funduszy z zewnątrz (z UE) można przyrównać do efektu „drukowania pieniądza” bez pokrycia. Nie wymuszają bowiem wytwarzania za nie żadnych dóbr. Przeznaczone - na pewno w jakiejś części - na popyt konsumpcyjny, tworzą presję na wzrost cen dóbr konsumpcyjnych, czyli wzrost inflacji. Jeśli chodzi o poszczególne działania będące największymi reprezentantami swoich grup, to ONW (w kategorii SO) oraz renty strukturalne (w kategorii TB), każde z nich przyczyniało się do wzrostu inflacji o 0,1\%. Z kolei inwestycje w gospodarstwach (w kategorii SI_b) oraz doradztwo wraz ze szkoleniami (w kategorii SI_e) przyczyniały się do spadku inflacji, odpowiednio o $0,9 \%$ i $0,1 \%$.

- WPEYW FUNDUSZY ROW NA ZATRUDNIENIE. Największy pozytywny wpływ na zatrudnienie $\mathrm{w}$ gospodarce miały subsydia inwestycyjne $\mathrm{w}$ infrastrukturę (SI_b), dzięki którym wzrosło ono o 1,7\%. Pozostałe typy instrumentów ekonomicznych, takich jak transfery bezpośrednie (TB) czy subsydia obszarowe (SO), miały znikomy wpływ na wzrost zatrudnienia (0,1\%), mimo znaczących środków przeznaczonych na nie w skali ROW. Podobnie - subsydia inwestycyjne w kapitał ludzki (SI_e), ale to wynikało głównie z bardzo małych funduszy przeznaczonych 
na nie w skali całego ROW. Rozpatrując znaczenie poszczególnych działań, można stwierdzić, że największy wpływ na zatrudnienie mieli najwięksi reprezentanci subsydiów inwestycyjnych, czyli takie działania, jak „dostosowanie do standardów UE” oraz ,inwestycje w gospodarstwach”. Przyczyniły się one do wzrostu zatrudnienia odpowiednio o $0,6 \%$ i $0,7 \%$.

- WPLYW FUNDUSZY ROW NA ROZWÓJ REgIONów. W ujęciu regionalnym, wzrost gospodarczy wywołany funduszami ROW 2004-2006 wahał się pomiędzy województwami od 0,9\% (mazowieckie) do 7,8\% (podlaskie). Ranking województw według uzyskanego wzrostu gospodarczego prezentuje rysunek 4.3, a dekompozycje tego wzrostu względem poszczególnych grup działan przedstawia tabela 4.3 .

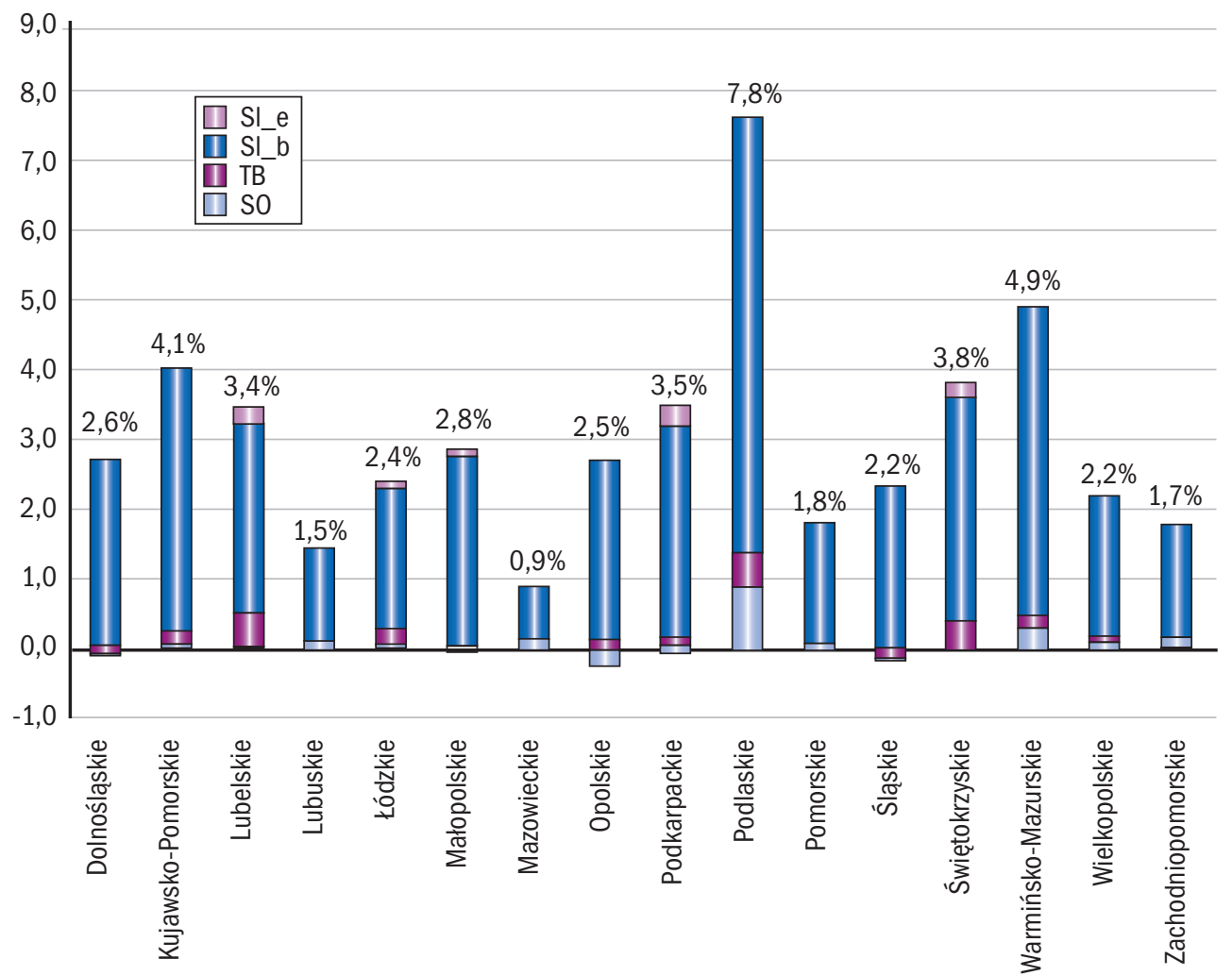

Rysunek 4.3. Regionalny rozkład skuteczności instrumentów polityki ROW 2004-2006 [zmiana PKB w \%]

Źródło: Obliczenia własne na podstawie modelu RegPOL. 
Największy wzrost gospodarczy województwa zawdzięczały w pierwszej kolejności instrumentom typu: subsydia inwestycyjne w infrastrukturę (SI_b), w drugiej kolejności transferom bezpośrednim (TB), a następnie w tym samym stopniu subsydiom obszarowym (SO) oraz subsydiom inwestycyjnym w kapitał ludzki (SI_e). Dzięki SI_b największy wzrost uzyskały województwa: podlaskie (o 6,3\%), warmińsko-mazurskie (4,4\%) i kujawsko-pomorskie (3,8\%). Z SI_e największy wzrost uzyskały podkarpackie (0,3\%) oraz lubelskie i świętokrzyskie (po 0,2\%). Z kolei dzięki TB najwięcej na wzroście gospodarczym zyskały lubelskie $(0,5 \%)$, podlaskie $(0,5 \%)$ oraz świętokrzyskie $(0,4 \%)$. A z SO najwyższy wzrost uzyskały podlaskie $(0,9 \%)$ i warmińsko-mazurskie $(0,3 \%)$. Trzeba tu podkreślić, że uzyskanie pomocy w ramach SO nie zawsze gwarantowało wzrost gospodarczy i pewne województwa straciły na tempie wzrostu - np. opolskie o - $0,2 \%$ oraz podkarpackie, małopolskie, dolnośląskie i śląskie o -0,1\%. Jak to możliwe? Otóż w gospodarce wszystkie sektory i regiony konkurują między sobą o środki produkcji (kapitał i pracę). Wymienione województwa uzyskały relatywnie najniższe wsparcie w formie SO, (czyli subsydiów do czynnika produkcji), w relacji do swoich PKB (tabela 4.1). Tak więc odczuły one relatywne podwyższenie średnich kosztów czynników produkcji i, co za tym idzie, presję na odpływ kapitału (ludzkiego i fizycznego), idącego za wyższym zwrotem w innych województwach. To z kolei przełożyło się na ich niższe możliwości produkcyjne i spadek tempa wzrostu w tych właśnie województwach.

Tabela 4.3. Ranking województw pod względem skuteczności polityki ROW

\begin{tabular}{|c|c|c|c|c|c|c|}
\hline & SO & TB & SI_b & SI_e & SUMA & Miejsce \\
\hline Podlaskie & 0,9 & 0,5 & 6,3 & 0,1 & 7,8 & 1 \\
\hline Warmińsko-Mazurskie & 0,3 & 0,2 & 4,4 & 0,0 & 4,9 & 2 \\
\hline Kujawsko-Pomorskie & 0,1 & 0,2 & 3,8 & 0,0 & 4,1 & 3 \\
\hline Świętokrzyskie & 0,0 & 0,4 & 3,2 & 0,2 & 3,8 & 4 \\
\hline Podkarpackie & $-0,1$ & 0,2 & 3,1 & 0,3 & 3,5 & 5 \\
\hline Lubelskie & 0,0 & 0,5 & 2,7 & 0,2 & 3,4 & 6 \\
\hline Małopolskie & $-0,1$ & 0,0 & 2,8 & 0,1 & 2,8 & 7 \\
\hline Dolnośląskie & $-0,1$ & 0,0 & 2,7 & 0,0 & 2,6 & 8 \\
\hline Opolskie & $-0,2$ & 0,1 & 2,6 & 0,0 & 2,5 & 9 \\
\hline Łódzkie & 0,0 & 0,2 & 2,0 & 0,1 & 2,3 & 10 \\
\hline Wielkopolskie & 0,1 & 0,1 & 2,0 & 0,0 & 2,2 & 11 \\
\hline Śląskie & $-0,1$ & 0,0 & 2,3 & 0,0 & 2,2 & 12 \\
\hline Pomorskie & 0,1 & 0,0 & 1,7 & 0,0 & 1,8 & 13 \\
\hline Zachodniopomorskie & 0,1 & 0,0 & 1,6 & 0,0 & 1,7 & 14 \\
\hline Lubuskie & 0,1 & 0,0 & 1,3 & 0,0 & 1,4 & 15 \\
\hline Mazowieckie & 0,1 & 0,0 & 0,7 & 0,0 & 0,8 & 16 \\
\hline
\end{tabular}

Źródło: Obliczenia własne na podstawie modelu RegPOL. 
Trzeba zaznaczyć, że nie jest to duży spadek, ale odzwierciedla mechanizmy gospodarki opartej na konkurencji. W takim układzie nie każdy przypływ funduszy skutkuje poprawą wzrostu gospodarczego dla wszystkich województw, bo dopiero relatywna wielkość wsparcia oraz indywidualne, regionalne relacje między zasobami pracy, ziemi i kapitału (które zależą z kolei od struktury sektorowej poszczególnych województw), decydują o rozkładzie rozwoju regionalnego. Niektóre województwa korzystają bardziej niż inne, a niektóre czasem tracą. Zwracał na tę kwestię uwagę m.in. Gorzelak [2007], krytykując takie modele, które zawsze wykazują dodatnie efekty finansowania pochodzącego z zewnątrz, co może wskazywać na słabość w ich konstrukcji - por. [Błąd 2007].

Jeśli chodzi o wpływ poszczególnych działań na rozwój województw, na przykładzie największych reprezentantów poszczególnych typów instrumentów można zauważyć, że inwestycje w gospodarstwa rolne (należące do typu SI_b) w dużo większym stopniu przyczyniły się do rozwoju regionów niż pozostałe działania (rysunek 4.4 oraz tabela 4.4). Przyczyniły się one do wzrostu gospodarczego o $2,1 \%$ w województwie podlaskim, o 1,3\% w świętokrzyskim oraz 1,2\% w dolno-

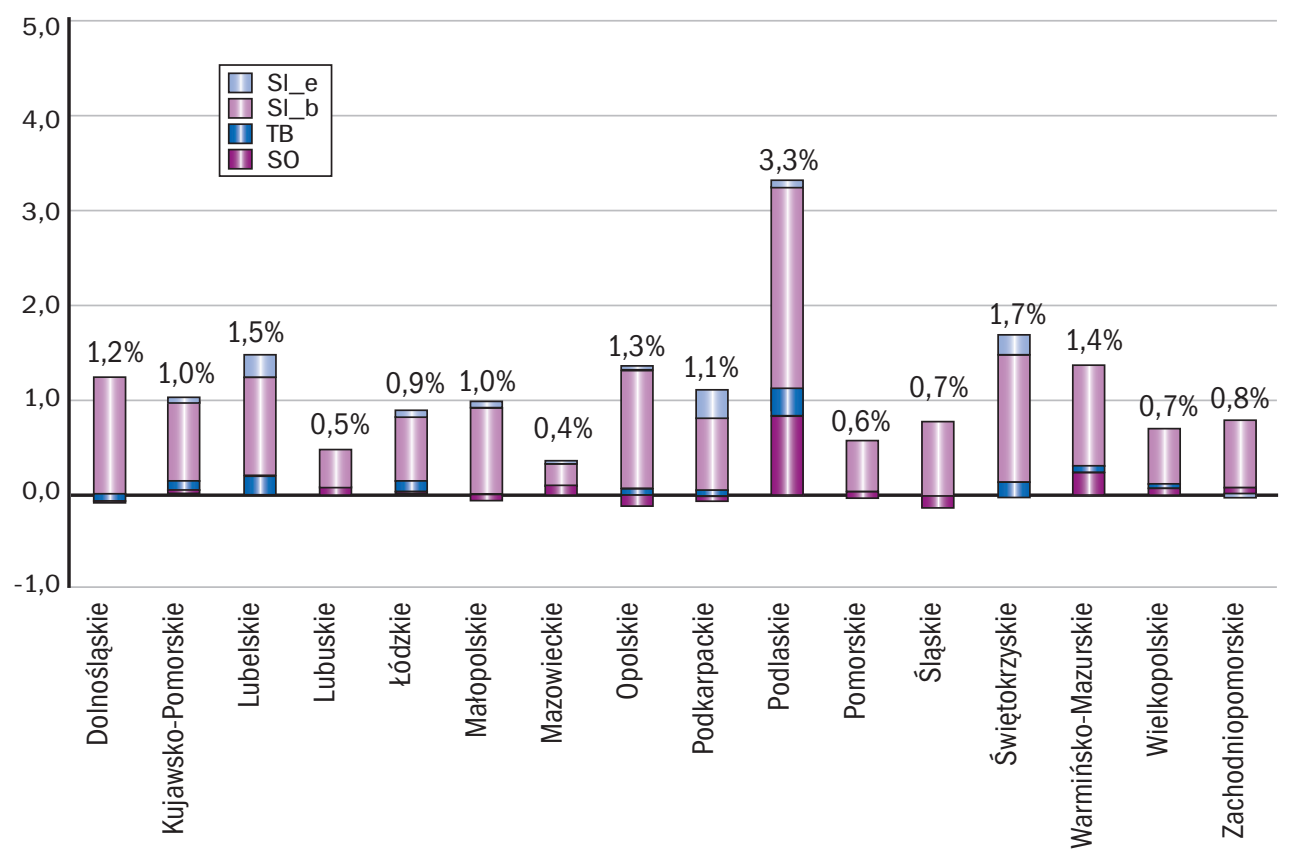

Rysunek 4.4. Regionalny rozkład skuteczności wybranych działań polityki ROW 2004-2006 [zmiana PKB w \%]

Źródło: Obliczenia własne na podstawie modelu RegPOL. 
śląskim. Renty strukturalne najwięcej przyczyniły się do wzrostu gospodarczego W województwie podlaskim $(0,3 \%)$ i lubelskim $(0,2 \%)$, a doradztwo i szkolenia w województwach podkarpackim $(0,3 \%)$, oraz świętokrzyskim i lubelskim $(0,2 \%)$. Wpływ działania ONW na rozwój regionalny był mieszany - nie we wszystkich województwach przyczyniał się do wzrostu gospodarczego, ze względu na swój specyficzny charakter, czyli subsydium do czynnika produkcji. Rywalizacja regionów o czynniki produkcji (o czym była już mowa powyżej) powoduje, że jedne województwa uzyskują pozytywną zmianę PKB (większość województw), a inne tracą na takim działaniu.

Tabela 4.4. Zmiana w PRB na skutek wybranych działań polityki ROW z okresu 2004-2006 wg województw [w \%]

\begin{tabular}{lcc|c|c}
\hline $\begin{array}{c}\text { Zmiana w PKB, w \% } \\
\text { na skutek działań }\end{array}$ & $\begin{array}{c}\text { Wsparcie } \\
\text { ONW (SO) }\end{array}$ & $\begin{array}{c}\text { Renty } \\
\text { strukturalne (TB) }\end{array}$ & $\begin{array}{c}\text { Inwestycje } \\
\text { w gospodarstwach } \\
\text { (SI_b) }\end{array}$ & $\begin{array}{c}\text { Doradztwo } \\
\text { i Szkolenia } \\
\text { (SI_e) }\end{array}$ \\
\hline Dolnośląkie & $-0,06$ & 0,02 & 1,22 & $-0,02$ \\
Kujawsko-Pomorskie & 0,05 & 0,11 & 0,86 & 0,03 \\
Lubelskie & 0,02 & 0,19 & 1,04 & 0,23 \\
Lubuskie & 0,07 & 0,00 & 0,41 & 0,00 \\
Łódzkie & 0,04 & 0,11 & 0,67 & 0,09 \\
Małopolskie & $-0,05$ & 0,01 & 0,90 & 0,08 \\
Mazowieckie & 0,12 & 0,01 & 0,21 & 0,02 \\
Opolskie & $-0,11$ & 0,07 & 1,26 & 0,04 \\
Podkarpackie & $-0,06$ & 0,06 & 0,75 & 0,30 \\
Podlaskie & 0,83 & 0,29 & 2,14 & 0,06 \\
Pomorskie & 0,04 & 0,01 & 0,53 & $-0,03$ \\
Ślaskie & $-0,12$ & $-0,02$ & 0,78 & 0,01 \\
Świętokrzyskie & $-0,02$ & 0,15 & 1,34 & 0,21 \\
Warmińsko-Mazurskie & 0,24 & 0,07 & 1,04 & 0,01 \\
Wielkopolskie & 0,08 & 0,04 & 0,57 & 0,00 \\
Zachodniopomorskie & 0,08 & 0,02 & 0,70 & $-0,03$ \\
SUMA & $\mathbf{1 , 2}$ & $\mathbf{1 , 1}$ & $\mathbf{1 4 , 4}$ & $\mathbf{1 , 0}$ \\
\hline
\end{tabular}

Żródło: Obliczenia własne na podstawie modelu RegPOL.

Analizując wszystkie typy instrumentów razem, trzeba zauważyć, że wszystkie województwa, w mniejszym czy większym stopniu, skorzystały na polityce rozwoju obszarów wiejskich prowadzonej w latach 2004-2006. Zdecydowanie w największym stopniu skorzystało województwo podlaskie. Na skutek tej polityki uzyskało skumulowany długookresowy wzrost PKB o 7,8\% (tabela 4.3). Jest to jedno z najbiedniejszych województw (ok. 2,4\% PKB), o najwyższym odsetku ludności wiejskiej pracującej w rolnictwie (69\%). Udało mu się jednak zdobyć najwyższe wsparcie w relacji do własnego produktu regionalnego brutto (PRB), tj. 6,3\%. 
Również w wielkościach absolutnych wsparcie to było wyższe niż przeciętna dla województw. W strukturze tego wsparcia przeważały SI_b (jak mówiliśmy powyżej, najbardziej skuteczne wśród instrumentów) oraz SO, co pomogło w przyciągnięciu kapitału do tego województwa i uzyskaniu wysokiego wzrostu gospodarczego przy niskim stanie początkowym PKB.

W drugiej kolejności najwięcej skorzystały województwa warmińsko-mazurskie (wzrost PKB o 4,9\%) oraz kujawsko-pomorskie (wzrost o 4,1\%). Są to województwa, które w strukturze zrealizowanych środków charakteryzowały się jednymi z najwyższych udziałów subsydiów inwestycyjnych, czyli instrumentów proefektywnościowych. Ich udział w całości środków zaabsorbowanych przez te województwa wyniósł odpowiednio 58\% i 46\%. Oba te województwa należą do znacząco rolniczych, ale nie przeważająco rolniczych. Oba zajęły wyższą lokatę pod względem wykorzystanych funduszy niż pod względem zamożności, czyli uzyskały pozytywny efekt proporcji, odpowiednio 2,21 oraz 1,68 (szczegółowo omawialiśmy tę kwestię powyżej). Jednak województwa te różnią się dość znacznie pod względem zamożności - województwo warmińsko-mazurskie zajmuje miejsce 13. a kujawsko-pomorskie 8 . w rankingu krajowym pod względem PKB na mieszkańca.

Najmniej z kolei skorzystało z polityki ROW 2004-2006 województwo mazowieckie, jedno z najbardziej zurbanizowanych i najbogatsze (1. lokata w PKB na mieszkańca). Charakteryzowało się niekorzystnym stosunkiem kwoty funduszy do siły ekonomicznej $(0,78)$. W strukturze zaabsorbowanych środków przeważało „wsparcie dla obszarów ONW” (27\%), w drugiej „dostosowania do standardów UE” (18\%) a w trzeciej „renty strukturalne” (14\%) - tabela A.2.9. Z drugiej strony, z danych statystycznych GUS oraz różnych opracowań [Kalinowski 2006] wiadomo, że Mazowsze jest liderem, jeśli chodzi o rozwój. Jest to region o zdecydowanie najwyższej dynamice produktu regionalnego brutto i charakteryzuje się najwyższymi zmianami w dostępności czynników produkcji (zasobów). Jednak można stwierdzić, że efekty polityki obszarów wiejskich są w tym województwie najniższe w całym kraju (wzrost o 0,9\% regionalnego PKB).

- SKUTECZnOŚć POLITYKi ROW A WIELKOŚć, RANGa I STRUKTURA FUNDUSZY ROW. Na koniec ważne jest postawienie pytania, od czego mogła zależeć skuteczność regionów w wykorzystaniu instrumentów polityki ROW. Obierając za miarę skuteczności najbardziej wymierną zmienną ekonomiczną, czyli zmianę w wojewódzkich PRB na skutek polityki ROW, spróbujemy zweryfikować kilka najbardziej prawdopodobnych i łatwych do sprawdzenia w sposób ilościowy, determinantów skuteczności tej polityki. 
Pierwsze, co w oczywisty sposób nasuwa się do przeanalizowania, to, w jakim stopniu skuteczność zależała od wielkości uzyskanych funduszy. W tym celu porównaliśmy skuteczność z wielkością funduszy uzyskanych przez województwa, jako \% ich PRB. Jak pokazuje rysunek 4.5, zgodnie z tym, czego mogliśmy oczekiwać, istnieje wyraźna i pozytywna zależność między skutecznością a wielkością uzyskanych funduszy na ROW. Współczynnik korelacji Pearsona wyniósł +0,87, a wartość R2 dopasowania do linii trendu wyniosła 0,81 .

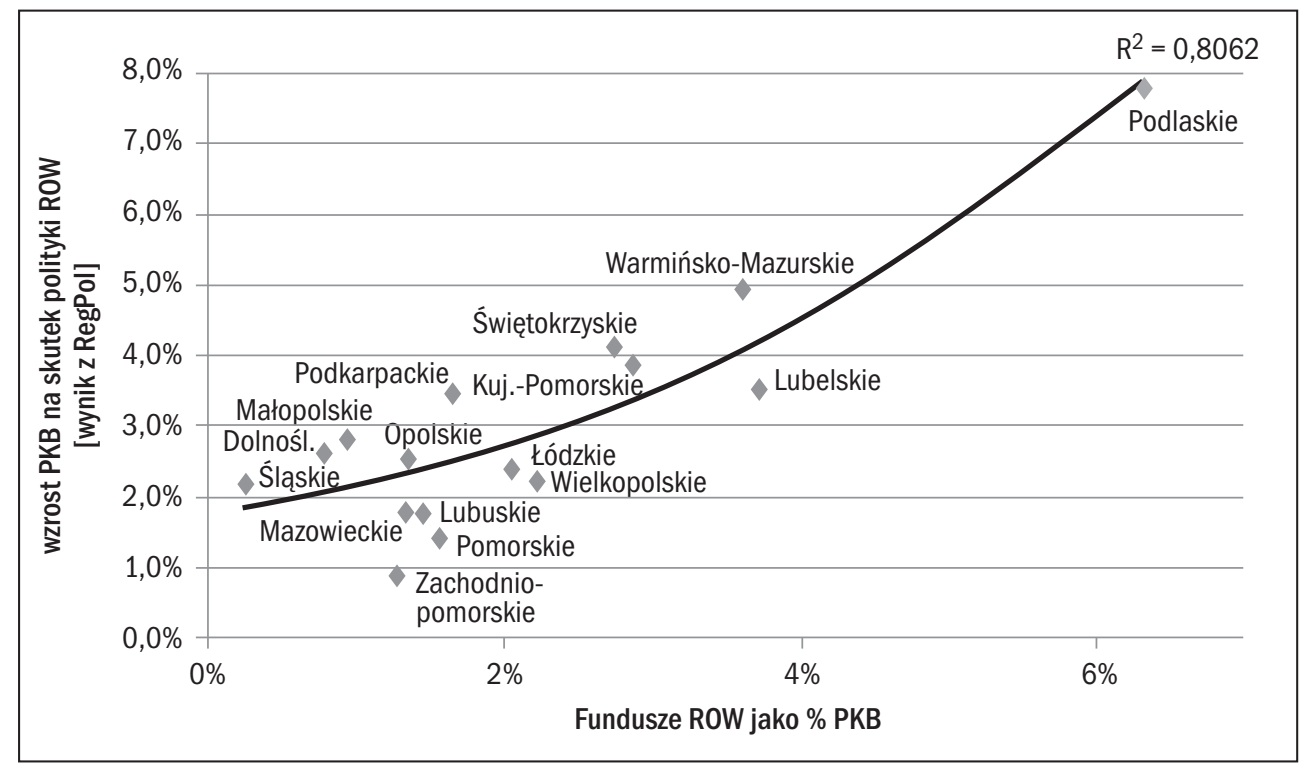

Rysunek 4.5. Zależność między skutecznością polityki ROW a wielkością uzyskanych funduszy na ROW w latach 2004-2006

Źródło: Obliczenia własne na podstawie wyników modelu RegPOL i Roczników Statystycznych GUS.

Warto też porównać zależność między skutecznością polityki ROW a zamożnością województw, sprawdzając czy rzeczywiście i w jakim stopniu polityka ta była ważniejsza dla biedniejszych województw niż dla bogatych. Wyniki porównania obrazuje rysunek 4.6.

Daje się zauważyć pewną ujemną zależność, ale jest ona znacznie słabsza niż w przypadku wielkości funduszy. Współczynnik korelacji Pearsona wyniósł -0,49, a wartość R-kwadrat dla linii trendu zaledwie 0,25. Można więc jedynie zaryzykować ogólne stwierdzenie, że ponieważ biedniejszym województwom udało się pozyskać relatywnie więcej funduszy ROW niż bogatym i ponieważ znaczyły one dla 
Rozdział 4. Analiza efektów wsparcia rozwoju obszarów wiejskich przy zastosowaniu modelu RegPOL

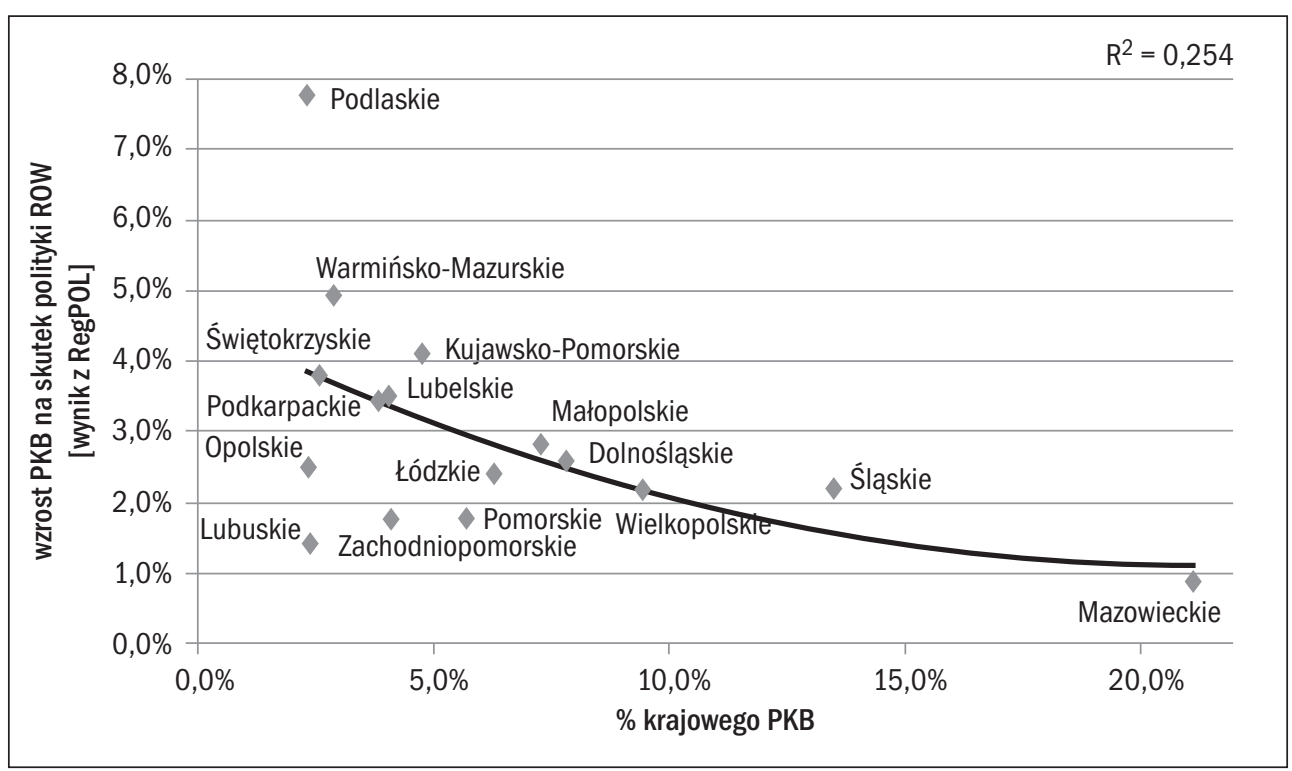

Rysunek 4.6. Zależność między skutecznością polityki ROW a siłą ekonomiczną/zamożnością województw w latach 2004-2006

Źródło: Obliczenia własne na podstawie danych [GUS 2008a] oraz wyników modelu RegPOL.

ich gospodarek relatywnie więcej, to nie dziwi, że wykazały się dzięki nim większą skutecznością w osiągnięciu rozwoju. W ten sposób pośrednio obserwujemy negatywną zależność między dobrobytem a skutecznością.

Po przeanalizowaniu takich determinantów skuteczności, jak wielkość pozyskanych funduszy i ich ważność w relacji do zamożności województw, zbadano, czy skuteczność zależała od struktury wchłoniętych funduszy ROW. Można bowiem przypuszczać, że województwa, które pozyskały więcej funduszy proefektywnościowych, osiągnęły lepszą skuteczność niż te, bazujące na funduszach prorównościowych. Ale niekoniecznie musi tak być, bo województwa mogły różnić się efektywnością ich wykorzystania, więc zależność ta nie musi wystąpić. W celu jej zweryfikowania porównujemy skuteczność polityki ROW z wielkością funduszy ( $w$ \% PRB) pozyskanych w formie subsydiów inwestycyjnych. Zależność tę przedstawia rysunek 4.7 .

W poszczególnych województwach zależność między funduszami przeznaczonymi na subsydia inwestycyjne a ich skutecznością nie jest liniowa. Gdyby pominąć dwa wyróżniające się województwa, tj. wielkopolskie i mazowieckie, w pozostałych można zauważyć, że występuje wyraźna pozytywna zależności między środkami przeznaczonymi na inwestycje a skutecznością. To może mieć zwią- 


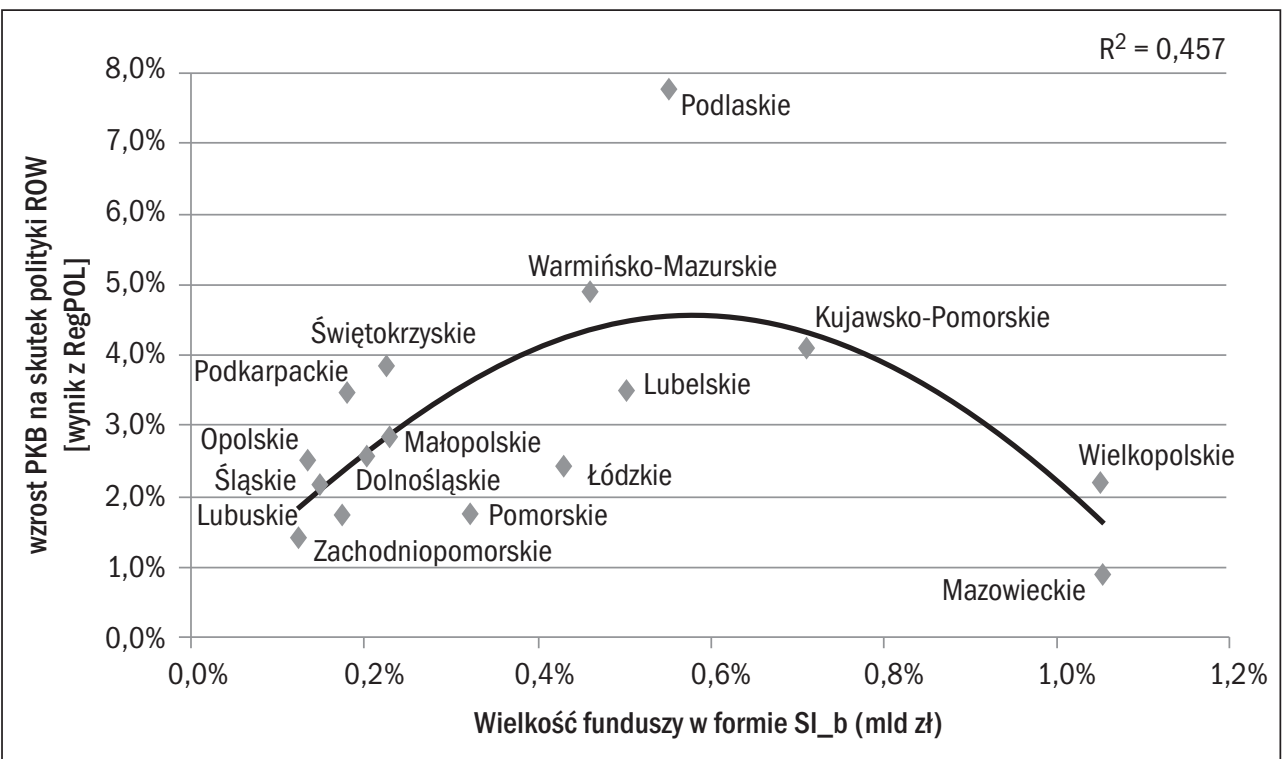

Rysunek 4.7. Zależność między wzrostem PRB a wielkością funduszy ROW na rzecz inwestycji w infrastrukturę, według województw w latach 2004-2006

Źródło: Obliczenia własne na podstawie danych ARiMR oraz wyników modelu RegPOL.

zek ze zróżnicowaną efektywnością inwestycji. Możliwa jest bowiem taka sytuacja, że w województwach nasyconych już w dużym stopniu inwestycjami w rolnictwie, efektywność zainwestowanego kapitału jest mniejsza niż w województwach ubogich w ten kapitał. Takie rozumowanie jest zgodne z prawem malejących krańcowych przychodów z kapitału. To uzasadniałoby paraboliczny kształt krzywej (odwrócone U), charakteryzujący skuteczność wykorzystania funduszy ROW w zależności od wielkości pozyskanych subsydiów inwestycyjnych.

Oczywiście powyższe rozważania na temat przyczyn zróżnicowania skuteczności polityki ROW są dalece niewystarczające. Zbadaliśmy zaledwie kilka najbardziej oczywistych i najłatwiejszych do skwantyfikowania hipotetycznych determinantów skuteczności, nie uwzględniliśmy natomiast całego spektrum, chociażby różnic jakościowych. Z całą pewnością pomiędzy województwami zachodzą różnice w jakości inwestycji, w proporcji wydatkowania transferów bezpośrednich pomiędzy inwestycje a konsumpcję, w strategii wykorzystania funduszy i inne różnice, które też determinują skuteczność polityki, a nie dały się tu ująć w sposób ilościowy (np. poziom kultury rolnej, nasycenie inwestycji, jakość inwestycji etc.). Zbadanie wszystkich determinantów skuteczności tej polityki wymagałoby osobnego opracowania, a tak daleko idąca analiza, również jakościowa, 
wykracza zdecydowanie poza tematykę tego opracowania. Pozostawia jednak otwarte pole do dalszych badań w tym kierunku.

Podsumowując, pozytywne skutki ekonomiczne wywołane działaniami proefektywnościowymi były wielokrotnie większe, niż te spowodowane działaniami prorównościowymi. Nie widać prostej zależności między siłą ekonomiczną województw a skutkami polityki ROW, czy między absolutną wielkością zaabsorbowanych środków a skutkami polityki ROW. W dużej mierze skuteczność polityki ROW dla poszczególnych województw zdeterminowana była: proporcją działań prorównościowych w stosunku do proefektywnościowych w strukturze zaabsorbowanych środków ROW oraz proporcją uzyskanych środków ROW do siły ekonomicznej poszczególnych województw.

\subsection{Efektywność instrumentów ROW w skali krajowej i regionalnej}

Do tej pory rozważaliśmy skutki ekonomiczne realizacji różnych typów instrumentów i działań, pomijając różnice w poniesionych na nie wydatkach. Kiedy chcemy jednak ocenić efektywność tych działań i instrumentów, musimy wziąć pod uwagę różnice w poniesionych na nie kosztach/nakładach, czyli uwzględnić fakt, że na poszczególne działania w województwach przypadały odmienne wielkości funduszy, które w dodatku miały zróżnicowane relatywne znaczenie dla poszczególnych województw. Jeśli chodzi o efektywność, to mierzona jest ona jako rezultat uzyskany przy danych nakładach, czyli, innymi słowy, jako relacja korzyści do kosztów [Oxford Economic Dictionary 1997, s. 139, ODPM 2004, s. 113, The Economists Dictionary]. Oczywiście korzyści i koszty można mierzyć na różne sposoby, dlatego dostępnych jest wiele wskaźników efektywności. W naszym przypadku posłużymy się prostą miarą relacji korzyści do kosztów (benefits-cost ratio), gdzie za korzyści z poszczególnych działań przyjęliśmy wzrost gospodarczy zarówno krajowy, jak i w poszczególnych województwach, w następstwie implementacji poszczególnych działań. Za koszty zaś przyjęliśmy fundusze wydatkowane na te działania na poziomie krajowym i wojewódzkim. Jednak ze względu na duże zróżnicowanie tych kosztów, i w rozbudowanym układzie przestrzennym (analizujemy 19 działań w 16 województwach), trudno jest przedstawić w usystematyzowany i jasny sposób zmiany w efektywności przy takiej zmienności kosztów. Dlatego dla większej klarowności pełne koszty działań dla wszystkich województw sprowadzone zostały do tej samej wielkości. W takiej sytuacji przy tych samych nakładach zmieniające się korzyści wprost odzwierciedlają zmiany w efektywności. Mierząc zatem efektywność jako stosunek korzyści do kosztów przy stałym mianowniku (koszty), zmieniające się w liczniku korzyści będę odzwierciedlały zmiany efektywności. 
Zrównanie kosztów było możliwe dzięki wykorzystaniu modelu RegPOL, który pozwolił na symulację hipotetycznego scenariusza polityki ROW, w którym wszystkie regiony otrzymują tę samą kwotę wsparcia na realizację każdego z 4 typów instrumentów, przypomnijmy: subsydiów inwestycyjnych (SI_b i SI_e), subsydiów obszarowych (SO) oraz transferów bezpośrednich (TB). W naszym scenariuszu symulacyjnym każde województwo otrzymało po $50 \mathrm{mln}$ zł na każde z 4 typów działań, zatem w sumie dostało $200 \mathrm{mln}$ zł. Zrównując w ten sposób fundusze na działania (stanowiące koszty polityki ROW), możemy dużo łatwiej ocenić ich efektywność, nie tracąc przy tym prawdziwego obrazu. Przeskalowaliśmy tylko stosunek korzyści do kosztów, nie wpływając na zmianę proporcji. Interpretacja naszych wyników w tym scenariuszu sprowadza się do tego, że efektywność funduszy jest tym większa, im większe generują one efekty, mierzone różnymi wskaźnikami ekonomicznymi - tymi samymi, co w przypadku skuteczności. Jednak tu przy interpretacji musimy pamiętać, że sens mają wielkości wyrażone w sposób relatywny, a nie absolutny, ze względu na przeskalowanie kosztów. Podawane wielkości absolutne służą jedynie jako podstawa do oceny wartości relatywnych, a nie są informacją samą w sobie. Ważne jest, które działania są bardziej/mniej efektywne w kreowaniu rozwoju mierzonego zmianami procentowymi wybranych wskaźników ekonomicznych; ważna jest też skala różnic w tak mierzonej efektywności.

- EFEKTYWNość FUNDUSzy ROW A ROZWóJ GOSPODARKI. Wyniki symulacji modelowych pokazały, że różnice w efektywności działań w skali kraju są duże $\mathrm{i}$ istotne. Nasze 4 typy działań można podzielić na dwie grupy inaczej oddziałujące na gospodarkę, kreujące odmienne mechanizmy. Inaczej oddziaływały transfery bezpośrednie (TB) i subsydia obszarowe ( $\mathrm{SO}$ ), a inaczej subsydia inwestycyjne (SI_b i SI_e). Obrazuje to rysunek 4.8.

Najefektywniejsze okazały się działania o charakterze subsydiów inwestycyjnych, ale w odróżnieniu od badań skuteczności, nie tylko tych, które związane były z budownictwem/infrastruktura, ale też tych związanych z kapitałem ludzkim (z małą tylko przewagą tych pierwszych). Przy subsydiach w kapitał ludzki, wyraźnie widać różnicę w stosunku do analizy skuteczności, gdzie ze względu na ich bardzo mały udział w całej polityce ROW miały znikomą skuteczność. Natomiast jak wskazuje analiza, ich efektywność jest bardzo wysoka, prawie na równi z efektywnością inwestycji w infrastrukturę. Zatem działania o charakterze subsydiów inwestycyjnych $\mathrm{w}$ największym stopniu w porównaniu z innymi przyczyniały się do wzrostu PKB, zatrudnienia w gospodarce oraz wzrostu eksportu. Jednocześnie jako jedyne nie tworzyły presji inflacyjnej. 
Rozdział 4. Analiza efektów wsparcia rozwoju obszarów wiejskich przy zastosowaniu modelu RegPOL

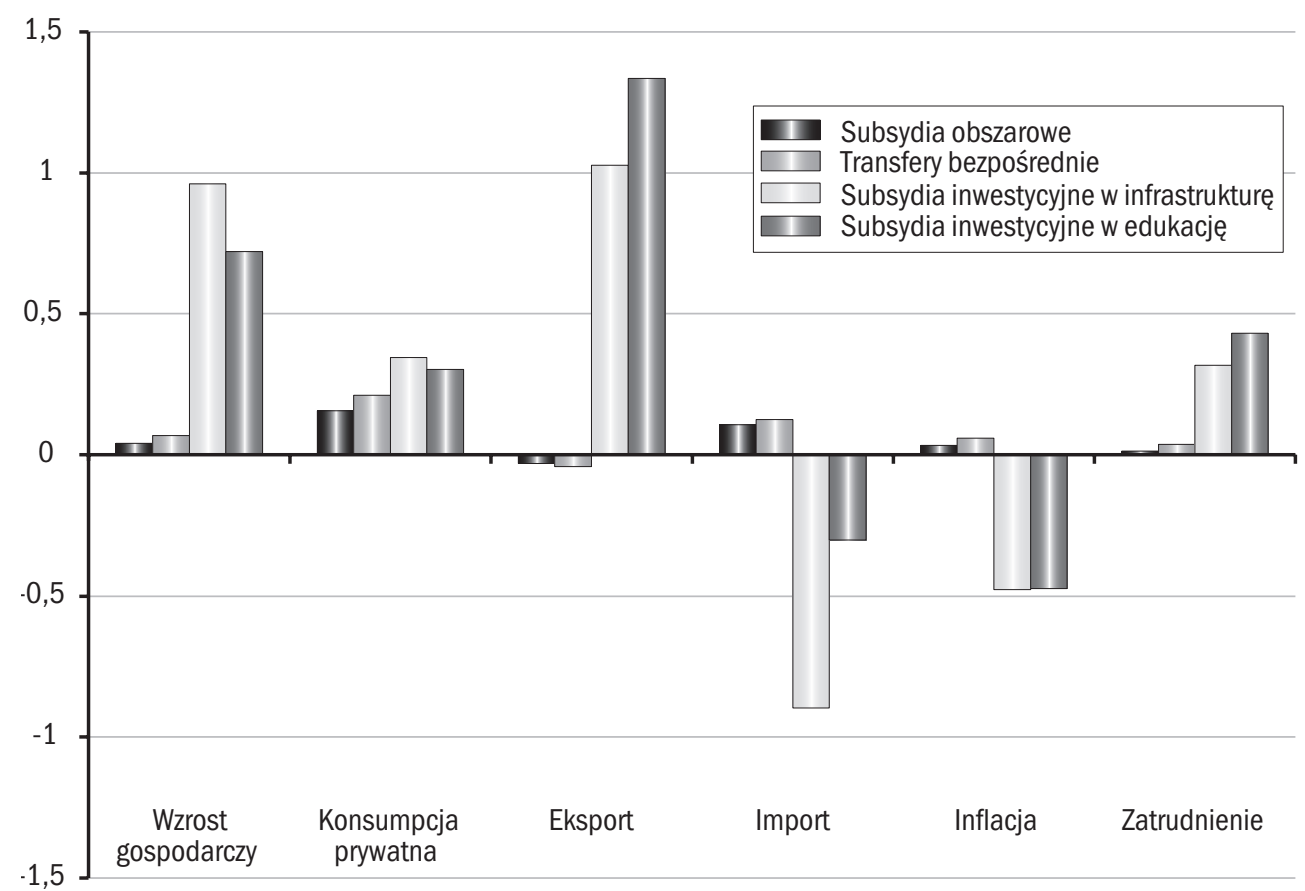

Rysunek 4.8. Efektywność działań ROW w skali całego kraju [w \%]

Źródło: Obliczenia własne na podstawie modelu RegPOL.

- Efektywność dziąań ROW a wZrost PKB. Porównując efekt tej samej kwoty funduszy wydanej w formie subsydiów inwestycyjnych z pozostałymi formami działań, stwierdziliśmy, że przynoszą one wielokrotnie większy pozytywny impuls do wzrostu PKB niż pozostałe formy wsparcia. Jeśli porównać z kolei transfery bezpośrednie z płatnościami obszarowymi, to widać, że te pierwsze tylko nieznacznie bardziej stymulują rozwój niż te drugie. Prawdopodobnie jest to spowodowane mniejszymi zakłóceniami rynku przy wsparciu bezpośrednim dochodów niż w przypadku wsparcia poprzez wynagrodzenie czynników produkcji. Takie zachowanie jest zgodne z teorią ekonomii.

- EFeKTywność fUnduszy ROW a wZrost KONSUMPCJI. Mimo iż fundusze ROW były zróżnicowane pod względem charakteru ekonomicznego, to ich efektywność w podwyższaniu konsumpcji prywatnej była bardzo podobna. Największy pozytywny wpływ miały subsydia inwestycyjne SI_b, potem kolejno były to SI_e, TB i na końcu SO. Wpływ ten we wszystkich przypadkach był pozytywny. Zatem można zaryzykować stwierdzenie, że jeśli celem polityki byłby nie rozwój 
ekonomiczny obszarów wiejskich, lecz poprawa dochodów i możliwość zwiększenia wydatków konsumpcyjnych, to wybór narzędzi wsparcia nie miałby takiego znaczenia, gdyż wszystkie one spełniałyby ten cel z podobną efektywnością.

- EFEKTYWNOŚć FUNDUSZY ROW a BILANS HANDLOWy. Najbardziej efektywnymi działaniami w promowaniu pozytywnego wyniku wymiany handlowej były subsydia inwestycyjne. Subsydia w edukację miały największy wpływ na wzrost eksportu, a z kolei subsydia inwestycyjne w infrastrukturę, przy niewiele niższym pozytywnym wpływie na eksport, dodatkowo wyróżniały się największą efektywnością w ograniczaniu importu. Subsydia obszarowe i transfery bezpośrednie nie miały dużego znaczenia dla eksportu, nieznacznie oddziaływały jednak na jego spadek, jednocześnie przyczyniały się do wzrostu importu. Z tego powodu ich wpływ na bilans handlu można ocenić negatywnie.

- EFEKTywność FUNDUSZY ROW a EFEKT CENOWY. Najbardziej efektywne w obniżaniu inflacji były subsydia inwestycyjne, tak samo SI_b, jak i SI_e, powodując jej spadek o ok. 0,5\%, podczas gdy ta sama kwota funduszy przeznaczona na TB i SO przyczyniała się do jej nieznacznego wzrostu. Podobnie jak przy interpretacji skuteczności można stwierdzić, że jest to dość oczekiwany rezultat - wzrost inwestycji nie podwyższa wskaźnika cen dóbr konsumpcyjnych, najwyżej dóbr produkcyjnych (w naszym przypadku były to z pewnością materiały budowlane i inne dobra $\mathrm{z}$ nimi związane).

- EFEKTYwność FUNDUSZY ROW a ZATRUDNIENIE. Najbardziej efektywne w kreowaniu zatrudnienia w gospodarce były fundusze udzielane w formie subsydiów na inwestycje w kapitał ludzki. Nieco mniej efektywne były subsydia w inwestycje infrastrukturalne, a zupełnie nieefektywne TB i SO.

- EFEKTyWNOŚć dZIAŁAŃ W POSZCZEgólNYCH REgIONACH. W większości województw najbardziej efektywną formą wsparcia rozwoju obszarów wiejskich były, podobnie jak na poziomie krajowym, inwestycje w infrastrukturę. Zaliczyć tu należy województwa: śląskie, świętokrzyskie, opolskie i małopolskie. Drugie pod względem efektywności w większości województw okazały się subsydia w kapitał ludzki ${ }^{57}$, w tym

\footnotetext{
${ }^{57}$ Inwestycjami w kapitał ludzki w ramach polityki ROW były szkolenia i doradztwo, które należą do usług edukacyjnych. Badanie ich efektywności nie uwzględnia jednak jakości tych usług w poszczególnych województwach, a jedynie ilościową charakterystykę sektora edukacyjnego i jego powiązań $\mathrm{z}$ resztą gospodarki. Zatem implicite zakładamy, że usługi doradcze i szkolenia w danym województwie reprezentują taki sam poziom, jak cały sektor edukacji w tym województwie.
} 
W szczególności w województwach śląskim, podkarpackim i dolnośląskim. W dwóch województwach inwestycje te były najbardziej efektywną formą wsparcia rozwoju tamtejszych obszarów wiejskich (w lubelskim i mazowieckim). Z kolei w większości województw mało efektywne okazały się transfery bezpośrednie i subsydia obszarowe. W ujęciu regionalnym różnice w efektywności poszczególnych działań prezentują tabela 4.5 i rysunek 4.9 .

Tabela 4.5. Ranking województw pod względem efektywności polityki ROW w latach 2004-2006

\begin{tabular}{lcc|c|c|c|c}
\hline \multicolumn{1}{c|}{ Wzrost PKB } & SO & TB & IS_b & IS_e & Razem & Miejsce \\
\hline Sląskie & $-0,08$ & 0,15 & 3,17 & 3,02 & 6,26 & 1 \\
Kujawsko-Pomorskie & 1,44 & 0,15 & 2,46 & 1,46 & 5,51 & 2 \\
Dolnośląskie & 0,41 & 0,15 & 2,52 & 2,00 & 5,08 & 3 \\
Małopolskie & $-0,16$ & 0,15 & 2,70 & 1,95 & 4,64 & 4 \\
Podkarpackie & $-0,38$ & 0,14 & 2,45 & 2,36 & 4,57 & 5 \\
Warmińsko-Mazurskie & 0,80 & 0,14 & 2,33 & 1,28 & 4,55 & 6 \\
Opolskie & $-0,02$ & 0,14 & 2,71 & 1,51 & 4,34 & 7 \\
Świętokrzyskie & $-0,32$ & 0,14 & 2,86 & 1,41 & 4,09 & 8 \\
Pomorskie & $-0,15$ & 0,14 & 2,53 & 1,54 & 4,06 & 9 \\
Zachodniopomorskie & 0,33 & 0,15 & 2,50 & 1,04 & 4,02 & 10 \\
Podlaskie & 0,68 & 0,13 & 1,99 & 1,03 & 3,83 & 11 \\
Lubelskie & 0,49 & 0,14 & 1,55 & 1,44 & 3,62 & 12 \\
Wielkopolskie & 0,81 & 0,14 & 1,61 & 0,72 & 3,28 & 13 \\
Lubuskie & $-0,03$ & 0,15 & 1,50 & 1,65 & 3,27 & 14 \\
Lódzkie & $-0,20$ & 0,15 & 1,85 & 1,03 & 2,83 & 15 \\
Mazowieckie & 0,42 & 0,09 & 1,06 & 1,07 & 2,64 & 16 \\
\hline
\end{tabular}

Źródło: Obliczenia własne na podstawie modelu RegPOL.

Ranking województw ze względu na efektywność wykorzystania działań polityki ROW wskazuje na to, że najbardziej efektywne w wykorzystaniu środków na ROW okazały się województwa śląskie, kujawsko-pomorskie, dolnośląskie, małopolskie, podkarpackie, warmińsko-mazurskie i opolskie. Z kolei na końcu w rankingu znalazły się województwa mazowieckie, lubuskie i lubelskie.

Dla upewnienia się, że wyniki hipotetycznej symulacji są wiarygodne, zastosowaliśmy jeszcze jedną metodę obliczenia efektywności. Zamiast sprowadzania kosztów dla każdego województwa do tego samego poziomu, przyjęliśmy koszty faktyczne według wydatkowanych funduszy ROW, zrelatywizowane w odniesieniu do PRB (w procentach) dla każdego województwa. Za korzyści zaś przyjęliśmy wzrost PKB (w procentach) uzyskany dzięki tym funduszom, zaprezentowany w poprzednim podrozdziale, (uzyskanym z symulacji opartej na faktycznie wydatkowanych funduszach w każdym województwie). Uzyskany za pomocą tej metody ranking województw przedstawia tabela 4.6. 


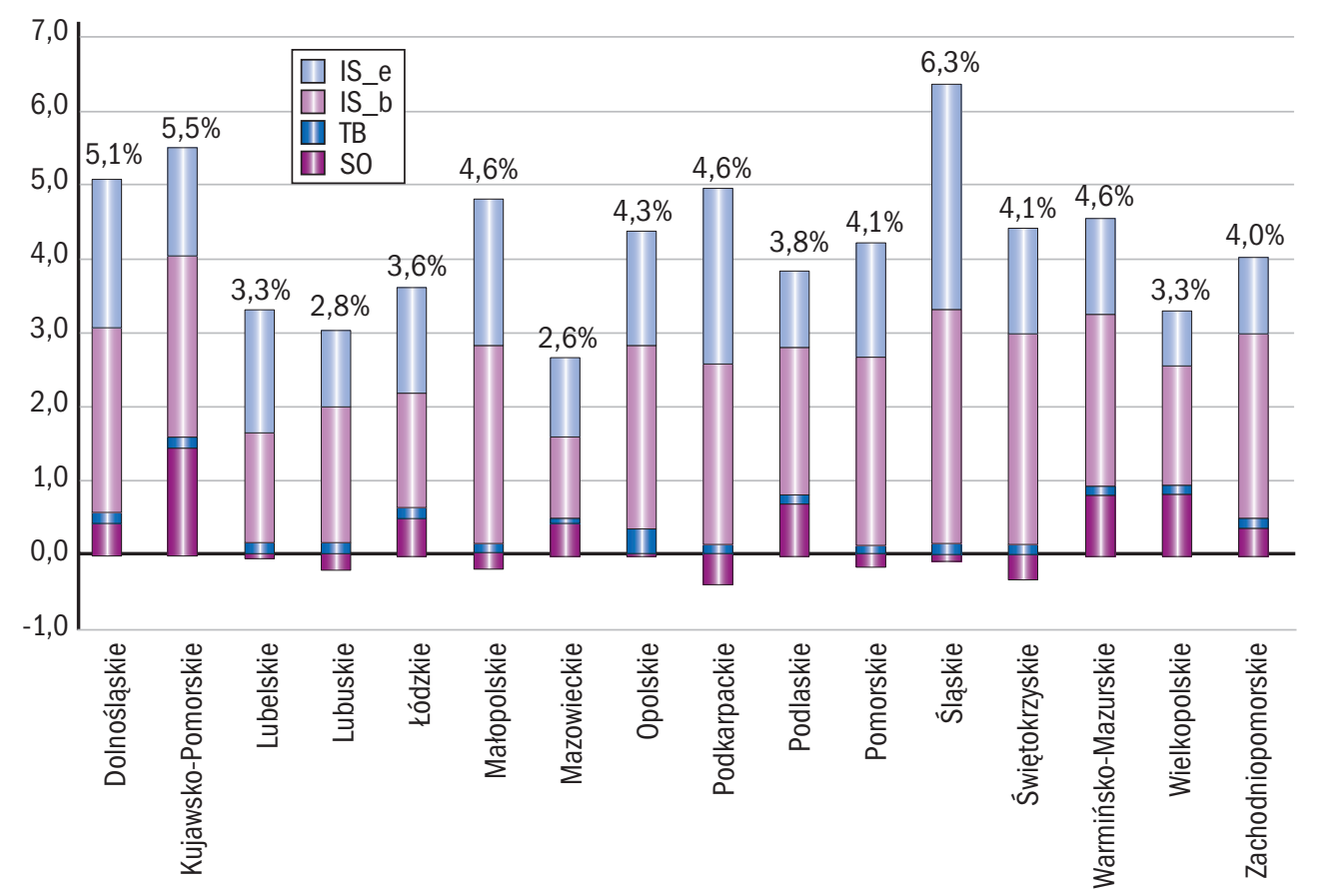

Rysunek 4.9. Efektywność polityki ROW w województwach, według wzrostu PRB [w \%] Źródło: Obliczenia własne na podstawie modelu RegPOL.

Tabela 4.6. Szacunek kosztów i korzyści z polityki ROW, wg województw

\begin{tabular}{lcc|c|c}
\hline \multicolumn{1}{c|}{ Działania/Regiony } & $\begin{array}{c}\text { Koszty } \\
\text { (w \% PKB) }\end{array}$ & $\begin{array}{c}\text { Korzyści } \\
\text { (wzrost PKB) }\end{array}$ & Korzyści/koszty & Miejsce \\
\hline Sląskie & 0,3 & 2,2 & 7,3 & 1 \\
Dolnośląskie & 0,8 & 2,6 & 3,3 & 2 \\
Małopolskie & 0,9 & 2,8 & 3,1 & 3 \\
Podkarpackie & 1,7 & 3,4 & 2,0 & 4 \\
Opolskie & 1,3 & 2,5 & 1,9 & 5 \\
Kujawsko-Pomorskie & 2,7 & 4,1 & 1,5 & 6 \\
Warmińsko-Mazurskie & 3,6 & 4,9 & 1,4 & 7 \\
Świętokrzyskie & 2,9 & 3,8 & 1,4 & 8 \\
Pomorskie & 1,3 & 1,8 & 1,3 & 9 \\
Podlaskie & 6,3 & 7,8 & 1,2 & 10 \\
Zachodniopomorskie & 1,4 & 1,7 & 1,2 & 11 \\
Lódzkie & 2,0 & 2,4 & 1,2 & 12 \\
Wielkopolskie & 2,2 & 2,2 & 1,0 & 13 \\
Lubelskie & 3,7 & 3,5 & 0,9 & 14 \\
Lubuskie & 1,5 & 1,4 & 0,9 & 15 \\
Mazowieckie & 1,3 & 0,9 & 0,7 & 16 \\
\hline
\end{tabular}

Żródło: Obliczenia własne na podstawie wyników modelu RegPOL i [ARiMR 2008]. 
Stopień efektywności wahał się dla najlepszych trzech województw między 3,1 (małopolskie) a nieco ponad 7 (śląskie). O tyle razy korzyści przekroczyły koszty. Dla kolejnej grupy stopień efektywności wahał się między 1 (wielkopolskie) a 2 (podkarpackie), pozostałe zaś województwa osiągnęły wartości poniżej progu efektywności, czyli poniżej jedności. Należały tu: mazowieckie $(0,7)$, lubuskie $(0,9)$ i lubelskie $(0,9)$. Rozkład województw względem progu efektywności dobrze obrazuje rysunek 4.10 .

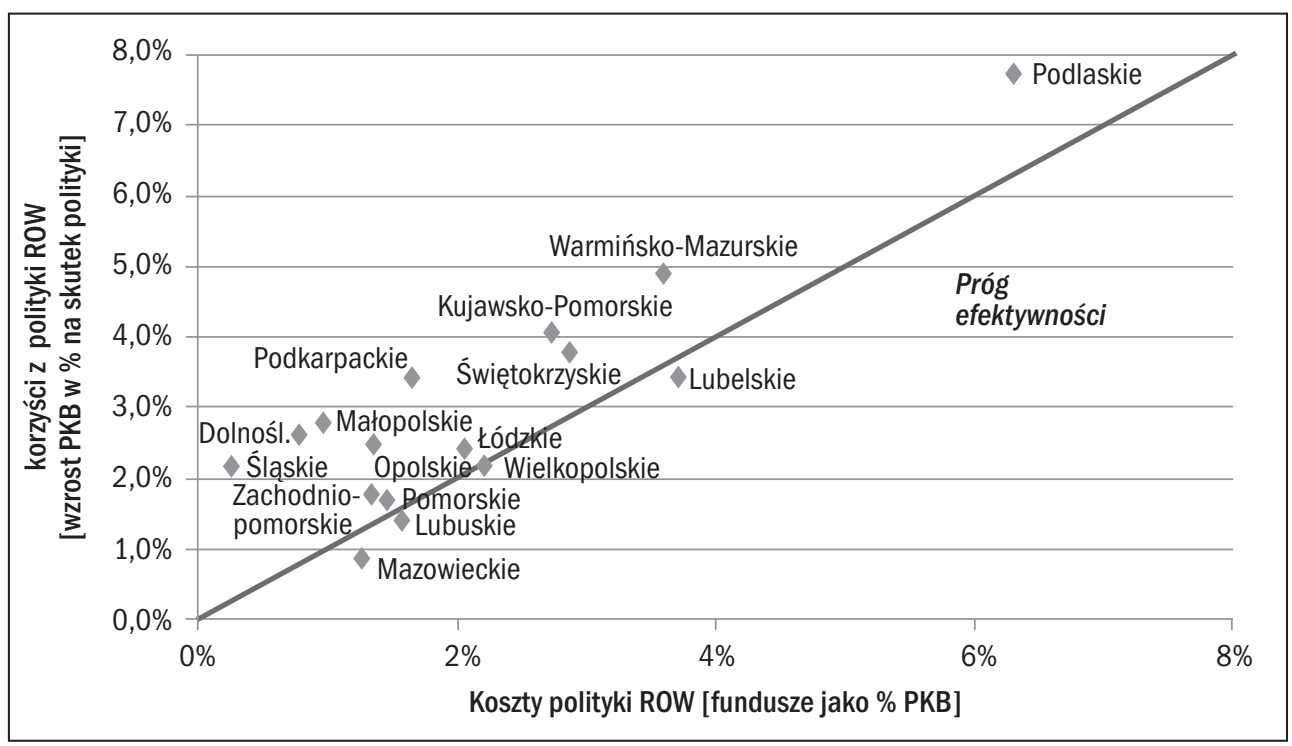

Rysunek 4.10. Stosunek korzyści do kosztów polityki ROW w układzie wojewódzkim Źródło: Prezentacja na podstawie tabeli 4.6.

Nasuwa się pytanie, czy zachodzi związek między skutecznością a efektywnością wykorzystania polityki ROW między województwami. Relację tę obrazuje rysunek 4.11. Już na pierwszy rzut oka widać, że województwa, które były najbardziej skuteczne w wykorzystaniu funduszy (linia przerywana), nie były tymi, które najbardziej efektywnie wykorzystują to wsparcie (linia ciąła). Jest to ciekawa obserwacja, gdyż poddaje pewne wnioski do ogólnej debaty na temat polityki kohezji (spójności) i podstawowego dylematu, czy warto wspierać regiony zapóźnione, czy nie. Otóż na przykładzie polityki ROW można zauważyć, że zgodnie z intencją, największe wsparcie (przynajmniej w ujęciu relatywnym, jako \% PRB) udało się uzyskać regionom, które są najbardziej wiejskie i rolnicze. Aż pięć z sześciu najbardziej skutecznie wykorzystujących pomoc województw ma 
charakter przeważająco wiejski (PW), połowa z nich jest przeważająco rolnicza, a druga połowa znacząco rolnicza (patrz typologia z rozdziału 2). Świadczy to o tym, że dobrze zdefiniowane były kryteria dostępności tych środków. Gdyby jednak przydzielać je, kierując się kryterium największej efektywności, to choć ogólny wzrost gospodarczy byłby większy, doszłoby do paradoksu polegającego na tym, że największe wsparcie dostałyby województwa najbardziej zurbanizowane. Poza tym wystąpiłby efekt zwiększania się nierówności między regionami wiejsko-rolniczymi a miejskimi. Jak zatem widać, akurat w przypadku polityki ROW wydaje się, że polityka kohezji jest uzasadniona sama przez się, gdyż właśnie najbardziej wiejskie i rolnicze regiony są jednocześnie najbardziej zapóźnione i biedne. Dla nich ta sama kwota funduszy, choć przynosi mniejszy zwrot w ujęciu relatywnym (koszty do korzyści), to jednak zwiększa skuteczność polityki ROW,

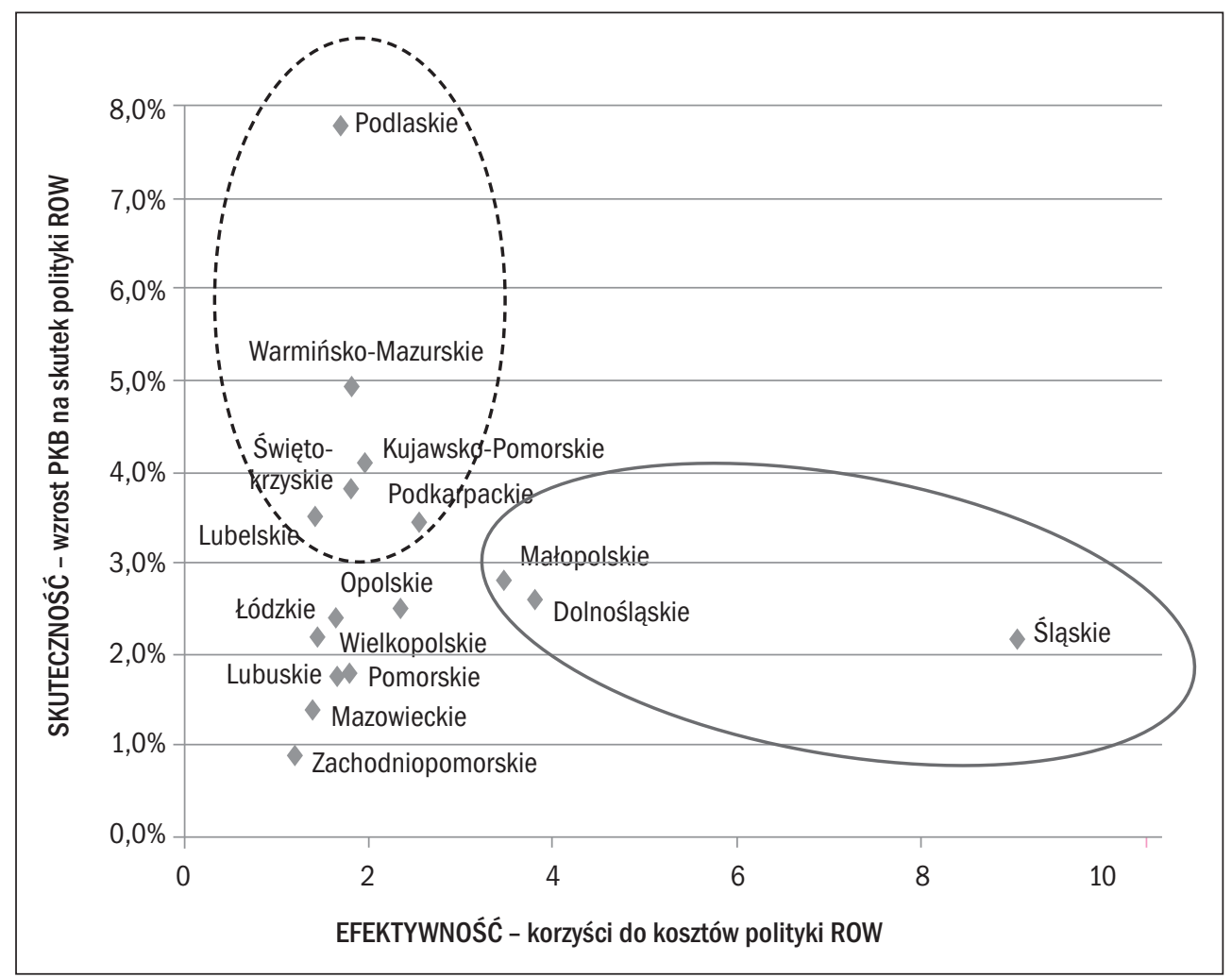

Rysunek 4.11. Regionalne zróżnicowanie związku między skutecznością a efektywnością polityki ROW

Źródło: Obliczenia własne na podstawie modelu RegPOL. 
której celem jest rozwój obszarów najbardziej wiejskich i rolniczych. Powyższy wywód w żaden sposób nie oznacza, że w polityce ROW nie należy kierować się kryterium efektywnościowym. Wprost przeciwnie (o czym piszemy dalej), kryterium efektywnościowe powinno być stosowane na etapie wyboru działań do realizowania tej polityki (wybór działań z oferty UE), a nie przy kryteriach dostępu do niej na poziomie województw.

Zanim przejdziemy do omówienia determinantów efektywności i porównamy je z tymi dla skuteczności, przeanalizujmy najpierw skutki wyboru instrumentów mniej lub bardziej efektywnych.

- KRYTERIUM EFEKTYWNOŚCIOWE A WYBÓR INSTRUMENTÓW DO REALIZACJI POLITYKI ROW. Obserwując, jak bardzo poszczególne typy instrumentów polityki różnią się między sobą efektywnością, oczywiste jest, że wybierając narzędzia mniej efektywne traci się na tempie rozwoju, który mierzymy tu wzrostem PKB. Wprawdzie nie jest to doskonały miernik rozwoju, pomija bowiem aspekty społeczne, środowiskowe, różne efekty zewnętrzne etc. jednak jego przyjęcie jest tu uzasadnionym uproszczeniem w celu weryfikacji przyjętych hipotez. W krajach rozwiniętych jest on lepszym przybliżeniem faktycznego rozwoju niż w przypadku krajów rozwijających się, gdzie uproszczenie to z pewnością obarczone byłoby dużo większym błędem.

Jak wykazaliśmy powyżej, najbardziej efektywne (według przyjętych definicji) są subsydia inwestycyjne (w infrastrukturę i kapitał ludzki), a dużo mniej transfery bezpośrednie i subsydia obszarowe. Dlaczego zatem nie zrezygnować w polityce rozwoju obszarów wiejskich z instrumentów najmniej efektywnych? Koronnym argumentem za utrzymaniem tych form pomocy jest to, że z punktu widzenia beneficjentów są najłatwiejsze do pozyskania i realizacji, a w związku z tym zapewniają wysoką absorpcję środków unijnych. To z kolei cieszy polityków, bowiem nie dochodzi do sytuacji, w której trzeba by zwracać niewykorzystane środki do budżetu UE. Jednak taki sposób myślenia w tworzeniu polityki ROW, tj. polegający na zwiększaniu absorpcji kosztem rozwoju, jest nieprawidłowy, co więcej, nie jest konieczny. Można bowiem pogodzić utrzymanie wysokiego poziomu wykorzystania funduszy, stosując jednocześnie efektywne formy wsparcia. Jak można to osiągnąć? Zamiast uciekać się do najłatwiejszych, ale mało efektywnych form wsparcia, należy uczynić wszystko, by z najbardziej efektywnych form wsparcia mogli łatwo skorzystać beneficjenci.

$\mathrm{Z}$ badań ankietowych przeprowadzonych na celowej próbie 80 pracowników regionalnych ośrodków ARiMR wynika, że istnieje bardzo duża korelacja między działaniami łatwymi i nieefektywnymi oraz działaniami trudnymi i efektywnymi (opis 
ankiety zawiera aneks 2.4). Pracownicy zapytani o to, które działania były najłatwiejsze, a które najskuteczniejsze w SPO i PROW 2004-2006, do najłatwiejszych zaliczyli: - wsparcie dla gospodarstw działających na terenach ONW - wspieranie gospodarstw niskotowarowych - wspieranie przedsięwzięć rolno-środowiskowych i poprawy dobrostanu zwierząt oraz • działanie „młody rolnik”. Są to działania, które zdefiniowaliśmy (w większości) jako prorównościowe, a które w późniejszej analizie okazały się również dużo mniej efektywne. Z kolei do najbardziej skutecznych zaliczyli oni: - dostosowanie gospodarstw do standardów UE • inwestycje w gospodarstwach rolnych • poprawa przetwórstwa i marketingu artykułów rolnych • tworzenie i rozwój infrastruktury na obszarach wiejskich oraz • różnicowanie działalności. Są to działania, które zdefiniowaliśmy jako proefektywnościowe i które okazały się w praktyce najbardziej efektywne. Zasadne jest zatem ułatwianie beneficjentom dostępu do najbardziej efektywnych działań, takich jak subsydia inwestycyjne.

Być może procedury uzyskania subsydiów inwestycyjnych byłoby łatwiej wypełniać, gdyby wymagano mniej formalności, a biznesplany byłyby mniej szczegółowe. Można też pomyśleć o zróżnicowaniu trudności wniosków, w zależności od wysokości środków. Na przykład bardzo wysokie subsydia inwestycyjne mogą być trudniejsze do zdobycia, z bardziej restrykcyjnymi procedurami, a niewielkie - mogą mieć je uproszczone. Możliwe jest też przekształcenie zwykłych transferów dochodowych w proste subsydia inwestycyjne. Najlepszym przykładem jest działanie wsparcie dla młodych rolników, które w ramach SPO Rolnictwo 2004-2006 było transferem dochodowym i z wywiadów przeprowadzonych z pracownikami ODR-ów wynika, że nierzadko przeznaczano je na cele konsumpcyjne. $\mathrm{Z}$ kolei w ramach PROW 2007-2013 przekształcono je w proste subsydium inwestycyjne: rolnik deklarował sposób wydatkowania tego wsparcia na rozwój gospodarstwa i rozliczał w dużej mierze na podstawie faktury. Jest to przykład na to, że zapis celu działania musi być poparty adekwatnym doborem narzędzia ekonomicznego, żeby instrument był skuteczny i efektywny. W tym przypadku bardziej odpowiednią formą dla tego działania (którego celem była poprawa konkurencyjności rolnictwa) była prosta mikropożyczka, a nie bezpośredni transfer dochodowy, który początkowo sprowadził to działanie do roli wsparcia socjalnego. Takie podejście zgodne jest z paradygmatem lansowanym przez OECD, promującym „inwestowanie w rozwój”, a nie „subsydiowanie rozwoju” (zagadnienie to omówiono w rozdziale 2.1).

Najlepszym dowodem na to, że system mikropożyczek inwestycyjnych (a nie transferów dochodowych) może być zarówno prostym, jak i efektywnym narzędziem wspierania i rozwoju i dochodów, jest przykład Grameen Banku z Bangladeszu. Przyczynił się on do wyciągnięcia z biedy setek tysięcy osób dzięki temu, że oferował nisko oprocentowane kilkudolarowe pożyczki dla najbiedniejszej ludno- 
ści wiejskiej i tym samym promował inwestycyjne zachowania tamtejszej ludności. System sprawdził się tak dobrze, przyczyniając się do rozwoju najbiedniejszych obszarów wiejskich w Bangladeszu i krajach ościennych, że w 2006 roku Grameen Bank i twórca całego systemu prof. Muhammad Yunus otrzymali Pokojową Nagrodę Nobla [Yunus 2003, 2007, Counts 2008]. Ten przykład pokazuje, że nie musimy stosować głównie transferów dochodowych, aby dotrzeć do najbiedniejszych i najbardziej potrzebujących mieszkańców wsi.

Warto porównać wyżej omówione opinie pracowników ARiMR (dotyczące łatwości działań) z opiniami samych rolników. Według analiz B. Fedyszak-Radziejowskiej [2008b], opartej na próbie 106 rolników, najlepszą opinią z działań PROW cieszyło się wsparcie dla ONW (średnia ocen 3,9), następnie program rolno-środowiskowy (średnia 3,7) oraz renty strukturalne (średnia ocen 3,6). Z kolei z działań SPO Rolnictwo najwyżej oceniono różnicowanie działalności rolniczej i wsparcie dla gospodarstw niskotowarowych (średnia ocen 3,4). Zatem generalnie dobrą opinię miały działania, które były łatwe, głównie o charakterze transferów bezpośrednich i subsydiów obszarowych, ale nie te należące do najbardziej efektywnych.

Kosztami narzędzi prorównościowych są zatem utracone możliwości rozwoju (koszty alternatywne). Zasadne jest więc pytanie o możliwości ich oszacowania. Zacznijmy od koszów polityki „maksymalizacji absorpcji środków” w sytuacji, kiedy łatwe do uzyskania są mało efektywne środki prorównościowe, a trudne - środki proefektywnościowe, przynoszące relatywnie wyższe efekty. Koszt ten można przedstawić, porównując efekty ekonomiczne dwóch skrajnych wariantów. W pierwszym, wszystkie fundusze przeznacza się na działania proefektywnościowe (wariant maksymalizacji środków trudnych), w drugim zaś, wszystkie fundusze przeznacza się na działania prorównościowe (wariant maksymalizacji środków łatwo dostępnych). Wyniki takiego porównania prezentuje tabela 4.7.

Tabela 4.7. Koszty ekonomiczne maksymalizowania środków łatwo dostępnych

\begin{tabular}{l|c|c|c}
\hline & $\begin{array}{c}\text { Wariant I } \\
\text { wszystkie środki latwe* } \\
\text { (A) }\end{array}$ & $\begin{array}{c}\text { Wariant II } \\
\text { wszystkie środki trudne* } \\
\text { (B) }\end{array}$ & $\begin{array}{c}\text { Różnica w pkt \% } \\
\text { B-A }\end{array}$ \\
\hline Wzrost gospodarczy & 0,1 & 0,8 & 0,7 \\
Konsumpcja prywatna & 0,1 & 0,3 & 0,2 \\
Eksport zagr. & $-0,04$ & 1,2 & 1,24 \\
Import zagr. & 0,1 & $-0,6$ & $-0,7$ \\
Inflacja & 0,2 & $-0,5$ & $-0,7$ \\
Zatrudnienie & 0,01 & 0,4 & 0,39 \\
\hline
\end{tabular}

* gdzie „środki łatwe” to transfery bezpośrednie oraz płatności obszarowe, natomiast „środki trudne” to wszystkie subsydia inwestycyjne

Źródło: Opracowanie własne. 
Wynika z niej, że do „kosztów utraconego rozwoju” możemy zaliczyć:

- relatywnie dużo wolniejsze tempo wzrostu gospodarczego,

- wolniejszy wzrost realnej konsumpcji prywatnej,

- spadający eksport kompensowany wzrostem importu,

- rosnącą inflację oraz

- minimalny wzrost zatrudnienia.

Struktura dystrybucji środków prorównościowych w stosunku do proefektywnościowych w polityce krajowej i regionalnej jest oczywiście nie tylko wypadkową kryteriów ekonomicznych, lecz także decyzji politycznych (o czym pisaliśmy w rozdziale 2.3.4). Jednak szacunek kosztów „utraconego rozwoju” możemy tu przedstawić jedynie w ujęciu ekonomicznym.

- EFEKTYWNOŚĆ POLITYKI ROW, A RANGA I STRUKTURA POZYSKANYCH FUNDUSZY ROW. Podobnie jak w przypadku skuteczności, odnosimy efektywność do kilku podstawowych cech wykorzystanych środków ROW, aby zbadać, od jakich determinantów mogła zależeć. W pierwszej kolejności zastanawiamy się, czy efektywność mogła zależeć od wielkości uzyskanych środków. Zależność tę przedstawia rysunek 4.12.

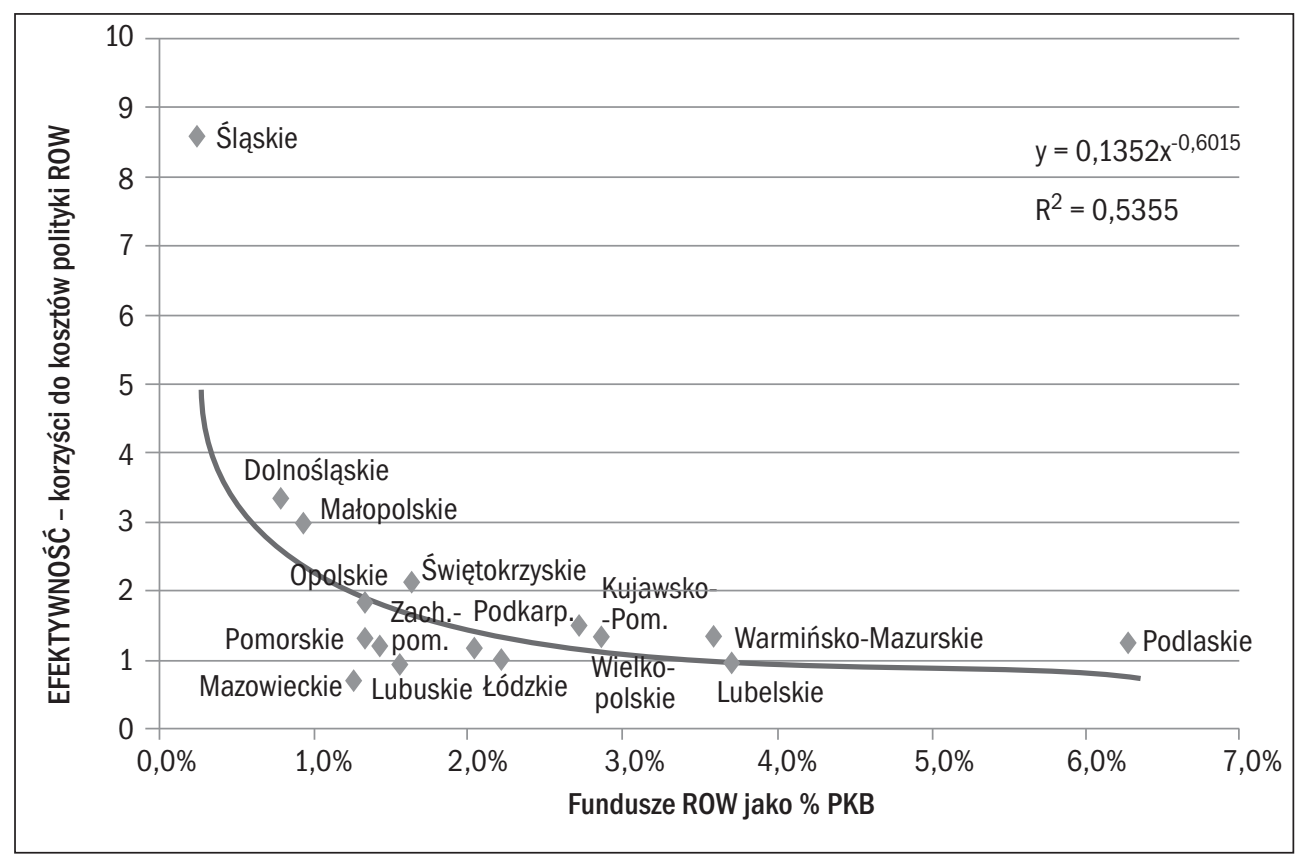

Rysunek 4.12. Zależność między efektywnością a wielkością uzyskanych funduszy na ROW Źródło: Obliczenia własne na podstawie modelu RegPOL. 
O ile wielkość funduszy ROW, jakie przypadały na każde województwo (liczona relatywnie jako \% PRB), miała pozytywne i silne znaczenie dla skuteczności działań, o tyle w przypadku efektywności zależność ta jest mniej oczywista. Po pierwsze, siła tej zależności jest mniejsza (współczynnik Pearsona -0,45, R-kwadrat dopasowania trendu 0,53), po drugie, zależność ta jest odwrotna, tzn. efektywność wykorzystania środków zdawała się maleć wraz z ich wzrostem przypadającym na województwo. Logicznie można to wyjaśnić, przyjmując, że relacja ta jest pozorna, tzn. nie wynika ona bezpośrednio z tego, że efektywność spada wraz ze wzrostem środków, ale z tego, że występuje pozytywna relacja między wielkością pozyskanych środków a zapóźnieniem regionów. Efektywność spada nie dlatego, że rosną środki przeznaczone na ROW, ale dlatego, że większe środki przypadły akurat bardziej zapóźnionym województwom, które mniej efektywniej je wykorzystały. Generalnie nie powinniśmy się spodziewać silnej relacji między wysokością pozyskanych środków a efektywnością ich wykorzystania, bo efektywność ta zależy od wielu czynników zewnętrznych i uwarunkowań wewnętrznych województw, a nie bezpośrednio od wielkości pozyskanych środków. Dziwne lub przypadkowe byłoby, gdybyśmy uzyskali istotną i silną zależność między efektywnością a wielkością środków. Trzeba jednak pamiętać o prawie malejących krańcowych przychodów z kapitału ${ }^{58}$, czyli liczyć się z tym, że w przypadku województw o większych zasobach kapitałowych (przy niezmiennych zasobach ziemi), przyrost kapitału tej samej wielkości co w przypadku województw niedoinwestowanych przynosi relatywnie mniejszy przyrost dochodów, a w konsekwencji i inwestycji. W dodatku po przekroczeniu pewnej wielkości kapitału (nasyceniu kapitału), przyrosty krańcowe mogą być nawet ujemne. Do pewnego stopnia może to tłumaczyć, dlaczego - w naszym rankingu - wśród najmniej efektywnych województw w wykorzystaniu środków związanych z rolnictwem i obszarami wiejskimi (gdzie ograniczeniem jest stały czynnik ziemi) są m.in. takie województwa, jak mazowieckie czy wielkopolskie.

O ile zamożność województw miała wyraźnie ujemną korelację ze skutecznością (większą skuteczność osiągnęły biedniejsze województwa ze względu na relatywnie więcej uzyskanych środków), o tyle inaczej przedstawia się sprawa związku efektywności z zamożnością (rys. 4.13). Relacja ta (w przeciwieństwie do poprzedniej) jest bardzo słaba i wskazuje na rosnącą dyspersję efektywności wraz ze wzrostem zamożności województw. Na przykład województwa w przedziale zamożności od 2\% do 6\% PKB charakteryzowały się efektywnością (liczoną jako

${ }^{58}$ Prawo malejących przychodów krańcowych mówi, że jeżeli kolejne jednostki zasobu zmiennego są zużywane wraz ze stałą ilością innego zasobu, to w pewnym momencie przychód, jaki mógłby być osiągnięty z kolejnej jednostki zasobu zmiennego, zacznie maleć. 
indeks korzyści do kosztów) w małym przedziale, od 0,95 do 2,1. Z kolei województwa o zamożności od $7 \%$ do $10 \%$ PKB charakteryzowały się efektywnością z większego przedziału od 0,99 do 3 . Najzamożniejsze województwa już miały skrajnie różne wskaźniki efektywności, tj. od 0,72 do 8,59. Trudno tu zatem mówić o jakiejś uniwersalnej zależności.

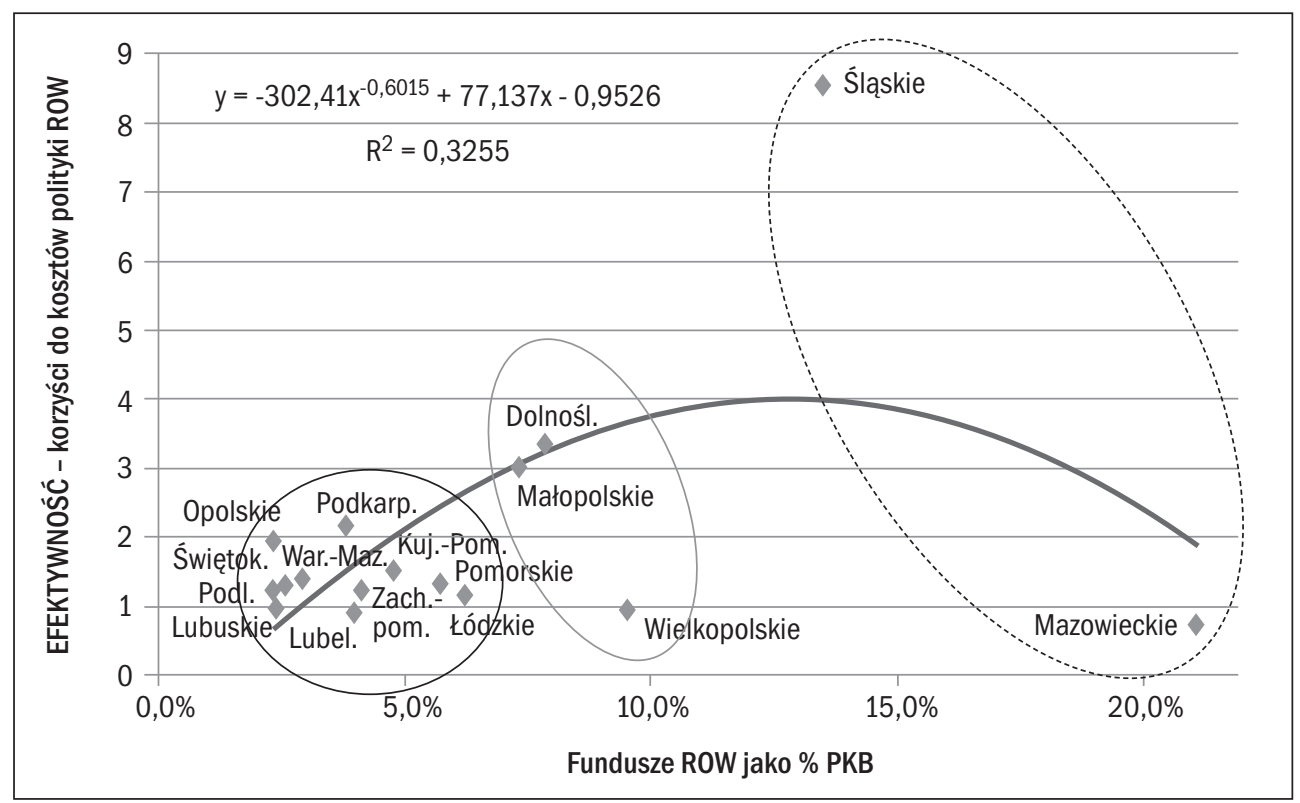

Rysunek 4.13. Zależność między efektywnością a siłą ekonomiczną/zamożnością województw Źródło: Obliczenia własne na podstawie modelu RegPOL.

Jak podkreślaliśmy w rozdziale 2.3.3, województwa różniły się znacznie strukturą uzyskanych środków na ROW. Skoro doszliśmy do wniosku, że subsydia inwestycyjne wykazywały się o wiele większą efektywnością niż transfery bezpośrednie i subsydia obszarowe, to powinniśmy zaobserwować większą efektywność wśród województw, które otrzymały więcej subsydiów inwestycyjnych niż pozostałe województwa. Żeby to sprawdzić, stworzyliśmy bardzo prosty indeks struktury absorpcji środków ROW, biorąc proporcję sumy SI_b i SI_e do sumy TB i SO. Zatem im indeks jest większy, tym struktura pozyskanych środków ROW jest korzystniejsza dla województwa. Wynik tego porównania przedstawia rysunek 4.14.

Rzeczywiście można zauważyć pozytywny związek między efektywnością a strukturą funduszy ROW z większym udziałem subsydiów inwestycyjnych. Jednak 
Rozdział 4. Analiza efektów wsparcia rozwoju obszarów wiejskich przy zastosowaniu modelu RegPOL

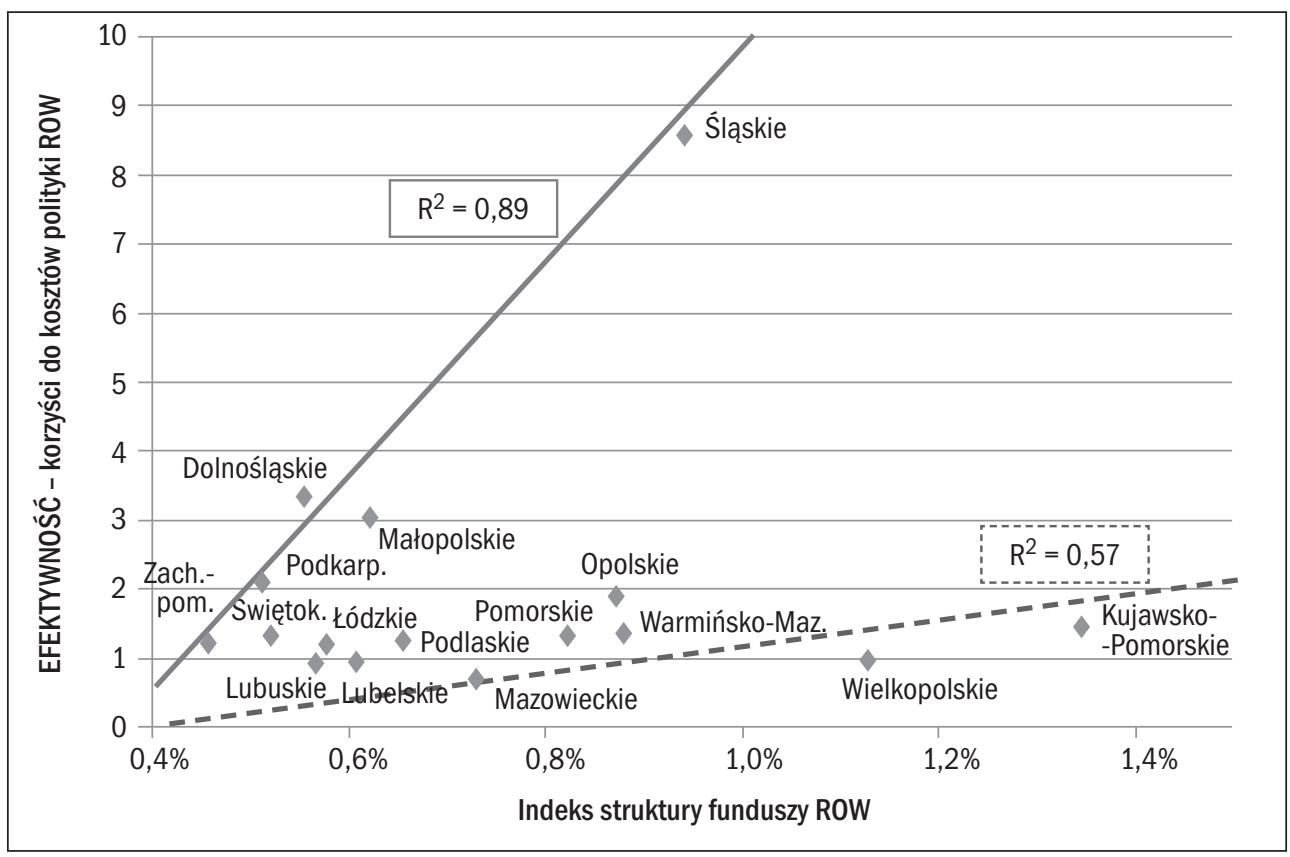

Rysunek 4.14. Zależność między efektywnością a strukturą funduszy

Uwaga: im większe wartości indeksu struktury funduszy ROW, tym wyższy odsetek subsydiów inwestycyjnych w strukturze środków, a wartości powyżej jedności oznaczają przewagę inwestycji nad pozostałymi formami wsparcia

Źródło: Obliczenia własne na podstawie modelu RegPOL.

związek ten jest różny dla dwóch grup województw. W grupie pierwszej są te, dla których związek ten jest silny i istotny, a należą tu województwa: śląskie, dolnośląskie, małopolskie, świętokrzyskie, łódzkie i lubuskie. W drugiej są te, dla których związek efektywności ze strukturą pozyskanych środków na inwestycje w rolnictwo i obszary wiejskie nie jest tak silny. Mimo iż mają przeciętnie lepszą strukturę pozyskanych środków, to ich efektywność nie jest najwyższa. Znów nasuwa się przypuszczenie, że inwestycje poczynione tam, gdzie jest już ich nasycenie (np. w gospodarstwach rolnych w województwach wielkopolskim czy kujawsko-pomorskim) mają niższą efektywność niż tam, gdzie początkowy stan inwestycji jest niższy. Ponownie jest to refleksja mająca odniesienie do prawa malejących krańcowych przychodów z kapitału. Raczej jest to naturalna kolej rzeczy niż jakaś ukryta niezdolność tych województw do generowania wyższych efektów z poczynionych inwestycji. Podsumowując, można powiedzieć, że im większy odsetek subsydiów inwestycyjnych w strukturze pozyskanych funduszy, tym wyższa efektywność województw w wykorzystywaniu polityki ROW. Jednak zależność ta 
jest znacznie osłabiona w przypadku województw, które na początku odznaczały się wyższym nasyceniem inwestycji w rolnictwie.

Wynik weryfikacji hipotezy drugiej

Z ekonomicznego punktu widzenia wspieranie rozwoju poprzez inwestycje jest dużo skuteczniejsze niż poprzez inne subsydia nieinwestycyjne. Generalnie spośród narzędzi polityki rozwoju obszarów wiejskich najefektywniejsze okazaty się inwestycje $w$ infrastrukture (inwestycje w gospodarstwach, dostosowanie do standardów, poprawa przetwórstwa i marketingu etc.) i w kapitat ludzki (doradztwo oraz szkolenia), a najmniej efektywne ptatności obszarowe (takie jak ONW) oraz transfery bezpośrednie (takie jak renty strukturalne, gospodarstwa niskotowarowe etc.). Regiony różnia się między soba efektywnościa wykorzystania różnych dziatań. Mamy zatem regiony, w których na pierwszym miejscu efektywności sa subsydia inwestycyjne $w$ kapitat ludzki, i regiony, w których najbardziej efektywne sa subsydia o charakterze inwestycyjnym. W kazdym razie te dwa instrumenty sa najefektywniejsze w catej gospodarce $i w$ regionach. Zatem hipoteza druga została potwierdzona.

\subsection{Efekty mnożnikowe instrumentów wsparcia ROW}

Działania, mimo iż adresowane były bezpośrednio do obszarów wiejskich i rolnictwa, to wydatkowane były przez rolników na różne pozarolnicze dobra i usługi (np. usługi budowlane, konsumpcję bieżącą etc.), a to wpływało na zmienne ekonomiczne (np. produkcję czy zatrudnienie w pozarolniczych sektorach gospodarki etc.) także w innych sektorach gospodarki. Ten pośredni wpływ funduszy ROW nazywamy efektami mnożnikowymi. Prześledzimy to, analizując wybrane typy działań w województwach, które były - w wartościach absolutnych ${ }^{59}$ - największymi ich beneficjentami:

- podlaskie (wsparcie dla ONW),

- łódzkie (renty strukturalne),

- wielkopolskie (dostosowania do EU) oraz

- lubelskie (doradztwo).

Porównaliśmy wpływ poszczególnych działań na wartość produkcji lub usług generowanych w poszczególnych sektorach gospodarki narodowej zagregowanych do 15 sekcji PKD dla każdego z tych województw (sekcje te zostały opisane dokładniej w tabeli A.3.2). Posłużyliśmy się wynikami symulacji wpływu poszczegól-

\footnotetext{
${ }^{59}$ Włączyliśmy do analizy województwa będące największymi beneficjentami poszczególnych działań, ale pominęliśmy mazowieckie, które ze względu na swoją wielkość było największym beneficjentem wszystkich działań, więc nie byłoby miarodajne.
} 
nych działań na produkcję/usługi w poszczególnych sektorach, opierając się na płatnościach faktycznie zrealizowanych na te działania (por. rozdział 4.1).

Na przykładzie województwa podlaskiego możemy stwierdzić, że subsydia obszarowe w postaci płatności ONW miały pewien umiarkowany, ale pozytywny wpływ na wzrost produkcji w większości sektorów gospodarki poza rolnictwem. Płatności obszarowe nie powinny wywoływać efektu wzrostu produkcji w rolnictwie zgodnie z zasadą decouplingu, czyli wsparcia niezwiązanego z produkcją i to właśnie obserwujemy. Wyraźnie jednak wsparcie ONW miało pozytywny wpływ, w sposób pośredni, na sektor turystyczny, tj. hotele i restauracje (wzrost o 4,5\%) oraz niektóre związane z nim usługi, np. usługi finansowe (wzrost o 3,9\%), usługi mieszkaniowe (wzrost o 3,6\%). W dalszej kolejności pozytywny wpływ tego działania można zaobserwować w sektorze handlowym (wzrost o 3,1\%) oraz transportowym (wzrost o 3\%). Zależności te przedstawia rysunek 4.15.

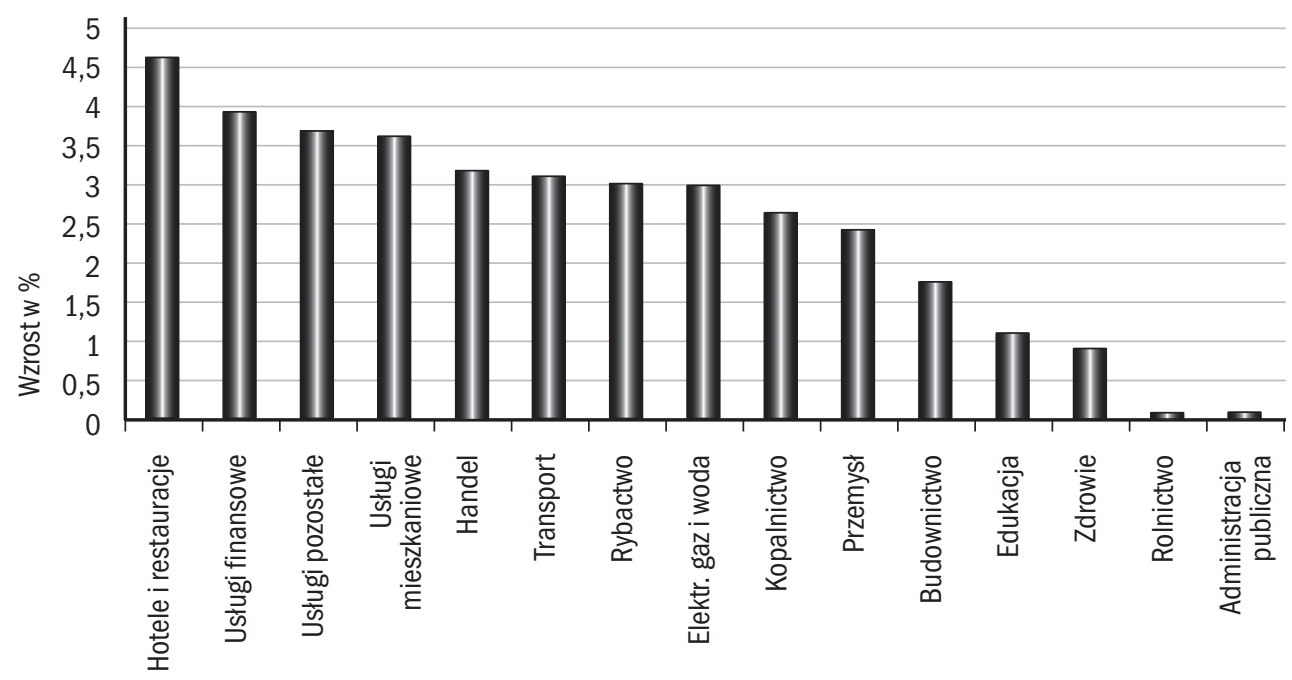

Rysunek 4.15. Wpływ płatności ONW w ramach PROW 2004-2006 na sektory gospodarki w województwie podlaskim

Źródło: Obliczenia własne na podstawie modelu RegPOL.

Efekty mnożnikowe rent strukturalnych, których najwięcej (w ujęciu wartościowym) przyznano w województwie łódzkim, są nieco podobne do tych wywołanych wsparciem ONW (rys. 4.16), jednak skala ich wpływu jest dużo mniejsza. Największy pozytywny wpływ tego działania jest widoczny w podstawowych sektorach usługowych, np. w turystyce (hotele i restauracje, wzrost o $0,7 \%$ ), usługach 
mieszkaniowych (wzrost o $0,53 \%)$, finansowych $(0,51 \%)$ oraz handlu $(0,45 \%)$ i transporcie $(0,31 \%)$. Podobnie jak w poprzednim przypadku, tak i tutaj na skutek transferu dochodowego (jakim są renty) nie rośnie produkcja rolnicza, gdyż nie jest on związany z wielkością produkcji rolnej.

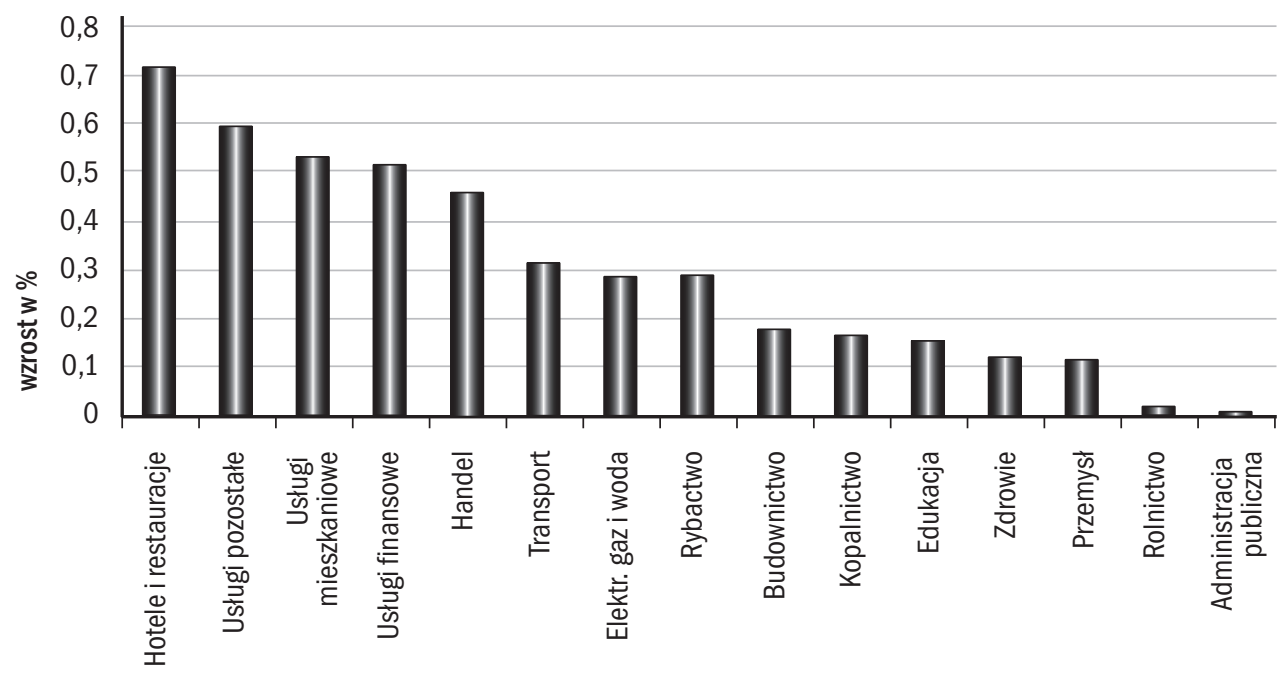

Rysunek 4.16. Wpływ rent strukturalnych w ramach PROW 2004-2006 na sektory gospodarki w województwie łódzkim

Źródło: Obliczenia własne na podstawie modelu RegPOL.

Analizowane na przykładzie województwa wielkopolskiego dostosowanie do standardów UE największy wpływ wywarło na sektor budowlany (rys. 4.17), gdyż de facto koszty kwalifikowane ${ }^{60} \mathrm{w}$ tym działaniu związane były $\mathrm{z}$ budową i wyposażeniem w narzędzia i maszyny (np. budowane były głównie płyty obornikowe oraz kupowano urządzenia związane z przechowaniem nawozów naturalnych). Chociaż beneficjentem końcowym były gospodarstwa rolne, to beneficjentem pośrednim były też firmy budowlane, zwykle lokalne, które wykorzystały te środki. Sektor budowlany zyskał $11 \%$ skumulowanego wzrostu produkcji na skutek tego działania w badanym województwie. Inne sektory skorzystały na tym działaniu w znacznie mniejszym stopniu. Drugim sektorem w kolejności był sektor energetyczny (wzrost o 2,8\%), a dalej sektor kopalnictwa (wzrost o 2\%), przemysłu

\footnotetext{
${ }^{60}$ Koszty kwalifikowane są kategorią ściśle związaną ze wsparciem unijnym i determinują zakres oraz wielkość wydatków, które mogą zostać sfinansowane lub refundowane beneficjentom.
} 
$(1,6 \%)$ oraz transportu $(1,4 \%)$. Pozostałe sektory gospodarki praktycznie nie skorzystały z tego działania, ze względu na silne „wysysanie” środków i czynników produkcji (zatrudnienia i kapitału) przez jeden dominujący sektor (budownictwo), do którego trafiły fundusze $\mathrm{z}$ omawianego działania.

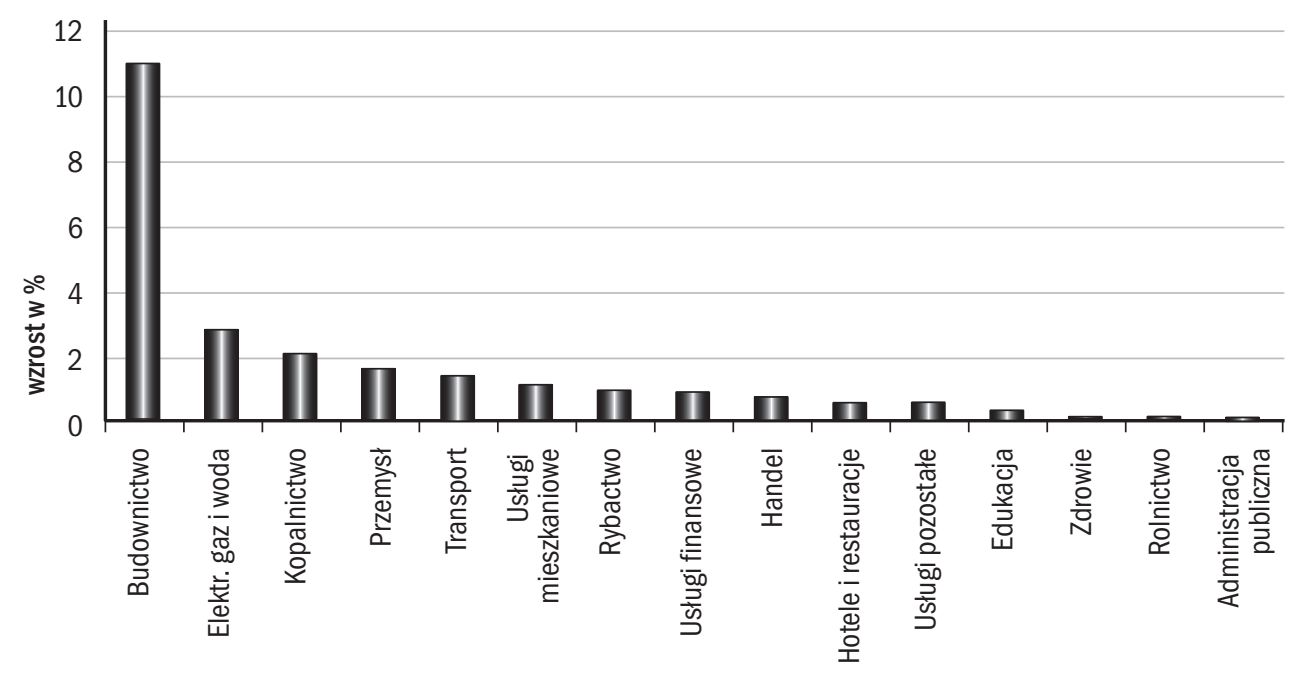

Rysunek 4.17. Wpływ działania Dostosowanie do standardów UE w ramach PROW 2004-2006 na sektory gospodarki w województwie wielkopolskim

Źródło: Obliczenia własne na podstawie modelu RegPOL.

Działanie związane z doradztwem, analizowane tu na przykładzie województwa lubelskiego (rys. 4.18), miało największy wpływ na sektor usług edukacyjnych (wzrost o 5,2\%). Tak znaczący wzrost można tłumaczyć tym, że wcześniej nie było praktycznie żadnych środków na tego typu działania (poza budżetami ODR-ów), zatem powstał podatny grunt dla rozwoju prywatnych usług tego typu. Omawiane działanie w pewnym stopniu przełożyło się też na usługi transportowe oraz energetyczne (wzrost po $0,6 \%$ ). Podobnie jak poprzednie działania nie ma ono wpływu na produkcję rolną.

Jak wynika z analizy, efekty mnożnikowe w poszczególnych sektorach gospodarki są zróżnicowane, w zależności od działania i województwa. Jednak we wszystkich przypadkach sektor rolny nie wykazuje istotnego wzrostu wskutek ich oddziaływania. Ważniejszy i bardziej pożądany jest jednak wzrost zatrudnienia mieszkańców wsi, w tym rolników, w pozarolniczych sektorach gospodarki. Zasadne jest pytanie, jakie korzyści mogły przynieść efekty mnożnikowe dla ludności 


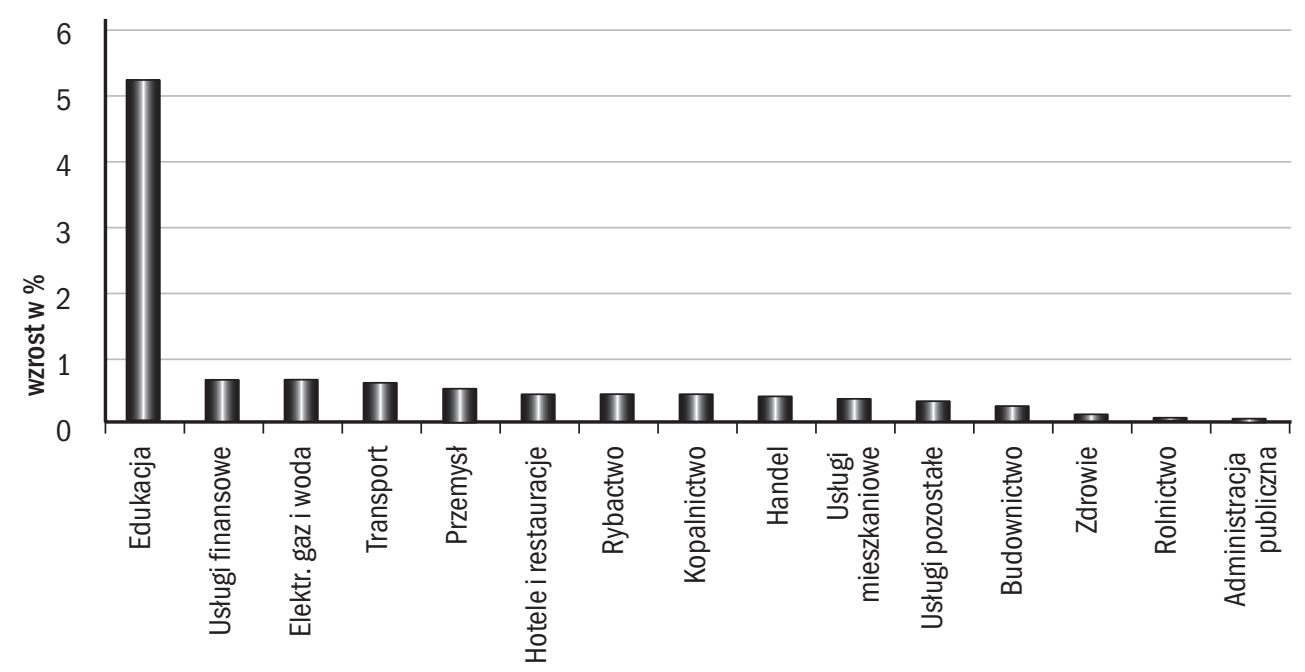

Rysunek 4.18. Wpływ doradztwa w ramach SPO Rolnictwo 2004-2006 na sektory gospodarki w województwie lubelskim

Źródło: Obliczenia własne na podstawie modelu RegPOL.

wiejskiej zatrudnionej poza rolnictwem. Model RegPOL, niestety, nie różnicuje wyników w podziale na ludność wiejską i miejską. Można jednak oszacować wpływ działań na zatrudnienie pozarolnicze ludności wiejskiej, wykorzystując wyniki modelu RegPOL i uzupełniając je dodatkowymi danymi statystycznymi, dotyczącymi struktury zatrudnienia ludności wiejskiej w pozarolniczych sektorach gospodarki w ujęciu wojewódzkim (tab. 4.8). Głównym pracodawcą dla ludności wiejskiej wciąż jest rolnictwo, przeciętnie jest w nim zatrudnione 40\% ludności wiejskiej. Wartość ta jednak waha się między województwami - od 18\% w śląskim, do 69\% w podlaskim. Drugim w kolejności sektorem zatrudniającym ludność wiejską jest sektor przemysłowy, przeciętnie zatrudnia on 18\% ludności wiejskiej, w szczególności w przetwórstwie artykułów spożywczych, napojów i wyrobów tytoniowych. W ujęciu wojewódzkim odsetek zatrudnionych mieszkańców wsi w przemyśle przetwórczym waha się od $10 \%$ w lubelskim do $23 \%$ w lubuskim i śląskim. W trzeciej kolejności największe zatrudnienie ludności wiejskiej ma miejsce w handlu i naprawach. Przeciętnie zatrudnione jest tam 10\% ludności wiejskiej (od 6\% w lubelskim do $13 \%$ w śląskim). Nieco ponad 5\% ludności wiejskiej ma zatrudnienie w budownictwie, transporcie, edukacji i administracji publicznej. Struktura zatrudnienia pozarolniczego ludności wiejskiej jest bardzo stabilna i prawie się nie zmieniła w latach 2000-2007 (por. tab. 1.8, rozdział 1). 
$\mathrm{Z}$ analizy całkowitych efektów mnożnikowych (wynikających ze wszystkich działań razem) wynika, że największe efekty wtórne wzrostu produkcji na skutek polityki ROW ujawniły się w sektorze budowlanym (średnio produkcja wzrosła tam o 5,2\%) oraz w sektorze wytwarzania i zaopatrywania w energię (średnio produkcja wzrosła tam o 3,6\%). W drugiej kolejności efekty te ujawniły się w usługach finansowych i kopalnictwie (wzrost usług o 2,4\% w obu przypadkach). $\mathrm{W}$ trzeciej zaś wzrost dotyczył takich sektorów, jak usługi finansowe i usługi mieszkaniowe, gdzie nastąpił wzrost średnio o 2,2\%.

Sektory, które zyskały najwięcej na efektach mnożnikowych polityki ROW, nie należą do tych, w których ludność wiejska znajduje największe zatrudnienie. Trudno więc oczekiwać, że ludność ta zyskała dużo nowych miejsc pracy w pozarolniczych sektorach gospodarki. Ekspansji bowiem ulegały na ogół te sektory, w których zatrudnienie ludności wiejskiej było tradycyjnie stosunkowo niewielkie. Jeśli więc nie uległa zmianie struktura zatrudnienia ludności wiejskiej w stosunku do miejskiej, to można raczej przypuszczać, że więcej miejsc pracy pozyskały osoby z miast. Najwięcej pozarolniczych miejsc pracy powstało w województwach o największych efektach mnożnikowych, do których należały: podlaskie, gdzie średni wzrost produkcji na skutek polityki ROW wyniósł 9,4\%, następnie w kujawsko-pomorskim (wzrost o 5,6\%) oraz warmińsko-mazurskim (wzrost o 4,4\%).

W województwie podlaskim poza rolnictwem ludność wiejska w największym odsetku zatrudniona była w przemyśle (7\%) oraz w handlu z naprawami $(5,3 \%)$, podczas gdy województwo to największego wzrostu produkcji doświadczyło w sektorze budowlanym (o 20,3\%), gdzie zatrudnienie ludności wiejskiej wynosiło ok. $2 \%$, energetycznym (o $15,7 \%$ ), gdzie zatrudnienie wynosiło poniżej $1 \%$ oraz kopalnictwie i usługach finansowych (o 12,5\%), gdzie zatrudnienie wynosiło odpowiednio $0,1 \%$ i $0,7 \%$. Na skutek działania „wsparcie dla ONW” w tym województwie (jak omawialiśmy powyżej), największa ekspansja dotyczyła takich sektorów, jak: hotelarstwo, usługi finansowe i mieszkaniowe, ale zatrudnienie ludności wiejskiej w każdym z tych sektorów w tym województwie wyniosło zaledwie ok. $1 \%$.

W województwie kujawsko-pomorskim uzależnienie ludności wiejskiej od rolnictwa było znacznie mniejsze, co skutkowało z kolei większym zatrudnieniem jej w innych sektorach gospodarki. Przede wszystkim w przemyśle (17\%), usługach handlowych i naprawczych $(10 \%)$ oraz budownictwie i administracji publicznej (po 5\%). W tym wypadku efekty mnożnikowe polityki ROW dość korzystnie pokrywały się z pozarolniczym zatrudnieniem ludności wiejskiej. Największy wzrost w produkcji odczuł sektor budowlany (o 14\%), gdzie zatrudnienie ludności wiejskiej wynosiło ok. $5 \%$. W przemyśle, który dawał największe zatrudnienie, wzrost też był dość znaczny, bo wyniósł ponad 5\%. Ponadto dość znaczny 


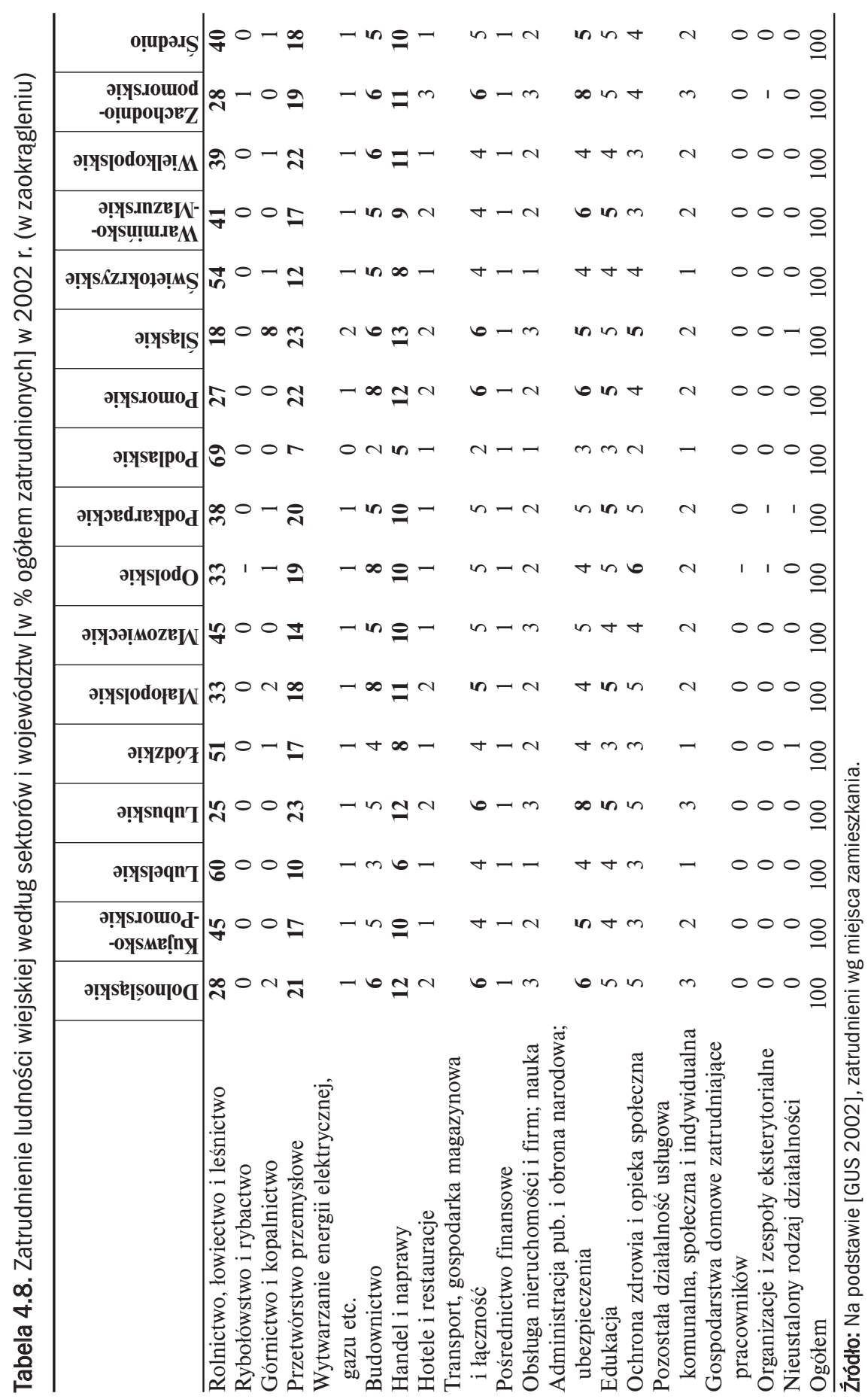




\begin{tabular}{|c|c|c|c|c|c|}
\hline оฺ̣upə.IS & 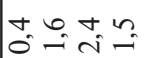 & 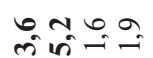 & 푸로 & $2=$ & $\stackrel{\infty}{-}$ \\
\hline 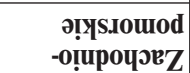 & $\begin{array}{llll}n & 0 & 0 & m \\
0 & -1 & 0 & 0\end{array}$ & 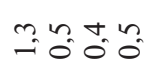 & ôn & $\overrightarrow{9}=0$ & $\begin{array}{lll}n & n \\
0 & 0 & 0\end{array}$ \\
\hline 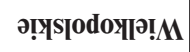 & 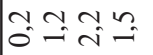 & $\stackrel{n=}{m}=\simeq$ & $\stackrel{\infty}{-1}=$ & :00 & 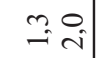 \\
\hline 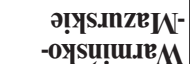 & 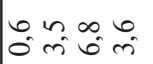 & 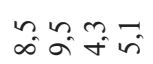 & 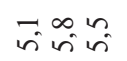 & 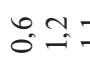 & $\because \begin{array}{l}\approx \\
\forall \\
\forall\end{array}$ \\
\hline 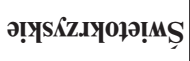 & $\overrightarrow{0} \dot{0}=\infty$ & 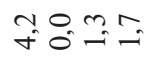 & तiç & $\begin{aligned}+0,4 \\
0,0\end{aligned}$ & $\Rightarrow=$ \\
\hline 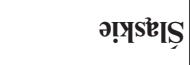 & $\begin{array}{llll}\pi & n & m & + \\
0 & 0 & 0 & 0 \\
0 & 0 & 0\end{array}$ & 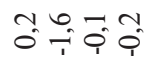 & ma $\overrightarrow{0}=$ & on & $\because=$ \\
\hline ә!YS. & $\left(\begin{array}{lll}0 & 0 & 0 \\
0 & - & -1\end{array}=\right.$ & 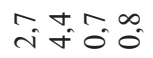 & $\begin{array}{l}+\infty \\
-\infty \\
0\end{array}=$ & กี & $\begin{array}{l}\infty \\
0\end{array}=$ \\
\hline ә!YSSEIPOd & 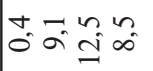 & 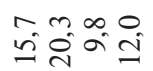 & 을 & $\stackrel{m}{\circ}+$ & $\begin{array}{lll}r & \pi \\
0 & 0 & 0\end{array}$ \\
\hline ә!уреd.ıечро $\mathbf{d}$ & 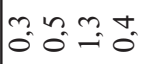 & 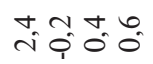 & $\underset{-}{0} \underset{-}{-} 0$ & $\overline{0} \hat{0}=0$ & $\overline{0}=$ \\
\hline ə!yssodo & $\overrightarrow{0} \overrightarrow{0}=\overrightarrow{0}$ & 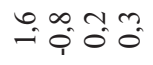 & $\stackrel{0}{-} 0^{-\infty}$ & $=0 ?$ & $\begin{array}{ll}0 & n \\
0 & 0 \\
0 & 0\end{array}$ \\
\hline ә!үрә!моzв $\mathbf{W}$ & $\begin{array}{lll}0 & 0 & n \\
0 & = & 0\end{array}$ & $\hat{T}=\overrightarrow{0} \hat{\varphi}$ & $\begin{array}{l}a \\
\hat{\varphi}\end{array}$ & : & $\stackrel{\infty}{0}=$ \\
\hline 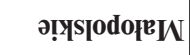 & 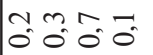 & 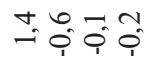 & $\overrightarrow{0} \tilde{0}_{0}^{+}$ & m. & $\overrightarrow{0}=0$ \\
\hline ә!уZрот & $\hat{0}=\hat{i}=$ & mitr & $\begin{array}{l}+\infty \\
i \\
i\end{array}$ & 요 & $\begin{array}{lll}0 & 1 \\
i & i\end{array}$ \\
\hline ә!̣[snqn & 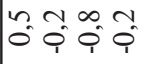 & 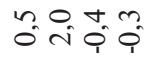 & त̂ & ㄴ. & $\overrightarrow{0}=$ \\
\hline ә!үS|әqn T & $\overrightarrow{0} \cong 0$. & $\vec{m} \overrightarrow{+} \overrightarrow{-i}$ & जेत्रi & ô in & $\Rightarrow \begin{array}{cc}0 \\
-i\end{array}$ \\
\hline 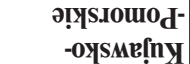 & Oñ & 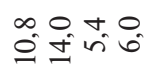 & 중ㅎํ & ò. & 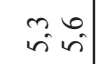 \\
\hline 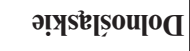 & $\begin{array}{llll}n & 0 & -1 & m \\
0 & 0 & 0 & 0\end{array}$ & $\begin{array}{llll}m & m & 0 & 0 \\
0 & 0 & 0 & 0 \\
0 & 0 & 1\end{array}$ & $\overrightarrow{0}+\overrightarrow{0}$ & $\because 0$ & $\begin{array}{ll}m & m \\
0 & 0 \\
1 & 0\end{array}$ \\
\hline & 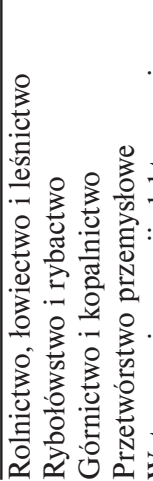 & (0) & 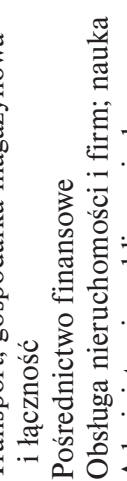 & 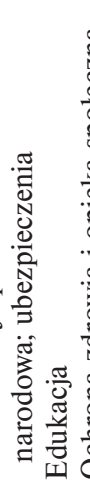 & 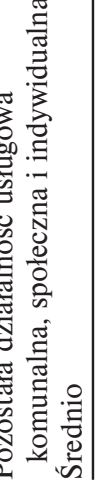 \\
\hline
\end{tabular}


wzrost nastąpił w wielu sektorach, w których zatrudnienie ludności wiejskiej było niewielkie: energetyka (o 10,8\%), kopalnictwo (7,4\%), usługi mieszkaniowe (o $6,8 \%)$ oraz usługi finansowe $(6,7 \%)$. W województwie warmińsko-mazurskim, gdzie w porównaniu z wyżej omówionymi województwami zatrudnienie ludności wiejskiej w rolnictwie było najmniejsze, struktura zatrudnienia pozarolniczego była najbardziej zdywersyfikowana. W przemyśle znalazło zatrudnienie $17 \%$ ludności, w handlu z naprawami 9\%, w administracji publicznej $6 \%$, a w budownictwie i edukacji po $5 \%$. Z tych sektorów tylko budownictwo odnotowało znaczny wzrost $(9,5 \%)$, a pozostałe sektory zaledwie od 0,6\% wzrostu do 4,3\%. Z kolei w sektorach, które zyskały najwięcej na wzroście, tak jak energetyka (o 8,5\%) czy usługi finansowe $(5,8 \%)$ i mieszkaniowe $(5,5 \%)$, zatrudnienie ludności wiejskiej wynosiło zaledwie $1 \%$. Porównanie struktury wiejskiej z efektami mnożnikowymi uzyskanymi na skutek polityki ROW dla wszystkich województw pokazuje rysunek A.4.1 w aneksie ${ }^{61}$.

Badanie dowiodło, że na narzędziach polityki rozwoju obszarów wiejskich zyskują różne sektory gospodarki, w zależności od tego, jakie aktywności zdefiniowano i jakie koszty kwalifikowane dopuszczono w ramach każdego działania. Tak więc polityka ROW nie tylko bezpośrednio, lecz także pośrednio, wspiera cel ostateczny. Na przykład działanie „dostosowania do standardów UE” ma na celu poprawę konkurencyjności, ale żeby ją osiągnąc potrzebne były usługi budowlane, zatem fundusze przyznane na to działanie przyczyniły się do zasilenia sektora budowlanego i powstania pozarolniczych miejsc pracy. $\mathrm{Na}$ działaniach polityki ROW korzysta zatem nie tylko sektor rolny, lecz także pozarolnicze sektory gospodarki, takie jak budownictwo, turystyka czy sektor mieszkaniowy. To z kolei może rodzić pozytywne skutki dla pozarolniczego zatrudnienia ludności wiejskiej, jeśli w sektorach, które korzystają na działaniach dla rolnictwa, są w dużej mierze zatrudnieni mieszkańcy wsi. Nie zawsze jednak sektory rozwijające się dzięki działaniom polityki rozwoju obszarów wiejskich są tymi, w których ludność wiejska ma szanse na największe zatrudnienie. Sektor rolny zyskuje na tych działaniach niejako w drugiej kolejności, gdyż oczekiwane efekty tych działań (takie jak poprawa produktywności, technologii, jakości produkcji itp.) odczuje on w późniejszym okresie niż pozostałe sektory gospodarki, które bezpośrednio odebrały fundusze ROW. Oczywiście wzrost zatrudnienia pozarolniczego na obszarach wiejskich i w miastach jest pozytywnym i pożądanym efektem, jeśli ma w nim swój udział ludność wiejska.

${ }_{61}$ Porównanie struktury zatrudnienia ludności wiejskiej z efektami mnożnikowymi nie uwzględnia emigracji zarobkowych, tj. struktury zatrudnienia ludności wiejskiej za granicą. Na ten temat można znaleźć pewne informacje w [Wieruszewska 2007]. 
Wynik weryfikacji hipotezy trzeciej

$W$ wyniku przeprowadzonych badań, hipoteza mówiaca, że choć środki na rozwój obszarów wiejskich sa $w$ dużej mierze udzielane sektorowi rolnemu, to jednak korzystaja na tym też inne sektory gospodarki, została potwierdzona. Sektory pozarolnicze, w przeciwieństwie do sektora rolnego, zyskuja bowiem fundusze, które beneficjenci polityki ROW otrzymali w ramach działań PROW i SPO Rolnictwo 2004-2006 i przeznaczyli je głównie na zakup dóbr i ustug pozarolniczych. To z kolei wywołało wiele efektów mnożnikowych w innych sektorach gospodarki, co stworzyło większe możliwości pozarolniczego zatrudnienia ludności wiejskiej.

\subsection{Rozkład korzyści z polityki ROW w ujęciu typologicznym}

W celu zweryfikowania hipotezy czwartej, mówiącej o tym, że to regiony najbardziej wiejskie i najbardziej rolnicze zyskują na polityce ROW, posłużymy się typologią wiejsko-rolniczą, będącą rozwinięciem najbardziej rozpowszechnionej w EU typologii OECD. Jej celem jest też stworzenie lepszej, choć wciąż prostej i transparentnej platformy porównawczej „wiejskości” i „rolniczości” regionów w Europie. Typologia ta została opisana w rozdziale 1.1.2, a tu posługujemy się nią, żeby przedstawić wyniki wcześniejszych symulacji.

Przypomnijmy tylko, że do Typu 1 (przeważająco wiejskiego-przeważająco rolniczego) należą dwa województwa: lubelskie i świętokrzyskie, do Typu 2 (przeważająco wiejskiego-znacząco rolniczego) należą cztery województwa: warmińsko-mazurskie, podkarpackie, wielkopolskie i lubuskie. Typ 3 (przeważająco wiejski-przeważająco nierolniczy) nie ma swoich reprezentantów w Polsce, a do Typu 4 (znacząco wiejskiego-przeważająco rolniczego) wchodzą województwa podlaskie i łódzkie. Najliczniejszy Typ 5 (znacząco wiejski-znacząco rolniczy) obejmuje takie województwa, jak mazowieckie, kujawsko-pomorskie, opolskie, zachodniopomorskie, małopolskie, dolnośląskie, pomorskie. Typ 6 i Typ 7 nie występują w Polsce, a kryteria Typu 8 wypełnia jedynie województwo śląskie.

Zgodnie z naszą hipotezą i typologią spodziewamy się, że największe korzyści z polityki ROW powinny odnotować województwa należące do Typu 1 (przeważająco wiejskie-przeważająco rolnicze), a najmniej województwa należące do Typu 8 (przeważająco miejskie-znacząco rolnicze). Weryfikację hipotezy przeprowadziliśmy za pomocą wskaźników ekonomicznych, pokazujących zmiany wywołane na skutek polityki ROW. Wskaźnikami tymi były m.in. zmiany we: wzroście gospodarczym regionów, zatrudnieniu, stopach bezrobocia, migracji netto, inflacji i popycie inwestycyjnym. Te zmienne najlepiej odzwierciedlają w naszym modelu zmiany w konkurencyjności i jakości życia regionów. 
Jeśli chodzi o wzrost gospodarczy, województwa należące do najbardziej wiejskich i rolniczych, Typu 1 (PW-PR), odczuły go bardziej niż województwa najbardziej miejskie i nierolnicze, Typu 8 (PM-ZR) - tabela 4.10. W tych pierwszych wzrost gospodarczy na skutek działania polityki rozwoju obszarów wiejskich wynosił średnio $2,5 \%$, podczas gdy w tym drugim tylko $0,5 \%$. Jednak trzeba zauważyć, że nie oznacza to, że regiony Typu 1 rozwijały się najszybciej, bowiem największy wzrost odczuły województwa umiarkowanie wiejskie i rolnicze, Typu 4 (ZW-PR). Tam wzrost wyniósł średnio aż 6,8\%. Zmiany w zatrudnieniu również były bardziej korzystne w regionach Typu 1 (PW-PR), gdzie wzrost wyniósł średnio 1,1\%, niż regionu Typu 8 (PM-ZR), gdzie zatrudnienie wykazywało lekką tendencję malejącą (-0,2\%). Podobnie jak w poprzednim przypadku, tak i tutaj najwięcej jednak ze wszystkich regionów zyskały ostatecznie województwa Typu 4 (ZW-PR), odnotowując średnio wzrost w zatrudnieniu o 3,4\%.

Tabela 4.10. Zmiany we wzroście gospodarczym i zatrudnieniu w ujęciu typologicznym

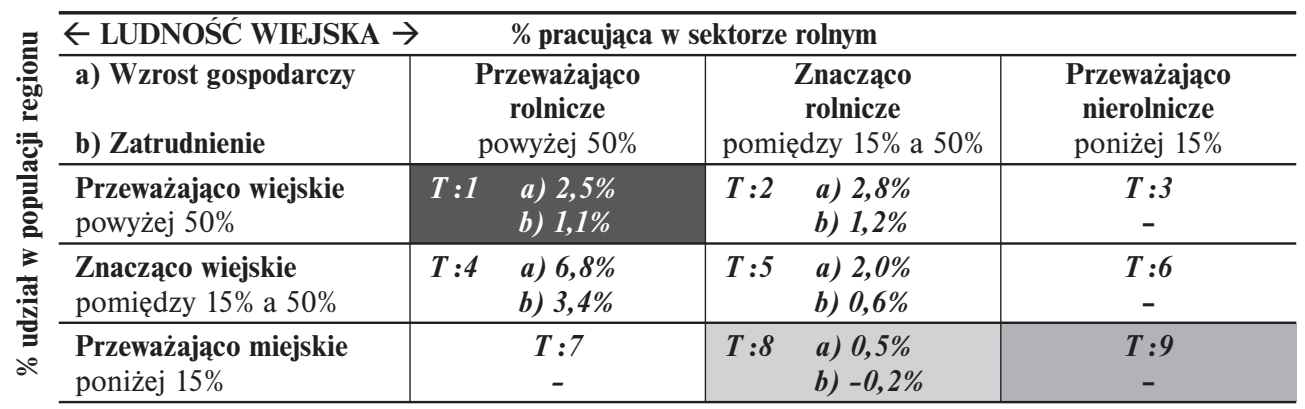

a) i b) - średnio, zmiany w \%

Źródło: Obliczenia własne na podstawie modelu RegPOL i zmodyfikowanej typologii wiejskości OECD.

Analizując wskaźniki ekonomiczne, należy zauważyć, że polityka rozwoju obszarów wiejskich miała mały wpływ na zmiany w bezrobociu i ruchach migracyjnych (tab. 4.11). W regionach najbardziej rolniczych i wiejskich Typu 1 (PW-PR), spadek w stopie bezrobocia wyniósł ok. 1 punktu procentowego, podczas gdy w regionie najbardziej miejsko-nierolniczym Typ 8 (PM-ZR) stopa bezrobocia niewiele się zmieniła na skutek polityki rozwoju obszarów wiejskich. Najbardziej jednak znaczący efekt pozytywny znów odczuły województwa Typu 4 (ZW-PR), gdzie spadek stopy bezrobocia wyniósł 2,8 punktu procentowego. Jeszcze mniejszy był wpływ polityki na ruchy migracyjne. Stopa migracji netto ${ }^{62}$ była bardzo bliska zeru.

${ }^{62}$ Migrację netto definiujemy jako przypływ ludności minus odpływ ludności z danego województwa. 
W liczbach absolutnych, jak pokazuje tabela 4.11, najwieksze dodatnie saldo migracji netto odnotowały województwa Typu 4 (ZW-PR). Natomiast województwa Typu 1 (PW-PR) praktycznie nie odczuły zmiany. Województwo bardziej zurbanizowane Typu 8 (PM-ZR) razem z województwami Typu 5 (ZW-ZR), wykazywały tendencję do odpływu ludności na korzyść pozostałych typów regionów na skutek polityki ROW.

Tabela 4.11. Zmiany w stopie bezrobocia i migracjach netto w ujęciu typologicznym

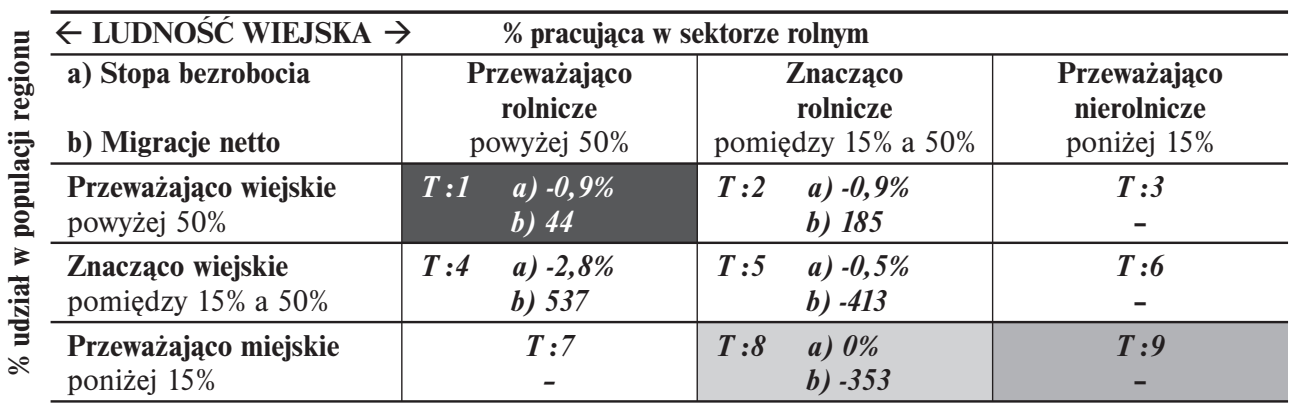

a) - średnio, zmiany w punktach \%, b) - suma, zmiany w osobach

Źródło: Obliczenia własne na podstawie modelu RegPOL i zmodyfikowanej typologii wiejskości OECD.

Inflacja miała tendencję malejącą we wszystkich typach regionów, i to w zbliżonym stopniu. Województwa znacznie bardziej wiejsko-rolnicze (Typ 1 i Typ 4) odnotowały szybszy spadek inflacji niż regiony bardziej zurbanizowane (Typ 8 i Typ 5). Spadek inflacji w regionach Typu 1 i 4 wyniósł -1,1\%, natomiast we wszystkich pozostałych typach $-0,9 \%$. Podobnie rzecz się miała z popytem na inwestycje, który wzrastał na skutek polityki ROW szybciej w regionach bardziej wiejsko-rolniczych niż w bardziej zurbanizowanych, gdzie tempo nawet się zmniejszyło na korzyść tych pierwszych. Po raz kolejny powtórzyło się, że regiony Typu 4 (ZW-PR) doświadczają najbardziej pozytywnych zmian, tam bowiem tempo wzrostu popytu na inwestycje osiągnęło średnio wzrost o $4,4 \%$, podczas gdy w województwach Typu 1 tylko o 0,1\% (tab. 4.12).

Analiza sześciu głównych wskaźników ekonomicznych w układzie dwuwymiarowej regionalnej typologii wiejsko-rolniczej wykazała, iż regiony najbardziej wiejsko-rolnicze (PW-PR) zyskały więcej na polityce rozwoju obszarów wiejskich niż regiony najbardziej zurbanizowane (PM-ZR). Jednak w tej pierwszej grupie najwięcej na polityce rozwoju obszarów wiejskich zyskały regiony Typu 4 (przeważająco rolnicze-znacząco wiejskie) i Typu 2 (przeważająco wiejskie-znacząco 
Tabela 4.12. Zmiany w inflacji i popycie inwestycyjnym w ujęciu typologicznym

\begin{tabular}{|c|c|c|c|}
\hline$\leftarrow$ LUDNOŚ́ WIEJSKA $\rightarrow$ & $\%$ pracując: & ktorze rolnym & \\
\hline $\begin{array}{l}\text { a) Inflacja } \\
\text { b) Popyt na inwestycje }\end{array}$ & $\begin{array}{c}\text { Przeważająco } \\
\text { rolnicze } \\
\text { powyżej } 50 \%\end{array}$ & 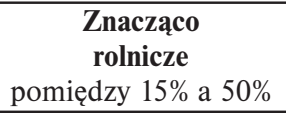 & $\begin{array}{c}\text { Przeważająco } \\
\text { nierolnicze } \\
\text { poniżej } 15 \% \\
\end{array}$ \\
\hline $\begin{array}{l}\text { Przeważająco wiejskie } \\
\text { powyżej } 50 \%\end{array}$ & $\begin{array}{ll}T: 1 & \text { a) }-1,1 \% \\
& \text { b) } 0,1 \%\end{array}$ & $\begin{array}{cl}T: 2 & \text { a) }-0,9 \% \\
& \text { b) } 0,3 \%\end{array}$ & $\begin{array}{c}T: 3 \\
-\end{array}$ \\
\hline $\begin{array}{l}\text { Znacząco wiejskie } \\
\text { pomiędzy } 15 \% \text { a } 50 \%\end{array}$ & $\begin{array}{ll}T: 4 & \text { a) }-1,1 \% \\
& \text { b) } 4,4 \%\end{array}$ & $\begin{array}{ll}T: 5 & \text { a) }-0,9 \% \\
& \text { b) }-0,2 \%\end{array}$ & $\begin{array}{c}T: 6 \\
-\end{array}$ \\
\hline $\begin{array}{l}\text { Przeważająco miejskie } \\
\text { poniżej } 15 \%\end{array}$ & $\begin{array}{c}T: 7 \\
-\end{array}$ & $\begin{array}{ll}T: 8 & \text { a) }-0,9 \% \\
& \text { b) }-1,2 \%\end{array}$ & $\begin{array}{c}T: 9 \\
-\end{array}$ \\
\hline
\end{tabular}

a) i b) - średnio, zmiany w \%

Źródło: Obliczenia własne na podstawie modelu RegPOL i zmodyfikowanej typologii wiejskości OECD.

rolnicze). Gdy porównamy poszczególne województwa, które najwięcej zyskały na polityce ROW, to potwierdza się, że są to województwa mieszane pod względem wiejskości i rolniczości. Pierwsze w rankingu województwo podlaskie jest regionem Typu 4 (znacząco wiejskim i przeważająco rolniczym), drugie województwo warmińsko-mazurskie należy do Typu 2 (przeważająco wiejskie-znacząco rolnicze), na trzecim miejscu jest województwo kujawsko-pomorskie, należące do Typu 5 (znacząco wiejskie-znacząco rolnicze). Następnie na czwartym i piątym miejscu są województwa, które są zarówno przeważająco wiejskie, jak i przeważająco rolnicze, czyli Typu 1 - świętokrzyskie i lubelskie.

Trzeba jednak przyznać, że patrząc na rezultaty w postaci graficznej typologii (obrazuje to rysunek 4.19), wyraźnie widać, że wszystkie województwa, które najbardziej zyskały na polityce ROW (przedstawione w szarym kole), były zbliżone do siebie pod względem kombinacji wiejskości i rolniczości, mimo iż pochodziły $\mathrm{z}$ regionów różnych typów. Porównując je z resztą regionów, trudno nie zauważyć, że wszystkie one pochodzą z najbardziej peryferyjnego miejsca całego układu współrzędnych (górnego prawego rogu), gdzie na osi X odłożone są coraz wyższe jednostki „wiejskości”, a na osi Y jednostki „rolniczości”. Wyraźnie wskazuje to, że grupa pięciu województw, które najbardziej zyskały na polityce ROW, była najbardziej rolniczo-wiejską grupą województw.

Podsumowując, analiza uzyskanych rezultatów z modelu RegPOL z wykorzystaniem dwuwymiarowej typologii wiejsko-rolniczej pozwoliła na ustalenie, jakiego rodzaju regiony/województwa najbardziej zyskały na polityce ROW. Analiza w układzie współrzędnych wskazuje na to, że istotnie to najbardziej wiejsko-rolnicze regiony skorzystały z polityki ROW. Gdybyśmy opierali się jedynie na przynależności województw do poszczególnych typów wiejskości-rolniczości, 
Rozdział 4. Analiza efektów wsparcia rozwoju obszarów wiejskich przy zastosowaniu modelu RegPOL

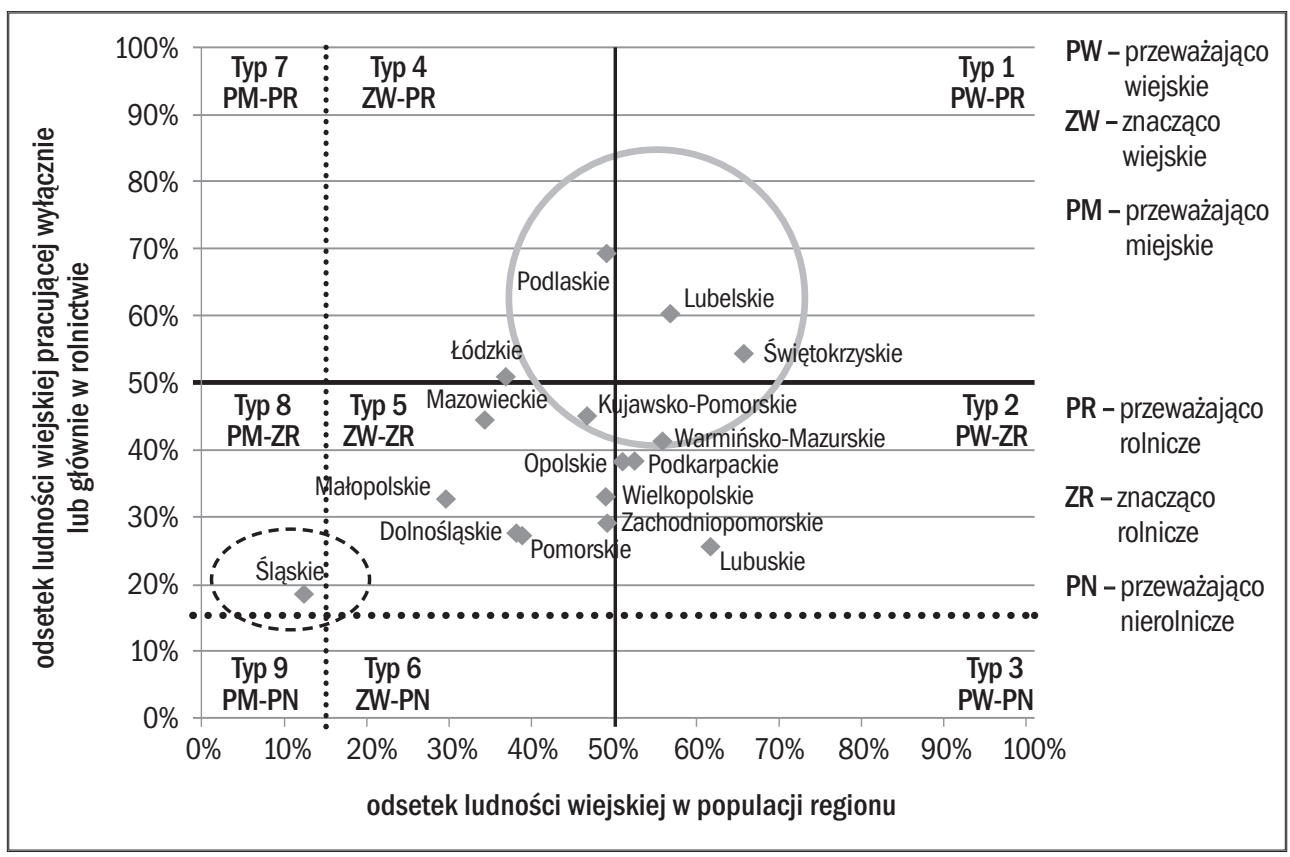

Rysunek 4.19. Ranking województw zyskujących na polityce ROW z lat 2004-2006 w typologii wiejsko-rolniczej

* w kółku ujęto województwa, które najwięcej zyskały na polityce ROW 2004-2006

Źródło: Opracowanie własne na podstawie zmodyfikowanej typologii wiejskości OECD.

doszlibyśmy do wniosku, że najwięcej zyskały typy pośrednie. Jednak pominęlibyśmy ważny fakt, że w rzeczywistości te pięć województw, które są w różnych typach regionów, są w gruncie rzeczy bardzo zbliżone do siebie pod względem wiejskości-rolniczości, co widać w kole - rys. 4.19. Ogólnie można stwierdzić, że w grupie najbardziej wiejsko-rolniczych województw najwięcej z polityki ROW zyskały te, które są mieszane pod względem wiejskości-rolniczości.

\section{Weryfikacja hipotezy czwartej}

Uzyskaliśmy pozytywne rozstrzygnięcie naszego przypuszczenia, że to najbardziej wiejsko-rolnicze regiony zyskaty najwięcej na polityce ROW. Jednak jednocześnie doszliśmy do wniosku, że wśród tych regionów, w ścistej czołówce sa te, które sa albo przeważajaco rolnicze, albo przeważajaco wiejskie, a dopiero $w$ drugiej kolejności te przeważajaco wiejskie i rolnicze naraz. 
Rolę nauki w odniesieniu do obszarów wiejskich można ują́ w następujacym haśle: poprzez kompleksowe badanie starać się zrozumieć wieś, by ja polubić, a nastęnie rzetelnie opisać i mąrze wspierać

Jerzy Wilkin

\section{WNIOSKI I REKOMENDACJE}

\subsection{Wnioski z badań}

W książce zostały zweryfikowane 4 główne hipotezy badawcze wraz z towarzyszącymi im pytaniami, które skupiały się na pogłębieniu omawianego problemu badawczego. Sformułowanie hipotez oraz sposób i wynik ich weryfikacji przedstawia tabela 5.1. Proces ten doprowadził do następujących wniosków:

- Prowadząc politykę rozwoju obszarów wiejskich po wstąpieniu do UE Polska mogła podjąć co najmniej trzy autonomiczne decyzje co do: • liczby działań jakie chce realizować w ramach polityki ROW • typów działań • alokacji środków pieniężnych pomiędzy działania i województwa.

W Polsce przyjęto strategię realizowania dużej liczby działań, co doprowadziło do rozdrobnienia środków na poszczególne cele i poniesienia wysokich kosztów transakcyjnych związanych z budową, obsługą i kontrolą całego systemu zarządzania. Większość wybranych typów działań miała charakter subsydiów inwestycyjnych, w drugiej kolejności transferów bezpośrednich oraz subsydiów obszarowych. System przydzielania określonego zasobu środków pomiędzy poszczególne województwa był dość transparentny (tzw. koperty regionalne), oparty na zrozumiałych i upublicznionych wskaźnikach (choć można by dyskutować czy właściwych), natomiast podział środków między poszczególne działania na poziomie krajowym był niejawny i trudny do wyjaśnienia w sposób naukowy, co wskazuje na duże upolitycznienie decyzji w tym zakresie.

- Na poziomie krajowym występuje zbliżona proporcja między funduszami efektywnie wspierającymi rozwój obszarów wiejskich a działaniami wyrównującymi dochody mieszkańców obszarów wiejskich.

Jak każda polityka rozwoju, również polityka ROW jest pewnym kompromisem między wspieraniem szybkiego wzrostu gospodarczego obszarów wiejskich a celami społecznymi (spokojem społecznym i wyrównywaniem szans zapóźnionych 
obszarów wiejskich). Kompromis ten jest również jasno widoczny na poziomie całej polityki UE, gdzie obok idei wyrównywania szans, manifestowanej choćby poprzez politykę spójności, mamy też ideę wzrostu konkurencyjności, realizowaną poprzez strategię lizbońską. Niestety, pogodzenie tych dwóch kierunków jest zwykle bardzo trudne, gdyż najczęściej jeden odbywa się kosztem drugiego. Jednak w przypadku polityki ROW wydaje się, że na poziomie krajowym środki proefektywnościowe i prorównościowe rozłożyły się dość równomiernie. Jak ustaliliśmy, subsydia inwestycyjne miały charakter proefektywnościowy, a transfery bezpośrednie i subsydia obszarowe - głównie prorównościowy. Największe wsparcie na rozwój obszarów wiejskich w ramach SPO Rolnictwo i PROW 2004-2006 przyznano w formie subsydiów inwestycyjnych (42\%), następnie w formie subsydiów obszarowych $(29 \%)$ oraz w formie transferów bezpośrednich (29\%). Stosunek środków proefektywnościowych do prorównościowych był bliski równowagi i wynosił 53\% do 47\%. Z kolei w latach 2007-2013 planowane subsydia inwestycyjne wynoszą 55\%, transfery bezpośrednie $15 \%$, a subsydia obszarowe $30 \%$. Tak więc relacja środków proefektywnościowych do prorównościowych będzie korzystniejsza dla tych pierwszych, mniej więcej $64 \%$ do 36\%. Oznacza to, że zwiększy się przewaga środków proefektywnościowych.

- Na poziomie województw widoczne są wyraźne różnice w strukturze absorpcji przyznanych środków.

W strukturze przyznawanych funduszy ważne jest nie tylko to, ile ich przypadło na dane województwo, ale przede wszystkim, na jakie instrumenty ekonomiczne, bo to ma decydujący wpływ na efektywność wykorzystania tych środków. Największy odsetek transferów bezpośrednich (TB) w strukturze wykorzystanych środków miało województwo świętokrzyskie (47\%), a największy odsetek subsydiów obszarowych (SO) - województwo zachodniopomorskie (50\%). Wśród województw pozytywnie wyróżniało się województwo kujawsko-pomorskie, które w strukturze wykorzystanych środków miało najwięcej subsydiów inwestycyjnych w infrastrukturę (SI_b) - 56\% wykorzystanych środków. Inwestycje w edukację stanowiły zwykle bardzo mały odsetek działań, ale największy miało województwo podkarpackie i małopolskie, po 4\% w każdym z nich. Różnice w strukturze tych środków są z pewnością wypadkową wielu czynników zarówno popytowych, jak i podażowych, których nie sposób wszystkich wymienić. $Z$ jednej strony, znaczenie miały czynniki zewnętrzne (np. odgórny podział środków na województwa i algorytmy kryteriów dostępu do działań), z drugiej, decydowały o tym uwarunkowania wewnętrzne, np. potrzeby inwestycyjne samych gospodarstw, ich aktywność i umiejętności ich pozyskiwania, zaangażowanie różnego rodzaju instytucji dorad- 
czych i pośredniczących, poziom rozwoju województw, uwarunkowania przyrodnicze, stan początkowego nasycenia inwestycjami itp.

- Wspieranie rozwoju poprzez subsydia inwestycyjne jest dużo efektywniejsze niż poprzez transfery dochodowe czy subsydia obszarowe.

Wśród narzędzi polityki rozwoju obszarów wiejskich najefektywniejsze okazały się inwestycje w infrastrukturę (inwestycje w gospodarstwach, dostosowanie do standardów UE, poprawa przetwórstwa i marketingu). W niektórych województwach bardzo efektywne okazały się inwestycje w edukację (doradztwa i szkolenia). Natomiast najmniej efektywne były płatności obszarowe oraz transfery bezpośrednie. Relacje między tymi rodzajami środków w funduszach ogółem pozyskanych przez województwa, miały znaczenie dla ich rozwoju. Można powiedzieć, że im większy odsetek subsydiów inwestycyjnych w strukturze pozyskanych funduszy, tym wyższa efektywność województw w wykorzystywaniu polityki ROW. Ale zależność ta była znacznie osłabiona w przypadku województw, w których rolnictwo jest już w wyższym stopniu nasycone inwestycjami.

- Działania postrzegane jako łatwo dostępne, charakteryzują się dużo mniejszą efektywnością niż działania trudno dostępne.

Jak wykazała analiza jakościowa, działania wyraźnie różniły się stopniem trudności w ich pozyskiwaniu i realizacji. Do działań łatwo dostępnych zaliczały się głównie te, które udzielane były w formie transferów bezpośrednich i subsydiów obszarowych, a do trudno dostępnych te, które występowały jako subsydia inwestycyjne w infrastrukturę. Niestety, działania łatwo dostępne okazały się dużo mnie efektywne niż działania trudno dostępne. Dlatego można przypuszczać, że jedną z przyczyn pozyskiwania proporcjonalnie małej ilości wysokoefektywnych działań przez niektóre województwa (nie licząc działań SPO, których alokacja była zdeterminowana kopertowaniem) mógł być fakt, że subsydia te były relatywnie trudnymi środkami do uzyskania. Dużo mniej formalności i kontroli związanych było z transferami bezpośrednimi czy obszarowymi niż z subsydiami inwestycyjnymi.

- W ujęciu regionalnym zwykle najbardziej efektywną formą wsparcia były inwestycje w infrastrukturę, a na drugim miejscu inwestycje w kapitał ludzki.

W większości województw najbardziej efektywną formą wsparcia rozwoju obszarów wiejskich były inwestycje w infrastrukturę (podobnie jak na poziomie krajowym). Dotyczyło to głównie takich województw, jak: śląskie, świętokrzyskie, opolskie i małopolskie. Drugim pod względem efektywności w większości woje- 
wództw okazały się subsydia w kapitał ludzki, w tym w szczególności w województwach: śląskim, podkarpackim i dolnośląskim. W dwóch województwach inwestycje te były nawet najbardziej efektywną formą wsparcia ze wszystkich dla rozwoju tamtejszych obszarów wiejskich - tak było w województwach lubelskim i mazowieckim. W większości województw zupełnie nieefektywne są transfery bezpośrednie czy subsydia obszarowe (z wyjątkiem województwa kujawsko-pomorskiego).

- Skuteczność względna polityki ROW w ujęciu regionalnym najbardziej zależała od wielkości funduszy pozyskanych przez województwa w relacji do ich siły ekonomicznej, mierzonej produktem regionalnym brutto (PRB) i PRB na mieszkańca.

Najwięcej na polityce ROW zyskały województwa, które pozyskały największe fundusze w relacji do swojego PRB. Kryteria dostępu były tak ustalone, że to najbardziej rolnicze i średnio biedniejsze województwa uzyskały relatywnie większe wsparcie w stosunku do swojej zamożności i siły ekonomicznej. Zamożność województw była negatywnie skorelowana ze skutecznością, tj. większą skuteczność osiągnęły biedniejsze województwa. A ponieważ biedniejsze województwa zwykle były też bardziej wiejsko-rolniczymi, nie dziwi, że aż pięć z sześciu najszybciej rozwijających się województw korzystających z funduszy ROW ma charakter przeważająco wiejski, połowa $\mathrm{z}$ nich jest przeważająco rolnicza, a druga połowa znacząco rolnicza, według dwukierunkowej typologii wiejsko-rolniczej zaproponowanej w niniejszej książce opartej na metodologii OECD.

- Dzięki różnorodności działań ujawniły się pozytywne efekty mnożnikowe polityki ROW w różnych pozarolniczych sektorach gospodarki.

Wprawdzie bezpośrednim beneficjentem polityki ROW jest sektor rolny (rolnicy), ale z powodu przepływów zasobów i rent również inne sektory odnoszą konkretne korzyści. Kierunek tych przepływów w dużej mierze wyznaczyły koszty kwalifikowane ${ }^{63}$ różnych działań, ustalone przez KE. Lista takich kosztów określa, jakiego rodzaju wydatki mogą być refundowane rolnikom, a zatem też rodzaj i wielkość inwestycji, stąd wśród sektorów będących największymi beneficjentami są głównie: sektor budowlany (głównie dzięki takim działaniom, jak dostosowania do standardów UE i inwestycje w gospodarstwa rolne), sektor energetyczny, kopalnictwo, przemysł, usługi finansowe, transport i usługi mieszkaniowe. Efekty mnożnikowe różnią się w zależności od typu działania i struktury sektorowej województwa. Najwięcej na efektach mnożnikowych zyskały takie województwa, jak: podlaskie, warmińsko-mazurskie i kujawsko-pomorskie.

${ }^{63}$ Koszty kwalifikowane są odgórnie ustalone i definiują wydatki, które mogą być finansowane lub refundowane beneficjentom. 
- Efekty mnożnikowe (w zakresie produkcji i usług) mają wpływ na zatrudnienie w pozarolniczych sektorach gospodarki, ale w niewielkim stopniu pokrywają się one z sektorami, w których zatrudniana jest ludność wiejska.

Ludność wiejska w największym stopniu, poza rolnictwem, znajduje zatrudnienie w takich sektorach, jak przetwórstwo przemysłowe (głównie w przemyśle żywnościowym), handel i naprawy, budownictwo, transport, administracja państwowa i edukacja. Efekty mnożnikowe akurat w tych sektorach ujawniły się w niewielkim stopniu. Jedynie ekspansja sektora budowlanego i transportowego - gdzie tradycyjnie zatrudnia się mieszkańców wsi - najbardziej mogła sprzyjać zatrudnieniu pozarolniczemu ludności wiejskiej.

- Polityka ROW miała nieduży, ale pozytywny wpływ na takie zmienne ekonomiczne, jak wzrost gospodarczy, konsumpcja prywatna, handel krajowy i zagraniczny, w mniejszym stopniu na zatrudnienie i inflację, a prawie bez znaczenia była dla bezrobocia i migracji.

Polityka ROW w skali kraju stanowiła 1,6\% ówczesnego PKB, jednak było duże regionalne zróżnicowanie jej znaczenia, od 0,8\% PRB w województwie dolnośląskim, do 6,3\% PRB w województwie podlaskim. Jej wpływ na poszczególne zmienne ekonomiczne też był zróżnicowany. Największy wpływ wywarła na wzrost PKB (1,5\%), oraz wzrost eksportu (1,5\%) nieco mniejszy na wzrost konsumpcji prywatnej $(0,8 \%)$ i inflację $(-0,7 \%)$ oraz wzrost zatrudnienia $(0,8 \%)$. Bardzo małe znaczenie natomiast polityka miała dla zmian w bezrobociu $(-0,14 \mathrm{pkt}$ proc.), a prawie w ogóle nie miała wpływu na ruchy migracyjne.

- Regiony wiejsko-rolnicze zyskały więcej na polityce ROW niż regiony bardziej zurbanizowane i mniej zależne od rolnictwa.

Analiza sześciu głównych wskaźników ekonomicznych w układzie typologii wiejsko-rolniczej wykazała, iż regiony najbardziej wiejsko-rolnicze zyskały więcej na polityce rozwoju obszarów wiejskich niż regiony bardziej zurbanizowane. Jednak w grupie tej najwięcej na polityce rozwoju obszarów wiejskich zyskały regiony mieszane, czyli takie, które jeśli są przeważająco rolnicze, to tylko znacząco wiejskie oraz, jeśli są przeważająco wiejskie, to tylko znacząco rolnicze. Najwięcej na polityce ROW zyskały kolejno województwa: podlaskie (znacząco wiejskie - przeważająco rolnicze), warmińsko-mazurskie (przeważająco wiejskie-znacząco rolnicze), kujawsko-pomorskie (znacząco wiejskie-znacząco rolnicze), świętokrzyskie i lubelskie (przeważająco wiejskie-przeważająco rolnicze). Województwa o względnie wyższym poziomie rozwoju i inwestycji zyskały relatywnie najmniej (np. śląskie czy wielkopolskie). 
Tabela 5.1. Podsumowanie sposobów i wyników weryfikacji hipotez i pytań badawczych

\begin{tabular}{|c|c|c|}
\hline $\begin{array}{l}\text { Hipotezy i pomocnicze pytania } \\
\text { badawcze }\end{array}$ & Sposoby weryfikacji hipotez & Rozstrzygnięcie hipotez \\
\hline 1 & 2 & 3 \\
\hline $\begin{array}{l}\text { HIPOTEZA 1: Polityka rozwoju } \\
\text { obszarów wiejskich w Polsce } \\
\text { faworyzuje działania } \\
\text { prorównościowe nad rozwiązaniami } \\
\text { proefektywnościowymi } \\
\text { Pytania badawcze: } \\
\text { Jaka była proporcja działań } \\
\text { proefektywnościowych w stosunku } \\
\text { do działań prorównościowych } \\
\text { w polityce rozwoju obszarów } \\
\text { wiejskich w latach } 2004-2006 ?\end{array}$ & $\begin{array}{l}\text { - Weryfikacja poprzez analizę } \\
\text { statystyczną narzędzi polityki } \\
\text { ROW, popartą analizą } \\
\text { literatury oraz wynikami ankiet } \\
\text { z regionalnych ośrodków } \\
\text { ARiMR. }\end{array}$ & $\begin{array}{l}\text { Hipoteza ODRZUCONA } \\
\text { (rozdział 2.3.3) } \\
\text { Z ekonomicznego punktu } \\
\text { widzenia rozkład środków } \\
\text { proefektywnościowych } \\
\text { i prorównościowych był dość } \\
\text { wyrównany, nawet z pewną } \\
\text { przewagą tych pierwszych. } \\
\text { Jednak widoczne były duże } \\
\text { różnice regionalne }\end{array}$ \\
\hline $\begin{array}{l}\text { HIPOTEzA 2: Wspieranie rozwoju } \\
\text { poprzez inwestycje jest dużo } \\
\text { skuteczniejszą i efektywniejszą } \\
\text { polityką rozwoju obszarów } \\
\text { wiejskich niż wspieranie rozwoju } \\
\text { poprzez różnego rodzaju subsydia } \\
\text { nieinwestycyjne } \\
\text { Pytania badawcze: } \\
\text { Jakie skutki ekonomiczne } \\
\text { wywołały działania } \\
\text { proefektywnościowe, a jakie } \\
\text { prorównościowe? } \\
\text { Jakie są różnice w skutkach } \\
\text { ekonomicznych, gdy tę samą ilość } \\
\text { funduszy przeznaczymy na rozwój } \\
\text { obszarów wiejskich w postaci: } \\
\text { a) subsydiów inwestycyjnych } \\
\text { b) subsydiów/transferów } \\
\text { dochodowych, } \\
\text { c) subsydiów do czynników } \\
\text { produkcji, } \\
\text { d) subsydiów do produkcji? } \\
\text { p Jakie są koszty ewentualnej } \\
\text { polityki „maksymalizacji absorpcji } \\
\text { śodków”? }\end{array}$ & $\begin{array}{l}\text { - Symulacja modelowa } \\
\text { rzeczywistych wydatków na } \\
\text { rozwój obszarów wiejskich } \\
\text { w PROW i SPO Rolnictwo } \\
\text { 2004-2006. } \\
\text { - Symulacja modelowa } \\
\text { hipotetycznego wariantu, gdy } \\
\text { na różne narzędzia polityki } \\
\text { rozwoju obszarów wiejskich } \\
\text { przeznaczymy dokładnie tę } \\
\text { samą ilość funduszy. Pozwoliło } \\
\text { to na porównanie relatywnej } \\
\text { efektywności i skuteczności } \\
\text { poszczególnych narzędzi. } \\
\text { - Wyniki symulacji modelowej } \\
\text { wskazujące na to, ile razy } \\
\text { mniejsze efekty ekonomiczne } \\
\text { (w postaci PKB, zatrudnienia } \\
\text { etc.) osiąga się, przeznaczając } \\
\text { fundusze na najłatwiejsze } \\
\text { rodzaje subsydiów } \\
\text { w porównaniu z niewielkim } \\
\text { przesunięciem środków na } \\
\text { trudniejsze z punktu widzenia } \\
\text { absorpcji inwestycje. }\end{array}$ & $\begin{array}{l}\text { Hipoteza POTWIERDZONA } \\
\text { (rozdział 4.1 i 4.2) } \\
\text { Inwestowanie w rozwój } \\
\text { przynosi o wiele większe efekty } \\
\text { niż jego subsydiowanie. } \\
\text { Polityka maksymalizująca } \\
\text { uzyskiwanie „łatwych } \\
\text { środków”, odgrywających rolę } \\
\text { prorównościową, jest } \\
\text { kosztowna ekonomicznie, choć } \\
\text { może być uzasadniona do } \\
\text { pewnego stopnia politycznie, } \\
\text { na gruncie równości } \\
\text { społecznej. W ocenie rozwoju } \\
\text { ekonomicznego, z konieczności } \\
\text { posłużono się jego wąską } \\
\text { definicją (wzrostu } \\
\text { gospodarczego) oraz innymi } \\
\text { zmiennymi ekonomicznymi, } \\
\text { jak zatrudnienie itp., ale nie } \\
\text { skwantyfikowano efektów } \\
\text { społecznych i środowiskowych. }\end{array}$ \\
\hline $\begin{array}{l}\text { HIPOTEzA 3: Polityka rozwoju } \\
\text { obszarów wiejskich nakierowana } \\
\text { jest głównie na sektor rolny, ale ze } \\
\text { względu na dużą różnorodność } \\
\text { instrumentów generuje również } \\
\text { znaczące efekty mnożnikowe } \\
\text { w różnych innych sektorach } \\
\text { gospodarki }\end{array}$ & $\begin{array}{l}\text { - Symulacja modelowa } \\
\text { sektorowych skutków płatności } \\
\text { zrealizowanych w latach } \\
\text { 2004-2007 w ramach } \\
\text { programów SPO Rolnictwo } \\
\text { i PROW 2004-2006. }\end{array}$ & $\begin{array}{l}\text { Hipoteza POTWIERDZONA } \\
\text { (rozdział 4.3) } \\
\text { Choć beneficjentami } \\
\text { bezpośrednimi większości } \\
\text { środków są rolnicy, to jednak } \\
\text { nie tylko oni korzystają na tych } \\
\text { środkach. Poprzez przepływy }\end{array}$ \\
\hline
\end{tabular}




\begin{tabular}{|c|c|c|}
\hline 1 & 2 & 3 \\
\hline $\begin{array}{l}\text { Pytania badawcze: } \\
\text { - Które sektory zyskały najwięcej, } \\
\text { a które najmniej na polityce } \\
\text { rozwoju obszarów wiejskich } \\
\text { w ujęciu krajowym i regionalnym? } \\
\text { - Jaki wpływ mają efekty } \\
\text { mnożnikowe na pozarolnicze } \\
\text { zatrudnienie ludności wiejskiej? }\end{array}$ & & $\begin{array}{l}\text { zasobów pieniężnych } \\
\text { i czynników wytwórczych } \\
\text { ujawniają się pozytywne efekty } \\
\text { ekonomiczne (mnożnikowe) } \\
\text { również w innych sektorach } \\
\text { gospodarki. }\end{array}$ \\
\hline $\begin{array}{l}\text { HIPOTEZA 4: Najwięcej na polityce } \\
\text { rozwoju obszarów wiejskich } \\
\text { zyskują regiony najbardziej wiejskie } \\
\text { i najbardziej uzależnione od } \\
\text { rolnictwa } \\
\text { Pytanie badawcze: } \\
\text { - Które regiony pogrupowane } \\
\text { według typologii wiejsko-rolnej } \\
\text { odniosły największe, a które } \\
\text { najmniejsze pozytywne/ } \\
\text { negatywne skutki ekonomiczne } \\
\text { polityki rozwoju obszarów } \\
\text { wiejskich? }\end{array}$ & $\begin{array}{l}\text { - Przełożenie wyników } \\
\text { symulacji skutków } \\
\text { ekonomicznych narzędzi } \\
\text { PROW i SPO Rolnictwo } 2004 \\
\text {-2006 na zaproponowaną } \\
\text { typologię wiejsko-rolną } \\
\text { regionów w Polsce. }\end{array}$ & $\begin{array}{l}\text { Hipoteza POTWIERDZONA } \\
\text { (rozdział 4.4) } \\
\text { Wprawdzie najbardziej } \\
\text { wiejsko-rolnicze typy regionów } \\
\text { uzyskują więcej funduszy ROW } \\
\text { niż zurbanizowane, ale to } \\
\text { pośrednie typy województw } \\
\text { (pod względem wiejskości } \\
\text { i rolniczości) odczuwają } \\
\text { najwięcej pozytywnych efektów } \\
\text { tej polityki. }\end{array}$ \\
\hline
\end{tabular}

Źródło: Opracowanie własne na podstawie wyników badań modelu RegPOL dla lat 2004-2008.

\subsection{Sugestie co do dalszych badań}

W opracowaniu pojawiło się kilka kwestii, które z pewnością zasługują na szersze potraktowanie, niż to miało miejsce w tej pracy. Mogłyby one stanowić odrębne tematy badawcze. Poniżej przedstawiamy sugestie tematów wartych podjęcia badań.

- Dyskusja prowadzona w rozdziale 1 na temat różnych definicji obszarów wiejskich i sposobów ich delimitacji doprowadziła do konkluzji, iż istnieje potrzeba opracowywania typologii obszarów wiejskich bardziej zorientowanych na prowadzenie polityki wobec tych obszarów. Nowe propozycje powinny jak najlepiej delimitować różne typy obszarów wiejskich, ale jednocześnie powinny pozostać proste i transparentne. Przykład Finlandii pokazuje, że dobra typologia obszarów wiejskich zwiększa skuteczność polityki adresowanej do nich, gdyż jest bardziej nastawiona na specyficzne problemy, a nie same obszary. Zachęca to do dalszych badań nad metodologią wiejskości i rolniczości regionów. Ponadto na opracowanie czeka swoisty atlas, w którym byłyby przedstawione regiony wszystkich krajów UE, opracowane według zaproponowanej już tutaj typologii wiejsko- 
-rolniczej. Wizualizacja uzależnienia regionów wiejskich od rolnictwa dziś i przed kilkudziesięcioma laty, mogłaby dostarczyć ciekawych wniosków dotyczących tempa przemian strukturalnych w różnych krajach według różnych typów regionów $\mathrm{UE}$.

- W rozdziale 2 dyskutowana była kwestia determinantów różnic występujących pomiędzy województwami w strukturze środków pozyskanych z poszczególnych działań. Potrzebne byłyby badania pokazujące, jakie czynniki (nie licząc kopert regionalnych) determinowały strukturę pozyskanych funduszy ROW w poszczególnych województwach. Analiza taka, pogłębiona badaniami jakościowymi, powinna skupić się na zdefiniowaniu czynników decydujących o sposobie wydatkowania funduszy unijnych. Powinna pokazywać, od czego to zależy w różnych typach województw i gospodarstw.

- Metodologiczny rozdział 3 oparty jest na jednej metodzie konstrukcji regionalnych tablic przepływów międzygałęziowych, ale istnieje całe spektrum możliwości, które warto przebadać i porównać różnice wynikające z zastosowania różnych metod. Celem byłoby wypracowanie najlepszej techniki i doprowadzenie do regularnego publikowania regionalnych tablic przepływów międzygałęziowych. Drugą bardzo ciekawą analizą, którą zasygnalizowano w rozdziale 3 (ale wykroczyła ona poza jego ramy), jest potraktowanie wojewódzkich tablic przepływów międzygałęziowych jako osobnego narzędzia ekonomicznego i przeanalizowanie związków rolnictwa z pozostałymi sektorami gospodarki. Do tej pory analizy takie opierały się tylko na krajowych tablicach (np. z lat 1977, 1995, 2000), a więc warto byłoby poszerzyć tę wiedzę o relacje zachodzące na poziomie województw.

- Analizy prowadzone w rozdziale 4 byłyby bogatsze, gdyby istniały reprezentatywne badania wskazujące, na jakie cele spożytkowane zostały fundusze przez beneficjentów w ramach poszczególnych działań. Istotne jest pytanie, jaka część transferów bezpośrednich oraz subsydiów obszarowych wydatkowana została na inwestycje (i jakie) w podziale na różne typy gospodarstw, a jaka część działań posłużyła wydatkom konsumpcyjnym. Niezwykle ciekawe byłoby poznanie, od czego to zależało i jak kształtują się różnice w zachowaniach i motywacjach beneficjentów poszczególnych działań w poszczególnych województwach, a może nawet różnych typach gmin. Niezwykle interesujące również byłyby badania, poświęcone ustaleniu determinantów zatrudnienia pozarolniczego ludności wiejskiej w ujęciu sektorów PKD w poszczególnych województwach, co bardzo wzbogaciłoby wnioskowanie o skutkach efektów mnożnikowych.

Oczywiście powyższe propozycje nie wyczerpują możliwości, są jedynie przykładami problemów wartych zbadania. 


\subsection{Rekomendacje dla polityki rozwoju obszarów wiejskich}

Polityka rozwoju obszarów wiejskich, jeśli ma doprowadzić do szybkiej poprawy warunków ekonomicznych mieszkańców wsi, powinna koncentrować się na dzialaniach charakteryzujących się jak najwyższą efektywnością. W polskiej polityce ROW zachowana jest proporcja między funduszami przeznaczonymi na poprawę efektywności a tymi na wyrównywanie szans, więc istnieje duże pole manewru, aby przesunąć więcej środków w stronę bardziej efektywnych rozwiązań. Zwiększając udział instrumentów proefektywnościowych, można będzie uzyskać szybszy rozwój obszarów wiejskich. W polityce na lata 2007-2013 udział ten jest już nieco większy niż w poprzednim okresie i trzeba zabiegać, żeby w kolejnym okresie budżetowym, tj. po 2013 r., był jeszcze większy. Oczywiście trzeba pamiętać o zachowaniu bezpiecznej relacji między efektywnością a równością wsparcia, która jest ważna w każdej polityce rozwoju.

Warto zastępować transfery bezpośrednie oraz subsydia obszarowe bardziej efektywnymi instrumentami, takimi jak subsydia inwestycyjne. Transfery bezpośrednie i subsydia obszarowe w formie, w której były realizowane w latach 2004-2006, okazały się mało efektywną formą wsparcia. Przeznaczając te same fundusze na subsydia inwestycyjne, można byłoby osiągnąć wyższy wzrost gospodarczy, wyższe zatrudnienie, mniejszą inflację i poprawę w bilansie handlowym. To tylko niektóre z korzyści poprawy struktury wsparcia ROW, które można osiągnąć dzięki przejściu z ,zasilania obszarów wiejskich” na „inwestowanie w obszary wiejskie”, spójnemu z nowym paradygmatem wiejskim lansowanym m.in. przez [OECD 2006].

Należy zmienić zasady, które powodują, że najbardziej efektywne działania są jednocześnie najtrudniejsze w pozyskaniu i realizacji, a te najmniej efektywne są najlatwiej dostępne dla beneficjentów. Ta niekorzystna zależność: w im bardziej efektywnej formie jest udzielane wsparcie finansowe $\mathrm{w}$ ramach działania, tym jest trudniej dostępne dla beneficjentów, wywołuje również obawę przed zwiększaniem na nie puli środków, gdyż mogą nie zostać w pełni wykorzystane ${ }^{64}$. Zwykle, żeby pozyskać subsydium inwestycyjne, trzeba spełnić wiele trudnych warunków i wypełnić formularze trudniejsze niż w przypadku nieinwestycyjnych form wsparcia.

Dostępność do wysokoefektywnych działań powinna być ułatwiona poprzez: - uproszczenie formalności i wymagań stawianych beneficjentom • różnicowanie

\footnotetext{
${ }^{64}$ Wyjątek stanowi tu wsparcie na rzecz inwestycji dostosowujących gospodarstwa do standardów UE, na które zwiększono budżet w trakcie programu.
} 
stopnia trudności ich uzyskania, w zależności od stopnia ich efektywności oraz wysokości udzielanego wsparcia. Jednocześnie im większe inwestycje, tym dokładniejsza powinna być kontrola prawidłowości wykorzystania środków. Niekorzystna sytuacja może się zmienić po uproszczeniu procedur uzyskania subsydiów inwestycyjnych, a wzorem może być SAPARD. Na przykład, gdy biznesplany będą mniej szczegółowe, gdy mniej formalności będzie wymaganych przy wnioskach z nimi związanych. Można też pomyśleć o zróżnicowaniu trudności wniosków, w zależności od wysokości środków, o które beneficjent się ubiega. Wtedy bardzo wysokie subsydia inwestycyjne mogą być trudniejsze do uzyskania i bardziej restrykcyjnie kontrolowane, a małe subsydia inwestycyjne powinny być łatwiej dostępne dzięki uproszczonym wymaganiom i procedurom.

Trzeba starać się również, żeby działania występujące w mało efektywnej formie zamieniać na formy bardziej efektywne. Różne działania, które zaprojektowano jako bezpośrednie transfery dochodowe, można zamienić na inną formę wsparcia. Na przykład, działanie „ułatwianie startu młodym rolnikom”, realizowane w ramach SPO Rolnictwo 2004-2006, było czystym transferem dochodowym, a już w PROW 2007-2013 zmieniono go na proste subsydium inwestycyjne, gdzie wymagany był prosty biznesplan i wydatkowanie co najmniej 70\% kwoty wsparcia na rozwój gospodarstwa. W pierwszym przypadku z analiz wynika, że fundusze te spożytkowane zostały w dużej mierze na konsumpcję, co zresztą nie było zabronione. Nie taki jednak był cel tego działania. W zapisie programu działanie to miało wspierać konkurencyjność polskiego rolnictwa. Widać jasno z tego przykładu, że nieadekwatny dobór narzędzia ekonomicznego prowadzi do innych od zamierzonych efektów.

Planując wykorzystanie unijnej polityki ROW w Polsce, powinniśmy koncentrować się na charakterze ekonomicznym wybieranych działań, a nie głównie na ich liczbie. W debacie publicznej, jaka towarzyszy kolejnym edycjom programów w ramach polityki ROW, przeważają dyskusje dotyczące liczby wybieranych działań, jednak nie mówi się wystarczająco o ich jakości i skutkach, jakie wywołuje wybór konkretnych instrumentów ekonomicznych. Nawet największa liczba funduszy przekazywana w nieefektywnej i niespójnej formie nie doprowadzi do uzyskania pożądanych i szybkich efektów - jednoczesnego wzrostu konkurencyjności, poprawy środowiska i lepszej jakości życia ludności wiejskiej, a takie trzy cele zakłada polityka ROW. Dlatego warto ustalić, jakie są mechanizmy ekonomiczne i kanały przenikania tych funduszy między sobą i w obiegu całej gospodarki. Praktyczny wymiar tych działań zależy od tego, jak je zaprogramujemy, 
a nie ile ich zakontraktujemy. Należy przy tym pamiętać, że większa liczba działań nie oznacza większych funduszy, wprost przeciwnie, następuje ich rozproszenie. Zmniejszenie liczby działań oznaczałoby koncentrację środków na najważniejszych zadaniach, a oprócz tego obniżenie kosztów administracyjnych i podwyższenie jakości obsługi beneficjentów, co też ma duże znaczenie dla efektywnego wykorzystania tych programów.

Największy wpływ na osiągnięcie założonych celów poszczególnych działań ma forma, w jakiej są przyznawane, a nie ich kategoryzacja na osie priorytetowe, która oparta została na „życzeniach". Przyzwyczajeni jesteśmy do unijnej kategoryzacji działań, które w dużej mierze oparte są tylko na życzeniach co do tego, jakie cele powinny spełniać poszczególne działania, a nie są one poparte doborem odpowiednich instrumentów ekonomicznych. Przyjmujemy zatem, że np. działania przypisane do osi 1 „konkurencyjność” będą wspierać właśnie konkurencyjność, a nie zawsze tak jest. Nawet jeśli intencje działań pokrywają się z nazwami priorytetów, w praktyce często forma przyznawania tych działań wręcz nie sprzyja ich osiągnięciu. Na przykład, jeśli celem działania jest poprawa konkurencyjności (poprzez działanie „ułatwienie startu młodym rolnikom” czy „wsparcie dla gospodarstw niskotowarowych” itd.), a formą przyznania działania są transfery bezpośrednie, to nie ma tu zapewnionego mechanizmu, wymuszającego poprawę konkurencyjności u beneficjentów. Konieczne jest powiązanie nazewnictwa unijnego z instrumentami ekonomicznymi. Jeśli mają zostać osiągnięte konkretne cele ekonomiczne, to klasyfikacja działań musi spełniać kryteria ekonomiczne.

Powinno się zwiększyć przejrzystość procesu alokacji środków pomiędzy poszczególne działania, województwa oraz beneficjentów. Istnieje już wiele metod, które można stosować do symulacji różnych scenariuszy „przypisywania” środków finansowych do poszczególnych działań, województw czy nawet grup beneficjentów, w zależności o przyjętych priorytetów. Jedną z technik, która się sprawdziła we wspieraniu procesów decyzyjnych, są modele optymalizacyjne. Jednak niezależnie od tego, czy wykorzystywane będą modele, czy tylko proste wskaźniki, potrzebna jest debata publiczna o tym, jak wyznaczać kryteria podziału środków, w jakim stopniu podział ten powinien być sterowany odgórnie, a w jakim powinien wynikać z mechanizmów rynkowych, opartych na zasadach konkurencji. Brak takiej dyskusji i określenia zasad podziału środków budzić będzie wiele kontrowersji oraz podejrzeń o wpływ różnych grup interesów na wynik alokacji. 
Bardzo ważnym zadaniem polityki ROW powinno być zwiększanie pozarolniczych miejsc pracy, co w pewnym stopniu mogłoby się odbywać poprzez wzmocnienie efektów mnożnikowych tej polityki, uzyskanych poprzez zwiększoną różnorodność działań. Polityka ROW, mimo iż z założenia faworyzuje sektor rolniczy poprzez liczbę działań adresowanych do rolników, jednak dzięki swojej różnorodności i szerokiemu spektrum przepływów rzeczowo-finansowych pozwala korzystać również pozarolniczym sektorom gospodarki. Beneficjenci wydają uzyskane fundusze na dobra i usługi spoza sektora rolnego, zwykle budowlanego, edukacyjnego, a te z kolei przez to, że korzystają z usług kolejnych sektorów, tworzą efekt mnożnikowy w gospodarce. Jest to pozytywne, ważnym bowiem aspektem polityki ROW jest tworzenie miejsc pracy w innych niż rolniczy sektorach gospodarki.

Efekty mnożnikowe powinny być większe i bardziej ukierunkowane na zawody, w których ludność wiejska może latwiej znaleźć zatrudnienie. Efekty mnożnikowe działań polityki ROW mogłyby być większe, gdyby zwiększyć zakres kosztów kwalifikowanych przypisanych przez KE do poszczególnych działań. W obecnym układzie ujawniają się one w sektorach, w których ludność wiejska tradycyjnie odnotowuje niewielkie zatrudnienie ( $\mathrm{tj}$. w sektorze energetycznym, usługach finansowych, usługach mieszkaniowych). Tylko w dwóch sektorach efekty mnożnikowe pokrywają się ze znaczącym zatrudnieniem ludności wiejskiej: w budownictwie i transporcie. Można zatem pomyśleć o skonstruowaniu działań w taki sposób, by efekty pośrednie tych działań przejawiały się jeszcze bardziej w sektorach, w których ludność wiejska tradycyjnie znajduje większe zatrudnienie: w sektorze przetwórstwa przemysłowego, w usługach handlowych i naprawczych oraz edukacji. Dobrym przykładem takiego wsparcia jest działanie „poprawa przetwórstwa i marketingu” (wsparcie dla sektora przetwórczego), czy „dostosowanie do standardów UE” (wsparcie pośrednie dla sektora budowlanego).

Powinno się rozstrzygnąć dylemat polityki ROW polegający na tym, czy ma ona za zadanie wspierać najbardziej efektywne obszary wiejskie, czy najbardziej zapóźnione, które $z$ reguły są bardziej uzależnione od rolnictwa i jednocześnie biedniejsze. Niejako z definicji wydaje się, że polityka ROW nie może być tak efektywna jak inne, skoro adresowana jest do obszarów zapóźnionych. Jednak trzeba pamiętać, że dla nich ta sama kwota funduszy, choć przynosi mniejszy zwrot w ujęciu relatywnym (korzyści do kosztów), to jednak przynosi szybszy wzrost w ujęciu absolutnym, a więc świadczy o skuteczności polityki ROW, dla której głównym celem jest rozwój właśnie najbardziej wiejskich i rolniczych regio- 
nów, a nie dobrze rozwiniętych i bogatych. Powyższy wywód w żaden sposób nie oznacza, że w polityce ROW nie należy kierować się kryterium efektywnościowym. Wprost przeciwnie, tylko, że kryterium efektywnościowe powinno być stosowane już na etapie wyboru działań z menu oferowanego przez UE do realizowania tej polityki w Polsce, a nie na etapie dostępu do niej poszczególnych województw.

Należy częściej brać przykład z dobrych praktyk światowych. Wynika z nich, że najskuteczniejsze wsparcie dla biednych beneficjentów i regionów powinno odbywać się za pomocą instrumentów proefektywnościowych, a nie prorównościowych. Problem rozwoju najbiedniejszych regionów występuje na całym świecie i mimo zaangażowania znacznych środków finansowych pozostaje nadal nie rozwiązany, co tylko potwierdza złożoność problemu. Ale jednocześnie jest wiele przykładów, które potwierdzają możliwość odniesienia sukcesu w tej walce. Na przykład system mikropożyczek (za pośrednictwem Grameen Banku) dla ludności wiejskiej, który się sprawdził w najbiedniejszych regionach świata. Sukces ten udowodnił, że najskuteczniejsze formy wsparcia występują jednak w postaci instrumentów proefektywnościowych, choćby najprostszych, takich jak mikropożyczki. Forma wsparcia ma zatem kluczowe znaczenie dla wspierania rozwoju. 
r05.qxd 2011-10-31 09:44 Page 242 


\section{ANEKSY}

\section{Aneksy do rozdziału 2}

\section{ANEKS 2.1. WYPROWADZENIE KLASYFIKACJI WEDŁUG KRYTERIÓW EKONOMICZNYCH}

Aneks ten poświęcony jest odpowiedzi na pytanie, jakie instrumenty ekonomiczne kryją się za poszczególnymi działaniami polityki ROW. Przykładami podstawowych narzędzi polityki rozwoju znanymi w teorii ekonomii są: podatki (bezpośrednie i pośrednie), transfery dochodowe, subsydia do czynników produkcji (ziemi, pracy, kapitału), subsydia do produkcji i wiele innych. A jakimi instrumentami posłużono się w polityce ROW?

Podstawą klasyfikacji poszczególnych działań polityki ROW nie były cele, jakie stawiano poszczególnym działaniom (tym kryterium posługuje się KE, co jest mylące, jak staraliśmy się udowodnić w rozdziale 2.3.3), ale forma, w jakiej było udzielane wsparcie w ich ramach oraz sposób, w jaki zostały one faktycznie wykorzystane. Te dwa kryteria właśnie najbardziej determinują osiągnięcie celów. Samo zdefiniowanie celu (np. wzrostu konkurencyjności, poprawy środowiska czy poprawy jakości życia na wsi) nie przesądza o jego osiągnięciu. Bardziej zależy to od formy, w jakiej udzielane jest wsparcie. Dlatego w tworzeniu klasyfikacji starano się odwoływać jedynie do faktów związanych z realizacją programów (np. struktura faktycznie poniesionych kosztów), a nie do intencji w nich zawartych (np. opis celów). To, czy cele zostały osiągnięte czy nie, weryfikujemy w dalszej części książki, tu jedynie klasyfikujemy działania według ich formy ekonomicznej.

Do klasyfikacji działań wykorzystane były następujące źródła danych: • analiza płatności zrealizowanych w podziale na koszty kwalifikowane [ARiMR 2007, 2008] - sposób przekazania płatności (dokumenty programowe) • praktyczne wykorzystanie działania (ankieta i wywiady z pracownikami regionalnych oddziałów ARiMR oraz ODR-ów) i dostępna literatura/analizy dla poszczególnych działań. 
W wyniku analizy wyszczególniono 4 typy instrumentów ekonomicznych: transfery dochodowe/bezpośrednie (TB), subsydia do czynnika produkcji (ziemia), nazwane subsydiami obszarowymi (SO), subsydia inwestycyjne w infrastrukturę/budownictwo (SI_b), subsydia inwestycyjne w kapitał ludzki/edukację (SI_e). Poniżej znajduje się szczegółowe omówienie, czym kierowano się, przypisując poszczególnym działaniom typ instrumentu, jaki reprezentują. Podsumowanie klasyfikacji zawiera tabela A.2.1.

Tabela A.2.1. Klasyfikacja działań SPO Rolnictwo i PROW 2004-2006 ze względu na charakter płatności

\begin{tabular}{|c|c|c|c|}
\hline Działanie & $\begin{array}{l}\text { Kryteria kwalifikowalności } \\
\text { /Koszty kwalifikowane }\end{array}$ & Sposób płatności & $\begin{array}{c}\text { Decyzja o } \\
\text { zakwalifikowa- } \\
\text { niu instrumentu }\end{array}$ \\
\hline 1 & 2 & 3 & 4 \\
\hline $\begin{array}{l}\text { 1. Renty struktu- } \\
\text { ralne (PROW) }\end{array}$ & $\begin{array}{l}\text { Kwalifikacja na podstawie spełnienia warunków } \\
\text { związanych z wiekiem (ukończone } 55 \text { 1.), prowa- } \\
\text { dzeniem działalności rolnej (10 1.), ubezpiecze- } \\
\text { niem w KRUS (5 1.) i wielkością gospodarstwa. }\end{array}$ & $\begin{array}{l}\text { Transfer dochodowy, } \\
\text { wypłacany do mo- } \\
\text { mentu uzyskania eme- } \\
\text { rytury. }\end{array}$ & $\begin{array}{l}\text { Transfer bezpo- } \\
\text { średni (TB) }\end{array}$ \\
\hline $\begin{array}{l}\text { 2. Gospodarstwa } \\
\text { niskotowarowe } \\
\text { (PROW) }\end{array}$ & $\begin{array}{l}\text { Kryterium wielkości (między 2-4 ESU) i plan } \\
\text { rozwoju gospodarstwa niskotowarowego. }\end{array}$ & $\begin{array}{l}\text { Transfer dochodowy, } \\
\text { wypłacany przez } 5 \text { lat. }\end{array}$ & $\begin{array}{l}\text { Transfer bezpo- } \\
\text { średni (TB) }\end{array}$ \\
\hline $\begin{array}{l}\text { 3. Wsparcie } \\
\text { dla obszarów } \\
\text { ONW (PROW) }\end{array}$ & $\begin{array}{l}\text { Kryterium przynależenia do obszaru ONW np. } \\
\text { terenów o trudnych warunkach klimatycznych, } \\
\text { niekorzystnej konfiguracji terenu czy słabej jako- } \\
\text { ści gleb. }\end{array}$ & $\begin{array}{l}\text { Płatność od hektara } \\
\text { ziemi. }\end{array}$ & $\begin{array}{l}\text { Subsydium } \\
\text { obszarowe } \\
\quad \text { (SO) }\end{array}$ \\
\hline $\begin{array}{l}\text { 4. Programy rol- } \\
\text { no-środowiskowe } \\
(\mathrm{PROW})\end{array}$ & $\begin{array}{l}\text { Podjęcie się przez rolnika wdrażania od jednego } \\
\text { do trzech z wyznaczonych pakietów, m.in. rol- } \\
\text { nictwo ekologiczne, ochrona gleb i wód itd. }\end{array}$ & $\begin{array}{l}\text { Płatność dokonywana } \\
\text { raz w roku przez } 5 \text { lat } \\
\text { zależna od powierzch- } \\
\text { ni hektarowej. }\end{array}$ & $\begin{array}{l}\text { Subsydium } \\
\text { obszarowe } \\
\quad \text { (SO) }\end{array}$ \\
\hline $\begin{array}{l}\text { 5. Zalesianie } \\
\text { gruntów rolnych } \\
\text { (PROW) }\end{array}$ & $\begin{array}{l}\text { Wsparcie bezpośrednie dla procesu zalesiania } \\
\text { gruntów użytkowanych rolniczo nienależących } \\
\text { do Skarbu Państwa, a także zapewnienie odpo- } \\
\text { wiedniej pielęgnacji nowych nasadzeń. }\end{array}$ & $\begin{array}{l}\text { Płatność w formie } \\
\text { premii zryczałtowa- } \\
\text { nej, w zależności od } \\
\text { zalesionych gruntów } \\
\text { lub poniesionych } \\
\text { kosztów pielęgnacji. }\end{array}$ & $\begin{array}{l}\text { Transfer bezpo- } \\
\text { średni (TB) }\end{array}$ \\
\hline $\begin{array}{l}\text { 6. Dostosowanie } \\
\text { do standardów } \\
\text { UE (PROW) }\end{array}$ & $\begin{array}{l}\text { Wsparcie dla rolników chcących: wyposażyć go- } \\
\text { spodarstwo w urządzenia do przechowywania } \\
\text { nawozów naturalnych (schemat 1), dostosować } \\
\text { gospodarstwo produkujące mleko do standar- } \\
\text { dów zdrowia publicznego (schemat 2) czy zmo- } \\
\text { dernizować fermę specjalizującą się w produkcji } \\
\text { jaj konsumpcyjnych (schemat } 3 \text { ). }\end{array}$ & $\begin{array}{l}\text { Płatność w formie } \\
\text { zryczałtowanej opar- } \\
\text { tej na kosztach stan- } \\
\text { dardowych, pokry- } \\
\text { wająca } 100 \% \text { inwesty- } \\
\text { cji. }\end{array}$ & $\begin{array}{l}\text { Subsydium } \\
\text { inwestycyjne } \\
\text { w infrastruktu- } \\
\text { rę (SI_b) }\end{array}$ \\
\hline
\end{tabular}




\begin{tabular}{|c|c|c|c|}
\hline 1 & 2 & 3 & 4 \\
\hline $\begin{array}{l}\text { 7. Wsparcie dla } \\
\text { grup producenc- } \\
\text { kich (PROW) }\end{array}$ & $\begin{array}{l}\text { Pomoc kierowana do zarejestrowanych grup pro- } \\
\text { ducentów, polegająca na refinansowaniu kosz- } \\
\text { tów zakładania i funkcjonowania grup w ciągu } \\
\text { pierwszych pięciu lat ich istnienia. }\end{array}$ & $\begin{array}{l}\text { Pomoc w formie pro- } \\
\text { centowego ryczałtu } \\
\text { naliczana na podsta- } \\
\text { wie rocznej wartości } \\
\text { netto przychodów ze } \\
\text { sprzedaży produktów } \\
\text { lub grup produktów } \\
\text { wytworzonych w go- } \\
\text { spodarstwach człon- } \\
\text { ków grupy. }\end{array}$ & $\begin{array}{c}\text { Transfer bezpo- } \\
\text { średni (TB) }\end{array}$ \\
\hline $\begin{array}{l}1.1 \text { Inwestycje } \\
\text { w gospodar- } \\
\text { stwach rolnych } \\
\text { (SPO Rolnictwo) }\end{array}$ & $\begin{array}{l}\text { Spełnienie warunków żywotności i ochrony śro- } \\
\text { dowiska. Koszty kwalifikowane to m.in. budowa } \\
\text { i modernizacja budynków gospodarczych, zakup } \\
\text { lub instalacja maszyn i urządzeń, zakup gruntów } \\
\text { rolnych, zakup budynków inwentarskich etc. }\end{array}$ & $\begin{array}{l}\text { Refinansowanie od } \\
50 \% \text { do } 65 \% \text { poniesio- } \\
\text { nych kosztów kwalifi- } \\
\text { kowanych inwestycji. }\end{array}$ & $\begin{array}{l}\text { Subsydium } \\
\text { inwestycyjne } \\
\text { w infrastruktu- } \\
\text { rę (SI_b) }\end{array}$ \\
\hline $\begin{array}{l}1.2 \text { Ułatwianie } \\
\text { startu młodym } \\
\text { rolnikom (SPO } \\
\text { Rolnictwo) }\end{array}$ & $\begin{array}{l}\text { Kwalifikacja na podstawie wieku rolnika (18-40 } \\
\text { lat), prowadzenia gospodarstwa (maksimum } 12 \\
\text { mies.), posiadanych kwalifikacji, praw własno- } \\
\text { ści/dzierżawy i ubezpieczeniem w KRUS (5 lat). }\end{array}$ & $\begin{array}{l}\text { Jednorazowa premia } \\
\text { niezwiązana z ko- } \\
\text { niecznością realizacji } \\
\text { konkretnego projektu. }\end{array}$ & $\begin{array}{c}\text { Transfer bezpo- } \\
\text { średni (TB) }\end{array}$ \\
\hline $\begin{array}{l}\text { 1.3 Szkolenia } \\
\text { (SPO Rolnictwo) }\end{array}$ & $\begin{array}{l}\text { Koszty kwalifikowane to: koszty związane z przy- } \\
\text { gotowaniem i zrealizowaniem szkoleń; koszty za- } \\
\text { kupu sprzętu i pomocy dydaktycznych niezbęd- } \\
\text { nych do realizacji szkolenia; koszty operacyjne, } \\
\text { związane z obsługą i zarządzaniem projektem. }\end{array}$ & $\begin{array}{l}\text { Pomoc polegała na re- } \\
\text { fundacji } 100 \% \text { kosztów } \\
\text { kwalifikowanych, po- } \\
\text { niesionych w związku } \\
\text { z realizacją projektu. }\end{array}$ & $\begin{array}{l}\text { Subsydium } \\
\text { inwestycyjne } \\
\text { w edukację } \\
\text { (SI_e) }\end{array}$ \\
\hline $\begin{array}{l}1.4 \text { Wsparcie do- } \\
\text { radztwa rolnicze- } \\
\text { go (SPO } \\
\text { Rolnictwo) }\end{array}$ & $\begin{array}{l}\text { Koszty kwalifikowane to: } \bullet \text { koszty związane } \\
\text { z przygotowaniem wniosków o pomoc, wniosków } \\
\text { o płatność, projektów, przedsięwzięć lub planów } \\
\text { rozwoju gospodarstwa oraz koszty usług dorad- } \\
\text { czych, świadczonych w trakcie realizacji projek- } \\
\text { tów } \bullet \text { koszty organizacji doradztwa grupowego } \\
\bullet \text { Koszty przygotowania ulotek doradczych. }\end{array}$ & $\begin{array}{l}\text { Pomoc finansowa po- } \\
\text { legała na refundacji } \\
100 \% \text { kosztów kwalifi- } \\
\text { kowanych, poniesio- } \\
\text { nych w związku } \\
\text { z realizacją projektu. }\end{array}$ & $\begin{array}{l}\text { Subsydium } \\
\text { inwestycyjne } \\
\text { w edukację } \\
\text { (SI_e) }\end{array}$ \\
\hline $\begin{array}{l}\text { 1.5 Poprawa prze- } \\
\text { twórstwa } \\
\text { i marketingu } \\
\text { (SPO Rolnic- } \\
\text { two) }\end{array}$ & $\begin{array}{l}\text { Wśród kosztów kwalifikowanych dominowały } \\
\text { koszty zakupu lub instalacji maszyn i urządzeń } \\
\text { do przetwarzania produktów rolnych }(43,1 \%) \\
\text { oraz koszty budowy lub remontu połączonego } \\
\text { z modernizacją budynków lub budowli produk- } \\
\text { cyjnych, magazynowych, w których prowadzi się } \\
\text { kontrolę laboratoryjną, socjalnych lub służących } \\
\text { do prowadzenia handlu hurtowego }(25,4 \%) \text {. }\end{array}$ & $\begin{array}{l}\text { Pomoc była udzielana } \\
\text { w formie zwrotu do } \\
50 \% \text { kwalifikowanych } \\
\text { wydatków (w tym } \\
\text { udział UE do } 35 \% \text { ). }\end{array}$ & $\begin{array}{l}\text { Subsydium } \\
\text { inwestycyjne } \\
\text { w infrastruktu- } \\
\text { rę (SI_b) }\end{array}$ \\
\hline $\begin{array}{l}\text { 2.1 Przywracanie } \\
\text { potencjału pro- } \\
\text { dukcji leśnej } \\
\text { (SPO Rolnictwo) }\end{array}$ & $\begin{array}{l}\text { Przeważały koszty budowy i modernizacji dróg } \\
\text { technologicznych i przeciwpożarowych oraz in- } \\
\text { frastruktury drogowej zapewniającej udostępnie- } \\
\text { nie i ochronę kompleksów leśnych. }\end{array}$ & $\begin{array}{l}\text { Pomoc była udzielana } \\
\text { w formie całkowitego } \\
\text { zwrotu } 100 \% \text { kosztów } \\
\text { kwalifikowanych, przy } \\
\text { czym poziom udziału } \\
\text { UE wynosił do } 80 \% \\
\text { całkowitego kwalifiku- } \\
\text { jącego się kosztu. }\end{array}$ & $\begin{array}{l}\text { Subsydium } \\
\text { inwestycyjne } \\
\text { w infrastruktu- } \\
\text { rę (SI_b) }\end{array}$ \\
\hline
\end{tabular}




\begin{tabular}{l|l}
\hline \multicolumn{1}{c|}{1} & \multicolumn{1}{c}{$\mathbf{2}$} \\
\hline $\begin{array}{l}\text { 2.2 Scalanie } \\
\text { gruntów (SPO } \\
\text { Rolnictwo) }\end{array}$ & $\begin{array}{l}\text { Finansowaniem objęto koszty: opracowania do- } \\
\text { kumentacji geodezyjno-prawnej; koszty zago- } \\
\text { spodarowania poscaleniowego, w tym } \\
\text { urządzenie dróg transportu rolnego, uporządko- } \\
\text { wanie terenu umożliwiające objęcie w posiada- } \\
\text { nie nowo wydzielonych działek, korekta } \\
\text { przebiegu rowów melioracyjnych, urządzanie } \\
\text { przepustów itp. }\end{array}$ \\
\hline
\end{tabular}

2.3 Odnowa wsi Koszty kwalifikowane objęły m.in.: koszty prac i dziedzictwo kul- projektantów oraz doradztwa związanego z returowe (SPO Rolnictwo) alizacją inwestycji; koszty modernizacji prze-

strzeni publicznej; koszty budowy i modernizacji infrastruktury publicznej związanej z turystyką

i kulturą; koszty modernizacji obiektów pełniących funkcje kulturalne oraz podtrzymujące tradycje wiejskie regionu.
2.4 Różnicowanie Do kosztów kwalifikowanych zaliczano koszty: działalności rolni- budowy lub adaptacji obiektów budowlanych; czej (SPO Rolnic- zakupu i instalacji maszyn, urządzeń i sprzętu, two) $\quad$ w tym oprogramowania; zakupu środków transportu; zakupu zwierząt służących rozwojowi funkcji rekreacyjnych; zagospodarowania terenu; transportu, materiałów i wyposażenia; koszty ogólne.

2.5 Gospodarowanie zasobami wodnymi (SPO Rolnictwo)

Koszty kwalifikowane obejmowały m.in.: opracowanie dokumentacji technicznych projektów; budowę lub modernizację urządzeń melioracji podstawowych: różnego rodzaju budowle regulacyjne, przeciwpowodziowe wraz z drogami dojazdowymi; budowę lub modernizację urządzeń melioracji szczegółowych.

2.6 Rozwój infrastruktury technicznej (SPO Rolnictwo)

W strukturze kosztów kwalifikowanych największy udział miały projekty, których celem była poprawa lub umożliwienie rolnikom dostępu do infrastruktury technicznej $(63,6 \%)$ oraz poprawa organizacji produkcji rolniczej $(26,7 \%)$. W układzie rodzajowym w strukturze tej dominowały koszty budowy i remontu dróg wewnętrznych $(88,0 \%)$.

2.7 LEADER + W ramach schematu I realizowane były działa(SPO Rolnictwo) nia szkoleniowe, informacyjne oraz doradcze, a w ramach schematu II działania wdrożeniowe i animowanie współpracy partnerów lokalnych.
Poziom pomocy wynosił do $80 \%$ kosztów kwalifikowanych,

z czego pomoc UE wynosiła maksymalnie do $80 \%$.

Maksymalny poziom pomocy wynosił 50\% kosztów kwalifikowanych projektu, w tym poziom udziału UE do $35 \%$.

Pomoc występowała w formie zwrotu od $50 \%$ do $80 \%$ całkowitego kwalifikującego się kosztu.

Pomoc w postaci refinansowania do $50 \%$ kosztów kwalifikowanych poniesionych inwestycji.

Maksymalny poziom pomocy finansowej wynosił $100 \%$ całkowitego kwalifikującego się kosztu, z tego udział UE do $80 \%$.
Subsydium inwestycyjne w infrastrukturę (SI_b)

Subsydium inwestycyjne w infrastrukturę (SI_b)

Subsydium inwestycyjne w infrastrukturę (SI_b)

Subsydium inwestycyjne w edukację (SI_e)

Źródło: Opracowanie własne na podstawie [ARiMR 2007], [PROW 2004-2006], [SPO Rolnictwo 2004]. 


\section{Analiza działań Programu Rozwoju Obszarów Wiejskich 2004-2006}

RENTY STRUKTURALNE Renta strukturalna to wypłacane co miesiąc świadczenie, mające zapewnić dochód rolnikom, którzy zdecydowali się zrezygnować z prowadzenia działalności rolniczej. Mogły z nich skorzystać osoby w wieku przedemerytalnym, które ukończyły 55 lat, prowadziły działalność rolniczą w gospodarstwie o powierzchni co najmniej 1 ha, przez co najmniej 10 lat poprzedzających złożenie wniosku o rentę strukturalną i co najmniej przez 5 lat były ubezpieczone w KRUS. Działanie to miało przynieść efekt wzrostu produktywności. W przypadku „przekazania gospodarstwa na powiększenie innego gospodarstwa”, takiego wzrostu można było oczekiwać ze względu na skutek działania pozytywnych efektów skali, a w przypadku „przekazania gospodarstwa na rzecz następcy" ze względu na objęcie gospodarstw przez młodsze pokolenie rolników (w domyśle bardziej wykształcone i produktywne). Jednak, jak wynika z danych ARiMR [2007] renty strukturalne nie wywołały znaczącej koncentracji gospodarstw. Jest to skutkiem, po pierwsze, za małej skali działania - działanie objęło ok. 53 tys. gospodarstw, a zatem niewielki ich odsetek w kraju (ok. 2\%). Po drugie, gospodarstwa często przekazywano następcom, co było równoznaczne z kontynuacją prowadzenia gospodarstwa już istniejącego, a więc utrwalaniem obecnego stanu. Można też sądzić, że realizacja działania nie wpłynęła w zauważalny sposób na poprawę struktury agrarnej. Chociaż na powiększenie przekazywano gospodarstwa rolne, w których powierzchnia użytków rolnych wynosiła średnio 10,13 ha (a więc większe niż średnia w kraju), to partycypowało w tym około połowy użytków rolnych w tym działaniu, tj. 262331 ha, co stanowiło zaledwie 1,5\% wszystkich użytków rolnych w kraju. Na rzecz następcy przekazano 219623 ha - tabela A.2.2. Jeśli zaś chodzi o poprawę struktury wiekowej zarządców, to nawet jeśli się poprawiła, mało prawdopodobne jest, żeby w praktyce przełożyło się to na zmianę zarządzania. Przypuszczenie to wynika z faktu, że 95\% osób, które przekazały gospodarstwo, było pomiędzy 55 a 60 rokiem życia, a więc mogło nadal aktywnie uczestniczyć w jego zarządzaniu, czyli zmiana właściciela de jure nie wpłynęła de facto na zmianę zarządzania. Taką opinię potwierdziły ankiety przeprowadzone wśród pracowników ARiMR (patrz aneks 2.4) oraz wywiady z pracownikami ODR-ów. Można zatem powiedzieć, że działanie było na pewno transferem bezpośrednim, i w skali kraju prawdopodobnie w dużej mierze o charakterze socjalnym, choć nie jest wykluczone, że w poszczególnych przypadkach oczekiwane mechanizmy zadziałały - por. też [Paszkowski 2006]. 
Tabela A.2.2. Powierzchnia gospodarstw przekazanych w ramach działania Renty strukturalne, wg powierzchni i celów [ha] w latach 2004-2006

\begin{tabular}{|c|c|c|c|c|c|c|c|}
\hline \multirow[b]{2}{*}{ Województwo } & \multirow[b]{2}{*}{$\begin{array}{l}\text { Powierz- } \\
\text { chnia } \\
\text { (ha) }\end{array}$} & \multirow[b]{2}{*}{$\begin{array}{l}\text { Użytki } \\
\text { rolne } \\
\text { (ha) }\end{array}$} & \multicolumn{5}{|c|}{ Powierzchnia [ha] przekazanych użytków rolnych wg celów } \\
\hline & & & $\begin{array}{l}\text { powiększe- } \\
\text { nie innego } \\
\text { gospod. }\end{array}$ & $\begin{array}{l}\text { na rzecz } \\
\text { następcy }\end{array}$ & $\begin{array}{c}\text { Skarb } \\
\text { Państwa }\end{array}$ & $\begin{array}{c}\text { ochrona } \\
\text { środowiska }\end{array}$ & zalesienia \\
\hline Dolnośląskie & 29149 & 28183 & 18929 & 9253 & 0 & 0 & 0 \\
\hline Kujawsko-Pomorskie & 50434 & 47317 & 27977 & 19340 & 0 & 0 & 0 \\
\hline Lubelskie & 46775 & 41140 & 21469 & 19646 & 24,02 & 0 & 0,8 \\
\hline Lubuskie & 6558 & 6197 & 3677 & 2505 & 11,37 & 0 & 3,28 \\
\hline Łódzkie & 49794 & 46036 & 23756 & 22277 & 3,55 & 0 & 0 \\
\hline Małopolskie & 10721 & 9582 & 2863 & 6715 & 5,01 & 0 & 0 \\
\hline Mazowieckie & 92964 & 82301 & 43019 & 39256 & 26,22 & 0 & 0 \\
\hline Opolskie & 15189 & 14719 & 9031 & 5681 & 7,58 & 0 & 0 \\
\hline Podkarpackie & 12778 & 11303 & 3957 & 7315 & 25,36 & 0 & 5,62 \\
\hline Podlaskie & 61466 & 50127 & 30291 & 19820 & 6,19 & 0 & 10,20 \\
\hline Pomorskie & 21163 & 18811 & 11078 & 7726 & 1,26 & 0 & 6,36 \\
\hline Śląskie & 9094 & 8199 & 3635 & 4561 & 2,46 & 0 & 0 \\
\hline Świętokrzyskie & 21892 & 20267 & 7968 & 12275 & 23,82 & 0 & 0 \\
\hline Warmińsko-Mazurskie & e 29717 & 27549 & 17499 & 10009 & 0 & 14,35 & 27,27 \\
\hline Wielkopolskie & 56213 & 53072 & 25488 & 27584 & 0,31 & 0 & 0 \\
\hline Zachodniopomorskie & 18317 & 17376 & 11695 & 5658 & 22,35 & 0 & 0 \\
\hline Razem & 532224 & 482181 & 262331 & 219623 & 159,50 & 14,35 & 53,53 \\
\hline
\end{tabular}

Źródło: [ARiMR 2007].

WSPIERANIE GOSPODARSTW NISKOTOWAROWYCH. Z dokumentów programowych wynika, że pomoc w tym działaniu polegała na wypłacie gospodarstwom, których wielkość ekonomiczna wynosiła od 2 do 4 ESU ${ }^{65}$, premii przez okres 5 lat (jeśli beneficjenci spełnili określone warunki; w przeciwnym wypadku wypłacana była przez 3 lata bez konieczności zwrotu pobranych zaliczek). Wysokość premii stanowiła równowartość 1250 EUR rocznie. Z publikacji ARiMR [2007] wynika, że najchętniej gospodarstwa deklarowały w ramach tego działania zakup maszyn, zwierząt oraz zakup lub dzierżawę gruntu. Celem tego działania było zwiększenie możliwości inwestycyjnych tych gospodarstw, a w rezultacie ułatwienie im osiągnięcia żywotności ekonomicznej. Rozkład wojewódzki tego działania prezentuje tabela A.2.3. Weryfikacja tego, w jakim stopniu rolnicy osiagnęli zadeklarowane cele, następuje po trzecim roku od udzielenia beneficjentom pierwszej płatności, a więc pod koniec lat 2008 i 2009. Tymczasem działanie to zaliczyliśmy

${ }^{65}$ ESU, czyli EJW - Europejska Jednostka Wielkości (ESU - European Size Unit) - jednostka wielkości ekonomicznej gospodarstwa mierzona wysokością standardowej nadwyżki bezpośredniej. Standardowa nadwyżka bezpośrednia jest to przeciętna dla danego regionu wartość produkcji uzyskiwanej z jednego hektara lub od jednego zwierzęcia, pomniejszona o przeciętne koszty bezpośrednie, niezbędne do wytworzenia tej produkcji. 1 EJW $=1200$ EUR. 
do transferów bezpośrednich, gdyż wypłacane było bezpośrednio do dochodów, bez konieczności współfinansowania ze strony gospodarstw i charakteryzowało się dość dużą dowolnością wydatkowania przez rolników. Ponadto trzeba zauważyć, że transfer roczny był tak mały, że najwyżej mógł posłużyć zakupom drobnych urządzeń czy niewielkim remontom.

Tabela A.2.3. Wspieranie gospodarstw niskotowarowych: liczba złożonych wniosków i wydanych decyzji, wg województw

\begin{tabular}{l|r|r|r|r|r|r}
\hline \multirow{2}{*}{ Województwo } & \multicolumn{3}{c|}{ Wnioski } & \multicolumn{3}{c}{ Decyzje pozytywne } \\
\cline { 2 - 7 } & I nabór & II nabór & II nabór & I nabór & II nabór & II nabór \\
\hline Dolnośląskie & 2008 & 1276 & $2 \%$ & 1844 & 1150 & $2 \%$ \\
Kujawsko-Pomorskie & 4771 & 2055 & $4 \%$ & 4246 & 1860 & $4 \%$ \\
Lubelskie & 20315 & 9145 & $16 \%$ & 19248 & 8461 & $16 \%$ \\
Lubuskie & 916 & 385 & $1 \%$ & 781 & 347 & $1 \%$ \\
Łódzkie & 14587 & 6888 & $12 \%$ & 13552 & 6202 & $12 \%$ \\
Małopolskie & 10474 & 4841 & $9 \%$ & 9770 & 4514 & $9 \%$ \\
Mazowieckie & 20111 & 7693 & $14 \%$ & 18228 & 6949 & $14 \%$ \\
Opolskie & 1327 & 496 & $1 \%$ & 1218 & 449 & $1 \%$ \\
Podkarpackie & 6823 & 4187 & $7 \%$ & 6348 & 3846 & $7 \%$ \\
Podlaskie & 5633 & 2840 & $5 \%$ & 5036 & 2634 & $5 \%$ \\
Pomorskie & 2413 & 1671 & $3 \%$ & 2191 & 1496 & $3 \%$ \\
Śląskie & 1695 & 1186 & $2 \%$ & 1560 & 1088 & $2 \%$ \\
Świętokrzyskie & 14384 & 7374 & $13 \%$ & 13337 & 6787 & $13 \%$ \\
Warmińysko-Mazurskie & 1512 & 1262 & $2 \%$ & 1363 & 1152 & $2 \%$ \\
Wielkopolskie & 6605 & 4294 & $8 \%$ & 5891 & 3681 & $7 \%$ \\
Zachodniopomorskie & 1163 & 954 & $2 \%$ & 924 & 783 & $2 \%$ \\
Razem & $\mathbf{1 1 4} \mathbf{7 3 7}$ & $\mathbf{5 6} \mathbf{5 4 7}$ & $\mathbf{1 0 0 \%}$ & $\mathbf{1 0 5} \mathbf{5 3 7}$ & $\mathbf{5 1 3 9 9}$ & $\mathbf{1 0 0 \%}$ \\
\hline
\end{tabular}

Źródło: [ARiMR 2007].

WSPIERANIE DZIAEALNOŚCI ROLNICZEJ NA OBSZARACH O NIEKORZYSTNYCH WARUNKACH GOSPODAROWANIA (ONW). Wsparcie finansowe gospodarstw rolnych, znajdujących się na terenach, na których produkcja rolnicza jest utrudniona ze względu na niekorzystne warunki naturalne (klimatyczne, terenowe, glebowe etc.), ma rekompensować rolnikom mniejsze zyski z tytułu niższych plonów przy relatywnie wyższych nakładach oraz stanowić zachętę do dalszego rolniczego użytkowania gruntów położonych na obszarach, gdzie warunki gospodarowania są niekorzystne. W praktyce były to obszary nizinne w strefie I (72\%), nizinne w strefie II (21\%), obszary o specyficznych utrudnieniach (5\%) i obszary górskie (2\% obszaru dopłat zgłoszonych do płatności).

Uzyskanie dopłaty uwarunkowane było nie tylko położeniem gospodarstwa na terenach uznanych za ONW, lecz także podjęciem przez wnioskodawcę zobowiązania do przestrzegania zasad zwykłej dobrej praktyki rolniczej w swoim 
gospodarstwie oraz pięcioletniego okresu prowadzenia działalności rolniczej na tym obszarze, za który otrzymał pierwszą płatność. Jeśli chodzi o formę wsparcia, były to subsydia obszarowe do 1 ha, zróżnicowane w zależności od typu ONW i wynosiły od 179 zł w strefie nizinnej do 320 zł na obszarach górskich. Zróżnicowanie dopłat w ujęciu wojewódzkim prezentuje tabela A.2.4. W naszej klasyfikacji jest to subsydium obszarowe, tzn. subsydium do czynnika produkcji, jakim jest ziemia (więcej analiz dotyczących tego działania można znaleźć w pracach, np. [Józwiak, Niewęgłowska i Czekaj 2006], [Klepacka-Kołodziejska 2007], [Henisz-Matuszczak 2007], [Roszkowska-Mądra 2008], [Zawalińska 2009b]).

Tabela A.2.4. Zrealizowane płatności z tytułu ONW [wg województw]

\begin{tabular}{|c|c|c|c|c|c|c|}
\hline \multirow[b]{2}{*}{ Województwo } & \multicolumn{2}{|c|}{2004 r. } & \multicolumn{2}{|c|}{2005 r. } & \multicolumn{2}{|c|}{2006 r. } \\
\hline & $\begin{array}{c}\text { Liczba } \\
\text { wniosków }\end{array}$ & $\begin{array}{l}\text { UR } \\
\text { [ha] }\end{array}$ & $\begin{array}{c}\text { Liczba } \\
\text { wniosków }\end{array}$ & $\begin{array}{c}\text { UR } \\
\text { [ha] }\end{array}$ & $\begin{array}{c}\text { Liczba } \\
\text { wniosków }\end{array}$ & $\begin{array}{c}\text { UR } \\
\text { [ha] }\end{array}$ \\
\hline Dolnośląskie & 18245 & 234314 & 20541 & 251078 & 21009 & 255963 \\
\hline Kujawsko-Pomorskie & 27856 & 380107 & 30259 & 401890 & 30733 & 407412 \\
\hline Lubelskie & 56224 & 441200 & 63523 & 491350 & 65041 & 500980 \\
\hline Lubuskie & 13840 & 263960 & 15730 & 294897 & 16398 & 307682 \\
\hline Łódzkie & 64661 & 459686 & 72959 & 509457 & 74348 & 520148 \\
\hline Małopolskie & 48820 & 167712 & 55863 & 190930 & 56170 & 191966 \\
\hline Mazowieckie & 113709 & 1055982 & 131201 & 1179349 & 134262 & 1204768 \\
\hline Opolskie & 6062 & 60041 & 6383 & 63488 & 6470 & 64347 \\
\hline Podkarpackie & 38610 & 175342 & 42999 & 195521 & 43420 & 198097 \\
\hline Podlaskie & 57503 & 751244 & 67234 & 860017 & 69109 & 877291 \\
\hline Pomorskie & 19605 & 315675 & 22639 & 343135 & 23293 & 353507 \\
\hline Śląskie & 15455 & 84233 & 16500 & 92520 & 17268 & 96206 \\
\hline Świętokrzyskie & 33909 & 162347 & 36012 & 175852 & 36725 & 178555 \\
\hline Warmińsko-Mazurskie & 26866 & 566555 & 30429 & 608595 & 31236 & 618765 \\
\hline Wielkopolskie & 70771 & 868093 & 75781 & 917287 & 76211 & 925394 \\
\hline Zachodniopomorskie & 16626 & 452819 & 18312 & 482293 & 18804 & 489968 \\
\hline Razem & 628762 & 6439309 & 706365 & 7057659 & 720497 & 7191049 \\
\hline
\end{tabular}

Žródło: [ARiMR 2007].

WSPIERANIE PRZEDSIĘWZIĘĆ ROLNO-ŚRODOWISKOWYCH I POPRAWY DOBROSTANU ZWIERZĄT. Polegało na dobrowolnej realizacji przez rolnika działań, które miały przyczynić się do promocji systemów produkcji rolniczej zgodnych z wymogami ochrony środowiska oraz ochrony zasobów genetycznych zwierząt gospodarskich. W ramach PROW rolnik mógł podjąć się wdrażania od jednego do trzech z następujących pakietów: Rolnictwo zrównoważone ( $2 \%$ wniosków); Rolnictwo ekologiczne (14\%); Utrzymanie łąk ekstensywnych (19\%); Utrzymanie pastwisk ekstensywnych (2\%); Ochrona gleb i wód (62\%); Tworzenie stref buforowych $(0,1 \%)$; Zachowanie lokalnych ras zwierząt gospodarskich $(0,9 \%)$. Udział poszcze- 
gólnych województw w tym działaniu prezentuje tabela A.2.5. Pomoc ma formę płatności dokonywanej raz w roku przez 5 kolejnych lat. Jej wysokość zależy od powierzchni hektarowej objętej programem rolno-środowiskowym oraz realizowanego pakietu. Stawki dopłat do hektara są zróżnicowane i wahają się od 160 zł (rolnictwo zrównoważone) do $1800 \mathrm{zł}$. Działanie to zatem ma charakter subsydium obszarowego.

Tabela A.2.5. Realizacja programu rolno-środowiskowego (PRŚ) w roku 2006 [wg województw]

\begin{tabular}{|c|c|c|c|c|}
\hline Województwo & $\begin{array}{l}\text { Powierzchnia } \\
\text { zgłoszona } \\
\text { do płatności } \\
\text { bezpośrednich } \\
\text { [ha] }\end{array}$ & $\begin{array}{c}\text { Powierzchnia } \\
\text { realizacji PRŚ } \\
\text { [ha] }\end{array}$ & $\begin{array}{c}\text { Powierzchnia } \\
\text { realizacji PRŚ } \\
\text { w województwie } \\
\text { do powierzchni } \\
\text { realizacji PRŚ } \\
\text { w kraju } \\
\text { [ha] }\end{array}$ & $\begin{array}{c}\text { Powierzchnia } \\
\text { realizacji PRŚ } \\
\text { do UR } \\
\text { w województwie } \\
\text { [ha] }\end{array}$ \\
\hline Dolnośląskie & 883837 & 64590 & $7,18 \%$ & $7,31 \%$ \\
\hline Kujawsko-Pomorskie & 1043530 & 49818 & $5,54 \%$ & $4,77 \%$ \\
\hline Lubelskie & 1347810 & 83953 & $9,33 \%$ & $6,23 \%$ \\
\hline Lubuskie & 391142 & 60268 & $6,70 \%$ & $15,41 \%$ \\
\hline Łódzkie & 981726 & 25886 & $2,88 \%$ & $2,64 \%$ \\
\hline Małopolskie & 524161 & 22997 & $2,56 \%$ & $4,39 \%$ \\
\hline Mazowieckie & 1913464 & 55928 & $6,22 \%$ & $2,92 \%$ \\
\hline Opolskie & 504278 & 35054 & $3,90 \%$ & $6,95 \%$ \\
\hline Podkarpackie & 544691 & 48699 & $5,41 \%$ & $8,94 \%$ \\
\hline Podlaskie & 1018606 & 31182 & $3,47 \%$ & $3,06 \%$ \\
\hline Pomorskie & 715523 & 72614 & $8,07 \%$ & $10,15 \%$ \\
\hline Śląskie & 349104 & 14651 & $1,63 \%$ & $4,20 \%$ \\
\hline Świętokrzyskie & 510312 & 31004 & $3,45 \%$ & $6,08 \%$ \\
\hline Warmińsko-Mazurskie & 974154 & 70898 & $7,88 \%$ & $7,28 \%$ \\
\hline Wielkopolskie & 1727784 & 100559 & $11,18 \%$ & $5,82 \%$ \\
\hline Zachodniopomorskie & 813595 & 131741 & $14,64 \%$ & $16,19 \%$ \\
\hline Razem & 14243719 & 899842 & $100,00 \%$ & $6,32 \%$ \\
\hline
\end{tabular}

Źródło: [ARiMR 2007].

ZALESIANIE GRUNTÓw ROLNYCH. Celem działania było wsparcie procesu zalesiania gruntów użytkowanych rolniczo nienależących do Skarbu Państwa, a także zapewnienie odpowiedniej pielęgnacji nowych nasadzeń we wczesnych etapach ich rozwoju. Pomoc finansowa wypłacana była w trzech formach: • jednorazowego ryczałtu (od 4300 do 8300 zł/ha) na pokrycie poniesionych kosztów zalesienia i ogrodzenia uprawy leśnej, wypłacanego w pierwszym roku po założeniu uprawy (wsparcia na zalesienie) - zryczałtowanej płatności do powierzchni zalesionych gruntów. Wysokość premii (od 420 do $1100 \mathrm{zl} /$ ha) obejmuje koszty prac pielęgnacyjnych, czyszczenia wczesnego oraz ewentualnego zastosowania repelentów. Premię wypłaca się co roku 
przez 5 lat od roku założenia uprawy (premia pielęgnacyjna) • zryczałtowanej płatności do powierzchni zalesionych gruntów. Premia (360 zł/ha albo 1400 zł/ha) stanowi rekompensatę dochodów utraconych wskutek zaprzestania prowadzenia działalności rolniczej na zalesionych gruntach. Premię wypłaca się co roku przez 20 lat od roku założenia uprawy (premia zalesieniowa). Rozkład wniosków w ujęciu wojewódzkim przedstawia tabela A.2.6. Działanie to związane jest z produkcją leśną i wielkością obszarową (co mogłoby wskazywać na subsydium obszarowe), ale ze względu na mały związek tego działania z faktyczną produkcja, a raczej z rekompensatą dochodową działanie to zaklasyfikowaliśmy jako transfer bezpośredni.

Tabela A.2.6. Zalesianie gruntów rolnych - złożone wnioski, wydane postanowienia oraz decyzje przyznające pomoc [wg województw]

\begin{tabular}{|c|c|c|c|c|}
\hline Województwo & Wnioski & $\begin{array}{c}\text { Wydane } \\
\text { postanowienia }\end{array}$ & $\begin{array}{c}\text { Decyzje } \\
\text { przyznające pomoc } \\
\end{array}$ & Udzial procentowy \\
\hline Dolnośląskie & 425 & 385 & 369 & $4 \%$ \\
\hline Kujawsko-Pomorskie & 627 & 589 & 535 & $5 \%$ \\
\hline Lubelskie & 898 & 862 & 814 & $8 \%$ \\
\hline Lubuskie & 299 & 251 & 257 & $3 \%$ \\
\hline Łódzkie & 743 & 685 & 655 & $7 \%$ \\
\hline Małopolskie & 308 & 281 & 278 & $3 \%$ \\
\hline Mazowieckie & 1502 & 1428 & 1389 & $14 \%$ \\
\hline Opolskie & 152 & 140 & 136 & $1 \%$ \\
\hline Podkarpackie & 1561 & 1515 & 1406 & $14 \%$ \\
\hline Podlaskie & 781 & 749 & 728 & $7 \%$ \\
\hline Pomorskie & 464 & 425 & 424 & $4 \%$ \\
\hline Śląskie & 211 & 198 & 196 & $2 \%$ \\
\hline Świętokrzyskie & 798 & 753 & 735 & $8 \%$ \\
\hline Warmińsko-Mazurskie & 1228 & 1126 & 1081 & $11 \%$ \\
\hline Wielkopolskie & 657 & 584 & 555 & $6 \%$ \\
\hline Zachodniopomorskie & 259 & 234 & 228 & $2 \%$ \\
\hline Razem & 10913 & 10205 & 9786 & $100 \%$ \\
\hline
\end{tabular}

Żródło: [ARiMR 2007].

DOSTOSOWANIE GOSPODARSTW ROLNYCH DO STANDARDÓW UNII EUROPEJSKIEJ. Wsparcie to polegało na pokryciu kosztów przedsięwzięcia, dostosowującego gospodarstwo rolne do standardów Unii Europejskiej w dziedzinie ochrony środowiska, zdrowia publicznego, zdrowia i dobrostanu zwierząt. Pomoc kierowana była do rolników chcących: wyposażyć gospodarstwo w urządzenia do przechowywania nawozów naturalnych (schemat 1), dostosować gospodarstwo produkujące mleko do standardów zdrowia publicznego (schemat 2), zmodernizować fermę specjalizująca się w produkcji jaj konsumpcyjnych (schemat 3). Zdecydowanie największym powodzeniem cieszył się schemat 1 . Regionalny rozkład wsparcia w ramach tego działania 
przedstawia tabela A.2.7. Pomoc finansowa udzielana była w formie rocznej płatności wypłacanej w postaci zryczałtowanej, opartej na kosztach standardowych, określonych dla każdego przedsięwzięcia. Wsparcie było wypłacane w dwóch równych ratach i pokrywało całkowite koszty przedsięwzięcia, niezależnie, czy dotyczyło to dostosowania do jednego czy więcej standardów. Wysokość wsparcia nie mogła przekroczyć rocznie 25 tys. EUR na gospodarstwo. Ze względu na to, że przeznaczenie tego działania miało charakter inwestycyjny, zaklasyfikowaliśmy je jako subsydium inwestycyjne, a ponieważ wiązało się głównie z wyposażeniem gospodarstw (np. w płyty obornikowe), to miało też związek z infrastrukturą/budownictwem.

Tabela A.2.7. Dostosowanie gospodarstw rolnych do standardów UE w ramach PROW 2004-2006 - złożone wnioski, decyzje przyznające pomoc, kwota pomocy [wg schematów]

\begin{tabular}{|c|c|c|c|c|c|c|c|c|}
\hline \multirow[b]{2}{*}{ Województwa } & \multicolumn{4}{|c|}{ Schemat 1} & \multicolumn{4}{|c|}{ Schemat 2} \\
\hline & Wnioski & Decyzje & $\begin{array}{c}\text { Kwota } \\
\text { pomocy } \\
{[z \mathbf{z l}]}\end{array}$ & $\begin{array}{c}\text { Kwota } \\
\text { pomocy } \\
\%\end{array}$ & $\begin{array}{c}\text { Wnio- } \\
\text { ski }\end{array}$ & Decyzje & $\begin{array}{c}\text { Kwota } \\
\text { pomocy } \\
{[\mathrm{zl}]}\end{array}$ & $\begin{array}{c}\text { Kwota } \\
\text { pomocy } \\
\%\end{array}$ \\
\hline Dolnośląskie & 671 & 658 & 21321153 & 1 & 53 & 31 & 822200 & $\overline{1}$ \\
\hline Kujawsko-Pomorskie & 13320 & 12766 & 464994292 & 19 & 387 & 319 & 6188350 & 5 \\
\hline Lubelskie & 3043 & 2992 & 86292779 & 3 & 537 & 185 & 8539261 & 7 \\
\hline Lubuskie & 566 & 552 & 24542667 & 1 & 42 & 40 & 679250 & 1 \\
\hline Eódzkie & 5849 & 5580 & 172034259 & 7 & 1102 & 660 & 17442237 & 14 \\
\hline Małopolskie & 918 & 881 & 20331528 & 1 & 393 & 354 & 6105105 & 5 \\
\hline Mazowieckie & 13711 & 13300 & 453924394 & 18 & 2946 & 2474 & 52123429 & 41 \\
\hline Opolskie & 650 & 601 & 26421577 & 1 & 38 & 27 & 658750 & 1 \\
\hline Podkarpackie & 679 & 648 & 13842048 & 1 & 358 & 302 & 6234997 & 5 \\
\hline Podlaskie & 6036 & 5864 & 220252903 & 9 & 179 & 106 & 3244650 & 3 \\
\hline Pomorskie & 4624 & 4465 & 139920191 & 6 & 164 & 91 & 2596200 & 2 \\
\hline Śląskie & 651 & 635 & 19351246 & 1 & 172 & 153 & 2839520 & 2 \\
\hline Świętokrzyskie & 1482 & 1364 & 35942142 & 1 & 422 & 284 & 7110914 & 6 \\
\hline Warmińsko-Mazurskie & 4396 & 4206 & 184005395 & 7 & 354 & 324 & 6214356 & 5 \\
\hline Wielkopolskie & 15173 & 14625 & 577776251 & 23 & 183 & 137 & 2733815 & 2 \\
\hline Zachodniopom & 1299 & 1186 & 46967388 & 2 & 119 & 97 & 2197100 & 2 \\
\hline Razem & 73068 & 70323 & 2507920212 & 100 & 7449 & 5584 & 125730134 & 100 \\
\hline
\end{tabular}

Źródło: [ARiMR 2007].

WSPIERANIE GRUP PRODUCENTÓW ROLNYCH. Pomoc mogły uzyskać grupy producentów rolnych zakładane w celu wspólnego dostosowania standardów produkcji oraz wypracowania systemu wspólnej sprzedaży produktów. System taki dotyczyć mógł centralizacji sprzedaży, przygotowania sprzedaży, konfekcjonowania, dostaw do hurtowni, oraz ustanowienia wspólnych zasad w zakresie zapewniania informacji nt. produkcji, szczególnie w odniesieniu do zbiorów (plonów) i dostępności danych produktów rolnych. Wsparcie to kierowane było wyłącznie do grup producenckich 
wpisanych do rejestrów prowadzonych przez marszałków województw pomiędzy 1 maja 2004 r. a 31 grudnia 2006 r. Liczbę takich grup przypadających na województwo przedstawia tabela A.2.8.

Tabela A.2.8. Liczba grup producentów rolnych w ramach PROW 2004-2006 - wnioski, decyzje o przyznaniu pomocy oraz płatności i zrealizowane płatności [wg województw]

\begin{tabular}{l|r|r|r|r|r|r}
\hline \multicolumn{1}{c|}{ Województwo } & $\begin{array}{c}\text { Liczba grup } \\
\text { producen- } \\
\text { ckich } \\
\text { 2004-2006 }\end{array}$ & $\begin{array}{c}\text { Wnioski } \\
\text { o pomoc }\end{array}$ & $\begin{array}{c}\text { Decyzje } \\
\text { przyznające } \\
\text { pomoc }\end{array}$ & $\begin{array}{c}\text { Wnioski } \\
\text { o płatność }\end{array}$ & $\begin{array}{c}\text { Decyzje } \\
\text { przyznające } \\
\text { płatność }\end{array}$ & $\begin{array}{c}\text { Zrealizo- } \\
\text { wane } \\
\text { płatności } \\
\text { [zł] }\end{array}$ \\
\hline Dolnośląskie & 12 & 12 & 11 & 6 & 4 & 273161 \\
Kujawsko-Pomorskie & 20 & 20 & 20 & 22 & 21 & 3355027 \\
Lubelskie & 4 & 4 & 4 & 5 & 2 & 157346 \\
Lubuskie & 4 & 4 & 4 & 5 & 5 & 1265849 \\
Łódzkie & 0 & 0 & 0 & 0 & 0 & 0 \\
Małopolskie & 3 & 3 & 3 & 5 & 5 & 626394 \\
Mazowieckie & 3 & 3 & 3 & 3 & 2 & 442885 \\
Opolskie & 12 & 12 & 12 & 11 & 10 & 1294 \\
Podkarpackie & 6 & 5 & 5 & 6 & 5 & 271779 \\
Podlaskie & 0 & 0 & 0 & 0 & 0 & 0 \\
Pomorskie & 5 & 4 & 4 & 5 & 5 & 884568 \\
Śląskie & 1 & 1 & 1 & 0 & 0 & 0 \\
Śiętokrzyskie & 1 & 1 & 1 & 0 & 0 & 0 \\
Warmińsko-Mazurskie & 3 & 3 & 3 & 2 & 2 & 385493 \\
Wielkopolskie & 23 & 23 & 22 & 17 & 15 & 3048416 \\
Zachodniopomorskie & 7 & 7 & 6 & 2 & 2 & 393289 \\
Razem & $\mathbf{1 0 4}$ & $\mathbf{1 0 2}$ & $\mathbf{9 9}$ & $\mathbf{8 9}$ & $\mathbf{7 8}$ & $\mathbf{1 2} \mathbf{2 9 3} \mathbf{6 4 2}$ \\
\hline
\end{tabular}

Żródło: [ARiMR 2007].

Dofinansowanie można było przeznaczyć na pokrycie kosztów zakładania i funkcjonowania takich grup w ciągu pierwszych pięciu lat ich istnienia. Pomoc $\mathrm{w}$ formie procentowego ryczałtu - nalicza się na podstawie rocznej wartości netto przychodów ze sprzedaży produktów lub grup produktów wytworzonych w gospodarstwach członków grupy producenckiej. Wysokość wsparcia nie mogła przekroczyć: w pierwszym i drugim roku - 100 tys. EUR, w trzecim roku - 80 tys. EUR, w czwartym roku - 60 tys. EUR, w piątym roku - 50 tys. EUR. Ze względu na to, że wsparcie było wypłacane ryczałtem i pokrywało ogólne wydatki grup na działalność bieżącą, to zaliczamy je do transferów bezpośrednich.

\section{Analiza instrumentów SPO Restrukturyzacja i modernizacja sektora żywnościowego oraz rozwój obszarów wiejskich 2004-2006}

INWESTYCJE W GOSPODARSTWACH ROLNYCH. Pomoc przyznawana była gospodarstwom, które planowały inwestycje związane z modernizacją gospodarstw rolnych. Musiały one przy tym spełnić kryterium żywotności ekonomicznej, minimalne stan- 
dardy w zakresie ochrony środowiska, higieny i warunków utrzymania (dobrostanu) zwierząt oraz musiały być prowadzone przez osoby posiadające kwalifikacje rolnicze. Pomoc finansowa polegała na refinansowaniu części (od 50\% do 65\%) poniesionych kosztów kwalifikowanych inwestycji. Wśród kosztów kwalifikowanych były m.in. budowa i modernizacja budynków gospodarczych, zakup lub instalacja maszyn i urządzeń, zakup gruntów rolnych, zakup budynków inwentarskich lub gospodarczych, zakładanie sadów lub plantacji wieloletnich, wyposażanie pastwisk, zakup stada podstawowego zwierząt hodowlanych, inwestycje służące ochronie środowiska, poprawie warunków dobrostanu zwierząt i podniesieniu standardów higienicznych produkcji rolnej oraz koszty ogólne (dotyczące planowania wstępnego, w tym przygotowania dokumentacji technicznej i ekonomicznej przedsięwzięcia). Rysunek A.2.1 przedstawia strukturę poniesionych kosztów kwalifikowanych. Według kryteriów ekonomicznych były to subsydia do inwestycji z zakresu infrastruktury technicznej (sektora przetwórstwa przemysłowego) oraz do inwestycji z zakresu sektora budowlanego na rzecz rolnictwa.
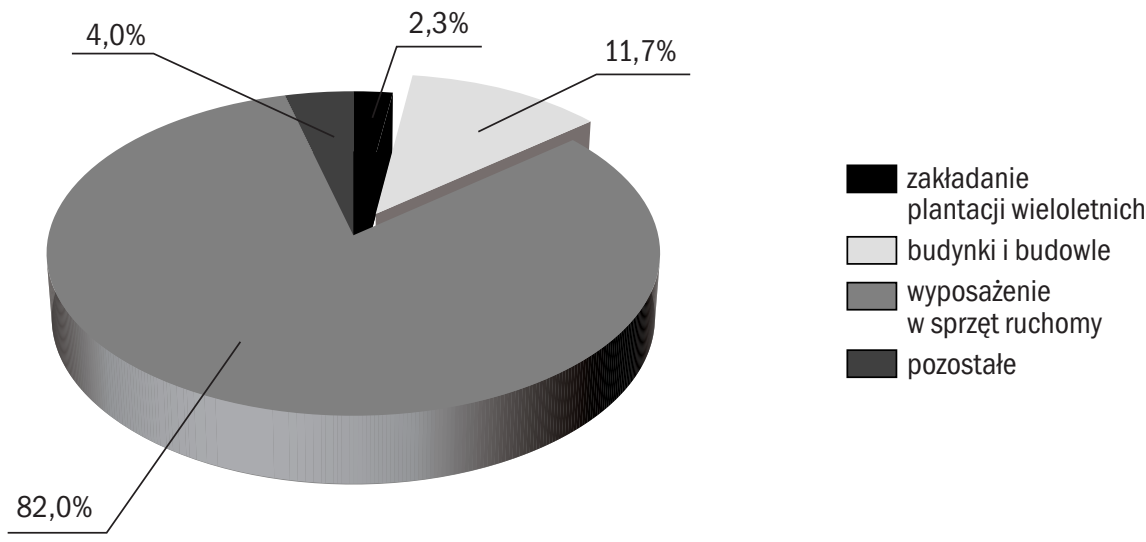

Rysunek A.2.1. Struktura kosztów kwalifikowanych w działaniu Inwestycje w gospodarstwa rolne w ramach SPO Rolnictwo 2004-2006 wg rodzajów [w \%]

Źródło: [ARiMR 2007].

UŁaTWianie STARTU MŁODym rolnikom. Działanie to adresowane było do młodych rolników (18-40 lat), którzy w okresie ostatnich 12 miesięcy podjęli się po raz pierwszy prowadzenia gospodarstwa rolnego, ponadto posiadali odpowiednie kwalifikacje zawodowe, byli właścicielami gospodarstwa lub dzierżawili je, byli ubezpieczeni w KRUS jako prowadzący gospodarstwo rolne oraz zobowiązali 
się do prowadzenia gospodarstwa przez okres co najmniej 5 lat od dnia wypłacenia pomocy finansowej. Ponadto gospodarstwo młodego rolnika musi spełniać wymogi żywotności ekonomicznej i ochrony środowiska. Rysunek A.2.2 przedstawia zainteresowanie tym działaniem według województw. Pomoc udzielana była w formie premii (transferu bezpośredniego), w wysokości określonej w uzupełnieniu programu. Premia ta nie była związana z koniecznością realizacji konkretnego projektu. Zatem $\mathrm{z}$ ekonomicznego punktu widzenia działanie to miało charakter typowego bezpośredniego transferu dochodowego.

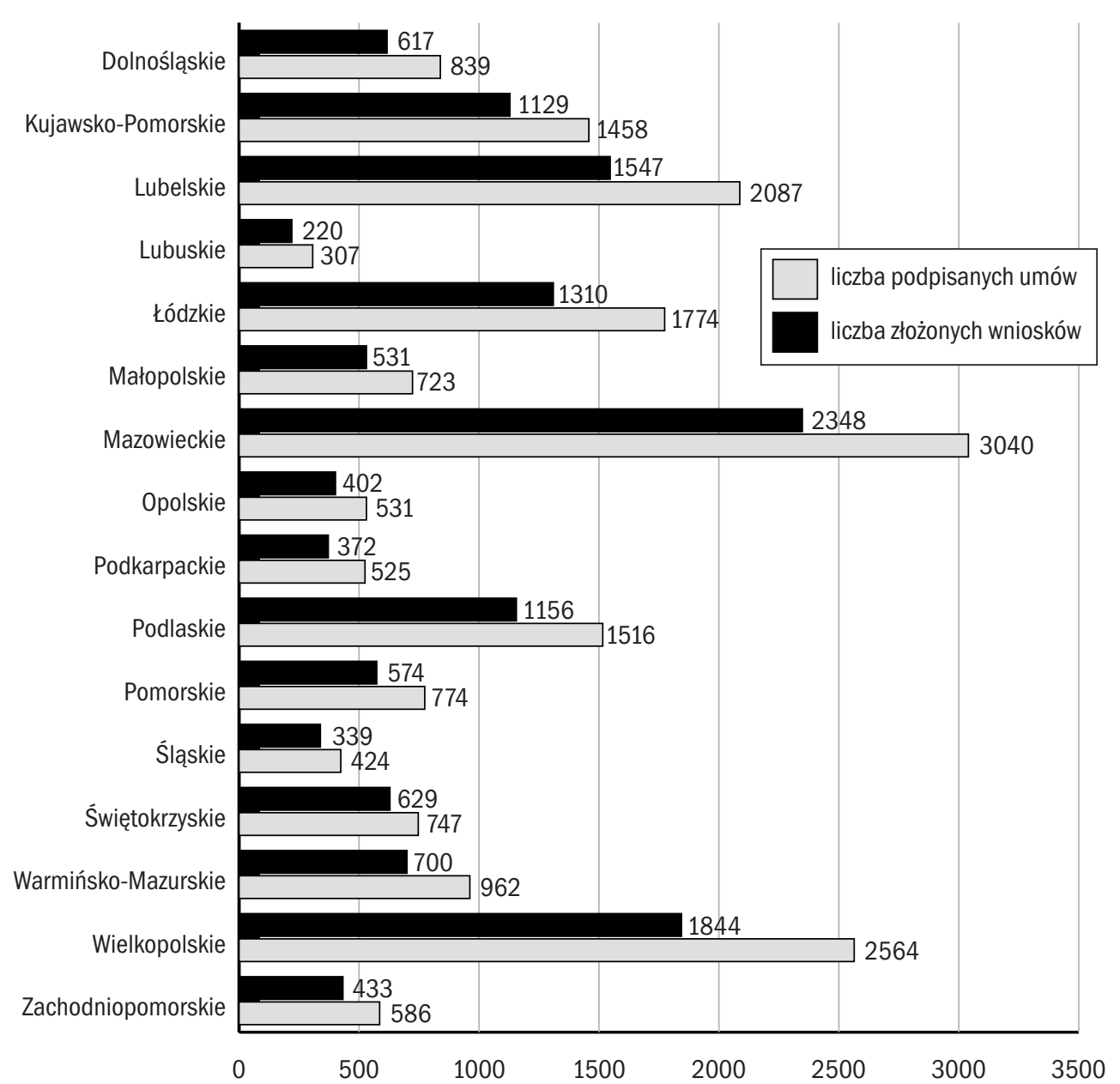

Rysunek A.2.2. Liczba złożonych wniosków i podpisanych umów w ułatwienie startu młodym rolnikom w ramach SPO Rolnictwo 2004-2006 [wg województw]

Źródło: [ARiMR 2007]. 
Szkolenia. Działanie to wspierało projekty, dotyczące realizacji szkoleń zawodowych dla rolników i innych osób pracujących w rolnictwie, z zakresu prowadzenia gospodarstwa rolnego oraz produkcji rolniczej lub leśnej. Pomocą finansową zostały objęte: koszty związane z przygotowaniem i zrealizowaniem szkoleń; koszty zakupu sprzętu i pomocy dydaktycznych niezbędnych do realizacji szkolenia; koszty operacyjne, związane z obsługą i zarządzaniem projektem. Beneficjentami bezpośrednimi pomocy były instytucje i podmioty (publiczne lub prywatne), prowadzące działalność szkoleniową. Formą finansowania była refundacja $100 \%$ kosztów kwalifikowanych, poniesionych w związku z realizacją projektu, w tym poziom udziału UE wynosił maksymalnie do 80\% całkowitych kosztów kwalifikowanych. Działanie to zaliczyliśmy do subsydiów o charakterze edukacyjnym.

WSPARCIE DORADZTwa ROLNICZEgo. Działanie wspierało działalność podmiotów oraz instytucji doradztwa rolniczego, świadczących usługi doradcze w zakresie korzystania $\mathrm{z}$ pomocy $\mathrm{w}$ ramach Wspólnej Polityki Rolnej, instrumentów towarzyszących WPR oraz polityki strukturalnej. Beneficjentami bezpośrednimi były instytucje i podmioty (publiczne lub prywatne), prowadzące działalność z zakresu doradztwa rolniczego lub leśnego. Pomocą finansową objęte były: • koszty związane z przygotowaniem wniosków o pomoc, wniosków o płatność, projektów, przedsięwzięć lub planów rozwoju gospodarstwa oraz koszty usług doradczych, świadczonych w trakcie realizacji projektów • koszty organizacji doradztwa grupowego • koszty przygotowania ulotek doradczych.

Pomoc finansowa polegała na refundacji 100\% kosztów kwalifikowanych, poniesionych w związku z realizacją projektu. Poziom udziału UE wynosił do 80\% całkowitych kosztów kwalifikowanych. W związku z charakterem działania (refundacja zainwestowanych funduszy w doradztwo), zaliczone zostało jako subsydium edukacyjne.

Poprawa PRZetwórstwa I MARKetingu. Działanie to zostało skierowane do podmiotów prowadzących działalność związaną z przetwórstwem i marketingiem produktów rolnych. W układzie rodzajowym dominowały koszty zakupu lub instalacji maszyn lub urządzeń do przetwarzania produktów rolnych $(43,1 \%)$ oraz koszty budowy lub remontu połączonego z modernizacją budynków lub budowli (wraz z infrastrukturą techniczną): produkcyjnych, magazynowych, w których prowadzi się kontrolę laboratoryjną, socjalnych lub służących do prowadzenia handlu hurtowego $(25,4 \%)$ - rysunek A.2.3. Pomoc była udzielana w formie zwrotu do 50\% kwalifikowanych wydatków (w tym udział UE do 35\%). Maksymalna wysokość pomocy, jaka w ramach niniejszego działania mogła być udzielona jed- 
nemu beneficjentowi, była określona w uzupełnieniu programu. Z ekonomicznego punktu widzenia, instrument ten był udzielany w formie subsydium inwestycyjnego do sektora przemysłu przetwórczego i budowlanego.

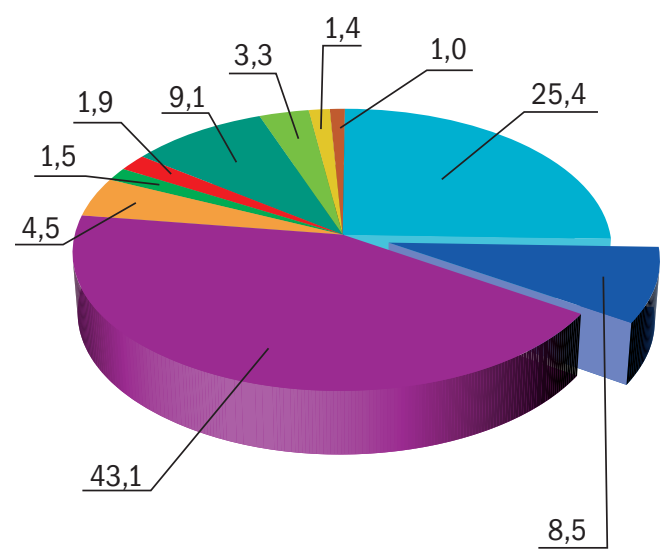

koszty budowy lub remontu połączonego z modernizacją budynków lub budowli

koszty zakupu lub instalacji maszyn lub urządzeń do magazynowania, lub przygotowywania produktów rolnych

koszty zakupu lub instalacji maszyn lub urządzeń do przetwarzania produktów rolnych

koszty zakupu lub instalacji maszyn lub urządzeń do magazynowania produktów koszty zakupu lub instalacji aparatury pomiarowej, kontrolnej oraz sprzętu do sterowania procesem produkcji koszty zakupu środków transportu niezbędnych dla sprawnego przebiegu procesu technologicznego

koszty zakupu specjalistycznych środków transportu związanych z dostawą surowca lub zbytem produktów koszty budowy lub modernizacji oczyszczalni ścieków wraz z siecią kanalizacyjną koszty budowy lub modernizacji kotłowni koszty ogólne

Rysunek A.2.3. Struktura kosztów kwalifikowanych w działaniu Poprawa przetwórstwa i marketingu w ramach SPO Rolnictwo 2004-2006

Źródło: [ARiMR 2007].

Przywracanie potencjąu ProdukCJi leŚnej. Działanie to przeznaczone było dla Nadleśnictw Państwowego Gospodarstwa Leśnego Lasy Państwowe oraz właścicieli lasów prywatnych, którzy zgłosili należące do nich tereny leśne do działania. W praktyce działanie objęło dwa województwa: opolskie i warmińsko-mazurskie. Większość projektów dotyczyła wprowadzania instrumentów zapobiegawczych, mających wpływ na zabezpieczenie obszarów leśnych bezpośrednio zniszczonych w wyniku katastrofy $(64,1 \%)$, pozostałe natomiast - przywracania potencjału produkcji leśnej zniszczonego wiatrem (35,9\%). Żaden projekt nie dotyczył przywracania potencjału produkcji leśnej zniszczonego przez pożar, powódź czy inne klęski. Średnia wysokość kosztów kwalifikowanych wyniosła 1,6 mln zł na jeden projekt. W układzie rodzajowym przeważały koszty budowy i modernizacji dróg technologicznych i przeciwpożarowych oraz infrastruktury drogowej zapewniającej udostępnienie i ochronę kompleksów leśnych - rysunek A.2.4. Pomoc była udzielona w formie zwrotu 100\% kosztów kwalifikowanych, przy czym poziom udziału UE wynosił do $80 \%$ całkowitego kwalifikującego się kosztu. 


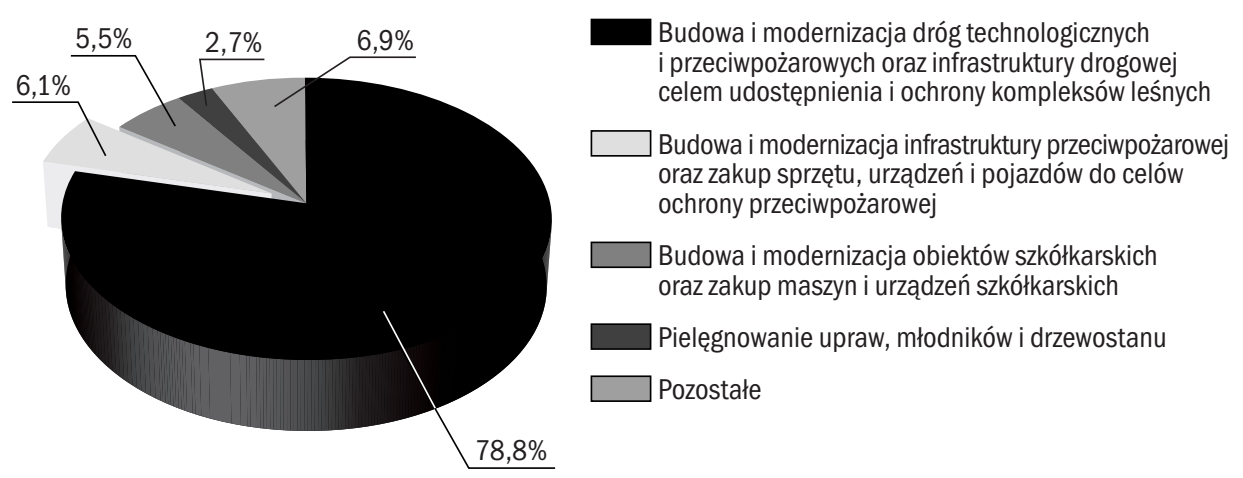

Rysunek A.2.4. Struktura kosztów kwalifikowanych w działaniu Przywracanie potencjału produkcji leśnej w ramach SPO Rolnictwo w latach 2004-2006

Źródło: [ARiMR 2007].

W związku z tym działanie to traktujemy jako subsydium inwestycyjne, gdyż finansowało koszty związane z inwestycjami w sektorze leśnym.

SCALANIE GRUNTów. Działanie to polegało na ułatwieniu procesu scalania gruntów rolnych. Beneficjentami bezpośrednimi działania byli starostowie powiatów, reprezentujący właścicieli gospodarstw rolnych, którzy byli beneficjentami ostatecznymi. W ramach tego działania finansowaniem objęto koszty: opracowania dokumentacji geodezyjno-prawnej; koszty zagospodarowania poscaleniowego związanego z organizacją przestrzeni produkcyjnej, w tym urządzenie dróg transportu rolnego, uporządkowanie terenu umożliwiające objęcie w posiadanie nowo wydzielonych działek, korekta przebiegu rowów melioracyjnych, urządzanie przepustów itp. Pomoc pozwalała na pokrycie całkowitych kosztów kwalifikowanych przedsięwzięcia. W związku z inwestycyjnym charakterem tego działania zaliczone ono zostało do subsydiów inwestycyjnych w infrastrukturę.

ODNOWA WSI ORAZ ZACHOWANIE I OCHRONA DZIEDZICTWA KULTUROWEGO. Wsparcie w ramach tego działania udzielane było na realizację projektów inwestycyjnych na terenach wiejskich. Beneficjentami bezpośrednimi działania były samorządy gmin wiejskich lub miejsko-wiejskich, instytucje kultury, dla których organem założycielskim jest samorząd terytorialny. Pomocą finansową objęte były koszty: prac projektantów, architektów, konserwatorów zabytków oraz doradztwa związanego z realizacją przedsięwzięć inwestycyjnych; koszty modernizacji przestrzeni publicznej; koszty budowy lub modernizacji publicznej infrastruktury zwią- 
zanej z rozwojem funkcji turystycznych i kulturalnych; koszty modernizacji i wyposażenia obiektów pełniących funkcje kulturalne, rekreacyjne i sportowe oraz koszty odnowy lub zakupu obiektów charakterystycznych dla tradycji budownictwa wiejskiego regionu oraz ich adaptacji na cele kulturalne i społeczne. Finansowaniu podlegały projekty realizowane w gminach wiejskich lub miejsko-wiejskich, w miejscowościach liczących nie więcej niż 5 tys. mieszkańców. Poziom pomocy wynosił do $80 \%$ kosztów kwalifikowanych, z czego pomoc UE wynosiła maksymalnie do $80 \%$ całkowitego kwalifikującego się kosztu. Działanie to zaliczyliśmy zatem do subsydiów inwestycyjnych w infrastrukturę (budownictwo).

RóżNICOWANIE DZIAŁALNOŚCI ROLNICZEJ I ZBLIŻONEJ DO ROLNICTWA W CELU ZAPEWNIENIA RÓŻNORODNOŚCI DZIAŁAŃ LUB ALTERNATYWNYCH ŹRÓDEŁ DOCHODÓW. POMOcą tą objęte były projekty związane $\mathrm{z}$ realizacją inwestycji, służących podjęciu dodatkowej działalności zbliżonej do rolnictwa przez rolników i domowników (którzy stanowili 98,2\% beneficjentów), a także osoby prawne. Do kosztów kwalifikowanych zaliczano koszty: rozbudowy, przebudowy, budowy lub adaptacji obiektów budowlanych; zakupu i instalacji wyposażenia, zakupu maszyn, urządzeń i sprzętu, w tym oprogramowania; zakupu środków transportu (z wyłączeniem zakupu samochodów osobowych przeznaczonych do przewozu mniej niż 8 osób wraz z kierowca); zakupu zwierząt służących rozwojowi funkcji rekreacyjnych gospodarstwa; zagospodarowania terenu; robót budowlanych, transportu, materiałów i wyposażenia; koszty ogólne: planowania wstępnego, w tym przygotowania dokumentacji technicznej i ekonomicznej

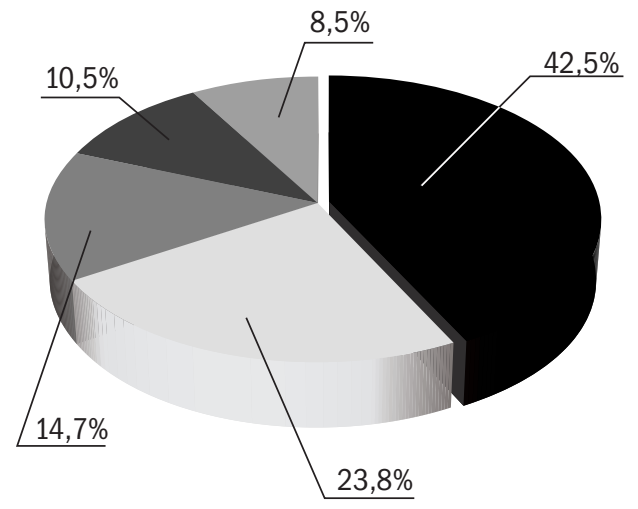

Maszyny, urządzenia, narzędzia i wyposażenie Środki transportu dla świadczenia wyłącznie usług transportowych

Budynki mieszkalne i gospodarcze wraz z wyposażeniem na cele agroturystyczne

$\square$ Obiekty budowlane dla celów projektu

Pozostałe

Rysunek A.2.5 . Struktura inwestycyjnych kosztów kwalifikowanych w działaniu Różnicowanie działalności rolniczej w ramach SPO Rolnictwo 2004-2006

Źródło: [ARiMR 2007]. 
projektu. Maksymalny poziom pomocy wynosił 50\% kosztów kwalifikowanych projektu, w tym poziom udziału UE mógł wynieść do 35\% całkowitego kwalifikującego kosztu. Podział kosztów inwestycyjnych na kategorie przedstawia rysunek A.2.5. Działanie to miało charakter subsydiów inwestycyjnych w maszyny, transport i budownictwo.

GOSPODAROWANIE ZASOBAMI WODNYMI. Działaniem tym objęte były projekty z zakresu melioracji oraz projekty związane z kształtowaniem koryta cieku naturalnego. Beneficjentem bezpośrednim tego działania był Wojewódzki Zarząd Melioracji i Urządzeń Wodnych, ale beneficjentami ostatecznymi - rolnicy i mieszkańcy obszarów wiejskich. Koszty kwalifikowane obejmowały m.in.: opracowanie dokumentacji technicznych projektów; budowę lub modernizację urządzeń melioracji podstawowych: różnego rodzaju budowle regulacyjne, przeciwpowodziowe wraz z drogami dojazdowymi; budowę lub modernizację urządzeń melioracji szczegółowych. Pomoc występowała w formie zwrotu od 50\% do $80 \%$ całkowitego kwalifikującego się kosztu. Działanie to zakwalifikowaliśmy zgodnie z jego charakterem jako subsydium inwestycyjne związane $\mathrm{z}$ infrastrukturą techniczną.

ROZWÓJ I ULEPSZANIE INFRASTRUKTURY TECHNICZNEJ ZWIĄZANEJ Z ROLNICTWEM. Działanie przeznaczone było na dofinansowanie projektów realizowanych w gospodarstwach rolnych. Beneficjentami były zarówno osoby fizyczne - rolnicy, będący samoistnymi lub zależnymi posiadaczami gospodarstw rolnych $(98,9 \%)$, jak i osoby prawne (1,1\%). Dużą grupę beneficjentów, tj. ok. 23\%, stanowiły osoby, które skorzystały wcześniej ze wsparcia w ramach programu SAPARD. Wsparcie mogło być przyznane na cztery typy projektów z zakresu budowy lub remontu połączonego z modernizacją: dróg wewnętrznych, urządzeń zaopatrzenia w wodę, urządzeń do odprowadzania i oczyszczania ścieków oraz sieci i urządzeń zaopatrzenia w energię. W strukturze kosztów kwalifikowanych największy udział miały projekty, których celem była poprawa lub umożliwienie rolnikom dostępu do infrastruktury technicznej $(63,6 \%)$ oraz poprawa organizacji produkcji rolniczej (26,7\%). Strukturę kosztów kwalifikowanych przedstawia rysunek A.2.6. W układzie rodzajowym w strukturze tej dominowały koszty budowy i remontu dróg wewnętrznych $(88,0 \%)$, a udział pozostałych kategorii kosztów był niewielki i wynosił w przypadku budowy lub remontu połączonego z modernizacją: 5,5\% dla urządzeń zaopatrzenia w wodę, 4,5\% dla urządzeń odprowadzania i oczyszczania ścieków, oraz 2,0\% w przypadku urządzeń zaopatrzenia w energię. Poziom pomocy wynosił do 50\% kosztów kwalifikowanych, z czego udział UE wynosił do 35\% całkowitego kwalifikującego kosztu. Zgodnie z nazwą i przeznaczeniem działania, zakwalifikowaliśmy je do subsydium inwestycyjnego w infrastrukturę (budownictwo). 


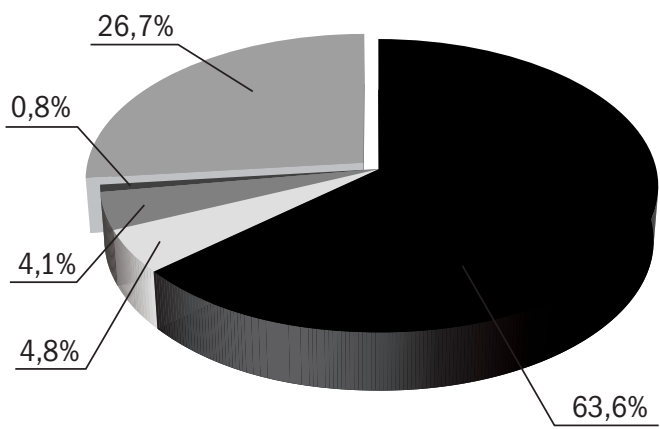

Poprawa lub umożliwienie rolnikom dostępu do infrastruktury technicznej

Ochrona i poprawa stanu środowiska naturalnego

Poprawa warunków sanitarnohigienicznych na obszarach wiejskich

Wzrost dochodu rolniczego

Poprawa organizacji produkcji rolniczej

Rysunek A.2.6. Struktura kosztów kwalifikowanych w działaniu Rozwój i ulepszanie infrastruktury technicznej wg głównego celu projektu w ramach SPO Rolnictwo 2004-2006

Źródło: [ARiMR 2007].

LEADER+. Ze względu na dużą różnorodność instrumentów w tym działaniu, niełatwo sklasyfikować tę formę pomocy z ekonomicznego punktu widzenia. Schemat I obejmował: • działania informacyjne, szkoleniowe i promocyjne związane ze stymulowaniem udziału mieszkańców i organizacji działających na obszarach wiejskich w procesie planowania ZSROW • opracowywanie ZSROW i wsparcie techniczne procesu ich przygotowywania (analizy, ekspertyzy, wsparcie doradcze, prace studialne itp.) • pomoc doradcza i ekspercka związana z tworzeniem LGD. Z kolei Schemat II obejmował: • działalność operacyjną LGD • promocję i informację dotyczącą założeń i sposobu realizacji strategii rozwoju obszarów wiejskich • pomoc szkoleniową i doradczą w zakresie przygotowywania i realizacji projektów w ramach ZSROW • przygotowywanie opracowań, analiz, dokumentacji związanej ze szczegółowym planowaniem inwestycji oraz kreowaniem nowych produktów i usług, zgodnie z założeniami ZSROW • organizację imprez promujących region, jego produkty, usługi, kulturę, sztukę itp. • współpracę i wymianę doświadczeń między LGD na poziomie krajowym i międzynarodowym w zakresie wdrażania strategii oraz organizacji pracy LGD, w tym zarządzania, monitorowania itp. Z analizy sposobu wykorzystania środków wydaje się, że można je zaliczyć do subsydiów inwestycyjnych w edukację, czyli podobnie jak działania związane z doradztwem i szkoleniami. Analityczne i naukowe opracowania na temat programu LEADER można znaleźć w pracach wielu autorów, m.in. [Budzich-Szukała 2008], [Kamiński 2008], [UKIE 2005], [Kamiński i Kwatera 2005]). 


\section{ANEKS 2.2. REGIONALNA STRUKTURA POZYSKANYCH FUNDUSZY ROW}

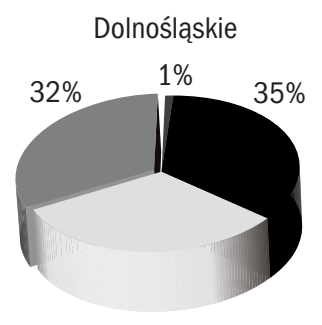

$32 \%$

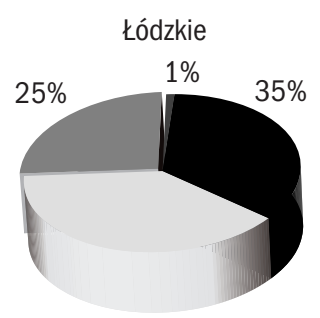

$39 \%$

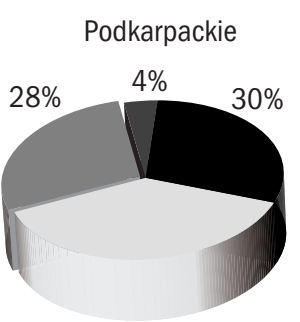

$38 \%$

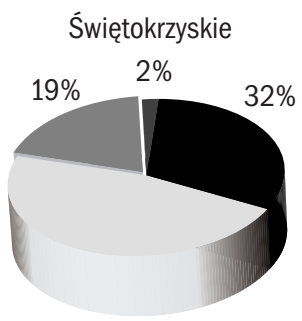

$47 \%$
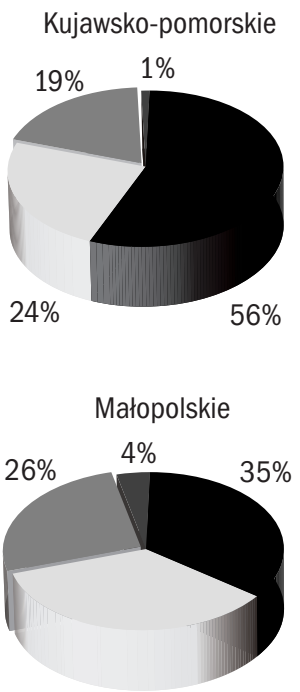

$35 \%$

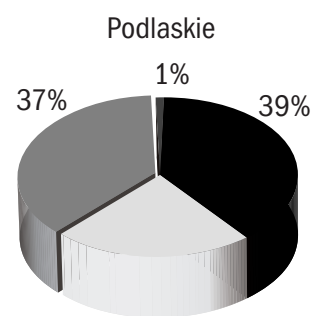

$23 \%$

Warmińsko-mazurskie

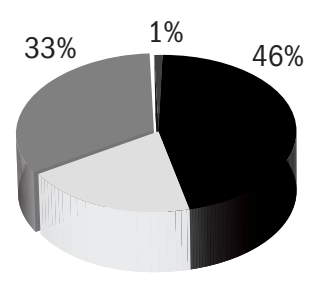

$20 \%$

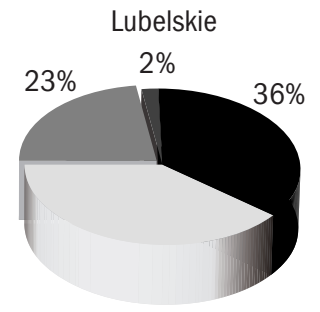

$39 \%$

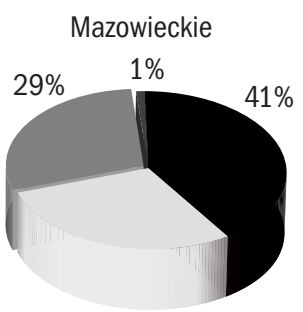

$29 \%$

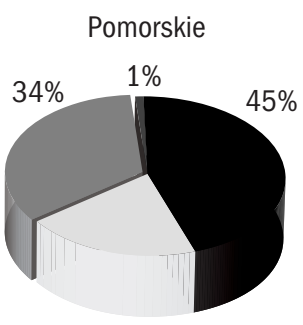

$20 \%$

Wielkopolskie

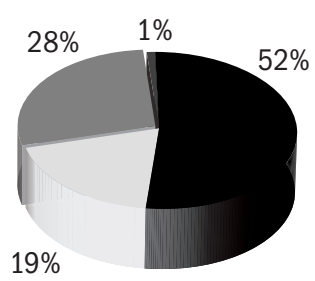

$19 \%$

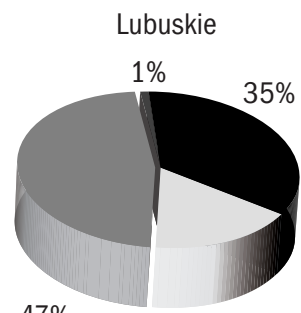

$47 \%$

$17 \%$

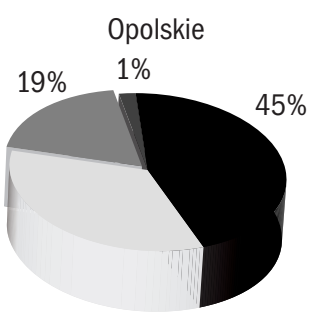

$34 \%$

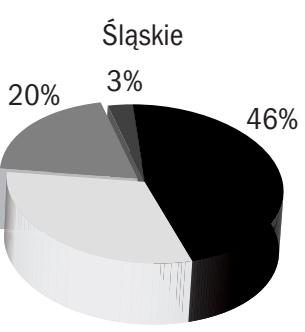

$31 \%$

Zachodniopomorskie

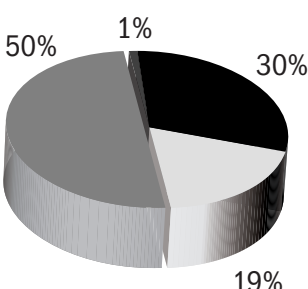

ISI_b $\square$ TB $\square$ SO $\square$ SI_e

TB - transfery bezpośrednie, SO - subsydia obszarowe, SI_e - inwestycje w edukację (szkolenia i doradztwo), SI_b - inwestycje w infrastrukturę

Rysunek A.2.7. Regionalna struktura pozyskanych funduszy ROW wg kryteriów ekonomicznych Źródło: Obliczenia własne na podstawie płatności zrealizowanych, stan na 31 grudnia 2007 r. [ARiMR 2008]. 


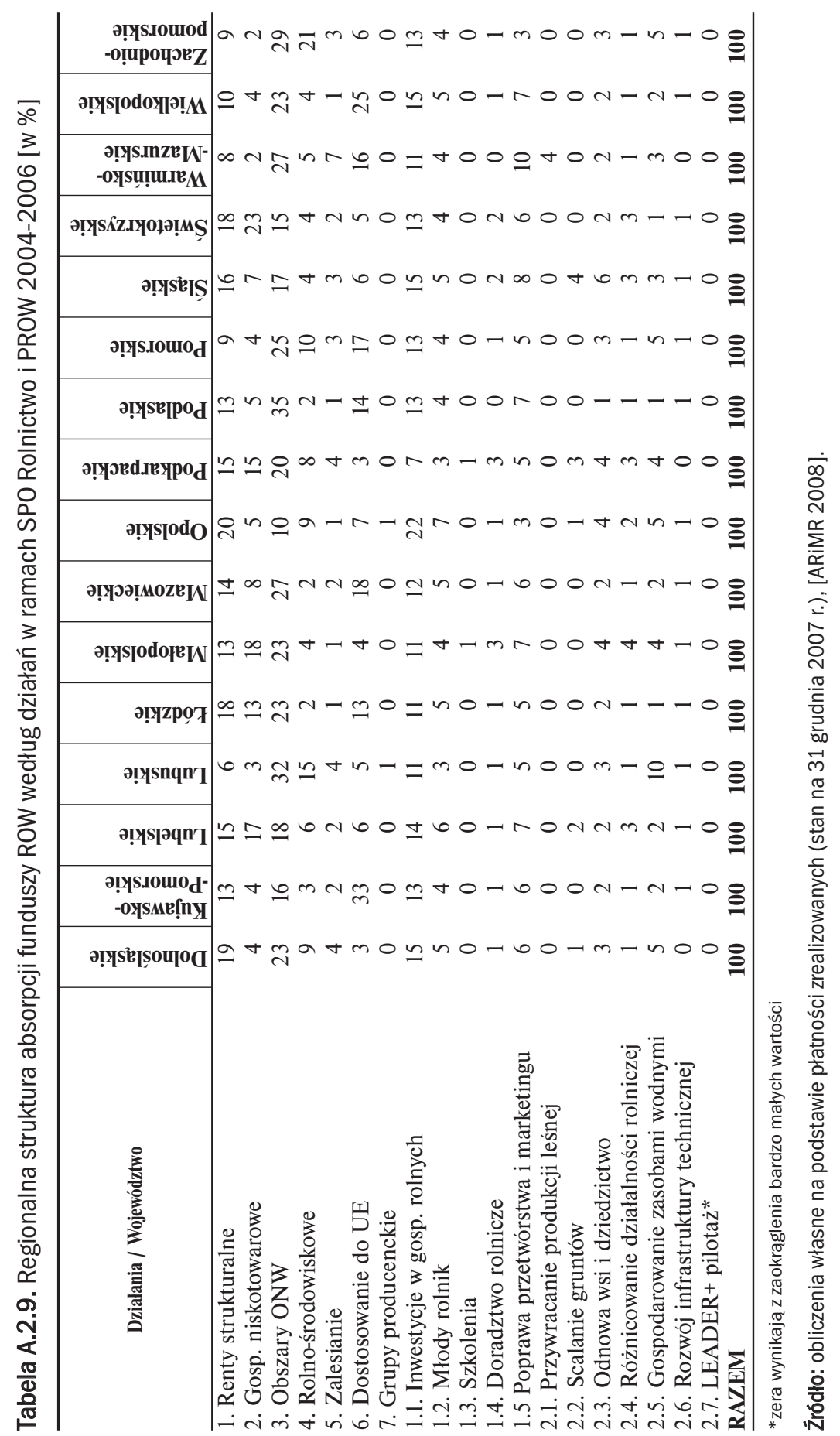




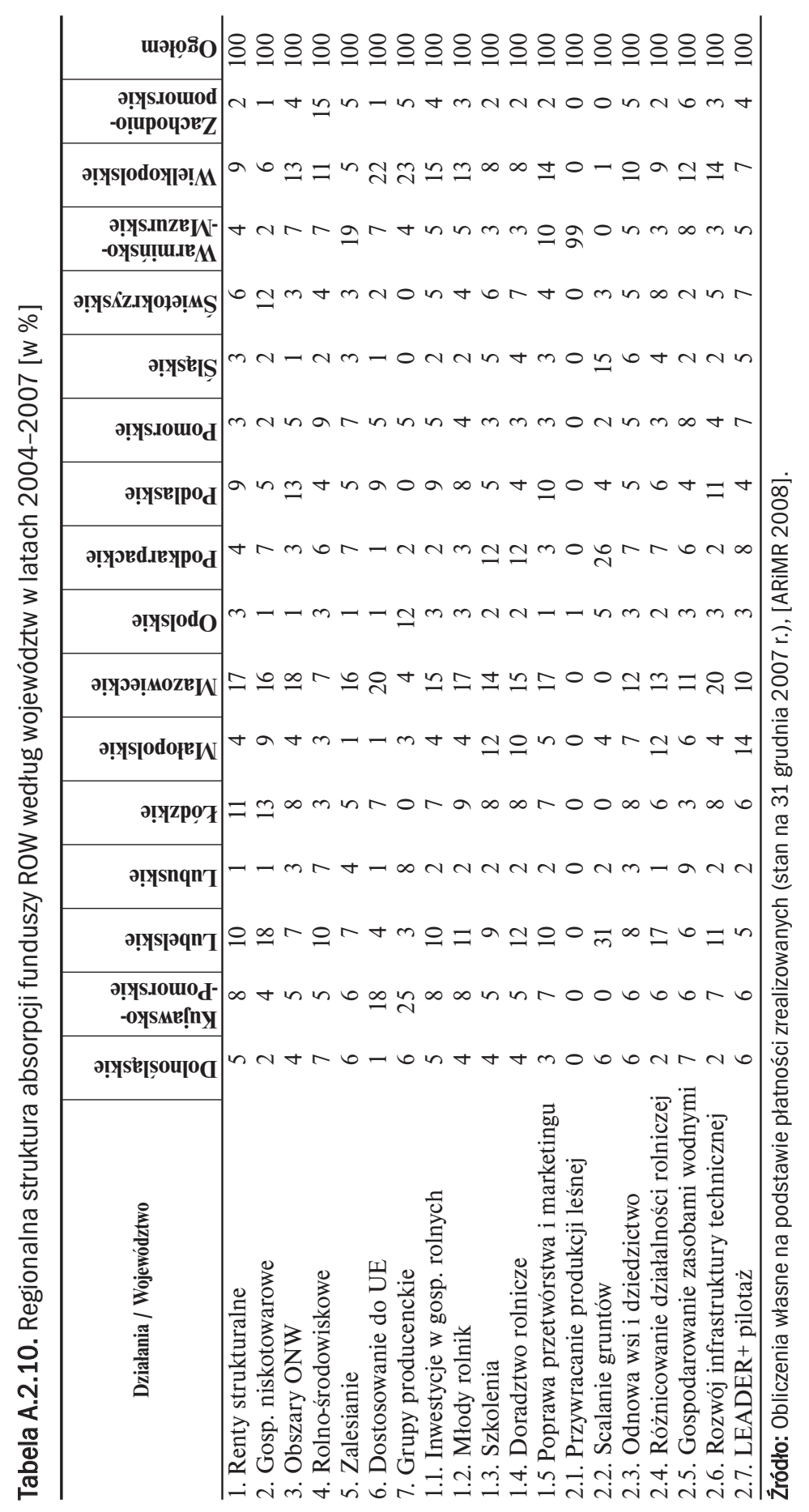




\section{ANEKS 2.3. ZASADY PODZIAŁU ŚRODKÓW SPO ROLNICTWO NA WOJEWÓDZTWA}

W ramach SPO Rolnictwo kopertowaniu poddano 7 działań. Podziału środków dla trzech działań 1.1 Inwestycje w gospodarstwach rolnych, 1.2 Ułatwienie startu młodym rolnikom i 2.6 Rozwój i ulepszanie infrastruktury technicznej związanej z rolnictwem, dokonano pomiędzy województwa na podstawie syntetycznego wskaźnika ekonomicznej wielkości gospodarstw (SWEk), który został skonstruowany na podstawie danych wielkości ekonomicznej gospodarstw oraz powierzchni użytków rolnych w poszczególnych województwach. Udział procentowy województwa $\mathrm{k}$ w puli środków przeznaczonych na każde $\mathrm{z}$ tych trzech działań określony jest wartością SWEk, po unormowaniu sumy składników SWE po wszystkich województwach do 100\%. Wzór na SWEk zawiera poniższy box A.2.1.

Box A.2.1. Wzór do indykatywnego podziału środków na koperty regionalne dla działań 1.1,

$$
1.2 \text { i } 2.6
$$

Syntetyczny miernik wielkości ekonomicznej gospodarstw SWEk

dla działań 1.1, 1.2 i 2.6 :

$$
\text { SWEk }=\text { UWEk } \times 80 \%+\text { UURk } \times 20 \%
$$

gdzie:

$\mathrm{k}=$ województwo,

UWEk - udział gospodarstw z województwa k w łącznej liczbie gospodarstw spełniających kryterium wielkości ekonomicznej

UURk - udział powierzchni użytków rolnych z województwa k w łącznej powierzchni użytków rolnych w kraju

UWEk $=W E_{k} / W E$, gdzie: WE - liczba gospodarstw spełniających kryterium wielkości ekonomicznej w całym kraju; $W_{k}$ - liczba gospodarstw spełniających kryterium wielkości ekonomicznej w województwie k, WEk $E_{k(2-4)} \times 15 \%$ Ek(4), gdzie $E_{k}(2-4)$ - liczba gospodarstw o wielkości ekonomicznej od 2 do 4 ESU w województwie $k, E_{k(>4)}$ - liczba gospodarstw o wielkości ekonomicznej powyżej 4 ESU w województwie k;

UURk = URk/UR, gdzie UR jest wielkością użytków rolnych w województwie k i w kraju

Box Wskaźniki przyjęte do podziału wybranych działań SPO na tzw. koperty wojewódzkie

Źródło: [KS 2/2004].

Jeśli chodzi o działanie 2.4 Różnicowanie działalności rolniczej..., to udział procentowy województwa $\mathrm{k}$ w puli środków przeznaczonych na to działanie określony został na podstawie wartości syntetycznego miernika liczebności grupy doce- 
lowej gospodarstw (SGEk), po unormowaniu sumy jego składników we wszystkich województwach do $100 \%$. Został on skonstruowany na podstawie danych wielkości ekonomicznej gospodarstw oraz liczby ludności zamieszkującej obszary wiejskie w poszczególnych województwach. Wzór na SGEk zawiera box A.2.2.

Udział województw w puli środków na działanie 2.2 Scalanie gruntów, oparty był na syntetycznym wskaźniku zróżnicowania terenu (Uk) liczonym według dwóch kryteriów: liczby obiektów i współczynników zróżnicowania terenu. Liczbę obiektów z uwzględnieniem ich wielkości (Pk, m) zgłaszały poszczególne województwa. Wskaźniki zróżnicowania terenu (różnicujące województwa ze względu na wielkość szachownicy gruntów i warunki terenowe), przyjęto zgodnie z obowiązującym rozporządzeniem Ministra Rolnictwa z dnia 19 kwietnia 2000 r. Wynosiły one odpowiednio dla poszczególnych województw: 2 (małopolskie, podkarpackie), 1,7 (śląskie), 1,3 (dolnośląskie, świętokrzyskie, lubelskie), 1 (dla pozostałych województw). Syntetyczny wskaźnik opisany był wzorem [KS 4/2004]:

$$
U_{k}=\frac{P_{k} \times T r_{k}}{\sum_{m=1}^{16}\left(P_{m} \times T r_{m}\right)} \times 100 \%
$$

Box A.2.2. Wzór do indykatywnego podziału środków na koperty regionalne dla działania 2.4

Syntetyczny miernik wielkości grupy docelowej gospodarstw SGEk dla działania 2.4:

$$
\text { SGEk }=\text { UGEk } * 80 \%+\text { ULRk } * 20 \%
$$

gdzie: k = województwo,

UGEk - Udział gospodarstw z województwa k w łącznej liczbie gospodarstw stanowiących grupę docelową; UGEk =GEk/GE

ULRk - Udział ludności zamieszkującej tereny wiejskie w województwie k w łącznej liczbie ludności zamieszkującej tereny wiejskie; ULRk= LRk/LR

$\mathrm{GE}_{\mathrm{k}}=\mathrm{E}_{\mathrm{k}(4)} \times 15 \% \mathrm{E}_{\mathrm{k}(2-4)}$,

gdzie $E_{k(2-4)}$ - liczba o wielkości ekonomicznej od 2 do 4 ESU w województwie $k$,

$E_{k(>4)}$ - liczba gospodarstw o wielkości ekonomicznej powyżej 4 ESU w województwie k;

$\mathrm{GE}$ - liczba gospodarstw stanowiących potencjalną grupę docelową (suma GEk).

LRK = Liczba ludności zamieszkującej tereny wiejskie w danym województwie,

LR suma LRK

Źródło: [KS 3/2004]. 
Udział województw w puli środków na działanie 2.3 Odnowa wsi oraz zachowanie i ochrona dziedzictwa kulturowego (UŚWk) obliczano jako średnią ważoną: udziału ludności zamieszkującej tereny wiejskie w danym województwie w stosunku do kraju (ULRk) z wagą 0.6 oraz udziału liczby miejscowości wiejskich w województwie w stosunku do kraju (UMWk) z wagą 0.4, po znormalizowaniu sumy UŚW we wszystkich województwach do 100\%. Przedstawia to następujące równanie [KS 5/2004]:

$$
\mathrm{UŚ} W \mathrm{UL}=\mathrm{ULRk} \times 60 \%+\mathrm{UMWk} \times 40 \% .
$$

Dokonanie podziału środków pomiędzy województwa w ostatnim kopertowanym działaniu 2.5. Gospodarowanie rolniczymi zasobami wodnymi odbyło na podstawie danych o potrzebach modernizacji urządzeń melioracji wodnych szcze-

Box A.2.3. Wzór do indykatywnego podziału środków na koperty regionalne dla działania 2.5

\section{Kwota środków dla województwa k:}

$$
\begin{gathered}
\text { Sk = } 140 \times K s G M E L \times W M E L k+140 K p \times(G W W W k+G R K W R K k+G p \times W P k) \\
:(G W+G R K+G p)
\end{gathered}
$$

gdzie: $k$ = województwo,

1) dla urządzeń melioracji wodnych szczegółowych przyjęto wagę $G_{M E L}=1$,

2) dla urządzeń melioracji wodnych podstawowych przyjęto następujące wagi:

- dla wałów przeciwpowodziowych przyjęto wagę GW = 5,

- dla regulacji rzek i kanałów przyjęto wagę $G_{R K}=3$,

- dla stacji pomp przyjęto wagę $G_{p}=1$.

Przyjęto ponadto podział środków przewidzianych na realizację działania w zależności od typu projektów:

- 20\% środków na realizację projektów z zakresu melioracji wodnych szczegółowych: wskaźnik Ks =0,2,

- 80\% środków na realizację projektów z zakresu melioracji wodnych podstawowych: wskaźnik Kp=0,8. WMELk - Wskaźnik potrzeb modernizacji urządzeń wodnych szczegółowych; WMELKk = MELk/MEL gdzie: MELk - Powierzchnia zmeliorowana, na której urządzenia melioracji wodnych szczegółowych wymagają modernizacji w województwie k, MEL dotyczy sumy wszystkich województw.

WWk - Wskaźnik potrzeb modernizacji wałów przeciwpowodziowych; WWk=Wk/W, gdzie Wk to długość wałów przeciwpowodziowych wymagających modernizacji w województwie $k$

WRKk - Wskaźnik potrzeb modernizacji rzek i kanałów; Wrak=RKk/RK, gdzie RKk to długość rzek i kanałow wymagających modernizacji w wojewodztwkie $k$ WPk - Wskaźnik potrzeb modernizacji stacji pomp w województwie k, WPk=Pk/P, gdzie Pk to wydajność stacji pomp wymagających modernizacji w województwie $k$

Źródło: [KS 6/2004]. 
gółowych i podstawowych w poszczególnych województwach. Zostały one określone w sprawozdaniu Głównego Urzędu Statystycznego RRW-10 ze stanu ilościowego i utrzymania urządzeń melioracyjnych, przy czym poszczególnym rodzajom urządzeń melioracji wodnych przypisano różne wagi, a ponadto przyjęto podział środków przewidzianych na realizację działania w zależności od typu projektów (więcej szczegółów opisuje box A.2.3).

\section{ANEKS 2.4. E-ANKIETA ROZESŁANA DO REGIONALNYCH ODDZIAŁÓW ARIMR}

Do różnych interesariuszy polityki rozwoju obszarów wiejskich w Polsce rozsyłana była od marca $2008 \mathrm{r}$. ankieta dotycząca problemów związanych z rozwojem obszarów wiejskich i możliwych sposobów ich rozwiązywania. W niniejszej książce posłużyliśmy się wynikami z odpowiedzi udzielonych przez 80 pracowników regionalnych oddziałów Agencji Restrukturyzacji i Modernizacji Rolnictwa. Ankieta ma charakter elektroniczny i zawieszona jest na stronie: http://www.irwirpan.waw.pl/ankieta, chroniona nazwą użytkownika: irwirpan i hasłem: ankieta. Schemat pytań w niej zawartych przedstawia niniejszy aneks. Całe badanie ankietowe realizowane było w ramach grantu Ministerstwa Nauki i Szkolnictwa Wyższego, pt. Badanie porównawcze efektów wpływu polityki rozwoju obszarów wiejskich na gospodarkę krajową i regiony w Polsce i Finlandii.

\section{ANKIETA \\ IDENTYFIKACJA PROBLEMÓW OBSZARÓW WIESKICH w REGIONACH}

1. Proszę wymienić trzy najważniejsze problemy obszarów wiejskich w województwie, które Pan(i) reprezentuje? (Uwaga: chodzi o województwo, w którym Pan(i) pracuje, mieszka, lub na temat, którego ma Pan(i) największą wiedzę. Ankieta odnosi się do wybranego przez Pana(ią) województwa, proszę podać jego nazwę).

Reprezentuję województwo:

Problem 1.

Problem 2.

Problem 3. 
2. Jakie działania należałoby podjąć, aby przeciwdziałać każdemu z tych problemów? Proszę podać jedno lub więcej działań dla każdego z problemów.

Ad.1

Ad. 2

Ad. 3

3. Które działania z poprzednich programów, tj. SPO 2004-2006 i PROW 2004-2006 okazały się: a) najłatwiejsze w sensie wykorzystania środków, a które b) najtrudniejsze, c) najbardziej skuteczne w rozwiązywaniu problemów obszarów wiejskich w Pana(i) województwie? A które d) miały charakter socjalny? Proszę o krótkie uzasadnienie.

a. najłatwiejsze działania to:

b. najtrudniejsze działania to:

c. najskuteczniejsze działania to:

d. w praktyce charakter socjalny miały działania:

Uzasadnienie:

4. Proszę wymienić główne czynniki, które w Pana(i) województwie przyczyniłyby się najbardziej do:

a. poprawy jakości życia na wsi:

b. poprawy środowiska naturalnego:

c. wzrostu konkurencyjności rolnictwa:

5. Proszę wymienić główne czynniki, które Pana(i) zdaniem najbardziej hamują rozwój przedsiębiorczości i powstawanie pozarolniczych miejsc pracy na obszarach wiejskich w Pana(i) województwie?

\section{OPINIE NA TEMAT PROGRAMU ROZWOJU OBSZARÓW WIESSKICH (PROW) 2007-2013}

6. Czy w obecnym PROW 2007-2013 są działania, które dotyczą problemów wymienionych przez Pana(ią) w pytaniu 1 niniejszej ankiety?
1. $\square$ tak
2. $\square$ nie (jeśli „nie” to przejdź do pytania 8)

7. Jeśli tak, to proszę je wymienić (lista wszystkich działań jest podana w pytaniu 13)?

Działania PROW dotyczące Problemu 1:

Działania PROW dotyczące Problemu 2:

Działania PROW dotyczące Problemu 3: 
8. Jak Pan(i) ocenia wybór działań ujętych w PROW 2007-2013 z punktu widzenia możliwości rozwiązywania problemów występujących na obszarach wiejskich w Pana(i) województwie?

a. $\square$ Nie ma tam działań, które odnosiłyby się do problemów obszarów wiejskich w moim województwie

b. $\square$ Znajduję tam tylko jedno działanie, które odnosi się do problemów obszarów wiejskich w moim województwie. Które to działanie?

c. $\square$ Jest kilka działań, które odnoszą się do problemów obszarów wiejskich w moim województwie.

d. $\square$ Wybrane działania odnoszą się do większości problemów występujących na obszarach wiejskich w moim województwie.

e. $\square$ Praktycznie dla rozwiązania wszystkich problemów obszarów wiejskich w moim województwie mogę znaleźć odpowiednie działania w PROW.

9. Które działania PROW 2007-2013 są Pana(i) zdaniem najważniejsze z punktu widzenia problemów obszarów wiejskich w Pana(i) województwie? Proszę podać 3 działania w kolejności ich ważności, począwszy od najważniejszego:

1.

2.

3.

a. Proszę podać krótkie uzasadnienie Pana(i) wyboru?

Ad. 1

Ad.2

Ad.3 
10. Jak zmienią się Pana(i) zdaniem poniższe kategorie ekonomiczne na skutek realizacji PROW 2007-2013 w Pana(i) województwie? Proszę zaznaczyć odpowiedzi „X”.

\begin{tabular}{|c|c|c|c|c|c|c|}
\hline & $\begin{array}{l}\text { Spadnie } \\
\text { znacznie }\end{array}$ & $\begin{array}{c}\text { Spadnie } \\
\text { nieznacznie }\end{array}$ & $\begin{array}{l}\text { Nie zmieni } \\
\text { się }\end{array}$ & $\begin{array}{c}\text { Wzrośnie } \\
\text { nieznacznie }\end{array}$ & $\begin{array}{l}\text { Wzrośnie } \\
\text { znacznie }\end{array}$ & Nie wiem \\
\hline a) Zatrudnienie w rolnictwie & $-2 \square$ & $-1 \square$ & $0 \square$ & $1 \square$ & $2 \square$ & $\mathrm{N} \square$ \\
\hline b) Zatrudnienie pozarolnicze & $-2 \square$ & $-1 \square$ & $0 \square$ & $1 \square$ & $2 \square$ & $\mathrm{N} \square$ \\
\hline c) Produkcja rolna & $-2 \square$ & $-1 \square$ & $0 \square$ & $1 \square$ & $2 \square$ & $\mathrm{N} \square$ \\
\hline d) Ceny produktów rolnych & $-2 \square$ & $-1 \square$ & $0 \square$ & $1 \square$ & $2 \square$ & $\mathrm{N} \square$ \\
\hline e) Ceny ziemi rolniczej & $-2 \square$ & $-1 \square$ & $0 \square$ & $1 \square$ & $2 \square$ & $\mathrm{N} \square$ \\
\hline f) Cena dzierżawy ziemi rolniczej & $-2 \square$ & $-1 \square$ & $0 \square$ & $1 \square$ & $2 \square$ & $\mathrm{N} \square$ \\
\hline g) Dochody realne ludności & $-2 \square$ & $-1 \square$ & $0 \square$ & $1 \square$ & $2 \square$ & $\mathrm{N} \square$ \\
\hline h) Ceny dóbr i usług konsumpcyjnych & $-2 \square$ & $-1 \square$ & $0 \square$ & $1 \square$ & $2 \square$ & $\mathrm{N} \square$ \\
\hline i) Rozwój gospodarczy województwa & $-2 \square$ & $-1 \square$ & $0 \square$ & $1 \square$ & $2 \square$ & $\mathrm{N} \square$ \\
\hline $\begin{array}{l}\text { j) Saldo migracji (różnica między } \\
\text { napływem a odpływem ludności } \\
\text { z województwa) }\end{array}$ & $-2 \square$ & $-1 \square$ & $0 \square$ & $1 \square$ & $2 \square$ & $\mathrm{N} \square$ \\
\hline
\end{tabular}

11. Jak zmienią się Pana(i) zdaniem poniższe czynniki na skutek realizacji PROW 2007-2013 w Pana(i) województwie? Proszę zaznaczyć odpowiedzi „X”.

\begin{tabular}{|c|c|c|c|c|c|c|}
\hline & $\mid \begin{array}{c}\text { Pogorszy się } \\
\text { znacznie }\end{array}$ & $\begin{array}{c}\text { Pogorszy się, } \\
\text { ale } \\
\text { nieznacznie }\end{array}$ & $\begin{array}{c}\mathrm{Nie} \\
\text { zmieni się }\end{array}$ & \begin{tabular}{|c} 
Poprawi się, \\
ale \\
nieznacznie
\end{tabular} & $\begin{array}{c}\text { Poprawi się } \\
\text { znacznie }\end{array}$ & $\begin{array}{l}\text { Nie mam } \\
\text { zdania }\end{array}$ \\
\hline & 1 & 2 & 3 & 4 & 5 & 6 \\
\hline a) Wiedza fachowa rolników & $-2 \square$ & $-1 \square$ & $0 \square$ & $1 \square$ & $2 \square$ & $\mathrm{N} \square$ \\
\hline $\begin{array}{l}\text { b) Struktura wiekowa pracujących } \\
\text { w gospodarstwie }\end{array}$ & $-2 \square$ & $-1 \square$ & $0 \square$ & $1 \square$ & $2 \square$ & $\mathrm{N} \square$ \\
\hline c) Struktura agrarna gospodarstw & $-2 \square$ & $-1 \square$ & $0 \square$ & $1 \square$ & $2 \square$ & $\mathrm{N} \square$ \\
\hline $\begin{array}{l}\text { d) Tempo dostosowań gospodarstw } \\
\text { rolnych do standardôw UE }\end{array}$ & $-2 \square$ & $-1 \square$ & $0 \square$ & $1 \square$ & $2 \square$ & $\mathrm{N} \square$ \\
\hline e) Stan przemysłu rolno-spożywczego & $-2 \square$ & $-1 \square$ & $0 \square$ & $1 \square$ & $2 \square$ & $\mathrm{N} \square$ \\
\hline f) Jakość produktów rolnych & $-2 \square$ & $-1 \square$ & $0 \square$ & $1 \square$ & $2 \square$ & $\mathrm{N} \square$ \\
\hline $\begin{array}{l}\text { g) Konsumpcja produktów } \\
\text { ekologicznych }\end{array}$ & $-2 \square$ & $-1 \square$ & $0 \square$ & $1 \square$ & $2 \square$ & $\mathrm{N} \square$ \\
\hline $\begin{array}{l}\text { h) Warunki dla powstawania grup } \\
\text { producenckich }\end{array}$ & $-2 \square$ & $-1 \square$ & $0 \square$ & $1 \square$ & $2 \square$ & $\mathrm{N} \square$ \\
\hline $\begin{array}{l}\text { i) Stosunek rolników do środowiska } \\
\text { naturalnego }\end{array}$ & $-2 \square$ & $-1 \square$ & $0 \square$ & $1 \square$ & $2 \square$ & $\mathrm{N} \square$ \\
\hline j) Bioróżnorodność & $-2 \square$ & $-1 \square$ & $0 \square$ & $1 \square$ & $2 \square$ & $\mathrm{N} \square$ \\
\hline $\begin{array}{l}\text { k) Wartość przyrodnicza obszarów } \\
\text { wiejskich }\end{array}$ & $-2 \square$ & $-1 \square$ & $0 \square$ & $1 \square$ & $2 \square$ & $\mathrm{N} \square$ \\
\hline $\begin{array}{l}\text { I) Wielkość obszaru zajmowanego } \\
\text { przez lasy }\end{array}$ & $-2 \square$ & $-1 \square$ & $0 \square$ & $1 \square$ & $2 \square$ & $\mathrm{N} \square$ \\
\hline m) Liczba pozarolniczych ofert pracy & $-2 \square$ & $\begin{array}{l}-1 \square \\
\square\end{array}$ & $0 \square$ & $1 \square$ & $2 \square$ & $\mathrm{N} \square$ \\
\hline
\end{tabular}




\begin{tabular}{l|c|c|c|c|c|c}
\hline & 1 & 2 & 3 & 4 & 5 & 6 \\
\hline n) Liczba mikroprzedsiębiorstw & $-2 \square$ & $-1 \square$ & $0 \square$ & $1 \square$ & $2 \square$ & $\mathrm{N} \square$ \\
\hline 0) Infrastruktura techniczna wsi & $-2 \square$ & $-1 \square$ & $0 \square$ & $1 \square$ & $2 \square$ & $\mathrm{N} \square$ \\
\hline p) Warunki dla rozwoju \\
przedsiębiorczości
\end{tabular}

12. Jakich zmian oczekuje Pan(i) na skutek realizacji PROW 2007-2013 w Pana(i) województwie w odniesieniu do poniższych priorytetów?

\begin{tabular}{|c|c|c|c|c|c|c|}
\hline & $\begin{array}{c}\text { Pogorszy sie } \\
\text { znacznie }\end{array}$ & \begin{tabular}{|c} 
Pogorszy się, \\
ale \\
nieznacznie
\end{tabular} & $\begin{array}{c}\mathrm{Nie} \\
\text { zmieni się }\end{array}$ & $\begin{array}{c}\text { Poprawi się, } \\
\text { ale } \\
\text { nieznacznie }\end{array}$ & $\begin{array}{l}\text { Poprawi się } \\
\text { znacznie }\end{array}$ & $\begin{array}{c}\text { Nie mam } \\
\text { zdania }\end{array}$ \\
\hline a) Konkurencyjność sektora rolnego & $-2 \square$ & $-1 \square$ & $0 \square$ & $1 \square$ & $2 \square$ & $\mathrm{N} \square$ \\
\hline b) Stan środowiska naturalnego & $-2 \square$ & $-1 \square$ & $0 \square$ & $1 \square$ & $2 \square$ & $\mathrm{N} \square$ \\
\hline $\begin{array}{l}\text { c) Jakość życia na obszarach } \\
\text { wiejskich }\end{array}$ & $-2 \square$ & $-1 \square$ & $0 \square$ & $1 \square$ & $2 \square$ & $\mathrm{N} \square$ \\
\hline
\end{tabular}

KOMENTARZ:

13. Proszę zaznaczyć w przypadku podjęcia następujących działań, jaki będzie ich wpływ na poniższe wskaźniki ekonomiczne: pozytywny (P), negatywny (N) czy neutralny $(0)$ ?

\begin{tabular}{|c|c|c|c|c|c|}
\hline $\begin{array}{c}\text { Działania } \\
\text { (nazwy podane w skrócie): }\end{array}$ & $\begin{array}{c}\text { Produktywność } \\
\text { rolnictwa }\end{array}$ & $\begin{array}{l}\text { Jakość } \\
\text { produktów } \\
\text { rolnych }\end{array}$ & $\begin{array}{l}\text { Ochrona } \\
\text { środowiska }\end{array}$ & $\begin{array}{l}\text { Pozarolnicze } \\
\text { miejsca pracy }\end{array}$ & $\begin{array}{l}\text { Jakość życia } \\
\text { na wsi }\end{array}$ \\
\hline 1 & 2 & 3 & 4 & 5 & 6 \\
\hline $\begin{array}{l}\text { Szkolenia zawodowe dla rolników } \\
\text { i leśników }\end{array}$ & $\mathrm{P} \square \mathrm{N} \square 0 \square$ & ] $\mathrm{N} \square 0$ & $\square \mathrm{N} \square 0$ & $\square \mathrm{N} \square 0 \square$ & $\mathrm{P} \square \square 0 \square$ \\
\hline Ułatwienie startu młodym rolnikom & $\mathrm{P} \square \mathrm{N} \square 0 \square \mathrm{F}$ & $\square \mathrm{N} \square 0 \square$ & $\square \mathrm{N} \square 0[$ & $\mathrm{P} \square \mathrm{N} \square 0 \square$ & $\mathrm{P \square} \square \mathrm{N \square \square}$ \\
\hline Renty strukturalne & $\mathrm{P} \square \mathrm{N} \square 0 \square \mathrm{F}$ & $\square \mathrm{N} \square 0 \square$ & $\square \mathrm{N} \square 0 \square$ & $P \square \mathrm{N} \square 0 \square$ & $\mathrm{P \square} \square \square 0 \square$ \\
\hline $\begin{array}{l}\text { Korzystanie z usług doradczych } \\
\text { przez rolników i leśników }\end{array}$ & $\mathrm{P} \square \mathrm{N} \square 0 \square$ & L & & & 난 \\
\hline $\begin{array}{l}\text { Modernizacja gospodarstw } \\
\text { rolnych }\end{array}$ & $\mathrm{P} \square \mathrm{N} \square 0 \square$ & $\mathrm{N} \square$ & IVL & IVL & $N \square 0 \square$ \\
\hline $\begin{array}{l}\text { Zwiększanie wartości dodanej, } \\
\text { czyli pomoc dla przetwórstwa } \\
\end{array}$ & $\mathrm{P} \square \mathrm{N} \square$ & & & & 0 L \\
\hline $\begin{array}{l}\text { Poprawa infrastruktury związanej } \\
\text { z dostosowaniem do UE }\end{array}$ & $\mathrm{P} \square \mathrm{N}$ & & & & $0 \sqcup$ \\
\hline $\begin{array}{l}\text { Uczestnictwo rolników } \\
\text { w systemach jakości }\end{array}$ & $\mathrm{P} \square \mathrm{N}[$ & $N$ & NL & OL & , \\
\hline $\begin{array}{l}\text { Działania informacyjne } \\
\text { i promocyjne dot. systemów } \\
\text { jakości }\end{array}$ & & & & & \\
\hline
\end{tabular}




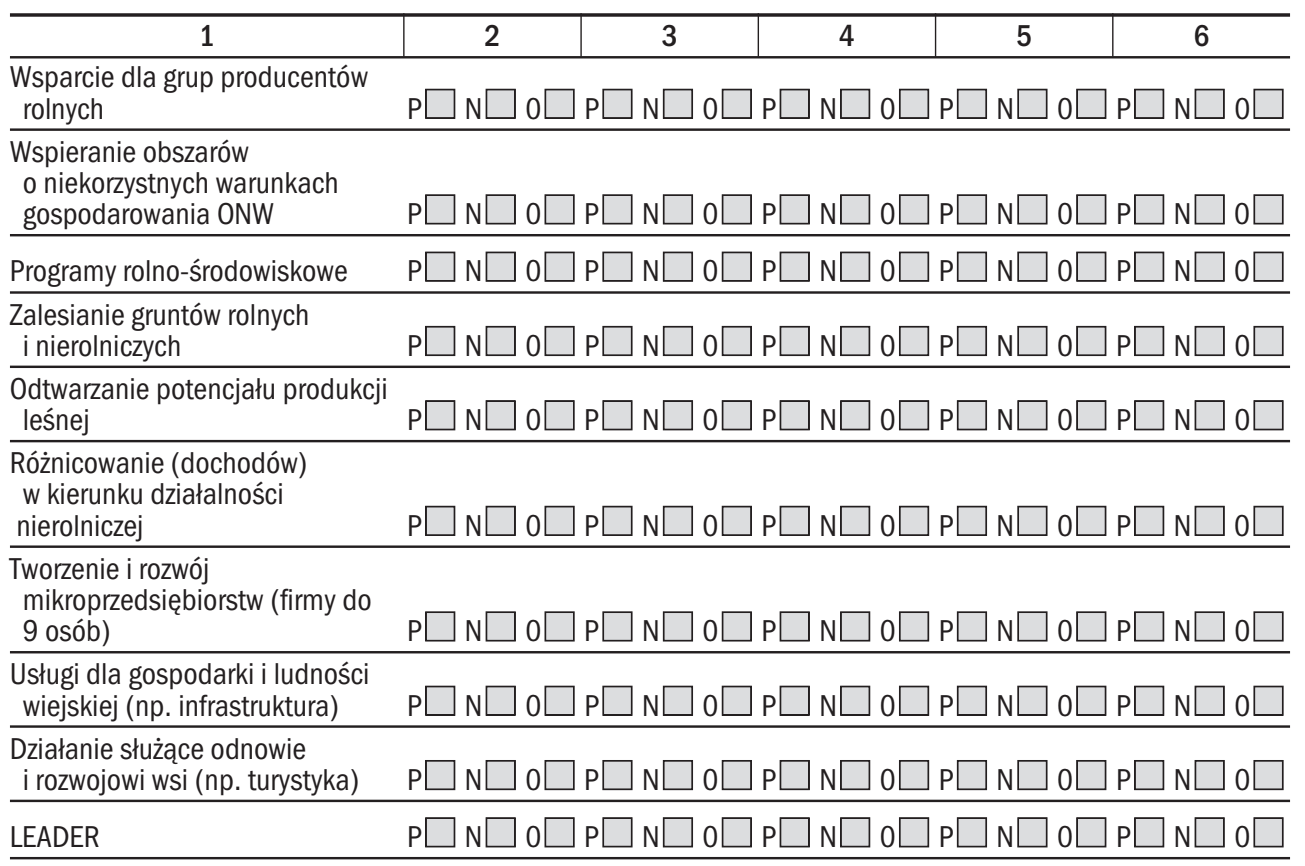

14. Proszę określić najbardziej prawdopodobny według Pana(i) stopień korzyści z PROW 2007-2013 dla każdej grupy poniższych beneficjentów:

\begin{tabular}{l|c|c|c|c|c}
\hline & $\begin{array}{c}\text { Prawdopodob- } \\
\text { nie stracą }\end{array}$ & $\begin{array}{c}\text { Prawdopodob- } \\
\text { nie nic nie } \\
\text { zyskają }\end{array}$ & $\begin{array}{c}\text { Prawdopodob- } \\
\text { nie trochę } \\
\text { zyskają }\end{array}$ & $\begin{array}{c}\text { Z pewnością } \\
\text { sporo zyskają }\end{array}$ & $\begin{array}{c}\text { Trudno } \\
\text { powiedzieć }\end{array}$ \\
\hline \multicolumn{1}{c}{1} & 2 & 3 & 4 & 5 & 6 \\
\hline a) Rolnicy & $-1 \square$ & $0 \square$ & $1 \square$ & $2 \square$ & $\square$ \\
\hline b) Dzieci rolników & $-1 \square$ & $0 \square$ & $1 \square$ & $2 \square$ & $\square$ \\
\hline c) Właściciele lasów & $-1 \square$ & $0 \square$ & $1 \square$ & $2 \square$ & $\square$ \\
\hline $\begin{array}{l}\text { d) Mikroprzedsiębiorstwa } \\
\text { (do 9 osób) } \\
\text { Jakiego sektora? }\end{array}$ & $-1 \square$ & $0 \square$ & $1 \square$ & $2 \square$ & $\square$ \\
\hline $\begin{array}{l}\text { e) Średnie i duże } \\
\text { przedsiębiorstwa } \\
\text { Jakiego sektora? }\end{array}$ & $-1 \square$ & $0 \square$ & $1 \square$ & $2 \square$ & $\square$ \\
\hline $\begin{array}{l}\text { f) Zakłady przetwórstwa } \\
\text { spożywczego }\end{array}$ & $-1 \square$ & $0 \square$ & $1 \square$ & $2 \square$ & $\square$ \\
\hline g) Grupy producentów & $-1 \square$ & $0 \square$ & $1 \square$ & $2 \square$ & $\square$ \\
\hline h) Gminy, powiaty & $-1 \square$ & $0 \square$ & $1 \square$ & $2 \square$ & $\square$ \\
\hline i) Organizacje pozarządowe & $-1 \square$ & $0 \square$ & $1 \square$ & $2 \square$ & $\square$ \\
\hline
\end{tabular}




\begin{tabular}{l|cccccc}
\hline \multicolumn{1}{c}{1} & $\mathbf{1}$ & 3 & 4 & 5 & 6 \\
\hline j) Przedsiębiorcy lokalni & $-1 \square$ & $0 \square$ & $1 \square$ & $2 \square$ & $\square$ \\
\hline k) Lokalne grupy działania & $-1 \square$ & $0 \square$ & $1 \square$ & $2 \square$ & $\square$ \\
\hline $\begin{array}{l}\text { I) Publiczne instytucje } \\
\text { edukacyjne }\end{array}$ & $-1 \square$ & $0 \square$ & $1 \square$ & $2 \square$ & $\square$ \\
\hline $\begin{array}{l}\text { m) Prywatne instytucje } \\
\text { edukacyjne }\end{array}$ & $-1 \square$ & $0 \square$ & $1 \square$ & $2 \square$ & $\square$ \\
\hline n) Konsumenci & $-1 \square$ & $0 \square$ & $1 \square$ & $2 \square$ & $\square$ \\
\hline o) Inni, proszę podać & $-1 \square$ & $0 \square$ & $1 \square$ & $2 \square$ & $\square$ \\
\hline
\end{tabular}

15. W jakiej proporcji Pana(i) zdaniem powinny być spożytkowane fundusze PROW 2007-2013 w Pana(i) województwie, w podziale na poniższe kategorie, biorąc pod uwagę potrzeby obszarów wiejskich:

Fundusze na działania dotyczące konkurencyjności rolnictwa:

$\square$ do $20 \%$, $\square$ 20\%-50\% $\square 50 \% \square$ więcej niż $50 \%$ funduszy

Fundusze na działania dotyczące środowiska naturalnego:

$\square$ do 20\%, $\square$ 20\%-50\% $\square 50 \% \square$ więcej niż 50\% funduszy

Fundusze na działania dotyczące jakości życia na obszarach wiejskich:

$\square$ do 20\%, $\square$ 20\%-50\% $\square 50 \% \square$ więcej niż 50\% funduszy

$\square$ Fundusze na konkurencyjność rolnictwa, środowisko i jakość życia powinny rozłożyć się mniej więcej równo

16. Jak Pan(i) sądzi, czy byłoby to korzystne dla ludności wiejskiej w Pana(i) województwie, gdyby część pomocy z PROW przeznaczono na wsparcie małych miasteczek, zlokalizowanych blisko obszarów wiejskich?

$\square$ Tak, byłoby to korzystne $\square$ Nie, raczej nie byłoby to korzystne $\square$ Nie wiem

Jeśli tak, to w przypadku których działań miałoby to sens:

$\square$ Tworzenie mikroprzedsiębiorstw działających na rzecz ludności wiejskich

$\square$ Różnicowanie działalności w kierunku tworzenia pozarolniczych miejsc pracy

$\square$ Inne, jakie?

\section{INFORMACJE DODATKOWE}

17. Proszę powiedzieć, na ile dobrze zna Pan(i) dokument PROW 2007-2013

$\square$ bardzo dobrze, uczestniczyłem(am) w pracach nad PROW $\square$ dość dobrze

$\square$ słabo

$\square$ tylko z nazwy 
18. Skąd Pan(i) dowiedział(a) się szczegółów o PROW 2007-2013?

$\square$ bezpośrednio z Ministerstwa lub innej instytucji rządowej

$\square$ bezpośrednio od mojego przełożonego

$\square$ ze szkoleń

$\square$ z konsultacji społecznych, konferencji, innych zgromadzeń publicznych

$\square$ z internetu

$\square$ za pośrednictwem innych mediów (gazety, telewizja etc.)

$\square$ inne, jakie?

19. Jaki byłby Pana(i) zdaniem najbardziej pożądany kierunek zmian we Wspólnej Polityce Rolnej UE w następnym okresie programowania 2014-2020?

\section{KOMENTARZ:}

20. Jaką instytucję lub grupę społeczną Pan(i) reprezentuje?
Środowisko akademickie/naukowe
Środowisko studenckie
Urząd wojewódzki
Regionalny oddział Agencji Restrukturyzacji i Modernizacji Rolnictwa
Regionalny oddział Agencji Rynku Rolnego
Urząd marszałkowski
Rolnicze związki zawodowe, branżowe i inne
Izby rolnicze
Ośrodek Doradztwa Rolniczego, Centrum Doradztwa Rolniczego itp.
Lokalna grupa działania
Grupa producentów
Prasa rolnicza/wiejska/lokalna
Organizacja pozarządowa
Środowisko pracodawców
$\square$ Mieszkaniec wsi
Inne, jakie? 


\section{Aneksy do rozdziału 3}

\section{ANEKS 3.1. STWORZENIE BAZY DANYCH DLA MODELU REGPOL}

Budowa bazy danych była zdecydowanie najtrudniejszym elementem potrzebnym do uruchomienia modelu RegPOL. Wymagała skonstruowania 16 wojewódzkich tablic przepływów międzygałęziowych, a następnie 16 regionalnych macierzy SAM, czego - o ile autorce wiadomo - nie dokonano wcześniej w Polsce. Chociaż w Finlandii tablice te są publikowane przez Główny Urząd Statystyczny (Tilastokeskus) dla 20 regionów NUTS 3, to jest to raczej wyjątek niż reguła w krajach UE. Dlatego, aby uruchomić model RegPOL, trzeba było samemu stworzyć dla niego bazę danych. Proces ten opisano szczegółowo w niniejszym aneksie. Same tablice IO i SAM będą częścią osobnej publikacji.

\section{Regionalne tablice przepływów międzygałęziowych}

W literaturze przytacza się wiele różnych metod konstruowania regionalnych tablic przepływów międzygałęziowych. Generalnie można je podzielić na trzy kategorie: ankietowe, nieankietowe (oparte na wyliczeniach) i hybrydowe (łączące różne podejścia). Tablice oparte na ankietach uważa się za najdokładniejsze, ale użyteczność tej metody ograniczają czynniki czasu i kosztów, gdyż zebranie niezbędnych danych pierwotnych wymaga przebadania ogromnej liczby przedsiębiorstw. W praktyce przeważnie tylko krajowe urzędy statystyczne dysponują odpowiednim potencjałem, by skorzystać z tej metody, a niewiele spośród nich publikuje uzyskane tą drogą wyniki (do wyjątków należą Finlandia ${ }^{66}$, Kanada i Stany Zjednoczone). Konstruowanie tablic IO na podstawie ankiet omówione jest na przykład w pracach T. Louhela [2006], Y. Ishikawa i T. Miyagi [2004], Statistics New Zeland [2003], Statistics Finland [2000].

Metody pozaankietowe polegają na opracowaniu tablic regionalnych na podstawie dezagregacji tablicy krajowej i obejmują następujące podejścia: podejście oparte na współczynniku lokalizacji (LQ, location quantients, zob. [Flegg, Webber i Elliott 1995, Flegg i Webber 1997, 2000, Tohmo 2004]), podejście iteracyjne (zob. [Ishikawa i Miyagi 2004]) i programowanie matematyczne [Canning i Wang 2005]. Ich bardziej szczegółowe, przekrojowe omówienie można znaleźć między innymi w pracach W. Morrisona i P. Smitha [1974] oraz J. Rounda [1978]. Większość metod w tej kategorii do konstruowania regionalnych tablic IO wykorzystuje symetryczną krajową tablicę IO. Jednak coraz popularniejsze staje się konstruowanie regionalnych tablic IO

${ }^{66}$ http://www.stat.fi/til/apt/kas_en.html 
przez regionalizację krajowych tablic podaży i zużycia, zob. [Piispala 2000, Louhela i Koutaniemi 2006]. Wszystkie podejścia typu polegające na przechodzeniu od poziomu wyższego do niższego (top-down) mają ten mankament, że z reguły nie doceniają znaczenia międzyregionalnych przepływów handlowych i zakładają, że technologia produkcji w wymiarze regionalnym i krajowym jest taka sama (na ten temat pisali m.in. S. Brand [1997] oraz [R. Harris i A. Liu 1998]).

Podejście hybrydowe polega na połączeniu metod ankietowych i nieankietowych, tak by jak najlepiej wykorzystać zalety każdej z nich. Pochłania ono więcej wysiłku niż metody nieankietowe, bo wymaga pewnych dodatkowych danych, które uzyskuje się za pośrednictwem ankiet. W związku z tym, że metody nieankietowe są dosyć ostro krytykowane, a metody czysto ankietowe wykraczają poza możliwości badaczy, większość niezależnych naukowców stosuje podejście hybrydowe, podobnie jak to ma miejsce w niniejszej pracy.

Najtrudniejszym elementem w procesie tworzenia regionalnych tablic IO jest oszacowanie międzyregionalnych przepływów handlowych. Zazwyczaj ani centralne, ani regionalne urzędy statystyczne nie dysponują pełnymi danymi na temat międzysektorowych i zbiorczych przepływów między regionami, potrzebnymi do stworzenia regionalnych tablic IO. W celu wypełnienia tej luki badacze muszą szukać różnych sposobów pozyskania danych lub opracowywać nieankietowe metody szacowania regionalnych i międzyregionalnych współczynników technicznych i handlowych. tabela A.3.1 przedstawia skrótowy przegląd opracowań naukowych opartych na każdym z omawianych wyżej podejść.

Tabela A.3.1. Przegląd metod szacowania międzyregionalnych przepływów handlowych

\begin{tabular}{|c|c|}
\hline Metody szacowania & Literatura i przykładowe modele \\
\hline & Metody bezpośrednie \\
\hline $\begin{array}{l}\text { Bezpośrednie ankietowanie producentów } \\
\text { i konsumentów }\end{array}$ & $\begin{array}{l}\text { [Miernyk, Shellhammer, Coccari i in. 1970], [Eding i Nijmijer } \\
\text { 1998], [Statistics Finland 1999] }\end{array}$ \\
\hline $\begin{array}{l}\text { Szacowanie oparte na rejestrze } \\
\text { przewozów towarowych }\end{array}$ & $\begin{array}{c}\text { [Statistics Finland 1999], [Hewings i Hulu 1993], MRIO-HERP } \\
\text { [Polenske 1980], [Kazumi 2000], INTERTIO [Llano 2000] }\end{array}$ \\
\hline $\begin{array}{l}\text { Szacowanie oparte na międzynarodowych } \\
\text { przepływach handlowych }\end{array}$ & model EU-IRIO [Oosterhaven i van der Linden 1995] \\
\hline \multirow{2}{*}{$\begin{array}{l}\text { Tablice fizycznych przepływów } \\
\text { międzygałęziowych }\end{array}$} & PIOT (Physical Input-Output Tables) [EUROSTAT 2001] \\
\hline & Metody pośrednie \\
\hline Modele grawitacji & TIM [Funck i Rembold 1975], [Louhela 2006] \\
\hline Metoda entropii & [Batten 1983], [Robinson, Cattaneo i El-Said 2001] \\
\hline Podejście zwane pool approach Leontiefa & $\begin{array}{l}\text { [Leontief, Carter i Petri 1977], INTEREG [Casini Benvenuti, } \\
\text { Martellato i Raffaelli 1995] }\end{array}$ \\
\hline Programowanie matematyczne & [Canning i Wang 2005] \\
\hline
\end{tabular}

Źródło: Na podstawie [Llano 2000] i innych opracowań powyżej wymienionych. 
Niestety, niewiele jest przykładów prób weryfikacji na podstawie empirycznych analiz porównawczych, które z tych metod generują najlepsze wyniki. Taką próbę podjął jednak T. Louhela [2006], który porównał międzyregionalne przepływy handlowe oszacowane przy użyciu trzech różnych metod: metody ankietowej, przewozów towarowych i modelu grawitacji, dla fińskich danych statystycznych za rok 1996. Okazało się, że wyniki uzyskane wszystkimi trzeba metodami były zbliżone, jeśli chodzi o kierunki przepływów, ale różniły się istotnie co do szacunku ich wartości. W porównaniu z metodą ankietową (uznaną za najdokładniejszą i dlatego potraktowaną jako punkt odniesienia), model przewozów towarowych zaniżał obroty handlowe między małymi regionami, natomiast wartości wygenerowane przez model grawitacji generalnie znacznie odbiegały od tych uzyskanych przy użyciu pozostałych dwóch metod.

Inne ciekawe porównanie przedstawił T. Tohmo [2004], który zestawił współczynniki i mnożniki przepływów międzygałęziowych opublikowane przez fiński Urząd Statystyczny [Statistics Finland 2000] dla jednego z regionów Finlandii, z wielkościami wyliczonymi przy użyciu różnych metod opartych na współczynnikach lokalizacji, takich jak proste współczynniki lokalizacji (Simple Location Quotients, SLQ), przekrojowe współczynniki lokalizacji (Cross-Industry Location Quotients, CILQ) i współczynniki lokalizacji Flegga (Flegg Location Quotients, FLQ). W rezultacie stwierdził, że metody SLQ i CILQ generują nadmiernie wysokie mnożniki produkcji regionalnej, ponieważ nie uwzględniają różnic $\mathrm{w}$ rozmiarach regionów, a przez to zaniżają skłonność do importu z innych regionów. Natomiast metoda FLQ opiera się na formule skorygowanej tak, by obejmowała względne rozmiary regionów, eliminując tendencje do wyolbrzymiania regionalnych mnożników w wypadku niewielkich, otwartych gospodarek, takich jak region będący przedmiotem analizy. Ponadto [Tohmo 2004] przytacza w swoim artykule inne interesujące porównania między różnego typu współczynnikami lokalizacji, w tym m.in. z opracowań P. Smitha i W. Morrisona [1974], F. Harrigana, J. McGilvraya i I. McNicolla [1980], A. Flegga i C. Webera [1996] i R. Harrisa i A. Liu [1998]. Autor rozszerzył też ostatnio swoje rozważania na wszystkie 20 regionów NUTS 3 w Finlandii, potwierdzając, że metoda FLQ i AFLQ przynosi najlepsze rezultaty [Flegg i Tohmo 2008].

Każde z przedstawionych wyżej podejść do regionalizacji tablic IO ma swoje wady i zalety, dlatego wybór metody zależy od dostępności danych regionalnych i umiejętności badacza. Mając to wszystko na uwadze, do konstruowania 16 regionalnych tablic przepływów gałęziowych na potrzeby modelu RegPOL wybrano metodę hybrydową, opierając się na: rozszerzonych współczynnikach lokalizacji Flegga (Augmented Flegg Location Quotients) [Flegg i Webber 2000], wszystkich 
dostępnych danych na temat rachunków regionalnych w ujęciu wojewódzkim (zamówionych z GUS) i współczynnikach wyliczonych z krajowej tablicy przepływów międzygałęziowych [GUS 2004]. Proces tworzenia tablic przebiegał następująco:

KroK 1: Wybór I DOSTOSOWANIE KRAJOWEJ TABLICY IO. W pierwszej kolejności należało wybrać odpowiednią krajową tablicę przepływów międzygałęziowych. Spośród dwóch publikacji prezentujących tablice IO wydane w 2004 (w cenach bazowych i w cenach producenta) wybrano Bilans przeptywów międzygałęziowych w bieżacych cenach bazowych w 2000 r., a stamtąd pozycję zatytułowaną „Tablica przepływów międzygałęziowych w cenach bazowych dla produkcji krajowej w roku 2000”, analogicznie do fińskiej tablicy IO wykorzystanej w modelu RegFIN. Następnie zmieniono rząd wartości z tysięcy PLN na miliony, stąd wszystkie wartości w modelu są wyrażone w milionach PLN. Ponieważ tablica ta przedstawia dane w podziale na 55 kategorii produktów zgodnych z klasyfikacją PKWiU, trzeba było ją przekształcić na układ sekcji Polskiej Klasyfikacji Działalności (PKD), gdyż większość statystyk wojewódzkich niezbędnych do konstruowania regionalnych tablic IO jest niedostępna w tak szczegółowym podziale. Dlatego pierwotne 55 kategorii produktów zagregowano do 15 sektorów odpowiadających sekcjom klasyfikacji PKD (sekcje od A do $\mathrm{N}$ oraz zagregowane w jedną sekcję $\mathrm{O}, \mathrm{P}, \mathrm{Q}$ ), dla których istniały dane regionalne. Kody klasyfikacji i agregacji w ujęciu pierwotnym i zagregowanym przedstawia tabela A.3.2. Tak więc wszelkie dalsze wyliczenia na podstawie krajowej tablicy przepływów międzygałęziowych opierały się na tablicy przekształconej w powyższy sposób, z 15 sektorami i danymi reprezentującymi produkcję krajową wyrażoną w cenach bazowych w milionach PLN.

Tabela A.3.2. Lista regionów oraz sektorów występujących w modelu, przed i po agregacji

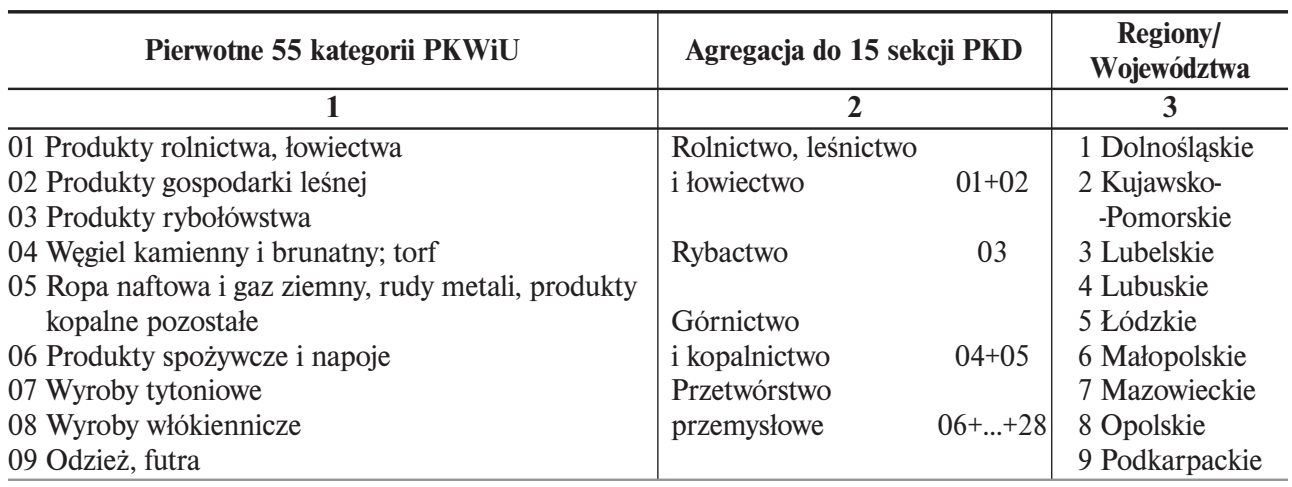




\begin{tabular}{l}
\hline 1 \\
10 Skóry wyprawione i wyroby ze skór wyprawionych \\
11 Drewno i wyroby z drewna \\
12 Papier i wyroby z papieru \\
13 Druki i zapisane nośniki informacji \\
14 Koks, produkty rafinacji ropy naftowej \\
15 Produkty chemiczne \\
16 Wyroby z gumy i tworzyw sztucznych \\
17 Wyroby z pozostałych surowców niemetalicznych \\
18 Metale
\end{tabular}

19 Wyroby metalowe

20 Maszyny i urządzenia

21 Maszyny biurowe i komputery

22 Maszyny elektryczne, urządzenia techniczne i aparaty

23 Sprzęt i urządzenia radiowe, telewizyjne i telekomunikacyjne

24 Aparatura oraz instrumenty medyczne i optyczne

25 Pojazdy mechaniczne

26 Sprzęt transportowy pozostały

27 Meble, produkty pozostałe

28 Usługi odzyskiwania materiałów z odpadów

29 Energia elektryczna, gaz, para wodna i gorąca woda

30 Woda zimna i usługi w zakresie jej rozprowadzania

31 Roboty budowlane

32 Usługi w zakresie handlu pojazdami mechanicznymi i ich naprawy

33 Usługi w zakresie handlu hurtowego i komisowego

34 Usługi w zakresie handlu detalicznego

35 Usługi hoteli i restauracji

36 Usługi transportu lądowego i rurociągowego

37 Usługi transportu wodnego i lotniczego

38 Usługi agencji turystycznych

39 Usługi pocztowe i telekomunikacyjne

40 Usługi pośrednictwa finansowego

41 Usługi ubezpieczeniowe

42 Usługi pomocnicze w stosunku do pośrednictwa finansowego

43 Usługi związane z nieruchomościami

44 Usługi wynajmu maszyn

45 Usługi informatyczne

46 Usługi badawczo-rozwojowe

47 Usługi związane z prowadzeniem działalności gospodarczej pozostałe

48 Usługi w zakresie administracji publicznej

49 Usługi w zakresie edukacji

50 Usługi w zakresie ochrony zdrowia

51 Usługi w zakresie gospodarki ściekami oraz wywozu i zagospodarowywania śmieci

52 Usługi świadczone przez organizacje członkowskie 53 Usługi związane z rekreacją, kulturą i sportem

54 Usługi pozostałe

55 Usługi świadczone w gospodarstwach domowych

\begin{tabular}{|c|c|c|}
\hline 2 & & 3 \\
\hline Wytwarzanie & & 10 Podlaskie \\
\hline i zaopatrywanie & & 11 Pomorskie \\
\hline w energię elektryczną, & & 12 Śląskie \\
\hline gaz i wodę & $29+30$ & 13 Świętokrzyskie \\
\hline Budownictwo & 31 & -Mazurskie \\
\hline & & 15 Wielkopolskie \\
\hline $\begin{array}{l}\text { Handel hurtowy } \\
\text { i detaliczny; naprawa }\end{array}$ & & $\begin{array}{l}16 \text { Zachodnio- } \\
\text { pomorskie }\end{array}$ \\
\hline
\end{tabular}

pojazdów samochodowych, motocykli i artykułów użytku osobistego

i domowego

Hotele i restauracje

Transport, gospodarka

magazynowa

i łączność

$36+\ldots+39$

Pośrednictwo

finansowe

$$
40+\ldots+42
$$

Obsługa nieruchomości,

wynajem i usługi związane

$\mathrm{z}$ prowadzeniem

działalności

gospodarczej

$43+\ldots+47$

Administracja publiczna

i obrona narodowa;

obowiązkowe

zabezpieczenia społeczne 48

Edukacja

49

Opieka zdrowotna

i pomoc społeczna

Działalność usługowa

komunalna, społeczna

$\mathrm{i}$ indywidualna,

pozostała

$51+\ldots+55$

Źródło: Opracowanie własne na podstawie [GUS 2007b], [GUS 2008b]. 
KROK 2: WYBÓR FORMUŁY WSPÓŁCZYNNIKÓW LOKALIZACJI UŻYTEJ DO BUDOWY REGIONALNYCH MACIERZY TRANSAKCJI ZUŻYCIA POŚREDNIEGO I OSZACOWANIA IMPORTU KRAJOWEGO. Jedną z metod, która umożliwia dekompozycję krajowej tablicy IO (z góry do dołu) i jednocześnie pozwala na wyliczenie importu między regionami, jest koncepcja tzw. współczynników lokalizacji (location quotients, LQ). Koncepcja ta stała się przedmiotem długiej dyskusji teoretycznej na łamach publikacji naukowych, w wyniku której powstawały kolejne wersje tych współczynników, udoskonalające tę metodę obliczeniową o coraz to nowe aspekty. Tak więc kolejno były to: proste współczynniki lokalizacji (SLQ), które sugerowały, że współczynniki handlu między regionami można oszacować, używając w przybliżeniu wagi wyliczone jako udział regionalnego zatrudnienia do krajowego zatrudnienia dla każdego regionu. Następnie przekrojowe współczynniki lokalizacji (CILQ) uwzględniały dodatkowo strukturę sektorową, zalecając obliczenie wag na podstawie nie tylko porównania zatrudnienia regionalnego z krajowym, lecz także między sektorami. Kolejna wersja, współczynnik lokalizacji Flegga (FLQ) wprowadził do formuły dodatkowy parametr lambda $(\lambda)$, który kontroluje poprzedni współczynnik o nowy aspekt. Uwzględnia mianowicie to, że regiony różnią się wielkością (np. wartość handlu dużych regionów jest większa niż mniejszych regionów). Na końcu powstała formuła na rozszerzony współczynnik lokalizacji Flegga (AFLQ), która zawiera elementy wszystkich poprzednich oraz posiada dodatkową formułę, która kontroluje specjalizację regionów. Taką wersją do wyliczenia współczynników handlu w rozdrobnieniu krajowej tablicy IO dla Polski posłużyliśmy się w tej książce równanie 3.3 [Flegg i Webber 2000, s. 566].

Równanie 3.3. Ulepszona wersja współczynnika lokalizacji Flegga

$$
A F L Q_{i j} \equiv C I L Q_{i j} \times \lambda \times \log _{2}\left(1+S L Q_{j}\right)
$$

gdzie:

i oznacza sektor sprzedający, j oznacza sektor kupujący, CILQ wyrażony jest formułą:

$C I L Q_{i j} \equiv \frac{S L Q_{i}}{S L Q_{j}} \equiv \frac{R E_{i} / N E_{i}}{R E_{j} / N E_{j}}$,

gdzie $\mathrm{RE}_{\mathrm{i}}$ jest regionalnym zatrudnieniem w sektorze sprzedającym, $\mathrm{NE}_{\mathrm{i}}$ jest krajowym zatrudnieniem w sektorze sprzedającym, $R_{\mathrm{j}}$ jest regionalnym zatrudnieniem w sektorze kupującym, zaś $\mathrm{NE}_{\mathrm{j}}$ jest krajowym zatrudnieniem w sektorze kupującym. Ponadto $\lambda \equiv\left[\log _{2}(1+T R E / T N E)\right]^{\delta}$, gdzie TRE oznacza całkowite zatrudnienie w regionie (we wszystkich sektorach) a TNE, całkowite zatrudnienie 
W gospodarce; delta jest wartością dodatnią, ale mniejszą od jedności $(0<\delta<1)$ i lambda z gwiazdką też jest wartością dodatnią najwyżej równą $1(0<\lambda \leq 1)$. Na końcu $S L Q_{j} \equiv \frac{R E_{j} / T R E_{i}}{N E_{j} / T N E_{j}}$.

Przy praktycznym wyliczeniu tych współczynników pojawiło się kilka kwestii. Po pierwsze, zamiast zatrudnienia użyliśmy wartości dodanej brutto dla kraju i województw, gdyż dawało to większą gwarancję spójności danych - suma wartości dodanych z rachunków regionalnych, jakie uzyskaliśmy z GUS, równała się wartości dodanej z krajowej tablicy IO, a biorąc wielkość zatrudnienia, która nie występuje w tablicach, nie można było sprawdzić spójności tego wskaźnika jako wagi. Ponadto dane o zatrudnieniu czy o pracujących są problematyczne na poziomie sekcji PKD, gdyż w niektórych przypadkach są zabezpieczone ustawą o ochronie danych i podawane wielkości wypaczają rzeczywistość.

Dodatkowo, jak widać w powyższych wzorach, pojawia się w nich parametr $\delta$, o którym niewiele wiadomo, oprócz tego, z jakiego jest przedziału, i że determinuje zależność wielkości handlu od wielkości gospodarki regionalnej. W literaturze niewiele można znaleźć sugestii na jego temat. Na przykład T. Tohmo [2004] podaje swoje estymacje dla jednego regionu Finlandii (Keski-Pohjanmaa), dla którego delta wyniosła 0,3. W niniejszej książce, w celu wyliczenia tej wartości, posłużyliśmy się eksperymentami na próbie wszystkich regionów Finlandii (dla których istniały regionalne IO), żeby określić wyjściowe wartości dla wyliczenia parametru delta (na zasadzie podobieństw regionalnych pod względem wielkości w Finlandii i Polsce). Następnie parametr ten ulegał zmianom w kolejnych iteracjach w procesie oddolnego budowania regionalnych tablic IO, opierając się na regionalnych rachunkach dla województw.

KroK 3: Powiązanie RaCHUNKów REgIONALNYCH ZE WSPÓlCZYNNIKAMI LOKALIZACJI FLEgGa W CELU OSZACOWANIA IMPORTU KRAJOWEgo. Dojście do ostatecznych wartości współczynników lokalizacji odbywało się przez kolejne iteracje, prowadzące do uzyskania (przy zachowaniu wszystkich założeń co do wartości delta i lambda) pozytywnej zależności między deltą a rozmiarem regionów, co sugeruje literatura (nie podając dokładnie, jaka to zależność) i nie pozwalając importowi spaść poniżej zera (import, o czym piszemy dalej, jest wartością rezydualną). Rozmiar regionów ważony jest udziałem wartości dodanej brutto każdego z nich, w relacji do wartości dodanej brutto całej gospodarki. Budowanie tablicy dla każdego regionu polegało zatem na budowaniu od góry macierzy popytu pośredniego na podstawie współczynników AFLQ dla transakcji między sek- 
torami i przemnożeniu tych współczynników przez wartości krajowej macierzy transakcji (macierzy popytu pośredniego), a jednocześnie dolną część regionalnych macierzy budowaliśmy, opierając się na rachunkach regionalnych - tabela A.3.3. W ten sposób pierwsze przybliżenie importu według sektorów dla każdego regionu było obliczone jako wartość rezydualna, tj. różnica między górną a dolną częścią macierzy dla każdego sektora (tę drugą przedstawia tabela A.3.3). Innymi słowy, parametr $\delta$ tak się zmieniał, aby wyliczona macierz popytu pośredniego wraz z macierzą czynników wytwórczych i rezydualną wartością importu krajowego w tablicy IO sumowały się w kolumnach do wartości regionalnych produktów ogółem pochodzących z GUS.

Tabela A.3.3. Dane regionalne wykorzystane do budowy tablic IO

\begin{tabular}{l}
\hline $\begin{array}{l}\text { Wykorzystanie produktów importowanych, cif } \\
\text { (wartość rezydualna) }\end{array}$ \\
\hline Podatki od produktów pomniejszone o dotacje do produktów \\
\hline Razem zużycie pośrednie \\
\hline Koszty związane z zatrudnieniem \\
\hline Podatki od producentów \\
\hline Dotacje dla producentów \\
\hline Nadwyżka operacyjna brutto \\
\hline Wartość dodana brutto \\
\hline Produkcja globalna w cenach bazowych \\
\hline Źódło: Opracowanie własne
\end{tabular}

Ponieważ GUS zmieniał w międzyczasie metodologię obliczania rachunków regionalnych, dane nie pochodziły z obecnych opracowań, ale z tego okresu, kiedy były spójne z opublikowaną tablicą przepływów międzygałęziowych. Stosując powyższą metodę, uzyskaliśmy wartości delta dla poszczególnych regionów. Udało się też uzyskać pewną prawidłowość funkcyjną dla parametrów delta, o dość dobrym dopasowaniu ( $\mathrm{R}^{2}$ wyniosła 0,94$)$. 


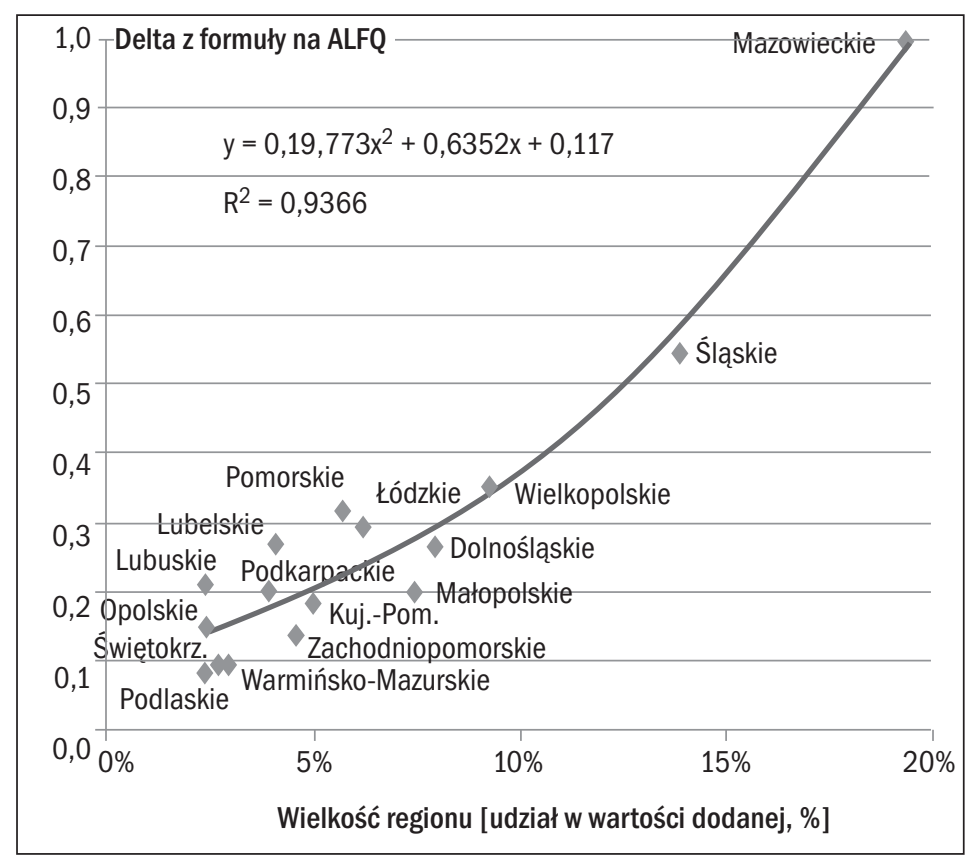

$\begin{array}{ll}\text { Województwo } & \text { Delta } \\ \text { Dolnośląskie } & 0.27 \\ \text { Kujawsko-Pomorskie } & 0.18 \\ \text { Lubelskie } & 0.27 \\ \text { Lubuskie } & 0.21 \\ \text { Łódzkie } & 0.29 \\ \text { Małopolskie } & 0.20 \\ \text { Mazowieckie } & 1.00 \\ \text { Opolskie } & 0.15 \\ \text { Podkarpackie } & 0.20 \\ \text { Podlaskie } & 0.08 \\ \text { Pomorskie } & 0.32 \\ \text { Śląskie } & 0.55 \\ \text { Świętokrzyskie } & 0.09 \\ \text { Warmińsko-Mazurskie } & 0.09 \\ \text { Wielkopolskie } & 0.35 \\ \text { Zachodniopomorskie } & 0.14\end{array}$

Rysunek A.3.1. Zależność między wartością delta z formuły na ALFQ a wielkością regionu Źródło: Obliczenia własne na podstawie AFLQ.

Zatem dzięki powyższej metodzie uzyskaliśmy wszystkie regionalne macierze transakcji. Przykładową, dla województwa dolnośląskiego, przedstawia rysunek A.3.2. Pokazuje ona, jak poszczególne sektory tej gospodarki zależą od innych, już w wartościach nominalnych (tj. mln PLN). Interpretacja rysunku jest analogiczna do interpretacji macierzy zużycia pośredniego w tablicy IO. Kolumny mówią o tym, ile każdy sektor potrzebuje nakładów z innych sektorów, np. sektor rolniczy (ROLN) najwięcej potrzebuje $\mathrm{z}$ sektora rolniczego, przemysłu (PRZEM) oraz handlowego (HAND), natomiast sam najwięcej wnosi do sektora rolniczego oraz przemysłu przetwórczego (PRZEM). 


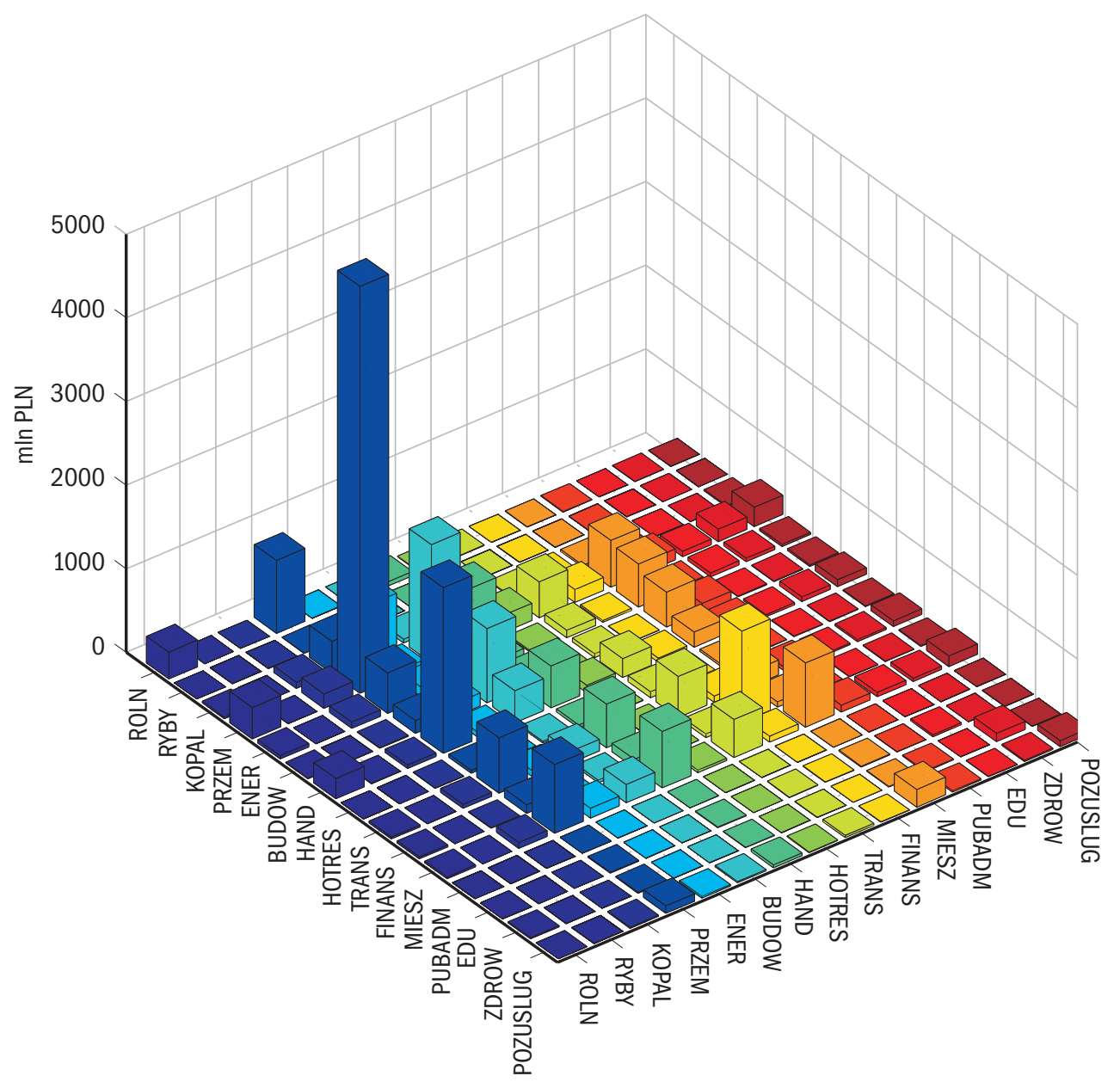

\section{Sektory}

ROLN - rolnictwo, leśnictwo, łowiectwo

RYBY - rybołówstwo i rybactwo RYBY

KOPAL - kopalnictwo

PRZEM - przetwórstwo przemysłowe

ENER - energia wodna i cieplna

BUDOW - budownictwo

HAND - handel i naprawy
HOTRE - hotele i restauracje
TRANS - transport
FINANS - usługi finansowe
MIESZ - usługi mieszkaniowe
PUBADM - administracja publiczna
EDUK - usługi edukacyjne
ZDROW - usługi zdrowotne
USŁPO - pozostałe usługi

Rysunek A.3.2. Graficzna prezentacja macierzy popytu pośredniego dla województwa dolnośląskiego

Źródło: Opracowanie własne na podstawie regionalnej tablicy IO. 
Weryfikacji uzyskanych macierzy można dokonać drogą ekspercką, czyli przedyskutować, czy współczynniki Flegga oddają dobrze charakterystykę gospodarek regionalnych. Druga metoda to porównanie z innymi pracami. Jeśli chodzi o ocenę ekspercką, to wydaje się, że podstawowa charakterystyka regionów jest zachowana, np. Podlaskie, Świętokrzyskie i Lubelskie specjalizują się w rolnictwie; Pomorskie, Warmińsko-Mazurskie i Zachodniopomorskie w rybactwie i rybołówstwie; Śląskie i Dolnośląskie w kopalnictwie; Opolskie w wytwarzaniu energii itd. Średnie współczynniki lokalizacji dla wszystkich regionów przedstawia tabela A.3.4, natomiast szczegółowe współczynniki dla wybranego województwa (wielkopolskiego) przedstawia tabela A.3.5. Interpretacja tych współczynników polega na tym, że im wyższe współczynniki Flegga, tym większa samowystarczalność danego regionu w zaspokajaniu potrzeb danego sektora. W szczególności wartości powyżej jedności oznaczają, że region jest eksporterem netto w danym sektorze $^{67}$. Samowystarczalność uwarunkowana jest $\mathrm{z}$ jednej strony możliwościami produkcyjnymi w ramach każdego sektora, $\mathrm{z}$ drugiej zaś zapotrzebowaniem danej gospodarki na produkty każdego sektora. Na przykład województwo wielkopolskie, o ile jest samowystarczalne w produkcji rolniczej dla sektora rolnego (współczynnik AFLQ dla sektora rolnego wynosi 1 - tabela A.3.5), o tyle produkcja rolnicza dla dużego sektora przemysłu przetwórczego w tym województwie nie jest w pełni zaspokajana (współczynnik AFLQ na przecięciu sektora rolnego z sektorem przemysłu przetwórczego wynosi $0,7 \mathrm{w}$ tabeli jw.). Średnie możliwości zaspokojenia potrzeb wszystkich sektorów przez sektor rolniczy w województwie wielkopolskim wynosi 0,9 (tab. A.3.4), a więc wykazuje duże pokrycie zapotrzebowania, ale nie całkowitą samowystarczalność. Nie wyklucza to faktu, że województwo to jest eksporterem produktów rolnych do innych województw i różnych sektorów w tych województwach.

\footnotetext{
${ }^{67}$ Wszystkie wartości AFLQ powyżej jedności zrównaliśmy z 1, gdyż wystarczy, iż osiągnięta jest ta wartość, aby uznać sektor za eksportera netto. Jest to zgodne z zaleceniem techniki liczenia współczynników AFLQ na potrzeby tworzenia regionalnych tablic IO.
} 


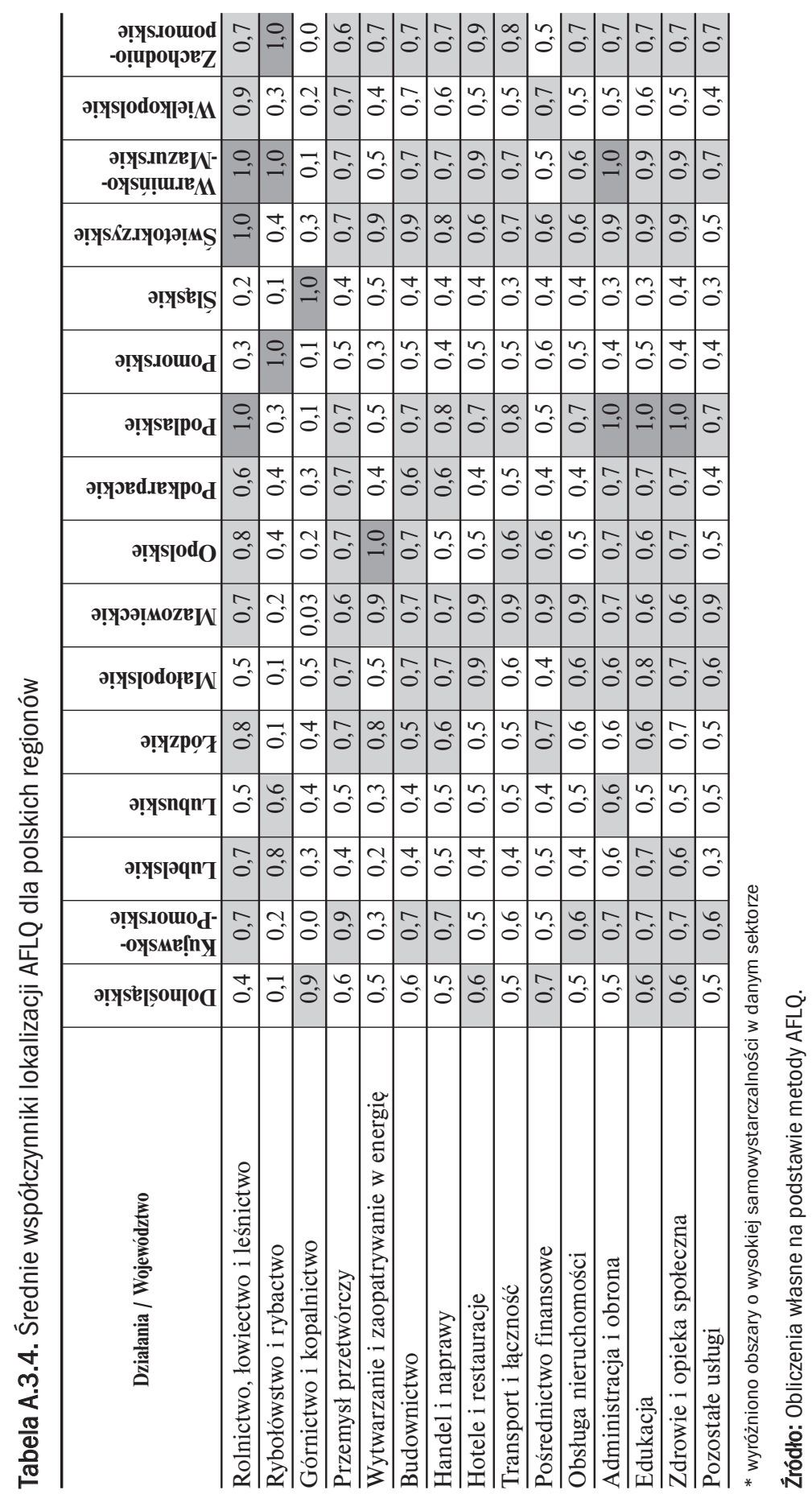




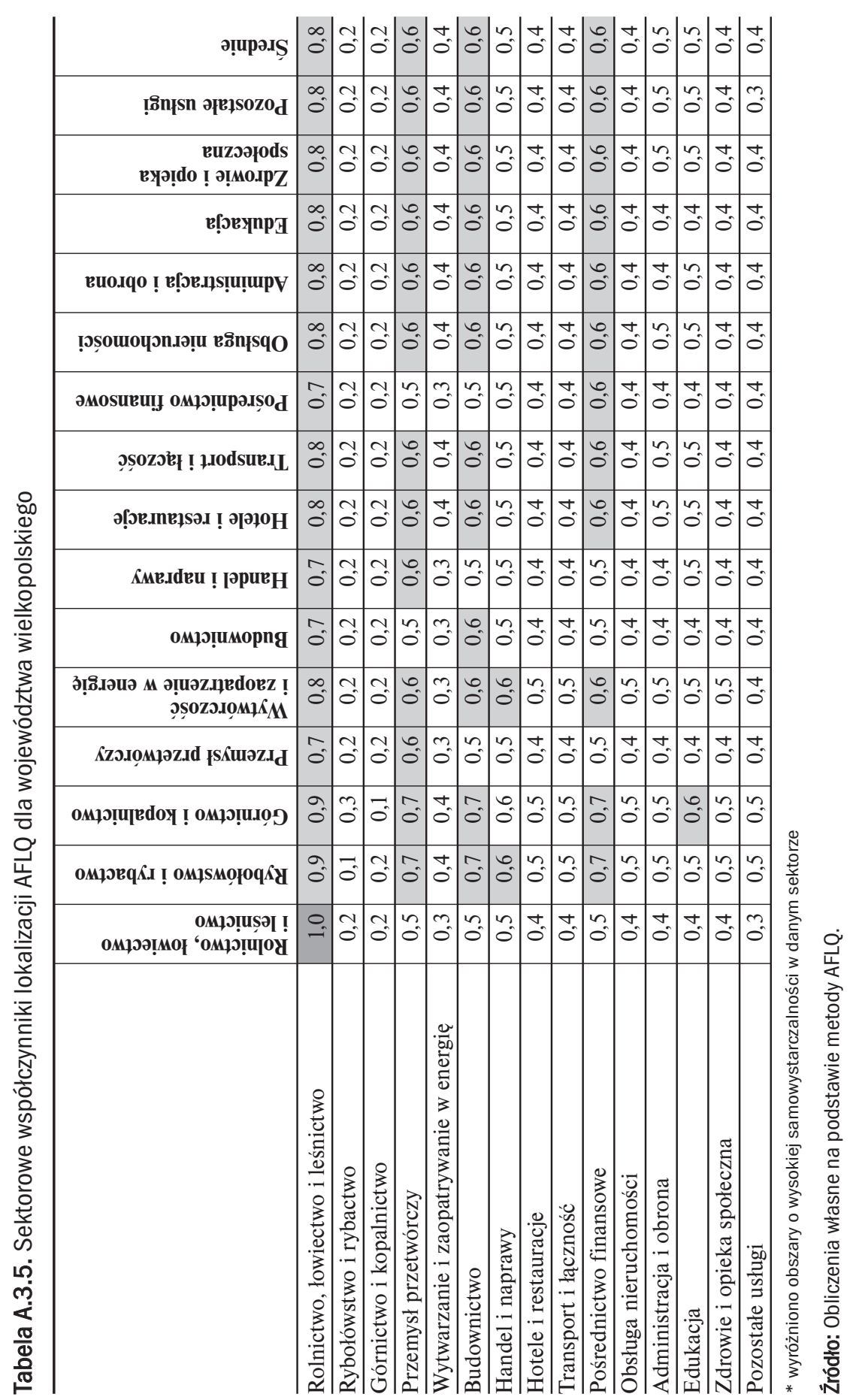


Jeśli chodzi o porównanie uzyskanych tablic z innymi badaniami, to jedyną dostępną pracą znaną autorce jest pionierska tablica IO dla województwa łódzkiego, skonstruowana przez Ł. Tomaszewicz i J. Trębską [2005], zob. też [Tomaszewicz 2000, Tomaszewicz i Boratyński 2003]. Interesujące rezultaty daje porównanie wyników tej pracy z naszymi dociekaniami, co przedstawia tabela A.3.6. Po pierwsze, zastosowany tam współczynnik to SLQ, który, jak omawialiśmy wcześniej, nie kontroluje wielkości ani specjalizacji regionu. Jak widać, skutkuje to generalnie zawyżonymi specjalizacjami w przypadku wartości ponad 1, a zaniżonymi dla niewyspecjalizowanych regionów (wartości poniżej 1), porównując z jego następcą CILQ (który uwzględnia strukturę sektorową regionu). Jeszcze większa różnica ujawnia się w porównaniu SLQ z naszymi współczynnikami lokalizacji AFLQ, które teoretycznie kontrolują i strukturę, i specjalizację regionu. Wtedy wszystkie wartości są niższe niż w przypadku SLQ, ale, co ciekawe, relatywnie struktura specjalizacji jest zachowana, tzn. np. i SLQ, i AFLQ pokazuje, że województwo łódzkie relatywnie bardziej specjalizuje się w rolnictwie i przemyśle przetwórczym niż w rybołówstwie czy górnictwie, a także to, że najbardziej specjalizuje się w sektorze energetycznym. Zatem struktura specjalizacji jest bardzo podobna, tylko jej siła inna. Badania nasze pokazały także, że wyniki SLQ są najbardziej podobne do wyników AFLQ, gdy delta jest bliska 0 . Wtedy $\lambda=1$ i AFLQ jest bliskie CILQ (najbliższe wyniki do SLQ osiągnęliśmy przy delta=0,025). Pokazaliśmy zatem empirycznie to, co wynikało ze wzorów, czyli że AFLQ powstało na bazie wszystkich poprzednich wersji współczynników

Tabela A.3.6. Porównanie różnych współczynników lokalizacji dla województwa łódzkiego

\begin{tabular}{l|c|c|c|c}
\hline & $\begin{array}{c}\text { SLQ } \\
\text { wg Tomaszewicz }\end{array}$ & CILQ & $\begin{array}{c}\text { AFLQ } \\
\text { przy } \delta=\mathbf{0 . 0 2 5}\end{array}$ & $\begin{array}{c}\text { AFLQ } \\
\text { przy } \delta=\mathbf{0 . 2 9} \\
\text { wg Zawalińskiej }\end{array}$ \\
\hline Rolnictwo, łowiectwo i leśnictwo & 1,244 & 0,978 & 0,984 & 0,80 \\
Rybołówstwo i rybactwo & 0,194 & 0,228 & 0,194 & 0,12 \\
Górnictwo i kopalnictwo & 0,784 & 0,813 & 0,734 & 0,44 \\
Przemysł przetwórczy & 1,102 & 0,986 & 0,996 & 0,65 \\
Wytwórczość i zaopatrzenie w energię & 1,389 & 1,000 & 1,000 & 0,76 \\
Budownictwo & 0,743 & 0,828 & 0,751 & 0,47 \\
Handel i naprawy & 1,173 & 0,979 & 0,985 & 0,62 \\
Hotele i restauracje & 0,793 & 0,839 & 0,764 & 0,48 \\
Transport i łączność & 0,859 & 0,865 & 0,799 & 0,52 \\
Pośrednictwo finansowe & 0,661 & 0,740 & 0,659 & 0,66 \\
Obsługa nieruchomości & 0,931 & 0,958 & 0,949 & 0,59 \\
Administracja i obrona & 1,071 & 0,974 & 0,976 & 0,61 \\
Edukacja & 1,047 & 0,969 & 0,968 & 0,61 \\
Zdrowie i opieka społeczna & 1,210 & 0,994 & 1,000 & 0,7 \\
Pozostałe usługi & 0,877 & 0,879 & 0,819 & 0,51 \\
\hline
\end{tabular}

Źródło: Obliczenia własne oraz [Tomaszewicz i Trębska 2005]. 
lokalizacji i uwidoczniliśmy, jak kolejne wersje tego współczynnika różnią się między sobą. Oczywiście porównanie to nie przesądza, które podejście jest najbliższe prawdzie, ale z racji tego, że AFLQ jest najbardziej udoskonaloną formą poprzednich współczynników oraz dlatego, że AFLQ okazało się najlepsze w Finlandii, dlatego wybraliśmy właśnie tę wersję współczynnika lokalizacji do naszego badania.

KROK 4: WYKORZYSTANIE WSPÓŁCZYNNIKÓW KRAJOWYCH DO OKREŚLENIA STRUKTURY POPYTU KOŃCOWEGO I EKSPORTU MIĘDZY REGIONAMI. Po stworzeniu macierzy zużycia pośredniego i wynagrodzenia czynników wytwórczych, do skończenia tablicy została strona popytu końcowego i podziału wytworzonych dochodów. Do określenia macierzy popytu końcowego zastosowano współczynniki krajowego popytu końcowego, zatem jest to odzwierciedlenie ważonej struktury krajowej tablicy IO. Jednak krajowa tablica przepływów międzygałęziowych ma nieco inną strukturę niż tablice regionalne, o czym już mówiliśmy wcześniej. Nie obejmuje ona importu i eksportu krajowego. Ściślej mówiąc, wykazane w niej wartości importu i eksportu krajowego wynoszą zero, nawet dla poszczególnych sektorów. Stąd po wyliczeniu, regionalne wartości dla popytu końcowego (ze współczynników krajowych) i po porównaniu z całkowitym popytem (znanym ze statystyk regionalnych) powstała różnica, którą potraktowaliśmy jako pierwsze przybliżenie brakujących wartości kolumny eksportu krajowego dla każdego sektora. Na koniec wartości eksportu krajowego zostały zbilansowane z importem krajowym (wyliczonym wcześniej), żeby na poziomie krajowym ich suma wynosiła 0 (gdyż wartość produkcji wyeksportowanej na rynek krajowy przez województwa musi się równać produkcji zaimportowanej z rynku krajowego przez województwa). W tym celu posłużono się techniką RAS, która zachowywała rzeczywiste proporcje wydatków w ramach poszczególnych kategorii popytu końcowego. Tak powstało 16 regionalnych tablic przepływów międzygałęziowych.

\section{Regionalne macierze rachunkowości społecznej}

W celu zbudowania regionalnych macierzy SAM najpierw skonstruowano krajową macierz SAM. Posłużyła ona za punkt odniesienia dla oszacowania jej regionalnych odpowiedników, tworzących po zagregowaniu jej bliską kopię. Budowa regionalnych macierzy SAM wiązała się ze zdobyciem dodatkowych danych, poza zawartością regionalnych tablic przepływów międzygałęziowych. Stanowią one macierz D (tab. A.3.7) w strukturze regionalnych macierzy SAM. Dane te w podziale na sektory instytucjonalne (gospodarstwa domowe, rząd oraz instytucje samorządowe centralne i lokalne, przedsiębiorstwa, instytucje finansowe i niekomercyjne) dotyczyły: płaconych podatków (związanych z zatrudnieniem, 
r06.qxd 2011-10-31 09:46 Page 292

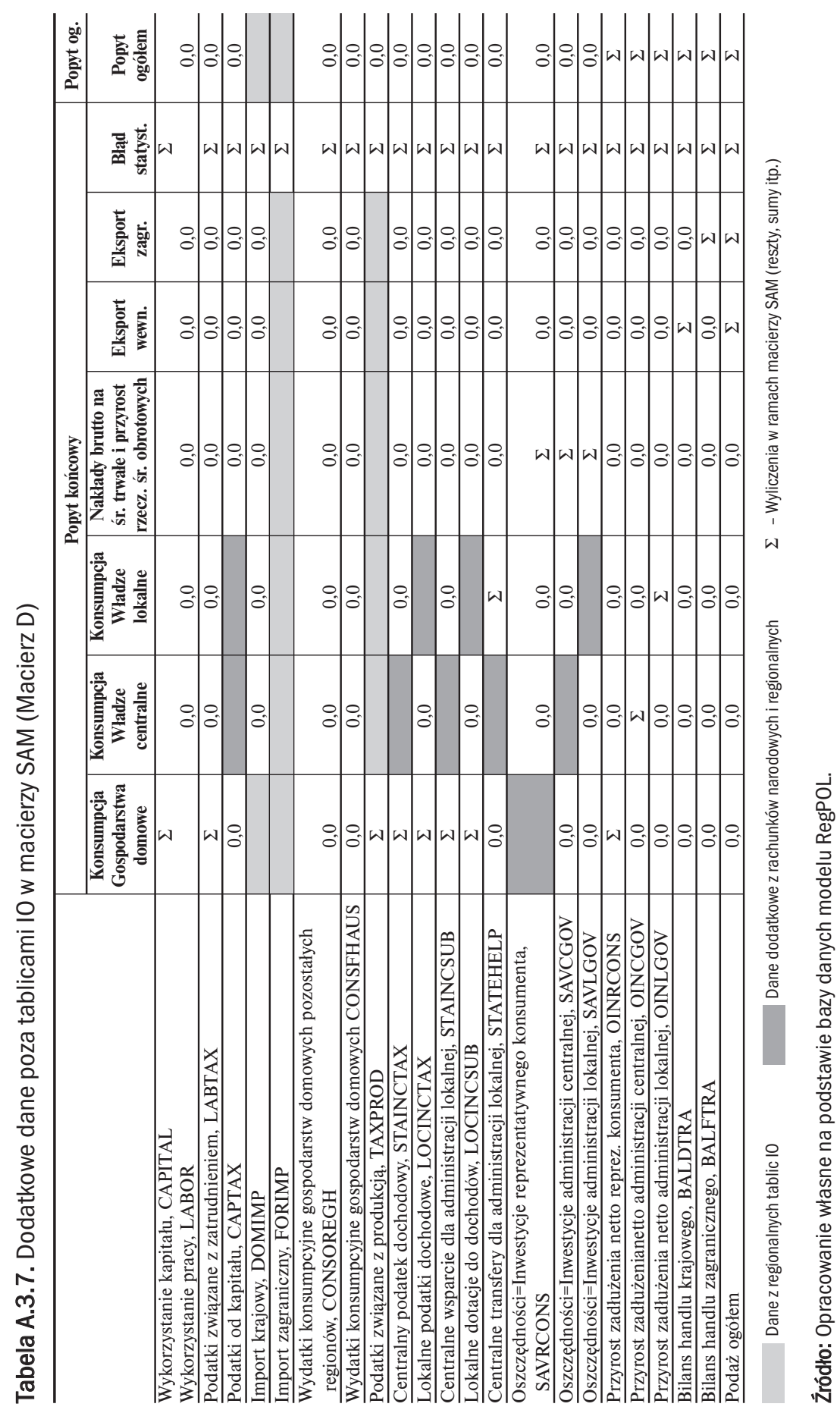


kapitałem, produkcją, dochodowych), otrzymanych transferów (dotacji), wykorzystania handlu (krajowego i zagranicznego) i generowanych oszczędności. Pozostałe kategorie z macierzy $\mathrm{D}$ były wyliczeniami wynikającymi z logiki przepływów i konieczności ich zbilansowania.

Dla poziomu krajowego informacje te pochodzily z Rachunków Narodowych [GUS 2005], a dla poziomów regionalnych - z rachunków regionalnych z pojedynczych roczników statystycznych dla poszczególnych województw. Jeśli informacja dla jakiegoś województwa nie istniała, była ona szacowana na podstawie krajowej macierzy SAM ważonej udziałem tego województwa w krajowej wartości dodanej brutto.

Ponieważ dane do budowy macierzy SAM pochodziły z różnych źródeł, na końcu pozostało ich zbilansowanie. W tym celu posłużono się metodą RAS - zapoczątkowaną przez R. Stone'a w latach 60. [Stone, Ingham i Ulph 1984]. Jest to powszechnie używana procedura w bilansowaniu i uaktualnianiu macierzy SAM i tablic IO [Schneider i Zenios 1990]. Wiele programów ma wbudowane różne algorytmy do RAS-ingu.

\section{ANEKS 3.2. RóWNANia MOdELU REgPOL W JĘZYKU TABLO}

REG, $r=16$ województw (jak przedstawiono $w$ tabeli A.3.2)

$\mathrm{IND}, \mathrm{i}=\mathrm{COM}, \mathrm{c}=15$ sektorów gospodarki ( $\mathrm{w}$ agregacji przedstawionej $\mathrm{w}$ tabeli A.3.2)

GVT, $\mathrm{g}$ = sektor rządowy: szczebel centralny, 16 szczebli regionalnych

małymi literami oznaczone są zmienne występujące $\mathrm{w}$ formie zmian procentowych DUŻYMI LITERAMI oznaczone są zmienne występujące w formie zmian w wartościach absolutnych

(1)

$* * * *$ Changes of factor tax rates $* * * *$

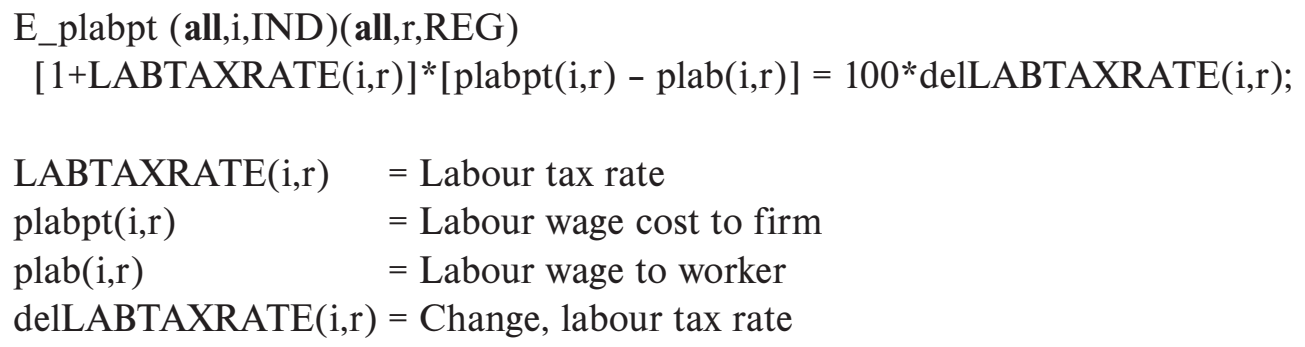


(2)

E_pcappt (all,i,IND)(all,r,REG)

$[1+\operatorname{CAPTAXRATE}(\mathrm{i}, \mathrm{r})]^{*}[\mathrm{pcappt}(\mathrm{i}, \mathrm{r})-\operatorname{pcap}(\mathrm{i}, \mathrm{r})]=100 * \operatorname{delCAPTAXRATE}(\mathrm{i}, \mathrm{r})$;

CAPTAXRATE $(\mathrm{i}, \mathrm{r}) \quad=$ Capital tax rate

pcappt $(\mathrm{i}, \mathrm{r}) \quad=$ Capital wage cost to firm

pcap $(i, r) \quad=$ Capital wage to owner

delCAPTAXRATE $(\mathrm{i}, \mathrm{r})=$ Change, capital tax rate

$* * * *$ Factor tax revenues $* * * *$

(3)

E_delLABTAX (all,i,IND)(all,r,REG) delLABTAX(i,r) $=0.01 * \mathrm{~F}($ "Lab-

Tax",i,r)*[plab(i,r)+ xlab(i,r)]

+ F("Labour",i,r)*delLABTAXRATE(i,r);

delLABTAX $(\mathrm{i}, \mathrm{r}) \quad=$ Change, labour tax revenue

$\mathrm{F}($ "LabTax",i,r) = Value of labour taxes in Flow of data

plab $(\mathrm{i}, \mathrm{r}) \quad=$ Labour wage to worker

$\operatorname{xlab}(\mathrm{i}, \mathrm{r}) \quad=$ Quantity of labour demanded

$\mathrm{F}($ "Labour",i,r) = Value of labour in Flow of data

delLABTAXRATE $(\mathrm{i}, \mathrm{r})=$ Change, labour tax rate

(4)

E_delCAPTAX (all,i,IND)(all,r,REG) delCAPTAX $(\mathrm{i}, \mathrm{r})=0.01$ *F("CapTax",i,r)

*[pcap(i,r)+ xcap(i,r)] + F("Capital",i,r)*delCAPTAXRATE(i,r);

delCAPTAX $(\mathrm{i}, \mathrm{r}) \quad=$ Change, capital tax revenue

$\mathrm{F}($ "CapTax",i,r $) \quad=$ Value of capital taxes in Flow of data

pcap(i,r) = Capital wage to owner

xcap (i,r) = Quantity of capital demanded

$\mathrm{F}($ "Capital",i,r) = Value of capital in Flow of data

delCAPTAXRATE $(\mathrm{i}, \mathrm{r})=$ Change, capital tax rate

(5)

$$
\text { **** Industry demands for value-added **** }
$$

E_xlab \# Industry demands for labour \#

$($ all,i,IND $)($ all,r,REG) xlab(i,r) - alab(i,r) $=$ xprim(i,r) - SIGMA-

$\operatorname{PRIM}(i) *[p l a b p t(i, r)+$ alab(i,r) - pprim(i,r)]; 


$\begin{array}{ll}\operatorname{xlab}(\mathrm{i}, \mathrm{r}) & =\text { Quantity of labour demanded } \\ \operatorname{alab}(\mathrm{i}, \mathrm{r}) & =\text { Labour-augmenting technical change } \\ \operatorname{xprim}(\mathrm{i}, \mathrm{r}) & =\text { Quantity, primary factor composite } \\ \operatorname{SIGMAPRIM(i)} & =\text { CES substitution elasticity between primary factors } \\ \operatorname{plabpt}(\mathrm{i}, \mathrm{r}) & =\text { Labour wage cost to firm } \\ \operatorname{pprim}(\mathrm{i}, \mathrm{r}) & =\text { Effective price, }\end{array}$

(6)

E_pcap \#\# Industry demands for capital \#

$($ all,i,IND)(all,r,REG) $\quad x c a p(i, r)-\operatorname{acap}(\mathrm{i}, \mathrm{r})=\operatorname{xprim}(\mathrm{i}, \mathrm{r})-$ SIGMA$\operatorname{PRIM}(\mathrm{i})^{*}[\operatorname{pcappt}(\mathrm{i}, \mathrm{r})+\operatorname{acap}(\mathrm{i}, \mathrm{r})-\operatorname{pprim}(\mathrm{i}, \mathrm{r})]$;

$\begin{array}{ll}\operatorname{xcap}(\mathrm{i}, \mathrm{r}) & =\text { Quantity of capital demanded } \\ \operatorname{acap}(\mathrm{i}, \mathrm{r}) & =\text { Capital-augmenting technical change } \\ \operatorname{xprim}(\mathrm{i}, \mathrm{r}) & =\text { Quantity, primary factor composite } \\ \operatorname{SIGMAPRIM(i)} & =\text { CES substitution elasticity between primary factors } \\ \operatorname{pcappt}(\mathrm{i}, \mathrm{r}) & =\text { Capital wage cost to firm } \\ \operatorname{pprim}(\mathrm{i}, \mathrm{r}) & =\text { Effective price, }\end{array}$

(7)

E_pprim \# Effective price term for factor demand equations \# $\left(\right.$ all,i,IND)(all,r,REG) ID01[VPRIM(i,r)] ${ }^{*}$ pprim(i,r) =

VLABPT(i,r)*[plabpt(i,r)+alab(i,r)]

+ CAPPT(i,r)*[pcappt(i,r) + acap(i,r)];

$\operatorname{VPRIM}(\mathrm{i}, \mathrm{r}) \quad=$ Total factor input to industry $\mathrm{i}$

pprim(i,r) = Effective price, primary factor composite

$\operatorname{VLABPT}(\mathrm{i}, \mathrm{r}) \quad=$ Labour cost to firm

plabpt $(\mathrm{i}, \mathrm{r}) \quad=$ Labour wage cost to firm

alab(i,r) = Labour-augmenting technical change

VCAPPT(i,r) = Capital cost to firm

pcappt(i,r) = Capital wage cost to firm

$\operatorname{acap}(\mathrm{i}, \mathrm{r}) \quad=$ Capital-augmenting technical change

(8)

E_xprim \# Use of composite primary factor is proportional to output \# $($ all,i,IND $)($ all,r,REG) $x \operatorname{xim}(\mathrm{i}, \mathrm{r})=\operatorname{xtot}(\mathrm{i}, \mathrm{r})+\operatorname{atot}(\mathrm{i}, \mathrm{r})+\operatorname{aprim}(\mathrm{i}, \mathrm{r})$; 
$\operatorname{xprim}(\mathrm{i}, \mathrm{r}) \quad=$ Quantity, primary factor composite

xtot(i,r) = Industry output

atot $(\mathrm{i}, \mathrm{r}) \quad=$ All-input-augmenting technical change

$\operatorname{aprim}(\mathrm{i}, \mathrm{r}) \quad=$ Primary-factor-augmenting technical change

(9)

E_delPRIM \# Ordinary change in total cost of primary factors \# (all,i,IND)(all,r,REG) 100*delPRIM(i,r) =

VLABPT $(i, r) *[\operatorname{plabpt}(\mathrm{i}, \mathrm{r})+\operatorname{xlab}(\mathrm{i}, \mathrm{r})]+\operatorname{VCAPPT}(\mathrm{i}, \mathrm{r}) *[\operatorname{pcappt}(\mathrm{i}, \mathrm{r})$

$+\operatorname{xcap}(\mathrm{i}, \mathrm{r})]$;

$\operatorname{delPRIM}(\mathrm{i}, \mathrm{r}) \quad=$ Ordinary change, cost of primary factors

VLABPT(i,r) = Labour cost to firm

plabpt(i,r) = Labour wage cost to firm

xlab(i,r) = Quantity of labour demanded

VCAPPT $(\mathrm{i}, \mathrm{r}) \quad=$ Capital cost to firm

pcappt $(\mathrm{i}, \mathrm{r}) \quad=$ Capital wage cost to firm

xcap $(\mathrm{i}, \mathrm{r}) \quad=$ Quantity of capital demanded

$* * * *$ Intermediate demands (Leontief) and total (ex-tax) production cost ****

(10)

E_xint (all,c,COM)(all,i,IND)(all,r,REG) xint(c,i,r) = atot(i,r) + xtot(i,r);

$\operatorname{xint}(\mathrm{c}, \mathrm{i}, \mathrm{r}) \quad=$ Industry demands for Armington composite

atot $(\mathrm{i}, \mathrm{r}) \quad=$ All-input-augmenting technical change

$\operatorname{xtot}(\mathrm{i}, \mathrm{r}) \quad=$ Industry output

(11)

E_pcost (all,i,IND)(all,r,REG) ID01[VCOST(i,r)]*[pcost $(\mathrm{i}, \mathrm{r})+\operatorname{xtot}(\mathrm{i}, \mathrm{r})]$

$=100 * \operatorname{delPRIM}(\mathrm{i}, \mathrm{r})+\operatorname{sum}\{\mathbf{c}, \mathbf{C O M}, \mathbf{F}(\mathbf{c}, \mathbf{i}, \mathbf{r}) *[\operatorname{parm}(\mathbf{c}, \mathbf{r})+\operatorname{xint}(\mathbf{c}, \mathbf{i}, \mathbf{r})]\}$

$\operatorname{VCOST}(\mathrm{i}, \mathrm{r}) \quad=$ Industry input cost (exc. production tax)

$\operatorname{pcost}(\mathrm{i}, \mathrm{r}) \quad=$ Industry input cost $($ exc. production tax $)$

$\operatorname{xtot}(\mathrm{i}, \mathrm{r}) \quad=$ Industry output

delPRIM(i,r) = Ordinary change, cost of primary factors

$\operatorname{parm}(\mathrm{c}, \mathrm{r}) \quad=$ Price of Armington composite

$\operatorname{xint}(\mathrm{c}, \mathrm{i}, \mathrm{r}) \quad=$ Industry demands for Armington composite 
(12)

E_ptot (all,i,IND)(all,r,REG)

$[1+\text { PRDTAXRATE }(\mathrm{i}, \mathrm{r})]^{*}[\operatorname{ptot}(\mathrm{i}, \mathrm{r})-\operatorname{pcost}(\mathrm{i}, \mathrm{r})]=100 * \operatorname{delPRDTAXRATE}(\mathrm{i}, \mathrm{r})$;

PRDTAXRATE(i,r) = Production tax rate

$\operatorname{ptot}(\mathrm{i}, \mathrm{r}) \quad=$ Industry output price (inc. production tax)

$\operatorname{pcost}(\mathrm{i}, \mathrm{r}) \quad=$ Industry input cost (exc. production tax)

delPRDTAXRATE $(\mathrm{i}, \mathrm{r})=$ Change, production tax rate

**** Production tax revenue ****

(13)

E_delPRDTAX (all,i,IND)(all,r,REG) delPRDTAX(i,r) =

$0.01 * \mathrm{~F}($ "ProdTax",i,r)*[pcost $(\mathrm{i}, \mathrm{r})+\mathrm{xtot}(\mathrm{i}, \mathrm{r})]+\operatorname{VCOST}(\mathrm{i}, \mathrm{r})$

*delPRDTAXRATE(i,r);

$\operatorname{delPRDTAX}(\mathrm{i}, \mathrm{r}) \quad=$ Change, production tax revenue

$\mathrm{F}($ "ProdTax",i,r $) \quad=$ Value of production taxes in Flow of data

$\operatorname{pcost}(\mathrm{i}, \mathrm{r}) \quad=$ Industry input cost (exc. production tax)

$\operatorname{xtot}(\mathrm{i}, \mathrm{r}) \quad=$ Industry output

$\operatorname{VCOST}(\mathrm{i}, \mathrm{r}) \quad=$ Industry input cost (exc. production tax)

delPRDTAXRATE $(i, r)=$ Change, production tax rate

**** SUBSTITUTION BETWEEN LOCALLY-MADE, ROP AND ROW GOODS. ****

**** Armington Nest Part 1: "POL" goods are a CES composite of local and ROP

(14) goods $* * * *$

E_xtot (all,i,IND)(all,r,REG) xtot(i,r) = xfin(i,r) - SIGMAFIN(i)*[ptot(i,r)-pfin(i,r)];

$\operatorname{xtot}(\mathrm{i}, \mathrm{r}) \quad=$ Industry output

xfin $(i, r) \quad=$ POL goods usage

SIGMAFIN(i) = CES substitution elasticity between local and rest-of-

Poland goods

ptot(i,r)

$=$ Industry output price (inc. production tax)

pfin $(\mathrm{i}, \mathrm{r})$

$=$ Price of POL goods 
(15)

E_xrofimpf (all,i,IND)(all,r,REG) xrofimpf(IND2ROF(i),r) = xfin(i,r) - SIGMAFIN(i)*[prof(IND2ROF(i)) - pfin(i,r)];

xrofimpf(IND2ROF(i),r) = ROP usage by corresponding firm

xfin(i,r)

SIGMAFIN(i)

$=$ POL goods usage

$=$ CES substitution elasticity between local and rest-of-Poland goods

prof(IND2ROF(i))

$=$ Price, $\mathrm{ROP}$ good

pfin(i,r)

$=$ Price of POL goods

**** Armington Nest Part 2: "ACT" is a CES composite of POL goods and foreign imports $* * * *$

(16)

E_xrowimp (all,i,IND)(all,r,REG)

$\operatorname{xrowimp}(\mathrm{i}, \mathrm{r})=\operatorname{xact}(\mathrm{i}, \mathrm{r})-\operatorname{SIGMAFINROW}(\mathrm{i}) *[\operatorname{prowimp}-\operatorname{pact}(\mathrm{i}, \mathrm{r})]$;

xrowimp(i,r) = Firms use of ROW imports

$\operatorname{xact}(\mathrm{i}, \mathrm{r}) \quad=$ Output of ACT composite

SIGMAFINROW(i) = CES substitution elasticity between ROW and Poland

prowimp $\quad=$ Price of imports (POL currency)

$\operatorname{pact}(\mathrm{i}, \mathrm{r}) \quad=$ Price of ACT composite

(17)

E_xfin (all,i,IND)(all,r,REG)

xfin $(\mathrm{i}, \mathrm{r})=\operatorname{xact}(\mathrm{i}, \mathrm{r})-\operatorname{SIGMAFINROW}(\mathrm{i}) *[\operatorname{pfin}(\mathrm{i}, \mathrm{r})-\operatorname{pact}(\mathrm{i}, \mathrm{r})]$;

xfin $(\mathrm{i}, \mathrm{r}) \quad=$ POL goods usage

$\operatorname{xact}(\mathrm{i}, \mathrm{r}) \quad=$ Output of ACT composite

SIGMAFINROW(i) = CES substitution elasticity between ROW and Poland

pfin $(\mathrm{i}, \mathrm{r}) \quad=$ Price of POL goods

$\operatorname{pact}(\mathrm{i}, \mathrm{r}) \quad=$ Price of ACT composite

E_pact (all,i,IND)(all,r,REG)

ID01[VACT(i,r)] ${ }^{*} \operatorname{pact}(\mathrm{i}, \mathrm{r})=\mathrm{VFIN}(\mathrm{i}, \mathrm{r}){ }^{*} \operatorname{pfin}(\mathrm{i}, \mathrm{r})+\mathrm{F}($ "Row",i,r)* prowimp;

$\operatorname{VACT}(\mathrm{i}, \mathrm{r}) \quad=$ ACT good value 


$$
\begin{array}{ll}
\operatorname{pact}(\mathrm{i}, \mathrm{r}) & =\text { Price of ACT composite } \\
\text { VFIN }(\mathrm{i}, \mathrm{r}) & =\text { POL good value } \\
\operatorname{pfin}(\mathrm{i}, \mathrm{r}) & =\text { Price of POL goods } \\
\mathrm{F}(" R o w ", \mathrm{i}, \mathrm{r}) & =\text { Value of foreign trade deficit in Flow of data } \\
\text { Prowimp } & =\text { Price of imports (POL currency) }
\end{array}
$$

*** Armington Nest Part 3: "ACT" is split via CET into ARM goods, exports to ROP, and exports to $\mathrm{ROW} * *$

**** Compute total demand for Armington composite ****

(19)

\begin{tabular}{|c|c|}
\hline $\operatorname{ADEM}(\mathrm{c}, \mathrm{r})$ & $=$ Demand for armington composite \\
\hline $\operatorname{xarm}(\mathrm{c}, \mathrm{r})$ & $=$ Output, Armington composite good \\
\hline $\operatorname{xint}(\mathrm{c}, \mathrm{i}, \mathrm{r})$ & $=$ Industry demands for Armington composite \\
\hline $\mathrm{F}\left(\mathrm{c}, " I N V^{\prime \prime}, \mathrm{r}\right)$ & $=$ Value of private investment in Flow of data \\
\hline $\operatorname{xinv}(c, r)$ & $\begin{aligned}= & \text { Investment demand for Armington composite (inclu- } \\
& \text { ding inventory change) }\end{aligned}$ \\
\hline $\mathrm{F}\left(\mathrm{c}, " H O U^{\prime}, \mathrm{r}\right)$ & $=$ Value of household demand in Flow of data \\
\hline $\operatorname{xhou}(\mathrm{c}, \mathrm{r})$ & $=$ Household demand for Armington composite \\
\hline $\operatorname{xgov}(\mathrm{c}, \mathrm{g}, \mathrm{r})$ & $\begin{aligned}= & \text { State and local government demand for Armington } \\
& \text { composite }\end{aligned}$ \\
\hline$(\mathrm{c}, " S E R R ", \mathrm{r})$ & $=$ Value of statistical error in Flow of data \\
\hline $\mathrm{rr}(\mathrm{c}, \mathrm{r})$ & $=$ Statistical error \\
\hline
\end{tabular}

E_parm (all,c,COM)(all,r,REG) ID01 $[\operatorname{ADEM}(\mathrm{c}, \mathrm{r})]^{*} \operatorname{xarm}(\mathrm{c}, \mathrm{r})=$ $\operatorname{sum}\left\{\mathrm{i}, \mathrm{IND}, \mathrm{F}(\mathrm{c}, \mathrm{i}, \mathrm{r}){ }^{*} \operatorname{xint}(\mathrm{c}, \mathrm{i}, \mathrm{r})\right\}+\mathrm{F}\left(\mathrm{c}, \mathrm{INN}^{\prime}, \mathrm{r}\right) * \operatorname{xinv}(\mathrm{c}, \mathrm{r})+$ $\mathrm{F}(\mathrm{c}, \mathrm{HOU} ", \mathrm{r}){ }^{*} \mathrm{xhou}(\mathrm{c}, \mathrm{r})$

+ $\operatorname{sum}\left\{\mathrm{g}, \mathrm{GVT}, \mathrm{F}(\mathrm{c}, \mathrm{g}, \mathrm{r}){ }^{*} \operatorname{xgov}(\mathrm{c}, \mathrm{g}, \mathrm{r})\right\}+\mathrm{F}(\mathrm{c}$, "SERR",r)*xserr(c,r);

**** CET nest: "ACT" is split into ARM, ROP, and ROW****

(20)

E_xarm (all,c,COM)(all,r,REG)

$\operatorname{xarm}(\mathrm{c}, \mathrm{r})=\operatorname{xact}(\mathrm{COM} 2 \mathrm{IND}(\mathrm{c}), \mathrm{r})+\operatorname{ETRN}(\mathrm{c}) *[\operatorname{parm}(\mathrm{c}, \mathrm{r})$

$-\operatorname{pact}(\mathrm{COM} 2 \operatorname{IND}(\mathrm{c}), \mathrm{r})]$;

$\operatorname{xarm}(\mathrm{c}, \mathrm{r}) \quad=$ Output, Armington composite good

$\operatorname{xact}(\mathrm{COM} 2 \mathrm{IND}(\mathrm{c}), \mathrm{r})=$ Output of ACT composite 
ETRN(c) = Substitution elasticity of transformation between domexp, forexp, and ArmCmp

$\operatorname{parm}(\mathrm{c}, \mathrm{r}) \quad=$ Price of Armington composite

$\operatorname{pact}(\mathrm{COM} 2 \mathrm{IND}(\mathrm{c}), \mathrm{r})=$ Price of $\mathrm{ACT}$ composite

E_xrofexp (all,c,COM)(all,r,REG)

$\operatorname{xrofexp}(\mathrm{c}, \mathrm{r})=\operatorname{xact}(\mathrm{COM} 2 \mathrm{IND}(\mathrm{c}), \mathrm{r})+\operatorname{ETRN}(\mathrm{c}) *[\operatorname{prof}(\mathrm{COM} 2 \mathrm{ROF}(\mathrm{c}))$

$-\operatorname{pact}(\mathrm{COM} 2 \mathrm{IND}(\mathrm{c}), \mathrm{r})]$;

$\operatorname{xrofexp}(\mathrm{c}, \mathrm{r}) \quad=$ Exports to ROP

$\operatorname{xact}(\mathrm{COM} 2 \mathrm{IND}(\mathrm{c}), \mathrm{r})=$ Output of ACT composite

ETRN $(\mathrm{c}) \quad=$ Substitution elasticity of transformation between domexp, forexp, and ArmCmp

$\operatorname{prof}(\mathrm{COM} 2 \mathrm{ROF}(\mathrm{c})) \quad=$ Price, $\mathrm{ROP}$ good

$\operatorname{pact}(\mathrm{COM} 2 \mathrm{IND}(\mathrm{c}), \mathrm{r})=$ Price of $\mathrm{ACT}$ composite

(22)

E_xrowexp (all,c,COM)(all,r,REG)

$\operatorname{xrowexp}(\mathrm{c}, \mathrm{r})=\operatorname{xact}(\mathrm{COM} 2 \mathrm{IND}(\mathrm{c}), \mathrm{r})+\operatorname{ETRN}(\mathrm{c}) *[\operatorname{prowexp}(\mathrm{c})$

$-\operatorname{pact}(\mathrm{COM} 2 \mathrm{IND}(\mathrm{c}), \mathrm{r})]$;

\begin{tabular}{|c|c|}
\hline $\operatorname{xrowexp}(\mathrm{c}, \mathrm{r})$ & $=$ Exports to ROW \\
\hline $\operatorname{xact}(\mathrm{COM} 2 \mathrm{IND}(\mathrm{c}), \mathrm{r})$ & $=$ Output of ACT composite \\
\hline $\mathrm{TRN}(\mathrm{c})$ & $\begin{aligned}= & \text { Substitution elasticity of transformation between } \\
& \text { domexp, forexp, and ArmCmp }\end{aligned}$ \\
\hline & $=$ Price, exports to ROW (in POL currency) \\
\hline $2 \operatorname{IND}(\mathrm{c}), \mathrm{r})$ & $=$ Price of ACT composite \\
\hline
\end{tabular}

(23)

E_xact $($ all,c,COM $)($ all,r,REG) ID01[VACT2(c,r)]* $\operatorname{pact}(\mathrm{COM} 2 \mathrm{IND}(\mathrm{c}), \mathrm{r})=$ $\operatorname{ADEM}(\mathrm{c}, \mathrm{r}) * \operatorname{parm}(\mathrm{c}, \mathrm{r})+\mathrm{F}\left(\mathrm{c},{ }^{\prime} R O P^{\prime \prime}, \mathrm{r}\right) * \operatorname{prof}(\mathrm{COM} 2 \mathrm{ROF}(\mathrm{c}))$

$+\mathrm{F}\left(\mathrm{c}, " R O W^{\prime \prime}, \mathrm{r}\right) * \operatorname{prowexp}(\mathrm{c})$;

$\operatorname{VACT} 2(\mathrm{c}, \mathrm{r}) \quad=\mathrm{ACT}$ good value

$\operatorname{pact}(\mathrm{COM} 2 \mathrm{IND}(\mathrm{c}), \mathrm{r})=$ Price of ACT composite

$\operatorname{ADEM}(\mathrm{c}, \mathrm{r}) \quad=$ Demand for armington composite

$\operatorname{parm}(\mathrm{c}, \mathrm{r}) \quad=$ Price of Armington composite 


$$
\begin{array}{ll}
\mathrm{F}\left(\mathrm{c}, " R O P^{\prime \prime}, \mathrm{r}\right) & =\text { Value of ROP consumption in Flow of data } \\
\operatorname{prof}(\mathrm{COM} 2 \mathrm{ROF}(\mathrm{c})) & =\text { Price, ROP good } \\
\mathrm{F}\left(\mathrm{c},{ }^{\prime} R O W^{\prime \prime}, \mathrm{r}\right) & =\text { Value of ROW consumption in Flow of data } \\
\operatorname{prowexp}(\mathrm{c}) & =\text { Price, exports to ROW (in POL currency) } \\
& * * * * \text { Trade within Poland } * * * *
\end{array}
$$

(24) E_xrofimp \# Total demand for each ROP good \# $($ all,c,ROP $)\left(\right.$ all,r,REG) ID01[VROFIMP(c,r)] ${ }^{*} \operatorname{xrofimp}(\mathrm{c}, \mathrm{r})=$ $\mathrm{F}\left(\mathrm{c}, " H O U^{\prime \prime}, \mathrm{r}\right) *$ xhrof(c,r)

+ F(c,ROF2IND(c),r)*xrofimpf(c,r) + F(c, IINV",r)*xirof(c,r);

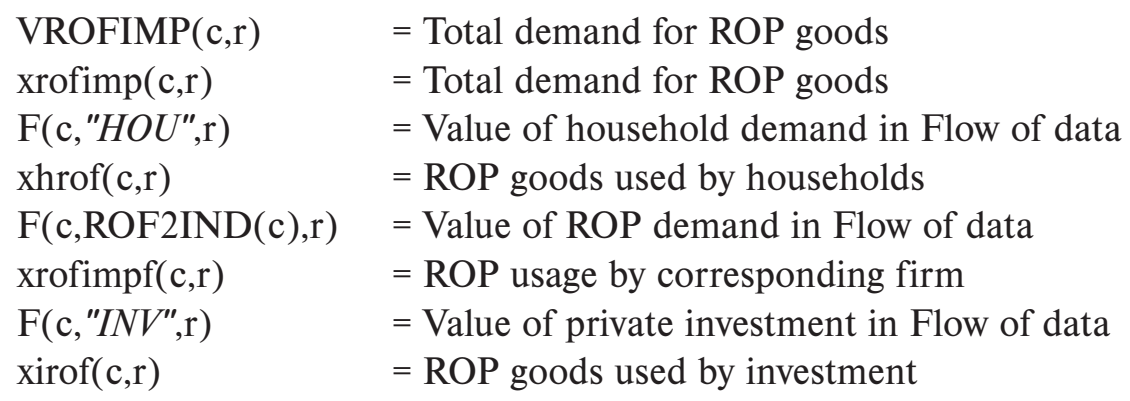

E_prof \# Demand $=$ supply for each ROP good \#

(all,c,ROP) $\operatorname{sum}\left\{\mathrm{r}, \mathrm{REG}, \mathrm{VROFIMP}(\mathrm{c}, \mathrm{r})^{*} \mathrm{xrofimp}(\mathrm{c}, \mathrm{r})\right.$

- F(ROF2COM(c),"ROP",r)*xrofexp(ROF2COM(c),r)] = 0;

$\operatorname{VROFIMP}(\mathrm{c}, \mathrm{r})=$ Total demand for ROP goods

xrofimp $(\mathrm{c}, \mathrm{r}) \quad=$ Total demand for ROP goods

$\mathrm{F}(\mathrm{ROF} 2 \mathrm{COM}(\mathrm{c}), " R O P$ ",r $)=$ Value of ROP demand in Flow of data $\operatorname{xrofexp}(\operatorname{ROF} 2 \mathrm{COM}(\mathrm{c}), \mathrm{r}) \quad=$ Exports to ROP

$$
* * * * \text { Household demand } * * * *
$$

**** Households are Cobb-Douglas users of Arm, ROP, and the ROW good. $* * * * A R M$ and ROP are taxed (but not ROW) ****

E_profhpt (all,c,ROP)(all,r,REG)

$[1+\operatorname{HOUTAXRATE}(\mathrm{r})]^{*}[\operatorname{profhpt}(\mathrm{c}, \mathrm{r})-\operatorname{prof}(\mathrm{c})]=100 * \operatorname{delHOUTAXRATE}(\mathrm{r})$; 
HOUTAXRATE(r) = Tax rate, ARM and ROP goods to households

$\operatorname{profhpt}(\mathrm{c}, \mathrm{r}) \quad=$ Price including tax, ROP goods to households

$\operatorname{prof}(\mathrm{c}) \quad=$ Price, rest-of-Poland $(\mathrm{ROP}) \operatorname{good}$

delHOUTAXRATE(r) = Change, Tax rate, ARM and ROP goods to households

E_parmhpt (all,c,COM)(all,r,REG)

$[1+\operatorname{HOUTAXRATE}(\mathrm{r})]^{*}[\operatorname{parmhpt}(\mathrm{c}, \mathrm{r})-\operatorname{parm}(\mathrm{c}, \mathrm{r})]$

$=100 *$ delHOUTAXRATE $(\mathrm{r})$;

HOUTAXRATE(r) = Tax rate, ARM and ROP goods to households

$\operatorname{parmhpt}(\mathrm{c}, \mathrm{r}) \quad=$ Price including tax, Armington goods to households

$\operatorname{parm}(\mathrm{c}, \mathrm{r}) \quad=$ Price of Armington composite

delHOUTAXRATE $(r)$ = Change, Tax rate, ARM and ROP goods to households

(28)

E_delHOUTAX (all,r,REG) delHOUTAX(r) =

$0.01{ }^{*} \operatorname{HOUTAXRATE}(\mathrm{r}){ }^{*} \operatorname{sum}\left[\mathrm{c}, \mathrm{COM}, \mathrm{F}\left(\mathrm{c},{ }^{\prime} H O U^{\prime \prime}, \mathrm{r}\right) *[\operatorname{parm}(\mathrm{c}, \mathrm{r})+\operatorname{xhou}(\mathrm{c}, \mathrm{r})]\right.$ ]

+ 0.01*HOUTAXRATE(r)*sum [c,ROP, F(c, "HOU",r)*[prof(c) + xhrof(c,r)]

$+\operatorname{sum}\left[\mathrm{c}, \mathrm{COM}, \mathrm{F}\left(\mathrm{c},{ }^{\prime} H O U^{\prime \prime}, \mathrm{r}\right){ }^{*}\right.$ delHOUTAXRATE(r)

$+\operatorname{sum}\left\{\mathrm{c}, \mathrm{ROP}, \mathrm{F}\left(\mathrm{c},{ }^{\prime} H O U^{\prime \prime}, \mathrm{r}\right)\right\}^{*}$ delHOUTAXRATE(r);

delHOUTAX(r) = Change, tax on ARM and ROP goods used by households

$\mathrm{F}\left(\mathrm{c},{ }^{\prime} H O U^{\prime \prime}, \mathrm{r}\right) \quad$ = Value of household demand in Flow of data

$\operatorname{parm}(\mathrm{c}, \mathrm{r}) \quad=$ Price of Armington composite

xhou $(\mathrm{c}, \mathrm{r}) \quad=$ Household demand for Armington composite

$\operatorname{prof}(\mathrm{c}) \quad=$ Price, rest-of-Poland $(\mathrm{ROP}) \operatorname{good}$

xhrof(c,r) $\quad=$ ROP goods used by households

delHOUTAXRATE(r) = Change, Tax rate, ARM and ROP goods to households

**** CPI, nominal and real household consumption,

and Cobb-Douglas demands ****

(29)

E_phou (all,r,REG) VHOUTOT(r)*phou(r)

$=\operatorname{sum}\{c, R O P, \operatorname{VHROFPT}(\mathrm{c}, \mathrm{r}) * \operatorname{profhpt}(\mathrm{c}, \mathrm{r})\}$

$+\operatorname{sum}\left[\mathrm{c}, \mathrm{COM}, \mathrm{VHOUPT}(\mathrm{c}, \mathrm{r}){ }^{*} \operatorname{parmhpt}(\mathrm{c}, \mathrm{r})\right\}$

+ F("ROW", "HOU",r)* prowimp; 


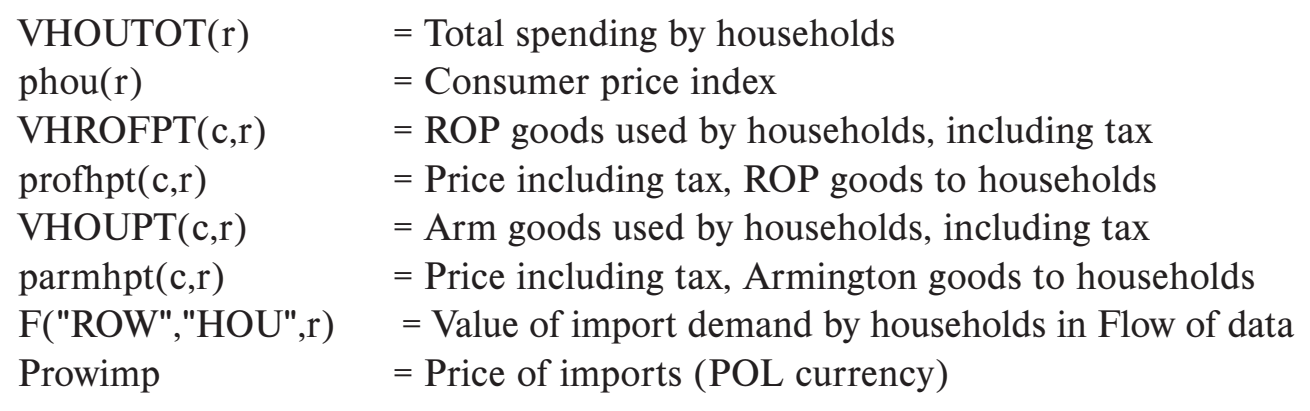

E_xhoutot $($ all,r,REG) xhoutot $(r)+\operatorname{phou}(r)=$ whou $(r)$;

xhoutot $(\mathrm{r}) \quad=$ Real spending by the households

phou(r) $\quad=$ Consumer price index

whou $(\mathrm{r}) \quad=$ Spending by households

\section{**** Cobb-Douglas demands ****}

E_xhrow (all,r,REG) prowimp + xhrow $(r)=$ whou $(r)$;

E_xhrof (all,c,ROP)(all,r,REG) profhpt $(\mathrm{c}, \mathrm{r})+\operatorname{xhrof}(\mathrm{c}, \mathrm{r})=$ whou(r);

E_xhou (all,c,COM)(all,r,REG) parmhpt $(\mathrm{c}, \mathrm{r})+\operatorname{xhou}(\mathrm{c}, \mathrm{r})=$ whou $(\mathrm{r})$;

Prowimp $\quad=$ Price of imports (POL currency)

xhrow $(\mathrm{r}) \quad=$ ROW goods used by households

whou $(\mathrm{r}) \quad=$ Spending by households

$\operatorname{profhpt}(\mathrm{c}, \mathrm{r}) \quad=$ Price including tax, ROP goods to households

$\operatorname{xhrof}(\mathrm{c}, \mathrm{r}) \quad=$ ROP goods used by households

$\operatorname{parmhpt}(\mathrm{c}, \mathrm{r}) \quad=$ Price including tax, Armington goods to households

xhou $(\mathrm{c}, \mathrm{r}) \quad=$ Household demand for Armington composite

$* * * *$ Investment $* * * *$

**** Investment uses Arm, ROP, and the ROW good (all taxed) ****

E_pinvex (all,r,REG) VINVTOTEX $(r) * \operatorname{pinvex}(r)=$ $\operatorname{sum}\left\{\mathrm{c}, \mathrm{COM}, \mathrm{F}\left(\mathrm{c},{ }^{\prime I N} V^{\prime \prime}, \mathrm{r}\right){ }^{*} \operatorname{parm}(\mathrm{c}, \mathrm{r})\right\}$

$+\operatorname{sum}\left[\mathrm{c}, \mathrm{ROP}, \mathrm{F}\left(\mathrm{c}, " I N V^{\prime \prime}, \mathrm{r}\right)^{*} \operatorname{prof}(\mathrm{c})\right\}+\mathrm{F}\left(" R O W^{\prime \prime}, " I N V^{\prime \prime}, \mathrm{r}\right){ }^{*}$ prowimp;

VINVTOTEX(r) = Investment spending excluding tax 


$\begin{array}{ll}\operatorname{pinvex}(\mathrm{r}) & =\text { Investment price index excluding tax } \\ \mathrm{F}\left(\mathrm{c}, " I N V^{\prime \prime}, \mathrm{r}\right) & =\text { Value of private investment in Flow of data } \\ \operatorname{parm}(\mathrm{c}, \mathrm{r}) & =\text { Price of Armington composite } \\ \operatorname{prof}(\mathrm{c}) & =\text { Price, rest-of-Poland (ROP) good } \\ \mathrm{F}\left(" R O W^{\prime \prime}, " I N V^{\prime \prime}, \mathrm{r}\right) & = \\ & \text { Value of import demand in private investment in Flow } \\ & \text { of data } \\ \text { Prowimp } & \text { Price of imports (POL currency) }\end{array}$

E_xinvtot (all,r,REG) VINVTOTEX(r)* $\operatorname{xinvtot}(\mathrm{r})=$ $\operatorname{sum}\left\{\mathrm{c}, \mathrm{COM}, \mathrm{F}\left(\mathrm{c},{ }^{\prime \prime} I N V^{\prime \prime}, \mathrm{r}\right){ }^{*} \operatorname{xinv}(\mathrm{c}, \mathrm{r})\right\}$

$+\operatorname{sum}\{\mathrm{c}, \mathrm{ROP}, \mathrm{F}(\mathrm{c}$, ,INV",r)*xirof(c,r) $\}+\mathrm{F}($ "ROW", "INV",r)*xirow(r);

VINVTOTEX(r) = Investment spending excluding tax

xinvtot $(r) \quad=$ Real investment

$\mathrm{F}\left(\mathrm{c},{ }^{\prime \prime} I N V^{\prime \prime}, \mathrm{r}\right) \quad$ = Value of private investment in Flow of data

$\operatorname{xinv}(\mathrm{c}, \mathrm{r}) \quad=$ Investment demand for Armington composite

(including inventory change)

xirof $(\mathrm{c}, \mathrm{r}) \quad=$ ROP goods used by investment

$\mathrm{F}($ "ROW", "INV",r) = Value of import demand in private investment in Flow of data

xirow $(\mathrm{r}) \quad$ ROW goods for investments

(34)

E_winvtot (all,r,REG) VINVTOT(r)* winvtot(r) =

$\operatorname{VINVTOTEX}(\mathrm{r}) *[\operatorname{pinvex}(\mathrm{r})+\operatorname{xinvtot}(\mathrm{r})]+100 * \operatorname{delINVTAX}(\mathrm{r})$;

$\begin{array}{ll}\text { VINVTOT(r) } & =\text { Investment spending including tax } \\ \text { winvtot(r) } & =\text { Investment spending including tax } \\ \text { VINVTOTEX(r) } & =\text { Investment spending excluding tax } \\ \text { pinvex(r) } & =\text { Investment price index excluding tax } \\ \text { xinvtot(r) } & =\text { Real investment } \\ \text { delINVTAX(r) } & =\text { Change, tax on investment }\end{array}$

E_pinv (all,r,REG) $\operatorname{pinv}(r)=\operatorname{winvtot}(r)-\operatorname{xinvtot}(r)$;

$\operatorname{pinv}(\mathrm{r}) \quad=$ Investment price index including tax 


$$
\begin{array}{ll}
\text { winvtot }(\mathrm{r}) & =\text { Investment spending including tax } \\
\operatorname{xinvtot}(\mathrm{r}) & =\text { Real investment }
\end{array}
$$

E_delINVTAX

(all,r,REG) delINVTAX(r) = 0.01*F("ComTax", "INV",r)*[pinvex(r) + xinvtot(r) $]$ $+\operatorname{VINVTOTEX}(\mathrm{r}) *$ delINVTAXRATE$(\mathrm{r})$;

delINVTAX $(\mathrm{r}) \quad=$ Change, tax on investment

$\mathrm{F}($ "ComTax", "INV",r) = Value of commodity taxes in private investment in Flow of data

$\operatorname{pinvex}(\mathrm{r}) \quad=$ Investment price index excluding tax

xinvtot(r) = Real investment

VINVTOTEX(r) = Investment spending excluding tax

delINVTAXRATE(r) = Change, tax rate on goods used by INV

**** Government demand ****

**** State and local governments use the ARM good only, not taxed ****

(37)

E_pgov (all,g,GVT)(all,r,REG)

$\operatorname{VGOVTOT}(\mathrm{g}, \mathrm{r}) * \operatorname{pgov}(\mathrm{g}, \mathrm{r})=\operatorname{sum}\{\mathrm{c}, \mathrm{COM}, \mathrm{F}(\mathrm{c}, \mathrm{g}, \mathrm{r}) * \operatorname{parm}(\mathrm{c}, \mathrm{r})\}$;

VGOVTOT $(\mathrm{g}, \mathrm{r}) \quad=$ Government spending on goods

$\operatorname{pgov}(\mathrm{g}, \mathrm{r}) \quad=$ Government price index

$\operatorname{parm}(\mathrm{c}, \mathrm{r}) \quad=$ Price of Armington composite

E_xgovtot (all,g,GVT)(all,r,REG)

VGOVTOT $(\mathrm{g}, \mathrm{r}) * \operatorname{xgovtot}(\mathrm{g}, \mathrm{r})=\operatorname{sum}\left\{\mathrm{c}, \mathrm{COM}, \mathrm{F}(\mathrm{c}, \mathrm{g}, \mathrm{r}){ }^{*} \operatorname{xgov}(\mathrm{c}, \mathrm{g}, \mathrm{r})\right\}$;

VGOVTOT $(\mathrm{g}, \mathrm{r}) \quad=$ Government spending on goods

$\operatorname{xgovtot}(\mathrm{g}, \mathrm{r}) \quad=$ Real government spending on goods

$\operatorname{xgov}(\mathrm{c}, \mathrm{g}, \mathrm{r}) \quad=$ State and local government demand for Armington composite

E_wgovtot (all,g,GVT)(all,r,REG)

$\operatorname{wgovtot}(\mathrm{g}, \mathrm{r})=\operatorname{pgov}(\mathrm{g}, \mathrm{r})+\operatorname{xgovtot}(\mathrm{g}, \mathrm{r})$; 
$\operatorname{wgovtot}(\mathrm{g}, \mathrm{r}) \quad=$ Government spending on goods

$\operatorname{pgov}(\mathrm{g}, \mathrm{r}) \quad=$ Government price index

$\operatorname{xgovtot}(\mathrm{g}, \mathrm{r}) \quad=$ Real government spending on goods

$* * * *$ add up ROW and ROP imports and exports ****

E_xrowimptot (all,r,REG)

VROWIMPtot(r)*xrowimptot(r) = sum $\{\mathrm{i}, \mathrm{IND}, \mathrm{F}($ "Row",i,r)*xrowimp (i,r)

+ F("ROW", "HOU",r)*xhrow(r) + F("ROW", "INV",r)*xirow(r);

VROWIMPtot(r) = Imports from ROW

$\operatorname{xrowimptot}(\mathrm{r}) \quad=$ Imports from ROW

$\mathrm{F}($ "Row",i,r) = Value of foreign trade deficit in Flow of data

Xrowimp(i,r) = Firms use of ROW imports

$\mathrm{F}\left(" R O W^{\prime}\right.$, "HOU",r) = Value of import demand by households in Flow of data

xhrow $(\mathrm{r}) \quad=$ ROW goods used by households

$\mathrm{F}\left(" R O W^{\prime \prime}, " I N V^{\prime}, \mathrm{r}\right) \quad=$ Value of import demand in private investment in Flow of data

xirow $(\mathrm{r}) \quad$ ROW goods for investments

(41)

E_xrowexptot (all,r,REG)

VROWEXPtot(r)*xROWEXPtot(r) = sum[c,COM, F(c, "ROW",r)*xrowexp(c,r)];

VROWEXPtot(r) = Exports to ROW

XROWEXPtot(r) = Exports to ROW

$\mathrm{F}\left(\mathrm{c}, " R O W^{\prime \prime}, \mathrm{r}\right) \quad$ = Value of ROW consumption in Flow of data

$\operatorname{xrowexp}(\mathrm{c}, \mathrm{r}) \quad$ Exports to ROW

E_xrofimptot (all,r,REG)

VROFIMPtot $(r) * x R O F I M P t o t(r)=\operatorname{sum}\{c, R O P, \operatorname{VROFIMP}(c, r) * x \operatorname{xrofimp}(c, r)]$;

VROFIMPtot(r) = Imports from ROP

$\mathrm{xROFIMPtot}(\mathrm{r}) \quad=$ Imports from ROP

$\operatorname{VROFIMP}(\mathrm{c}, \mathrm{r}) \quad=$ Total demand for ROP goods

$\operatorname{xrofimp}(\mathrm{c}, \mathrm{r}) \quad=$ Total demand for ROP goods 
(43)

E_xrofexptot (all,r,REG)

VROFEXPtot $(\mathrm{r}){ }^{*} x \operatorname{ROFEXPtot}(\mathrm{r})=\operatorname{sum}\left[\mathrm{c}, \mathrm{COM}, \mathrm{F}\left(\mathrm{c},{ }^{\prime R O P ", r}\right)^{*} \operatorname{xrofexp}(\mathrm{c}, \mathrm{r})\right.$ ];

VROFEXPtot $(\mathrm{r}) \quad=$ Exports to ROP

xROFEXPtot(r) = Exports to ROP

$\mathrm{F}(\mathrm{c}, " R O P$ ",r)

$\operatorname{xrofexp}(\mathrm{c}, \mathrm{r})$

$=$ Value of ROP consumption in Flow of data

$=$ Exports to ROP

$* * * * G D P * * * *$

(44)

E_xgdpexp

$($ all,r,REG) VGDPEXP(r)*xgdpexp(r) $=\operatorname{VHOUTOT}(\mathrm{r}) * \operatorname{xhoutot}(\mathrm{r})$

+ VINVTOT(r)*xinvtot(r)

$+\operatorname{sum}[\mathrm{g}, \mathrm{GVT}, \mathrm{VGOVTOT}(\mathrm{g}, \mathrm{r}) * \operatorname{xgovtot}(\mathrm{g}, \mathrm{r})$ ]

$+\operatorname{sum}\left[\mathrm{c}, \mathrm{COM}, \mathrm{F}\left(\mathrm{c},{ }^{\prime} S E R R^{\prime \prime}, \mathrm{r}\right) * \operatorname{xserr}(\mathrm{c}, \mathrm{r})\right.$ ]

+ VROFEXPtot(r)*xROFEXPtot(r) + VROWEXPtot(r)*xROWEXPtot(r)

- VROFIMPtot(r)*xrofimptot(r) - VROWIMPtot(r)*xrowimptot(r);

$\operatorname{VGDPEXP}(\mathrm{r}) \quad=$ Regional expenditure side GDP

$\operatorname{xgdpexp(r)}$

VHOUTOT(r)

$=$ Regional real expenditure side GDP

xhoutot(r)

$=$ Total spending by households

VINVTOT(r)

$=$ Real spending by the households

xinvtot(r)

$=$ Investment spending including tax

VGOVTOT $(\mathrm{g}, \mathrm{r})$

$=$ Real investment

xgovtot $(\mathrm{g}, \mathrm{r})$

$=$ Government spending on goods

$\mathrm{F}(\mathrm{c}$, "SERR",r)

$=$ Real government spending on goods

Xserr(c,r)

= Value of statistical error in Flow of data

VROFEXPtot(r)

= Statistical error (Armington composite)

xROFEXPtot(r)

$=$ Exports to ROP (nominal)

VROWEXPtot(r)

$=$ Exports to ROP (real)

xROWEXPtot(r)

$=$ Exports to ROW (nominal)

VROFIMPtot(r)

$=$ Exports to ROW (real)

xrofimptot(r)

$=$ Imports from ROP (nominal)

$=$ Imports from ROP (real)

VROWIMPtot(r)

= Imports from ROW (nominal)

xrowimptot(r)

= Imports from ROW (real) 
E_pgdpexp

(all,r,REG) VGDPEXP(r)*pgdpexp(r) = VHOUTOT(r)*phou(r)

$$
+\operatorname{VINVTOT}(r) * \operatorname{pinv}(r)
$$

$+\operatorname{sum}\{\mathrm{g}, \mathrm{GVT}, \mathrm{VGOVTOT}(\mathrm{g}, \mathrm{r}) * \operatorname{pgov}(\mathrm{g}, \mathrm{r})\}$

$+\operatorname{sum}\left[\mathrm{c}, \mathrm{COM}, \mathrm{F}\left(\mathrm{c},{ }^{\prime S E R R ", r}\right) * \operatorname{parm}(\mathrm{c}, \mathrm{r})\right.$ ]

$+\operatorname{sum}\left\{\mathrm{c}, \mathrm{COM}, \mathrm{F}\left(\mathrm{c},{ }^{\prime} R O P^{\prime \prime}, \mathrm{r}\right){ }^{*} \operatorname{prof}(\mathrm{COM} 2 \mathrm{ROF}(\mathrm{c}))+\mathrm{F}\left(\mathrm{c},{ }^{\prime} R O W^{\prime \prime}, \mathrm{r}\right){ }^{*} \operatorname{prowexp}(\mathrm{c})\right\}$

- $\operatorname{sum}\{\mathrm{c}, \operatorname{ROP}, \operatorname{VROFIMP}(\mathrm{c}, \mathrm{r}) * \operatorname{prof}(\mathrm{c})\}$ - VROWIMPtot(r)*prowimp;

$\begin{array}{ll}\text { VGDPEXP(r) } & =\text { Regional expenditure side GDP } \\ \operatorname{pgdpexp}(\mathrm{r}) & =\text { Price index of regional expenditure side GDP } \\ \text { VHOUTOT(r) } & =\text { Total spending by households } \\ \operatorname{phou}(\mathrm{r}) & =\text { Consumer price index } \\ \text { VINVTOT(r) } & =\text { Investment spending including tax } \\ \operatorname{pinv}(\mathrm{r}) & =\text { Investment price index including tax } \\ \text { VGOVTOT(g,r) } & =\text { Government spending on goods } \\ \operatorname{pgov}(\mathrm{g}, \mathrm{r}) & =\text { Government price index } \\ \left.\text { F(c, } S E R R^{\prime \prime}, \mathrm{r}\right) & =\text { Value of statistical error in Flow of data } \\ \operatorname{parm}(\mathrm{c}, \mathrm{r}) & =\text { Price of Armington composite } \\ \left.\text { F(c, } R O P^{\prime \prime}, \mathrm{r}\right) & =\text { Value of ROP consumption in Flow of data } \\ \operatorname{prof}(\mathrm{COM} 2 \mathrm{ROF}(\mathrm{c})) & =\text { Price, ROP good } \\ \operatorname{prowexp}(\mathrm{c}) & =\text { Price, exports to ROW (in POL currency) } \\ \text { VROFIMP(c,r) } & =\text { Total demand for ROP goods } \\ \text { VROWIMPtot(r) } & =\text { Imports from ROW } \\ \text { prowimp } & =\text { Price of imports (POL currency) }\end{array}$

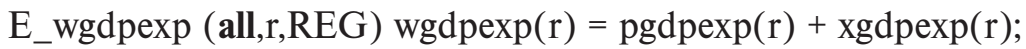

$\operatorname{wgdpexp}(\mathrm{r}) \quad=$ Regional nominal expenditure side GDP

$\operatorname{pgdpexp}(r) \quad=$ Price index of regional expenditure side GDP

$\operatorname{xgdpexp}(\mathrm{r}) \quad=$ Regional real expenditure side GDP

E_wgdpinc

(all,r,REG) $0.01 * \operatorname{VGDPINC}(r) * \operatorname{wgdpinc}(r)=\operatorname{delHOUTAX}(r)+\operatorname{delINVTAX}(r)$

$+\operatorname{sum}[\mathrm{i}, \mathrm{IND}, \operatorname{delPRIM}(\mathrm{i}, \mathrm{r})+\operatorname{delPRDTAX}(\mathrm{i}, \mathrm{r})\}$; 


$\begin{array}{ll}\text { VGDPINC(r) } & =\text { Regional nominal income side GDP } \\ \operatorname{wgdpinc}(\mathrm{r}) & =\text { Regional nominal income side GDP } \\ \operatorname{delHOUTAX}(\mathrm{r}) & =\text { Change, tax on ARM and ROP goods used by } \\ & \text { households } \\ \text { delINVTAX(r) } & =\text { Change, tax on investment } \\ \text { delPRIM(i,r) } & =\text { Ordinary change, cost of primary factors } \\ \text { delPRDTAX }(\mathrm{i}, \mathrm{r}) & =\text { Change, production tax revenue }\end{array}$

E_wgdpdif (all,r,REG) wgdpdif(r) = wgdpexp(r) - wgdpinc(r);

wgdpdif(r) = Nominal GDP check.. should be tiny

$\operatorname{wgdpexp}(\mathrm{r}) \quad=$ Regional nominal expenditure side GDP

$\operatorname{wgdpinc}(\mathrm{r}) \quad=$ Regional nominal income side GDP

$* * * *$ Add up regional results $* * * *$
E_xtot_r (all,i,IND) sum $\left\{r, \operatorname{REG}, \operatorname{VPRIM}(\mathrm{i}, \mathrm{r}) *\left[\operatorname{xtot}(\mathrm{i}, \mathrm{r})-\operatorname{xtot} \_r(\mathrm{i})\right]\right\}=0$;
$\operatorname{VPRIM}(\mathrm{i}, \mathrm{r}) \quad=$ Total factor input to industry $\mathrm{i}$
$\operatorname{xtot}(\mathrm{i}, \mathrm{r}) \quad=$ Industry output
xtot_r(i) = National industry output

E_xrowexp_r (all,c,COM) $\operatorname{sum}\left\{r, \operatorname{REG}, \operatorname{ID01}\left[\mathrm{F}\left(\mathrm{c}, " R O W^{\prime \prime}, \mathrm{r}\right)\right]^{*}\left[\operatorname{xrowexp}(\mathrm{c}, \mathrm{r})-\operatorname{xrowexp} \_\mathrm{r}(\mathrm{c})\right]\right\}=0$;

$\mathrm{F}\left(\mathrm{c}, " R O W^{\prime \prime}, \mathrm{r}\right)$ = Value of ROW consumption in Flow of data $\operatorname{xrowexp}(\mathrm{c}, \mathrm{r}) \quad=$ Exports to ROW xrowexp_r $r(c)=$ National exports

E_xgdpexp_r sum $\left[r, R E G, \operatorname{VGDPEXP}(r) *\left[\operatorname{xgdpexp}(r)-\operatorname{xgdpexp} \_r\right]\right\}=0$;

$\operatorname{VGDPEXP}(\mathrm{r})$ = Regional expenditure side GDP

$\operatorname{xgdpexp}(r) \quad=$ Regional real expenditure side GDP

xgdpexp_r $\quad=$ National real expenditure side GDP 
E_phou_rsum $[r, R E G, \operatorname{VHOUTOT}(r) *[\operatorname{phou}(r)-$ phou_r $]]=0$;

VHOUTOT(r) = Total spending by households

phou(r) $=$ Consumer price index

phou_r $\quad=$ National consumer price index

(53)

**** Factor income and household consumption ****

E_wfacinc (all,r,REG) VFACINC(r)*wfacinc(r)

$=\operatorname{sum}[\mathrm{i}, \mathrm{IND}, \mathrm{F}($ "Labour",i,r) *[xlab(i,r) + plab(i,r)]

$+\mathrm{F}($ "Capital",i,r)*[xcap(i,r) + pcap $(\mathrm{i}, \mathrm{r})]\}$;

VFACINC(r) = Factor income by region

wfacinc $(\mathrm{r}) \quad=$ Factor income by region

$\mathrm{F}($ "Labour",i,r) = Value of labour in Flow of data

xlab(i,r) = Quantity of labour demanded

$\operatorname{plab}(\mathrm{i}, \mathrm{r}) \quad=$ Labour wage to worker

$\mathrm{F}($ "Capital",i,r) = Value of capital in Flow of data

xcap (i,r) = Quantity of capital demanded

pcap $(\mathrm{i}, \mathrm{r}) \quad=$ Capital wage to owner

E_whou (all,r,REG) whou(r) = wfacinc(r) + fhou(r);

whou(r) = Spending by households

wfacinc $(\mathrm{r}) \quad=$ Factor income by region

fhou(r) $\quad=$ Propensity to consume

****Labour Union set real wage too high which causes unemployment **** (55)

E_plab (all,i,IND)(all,r,REG)

plab(i,r) - phou_r = flab $(i, r)+$ flab_r(i) + flab_i $(r)+$ flab_ir;

$\operatorname{plab}(\mathrm{i}, \mathrm{r}) \quad=$ Labour wage to worker

phou_r $\quad=$ National consumer price index

flab $(\mathrm{i}, \mathrm{r}) \quad=$ Real wage shifter

flab_r(i) $\quad=$ Real wage shifter 
$\begin{array}{ll}\text { flab_i(r) } & =\text { Real wage shifter } \\ \text { flab_ir } & =\text { Real wage shifter }\end{array}$

$* * * *$ Labour force and unemployment $* * * *$

E_employ (all,r,REG) sum $[\mathrm{i}, \mathrm{IND}, \operatorname{EMPLOYED}(\mathrm{i}, \mathrm{r}) *[\operatorname{employ}(\mathrm{r})-\mathrm{xlab}(\mathrm{i}, \mathrm{r})]]=0$;

EMPLOYED(i,r) = No of employed persons

employ $(r) \quad=$ No of employed persons

xlab(i,r) = Quantity of labour demanded

(57)

E_delUNEMPRAT (all,r,REG) delUNEMPRAT(r) =

0.01 *[EMPLOYED_I(r)/LABFORCE(r)]*[labrforce(r) - employ(r)];

delUNEMPRAT(r) = Change, unemployment rate $(\mathrm{eg}, 0.01)$

EMPLOYED_I $(r) \quad=$ No of employed persons

$\mathrm{LABFORCE}(\mathrm{r}) \quad=$ No of potential employed persons

labrforce(r) = Labour force

employ $(\mathrm{r}) \quad=$ No of employed persons

(58)

$* * * *$ Net Migration and unemployment rate $* * * *$

E_delNETMIGRATE (all,r,REG) delNETMIGRATE(r) $=0.00013 *[\operatorname{xgdpexp}(r)$

- labrforce(r)]

- $0.008 *$ delUNEMPRAT $(r)+$ dlambda;

delNETMIGRATE(r) = NETMIG(r)/LABFORCE0(r)

NETMIG(r) = Labour force persons moving to $r$ from another region

$\mathrm{LABFORCE0}(\mathrm{r}) \quad=$ Base level labor force

$\operatorname{xgdpexp}(\mathrm{r}) \quad=$ Regional real expenditure side GDP

labrforce $(r) \quad=$ Labour force

delUNEMPRAT(r) = Change, unemployment rate $(\mathrm{eg}, 0.01)$

dlambda $\quad=$ Slack variable

(59)

E_delNETMIG (all,r,REG) delNETMIG(r) = LABFORCE0(r)*delNETMIGRATE(r); 


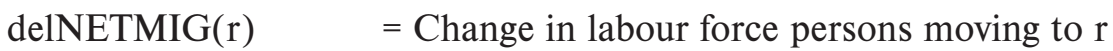

LABFORCE0 $(r)=$ Base level labor force

deINETMIGRATE(r) = NETMIG(r)/LABFORCE0(r)

NETMIG(r) = Labour force persons moving to $\mathrm{r}$ from another region

$\mathrm{LABFORCE0}(\mathrm{r})=$ Base level labor force

(60)

E_lambda sum $\{r, R E G$, delNETMIG(r) $\}=0$;

$\operatorname{delNETMIG}(\mathrm{r}) \quad=$ Change in labour force persons moving to $\mathrm{r}$

(61)

E_labrforce (all,r,REG) 0.01 *LABFORCE(r)*labrforce(r) = delNETMIG(r);

$\mathrm{LABFORCE}(\mathrm{r}) \quad=$ Labour force

labrforce(r) = Labour force

$\operatorname{delNETMIG(r)} \quad=$ Change in labour force persons moving to $\mathrm{r}$ 


\section{Aneks 3.3. Podstawowe zmienne W modelu RegPOL}

\begin{tabular}{|c|c|c|c|}
\hline & Zmienna & Rozmiar & Nazwa \\
\hline & 1 & 2 & 3 \\
\hline 1 & Makra & $\mathrm{I}$ & Zmienne skalarne (tylko jeden element) \\
\hline 2 & acap & IND*REG & $\begin{array}{l}\text { Postęp techniczny zwiększający intensywność } \\
\text { wykorzystania kapitału }\end{array}$ \\
\hline 3 & alab & IND*REG & $\begin{array}{l}\text { Postęp techniczny zwiększający intensywność } \\
\text { wykorzystania pracy }\end{array}$ \\
\hline 4 & aprim & $\mathrm{IND} * \mathrm{REG}$ & $\begin{array}{l}\text { Postęp techniczny zwiększający intensywność } \\
\text { wykorzystania podstawowych czynników produkcji }\end{array}$ \\
\hline 5 & atot & IND*REG & $\begin{array}{l}\text { Postęp techniczny zwiększający intensywność } \\
\text { wykorzystaniawszystkich czynników produkcji }\end{array}$ \\
\hline 6 & deICAPTAX & IND*REG & Zmiana, dochody z podatku od kapitału \\
\hline 7 & deICAPTAXRATE & IND*REG & Zmiana, stawka podatku od kapitału \\
\hline 8 & deIHOUTAX & REG & $\begin{array}{l}\text { Podatek od dóbr Armingtona i ROP wykorzystywanych } \\
\text { przez gospodarstwa domowe }\end{array}$ \\
\hline 9 & deIHOUTAXRATE & REG & $\begin{array}{l}\text { Stawka podatku, dobra Armingtona i ROP } \\
\text { dla gospodarstw domowych }\end{array}$ \\
\hline 10 & deIINVTAX & REG & Podatek od inwestycji \\
\hline 11 & deIINVTAXRATE & REG & $\begin{array}{l}\text { Stawka podatku od dóbr wykorzystywanych w ramach } \\
\text { inwestycji }\end{array}$ \\
\hline 12 & deILABTAX & IND*REG & Zmiana, dochody z podatku od pracy \\
\hline 13 & deILABTAXRATE & IND*REG & Zmiana, stawka podatku od pracy \\
\hline 14 & deINETMIG & REG & $\begin{array}{l}\text { Zmiana w liczbie osób w wieku produkcyjnym } \\
\text { napływających do regionu }\end{array}$ \\
\hline 15 & deINETMIGRATE & REG & NETMIG(r)/L,ABFORCEO(r) \\
\hline 16 & deIPRDTAX & IND*REG & Zmiana, dochody z podatku od produkcji \\
\hline 17 & deIPRDTAXRATE & IND*REG & Zmiana, stawka podatku od produkcji \\
\hline 18 & deIPRIM & IND*REG & Zmiana, cena podstawowych czynników produkcji \\
\hline 19 & deIUNEMPRAT & REG & Zmiana, stopa bezrobocia \\
\hline 20 & employ & REG & Wielkość zatrudnienia \\
\hline 21 & thou & REG & Skłonność do konsumpcji \\
\hline 22 & flab & IND*REG & Zmienna przełącznikowa w równaniu na płace realne \\
\hline 23 & flab_i & REG & Zmienna przełącznikowa w równaniu na płace realne \\
\hline 24 & flab_r & IND & Zmienna przełącznikowa w równaniu na płace realne \\
\hline 25 & labrforce & REG & Siła robocza \\
\hline 26 & pact & $\mathrm{IND} * \mathrm{REG}$ & Cena kompozycji ACT* \\
\hline 27 & parm & $\mathrm{COM} * \mathrm{REG}$ & Cena kompozycji Armingtona \\
\hline 28 & parmhpt & $\mathrm{COM} * \mathrm{REG}$ & $\begin{array}{l}\text { Cena łącznie z podatkiem, dobra ROP dla gospodarstw } \\
\text { domowych }\end{array}$ \\
\hline
\end{tabular}




\begin{tabular}{|c|c|c|c|}
\hline & 1 & 2 & 3 \\
\hline 29 & pcap & IND*REG & Cena kapitału dla właściciela \\
\hline 30 & pcappt & IND*REG & Cena kapitału ponoszona przez przedsiębiorstwo \\
\hline 31 & pcost & IND*REG & $\begin{array}{l}\text { Nakłady ponoszone przez przemysł (z wyłączeniem } \\
\text { podatku od produkcji) }\end{array}$ \\
\hline 32 & pfin & IND*REG & Cena dóbr „POL” (polskich) \\
\hline 33 & pgdpexp & REG & Deflator PKB \\
\hline 34 & pgov & $\mathrm{GVT}^{*} \mathrm{REG}$ & Indeks cen rządowych \\
\hline 35 & phou & REG & Wskaźnik cen konsumpcyjnych \\
\hline 36 & pinv & REG & $\begin{array}{l}\text { Wskaźnik cen dla zakupów inwestycyjnych (łącznie } \\
\text { z podatkiem) }\end{array}$ \\
\hline 37 & pinvex & REG & $\begin{array}{l}\text { Wskaźnik cen dla zakupów inwestycyjnych (z wyłączeniem } \\
\text { podatku) }\end{array}$ \\
\hline 38 & plab & IND*REG & Wynagrodzenie dla pracownika \\
\hline 39 & plabpt & IND*REG & $\begin{array}{l}\text { Koszty wynagrodzenia dla pracownika ponoszone przez } \\
\text { przedsiębiorstwo }\end{array}$ \\
\hline 40 & pprim & IND*REG & Cena efektywna, kompozycja podst. czynników produkcji \\
\hline 41 & prof & ROF & Cena dóbr z pozostałej części Polski (ROP) \\
\hline 42 & profhpt & ROF*REG & Cena łącznie z podatkiem, dobra ROP dla gosp. dom. \\
\hline 43 & prowexp & $\mathrm{COM}$ & Cena, eksport do ROW (w mln PLN) \\
\hline 44 & ptot & IND*REG & Cena produktu (łącznie z podatkiem od produkcji) \\
\hline 45 & wfacinc & REG & Dochód z czynników produkcji wg regionów \\
\hline 46 & wgdpdif & REG & Suma kontrolna PKB w ujęciu nominalnym \\
\hline 47 & wgdpexp & REG & PKB od strony nominalnych wydatków regionalnych \\
\hline 48 & wgdpinc & REG & PKB od strony nominalnych dochodów regionalnych \\
\hline 49 & wgovtot & $\mathrm{GVT}^{*} \mathrm{REG}$ & Wydatki administracji publicznej na dobra i usługi \\
\hline 50 & whou & REG & Wydatki gospodarstw domowych \\
\hline 51 & winvtot & REG & Wydatki inwestycyjne łącznie z podatkiem \\
\hline 52 & xact & IND*REG & Wielkość produkcji - kompozycja ACT* \\
\hline 53 & xarm & $\mathrm{COM} * \mathrm{REG}$ & Wielkość produkcji - kompozycja dóbr Armingtona \\
\hline 54 & xcap & IND*REG & Zapotrzebowanie na kapitał \\
\hline 55 & xfin & IND*REG & Wykorzystanie dóbr POL \\
\hline 56 & xgdpexp & REG & PKB od strony realnych wydatków regionalnych \\
\hline 57 & xgov & $\mathrm{COM}^{*} \mathrm{GVT}^{*} \mathrm{REG}$ & $\begin{array}{l}\text { Popyt ze strony administracji centralnej i lokalnej } \\
\text { na kompozycję dóbr Armingtona }\end{array}$ \\
\hline 58 & xgovtot & GVT*REG & Realne wydatki administracji publicznej na dobra \\
\hline 59 & xhou & COM*REG & $\begin{array}{l}\text { Popyt ze strony gosp. dom. na kompozycję dóbr } \\
\text { Armingtona }\end{array}$ \\
\hline 60 & xhoutot & REG & Realne wydatki gospodarstw domowych \\
\hline 61 & xhrof & $\mathrm{ROF}^{*} \mathrm{REG}$ & Dobra ROP wykorzystywane przez gospodarstwa domowe \\
\hline 62 & xhrow & REG & Dobra ROW wykorzystywane przez gospodarstwa domowe \\
\hline
\end{tabular}


Aneksy do rozdziału 3

\begin{tabular}{|c|c|c|c|}
\hline & 1 & 2 & 3 \\
\hline 63 & xint & $\mathrm{COM} * \mathrm{IND} * \mathrm{REG}$ & Popyt przemysłu na kompozycję dóbr Armingtona \\
\hline 64 & xinv & COM*REG & Popyt inwestycyjny na kompozycję dóbr Armingtona \\
\hline 65 & xinvtot & REG & Realna wartość inwestycji \\
\hline 66 & xirof & ROF*REG & Dobra ROP wykorzystywane w ramach inwestycji \\
\hline 67 & xirow & REG & Dobra ROW wykorzystywane w ramach inwestycji \\
\hline 68 & xlab & IND*REG & Zapotrzebowanie na siłę roboczą \\
\hline 69 & xprim & IND*REG & Ilość, kompozycja podstawowych czynników produkcji \\
\hline 70 & xrofexp & COM*REG & Eksport do ROP wg sektorów i regionów \\
\hline 71 & xROFEXPtot & REG & Eksport do ROP wg regionów \\
\hline 72 & xrofimp & ROF*REG & Całkowity popyt na dobra ROP \\
\hline 73 & xrofimpf & ROF*REG & Wykorzystanie dóbr ROP przez przedsiębiorstwa \\
\hline 74 & xROFIMPtot & REG & Import z ROP \\
\hline 75 & xrowexp & $\mathrm{COM} * \mathrm{REG}$ & Eksport do ROP \\
\hline 76 & xrowexp_r & $\mathrm{COM}$ & Eksport do ROP \\
\hline 77 & xROWEXPtot & REG & Eksport do ROW \\
\hline 78 & Xrowimp & IND*REG & Import z ROW wykorzystywany przez przedsiębiorstwa \\
\hline 79 & xROWIMPtot & REG & Import z ROW \\
\hline 80 & xserr & $\mathrm{COM} * \mathrm{REG}$ & Błąd statystyczny (kompozycja dóbr Armingtona) \\
\hline 81 & xtot & IND*REG & Produkcja przemysłowa \\
\hline 82 & xtot_r & IND & Krajowa produkcja przemysłowa \\
\hline
\end{tabular}

* ACT to kompozycja dóbr „POL” i importu zagranicznego oparta na funkcji CES

Źródło: Opracowanie własne na postawie modelu RegPOL. 


\section{ANEKS 3.4. DOMKNIĘCIE MAKROEKONOMICZNE MODELU}

! Automatic closure

! Variable Size

Exogenous acap ;! IND*REG Capital-augmenting technical change

Exogenous alab;! IND*REG Labor-augmenting technical change

Exogenous alnd;! IND*REG Land-augmenting technical change

Exogenous aprim;! IND*REG Primary-factor-augmenting tech change

Exogenous atot;! IND*REG All-input-augmenting technical change

Exogenous delCAPTAXRATE; ! IND*REG Change, capital tax rate

Exogenous delHOUTAXRATE;! REG Tax rate, Arm and ROP goods to hou

Exogenous delINVTAXRATE;! REG Tax rate on goods used by INV

Exogenous delLABTAXRATE; ! IND*REG Change, labour tax rate

Exogenous delLNDTAXRATE;! IND*REG Change, land tax rate

Exogenous delPRDTAXRATE;! IND*REG Change, prod tax rate

Exogenous fgov;! COM*GVT*REG Gov. demand shift variable

Exogenous fgov_c;! GVT*REG Gov. demand shift variable

Exogenous fgov_cgr;! 1 Gov. demand shift variable

Exogenous fgov_cr;! GVT Gov. demand shift variable

Exogenous fhou;! REG Propensity to consume

Exogenous flab;! IND*REG Real wage shifter

Exogenous flab_i;!REG Real wage shifter

Exogenous flab_ir;! 1 Real wage shifter

Exogenous flab_r;! IND Real wage shifter

Exogenous fxserr ; COM*REG Xserr shift variable

Exogenous prowexp ; ! COM Price, exports to ROW, POL currency

Exogenous prowimp;! 1 Price of imports (POL currency)

Exogenous xcap ;! IND*REG Quantity of capital demanded

Exogenous xlnd ;! IND*REG Quantity of land(resource) demanded

Exogenous xinv ; ! COM*REG Investment demand for Armington composite

Exogenous xirof ; $R O F^{*} R E G \quad R O P$ goods used by investment 
Exogenous xirow;! REG ROW goods for investment Rest endogenous; ! end of TABmate automatic closure

! Changes made to Automatic closure to obtain LR closure

! LABOR - exogenous in long run

swap flab_ir=xlab_ir;

!CAPITAL - endogenous in long run swap pcap $($ NonAgric,REG) = xcap (NonAgric,REG);

!swap pcap $=$ xcap;

! LAND - exogenous as specified in the automatic closure above "xlnd"

! Changes made to Automatic closure to obtain macroeconomic environment

! GOVERNMENT budget is exogenous (budget constraint)

swap fgov = xgov; ! real gov demand for Armingoton fixed

swap fgov_c $=x$ govtot; ! real gov spending fixed

! Investments xinv are exogenous

! Additional changes are made based on measure-by-measure simulations

Źródło: Zapis z modelu RegPOL. 


\section{Aneksy do rozdziału 4}

\section{ANEKS 4.1. WPŁYW POLITYKI ROW 2004-2006 NA POSZCZEGÓLNE SEKTORY GOSPODARKI}
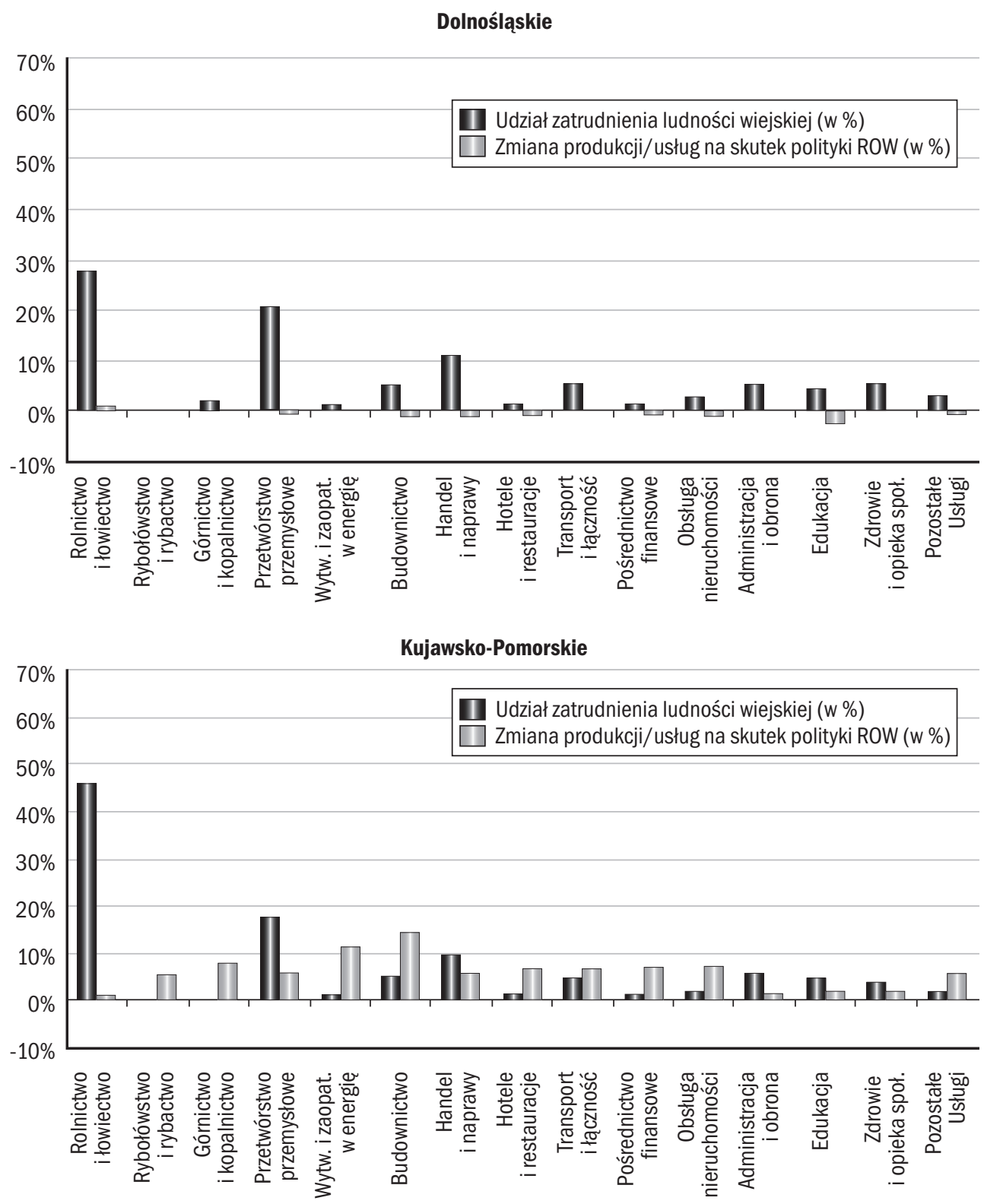


\section{Łódzkie}

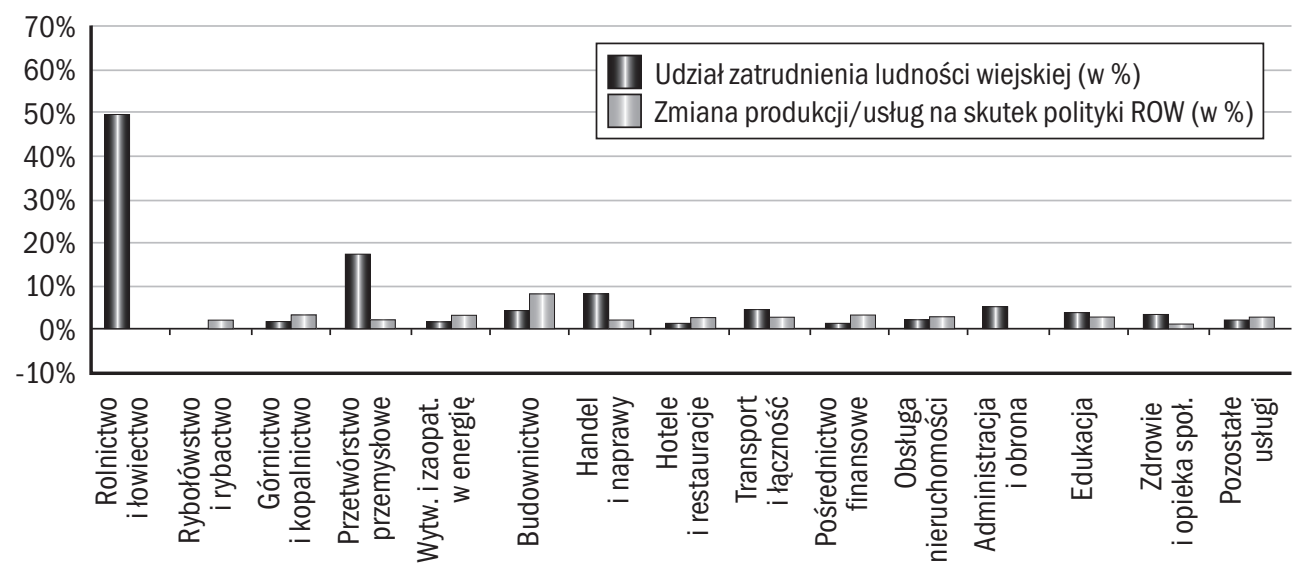

Małopolskie

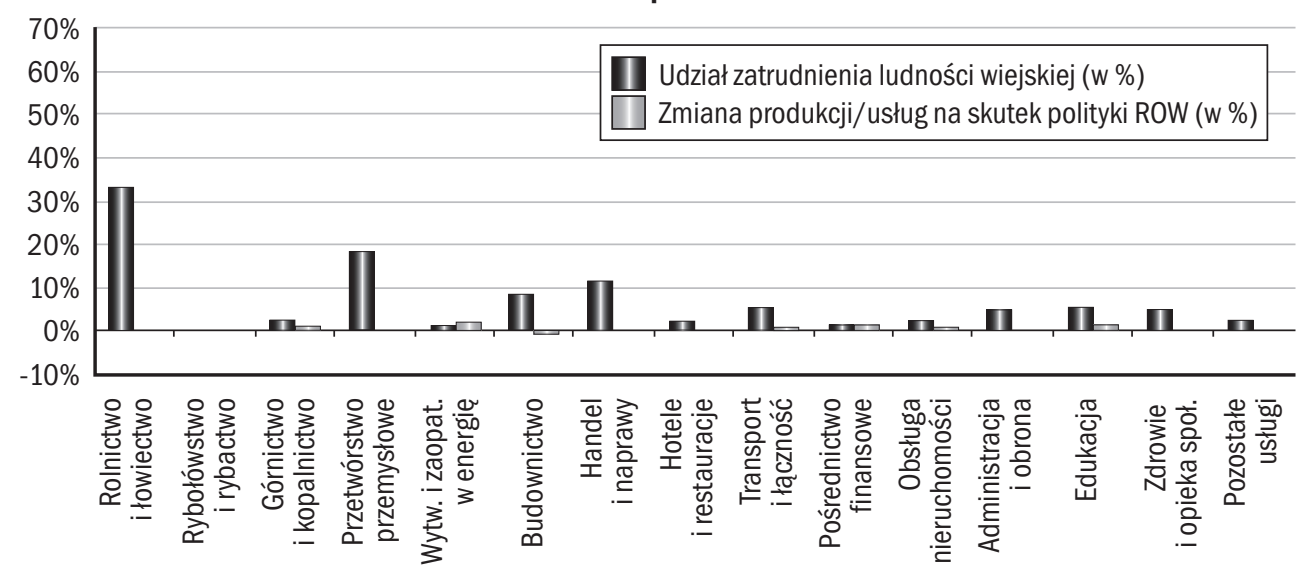

Mazowieckie

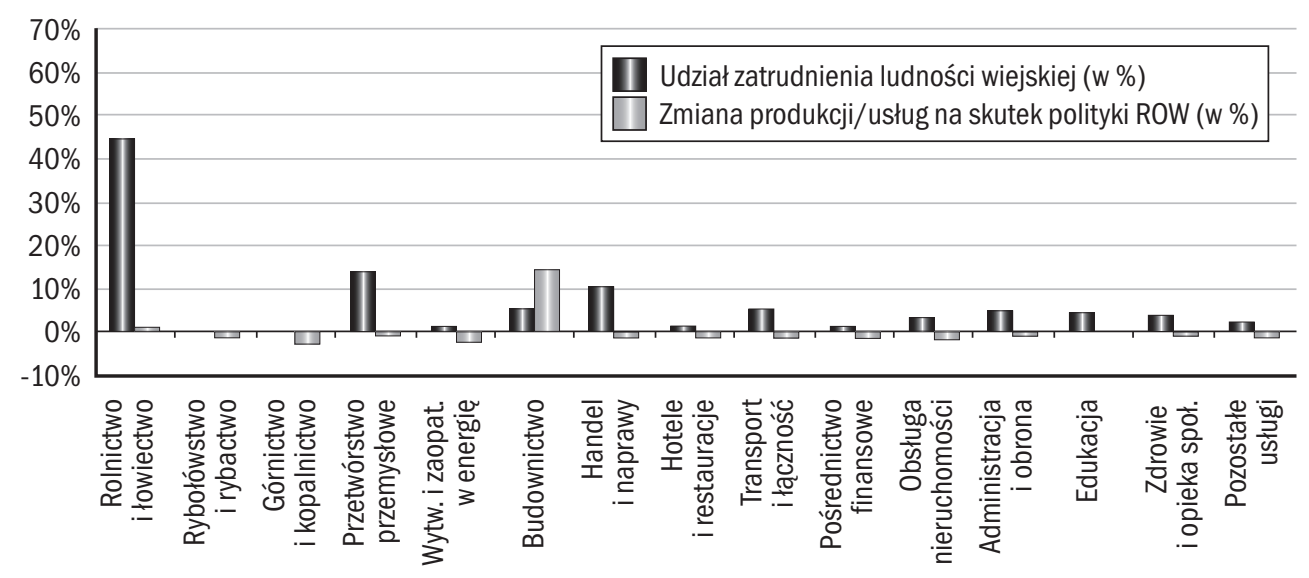




\section{Opolskie}

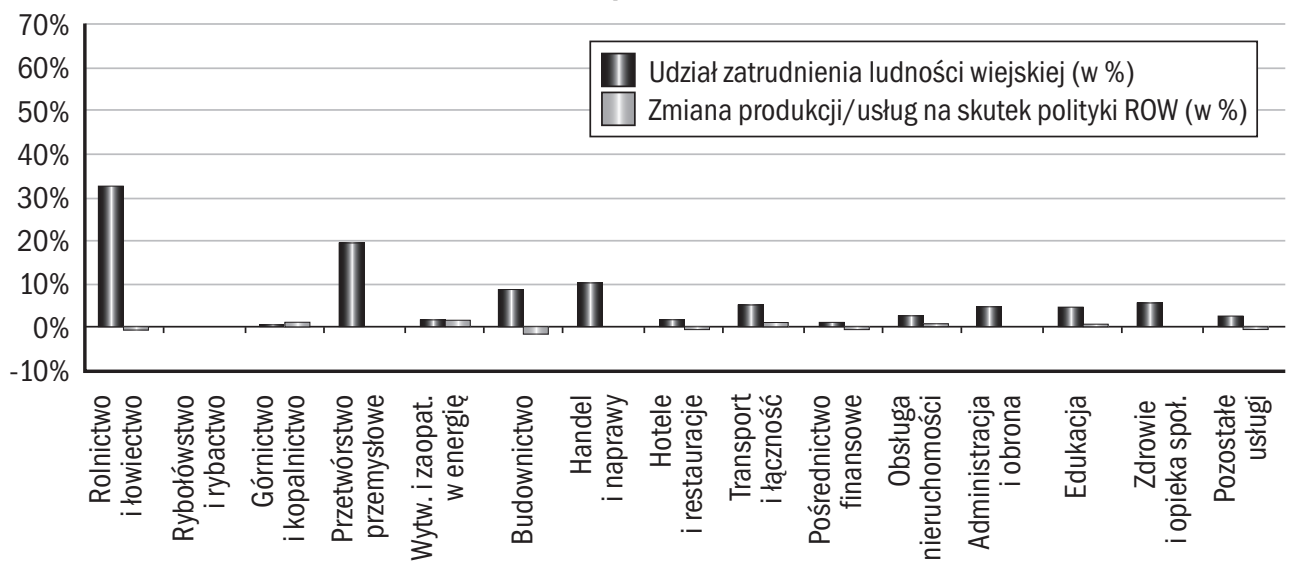

Podkarpackie

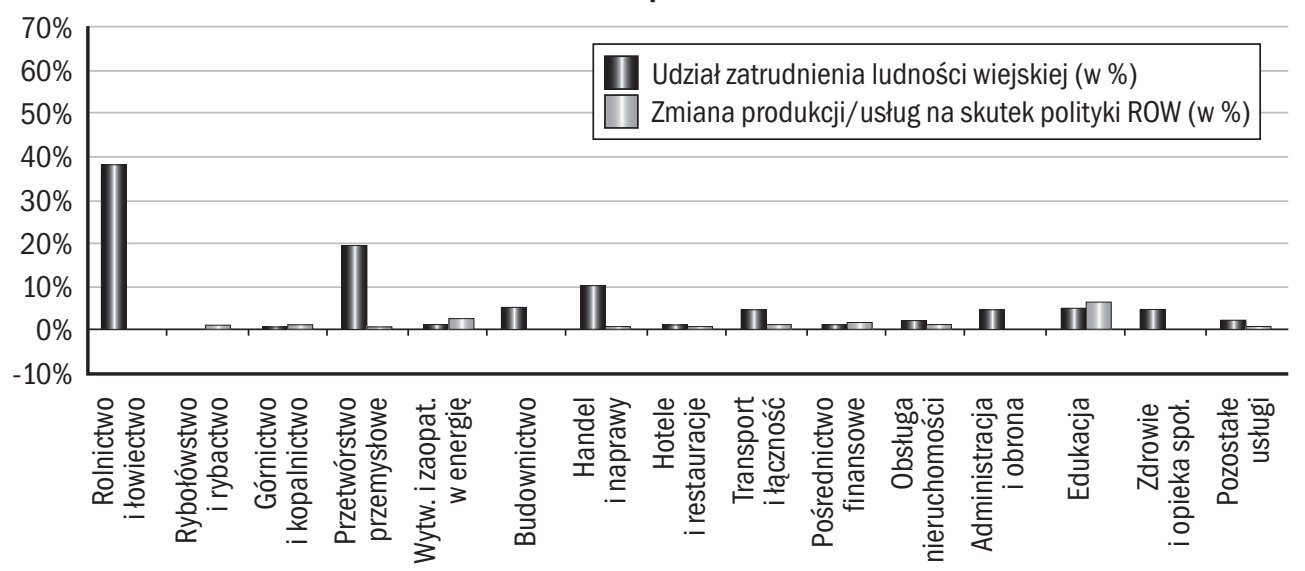

Podlaskie

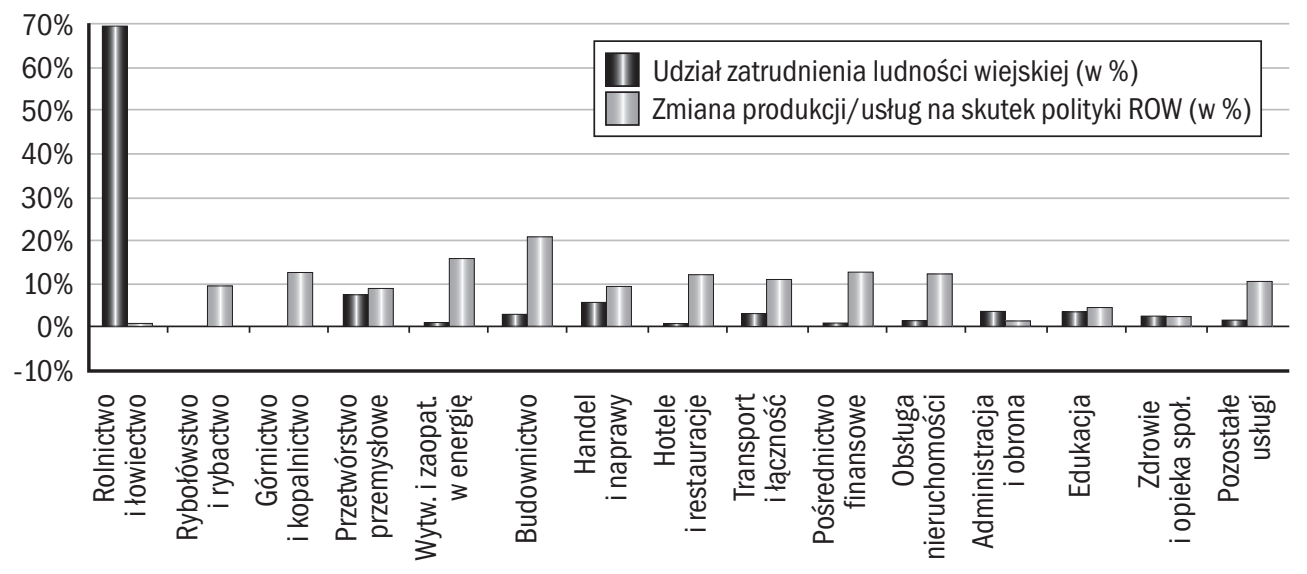




\section{Pomorskie}

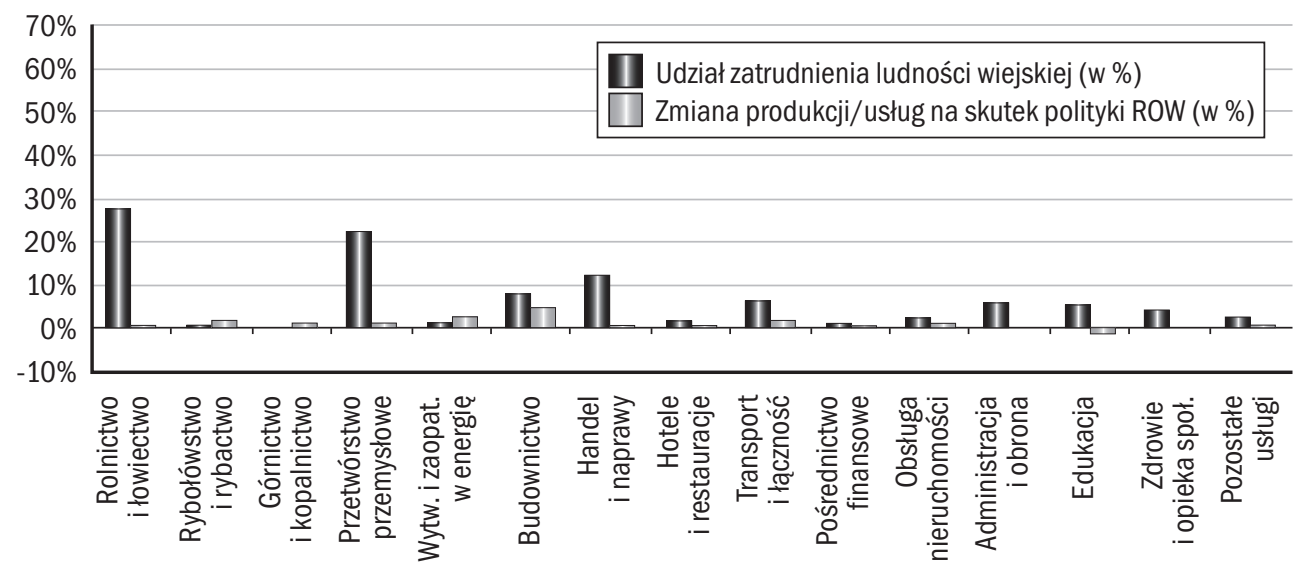

Śląskie

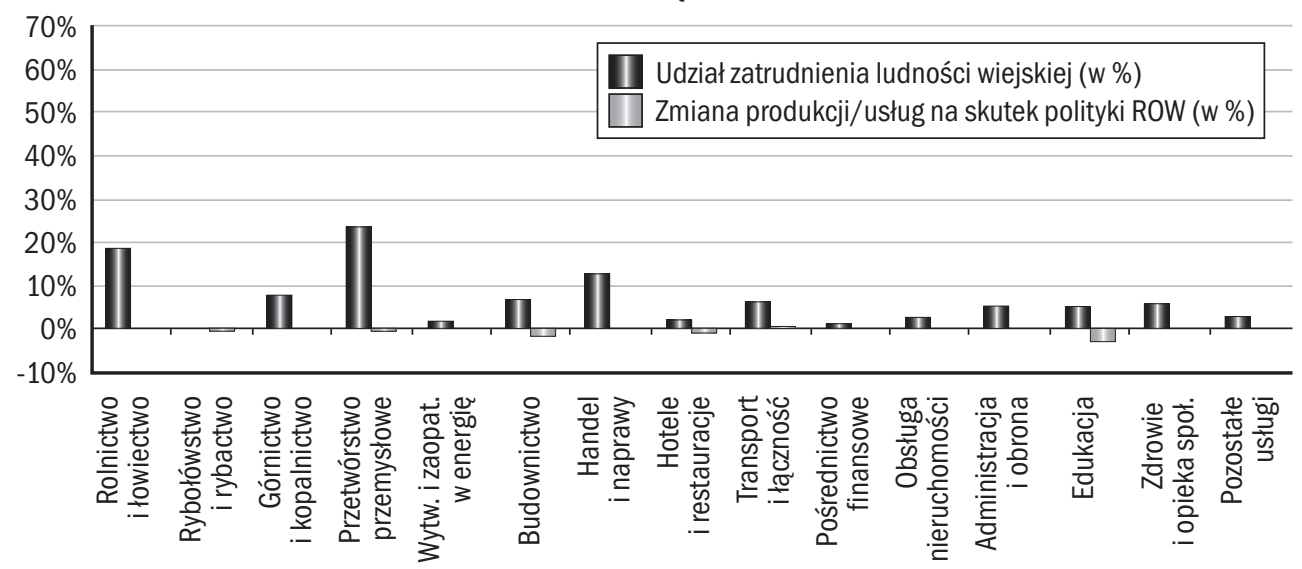

Świętokrzyskie

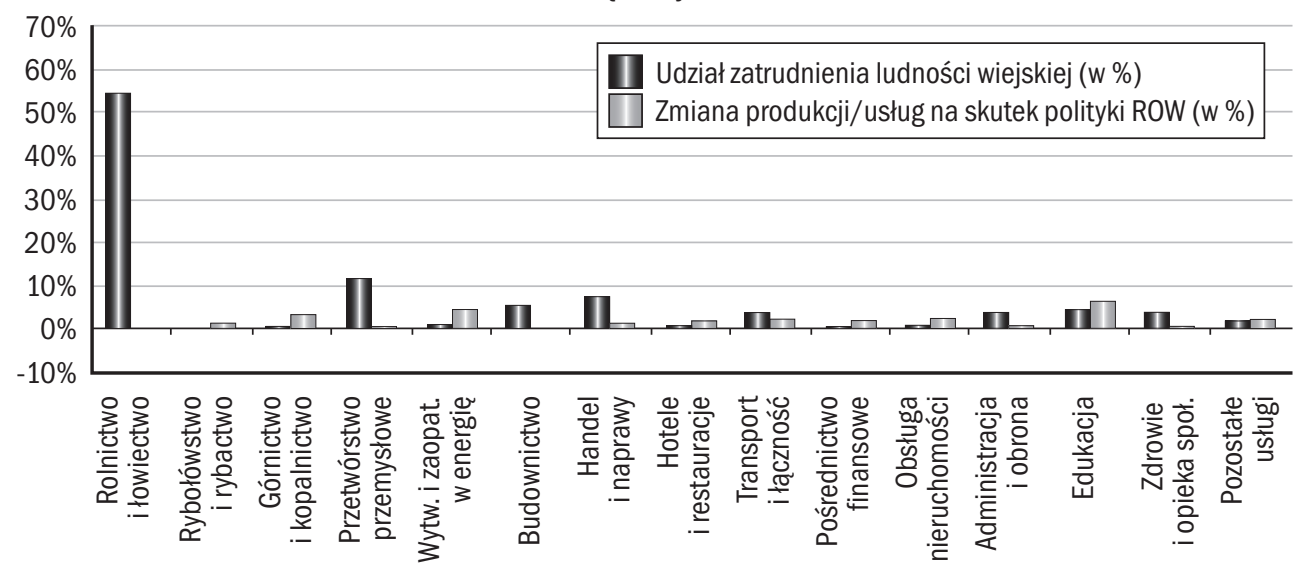




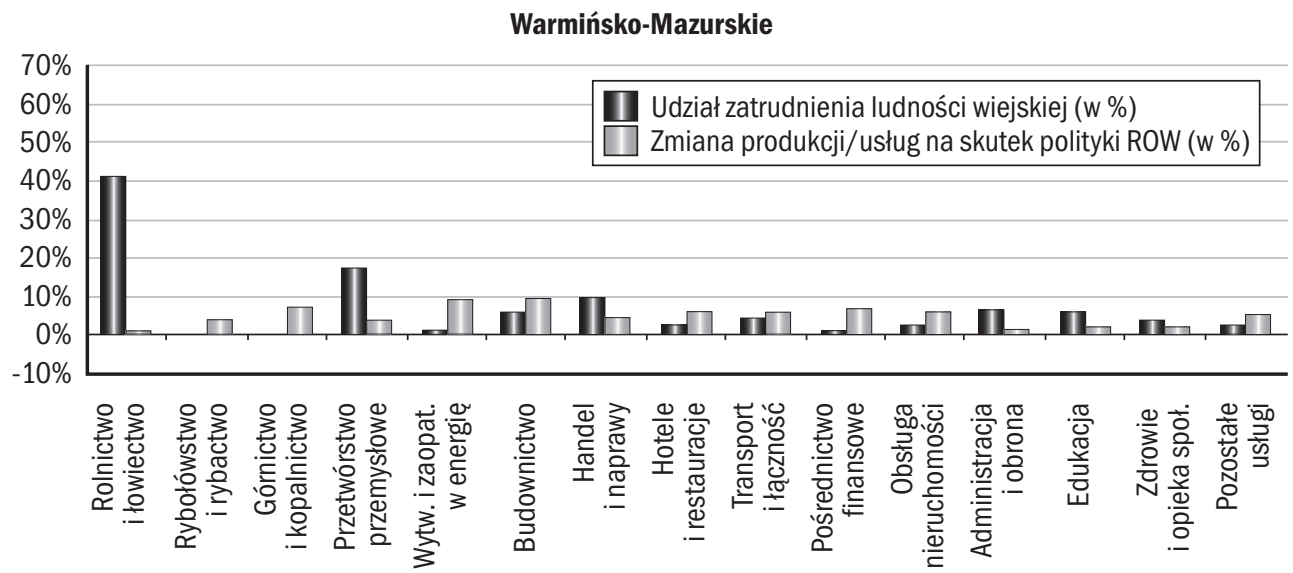

Wielkopolskie

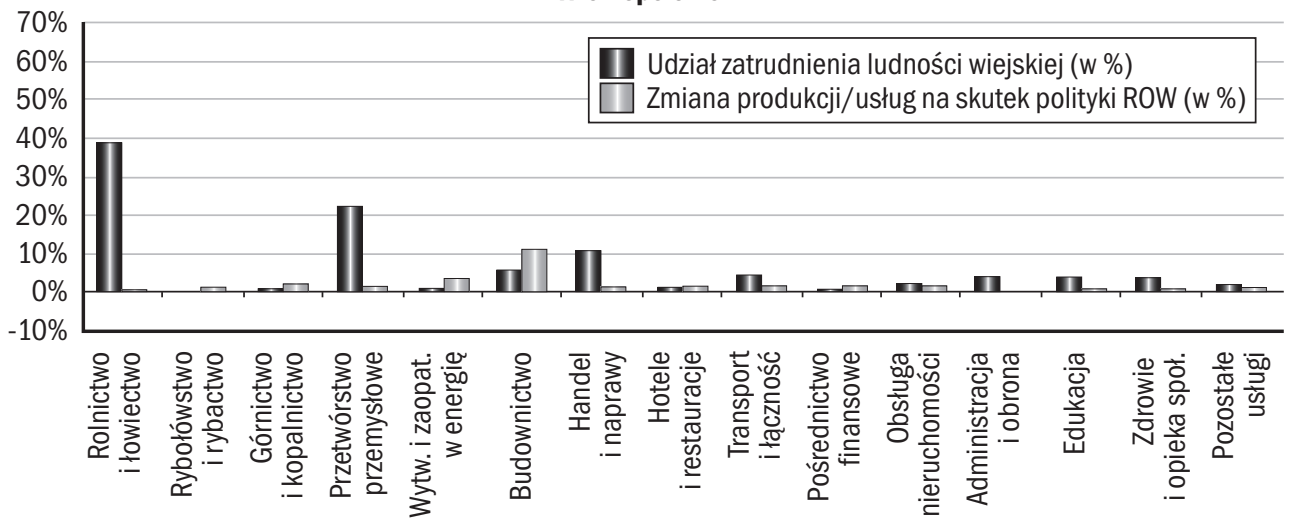

Zachodniopomorskie

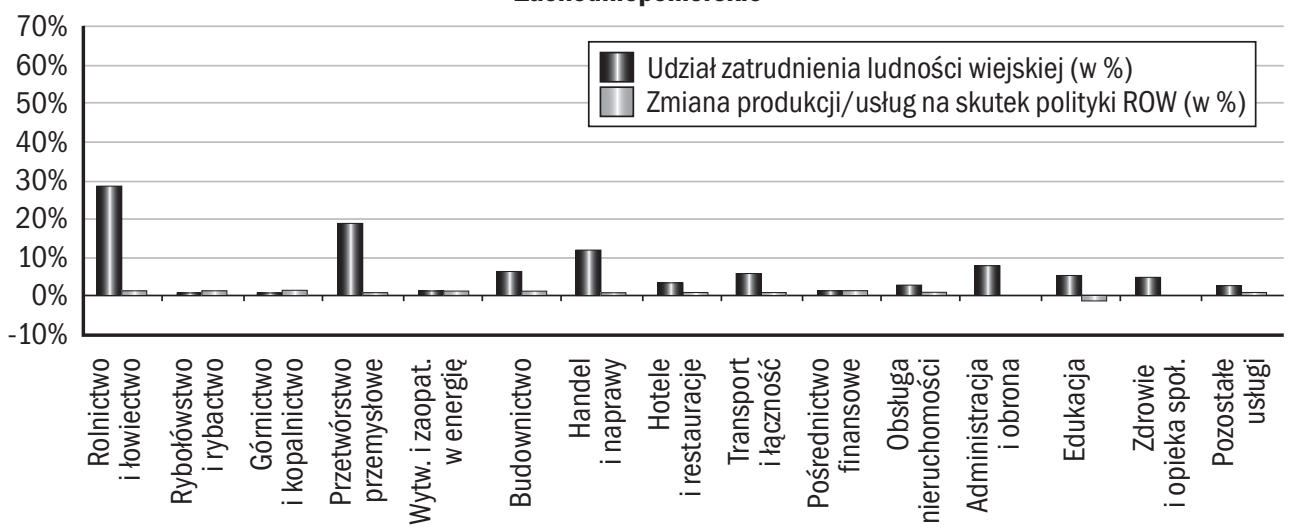

Rysunek A.4.1. Efekty mnożnikowe w zakresie produkcji i zatrudnienia ludności wiejskiej na skutek polityki ROW realizowanej w latach 2004-2006 wg województw

Źródło: Opracowanie własne na podstawie modelu RegPOL. 


\title{
WYKAZ SKRÓTÓW ZE SŁOWNICZKIEM TERMINÓW W JĘZYKU ANGIELSKIM
}

\author{
ARiMR Agencja Restrukturyzacji i Modernizacji Rolnictwa [ang. Agency \\ for Restructuring and Modernization of Agriculture, ARMA] \\ ANR Agencja Nieruchomości Rolnych [ang. Agricultural Property \\ Agency, APA] \\ ARR Agencja Rynku Rolnego [ang. Agricultural Markets Agency, AMA] \\ ASAL Program Dostosowawczy dla Sektora Rolniczego [ang. \\ Agricultural Structural Adjustment Loan] \\ AFLQ Rozszerzony Współczynnik Lokalizacji Flegga [ang. Augmented \\ Flegg's Location Quotient] \\ CAPRI Model do oceny regionalnego wpływu Wspólnej Polityki Rolnej \\ [ang. Common Agricultural Policy Regionalised Impact] \\ CDR Centrum Doradztwa Rolniczego [ang. Agricultural Advisory Center] \\ CES Stała elastyczność substytucji [ang. Constant Elasticity of \\ Substitution] \\ CGE model Obliczeniowy Model Równowagi Ogólnej [ang. Computable \\ General Equilibrium model, CGE] \\ CILQ Przekrojowy współczynnik lokalizacji [ang. Cross-Industry \\ Location Quotient, CILQ] \\ COP Centralny Ośrodek Przemysłowy [ang. Central Industry Area] \\ CPI Wskaźnik cen konsumpcyjnych [ang. Consumer Price Index, CPI] \\ DEFRA Brytyjski Departament do Spraw Środowiska, Żywności i Wsi \\ [ang. Departament for Environment, Food and Rural Affairs, \\ DEFRA] \\ DG-AGRI Dyrekcja Generalna ds. Rolnictwa i Rozwoju Wsi [ang. \\ Directorate-General for Agriculture and Rural Development] \\ EFFROW Europejski Fundusz Rolny (na rzecz) Rozwoju Obszarów \\ Wiejskich [ang. European Agricultural Fund for Rural \\ Development, EAFRD]
}


EFGR Europejski Fundusz Gwarancji Rolnej [ang. European Agriculture Guarantee Founds, EAGF]

EFOiGR Europejski Fundusz Orientacji i Gwarancji Rolnej [ang. European Agriculture Guidance and Guarantee Found, EAGGF]

ESIM Europejski Model Symulacyjny [ang. European Simulation Model]

ESU Europejska Jednostka Wielkości, EJW [ang. European Size Unit, ESU]

EUROSTAT Europejski Urząd Statystyczny [ang. European Statistical Office]

FADN Sieć Danych Rachunkowych z gospodarstw rolnych [ang. Farm Accountancy Data Network]

FAPA Fundacja Programów Pomocy dla Rolnictwa [ang. Foundation of Assistance Programmes for Agriculture]

FDPA Fundacja na Rzecz Rozwoju Polskiego Rolnictwa [ang. Foundation for the Development of Polish Agriculture]

FLQ Współczynnik Lokalizacji Flegga [ang. Flegg's Location Quotient]

GAMS Program używany do budowy i obsługi modeli równowagi ogólnej [ang. General Algebraic Modeling System]

GEMPACK Program opracowany w Monash University (Australia) do budowy i obsługi modeli równowagi ogólnej [ang. General Equilibrium Modelling PACKage]

GTAP Model równowagi ogólnej i baza danych służące do analiz światowego handlu [ang. Global Trade Analysis Project]

GUS Główny Urząd Statystyczny [ang. Main Statistical Office]

IERiGŻ Instytut Ekonomiki Rolnictwa i Gospodarki Żywnościowej, Państwowy Instytut Badawczy [ang. Institute of Agricultural and Food Economics, National Research Institute]

IUNG Instytut Uprawy Nawożenia i Gleboznawstwa [ang. Institute of Soil Science and Plant Cultivation]

IRWiR Instytut Rozwoju Wsi i Rolnictwa [ang. Institute of Rural and Agricultural Development]

IO Przepływy międzygałęziowe [ang. Input-Output, IO]

KE Komisja Europejska [ang. European Commission]

KRUS Kasa Rolniczego Ubezpieczenia Społecznego [ang. Agricultural Social Insurance Fund]

LAU Jednostka administracji lokalnej [ang. Local Administrative Units, LAU]

LEADER Program Unii Europejskiej wspierający rozwój obszarów wiejskich 


$\begin{array}{cl}\text { LGD } & \text { Lokalna Grupa Działania [ang. Local Action Group, LAG] } \\ \text { LQ } & \text { Współczynnik lokalizacji [ang. Location quotient, LQ] } \\ \text { MRiRW } & \text { Ministerstwo Rolnictwa i Rozwoju Wsi [ang. Ministry of } \\ & \text { Agriculture and Rural Development, MARD] } \\ \text { NAFTA } & \text { Północnoamerykański Układ Wolnego Handlu [ang. North } \\ & \text { American Free Trade Agreement, NAFTA] } \\ \text { NPK } & \text { Składniki nawozu: azot (N), fosfor (P) i potas (K) [ang. } \\ & \text { Nitrogen Phosphorus Potassium] } \\ \text { NUTS } & \text { Nomenklatura statystycznych jednostek terytorialnych [ang. } \\ & \text { Nomenclature of Units for Territorial Statistics, NUTS] } \\ \text { ODR } & \text { Ośrodki Doradztwa Rolnego [ang. Extension Services for Farmers] } \\ \text { OECD } & \text { Organizacja Współpracy Gospodarczej i Rozwoju [ang. } \\ & \text { Organization for Economic Co-operation and Development, OECD] } \\ \text { ONW } & \text { Obszary o niekorzystnych warunkach gospodarowania [ang. } \\ & \text { Less Favoured Areas, LFA] } \\ \text { ONZ } & \text { Organizacja Narodów Zjednoczonych [ang. United Nations] } \\ \text { PAOW } & \text { Program Aktywizacji Obszarów Wiejskich [ang. Rural } \\ & \text { Development Program] } \\ \text { PHARE } & \text { Przedakcesyjny Program dla Polski i Węgier wspierający } \\ & \text { restrukturyzację ich gospodarek [ang. Poland, Hungary } \\ & \text { Assistance to Restructuring their Economies, PHARE] } \\ \text { PKB } & \text { Produkt Krajowy Brutto [ang. Gross Domestic Product, GDP] } \\ & \text { Polska Klasyfikacja Działalności [ang. odpowiednik: Statistical } \\ & \text { Classification of Economic Activities in the European Community, } \\ & \text { NACE] }\end{array}$

PKWiU Polska Klasyfikacja Wyrobów i Usług [ang. Polish Classification of Goods and Services]

PRB Produkt regionalny (wojewódzki) brutto [ang. Gross regional product, GRP]

PROW Program Rozwoju Obszarów Wiejskich [ang. Rural Development Programme, RDP]

RegFIN Regionalny Model dla Finlandii

RegPOL Regionalny Model dla Polski

RK Rozporządzenie Komisji (WE) [ang. Commission Regulation, (EC)]

RoW Reszta świata [ang. rest of the world]

ROW Rozwój obszarów wiejskich [ang. rural development]

RR Rozporządzenie Rady (WE) [ang. Council Regulation, (EC)] 
SAM Macierz Rachunków Społecznych [ang. Social Accounting Matrix, SAM]

SAPARD Przedakcesyjny program dla rozwoju rolnictwa i obszarów wiejskich [ang. Special Accession Programme for Agriculture and Rural Development]

SAPS System jednolitej płatności obszarowej [ang. Single Area Payment Scheme]

SCENAR Projekt Komisji Europejskiej dot. scenariuszy rozwoju rolnictwa do 2020 r. [ang. Scenerio Study on Agriculture and the Rural Word]

SERA Projekt Komisji Europejskiej na temat zatrudnienia na obszarach wiejskich [ang. Study on Employment in Rural Areas, SERA]

SGM Standardowa nadwyżka bezpośrednia [ang. Standard Gross Margin]

SLQ Prosty Współczynnik Lokalizacji [ang. Simple Location Quotient, SLQ]

SPO Sektorowy Program Operacyjny [ang. Sectoral Operational Programme, SOP]

SPO Rolnictwo Sektorowy Program Operacyjny „Restrukturyzacja i modernizacja sektora żywnościowego oraz rozwój obszarów wiejskich” [ang. Sectoral Operational Programme Restructuring and Modernisation of the Food Sector and Rural Development 2004-2006]

SPS System jednolitej płatności [ang. Single Payment Scheme, SPS]

SWOT Metoda heurystyczna analizująca mocne i słabe strony oraz szanse i zagrożenia [ang. Strengths, Weaknesses, Opportunities, Threats, SWOT]

TABLO Język programowania używany w programie GEMPACK

TFP Produktywność całkowita czynników wytwórczych [ang. Total Factor Productivity]

ToT Warunki handlu [ang. Terms of Trade]

UE Unia Europejska [ang. European Union, EU]

US Urząd Statystyczny [ang. Statistical Office]

WPR Wspólna Polityka Rolna [ ang. Common Agricultural Policy, CAP]

WRMO Wspólne Ramy Monitorowania i Oceny [ang. Common Monitoring and Evaluation Framework (CMEF)]

WTO Światowa Organizacja Handlu [ang. World Trade Organization, WTO]

ZSROW Zintegrowana strategia rozwoju obszarów wiejskich (ang. Integrated Rural Development Strategy, IRDS) 


\section{SPIS TABEL, RYSUNKÓW I MAP}

\section{Spis tabel}

Tabela 1.1 Podstawowe kryteria wydzielenia obszarów wiejskich w wybranych

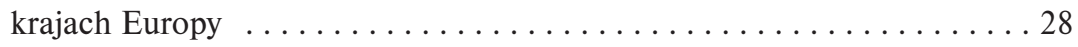

Tabela 1.2 Udział ludności wiejskiej w ludności ogółem według wybranych kryteriów i województw w latach 2000, 2005 i 2006 [w \%] . . . . . . . 30

Tabela 1.3 Podejście do polityki ROW w Finlandii w zależności od 3 głównych typów regionów $\ldots \ldots \ldots \ldots \ldots \ldots \ldots \ldots \ldots \ldots \ldots \ldots \ldots \ldots$

Tabela 1.4 Dwuwymiarowa typologia obszarów wiejskich

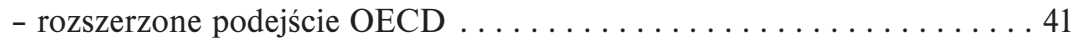

Tabela 1.5 Ludność wiejska według województw w latach $2000-2006 \ldots \ldots \ldots$. . . 45

Tabela 1.6 Ludność w wieku 15 lat i więcej według aktywności ekonomicznej, miejsca zamieszkania i związków z gospodarstwem rolnym na wsi

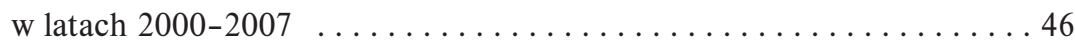

Tabela 1.7 Stopa bezrobocia według miejsca zamieszania i związków z gospodarstwem rolnym na wsi wg województw w latach 2002 i 2007 . . . 48

Tabela 1.8 Pracujący poza rolnictwem, ogółem i na własny rachunek, według miejsca zamieszkania i sekcji PKD w głównym miejscu pracy w latach 2000, 2006 i $2007 \ldots \ldots \ldots \ldots \ldots$. . . . . . . . . . . . 50

Tabela 1.9 Pracujący według miejsca zamieszkania, płci, wieku, wykształcenia oraz pracy $\mathrm{w}$ rolnictwie indywidualnym i poza nim w latach 2000 i $2007 \ldots \ldots \ldots \ldots \ldots \ldots$. . . . . . . . . . . . . . . . 51

Tabela 1.10 Przepływ dóbr materialnych i usług do rolnictwa z gałęzi gospodarki narodowej w $2000 \mathrm{r}$. [w cenach bieżących, mln PLN] . . . . . . . . 55

Tabela 1.11 Przepływy produktu globalnego z rolnictwa do poszczególnych gałęzi gospodarki narodowej w roku 2000 [w cenach bieżących, mln PLN] . . . 57

Tabela 1.12 Zależność ludności wiejskiej od zatrudnienia w rolnictwie w ujęciu

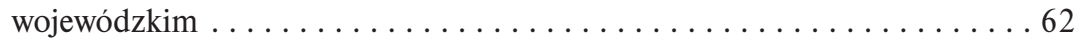

Tabela 1.13 Zatrudnienie ludności wiejskiej według grup PKD w 2002 r. . . . . . . . 64

Tabela 1.14 Efektywność nakładów w rolnictwie polskim według województw w 2000 i 2006 r. . . . . . . . . . . . . . . . . . . . . . . . . 68

Tabela 1.15 Różnica między produktywnością pracy w rolnictwie a przemyśle i budownictwie w latach $1995-2007 \ldots \ldots \ldots \ldots \ldots \ldots \ldots \ldots$ 
Tabela $2.1 \quad$ Nowy paradygmat wiejski według OECD $\ldots \ldots \ldots \ldots \ldots \ldots$

Tabela 2.2 Kontrybucje z modulacji do krajowych Programów Rozwoju Obszarów Wiejskich w latach 2000-2006 . . . . . . . . . . . 97

Tabela 2.3 Podział EFRROW w latach 2007-2013 między państwa członkowskie $[w \operatorname{mln}$ EUR] $\ldots \ldots \ldots \ldots \ldots \ldots \ldots \ldots \ldots \ldots \ldots \ldots \ldots \ldots$

Tabela 2.4 Środki z EFRROW rozdysponowane na poszczególne państwa członkowskie w okresie 2007-2013 w przeliczeniu na 1 ha użytków rolnych i jednego pracującego w rolnictwie [w cenach bieżących] . . . . 102

Tabela 2.5 Działania polityki ROW wybrane przez Polskę w latach 2004-2006 i w latach $2007-2013$. . . . . . . . . . . . . . . . . . . . . . . . . . 104

Tabela 2.6 Podział działań z PROW i SPO Rolnictwo 2004-2006

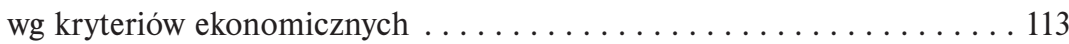

Tabela 2.7 Podział środków UE na województwa w ramach SPO Rolnictwo

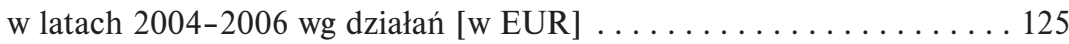

Tabela 2.8 Procentowy udział środków przypadających na województwa w ramach SPO Rolnictwo w latach 2004-2006 [w \%] . . . . . . . . . 126

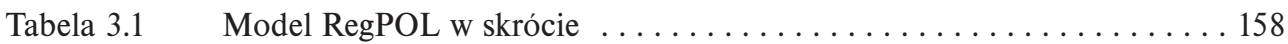

Tabela $3.2 \quad$ Źródła danych w podziale na grupy . . . . . . . . . . . . . . 160

Tabela 3.3 Baza danych modelu RegPOL w formie SAM . . . . . . . . . . . . 164

Tabela 3.4 Elastyczność substytucji pracy względem kapitału w Polsce

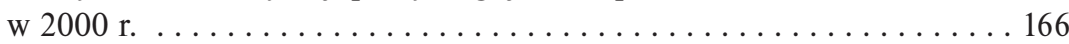

Tabela 4.1 Płatności zrealizowane w ramach SPO Rolnictwo i PROW 2004-2006 wg działań i województw [w \% PKB]

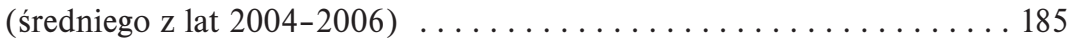

Tabela 4.2 Fundusze ROW w relacji do PKB i między województwami . . . . . . . 186

Tabela 4.3 Ranking województw pod względem skuteczności polityki ROW . . . . . 193

Tabela 4.4 Zmiana w PRB na skutek wybranych działań polityki ROW z okresu 2004-2006, wg województw [w \%] . . . . . . . . . 195

Tabela 4.5 Ranking województw pod względem efektywności polityki ROW w latach $2004-2006$. . . . . . . . . . . . . . . . . . . . . . . . 204

Tabela 4.6 Szacunek kosztów i korzyści z polityki ROW, wg województw . . . . . 205

Tabela 4.7 Koszty ekonomiczne maksymalizowania środków

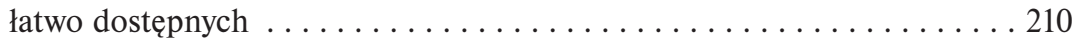

Tabela 4.8 Zatrudnienie ludności wiejskiej według sektorów i województw w \% ogółem zatrudnionych, w 2002 r. (w zaokrągleniu) .......... 221

Tabela 4.9 Efekty wzrostu produkcji w pozarolniczych sektorach gospodarki na skutek polityki ROW 2004-2006 [w \%] . . . . . . . . . . . . 222

Tabela 4.10 Zmiany we wzroście gospodarczym i zatrudnieniu w ujęciu

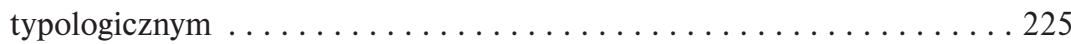

Tabela 4.11 Zmiany w stopie bezrobocia i migracjach netto w ujęciu typologicznym ............................. 226

Tabela 4.12 Zmiany w inflacji i popycie inwestycyjnym w ujęciu typologicznym . . . 227

Tabela 5.1 Podsumowanie sposobów i wyników weryfikacji hipotez i pytań

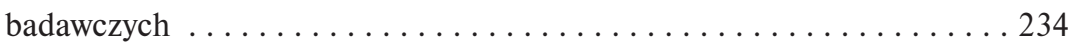




\section{Tabele w aneksach}

Tabela A.2.1 Klasyfikacja działań SPO Rolnictwo i PROW 2004-2006

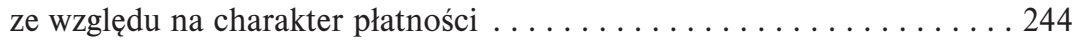

Tabela A.2.2 Powierzchnia gospodarstw przekazanych w ramach działania Renty strukturalne, wg powierzchni i celów [ha] w latach 2004-2006 . . . . . 248

Tabela A.2.3 Wspieranie gospodarstw niskotowarowych - liczba złożonych wniosków i wydanych decyzji, wg województw . . . . . . . . . . . 249

Tabela A.2.4 Zrealizowane płatności z tytułu ONW wg województw . . . . . . . 250

Tabela A.2.5 Realizacja programu rolno-środowiskowego (PRŚ) w roku 2006,

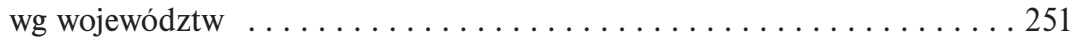

Tabela A.2.6 Zalesianie gruntów rolnych - złożone wnioski, wydane postanowienia oraz decyzje przyznające pomoc, wg województw . . . . 252

Tabela A.2.7 Dostosowanie gospodarstw rolnych do standardów UE w ramach PROW 2004-2006 - złożone wnioski, decyzje przyznające pomoc,

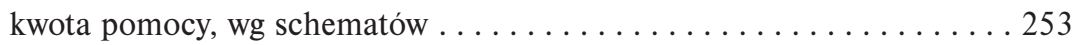

Tabela A.2.8 Liczba grup producentów rolnych w ramach PROW 2004-2006 - wnioski, decyzje o przyznaniu pomocy oraz płatności i zrealizowane

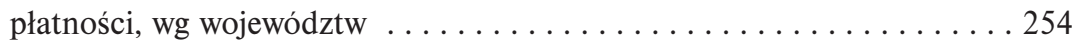

Tabela A.2.9 Regionalna struktura absorpcji funduszy ROW według działań w ramach SPO Rolnictwo i PROW 2004-2006 [w \%] . . . . . . . . . 264

Tabela A.2.10 Regionalna struktura absorpcji funduszy ROW według województw w latach 2004-2007 [w \%] . . . . . . . . . . . . . . . . . . . . 265

Tabela A.3.1 Przegląd metod szacowania międzyregionalnych przepływów

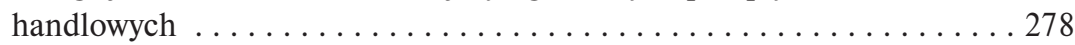

Tabela A.3.2 Lista regionów oraz sektorów występujących w modelu,

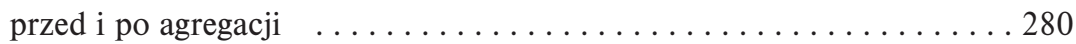

Tabela A.3.3 Dane regionalne wykorzystane do budowy tablic IO . . . . . . . . 284

Tabela A.3.4 Średnie współczynniki lokalizacji AFLQ dla polskich regionów . . . . . 288

Tabela A.3.5 Sektorowe współczynniki lokalizacji AFLQ dla województwa

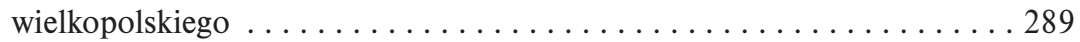

Tabela A.3.6 Porównanie różnych współczynników lokalizacji dla województwa

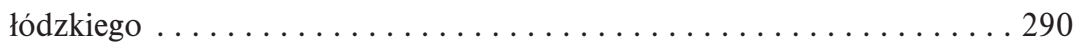

Tabela A.3.7 Dodatkowe dane poza tablicami IO w macierzy SAM

(Macierz D)

\section{Spis rysunków}

Rysunek 1.1 Porównanie oryginalnej i rozszerzonej typologii OECD

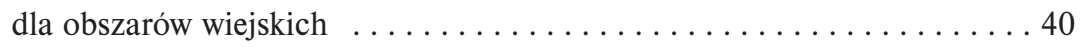

Rysunek 1.2 Dwuwymiarowa typologia wiejsko-rolnicza dla Polski . . . . . . . . 42

Rysunek 1.3 Dwuwymiarowa typologia wiejsko-rolnicza dla Finlandii $\ldots \ldots \ldots \ldots 43$

Rysunek 1.4 Dynamika realnych dochodów w gospodarstwach domowych ogółem i rolników w latach $1995-2007(1995=100) \ldots \ldots \ldots \ldots \ldots \ldots$ 
Rysunek 1.5 Wrażliwość bezrobocia (rejestrowanego) na zmiany tempa wzrostu gospodarczego w Polsce . . . . . . . . . . . . . . . . 61

Rysunek 1.6 Związek pomiędzy zamożnością województw a uzależnieniem ekonomicznym od rolnictwa w 2002 r. . . . . . . . . . . . . 67

Rysunek 1.7 Zależność między efektywnością nakładów w rolnictwie a zamożnością województw o charakterze przeważająco rolniczym w 2006 r. . . . . . . 69

Rysunek 1.8 Relatywna efektywność nakładów w rolnictwie według typów

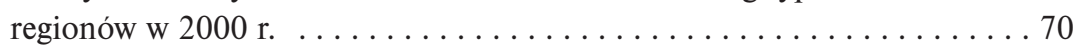

Rysunek 1.9 Środowiskowa krzywa Kuznetza $\ldots \ldots \ldots \ldots \ldots \ldots \ldots \ldots \ldots \ldots \ldots$

Rysunek 1.10 Przykład zintegrowanego systemu rozwoju obszarów wiejskich . . . . . . 81

Rysunek 2.1 Ewolucja polityki rolnej od CAP do CARPE . . . . . . . . . . . 92

Rysunek 2.2 Reformowanie wydatków na WPR w latach 1980-2007 . . . . . . . . 96

Rysunek 2.3 Porównanie sposobu finansowania rolnictwa i rozwoju obszarów wiejskich w UE w latach 2000-2006 i 2007-2013 . . . . . . . . . . 98

Rysunek 2.4 Spójność pomiędzy politykami wspólnotowymi i dokumentami

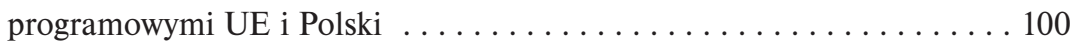

Rysunek 2.5 Redystrybucja dochodu kosztem efektywności ekonomicznej . . . . . . 106

Rysunek 2.6 Klasyfikacja funduszy ROW w latach 2004-2006

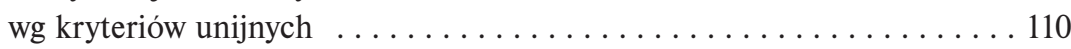

Rysunek 2.7 Klasyfikacja funduszy polityki ROW 2004-2006

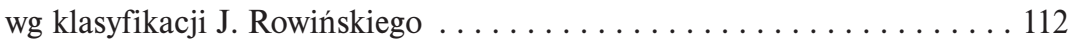

Rysunek 2.8 Klasyfikacja funduszy ROW w latach 2004-2006 wg kryteriów ekonomicznych . . . . . . . . . . . . . . . 114

Rysunek 2.9 Różnice w strukturze absorpcji środków w ramach SPO Rolnictwo i PROW 2004-2006 w wybranych województwach . . . . . . . . . 117

Rysunek 2.10 Porównanie wydatków na unijną politykę ROW w Polsce w dwóch okresach finansowych wg kryteriów unijnych . . . . . . . . 119

Rysunek 2.11 Porównanie planowanych wydatków z EFRROW w Polsce i w UE w latach $2007-2013 \ldots \ldots \ldots \ldots \ldots \ldots$. . . . . . . . . . . . . . . 120

Rysunek 2.12 Struktura podziału środków EFRROW 2007-2013 pomiędzy kraje i osie . . 121

Rysunek 2.13 Porównanie wydatków w ramach unijnej polityki ROW w dwóch okresach finansowych wg klasyfikacji J. Rowińskiego . . . . . 122

Rysunek 2.14 Porównanie wydatków w dwóch okresach finansowych

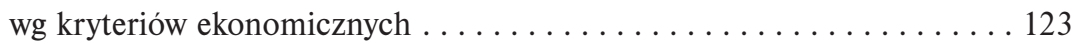

Rysunek 2.15 Logika interwencji i hierarchia celów w programach dotyczących

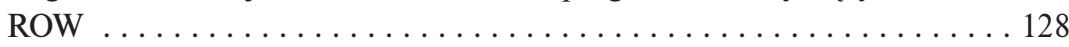

Rysunek 2.16 Sieć powiązań i zależności pomiędzy celami, działaniami i rezultatami programu oraz kryteriami ewaluacyjnymi dla programów społeczno-ekonomicznych . . . . . . . . . . . 131

Rysunek 2.17 Od efektu brutto do dodatkowego efektu netto programów ROW . . . . . 134 Rysunek 2.18 Schemat oceny efektów dodatkowych netto programów . . . . . . . 135

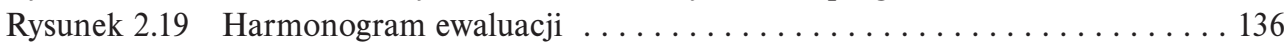
Rysunek $3.1 \quad$ Budowa modelu RegPOL w ujęciu graficznym . . . . . . . . . . . . . 157 Rysunek 3.2 Stopnie agregacji w zagnieżdżonej strukturze produkcji modelu RegPOL . . . 169 
Rysunek 3.3 Struktura popytu gospodarstw domowych w modelu RegPOL . . . . . 171

Rysunek 3.4 Struktura popytu sektora publicznego w modelu RegPOL . . . . . . . . . 172

Rysunek 3.5 Struktura popytu inwestycyjnego . . . . . . . . . . . . . . 172

Rysunek 3.6 Rynki pracy w modelu RegPOL . . . . . . . . . . . . . . 175

Rysunek 4.1 Relacja środków ROW do zamożności województwa . . . . . . . . 187

Rysunek 4.2 Skuteczność poszczególnych typów instrumentów polityki ROW

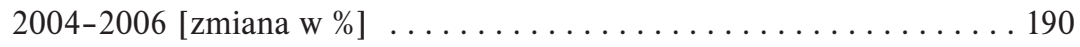

Rysunek 4.3 Regionalny rozkład skuteczności instrumentów polityki ROW 2004-2006 [zmiana PKB \%] . . . . . . . . . . . . . . . . . . 192

Rysunek 4.4 Regionalny rozkład skuteczności wybranych działań polityki ROW 2004-2006 [zmiana PKB w \%] . . . . . . . . . . . . . . . . . 194

Rysunek 4.5 Zależność między skutecznością polityki ROW a wielkością uzyskanych funduszy na ROW w latach $2004-2006$. . . . . . . . . . . . . . . . 197

Rysunek 4.6 Zależność między skutecznością polityki ROW a siłą ekonomiczną/zamożnością województw w latach 2004-2006 . . . . . . 198

Rysunek 4.7 Zależność między wzrostem PRB a wielkością funduszy ROW na rzecz inwestycji w infrastrukturę, według województw w latach 2004-2006 . . 199

Rysunek 4.8 Efektywność działań ROW w skali całego kraju [w \% ] . . . . . . . . . 202

Rysunek 4.9 Efektywność polityki ROW w województwach,

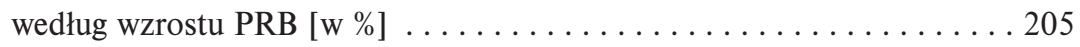

Rysunek 4.10 Stosunek korzyści do kosztów polityki ROW w układzie

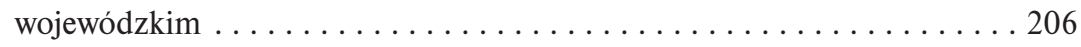

Rysunek 4.11 Regionalne zróżnicowanie związku między skutecznością a efektywnością polityki ROW . . . . . . . . . . . . . . . . 207

Rysunek 4.12 Zależność między efektywnością a wielkością uzyskanych funduszy

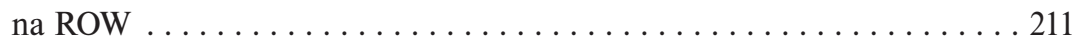

Rysunek 4.13 Zależność między efektywnością a siłą ekonomiczną/zamożnością

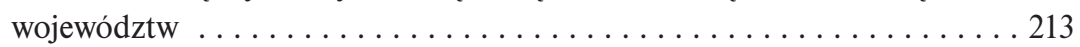

Rysunek 4.14 Zależność między efektywnością a strukturą funduszy $\ldots \ldots \ldots \ldots \ldots 214$

Rysunek 4.15 Wpływ płatności ONW w ramach PROW 2004-2006 na sektory gospodarki w województwie podlaskim $\ldots \ldots \ldots \ldots \ldots \ldots \ldots \ldots \ldots \ldots$

Rysunek 4.16 Wpływ rent strukturalnych w ramach PROW 2004-2006 na sektory

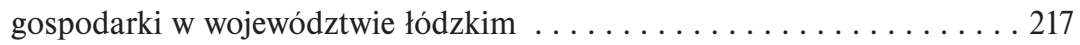

Rysunek 4.17 Wpływ działania Dostosowanie do standardów UE w ramach PROW 2004-2006 na sektory gospodarki w województwie wielkopolskim . . . . 218

Rysunek 4.18 Wpływ doradztwa w ramach SPO Rolnictwo 2004-2006 na sektory

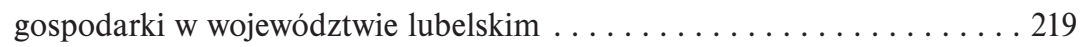

Rysunek 4.19 Ranking województw zyskujących na polityce ROW z lat 2004-2006

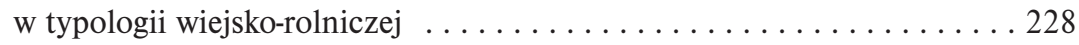

\section{Rysunki w aneksach}

Rysunek A.2.1 Struktura kosztów kwalifikowanych w działaniu inwestycje w gospodarstwa rolne w ramach SPO Rolnictwo 2004-2006

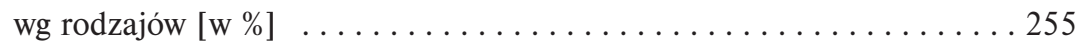


Rysunek A.2.2 Liczba złożonych wniosków i podpisanych umów w ułatwienie startu młodym rolnikom w ramach SPO Rolnictwo 2004-2006

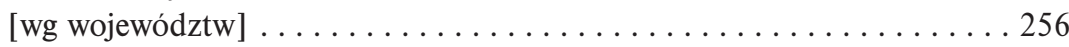

Rysunek A.2.3 Struktura kosztów kwalifikowanych w działaniu poprawa przetwórstwa i marketingu w ramach SPO Rolnictwo 2004-2006 . . . 258

Rysunek A.2.4 Struktura kosztów kwalifikowanych w działaniu przywracanie potencjału produkcji leśnej w ramach SPO Rolnictwo w latach 2004-2006

Rysunek A.2.5 Struktura inwestycyjnych kosztów kwalifikowanych w działaniu różnicowanie działalności rolniczej w ramach SPO Rolnictwo 2004-2006

Rysunek A.2.6 Struktura kosztów kwalifikowanych w działaniu rozwój i ulepszanie infrastruktury technicznej wg głównego celu projektu w ramach SPO Rolnictwo $2004-2006$. . . . . . . . . . . . . . . . . . 262

Rysunek A.2.7 Regionalna struktura pozyskanych funduszy ROW wg kryteriów

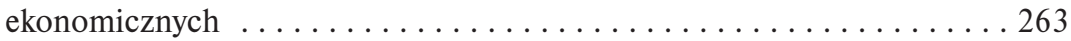

Rysunek A.3.1 Zależność między wartością delta $\mathrm{z}$ formuły na ALFQ

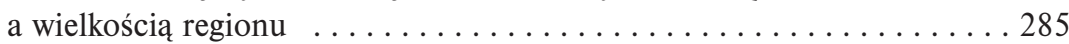

Rysunek A.3.2 Graficzna prezentacja macierzy popytu pośredniego

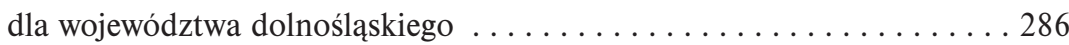

Rysunek A.4.1 Efekty mnożnikowe w zakresie produkcji i zatrudnienia ludności wiejskiej na skutek polityki ROW realizowanej w latach 2004-2006

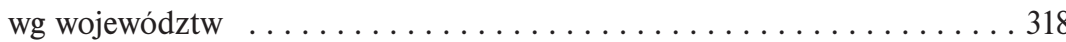

\section{Spis map}

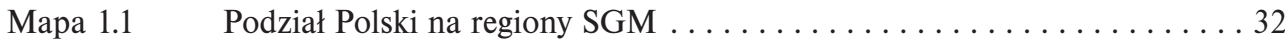

Mapa 1.2 Syntetyczna ocena poziomu rozwoju gospodarczego w Polsce

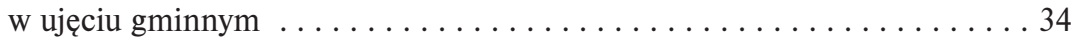

Mapa 1.3 Syntetyczna ocena poziomu rozwoju społecznego w Polsce w ujęciu

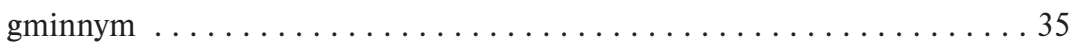

Mapa 1.4 Typologia województwa w Polsce wg OECD . . . . . . . . . . . . . . 38

Mapa $1.5 \quad$ Zatrudnienie ludności wiejskiej w rolnictwie $\ldots \ldots \ldots \ldots \ldots \ldots \ldots 6$

Mapa $1.6 \quad$ Zatrudnienie ludności wiejskiej w przemyśle $\ldots \ldots \ldots \ldots \ldots \ldots \ldots$

Mapa $1.7 \quad$ Zatrudnienie ludności wiejskiej w usługach $\ldots \ldots \ldots \ldots \ldots \ldots \ldots$ 


\section{BibLIOGRAFIA}

Acocella N. (1998). The Foundations of Economic Policy. Values and Techniques. Cambridge University Press, Cambridge.

Adamowicz M. i D. Guzal-Dec (2005). Przestrzenne zróżnicowanie uwarunkowań konkurencyjności rolnictwa w województwie lubelskim. Roczniki Naukowe SERiA IX, t. 2.

Adams P.D. i P.J. Higgs (1990). Calibration of Computable General Equilibrium Models from Synthetic Benchmark Equilibrium Data Sets. Economic Record 66 193, s. $110-26$.

Agenda 2000 (1997). Volume I - Communication: for a Stronger and Wider Union. Strasbourg, 15 July 1997, Komisja Europejska, DOC/97/6.

Amin A. i N. Thrift, Eds. (1994). Globalisation, Institutions, and Regional Development in Europe. Oxford University Press, Oxford.

Anania G., J.C. Blom, A. Buckwell i inni (2003). Policy Vision for Sustainable Rural Economies in an Enlarged Europe. Studies in Spatial Development. Hanover, DATAR i ARL. 4.

Andreoni J. i A. Levinson (2001). The Simple Analytics of the Environmental Kuznets Curve. Journal of Public Economics 80 (2), s. 269-286.

ARiMR (2007). Trzy lata po akcesji. Raport Agencji Restrukturyzacji i Modernizacji Rolnictwa, Warszawa.

ARiMR (2008). Wdrażane programy i działania - dane liczbowe, Agencja Restrukturyzacji i Modernizacji Rolnictwa. http://www.arimr.gov.pl, Warszawa.

Armington P.S. (1969a). The Geographic Pattern of Trade and the Effects of Price Changes. IMF Staff Papers XVI(Jully), s. 176-199.

Armington P.S. (1969b). A Theory of Demand for Products Distinguished by Place of Production. International Monetary Fund Staff Papers 16 1: 159-78.

Armington P.S. (1996). The Geographic Pattern of Trade and the Effects of Price Changes. IMF Staff Papers XVI(Jully), s. 176-199.

Arrow K.J., T.J. Kehoe, T.N. Srinivasan i inni (2005). Personal Reflections on Applied General Equilibrium Models. [w:] Frontiers in Applied General Equilibrium Modeling: In Honor of Herbert Scarf. Cambridge and New York, Cambridge University Press, s. 13-23.

BAEL (2008). Badanie Aktywności Ekonomicznej Ludności. GUS, Warszawa.

Balamou E., K. Pouliakas, D. Reberts i inni (2008). Modeling the Rural-Urban Effects of Changes in Agricultural Policies: a Bi-Regional CGE Analysis of Two Case Study Regions. 107th EAAE Seminar „Modelling of Agricultural and Rural Development Policies”, Sevilla, Spain, January 29th -February 1st, 2008. 
Bandara J.S. (1991). Computable General Equilibrium Models for Development Policy Analysis in LDCs. Journal of Economic Surveys (5) 1, s. 3-69.

Bański J. (2000). Typy rolniczych obszarów problemowych. [w:] Środowisko przyrodnicze i gospodarka Dolnego Ślaska u progu trzeciego tysiaclecia. 49 Zjazd PTG. J. Tomaszewski, red. Szklarska Poręba, Oddział Wrocławski PTG, Instytut Geograficzny Uniwersytetu Wrocławskiego, s. 167-169.

Bański J. (2007). Małe miasta - lokalne centra rozwoju obszarów wiejskich. Konferencja: Obszary wiejskie jako wyzwanie dla polityki rozwoju w Polsce, Warszawa, 9 października $2007 \mathrm{r}$.

Bański J. (2008). Wiejskie obszary sukcesu gospodarczego. Studia Obszarów Wiejskich, t. XIV. Warszawa, Komisja Obszarów Wiejskich, Polskie Towarzystwo Geograficzne.

Bański J., K. Czapiewski i D. Świątek (2002-2004). Projekt badawczy „Charakterystyka i typologia obszarów wiejskich w Polsce”. IGiPZ, Warszawa.

Batten D.F. (1983). Spatial Analysis of Interacting Economics, Kluwer-Nijhoff Publishing, the Netherlands.

Bayar A., F. Dramais, C. Mohora i inni (2006). GreenMod: A Multi-Region, Multi-Sector Dynamic General Equilibrium Model for Energy and Environmental Policy Analysis. International Conference on Regional and Urban Modelling (ECOMOD), Brussels.

BDR (1999-2007). Bank Danych Regionalnych, GUS.

Berck P., S. Robinson, G. Goldman i inni (1991). The Use of Computable General Equilibrium Models to Assess Water Policies. [w:] The economics and management of water and drainage in agriculture. Norwell, Mass. and Dordrecht, Kluwer Academic, s. 489-509.

Bergman L., D.W. Jorgenson i E. e. Zalai (1990). General equilibrium modeling and economic policy analysis. Oxford and Cambridge, Mass., Blackwell.

Bergman L., S. Lundgren, D.W. Jorgenson i inni (1990). General Equilibrium Approaches to Energy Policy Analysis in Sweden. [w:] General equilibrium modeling and economic policy analysis. Oxford and Cambridge, Mass., Blackwell: 351-82.

Bhattacharyya S.C. (1996). Applied General Equilibrium Models for Energy Studies: A Survey. Energy Economics 18 (3), s. 145-164.

Błąd M. (2007). Czy należy pomagać regionom słabo rozwiniętym, Wieś i Rolnictwo 2 (135), s. 164-169.

Böhringer C., T.F. Rutherford i W. Wiegard (2007). Computable General Equilibrium Analysis Opening a Black Box. Discussion Paper, Nr 03-56. Mannheim, Centre for European Economic Research, ZEW.

Borges A.M. (1986). Applied General Equilibrium Models: An Assessment of Their Usefulness for Policy Analysis. OECD Economic Studies 7, s. 7-43.

Borys T. (2007). W poszukiwaniu syntetycznego wskaźnika zrównoważonego rozwoju. [w:] Obszary badań nad trwatym i zrównoważonym rozwojem. B. Poskrobko, red. Białystok, Wydawnictwo Wyższej Szkoły Ekonomicznej w Białymstoku, Białystok.

Bourguignon F. i L.A. e. Pereira da Silva (2003). The impact of economic policies on poverty and income distribution: Evaluation techniques and tools. Washington, D.C., World Bank; Oxford and New York: Oxford University Press.

Brand S. (1997). On the Appropriate Use of Location Quotients in Generating Regional Input-Output Tables: A Comment. Regional Studies 31 (8), s. 791-794. 
Brodziński Z. (2004). Uwarunkowania procesu programowania rozwoju obszarów wiejskich w skali lokalnej. SGGW, Warszawa.

Bruton J. i J. Swinnen (2002). Towards a Sustainable European Agricultural Policy for the 21st Century. CEPS Task Force Report. Brussels, CEPS. 42.

Buckwell A. (1997). Towards a Common Agricultural and Rural Policy for Europe. European Economy 5.

Budzich-Szukała U. (2008). Program LEADER w Polsce - sposób na aktywizację wsi. [w:] Polska wieś 2008. Raport o stanie wsi, J. Wilkin i I. Nurzyńska, red., FDPA, Warszawa.

Bukraba-Rylska I. (2008). Socjologia Wsi Polskiej. Wydawnictwo Naukowe PWN, Warszawa.

Cambridge (2004). Training materials from Course on issues in public policy and regeneration (unpublished). By Peter Tylor, Land Economy Department (2003/2004), Cambridge University, UK.

Canning P. i Z. Wang (2005). A Flexible Mathematical Programming Model to Estimate Interregional Input-Output Accounts. Journal of Regional Science 45 (3), s. 539-63.

Capello R. (1996). Industrial enterprises and economic space: the network paradigm. European Planning Studies 4 (4), s. 485-498.

Casini Benvenuti S., D. Martellato i C. Raffaelli (1995). INTEREG: A Twenty-Region Input-Output Model for Italy. Economic Systems Research 7 (2), s. 101-116.

Chmiel J., L. Podkaminer, L. Zienkowski i inni (1991). Ocena możliwych kierunków rozwoju sytuacji gospodarczej w Polsce w 1990 r. ZBSE, Zeszyt 34, GUS i PAN, Warszawa.

Cloke P. (2006). Conceptualizing rurality. [w:] Handbook of Rural Studies, P. Cloke, T. Marsden i P. Mooney, red. London, Sage Publications.

Conrad K. (2001). Computable General Equilibrium Models in Environmental and Resource Economics. [w:] The International Yearbook of Environemental and Resource Economics 2002/2003,T. Tietenberg i H. Folmer, red.

Cooke P. i K. Morgan (1993). The network paradigm: new departures in corporate and regional development. Society and Space II, s. 543-564.

CoPS (2008). Comparing Regional CGE models: Top-down and bottom-up. IMPACT Project. Monash, Center of Policy Studies, www.monash.edu.au/policy/regmods.htm (ostatnio wizytowana strona 29.07.09).

Counts A. (2008). Small Loans, Big Dreams: How Nobel Prize Winner Muhammad Yunus and Microfinance are Changing the World. Hoboken, New Jersey, John Wiley \& Sons, Inc.

Czyżewski A. (1983). Ekonomiczne podstawy procesów urbanizacji wsi w Polsce Ludowej. Akademia Ekonomiczna w Poznaniu, Poznań.

Czyżewski A. (2000). Powiązania rolnictwa z gospodarką narodową w zależności od opcji polityki makroekonomicznej. Wieś i Rolnictwo 4 (190), s. 5-16.

Czyżewski A. (2001). Rola polityki makroekonomicznej w kształtowaniu warunków dla zrównoważonego rozwoju rolnictwa. [w:]: Jaka polityka gospodarcza dla Polski? U. Płowiec, red. Wydawnictwo PTE, Warszawa.

Czyżewski A. (2005a). Przeptywy międzygatęziowe jako makroekonomiczny model gospodarki. Wydawnictwo Akademii Ekonomicznej w Poznaniu, Poznań. 
Czyżewski A. (2007a). Makroekonomiczne uwarunkowania rozwoju sektora rolnego. [w:] Uniwersalia polityki rolnej w gospodarce rynkowej, ujęcie makro- $i$ mikroekonomiczne. A. Czyżewski, red. Wydawnictwo Akademii Ekonomicznej w Poznaniu, Poznań.

Czyżewski A. i A. Grzelak (2002). Wpływ polityki monetarnej i fiskalnej na pozycję rolnictwa w okresie transformacji. Wieś i Rolnictwo 2 (115), s. 49-67.

Czyżewski A. i A. Henisz-Matuszczak (2005). Makroekonomiczne uwarunkowania rolnictwa industrialnego i społecznie zrównoważonego. Refleksje na temat sprzężeń regulacyjnych i realnych. [w:] Koncepcja badań nad rolnictwem spotecznie zrównoważonym. J. Zegar, red. IERiGŻ, Warszawa.

Czyżewski A.B., W.M. Orłowski i L. Zienkowski (1999). Średniookresowe efekty członkostwa Polski w Unii Europejskiej. Integracja Europejska/Monografie. Instytut Europejski, Łódź.

Czyżewski B. (2005b). Zastosowanie teorii kosztów transakcyjnych w ekonomii rolnej. [w:] Funkcjonowanie gospodarki rynkowej w Polsce - aspekty makro- i mikroekonomiczne. W. Jarmołowicz, red. Zeszyty Naukowe Nr 65. Wydawnictwo Akademii Ekonomicznej w Poznaniu, Poznań.

Czyżewski B. (2007b). Instytucje w tworzeniu struktur agrobiznesu. [w:] Uniwersalia polityki rolnej w gospodarce rynkowej, ujęcie makro- i mikroekonomiczne, A. Czyżewski, red. Wydawnictwo Akademii Ekonomicznej w Poznaniu, Poznań.

Davidova S., M. Gorton, T. Ratinger, K. Zawalińska, B. Iraizoz (2005). Farm Productivity and Profitability: A Comparative Analysis of Selected New and Existing EU Member States. Comparative Economic Studies 47 (4), s. 652-674.

Davidova S., M. Gorton, T. Ratinger, K. Zawalińska, B. Iraizoz (2006). Variations in Farm Performance: Evidence from the New Meber States and EU-15 Member States. [w:] Integrated Development of Agriculture and Rural Areas in Central European Countries, S. Davidova, K. Bauer i M. Cuddy, red. Lexington Books, Oxford.

de Janvry A., E. Sadoulet i A. Fargeix (1991). Politically Feasible and Equitable Adjustment: Some Alternatives for Ecuador. World Development 19 (11), s. 1577-1594.

Decaluwe B. i A. Martens (1988). Bibliographie Relative aux Modeles Calculables D'equilibre Generale Appliques aux Economies En Developpement. Universite de Montreal, Departement de sciences economiques, Cahiers de recherche: 14P. pages.

Demos Polska (2008). Czy polityka klimatyczna może zwiększyć konkurencyjność gospodarcza? Konferencja zorganizowana przez Demos Polska, 30 września, Warszawa.

Dervis K., d. J. Melo i S. Robinson (1982). General Equilibrium Models for Development Policy. Cambridge, UK, Cambridge University Press.

Devarajan S. i S. Robinson (2005). The Influence of Computable General Equilibrium Models on Policy. [w:] Frontiers in Applied General Equilibrium Modeling: Essays in Honor of Herbert Scarf, T. Kehoe, T.N. Srinivasan i J. Whalley, red. Cambridge University Press, s. 402-428, Cambridge.

DG AGRI. (2008). Methodology-Guidelines for Evaluation of Rural Development Programs. Komisja Europejska. Aktualne na dzień: 20.07.2009, http://ec.europa.eu/agriculture/eval/index_en.htm

Dixon P.B., B.R. Parmenter, H.M. Amman i inni (1996). Computable General Equilibrium Modelling for Policy Analysis and Forecasting. [w:] Handbook of computatio- 
nal economics. Volume 1. Handbooks in Economics, vol. 13. Amsterdam; New York and Oxford, Elsevier Science, North-Holland, s. 3-85.

Dixon P.B. i M. Rimmer (1998). Forecasting and Policy Analysis with a Dynamic CGE Model of Australia. CoPS/IMPACT Working Paper Number OP-90. Monash University, Monash.

Dopfer K. (2001). Evolutionary Economics: Program and Scope. Kluwer Academic Publishers, London, .

Drygas M. i A. Rosner, red. (2008). Polska wieś i rolnictwo w Unii Europejskiej. Dylematy i kierunki przemian. IRWiR PAN, Warszawa.

Duczkowska-Małysz K. i A. Szymecka, red. (2009). Wokót trudnych problemów globalnego rozwoju obszarów wiejskich, gospodarki żywnościowej i rolnictwa. Szkoła Główna Handlowa, Warszawa.

Dugger W.M. i H.J. Sherman (2000). Reclaimin Evolution: A Dialogue between Marxism and Institutionalism on Social Change. Routledge, New York.

Dwyer J. (2005). Rural Development under the CAP: Signifance, likely impacts and modelling issues. JRC workshop, Włochy.

Ecologist (1972). The Blueprint for Survival. The Ecologist 2 (1).

Eding G. i H. Nijmijer (1998). The Estimation of Trade in Interegional Input-Output Tables. Seminar on Structures and Prospects of the Nordic Regional Exonomies, Savolina, Finland.

Esping-Andersen G. (1990). The three worlds of welfare capitalism. Cambridge University Press.

European (1995). European Charter for Rural Areas. Council of Europe, Strasbourg.

EUROSTAT (2001). Economy-wide material flow accounts and derived indicators: a methodological guide. European Commission.

FAPA (2004). Ocena Reformy WPR uzgodnionej w Luksemburgu 26 czerwca 2003 r. z Perspektywy Polski. FAPA, Sekcja Analiz Ekonomicznych Polityki Rolnej (SAEPR), Warszawa.

Fedyszak-Radziejowska B. (2008a). Polska wieś w cztery lata po akcesji - wymiar demarginalizacji [w:] Polska wieś 2008. Raport o stanie wsi, J. Wilkin i I. Nurzyńska, red. FDPA, Warszawa.

Fedyszak-Radziejowska B. (2008b). Psychospołeczny wymiar zmian na polskiej wsi. [w:] Polska wieś i rolnictwo w Unii Europejskiej. M. Drygas i A. Rosner, red. IRWiR PAN, Warszawa.

Ferguson L., D. Learmonth, P. G. McGregor i inni (2004). The National impact of regional policy: Policy simulation with labour market constraints in a two-region computable equlibrium model. Discussion papers in Economics $\mathrm{Nr}$ 04-20. Glasgow, Strathclyde University.

Flegg A.T. i T. Tohmo (2008). Regional Input Output Models and the FLQ Formula: A Case Study of Finland. IDEAS/RePEc.

Flegg A.T. i C.D. Webber (1997). On the Appropriate Use of Location Quotients in Generating Regional Input-Output Tables: Reply. Regional Studies 31 (8), s. 795-805.

Flegg A.T. i C.D. Webber (2000). Regional Size, Regional Specialization and the FLQ Formula. Regional Studies 34 (6), s. 563-69. 
Flegg A.T., C. D. Webber i M.V. Elliott (1995). On the Appropriate Use of Location Quotients in Generating Regional Input-Output Tables. Regional Studies 29 (6), s. 547-61.

Flegg A.T. i C. D. Weber (1996). Using location quotients to estimate regional input-output coefficients and multipliers. Local Economy Quarterly 4, s. 58-86.

Fotyma M. (2000). Problematyka rolnictwa zrównoważonego. Biuletyn Informacyjny IUNG. IUNG, Puławy.

Frenkel I. (2008a). Ludność wiejska. [w:] Polska Wieś 2008. Raport o stanie wsi, J. Wilkin i I. Nurzyńska, red., FDPA, Warszawa.

Frenkel I. (2008b). Przemiany demograficzne i aktywność ekonomiczna ludności wiejskiej w latach 2000-2006. Studia i monografie. IRWiR PAN, Warszawa.

Frenkel I. (2008c). Przemiany demograficzne i aktywność ekonomiczna ludności wiejskiej w pierwszych latach XXI wieku. [w:] Polska wieś i rolnictwo w Unii Europejskiej. Dylematy i kierunki przemian, M. Drygas i A. Rosner, red. IRWiR PAN, Warszawa.

Funck R. i G. Rembold (1975). A multiregion, multisector forecasting model for the Federal Republic of Germany. Papers in Regional Science 34(1), s. 69-82.

Gałęski B. (1966). Socjologia Wsi. Problemy podstawowe. Państwowe Wydawnictwo Naukowe, Warszawa.

Gallaway L.E. (1971). The „Backwash” Thesis, Neutral Growth, and the Incidence of Poverty. Revie Social Economy 29, s. 153-163.

Garson Jeon. i McCubbin (1997). The Relationships between Air Pollution Emission and Income: US Data. Environment and Development Economics.

Gelan A. (2002). Trade Liberalisation and Urban-Rural Linkages: A CGE Analysis for Ethiopia. Journal of Policy Modeling 24 (7-8), s. 707-738.

Gelles S.-P. (1995). Discussion [w:] The Economics of Sustainable Development. I. Golin i A. L. Winters, red.

Giesecke J.A. i J.R. Madden (2003). A large-scale dynamic multi-regional CGE model with an illustrative application. Review of Urban and Regional Development Studies 15, s. 2-25.

Gillespie G., P.G. McGregor, J.K. Swales i inni (2002). A Computable General Equilibrium Approach to the Ex Post Evaluation of Regional Development Agency Policies. [w:] Regional Policies and Comparative Advantage. B. Johansson, C. Karlsson i R. R. Slough, red. Cheltenham, UK, Edward Elgaar.

Ginsburgh V. i M. Keyzer (1997). The structure of applied general equilibrium models. Cambridge and London, MIT Press.

Golinowska S. (2003). Od państwa opiekuńczego (Welfare State) do państwa wspierającego pracę (Workfare State). [w:] Praca i polityka spoteczna wobec wyzwań integracji, B. Balcerzak-Paradowska, red. IPiSS, Warszawa.

Goodland R. (1995). The concept of environmental sustainability. Annual Review of Ecology and Systematics 26, s. 1-24.

Goraj L., Mańko S., Sass R. i inni (2004). Rachunkowość rolnicza. Centrum Doradztwa i Informacji Difin Sp. z o.o., Warszawa.

Goraj L. Malanowska B., Osuch D. i inni (2009). Opis realizacji planu wyboru próby gospodarstw rolnych dla Polskiego FADN w 2009 roku. IERiGŻ PIB, Warszawa. 
Gorlach K. (2004). Socjologia obszarów wiejskich. Wydawnictwo Naukowe Scholar, Warszawa.

Gorlach K. i G. Foryś (2006). W obliczu zmiany: wybrane strategie działania mieszkańców polskiej wsi na przełomie wieków. Wydawnictwo Uniwersytetu Jagiellońskiego, Kraków.

Gorzelak G. (2003). Bieda i zamożność regionów. Założenia, hipotezy, przykłady. Studia Regionalne i Lokalne 1: EUROREG.

Gorzelak G. (2004). Polska polityka regionalna wobec zróżnicowań polskiej przestrzeni. Studia Regionalne i Lokalne 4: EUROREG.

Gorzelak G. (2007). Dlaczego nie należy pomagać regionom słabiej rozwiniętym? W ramach Konferencji: Czy należy pomagać regionom słabo rozwiniętym?, 18 kwietnia, EUROREG, Warszawa.

Gorzelak G. i A. Tucholska, Red. (2007). Rozwój, region, przestrzeń. EUROREG, Uniwersytet Warszawski, Warszawa.

Grassini M. (2004). Rowing along the computable general equilibrium modelling mainstream. Konferencja EcoMod pt „Input-Output and General Equilibrium: Data, Modeling, and Policy Analysis”, Brussels, 2-4 września.

Grosse G. (2008). Zintegrowane podejście w polityce spójności: Przykład dyskusji na temat strategii lizbońskiej i spójności terytorialnej. [w:] Zintegrowane podejście do rozwoju - rola polityki spójności, G. Grosse i A. Galek, red. Ministerstwo Rozwoju Regionalnego, Warszawa.

GTAP. (2008). Global Trade Analysis Project. Perdue University. Aktualne na dzień: 20.07.2009, https://www.gtap.agecon.purdue.edu/models/current.asp.

Guba W. (2008). Przewidywany kształt WPR w latach 2013-2020 z uwzględnieniem polskich priorytetów. [w:] Wyzwania przed obszarami wiejskimi i rolnictwem w perspektywie lat 2014-2020, M. Kłodziński, red. IRWiR PAN, Warszawa.

Guba W. i K. Zawalińska (2002). Przyszłość Wspólnej Polityki Rolnej w Polsce - skutki przystąpienia do WPR dla rolnictwa i gospodarki polskiej. Polska Gospodarka - Tendencje, Oceny, Prognozy (PG-TOP) 2/2002. CASE, Warszawa.

Gunning J.W., M.A. Keyzer, J. Behrman i inni (1995). Applied General Equilibrium Models for Policy Analysis. [w:] Handbook of development economics. Volume 3A. Handbooks in Economics, vol. 9. Amsterdam; New York and Oxford, Elsevier Science, North Holland: 2025-2107.

GUS (2002). Narodowy Spis Powszechny. Warszawa, Główny Urząd Statystyczny.

GUS (2004). Bilans Przepływów Międzygatęziowych w Bieżacych Cenach Bazowych w 2000 r. Główny Urząd Statystyczny, Warszawa.

GUS (2005). Rachunki Narodowe Wedtug sektorów i podsektorów instytucjonalnych 2000-2003. Główny Urząd Statystyczny, Warszawa.

GUS (2006a). Charakterystyka obszarów wiejskich w 2005 r. Urząd Statystyczny w Olsztynie, GUS, Olsztyn.

GUS (2006b). Produkt krajowy brutto - Rachunki regionalne w 2006 r. GUS, Warszawa.

GUS (2006c). Rachunki Finansowe Wedtug Sektorów i Podsektorów Instytucjonalnych 2000-2005. Główny Urząd Statystyczny, Warszawa.

GUS (2007a). Informacja o zmianach i kierunkach emigracji z Polski w latach 2004-2006. GUS, Warszawa. 
GUS (2007b). Polska Klasyfikacja Działalności PKD. Główny Urząd Statystyczny, Warszawa.

GUS (2008a). Rocznik Statystyczny 2008 GUS, Warszawa.

GUS (2008b). Standardowe klasyfikacje i nomenklatury. Główny Urząd Statystyczny. Aktualne na dzień 20.12.2008, http://www.stat.gov.pl/Klasyfikacje/www/com.gus.Se$\operatorname{arch} /$.

GUS (2009). Rocznik Statystyczny 2008 GUS, Warszawa.

Hagemejer J. i J. Michałek (2008). Symulacja skutków liberalizacji handlu rolnego przy użyciu modelu równowagi ogólnej. Ekonomista 4/2008.

Halamska M. i R. Śpiewak (2008). Rozwój wiejski - nowa utopia czy konieczność? [w:] Polska wieś i rolnictwo w Unii Europejskiej. Dylematy i kierunki rozwoju, M. Drygas, red. IRWiR PAN, Warszawa.

Hałasiewicz A. (2008). Źródła finansowania inicjatyw i przedsięwzięć gospodarczych na wsi. [w:] Polska wieś 2008. Raport o stanie wsi, J. Wilkin i I. Nurzyńska, red. FDPA, Warszawa.

Halfacree K.H. (1993). Locality and Social Representation: Space, Discource and Alternative Definitions of Rural. Journal of Rural Studies 9 (1), s. 23-37.

Hansen J. i J. Owens (2000). Microeconomics: the Answers. Roseville, Irwin/McGraw-Hill.

Hardt Ł. (2008). Wspólna Polityka Rolna a polityka spójności w kontekście przeglądu budżetu UE. IRWiR PAN, Wieś i Rolnictwo 4 (141).

Harrigan F. i P. G. McGregor (1989). Neoclassical and Keynesian Perspectives on the Regional Macro-economy: A Computable General Equilibrium Approach. Journal of Regional Science 29 (4), s. 555-573.

Harrigan F.J., J.W. McGilvray i I.H. McNicoll (1980). A Comparison of Regional and National Technical Structures. Economic Journal 90 (363), s. 795-810.

Harris R.I.D. i A. Liu (1998). Input-Output Modelling of the Urban and Regional Economy: The Importance of External Trade. Regional Studies 32 (9), s. 851-862.

Harrison G.W. i inni (1993). How Robust Is Applied General Equilibrium Analysis? Journal of Policy Modeling 15 (1), s. 99-115.

Harrison G.W. i H.D. Vinod (1992). The Sensitivity Analysis of Applied General Equilibrium Models: Completely Randomized Factorial Sampling Designs. Review of Economics and Statistics 74 (2), s. 357-362.

Harrison W.J. i K.R. Pearson (1996). Computing Solutions for Large General Equilibrium Models Using GEMPACK. Computational Economics 9 (2), s. 83-127.

Harrison W.J. i K.R. Pearson (2002). GEMPACK User documentation. Center of Policy Studies and Impact Project, Monash University Melbourne, Australia.

Heffner K., A. Rosner, A. Czarnecki i R. Hoffmann (2004). Rola matych i średnich miast w rozwoju obszarów wiejskich. Raport dla Polski. Wyniki 5. Projektu Ramowego UE, IRWiR PAN, Warszawa.

Heller J. (2000a). Metody regionalnego i lokalnego kształtowania obszarów wiejskich stosowane w Polsce. Zagadnienia Ekonomiki Rolnej 1 (276).

Heller J. (2000b). Regionalizacja Obszarów Wiejskich w Polsce. Studia i Monografie $\mathrm{Nr}$ 99, IERiGŻ, Warszawa.

Heller J. (2000c). Teoretyczne podstawy regionalizacji obszarów wiejskich. [w:] Problemy regionalizacji rolnictwa w procesie ksztattowania obszarów wiejskich: materiały Ogólno- 
polskiej Konferencji Naukowej, Ciechocinek, 7-8 IX, Wydaw. AT-R 2000, Bydgoszcz.

Hellwig Z. (1968). Zastosowanie metody taksonomicznej do typologicznego podziału krajów ze względu na poziom ich rozwoju oraz zasoby i strukturę kwalifikowanych kadr. Przeglad Statystyczny 4.

Henisz-Matuszczak A. (2007). Dualny rozwój rolnictwa i obszarów wiejskich. [w:] Uniwersalia polityki rolnej w gospodarce rynkowej. Ujęcie makro- i mikroekonomiczne, A. Czyżewski, red. Wydawnictwo Akademii Ekonomicznej w Poznaniu, Poznań.

Henke R. i R. Sardone (2004). The Reorientation Process of the CAP Support: Modulation of Direct Payments. [w:] Role of Institutions in Rural Policies and Agricultural Markets, G. Van Huylenbroeck, W. Verbeke i L. Lauwers, red. ELSEVIER, London.

Herbst J. (2008). Wieś obywatelska. [w:] Polska wieś 2008. Raport o stanie wsi, J. Wilkin i I. Nurzyńska, red. FDPA, Warszawa.

Hertel T.W. (1985). Partial vs. General Equilibrium Analysis and Choice of Functional Form: Implications for Policy Modeling. Journal of Policy Modeling 7 (2), s. 281-303.

Hewings G. i E. Hulu (1993). The Development and Use of Interregional input-output models for Indonesia under conditions of limited information. Review of Urban and Regional Development Studies (5), s. 135-153.

Hodgson G.M. (2001). Is Social Evolution Lamarckian or Darwinian? [w:] Darwinism and Evolutionary Economics, J. Laurent i J. Nightinagel, red. Cheltenham, Edward Elgar, s. 87-118.

Hoggart K. i H. Buller (1987). Rural Development. A Geographical perspective. London, Croom Helm.

Honkatukia J. i R. Vaittinen (2003). POLGEM, A Computable General Equilibrium Model for Poland. Government Institute for Economic Research, Finland.

Horridge M. (1988). Tariffs in Australia: Theory, History and Effects. Australian Economic Review 82, s. 61-73.

Horridge M. i J. B. d. S. F. Filho (2005). The Doha Round, poverty, and regional inequality in Brazil. The World Bank, Policy Research Working Paper Series, 3701.

Horridge M., J. Madden i G. Wittwer (2005). The Impact of the 2002-2003 Drought on Australia. Journal of Policy Modeling 27 (3), s. 285-308.

Horridge P.M.W., G.A. Meagher, F. Naqvi, i inni (1999). The Theoretical Structure of MONASH-MRF. Preliminary Working Paper No. OP-85. Clayton, Australia, Monash University.

Hu D. (2002). Trade, Rural-Urban Migration, and Regional Income Disparity in Developing Countries: A Spatial General Equilibrium Model Inspired by the Case of China. Regional Science and Urban Economics 32 (3), s. 311-338.

Howe K.S. (2005). Perspektywy rozwoju obszarów wiejskich w Europie: kwestia zrównoważenia, [w:] Rozwój obszarów wiejskich. Doświadczenia krajów europejskich, K. Zawalińska, red. Problemy Rozwoju Wsi i Rolnictwa IRWiR PAN, Warszawa.

Iqubal Z. i S. Rizwana (2001). Critical Review of Literature on Computable General Equilibrium Models. MIMAP Technical Paper Series No. 9. Ottawa, Canada, International Development Research Centre. 
Ishikawa Y. i T. Miyagi (2004). The Construction of a 47-Region Inter-regional Input-Output Table, and Inter-regional Interdependence Analysis at Prefecture Level in Japan. EconPapers.

Jałowiecki B. (1987). Proces urbanizacji a relacje miasto-wieś. IRWiR PAN, Warszawa.

Jałowiecki B. (1999). Oddziaływanie granicy na gminy województw przygranicznych wyniki badań ankietowych. [w:] Rola wspótpracy transgranicznej w rozwoju regionalnym i lokalnym, A. Mync i R. Szul, red., Toruń.

Jankowska-Kłapkowska A. (1985). Ekologiczno-Ekonomiczna efektywność gosdpodarowania. [w:] Ekonomiczne i socjologiczne problemy ochrony środowiska, A. Ginsbert-Gebert, red. Ossolineum, Wrocław.

Jarociński M. (1998). Skutki nierównomiernego opodatkowania sektorów w Polsce - analiza równowagi ogólnej. Wydział Nauk Ekonomicznych. Uniwersytet Warszawski. Praca magisterska, Warszawa.

Johansen L. (1960). A Multi-Sectoral Study of Economic Growth. North-Holland.

Jones R. i J. Whalley (1989). A Canadian Regional General Equilibrium Model and Some Applications. Journal of Urban Economics 25 (3), s. 368-404.

Josling T.E. (1969). A Formal Approach to Agricultural Policy. [w:] Agricultural Economics, red. G.H. Peters. Edward Elgar Publishing.

Józwiak W., G. Niewęgłowska i T. Czekaj (2006). Zachowania gospodarstw działających na obszarach o niekorzystnych warunkach. Zagadnienia Ekonomiki Rolnej 3.

Józwiak W., G. Niewęgłowska, J. Świetlik i inni (1998). Pomiar wielkości ekonomicznej gospodarstw rolniczych. Zagadnienia Ekonomiki Rolnej 2 (3).

Just R.E. (2001). Addressing the Changing Nature of Uncertainty in Agriculture. American Journal of Agricultural Economics 83 (5), s. 1131-1153.

Kaczor T. (2006). Prognoza oddziatywania makroekonomicznego realizacji Regionalnego Programu Operacyjnego dla poszczególnych województwa na lata 2007-2013. Instytut Badań nad Gospodarką Rynkową, Warszawa.

Kaczor T. (2008). Modele ekonomiczne w ewaluacji, czyli o czym jej odbiorca wiedzieć powinien. [w:] Środowisko i warsztat ewaluacji, A. Haber i M. Szałaja, red. Polska Agencja Rozwoju Przedsiębiorczości, Warszawa.

Kaleta A. (1993). Socjologia wsi jako nauka. [w:] Studia z socjologii wsi. Dedykowane profesorowi Zbigniewowi T. Wierzbickiemu, W. Wincławski, red. Uniwersytet M. Kopernika, Torun.

Kaleta A. i G. Vonderach, red. (2006). Nowa socjologia wsi w Niemczech. Wydawnictwo Uniwersytetu Mikołaja Kopernika, Torun.

Kalinowski T., red. (2006). Sukces rozwojowy polskich województw. Instytut Badań nad Gospodarką Rynkową.

Kamiński R. (2008). Aktywność społeczności wiejskich. Lokalne inicjatywy organizacji pozarzadowych. IRWiR PAN, Warszawa.

Kamiński R. i K. Kwatera (2005). Jak budować Zintegrowana Strategię Rozwoju Obszarów Wiejskich $w$ ramach Pilotażowego programu LEADER+? Poradnik dla animatorów Lokalnych Grup Działania. Fundacja Fundusz Współpracy, Warszawa.

Kancs D.A. (2002). Modeling renewable energy policies. MIT paper. Cambridge.

Kancs D.A. (2006). Evaluation of Renewable Energy Policies. Energy Studies Review 14 (1), s. 1-34. 
Kazumi H. (2000). Development of Interregional Input-Output table for Japanese electricity supplier regions. Denryolcu Keizai Kenkyu 43 (2000.3).

KE (2004). Evaluating EU Activities: A Practical Guide for the Commission Services. DG Budget. Komisja Europejska, Bruksela.

KE (2006). Podręcznik Wspólnych Ram Monitorowania i Oceny. Wytyczne. Rozwój Obszarów Wiejskich 2007-2013. DG Agriculture, Komisja Europejska.

KE (2008). The EU Rural Development Policy:facing the challenges. Komisja Europejska, Bruksela (http://ec.europa.eu/agriculture/events/cyprus2008/brochure_ en.pdf).

Kilkenny M. (1998). Transport Costs and Rural Development. Journal of Regional Science 38 (2): 293-312.

Kilkenny M. i D. Otto (1994). A General Equilibrium Perspective on Structural Change in the Rural Economy. American Journal of Agricultural Economics 76 (5), s. 1130-1137.

Kinnunen J. (2005). Migration, imperfect competition and structural adjustment: essays on the economy of the Aland Islands. Acta Universitatis oeconomicae Helsingiensis. A-258. Helsinki School of Economics. Praca doktorska, Helsinki.

Kinnunen J. i R. Palmer (2006). Future Demand of Labour and the Need of Education in the Aland Islands. Konferencja EcoMod Bruksela, Free University of Brussels.

Kiryluk-Dryjska E. (2008). Możliwości zastosowania modelu optymalizacyjnego alokacji środków strukturalnych przeznaczonych na rozwój rolnictwa pomiędzy regiony o zróżnicowanym potencjale ekonomicznym. Wieś i Rolnictwo 4 (141).

Kiuiła O. (2003). Economic Repercussions of Sulfur Regulations in Poland. Journal of Policy Modeling 25 (4), s. 327-33.

Kiuiła O. (2000). Badanie kosztów dostosowywania polskiej gospodarki do drugiego protokotu siarkowego. Model równowagi ogólnej. Wydział Nauk Ekonomicznych. Uniwersytet Warszawski. Praca doktorska, Warszawa.

Kiuiła O. i G. Peszko (2006). Sectoral and Macroeconomic Impacts of the Large Combustion Plants in Poland: A General Equilibrium Analysis. Energy Economics 28 (3), s. $288-307$.

Kiuiła O. i J. Śleszyński (2003). Expected Effects of the Ecological Tax Reform for the Polish Economy. Ecological Economics 46 (1), s. 103-120.

Klekotko M. (2008). Społeczeństwo obywatelskie a rozwój zrównoważony wsi. Podejście poznawcze. [w:] Społeczne aspekty zrównoważonego rozwoju wsi w Polsce, H. Podedworna i P. Ruszkowski, red. Wydawnictwo Naukowe SCHOLAR, Warszawa.

Klepacka-Kołodziejska D. (2007). Wsparcie Unii Europejskiej dla Obszarów o Niekorzystnych Warunkach Gospodarowania - doświadczenia i wnioski dla Polski. Problemy Rozwoju Wsi i Rolnictwa, IRWiR PAN. Praca doktorska, Warszawa.

Kłodziński M. (2006). Aktywizacja społeczno-gospodarcza gmin wiejskich i małych miast. Problemy Rozwoju Wsi i Rolnictwa, IRWiR PAN, Warszawa.

Kłodziński M., red. (2008). Wyzwania przed obszarami wiejskimi i rolnictwem w perspektywie lat 2014-2020. Problemy Rozwoju Wsi i Rolnictwa. IRWiR PAN, Warszawa.

Knoke D. i J. Kuklinski (1990). Network analysis: basic concepts. [w:] Markets, hierarchies and networks, G. Thompson, red. Sage, London.

Kołodziej T. i B. Mrówka, red. (2007). PHARE w Polsce 1990-2007. UKIE, Warszawa. 
Kołodziejski J. (1995a). Ksztattowanie polityki przestrzennej państwa w procesie transformacji systemowej. Koncepcja polityki przestrzennego zagospodarowania kraju. Raport pod kierunkiem J. Kołodziejskiego, CUP, Warszawa.

Kołodziejski J. (1995b). Założenia koncepcji przestrzennego zagospodarowania kraju „POLSKA 2000 PLUS”. [w:] Polityka Regionalna w rozwoju obszarów wiejskich, K. Duczkowska-Małysz, M. Kłodziński i C. Siekierski, red. Ministerstwo Rolnictwa, FAPA i SGGW, Warszawa.

Kornai J. (1977). Anti-Equilibrium. Teoria systemów gospodarczych i kierunki badań. Państwowe Wydawnictwo Naukowe, wyd. II, Warszawa.

Kozłowski S., red. (2002). Ocena Zrównoważonego Rozwoju (Ekorozwoju) w procesie transformacji polskiej gospodarki. Komitet „Człowiek i Środowisko” przy Prezydium PAN, Zeszyty Naukowe Nr 30, Warszawa.

Krześniak A. (1998). Modelowanie integracji Polski ze Wspólnotami Europejskimi. (materiał powielony). Uniwersytet Warszawski, Warszawa.

KS (2004). Indykatywny podział środków UE na województwa na podstawie wskaźników przyjętych uchwałami (nr 2, 3, 4, 5 i 6). Komitet Sterujący Sektorowym Programem Operacyjnym „Restrukturyzacja i modernizacja sektora żywnościowego oraz rozwój obszarów wiejskich”. 25 listopada, http://www.minrol.gov.pl/FileRepozytory/FileRepozytoryShowImage.aspx?item_id=11156, Warszawa.

KS (2/2004). Uchwała Nr 2/2004. Komitet Sterujący Sektorowym Programem Operacyjnym „Restrukturyzacja i modernizacja sektora żywnościowego oraz rozwój obszarów wiejskich”. 25 listopada, Ministerstwo Rolnictwa i Rozwoju Wsi, Warszawa.

KS (3/2004). Uchwała Nr 3/2004. Komitet Sterujący Sektorowym Programem Operacyjnym „Restrukturyzacja i modernizacja sektora żywnościowego oraz rozwój obszarów wiejskich”. 25 listopada, Ministerstwo Rolnictwa i Rozwoju Wsi, Warszawa.

KS (4/2004). Uchwała Nr 4/2004. Komitet Sterujący Sektorowym Programem Operacyjnym „Restrukturyzacja i modernizacja sektora żywnościowego oraz rozwój obszarów wiejskich”. 25 listopada, Ministerstwo Rolnictwa i Rozwoju Wsi, Warszawa.

KS (5/2004). Uchwała Nr 5/2004. Komitet Sterujący Sektorowym Programem Operacyjnym „Restrukturyzacja i modernizacja sektora żywnościowego oraz rozwój obszarów wiejskich”. Ministerstwo Rolnictwa i Rozwoju Wsi, Warszawa.

KS (6/2004). Uchwała Nr 6/2004. Komitet Sterujący Sektorowym Programem Operacyjnym „Restrukturyzacja i modernizacja sektora żywnościowego oraz rozwój obszarów wiejskich”. Ministerstwo Rolnictwa i Rozwoju Wsi, Warszawa.

Kujaczyński T. (2007). Struktury wytwórcze w gospodarce żywnościowej w świetle przepływów międzygałęziowych. [w:] Uniwersalia polityki rolnej w gospodarce rynkowej, ujęcie makro- $i$ mikroekonomiczne, A. Czyżewski, red. Wydawnictwo Akademii Ekonomicznej w Poznaniu, Poznań.

Kulawik J. (2008). Efektywność finansowa w rolnictwie. Istota, pomiar i perspektywy. Zagadnienia Ekonomiki Rolnej 2 (315).

Lambert S., H. Schneider i A. Suwa (1991). Adjustment and Equity in Cote d'Ivoire: 1980-1986. World Development 19 (11), s. 1563-1576. 
Latruffe L., K. Balcombe, S. Davidova i inni (2005). Technical and Scale efficiency of Crop and Livestock Farms in Poland. Does Specialisation Matter? Agricultural Economics 32 (3), s. 281-296.

Lawrence G. (2005). Promoting Sustainable Development. The Question of Governance. [w:] New Directions in the Sociology of Global Development. Research in Rural Sociology and Development., F. H. Buttel i P. McMichael, red. Amsterdam, Elsevier. t. 11.

Lawson T. (2003). Reorienting Economics. London, Routledge.

Leontief W. (1937). Inter-relation of prices, output, savings and investment. Review of Economics and Statistics 19, s. 109-132.

Leontief W., A. Carter i P.A. Petri (1977). The Future of the World Economy. Oxford University Press, New York.

Lewis G. J. (1979). Rural Communities. A Social Geography. London, David \& Charles.

Liew L.H. (1984). „Tops-down” versus „Bottoms-up” Approaches to Regional Modeling. Journal of Policy Modeling 6 3, s. 351-367.

Llano C. (2000). The Estimation of the Interregional Trade in the Context of an Interregional Input-Output Model for the Spannish Economy. Econ Papers.

Lofgren H., R. Lee Harris i S. Robinson (2002). A Standard Computable General Equilibrium (CGE) Model in GAMS. IFPRI, Waszyngton.

Louhela T. (2006). Estimation of Interregional Trade for Finnish Regions in 1996 and 2002 - Freight Flow and Gravity Approaches. 46 Congress of the European Regional Science Association (ERSA), Greece.

Louhela T. i M. Koutaniemi (2006). Construction of Regional Input-Output Tables in Finland 2002. 46th Congress of the European Regional Science Association (ERSA), Greece.

Lowe P., J. Murdoch i N. Ward (1995). Network in rural development: beyond endogenous and exogenous approaches. [w:] Beyond modernization: the impact of endogenous rural development, J. D. Van der Ploeg i G. Van Dijk, red. Assen, The Netherlands: Van Gorcum.

Majewski E. (2008). Trwaty rozwój i trwate rolnictwo - teoria a praktyka gospodarstw rolniczych. SGGW, Warszawa.

Malinen P., R. Keränen i K. Keränen (1994). Rural area typology in Finland - a tool for rural policy. Research Reports University of Oulu, Research Institue of Northern Finland. 123.

Maliszewska M. (2004). EU Enlargement: Benefits of the Single Market Expansion for Current and New Member States. Studia i Analizy Nr 273. CASE, Warszawa.

Mańko S., T. Sobczyński i R. Sass (2007). Konkurencyjność większych ekonomicznie polskich gospodarstw rolniczych na tle wybranych krajów UE. http://www.ekrol.sggw.waw.pl/publikacje/pdf/prs17/Stanislaw_Manko_Tadeusz_Sobczynski_Roman_Sass.pdf

Marsden T. (2006). The road towards sustainable rural development: issues of theory, policy and practice in European context. [w:] Handbook of rural studies, P. Cloke, T. Marsden i P. Mooney, red. London, Sage.

Martin L.R., Ed. (1981). A Survey of Agricultureal Economics Literature. Economics of Welfare, Rural Develoment, and Natural Resources in Agriculture, 1940s to 1970s. University of Minesota Press. 
McGregor P.G., J.K. Swales i Y.P. Yin (1995). Migration Equilibria/Disequilibria and the Natural Rate of Unemployment in a Regional Context. International Journal of Manpower 16 2, s. 66-72.

Meier G.M. i J.E. Rauch (2000). Leading Issues in Economic Development. Oxford University Press, Oxford.

Meller P. (1991). Adjustment and Social Costs in Chile during the 1980s. World Development 19 11, s. 1545-61.

Michna W., red. (1998). Program Proekologicznego Rozwoju Wsi, Rolnictwa i Gospodarki Żywnościowej do 2015. Synteza. IERiGŻ, Warszawa.

Michna W. (1999). Polityka regionalna w sferze obszarów wiejskich i rolnictwa. Zeszyty Naukowe SGGW. Ekonomika i Organizacja Gospodarki Żywnościowej, SGGW. Warszawa 37.

Michna W. (2000). Jakość surowców rolnych i żywności jako ważny składnik oceny zrównoważonego rozwoju rolnictwa. Pamiętnik Putawski 2 (120), s. 317-323.

Miernyk W.H., K.L. Shellhammer, R.L. Coccari, i inni (1970). Simulating Regional Economic Development: an industry analysis of the West Virginia economy. Lexington, MA, Heath.

Mierosławska A. (1999). Potencjat gospodarczy województw Polski (ze szczególnym uwzględnieniem rolnictwa). IERiGŻ, Warszawa.

Milczarek D. i K. Zawalińska (2005). Wnioski i doświadczenia z programu Banku Światowego PAOW dla polityki rozwoju obszarów wiejskich w Polsce - na przykładzie podkomponentu „Reorientacji i Przekwalifikowań”. Roczniki Naukowe SERiA, Warszawa-Poznań tom VII (zeszyt 4).

Mitra-Kahn B.H. (2008). Debunking the Myths of Computable General Equilibrium Models. SCEPA Working Paper 2008-1. London, Schwartz Center for Economic Policy Analysis, City University.

Morrison W.I. i P. Smith (1974). Nonsurvey Input-Output Techniques at the Small Area Level: An Evaluation. Journal of Regional Science 14 1, s. 1-14.

Morrisson C. (1991). Adjustment, Incomes and Poverty in Morocco. World Development 19 (11), s. 1633-51.

Morten (2006). Materiaty treningowe w projekcie Zasady Programowania, Zarzadzania, Moniotorowania i Ewaluacji Programów UE na rzecz Rozwoju Obszarów Wiejskich Finansowanych z EFOIGR. AGROTEC.

Murdoch J. (2000). Networks - a new paradigm of rural development? Journal of Rural Studies 16, s. 407-419.

Murray M. i J. Greer (1992). Rural Development in Northern Ireland. Journal of Rural Studies 8(2).

Nemes G. (2005). Integrated Rural Development. The concept and its operation. Discussion Papers, MT-DP. 2005/6. Institute of Economics Hungarian Academy of Sciences, Budapeszt.

Nieć D. (1999). Pomiar rentowności gospodarstw rodzinnych i identyfikacja czynników ja ksztattujacych. IERiGŻ, (praca doktorska) Warszawa.

Niewęgłowska G. (2005). Zdolność rodzinnych gospodarstw rolnych do realizacji programu rolno-środowiskowego. Studia i Monografie, nr 130. Warszawa.

Nowak S. (1990). Models, of Directional Change and Human Values: the Theory of Progress as an Applied Social Science. [w:] Rethinking Progress. Movements, Forces, and 
Ideas at the End of the 20th Century, J. C. Alexander i P. Sztompka, red. Boston, Unwin Hyman.

ODPM (2004). Assessing the Impacts of Spatial Interventions: Regeneration, Renewal and Regional Development. „The 3Rs guidance”. London, Office of the Deputy Prime Minister.

OECD (1996). Networks for Rural Development. OECD, Paris.

OECD (2006). The New Rural Paradigm: Policies and Governance. OECD, Paris.

OECD (2008). Rural Policy Reviews:Finland. OECD, Paris.

Okun A. (1975). Equality and Efficiency: The big trade-off. Brooking Institution Washington, D.C.

Olson M. (1971). The Logic of Collective Actions. Public Goods and the Theory of Group. Harvards University Press Cambridge.

Oosterhaven J. i J.A. van der Linden (1995). European Community Intercountry InputOutput Relations: Construction Method and Main Results for 1965-85. Economic Systems Research 7 (3), s. 249-269.

Orłowski W.M. (1991). Opcje polityki monetarnej i fiskalnej okresu przejścia do gospodarki rynkowej: analizy z wykorzystaniem modelu równowagi ogólnej dla gospodarki polskiej. Uniwersytet Łódzki (praca doktorska), Łódź.

Orłowski W.M. (1996). Price Support at Any Price? Costs and Benefits of Alternative Agricultural Policies for Poland. The World Bank, Policy Research Working Paper Series, 1584.

Orłowski W.M. (1998). Droga do Europy. Makroekonomia wstępowania do Unii Europejskiej. Integracja Europejska/Monografie. Instytut Europejski, Łódź.

Orłowski W.M. (1999). A Computable General Equilibrium Model of the Polish Economy (main features). Research Bulletin Nr 1, tom 7. GUS i PAN, Warszawa.

Orłowski W.M. (2000). Koszty i korzyści z członkostwa w Unii Europejskiej. Metody, modele, szacunki. CASE, Warszawa.

Osuch D. (1999). Efektywność ekonomiczna zrestrukturyzowanych przedsiębiorstw rolnych powstatych $w$ oparciu o majątek skarbu państwa. IERiGŻ, Warszawa.

Partridge M. i D.S. Rickman (1998). Regional Computable General Equilibrium Modeling: A survey and critical appraisal. International Regional Science Review 21 (3), s. $205-248$.

Paszkowski P. (2006). Renty strukturalne $w$ rolnictwie. IRWiR PAN, Warszawa.

Pereira A.M. i J.B. Shoven (1988). Survey of Dynamic Computational General Equilibrium Models for Tax Policy Evaluation. Journal of Policy Modeling 10 (3), s. 401-36.

Perrier-Cornet P. (2001). La problematique du developpement rural en France: Une analyse critique. [w:] Agriculture et espace rural: quel developpement? Centre franco-autrichien pour le rapprochement economique en Europe-CFA, s. 65-68.

Peszko G. (1997). Integracja celów ekonomicznych i ekologicznych w strategiach rozwoju zrównoważonego. Akademia Ekonomiczna. (praca doktorska) Kraków.

Peter M.W., M. Horridge, G.A. Meagher i inni (1996). The Theoretical Structure of MONASH-MRF. CoPS/IMPACT Working Paper Number OP-85.

Piazolo D. (2000). Poland's membership in the European Union: an analysis with a dynamic Computable General Equilibrium (CGE) model. LICOS Discussion Paper. 
Piispala J. (2000). On Regionalising Input/Output Tables - Experiences from Compiling Regional Supply and Use Tables in Finland. XIII International Conference on Input-Output Techniques, Univeristy of Macerata, Italy.

Piontek B. (2002). Koncepcja rozwoju zrównoważonego i trwatego Polski. Wydawnictwo Naukowe PWN, Warszawa.

Piontek B., F. Piontek i W. Piontek (1997). Ekorozwój i narzędzia jego realizacji. Ekonomia i Środowisko, Wydawnictwo Uniwersytetu Białostockiego, Białystok.

Piontek F. (2001). Kontrowersje i dylematy wokół rozwoju zrównoważonego i trwałego. [w:] Ekonomia a rozwój zrównoważony. Teoria i ksztatcenie. Praca zbiorowa, F. Piontek, red. Wyd. Ekonomia i Środowisko, Białystok.

Plewa J. (2008). Ocena funkcjonowania Wspólnej Polityki Rolnej: propozycje legislacyjne. [w:] Rolnictwo i przemyst spożywczy w cztery lata po wejściu do Unii Europejskiej - czy wykorzystaliśmy szansę. SGH, Warszawa.

Poczta-Wajda A. (2008). Dostosowanie rynkowe w sektorze rolno-żywnościowym krajów wysokorozwiniętych w wyniku postanowień Rundy Urugwajskiej. Wydział Ekonomii. Akademia Ekonomiczna (praca doktorska), Poznań.

Poczta W. (2008). Rolnictwo. [w:] Polska wieś 2008. Raport o stanie wsi, J. Wilkin i I. Nurzyńska, red. FDPA, Warszawa.

Poczta W. i A. Mrówczyńska (2002). Regionalne zróżnicowanie polskiego rolnictwa. [w:] Zróżnicowanie regionalne gospodarki żywnościowej w Polsce w procesie integracji z Unia Europejska, W. Poczta i F. Wysocki, red. Wyd. AR w Poznaniu, Poznań.

Poczta W. i F. Wysocki, red. (2002). Zróżnicowanie regionalne gospodarki żywnościowej $w$ Polsce $w$ procesie integracji z Unia Europejska. Wydawnictwo Akademii Rolniczej im. A. Cieszkowskiego, Poznań.

Poczta W. (2003). Rolnictwo polskie w przededniu integracji z Unia Europejska. Wydawnictwo Akademii Rolniczej w Poznaniu, Poznań.

Podedworna H. i P. Ruszkowski, red. (2008). Społeczne aspekty zrównoważonego rozwoju wsi w Polsce. Wydawnictwo Naukowe SCHOLAR, Warszawa.

Polenske K. (1980). The U.S. Multiregional Input-Output Accounts and Model. Lexington Books Polska wieś 2008. Raport o stanie wsi, J. Wilkin i I. Nurzyńska, red. FDPA, Warszawa.

Polska wieś 2008. Raport o stanie wsi, J. Wilkin i I. Nurzyńska, red. FDPA, Warszawa.

Polski_FADN (2007). Plan wyboru próby gospodarstw rolnych polskiego FADN od roku obrachunkowego 2008. 17 maj 2007, IERiGŻ, Warszawa.

Porter M., C. Ketels, K. Miller i inni (2004). Competitiveness in Rural U.S. Regions: Learning and research agenda. Institute for Strategy and Competitiveness, Harvard Business School.

Poskrobko B., red. (2007). Obszary badań nad trwałym i zrównoważonym rozwojem. Wydawnictwo Wyższej Szkoły Ekonomicznej w Białymstoku, Białystok.

Powell A.A. i R.H. Snape (1993). The Contribution of Applied General Equilibrium Analysis to Policy Reform in Australia. Journal of Policy Modeling 15 (4), s. 393-414.

Powell W. (1990). Neither market nor hierarchy: network forms of organisation. Research in Organisational Behaviour 12, s. 295-336.

PROW (2004-2006). Plan Rozwoju Obszarów Wiejskich na lata 2004-2006 zatwierdzony na mocy Decyzji Komisji z 6 września 2004 r. zatwierdzającej dokument progra- 
mujący rozwój obszarów wiejskich w Polsce dla okresu 2004-2006. 14 listopada, Ministerstwo Rolnictwa i Rozwoju Wsi, Warszawa.

PROW (2007-2013). Program Rozwoju Obszarów Wiejskich na lata 2007-2013, lipiec 2007, Ministerstwo Rolnictwa i Rozwoju Wsi, Warszawa.

Purdon S., C. Lessof, K. Woodfield i inni (2001). Research Methods for Policy Evaluation. Working Paper No2. Department for Work and Pensions, UK.

Quesnay F. (1758). Tableau Economique. Reprodukcja. [w:] Oevreus Economiques et Philosphiques de F. Quesnay, foundateur du Systeme Physiocrates, J. Baer, red., Paryż.

Rembisz W. (2007). Mikroekonomiczne podstawy wzrostu dochodów producentów rolnych. Wyższa Szkoła Finansów i Zarządzania w Warszawie, Warszawa.

Rembisz W. (2008). Mikro- i Makroekonomiczne podstawy wzrostu w sektorze rolno-spożywczym. Wyższa Szkoła Finansów i Zarządzania w Warszawie, Warszawa.

Richardson J.D. (1989). Empirical Research on Trade Liberalisation with Imperfect Competition: A Survey. OECD Economic Studies 12, s. 7-50.

Rickman D.S. (1992). Estimating the impact of regional business assistance programs: Alternative closures in a computable general equilibrium model. Papers in Regional Science 71, s. 421-435.

Rickman D.S. (1995). A Bayesian Analysis of the Use of Pooled Coefficients in a Structural Regional Economic Model. International Journal of Forecasting 11 (3), s. 477-90.

Rickman D.S. i G.I. Treyz (1993). Alternative Labor Market Closures in a Regional Model. Growth and Change 24 (1), s. 32-50.

Ritson C. i D. Harvey, Eds. (1997). The Common Agricultural Policy. London, New York, CAB International.

Roberts B.M. (1994). Calibration Procedure and the Robustness of CGE Models: Simulations with a Model for Poland. Economics of Planning 27 3, s. 189-210.

Roberts B.M. (1996). Privatisation in Eastern Europe - Alternative Scenarios. Discussion Papers, Nr 16, University of Leicester.

Robinson S., A. Cattaneo i M. El-Said (2001). Updating and Estimating a Social Accounting Matrix Using Cross Entropy Methods. Economic Systems Research 13 1, s. 47-64.

Rosner A., red. (1999). Typologia wiejskich obszarów problemowych. Problemy Rozwoju Wsi i Rolnictwa. IRWiR PAN, Warszawa.

Rosner A., red. (2002). Wiejskie obszary kumulacji barier rozwojowych. Problemy Rozwoju Wsi i Rolnictwa IRWiR PAN, Warszawa.

Rosner A. (2007a). Uwarunkowania społeczno-gospodarcze zwiazane z restrukturyzacja funkcji rolniczej wsi - diagnoza i rekomendacje. Ekspertyza do Koncepcji przestrzennego zagospodarowania kraju na lata 2008-2033. Ministerstwo Rozwoju Regionalnego, Warszawa.

Rosner A., red. (2007b). Zróżnicowanie poziomu rozwoju społeczno-gospodarczego obszarów wiejskich a zróżnicowanie dynamiki przemian. Problemy Rozwoju Wsi i Rolnictwa IRWiR PAN, Warszawa.

Rosner A. i M. Stanny (2007). Zróżnicowanie poziomu rozwoju gospodarczego obszarów wiejskich w Polsce. [w:] Zróżnicowanie poziomu rozwoju społeczno-gospodarczego obszarów wiejskich a zróżnicowanie dynamiki przemian, A. Rosner, red. IRWiR PAN, Warszawa. 
Roszkowska-Mądra B. (2008). Sposoby Urzeczywistniania Koncepcji Zrównoważonego Rozwoju na Obszarach o Niekorzystnych Warunkach Gospodarowania (ONW). Wieś i Rolnictwo 3 (140).

Round J.I. (1978). An Interregional Input-Output Approach to the Evaluation of Nonsurvey Methods. Journal of Regional Science 18 2, s. 179-94.

Rowiński J. (2007). Program rozwoju obszarów wiejskich w latach 2007-2013 - kilka uwag. [w:] Rozwój rolnictwa, gospodarki żywnościowej i obszarów wiejskich Polski $w$ Unii Europejskiej, S. Zięba, A. Kowalski red. IERiGŻ i ALMAMER, Warszawa.

RURALIA. (2008). CGE literature. Aktualne na dzień 10.01.2009, http://ruralia.sjoki.uta.fi/hymakes/ytp/english/literature.pdf

RURALIA, PTT, MTTL i inni (2006). Ex-ante evaluation of RDP 2007-2013. [Orig. Ennakkoarviointi Manner-Suomen maaseudun kehittämisohjelma 2007-2013]. Ministry of Agriculture and Forestry, MMM, Helsinki, Finland.

Rutherford T.F. i H. Törmä (2009). Efficiency of Fiscal Measures in Preventing Out Migration from North Finland. Regional Studies (January 2009), s. 1-11.

Rydz E. (2006). Rola matych miast w rozwoju obszarów wiejskich. Komisja Obszarów Wiejskich PTG, tom XI, Warszawa.

Samuelson P.A. i W.D. Nordhaus (2004). Ekonomia 1. PWN, Warszawa.

Saraceno E. (1994). Alternative Readings of Spatial Differentiation: The Rural versus the Local Economy Approach in Italy. European Review of Agricultural Economics 21 3-4, s. 451-474.

Scarf H.E. (1967). On the computation of equlibrium prices. [w:] Ten Economic Studies in the tradition of Irving Fischer, W. J. Fellner, red. New York, Wiley.

Schneider M.H. i S.A. Zenios (1990). A Comparative Study of Algorithms for Matrix Balancing. Operations Research 38 (3): 439-455.

Schultz T. (1964). Transforming traditional agriculture. New Haven, Yale University Press.

Sen A. (1999). Development as Freedom. Oxford, Oxford University Press.

SERA (2006). Study on Employment in Rural Areas. Scottish Agricultural College, Edinborouhg.

Schiff M. i A. Valdes (1998). The plundering of agriculture in developing countries. [w:] International agricultural development, C. K. Eicher i J. M. Staatz, red. London, The John Hopkins University Press.

Shoven J.B. i J. Whalley (1984). Applied General-Equilibrium Models of Taxation and International Trade: An Introduction and Survey. Journal of Economic Literature 223 , s. $1007-1051$.

Shuckmith M., K. Thomson i D. Roberts, red. (2005). The CAP and the Regions: the Territorial Impact of the Common Agricultural Policy. CAB International Cambridge.

Śleszyński J. (2000). Ekonomiczne problemy ochrony środowiska. ARIES, Warszawa.

Smagacz J. (2000). Rola zmianowania w rolnictwie zrównoważonym. Pamiętnik Puławski 2 (120), s. 411-414.

Smith P. i W.I. Morrison (1974). Simulating the Urban Economy: Input-Output Techniques. Pion Limited, London.

Sotte F. (2004). From CAP to CARPE: the state of the question. 87th EAAE-Seminar on Assessing rural development of the CAP, 21-23 kwietnia, Wiedeń. 
SPO Rolnictwo (2004). Sektorowy Program Operacyjny „Restrukturyzacja i modernizacja sektora żywnościowego oraz rozwój obszarów wiejskich 2004-2006”. 3.09.2004, Ministerstwo Rolnictwa i Rozwoju Wsi, Warszawa.

Spychalski G. (2005). Mezoekonomiczne aspekty ksztattowania rozwoju obszarów wiejskich. Problemy Rozwoju Wsi i Rolnictwa IRWiR PAN, Warszawa.

Statistics Finland (1999). Regional Trade Flows in Finland 1996. Preliminary information from the input-output project. Statistics Finland, Helsinki.

Statistics Finland (2000). Regional Input-Output 1995 - Tables and Compilation Methods. Statistics Finland, Helsinki.

Stone R., A. Ingham i A.M. Ulph (1984). Balancing the National Accounts: The Adjustment of Initial Estimates-A Neglected Stage in Measurement. [w:] Demand, Equilibrium, and Trade: Essays in Honor of Ivor F. Pearce. New York, St. Martin's Press, s. 191-212.

Strategia Rozwoju Kraju (2006). Strategia Rozwoju Kraju 2007-2015. Załącznik 1: Powiazanie Strategii Rozwoju Kraju z innymi Strategiami i Programami. Ministerstwo Rozwoju Regionalnego, Warszawa.

Szemberg A. (1999). Społeczno-ekonomiczne regiony rolnictwa i obszarów wiejskich (nowa propozycja). Komunikaty, Raporty, Ekspertyzy, Zeszyt 453. IERiGŻ, Warszawa.

Tabeau A. (1996). The CGE Model for Polish Analyses. mimeo Hague.

Tarling R., J. Rhodes, J. North, i inni (1993). The Economy and Rural England. Rural Development Commission, UK, Salisbury.

Terluin I.J. (2001). Rural Regions in the EU: Exploring Differences in Economic Development. Ruimtelijke Wetenschappen. Groningen, Rijksuniversiteit Groningen, (praca doktorska).

Terluin I.J. i J.H. Post, red. (2000). Employment Dynamics in Rural Europe. CABI International, Haga.

Thorbecke E. (1991). Adjustment, Growth and Income Distribution in Indonesia. World Development 19 11, s. 1595-1614.

Tohmo T. (2004). New Developments in the Use of Location Quotients to Estimate Regional Input-Output Coefficients and Multipliers. Regional Studies 38 (1), s. 43-54.

Tomaszewicz Ł. (2000). New I-O table and SAMs for Poland. XIII International Conference on Input-Output Techniques University of Macerata, Italy.

Tomaszewicz Ł. i J. Boratyński (2003). Polish Economic Transformation from Perspective of SAM analysis. VII konferencja AMFET, Modelling Economies in Transition, Łódź.

Tomaszewicz Ł. i J. Trębska (2005). Regional and Interregional Input-Output Tables for Poland. [w:] Modeling Economies in Transition 2004, Łódź, W. Welfe i P. Wdowiński, red. Uniwersytet Łódzki, Łódź.

Tomczak F. (2004). Od rolnictwa do agrobiznesu. Transformacja gospodarki rolniczo-żywnościowej Stanów Zjednoczonych Ameryki Pótnocnej. Szkoła Główna Handlowa, Warszawa.

Törmä H. (2008). Do Small Town Development Projects Matter, and Can CGE Help? Spatial Economic Analysis Journal 3 (2).

Törmä H. i T.F. Rutherford (1993). Integrating Finnish Agriculture Into EC's Common Agricultural Policy. Research Reports 13: Government Institute For Economic Rese$\operatorname{arch}($ Vatt). 
Törmä H. i T.F. Rutherford (1998). Regional Computable General Equilibrium Model for Finland. Series E, Working Papers, nr 1. Kemi-Tornio Polytechnic, Finland.

Törmä H., T.F. Rutherford i R. Vaittinen (1995). What will EU Membership and the Value added tax reform do to Finnish Food Economy?-A computable general equilibrium analysis. Discussion Paper 88. Helsinki, Government Institute for Economic Research.

Törmä H., A. Sihvonen i A. Aku (1995). Suuri aluepolitiikka Suomessa: Valtion ja KELAn vuoden 1992 budjettien alueelliset vaikutukset (ang. The regional effects of the year 1992 budgets of the state of Finland and the social insurance institution of Finland). Joint authority of the county of Mikkeli, Raport $n r 20$.

Törmä H. i K. Zawalińska (2007). Technical Description of the CGE RegFin/RegPol models. Ruralia Institute Seinajoki, Finlandia (dostępne na: http://128.214.67.123/ruralia/asiantuntijapalvelut/ytp_fin/julkaisut.htm Aktualne na dzień 10.01.2009).

Turowski J. (1995). Socjologia wsi i rolnictwa. Towarzystwo Naukowe KUL, Lublin.

UKIE (2005). Inicjatywa LEADER $+w$ Polsce. Urząd Komitetu Integracji Europejskiej, Warszawa.

Umer A., B. Jankowski, M. Niemyski i inni (1998). Analiza możliwości ratyfikacji Protokotu Azotowego w oparciu o aktualna polityke przemystowa. Badania systemowe. EnergSys Sp. z o.o., Warszawa.

Van Huylenbroeck G., W. Verbeke i L. Lauwers (2004). Role of Institutions in Rural Policies and Agricultural Markets. ELSEVIER, London.

Vargas E.E., D.F. Schreiner, G. Tembo i inni (1999). Computable General Equilibrium Modeling for Regional Analysis. Virginia, Regional Research Institute, WVU.

Walras L. (1874). Éléments d'économie politique pure, ou théorie de la richesse sociale (Elements of Pure Economics, or the theory of social wealth). Przetłumaczony na ang. przez W. Jaffé w 1899 r.

Wasilewski A. (1999). Infrastruktura techniczna obszarów wiejskich w świetle nowego podziału administracyjnego. Komunikaty, Raporty, Ekspertyzy, Zeszyt 440. IERiGŻ, Warszawa.

White P. (1986). Rural-urban continuum. [w:] The Dictionary of Human Geography. R.J. Johnston, G. Derek i D.M. Smith, red. Oxford, Blackwell.

Wiatrak A.P. (1980). Czynniki różnicujace wydajność pracy w rolnictwie. PWN Warszawa.

Wiatrak A.P. (1996). Regionalne zróżnicowanie zachowań ludności wiejskiej. [w:] Produkcyjne i konsumpcyjne zachowania gospodarstw wiejskich $w$ okresie przemian systemowych. J. Lewandowski i J. Wilkin, red. Uniwersytet Warszawski, Wydział Nauk Ekonomicznych, Warszawa.

Wieruszewska M., red. (2007). Tu i tam. Migracje z polskich wsi za granice. Problemy Rozwoju Wsi i Rolnictwa IRWiR PAN, Warszawa.

Wilczyński R. (2008). Programy odnowy wsi w Polsce. [w:] Polska wieś 2008. J. Wilkin i I. Nurzyńska, red. FDPA, Warszawa.

Wilkin J. (1998). Rolnictwo i Obszary Wiejskie. [w:] Przystapienie czy integracja? Polska droga do Unii Europejskiej. EU-monitoring II, J. Hausner, M. Marody, J. Wilkin, A. Wojtyna, M. Zirk-Sadowski, red. Fundacja Ericha Brosta przy Fundacji Friedricha Eberta, Warszawa. 
Wilkin J., red. (2003). Podstawy Strategii Zintegrowanego Rozwoju Rolnictwa i Obszarów Wiejskich w Polsce. WNE, Uniwersytet Warszawski, Warszawa.

Wilkin J., red. (2005). Polska wieś 2025. Wizja rozwoju. IRWiR PAN, Fundusz Współpracy, Warszawa.

Wilkin J. (2006). Sami swoi? Polscy rolnicy w Unii Europejskiej. [w:] Polska wieś 2006, Raport o stanie wsi. FDPA, Warszawa.

Wilkin J. (2008a). Ewolucja paradygmatów rozwoju obszarów wiejskich. Wieś i Rolnictwo 3 (140).

Wilkin J. (2008b). Wielofunkcyjność rolnictwa i obszarów wiejskich. [w:] Wyzwania przed obszarami wiejskimi i rolnictwem w perspektywie lat 2014-2020, M. Kłodziński, red. IRWiR PAN, Warszawa.

Winiarski B. (2000). Zróżnicowanie poziomu konkurencyjności regionów a kierunki i cele polityki regionalnej oraz jej uwarunkowania makroekonomiczne w Polsce. [w:] Polityka regionalna i jej rola $w$ podnoszeniu konkurencyjności regionów, M. Klamuta i L. Cybulski, red. Akademia Ekonomiczna we Wrocławiu, Wrocław.

Woś A. (1975). Zwiazki rolnictwa z gospodarka narodowa. Państwowe Wydawnictwa Rolnicze i Leśne, Warszawa.

Woś A. (1998). Wzrost gospodarczy i strategie rozwoju polskiego rolnictwa. Eseje 2. IERiGŻ, Warszawa.

Woś A., red. (2000). Analiza produkcyjno-ekonomicznej sytuacji rolnictwa i gospodarki żywnościowej w $1999 r$. IERiGŻ, Warszawa.

Woś A. (2001a). Konkurencyjność potencjalna polskiego rolnictwa. IERiGŻ, Warszawa.

Woś A. (2001b). Konkurencyjność wewnętrzna rolnictwa. IERiGŻ, Warszawa.

Woś A., red. (2007). Analiza produkcyjno-ekonomicznej sytuacji rolnictwa i gospodarki żywnościowej w $2006 r$. IERiGŻ, Warszawa.

Woś A. i J. Zegar (2002). Rolnictwo społecznie zrównoważone. IERiGŻ, Warszawa.

WRMO (2006). Wspólne Ramy Monitorowania i Oceny. Wytyczne. Rozwój Obszarów Wiejskich 2007-2013. DG Agriculture, Komisja Europejska.

Yunus M. (2003). Banker To The Poor: Micro-Lending and the Battle Against World Poverty. Public Affairs New York.

Yunus M. (2007). Creating a World Without Poverty: Social Business and the Future of Capitalism. Public Affairs New York.

Zawalińska K. (2004a). The Competitiveness of Polish Agriculture in the Context of Integration with the European Union. WNE, Uniwersytet Warszawski, Warszawa.

Zawalińska K. (2004b). The Rural Development Index (RDI) as a Useful Tool for Agricultural Decision Modelling: Poland as a Case Study. (Praca magisterska, tekst dostępny w bibliotece Development Studies, Cambridge University, pod numerem 8704/2004.)

Zawalińska K. (2005a). Indeks rozwoju obszarów wiejskich dla Polski (IROW). [w:] Rozwój obszarów wiejskich. Doświadczenia krajów europejskich, K. Zawalińska, red. Problemy Rozwoju Wsi i Rolnictwa IRWiR PAN, Warszawa.

Zawalińska K., red. (2005b). Rozwój obszarów wiejskich. Doświadczenia krajów europejskich. Problemy Rozwoju Wsi i Rolnictwa IRWiR PAN, Warszawa.

Zawalińska K. (2009a). Zróżnicowanie regionalne efektywności unijnych instrumentów polityki rozwoju obszarów wiejskich w Polsce. [w:] Wokót trudnych problemów global- 
nego rozwoju obszarów wiejskich, gospodarki żywnościowej i rolnictwa, red. K. Duczkowska-Małysz, K. i A. Szymecka. Szkoła Główna Handlowa, Warszawa.

Zawalińska K. (2009b). Is 1FA support a good value for money? Regional CGE analysis for Finland and Poland, tekst przyjęty na konferencje IAAE 2008, Ghent.

Zegar, J. (2005). Koncepcja badań nad rolnictwem społecznie zrównoważonym. [w:] Koncepcja badań nad rolnictwem spotecznie zrównoważonym, praca zbiorowa. IERiGŻ, Warszawa.

Zegar J. (2008a). Dochody w rolnictwie (metodologia, stan i tendencje). Konferencja pt. Problemy kształtowania się dochodów rolniczych IERiGŻ, 4.07.2008, Warszawa.

Zegar J. (2008b). Z czego żyje polska wieś? [w:] Polska wieś 2008. Raport o stanie wsi, J. Wilkin i I. Nurzyńska, red. FDPA, Warszawa.

Żółkiewski Z. (1996). Economy-wide and Structural effects of market imperfections in economies in Transition: the results for Poland. Zeszyty ZBSE, Nr 240. GUS i PAN, Warszawa.

Żylicz T. (2004). Ekonomia środowiska i zasobów naturalnych. Polskie Wydawnictwo Ekonomiczne, Warszawa. 


\section{SUMMARY}

Thanks to its membership of the European Union (EU) and access to EU funds in particular, Poland has been able to strengthen the implementation of its rural development (RD) policy. In 2004-2006 the funding came from the European Agricultural Guidance and Guarantee Fund (EAGGF) and in 2007-2013 from the European Agricultural Fund for Rural Development (EAFRD). But even before EU entry, rural Poland had benefited from several EU assistance programmes, like for example SAPARD (2000-2004) and PHARE (1990-2007), as well as World Bank programmes (loans), including the Agricultural Sector Adjustment Loan (ASAL) scheme carried out in 1994-1996 and the Rural Development Project (PAOW) implemented in 2000-2004 [see Milczarek, Zawalińska, 2005]. Of course, all these foreign funds were supplemented by allocations from the national budget.

Poland, as a full member of the EU, can influence the process of shaping EU policies, at both national and community level by for example taking an active part in conceptual and legislative work. It may choose measures, from among those proposed, which best suit its own development goals; it may define their form, ways of implementation and eligibility criteria, and decide on the allocation of means among individual measures and even regions (provinces). This may create a chance or a threat to the development of rural areas, depending on whether the decisions taken are right or wrong. This is why one of the objectives of this book is to provide a scientific basis for making the right choices and working out better instruments supporting RD policy.

People living in rural areas are still often seen mainly as farmers, despite the fact that the number of farmers among the rural population is on the decrease. It is impossible to solve the complex economic and sociological problems of the rural population by applying instruments of a narrow sectoral (agricultural) policy. The development of rural areas should mainly involve the expansion of non-agricultural sources of income for the local residents. Therefore, another goal of this dissertation is to examine the economic effects of RD policy not only for 
the agricultural sector and rural areas but also for all other sectors and whole regions. Thanks to the implementation of the programmes mentioned above, many indirect and multiplier effects have been produced far beyond the agricultural sector. This is why the author proposes a method which makes it possible to capture the whole economy through the use of a regional general equilibrium model, which shows how effects of RD programmes are transmitted among all economic sectors in individual provinces.

The EU has formally pursued its policy on rural areas since the late 1990s when, with the adoption of the Agenda 2000 action programme, the policy officially became the second pillar of the Common Agricultural Policy. Earlier, the EU had focused on sectoral policy, which ignored the specific nature of rural development. Since Poland's EU entry RD policy has been pursued in the country by means of three programmes. Two of them - the Rural Development Programme (PROW 2004-2006) and the Sectoral Operational Programme Restructuring and Modernization of the Food Sector and the Development of Rural Areas (SOP Agriculture) - were carried out in 2004-2006 ${ }^{68}$. At present, within the 2007-2013 financial framework, Poland's RD policy is pursued through the Rural Development Programme (PROW 2007-2013), which is coherent with the National Strategic Plan for Rural Areas. PROW 2007-2013 uses most of the measures of the two programmes carried out in the previous period. As a result, it is easier to analyse it and monitor most of the measures over a longer time span. The programmes are funded both from public sources (EU sources and the national budget) and private sources (contributions from beneficiaries). In 2007-2013 Poland has the right to spend more than EUR28.4 billion of EU money for rural and agricultural development, of which around EUR13.2 billion may be used as part of PROW 2007-2013 and over EUR15.2 billion in the form of direct payments. This represents at least around EUR4 billion annually. Therefore, it is very important to make an in-depth analysis of instruments of this policy, especially the economic mechanisms behind individual measures of RD programmes, something which is often passed over in public debate. It is obvious that income transfers, investment subsidies and land subsidies produce different effects. Meanwhile, public debate is focused too much on the number of RD policy and goals measures rather than the quality of instruments used and the allocation of funding among individual measures. Although a consensus has been reached that RD policy should support an improvement in agricultural

\footnotetext{
${ }^{68}$ It should be noted that funds from these programmes were spent until the end of 2008 , in line with the $n+2$ rule, i.e. up to two years after the formal completion of the programme.
} 
competitiveness, environmental quality and the quality of life of the rural population, there is still no agreement as to the most efficient way of achieving these goals: which of the existing measures are the best, which could be improved and what new measures could be proposed in order to make RD policy more efficient. This is why another objective of this book is to point to differences among the economic mechanisms behind individual instruments of this policy and show how they determine the effectiveness and efficiency of the policy.

With the gradual development of RD policy, the European Commission (EC) has placed more emphasis on monitoring and evaluating RD programmes. Many methodological problems are usually involved in assessing RD programmes. The problems arise from difficulties in detecting the "pure impact" of the programmes on their beneficiaries - both positive and negative external effects - and in evaluating the impact of the programmes at their different levels (outputs, results, impact). The EC generally recommends a method based on indicators contained in the Common Monitoring and Evaluation Framework [CMEF, 2006]. They are quite useful at the level of outputs and results, but not sufficient at the level of impact on the whole economy. Therefore, another objective of this book is to make an attempt to assess basic evaluation criteria for RD policy - effectiveness, efficiency, sustainability and multiplier effects - at the level of the programme's impact, i.e. effects of RD policy in a wider context, something which is the most difficult to capture because of its wide geographic range and time span. As a result, the book partly represents an ex-post evaluation of two programmes, SOP Agriculture and PROW 2004-2006, which were completed more than two years ago. In line with the $n+2$ rule adopted by the EC, this means that an analysis of this kind can already be made because all the money allocated to the programmes should already have been spent and most effects of the programmes should already have become visible.

\section{Objectives of the book}

The main objective of the book is to analyse the instruments and effects of EU support for rural development in Poland, with a special focus on regional aspects. The analysis covered available data, i.e. the period from Poland's EU entry in 2004 to 2008. The findings were presented at both national and provincial level. The author formulated detailed research goals, which proved helpful in achieving the main objective. The first detailed goal was to make a comprehensive analysis of the policy designed to support rural development, both as a development factor and an element of welfare assistance. The second 
goal was to evaluate the effectiveness and efficiency of various instruments used in Poland as part of this policy in the period analysed. The third goal was to assess the impact of rural development policy not only on the agricultural sector but also on the wider economy because rural development policy does not affect the agricultural sector alone: money spent by farmers circulates in the economy and has an indirect impact on other sectors. The fourth goal was to examine the benefits of rural development policy at regional level, i.e. find out which provinces benefited the most and developed thanks to the funds they had acquired.

In line with the main assumption, the book is supposed to present a balanced combination of advanced analytical methods and their practical application. Its practical contribution to Polish research is in the form of regional input-output tables, as an important tool of regional economic analysis, and the use of a regional general equilibrium model to evaluate rural development programmes at the level of their influence. Scientific support to decision making in the process of selecting the most effective and efficient rural policy instruments seems especially important now when debate is underway on the shape of this policy after 2013. Another important thing is the modification of the OECD typology of rurality by adding an agricultural dimension to it. The book's theoretical contribution to literature on the subject includes its addition to the development of regional general equilibrium models for Poland and proposals for methods of developing regional input-output tables and social accounting matrices, the absence of which poses a barrier to the development of regional CGE models in Poland. Additionally, the book refers to many economic theories, including the theory of economic development, public choice, general equilibrium, agricultural and rural economics, and to achievements in the area of quantitative methods including structural economic models. The methodological contribution of the research studies presented in the book consists in combining a general equilibrium model with rural development problems, especially at regional level. Wherever possible, the publication also draws on international experience and comparisons.

\section{Hypotheses}

The book examines four research hypotheses. Supplemented with supporting questions, they were supposed to help the author achieve the objectives of the book. The hypotheses are presented and substantiated in detail in successive chapters, where they appear in the context of individual problems. Here they are outlined briefly one after another in order to introduce the reader to the scope 
and extent of the problems analysed in the book. Information on the way in which the hypotheses were examined and the outcome of this examination can also be found in the last chapter and Table 5-1.

The first hypothesis says that Poland's rural development policy favours pro-equality over pro-efficiency measures. It has its genesis in the public choice theory and is associated with the eternal dilemma of development policy, which represents a compromise between social equality and economic efficiency. The dilemma is reflected in the fundamental principles behind the functioning of the EU, which pursues a cohesion policy designed to equalise opportunities for poorer countries and regions but at the same time attaches great importance to a competitiveness policy, for example in the Lisbon Strategy, which is generally supposed to favour the fastest possible economic growth and technological progress. As Chapter 2.3.2 shows, these two goals do not always go hand in hand. This hypothesis is accompanied by an additional question, one about the proportion between pro-efficiency measures and pro-equality measures in the rural development policy implemented in 2004-2006 and planned for 2007-2013.

First, individual measures of RD policy were classified according to the character of instruments used to realise the goals of these measures. Then, the proportion between pro-equality and pro-efficiency measures was examined at national and regional level. The hypothesis was intentionally formulated as the first one because it serves as an introduction to discussion on the theoretical rationale for rural development policy. The discussion precedes an empirical analysis of the economic consequences of the policy, because these should be interpreted against a theoretical and historical background.

The second hypothesis says that support to rural development through investment is much more effective and efficient than support through noninvestment subsidies of various kind. We know that the use of any policy instrument has its pluses and minuses; the instruments also differ in their relative efficiency. On the one hand, one may expect that investment is a better instrument than the subsidies and should be used in the first place. But on the other hand, there is the absorption dilemma because pro-investment funds in RD policy are much more difficult for beneficiaries to acquire and apply than other funding, especially direct transfers. Therefore, if one faces the choice between low absorption coupled with highly efficient measures and high absorption coupled with generally less efficient measures the decision is not obvious. The analyses conducted show that benefits resulting from the use of pro-efficiency measures may be so much higher than benefits from pro-equality measures that it would be 
advisable to simplify the pro-efficiency measures in order to increase the absorption of funding allocated to them instead of settling for a large number of relatively inefficient pro-equality measures. The empirical comparative analysis shows the extent of this difference in efficiency. It is necessary to decide whether the difference is significant enough that it merits the effort of forcing through "difficult" measures or whether it is so insignificant that a reasonable amount of "easy" measures would offset the losses in efficiency and at the same time would help to maintain social peace, with a positive effect for economic development. The following supporting questions are connected with this issue:

- What economic effects were caused respectively by pro-efficiency and pro-equality measures?

- What are the differences in the efficiency of the RD policy instruments classified as investment subsidies, direct income transfers and land subsidies?

- What are the costs of the policy of "maximising the absorption of 'easy' funds"?

The third hypothesis says that rural development policy is mainly focused on the agricultural sector but generates significant multiplier effects in many other sectors of the economy thanks to the wide range of different instruments it uses. The first part of the hypothesis says something that one can often hear in public debate: that the rural development programme is targeted at farmers to a larger extent than at other rural residents, despite the fact that agriculture is losing importance in rural areas and it is necessary to support off-farm jobs. However, the other part of the hypothesis stresses that farmers are not the only beneficiaries of this policy because it contributes to the flow of production factors and resources to the remaining sectors of the economy. The supporting questions for this hypothesis are as follows:

- Which sectors at national and regional level gained the most and which gained the least from rural development policy?

- What is the impact of multiplier effects on non-agricultural employment of the rural population?

The fourth hypothesis, formulated in line with the obvious intention of RD policy, says that regions which are the most rural in the country and most dependent on agriculture benefit the most from rural development policy. This is consistent with the intuition that residents of rural areas - i.e. apart from farmers, also rural people not associated with farming - and the most rural and agricultural regions of the country - should be the largest beneficiaries of RD policy. However, if multiplier effects are taken into account it may turn out that other regions gained more. In order to check this hypothesis, the author proposed 
a typology of provinces, based on a modified OECD classification, according to their rurality and "agriculturality." The purpose was to define the provinces in the least controversial way in terms of their rurality and dependence on agriculture. The following supporting question was helpful in this respect:

- Which regions classified according to the rural-agricultural typology saw the greatest positive/negative economic effects of rural development policy and which saw the smallest effects?

The hypotheses mentioned above were checked by means of quantitative and qualitative methods, as described in successive chapters devoted to respective hypotheses. Table 5-1 sums them up.

\section{Research method and statistical data}

Quantitative methods dominate in the book and the main research tool is the RegPOL regional general equilibrium model. The model reflects the structure of the whole economy divided into 16 regional economies. It shows interactions among provinces - through internal trade, labour markets and production factors - and among all economic sectors aggregated to 15 PKD sections ${ }^{69}$. Thanks to the model, it is possible to show the impact of regional development policy on the agricultural sector and the remaining economic sectors, of which the following are mentioned in the book: fishing, industrial processing (including agri-food processing), mining and quarrying, energy sector, construction, trade and repairs, hotels and restaurants, transport, as well as financial, household, educational, health and public administration services, and other services. Regional social accounting matrices (SAM), built into the model as the main database, reflect detailed links between agriculture and other economic sectors for each province. The model can be used for both static and dynamic analyses (recursive dynamic) of the processes happening in the economy. It is based on the assumptions of neoclassical economics, i.e. maximization of utility (by households), minimisation of costs (by businesses), perfect competition, classical unemployment and migration. The RegPOL model describes the reality by means of over 50,000 equations characterising detailed economic relationships. Chapter 3.1.3 describes the genesis and structure of the RegPOL model and provides discussion on its adequacy.

The database created and used in the book is of significant value. The starting point was the updated national input-output table for 2000 and regional

$\overline{{ }^{69} \text { Only the last sections }} \mathrm{O}, \mathrm{P}, \mathrm{Q}$ have been aggregated together. 
databases for each province for the years 2000-2006. Thanks to the databases and with the help of literature on the subject, the author created 16 input-output (IO) tables and 16 social accounting matrices (SAM). The author used a hybrid method, combining the augmented Flegg's location quotients formula (AFLQ) with the regional statistics and coefficients from the national IO table. Additionally, the author also used the RAS method to balance the matrices (for details see Appendix 3-4). This required much effort and meant the need for the author to learn many techniques for regionalising IO tables and social accounting matrices. But this effort was necessary for creating a model which had never been constructed in Poland before. The very publication of the algorithms for creating the tables may be regarded as a contribution to literature on the subject because it is the first such study in Poland. Additionally, such tables are very desirable because they enable starting more advanced methods of regional analysis, including regional input-output models, SAM models and regional general equilibrium models ${ }^{70}$. A broader description of the data used for the model is in Chapter 3.2.1, which is additionally provided with extensive technical appendices, which explain the process of constructing the database.

The author also used many GUS studies for the years 2000-2008, including the Regional Data Bank, yearbooks of individual provinces, the HERMIN regional database, Labour Force Surveys (BAEL) and statistics commissioned by GUS, e.g. foreign trade by provinces, regional accounts consistent with the IO table and so on. Additionally, the author used data from the Agency for Restructuring and Modernisation of Agriculture (ARiMR) on regional differences in the expenditure of money from PROW and SOP Agriculture in 2004-2006, data and studies from the Ministry of Agriculture and Rural Development and many other statistical materials.

Individual in-Depth interviews, questionnaire surveys and documentation analyses were also conducted for the needs of this book. The questionnaire surveys were conducted by electronic means (on-line questionnaire survey) among 80 workers from all regional ARiMR branches. The main objective of collecting data by this method was to get to know the ARiMR workers' opinion on how farmers had coped with applications for assistance offered under the programmes. As regards the documentation, it included mainly directives and programme documents concerning the programmes analysed, i.e. SOP Agriculture, PROW 2004-2006 and PROW 2007-2013. Additionally, the author

\footnotetext{
${ }^{70}$ To the author's best knowledge, the RegPOL model is now the only Polish regional general equilibrium model which models individual provinces taking into account disaggregated economic sectors and trade among provinces on the basis of full SAMs.
} 
used materials collected during training sessions for workers of Agricultural Advisory Centres (ODR). All these techniques and materials are described in relevant chapters (also see Appendix 2-4).

Although the author used a large amount of data and many research methods, it is necessary to admit that there are some constraints which call for caution in interpreting the findings. Firstly, the reality depicted by the model is a reflection of the reality which emerges from the data and - as everyone knows - data are only an approximation of the real world. The model itself also contains many simplifications so its results indicate the scale and direction of change rather than exact values. Moreover, the analysis could be augmented by qualitative research conducted on a larger scale, i.e. one could ask about motivations of farmers when spending rural development funds or regional determinants behind efficiency in spending rural development funds in individual provinces. However, if such an analysis were to be made a much more extensive dissertation would be needed. But with future studies in mind, Chapter 5.3 contains several more detailed suggestions as to possible ways to expand and continue research initiated in this book.

To conclude, it is worthwhile to sum up briefly the literature used by the author. Of the 350 or so publications, slightly over $50 \%$ is in English. The literature mainly concerns problems associated with general equilibrium models, techniques for regionalising IO tables, methods of evaluating development programmes, advanced computational techniques used in the models and codes of the models, i.e. problems which are not raised by Polish authors often enough. From Polish literature, the author selected studies concerning the typology of rural areas, macroeconomic determinants of rural and agricultural development, special features associated with the development of Polish regions, a review of Polish and more universal models applied for agriculture, and studies on the ways in which farmers acquire and use EU funding. Most of the statistical materials and programme documents also comes from Polish sources. Therefore, this book may add to Polish theoretical and application achievements in such areas as development theory (using the example of agriculture and rural areas), political economics (using the example of the Common Agricultural Policy), regional development theories (by presenting analyses based on regional input-output tables and the regional general equilibrium model), public choice theories (by showing costs involved and benefits from adopting rural development support instruments of different degrees of efficiency) and the rural development theory (by showing rural areas in the context of the wider economy and the general equilibrium theory). 


\section{Stages of the analysis}

Starting with various definitions of rural areas and their development, the author proposed a rural-agricultural typology of these areas to make it easier to conduct a comparative analysis of the empirical results obtained. Then, the development of rural areas was analysed in a wider context, i.e. the context of agricultural development, sustainable development, integrated development, and the multifunctionality of rural areas. Hence, moving from theory to empirical research, the author analysed data on rural development and stylised facts emerging from the data (Chapter 1).

Then, on this theoretical and empirical basis, the author presented stylized facts and paradigms of rural development policy, including the instruments by means of which it is pursued. In particular, the author looked at measures implemented in Poland after its EU entry. Another step was to compare the structure of selected measures according to three classifications: the EU classification based of EC terminology, Rowiński's classification based on a larger number of criteria, and classification according to economic criteria, one based on real economic mechanisms behind individual measures. On this basis, $\mathrm{RD}$ funds were divided into pro-efficiency and pro-equality ones (Chapter 2).

Chapter 3 is wholly devoted to methodological issues and is provided with a number of extensive appendices concerning technical problems. The chapter describes the main quantitative research tool used in this book, i.e. the RegPOL regional general equilibrium model for Poland. A brief explanation why a model of this kind had been chosen to evaluate RD policy in Poland was followed by a more detailed description of its properties and characteristics. In successive stages, the author described the database created and used for the needs of the model and demonstrated the method by which the ultimate database was built. Then, the author described the structure of equations, which make up the model and its individual modules. The full code of the model in the Tablo language is to be found in an appendix to the book. Then, the author presented the main variables modelled in RegPOL and scenarios used for simulations. The chapter ends with a discussion on the usefulness of the model and the correctness of its use. This assessment concerns both the data used and the equations of the model.

The next part of the book presents findings of empirical research in the form of evaluations. The findings are divided into four parts, of which the first three are clearly associated with the main evaluation criteria. First, the author discussed the effectiveness of instruments used to support rural development, something which determined the scale of difference in benefits from RD policy in individual 
provinces. Then, the efficiency of individual groups of measures and the whole RD policy was presented. This was followed by a presentation of multiplier effects, i.e. the impact of RD policy on various sectors of the economy, apart from the agricultural sector. In this section, the author made an analysis of the impact of multiplier effects on non-agricultural employment for the rural population. In the end, benefits from RD policy were compared across provinces grouped according to the extent of their rurality and dependence on agriculture (Chapter 4).

In Chapter 5, the author presented the main conclusions from the research with reference to individual hypotheses and the ways in which they had been examined. The hypotheses and the supporting research questions were presented again, this time in a concise form of tables, together with the results of their examination. The chapter ends with recommendations for rural development policy at both national and EU level.

\section{Conclusions from the research}

The research process, aimed at examining four hypotheses, led to formulating the following conclusions:

When pursuing rural development policy after its EU entry, Poland could take at least three autonomous decisions as to: 1) the number of measures it wanted to implement within RD policy, 2) types of measures, 3) allocation of money among measures and provinces. The strategy Poland adopted was to implement a large number of measures, which resulted in the fragmentation of means for individual goals and high transaction costs associated with building, handling and controlling the whole management system. A majority of the measure types selected was in the form of investment subsidies, followed by direct transfers and land subsidies. The system of allocating funding among provinces was quite transparent (regional envelopes) and based on comprehensible public indicators, although it is debatable whether the indicators were appropriate. Meanwhile, the allocation of funding among individual measures at national level was not an open process and was difficult to explain scientifically, which indicates that decision making in this respect was politicised to a large extent.

At national level, the proportions of funds efficiently supporting rural development and measures equalising rural people's incomes are more or less the same. As any other development policy, RD policy is a compromise between support to economic growth and social goals: maintaining social peace and equalising opportunities for 
development of backward rural areas. This compromise is also well visible at the level of the EU policy framework, where the idea of equalising opportunities, exemplified by cohesion policy for instance, is coupled with the idea of enhancing competitiveness, reflected in the Lisbon Strategy. Unfortunately, it is usually very difficult to reconcile these two goals because in most cases one of them is achieved at the expense of the other. But in the case of RD policy, it seems that at national level pro-efficiency and pro-equality funding was distributed quite evenly. As has been found, investment subsidies were pro-efficiency, while direct transfers and land subsidies mainly pro-equality in nature. The largest support for the development of rural areas under SOP Agriculture and PROW 2004-2006 was provided in the form of investment subsidies (42\%), followed by land subsidies (29\%) and direct transfers (29\%). The proportions of pro-efficiency and pro-equality funding were almost equal: $53 \%$ and $47 \%$. In 2007-2013, investment subsidies are to account for 55\%, direct transfers $15 \%$ and land subsidies $30 \%$. The ratio of pro-efficiency to pro-equality funding will be $64 \%$ to $36 \%$, which means that the advantage of pro-efficiency measures will be extended.

Significant differences in the structure of funding absorbed can be seen at the level of provinces. As regards the structure of funding awarded, it is important how much of it has been allocated to a given province. But even more important is the question on which economic instrument the money has been spent because this is the most important factor determining the efficiency in using the funds. Świętokrzyskie province had the largest share of direct transfers in the structure of funds used (47\%) and Zachodniopomorskie province had the largest share of land subsidies (50\%). Kujawsko-Pomorskie province stood out favourably from other provinces because it had the largest share of infrastructure investment subsidies (SI_b) in the structure of all funds used - 56\%. Investment in education usually accounted for a very small percentage of all measures. The largest share was recorded by Podkarpackie and Małopolskie province - 4\% each. The differences in the structure of these funds are the outcome of many factors, both on the demand and supply side, and it is impossible to mention them all. On the one hand, there was an impact of external factors, like for example top-down decisions for the distribution of funding among provinces and algorithms of criteria for accessing the measures. On the other hand, internal factors also played a role. They included investment needs of farms, their activity level and ability to acquire funding, the involvement of advisory and intermediation institutions of various kind, the province's development level, natural conditions and the initial state of investment penetration in the province. 
Support for development is much more efficient through investment subsidies than through income transfers or land subsidies. Investment in infrastructure - i.e. investment in farms, adjustments to EU standards, improvements in processing and marketing - turned out to be the most efficient of all rural development policy instruments. In some provinces, investment in education (advisory services and training) turned out to be very efficient. Land payments and direct transfers were the least efficient. Relationships among these types of funds in the total funding acquired by individual provinces had an impact on their development. One can say that the higher the percentage of investment subsidies in the structure of funds acquired, the higher the efficiency of the province in using RD policy. But this relationship was much weaker in provinces where investment penetration in agriculture was higher.

Measures regarded as easy to access are much less efficient than those which are difficult to access. The qualitative analysis showed marked differences among measures in terms of the level of difficulty in acquiring and implementing them. A majority of the easily accessible measures were those in the form of direct transfers and land subsidies. The measures difficult to access were those in the form of infrastructure investment subsidies. Unfortunately, easily accessible measures turned out to be much less efficient than those difficult to access. One of the possible reasons why some provinces acquired a relatively small amount of highly efficient measures - except for SOP measures, whose allocation was through regional envelopes - may be that these subsidies were relatively difficult to acquire. Direct transfers and land subsidies involved a much smaller amount of formalities and control than investment subsidies.

At regional level, the most efficient form of support was usually investment in infrastructure, followed by investment in human capital. In most provinces especially in Śląskie, Świętokrzyskie, Opolskie and Małopolskie - the most efficient form of support for rural development was investment in infrastructure, just like at national level. Subsidies in human capital were the second most efficient measure in most provinces, especially in Śląskie, Podkarpackie and Dolnośląskie. In two provinces, Lubelskie and Mazowieckie, investment in human capital was the most efficient form of support for rural development. In most provinces, except for Kujawsko-Pomorskie, direct transfers and land subsidies were quite inefficient.

The relative efficiency of $\mathrm{RD}$ policy at regional level depended the most on the amount of funds acquired by provinces in relation to their economic power measured 
by Gross Regional Product (GRP) and GRP per head. Those provinces which acquired the largest amount of funding in relation to their GRP benefited the most from RD policy. The access criteria were defined in such a way that provinces most dependent on agriculture and poorer gained relatively larger support in relation to their affluence and economic strength. The affluence of provinces was negatively correlated with effectiveness, i.e. poorer provinces achieved higher effectiveness. Considering that most of the poorer provinces were more rural and agricultural in character than others, it comes as no surprise that five in six of the fastest developing provinces using RD funds were predominantly rural, half of them were predominantly agricultural and another half were significantly agricultural according to the rural-agricultural typology proposed in this book on the basis of the OECD methodology.

Thanks to the diversity of the measures used, positive multiplier effects of RD policy became apparent in various non-agricultural sectors of the economy. Although the agricultural sector (farmers) is the direct beneficiary of RD policy, other sectors also reap concrete benefits thanks to the flow of resources and bonuses. The direction of these flows was determined to a large extent by the eligible costs ${ }^{71}$ of various measures, defined by the European Commission. The list of such costs defines what kind of expenditures can be refunded to farmers, which means it also defines the type and size of investment. As a result, the largest beneficiaries are such sectors as construction (mainly thanks to such measures as adjustment to EU standards and investment in farms), energy, mining and quarrying, manufacturing, financial services, transport and household services. The multiplier effects differ depending on the type of measure and the province's sectoral structure. The Podlaskie, Warmińsko-Mazurskie and Kujawsko-Pomorskie provinces benefited the most from multiplier effects.

Multiplier effects (in the area of production and services) have an impact on employment in non-agricultural sectors of the economy but the overlap between these sectors and the sectors in which rural people are employed is small. Apart from agriculture, rural people usually find employment in such sectors as industrial processing (mainly food-processing industry), trade and repairs, construction, transport, public administration and education. But in these sectors multiplier effects were quite weak. Only the expansion of the construction and transport sectors, where rural people are traditionally employed, could be

\footnotetext{
71 Eligible costs are defined by the European Commission, which decides what kind of expenditures can be funded or refunded to beneficiaries.
} 
conducive to an increase in the non-agricultural employment of the rural population.

RD policy had a small but favourable impact on such economic variables as economic growth, private consumption, internal and foreign trade, and - to an even smaller extent - on employment and inflation. Its impact on unemployment and migration was insignificant. RD policy contributed $1.6 \%$ to Poland's GDP but there were large regional differences in its impact: from $0.8 \%$ of GRP in Dolnośląskie province to $6.3 \%$ of GRP in Podlaskie province. Its impact also varied across economic variables. It made the largest contribution to GDP growth (1.5\%), exports growth (1.5\%) and growth in private consumption $(0.8 \%)$. It had a smaller impact on inflation $(-0.7 \%)$ and employment growth $(0.8 \%)$. Its impact on changes in unemployment was very small ( -0.14 percentage points) and it had no impact on migration.

Rural-agricultural regions benefited more from $\mathrm{RD}$ policy than regions which are more urbanised and less dependent on agriculture. The analysis of six main economic indicators in the rural-agricultural typology showed that regions which are the most rural and agricultural gained more from RD policy than more urbanised regions. In the first group, however, mixed regions benefited the most. The mixed regions were those which were either predominantly agricultural and at the same time significantly rural or predominantly rural and at the same time significantly agricultural. The following provinces gained the most from RD policy: Podlaskie (significantly rural - predominantly agricultural), Warmińsko-Mazurskie (predominantly rural - significantly agricultural), Kujawsko-omorskie (significantly rural - predominantly agricultural), Świętokrzyskie and Lubelskie (predominantly rural - predominantly agricultural). Provinces with a relatively higher level of development and investment, e.g. Ślaskie and Wielkopolskie, gained relatively the least. 
r10.qxd 2011-10-31 09:48 Page 370 